\title{
Archeological Testing of TxDOT Right-of-Way through Site 41BL278, Bell County, Texas
}

\author{
J. Michael Quigg \\ Charles D. Frederick
}

Follow this and additional works at: https://scholarworks.sfasu.edu/ita

Part of the American Material Culture Commons, Archaeological Anthropology Commons, Environmental Studies Commons, Other American Studies Commons, Other Arts and Humanities Commons, Other History of Art, Architecture, and Archaeology Commons, and the United States History Commons

Tell us how this article helped you.

This Article is brought to you for free and open access by the Center for Regional Heritage Research at SFA ScholarWorks. It has been accepted for inclusion in Index of Texas Archaeology: Open Access Gray Literature from the Lone Star State by an authorized editor of SFA ScholarWorks. For more information, please contact cdsscholarworks@sfasu.edu. 


\section{Archeological Testing of TxDOT Right-of-Way through Site 41BL278, Bell County, Texas}

\section{Licensing Statement}

This is a work for hire produced for the Texas Department of Transportation (TxDOT), which owns all rights, title, and interest in and to all data and other information developed for this project under its contract with the report producer. The report may be cited and brief passages from this publication may be reproduced without permission provided that credit is given to TxDOT and the firm that produced it. Permission to reprint an entire chapter, section, figures or tables must be obtained in advance from the Supervisor of the Archeological Studies Branch, Environmental Affairs Division, Texas Department of Transportation, 125 East 11th Street, Austin, Texas, 78701 


\title{
Archeological Testing of TxDOT Right-of-Way through Site 41BL278, Bell County, Texas
}

\author{
By: \\ J. Michael Quigg, and Charles D. Frederick
}

with contributions by:

Steven Bozarth, Melanie Crisp, Phil Dering, Timothy Figol, Trisha-Ann P. Gonzales, Bruce L. Hardy, Mary F. Malainey, Linda Perry, and J. Byron Sudbury

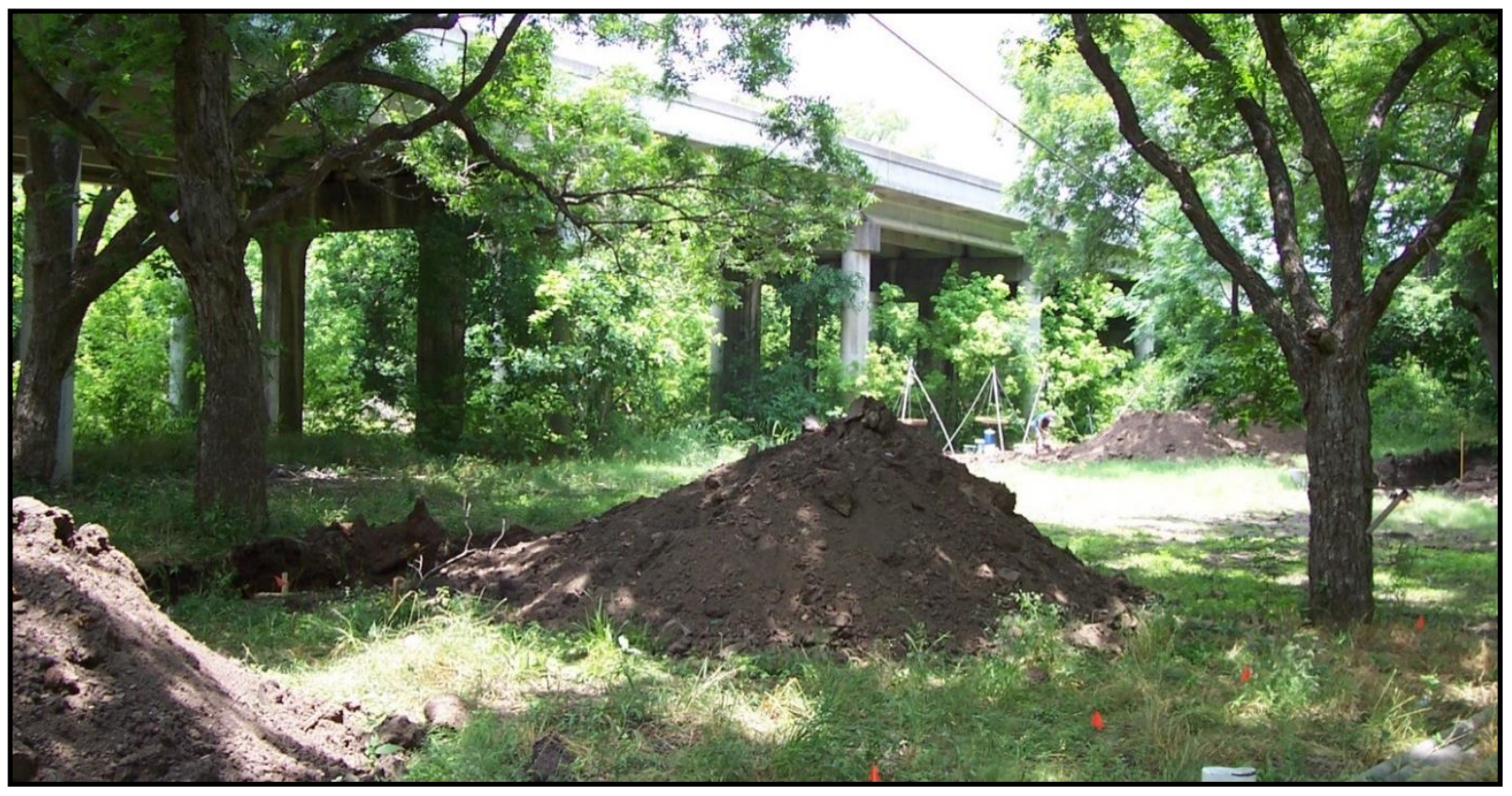

Prepared for:

Texas Department of Transportation

Environmental Affairs Division

Archeological Studies Program

Report No. 171

Austin, Texas
Prepared by:

TRC Environmental Corporation

TRC Technical Report Nos. 42568

(106760) and 211462

Austin, Texas

Texas Antiquities Committee Permit No. 3446 


\section{Archeological Testing of TxDOT Right-of-Way through Site 41BL278, Bell County, Texas}

By:

J. Michael Quigg, and Charles D. Frederick

with contributions by:

Steven Bozarth, Melanie Crisp, Phil Dering, Timothy Figol, Trisha-Ann P. Gonzales, Bruce L. Hardy, Mary F. Malainey, Linda Perry, and J. Byron Sudbury

Prepared for:

Texas Department of Transportation

Environmental Affairs Division

Archeological Studies Program

Report No. 171

Austin, Texas

Prepared by:

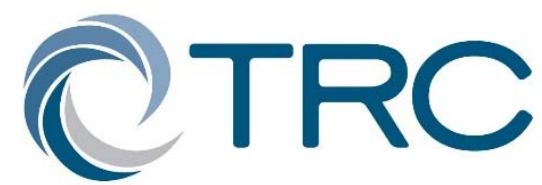

TRC Environmental Corporation

TRC Technical Report Nos. 42568 (106760) and 211462

Austin, Texas

J. Michael Quigg, Principal Investigator Texas Antiquities Committee Permit No. 3446

TXDOT Scientific Services Contract Nos. 573XXSA006 and 57-3XXSA004 
Texas Department of Transportation (TxDOT)

This is a work for hire produced for the Texas Department of Transportation (TxDOT), which owns all rights, title, and interest in and to all data and other information developed for this project under Contract 573XXSA006 and 57-3XXSA004. Brief passages from this publication may be reproduced without permission provided that credit is given to TxDOT and TRC Environmental Corporation. Permission to reprint an entire chapter, section, figures or tables must be obtained in advance from the Supervisor of the Archeological Studies Program, Environmental Affairs Division, Texas Department of Transportation, 125 East $11^{\text {th }}$ Street, Austin, Texas, 78701. Copies of this publication have been deposited with the Texas State Library in compliance with the State Depository Requirement.

Printed by:

Document Engine

Round Rock, Texas

Jointly published by:

Texas Department of Transportation

Environmental Affairs Division

Archeological Studies Program

Scott Pletka, Ph.D., Supervisor

Archeological Studies Program Report No. 171

and

TRC Environmental Corporation

TRC Technical Report Nos. 42568 (106760) and 211462

Austin, Texas

ISBN \#978-1-935545-38-5 


\section{EXECUTIVE SUMMARY}

In January 2004, Blanton \& Associates, Inc., conducted an archeological survey of 8.5 hectares (21.1 acres) for a proposed roadway improvement and bridge replacement project (CSJ: 0396-04-059) along roughly 1,800 meters $(\mathrm{m})$ of the Texas Department of Transportation (TxDOT) right-ofway where State Highway (SH) 317 crosses the Leon River in Bell County, Texas (Ringstaff 2004). That investigation consisted of three shovel tests, ten backhoe trenches, and five hand-excavated columns. Five backhoe trenches and the screened trench columns were excavated in the alluvial terrace on the southern side of the Leon River and encountered a single cultural component buried between 130 and 180 centimeters $(\mathrm{cm})$ below surface (bs). Wood charcoal from burned rock Feature 1 yielded an accelerated mass spectrometer date of $2490 \pm 50$ B.P. As a result, boundaries of a previously documented prehistoric cultural resource site to the southeast, 41BL278 were extended northwestward to include the river terrace on the southern side of the Leon River where the bridge development, area of potential effect (APE) is proposed. Ringstaff (2004) recommended archeological testing/evaluation in the area of the APE at site 41BL278, if that part of the site could not be avoided by planned bridge expansion. The Texas Historical Commission concurred with this recommendation.

In June 2004, archeologists from the Cultural Resources Section of the Planning, Permitting, and Licensing Practice of TRC Environmental Corporation's (TRC's) Austin office conducted archeological testing/evaluation for a National Register of Historic Places (NRHP) and State Antiquities Landmark (SAL) eligibility assessment at parts of site 41BL278. This investigation was conducted under TxDOT Contract for Scientific Services No. 573XXSA006 and Texas Antiquities Permit No. 3446 issued to J. Michael Quigg. The assessment of the previously identified, deeply buried cultural component in the proposed APE and part of prehistoric site 41BL278 was accomplished by an electrical resistivity survey of $840 \mathrm{~m}^{2}$ area, mechanical excavation of eight backhoe trenches (totaling nearly 34 linear meters), and 10 handexcavated 1-by-1 meter units (totaling $4.1 \mathrm{~m}^{3}$ ) off the sides of three backhoe trenches. The previously identified and targeted buried cultural component was determined to be vertically restricted between 130 and $180 \mathrm{cmbs}$ and horizontally restricted to the levee-like deposit towards the northern edge of the terrace. The levee appears to have been deposited relatively rapidly.

This eligibility assessment yielded nine cultural features that included at least one circular, rockringed hearth and various types of burned rock discard piles and dumps, some with only burned rocks, some combined with other classes of cultural material. A limited, but diverse cultural assemblage of chipped and ground stone tools, burned rocks, mussel shells, faunal bone, and organic materials was directly associated with the nine features. These material remains indicate two short-term events, which potentially reflect food processing activities that occurred between 3100 and 3300 B.P. and reflecting one cultural component.

Based on the investigations, it is apparent that the part of site 41BL278 within TxDOT's proposed APE contains a well-defined, $50 \mathrm{~cm}$ thick cultural component between 130 and $180 \mathrm{cmbs}$. This component is characterized by probably two, horizontal lenses of cultural material restricted to a narrow time period (ca. 3100 to 3300 B.P.). Relatively sterile alluvium overlies this component, and rodent activity and other sources of natural disturbance have not significantly affected this deeply buried component.

Following the fieldwork the chipped and ground stone tools, lithic debitage, mussel shell, faunal 
bone, charcoal, and other cultural materials were washed, sorted, and counted. A draft interim report of the fieldwork, findings, recommendations, and data recovery plan was prepared and submitted to TxDOT in 2004 (Quigg and Frederick 2004).

In November 2013, TxDOT issued Work Authorization 57-306SA004 to TRC under a Contract for Scientific Services (57-3XXSA004) to conduct limited technical analysis of samples, complete the draft and final technical reports, plus prepare the materials from the assessment phase for curation. Following completion of analyses, reporting and acceptance by TxDOT, these materials were permanently curated at the Center for Archaeological Studies (CAS) in San Marcos, Texas.

Multiple technical analyses included radiocarbon dating, starch grain, lipid residue, macrobotanical, high-powered use-wear, and phytolith studies. Poor preservation was the rule and definitely hindered, but did not prevent a greater understanding of the data. Poor preservation of the charcoal limited specific identification of most degraded samples, but at least two species, oak and cottonwood/willow were identified. Limited charcoal and other organic remains also restricted radiocarbon dating of the cultural activities. Tiny charcoal pieces provided five radiocarbon dates to aid in establishing the age of the targeted component to roughly 3200 B.P.

High-powered use-wear on at least three of the eight chipped stone tools analyzed documented cutting of wood products or other hard materials. Use-wear studies also revealed microscopic residues of wood, plant tissues, collagen, and feather fragments directly adhering to stone tools. Analyzed tools were also used to cut soft materials such as hides. Overall, the results reflect the occupants used chipped stone tools to conduct multiple processing tasks on diverse materials. Of considerable interest and quite rare is the feather fragments, which directly support the cutting of birds.
Starch analysis indicates at least two types of grasses, plus lily bulbs and other geophytes were collected, processed and cooked by burned rocks from multiple, small burned rock features. The presence of gelatinized starches on nearly 25 percent of the examined rocks indicates stone boiling likely occurred as a means of cooking starchy plant foods. Starch grain analysis has significantly broadened our understanding of exploited resources at this 3200 B.P. component, which would have otherwise gone undetected as the macrobotanical and vertebrate faunal remains are poorly preserved and very limited.

Phytolith analysis indicates very poor preservation of the important short cell phytoliths used to interpret grassland communities. Samples from three burned rock features yielded a variety of short cells (Pooids, Panicoids, and Chloridoids), but not sufficient for meaningful counts and interpretations. Also present were quantities of undiagnostic bulliforms, well-preserved burned tree phytoliths, and well-preserved freshwater sponge spicules, the latter are associated with water. Freshwater sponge spicule presence in features is indicative of water use in association with burned rocks. Due to improved phytolith processing techniques a variety of microscopic snail shells as well as charcoal flecks, bone fragments, burned shell (possibly snail), some lithic material, and other stone were present in the sand fractions.

Lipid residue analysis primarily yielded residues of medium fat content, with similar residues in plant and animal products. Residues from conifer products were on nearly every burned rock and likely testifies to the type of wood used to heat the rocks, here likely juniper or cypress.

Even though preservation was poor, the diverse technical analyses documented multiple plants, minimally grass and lilies/geophytes played a significant role, plus animals such as beaver and birds, combined with mussel shell meat provide a 
broad spectrum forager pattern at this location. These diverse resources were cooked with burned rocks from the multiple features represented.

The investigated portion of site 41BL278 has yielded significant information and the remaining deposits in the APE has the potential to yield further important information pertinent to answering multiple research questions about local and regional prehistory. Therefore, the investigated area of 41BL278 in the APE is recommended as eligible for listing on the NRHP under Criterion D and for designation as an SAL. If this area cannot be avoided during the expansion of the bridge over the Leon River, TRC recommends that the part of site 41BL278 lying within the existing and proposed new right-of-way along this roadway at the Leon River crossing, specifically the cultural component buried between 130 and 180 cmbs, be targeted for a mitigation excavation program prior to any earth-disturbing activities. 
This page intentionally left blank. 


\section{TABLE OF CONTENTS}

EXECUTIVE SUMMARY .......................................................................................................iii

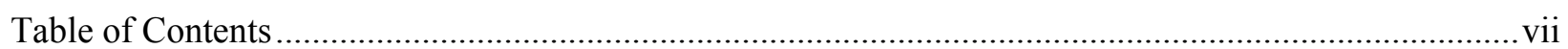

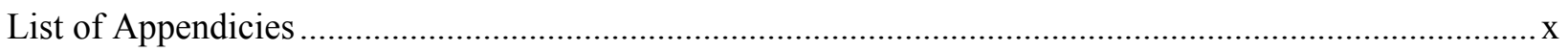

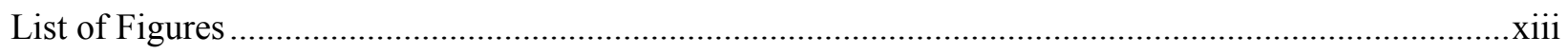

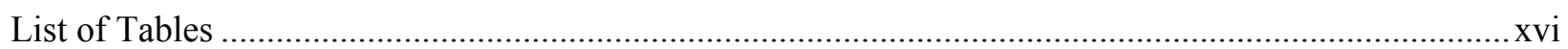

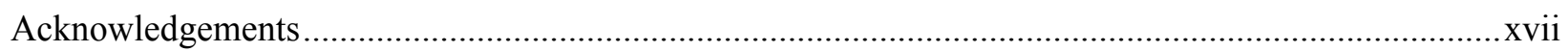

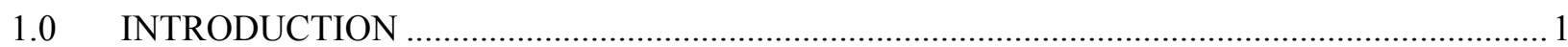

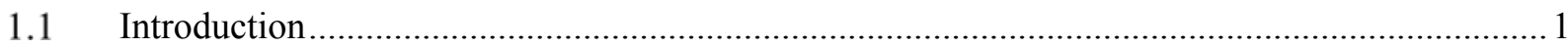

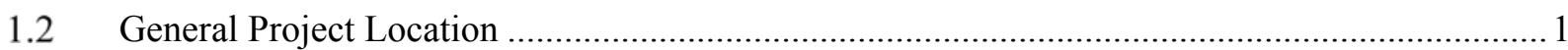

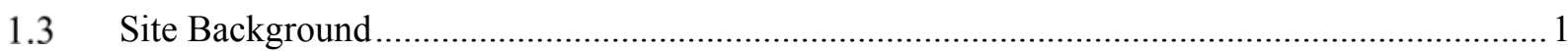

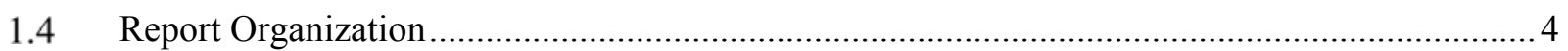

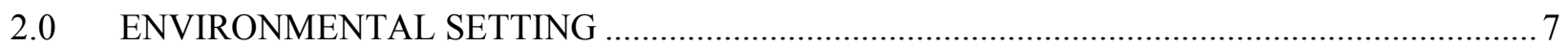

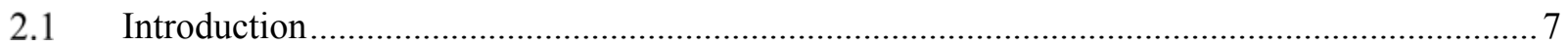

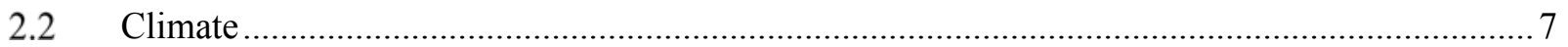

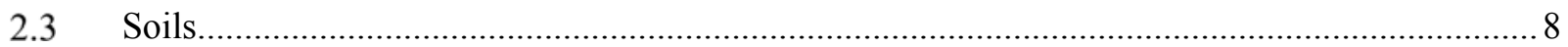

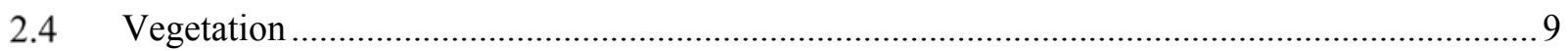

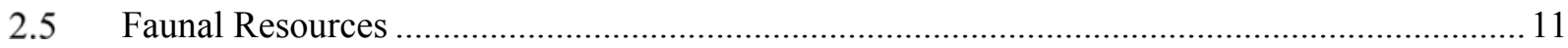

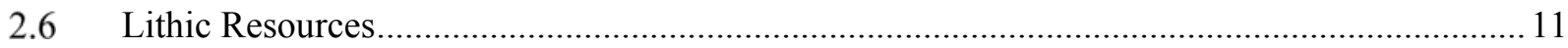

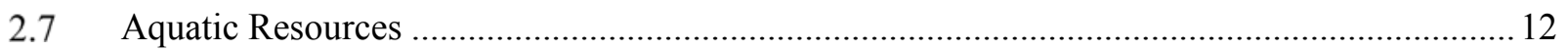

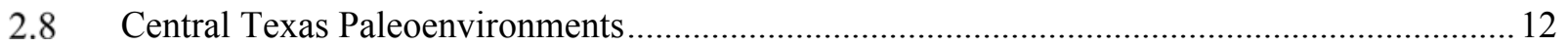

3.0 ARCHEOLOGICAL BACKGROUND AND CULTURAL HISTORY .................................... 17

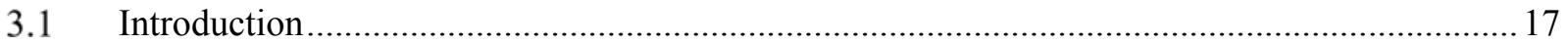

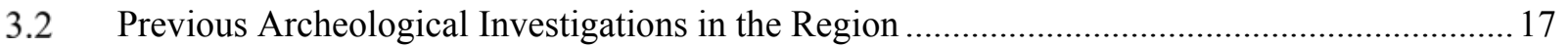

3.3 The Late Archaic Period (400 to 1300 B.P.) in Central Texas ..................................................23

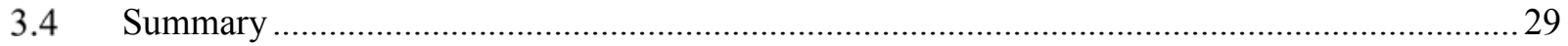

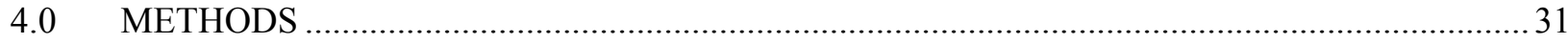

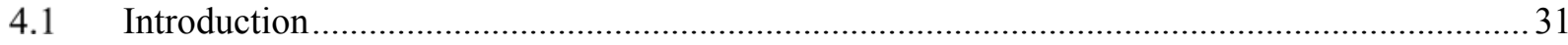

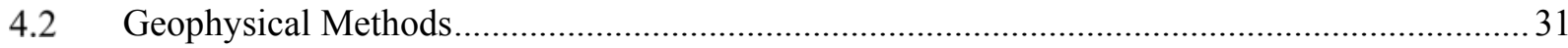

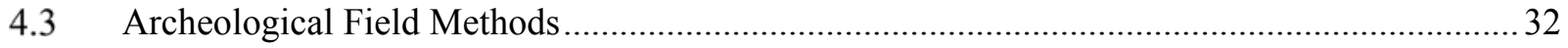

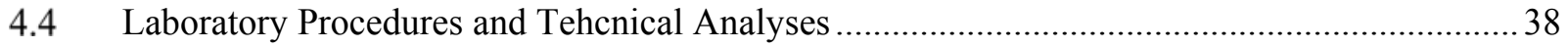

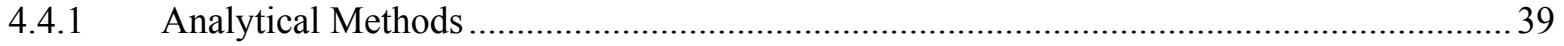

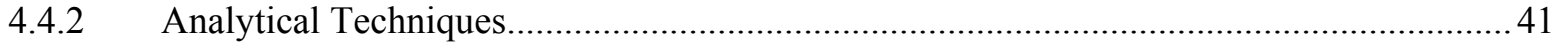

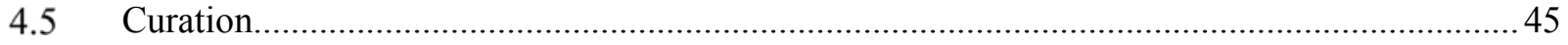




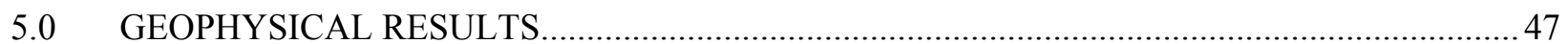

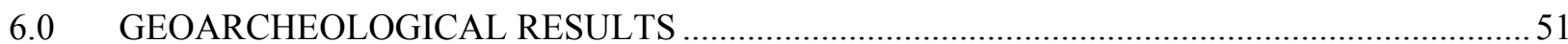

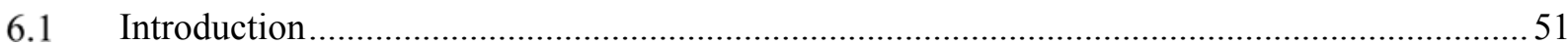

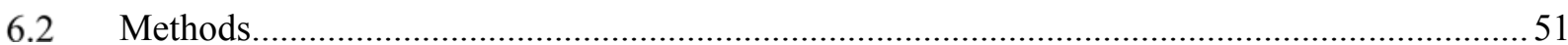

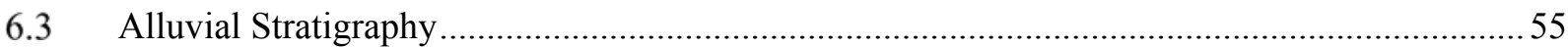

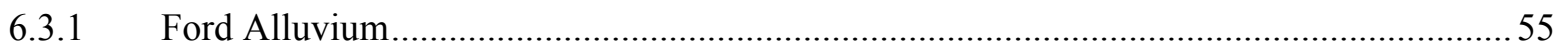

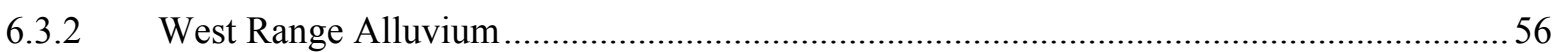

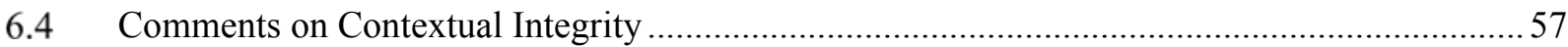

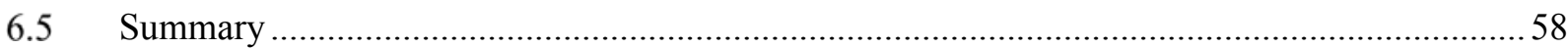

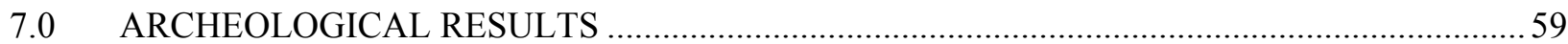

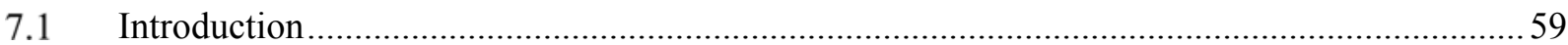

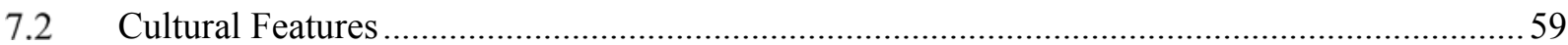

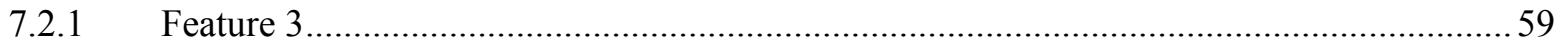

7.2.2 Feature 3A

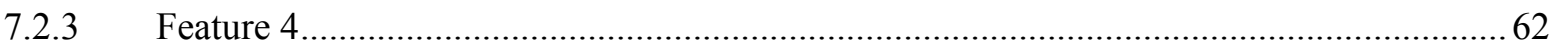

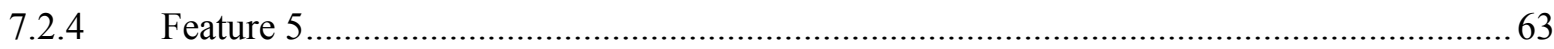

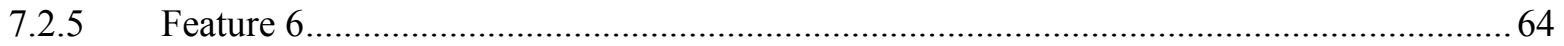

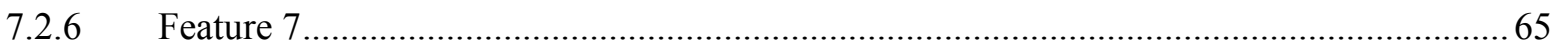

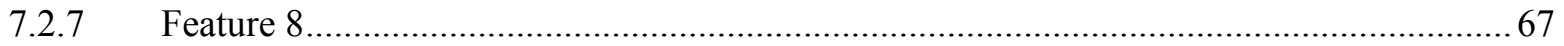

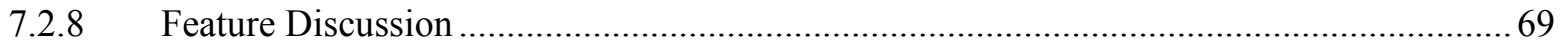

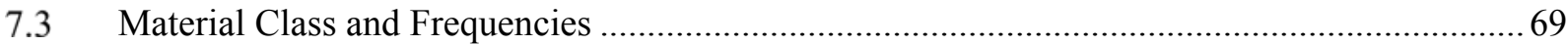

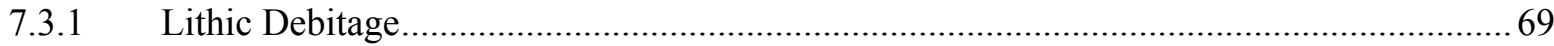

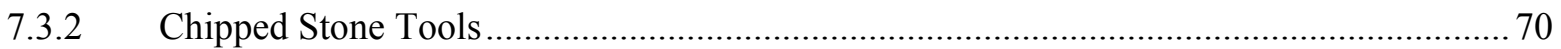

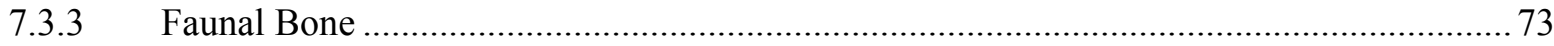

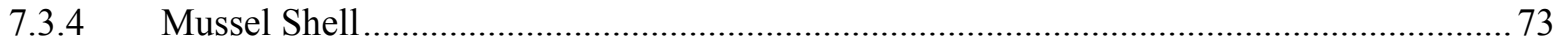

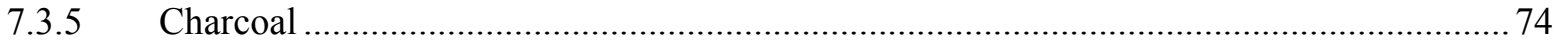

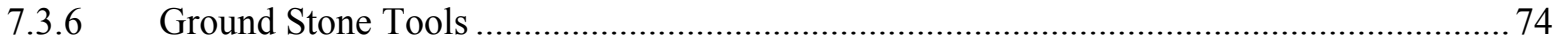

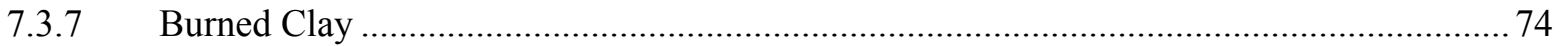

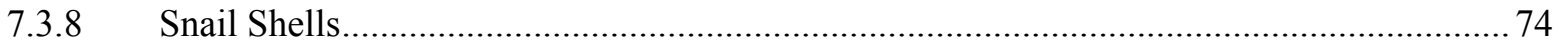

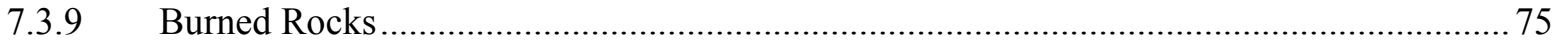

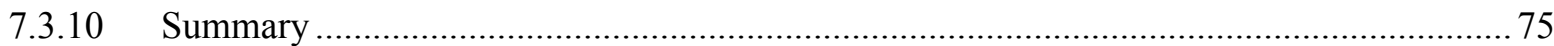

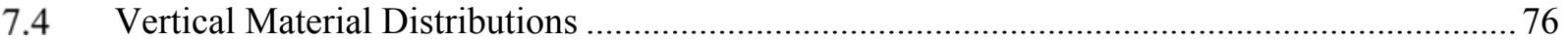

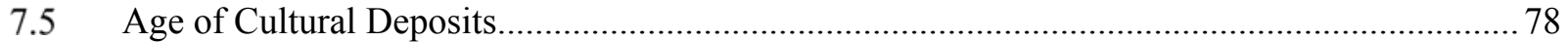

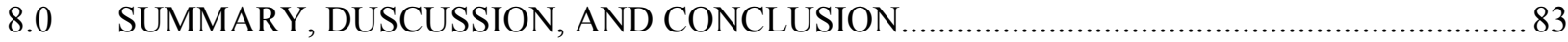

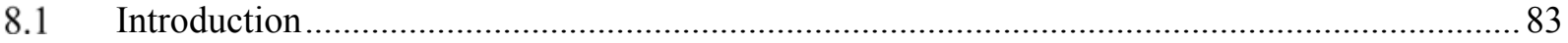




\begin{tabular}{|c|c|}
\hline 8.2 & ummary .......... \\
\hline 8.3 & Dis \\
\hline 8.4 & Conclusions.. \\
\hline & RECOMMENDATIONS . \\
\hline 9.1 & Introduction. \\
\hline 9.2 & Data Recovery Recommendations ............... \\
\hline 0 & DATA RECOVERY PLAN...... \\
\hline 10.1 & Introduction.. \\
\hline 10.2 & Site Function Issues ......... \\
\hline 10.3 & Paleoenvironmental Issues.. \\
\hline 10.4 & Cultural Historic Issues... \\
\hline 10.5 & Subsistence Issues ........ \\
\hline 10.6 & Technology Issues.................... \\
\hline 10.7 & Mobility, Trade, and Interactions Issues.. \\
\hline 10.8 & Field Approach...................... \\
\hline & REFERENCES CITED................. \\
\hline & OSSARY OF TECHNI \\
\hline
\end{tabular}




\section{LIST OF APPENDICIES}

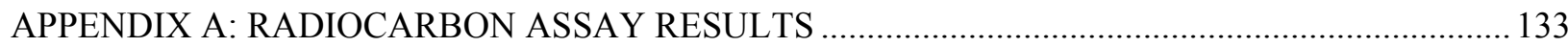

APPENDIX B: ASSESSMENT OF PHYTOLITH PRESERVATION AT 41BL278 ........................... 147

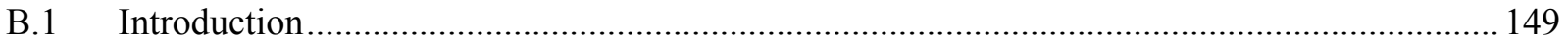

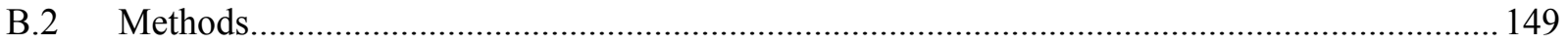

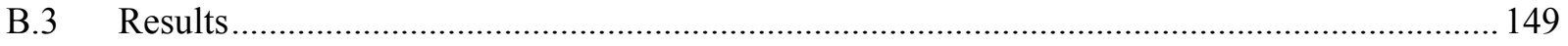

APPENDIX C: GEOPHYSICAL RESULTS FROM 41BL278 IN BELL COUNTY, TEXAS ............. 151

APPENDIX D: PHYTOLITH AND BIOGENIC SILICA ASSESSMENT OF SELECT SEDIMENT

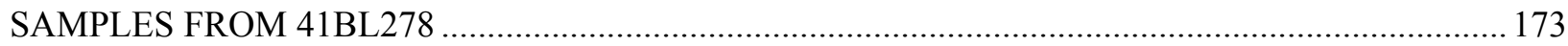

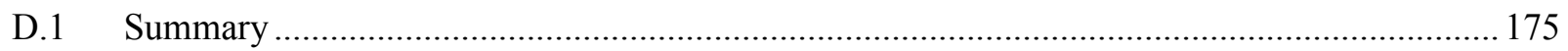

D.2 Introduction to Phytoliths and Biogenic Silica ....................................................................... 175

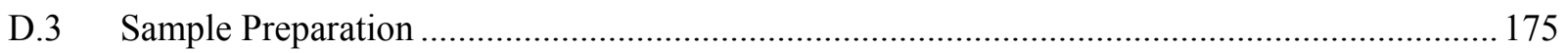

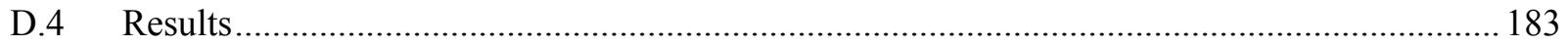

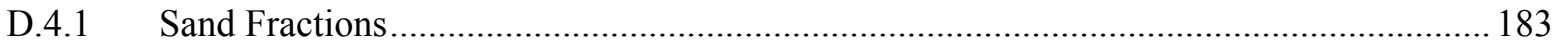

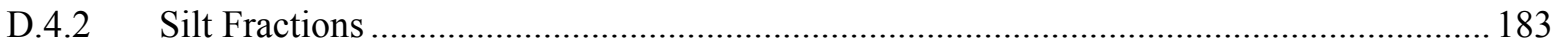

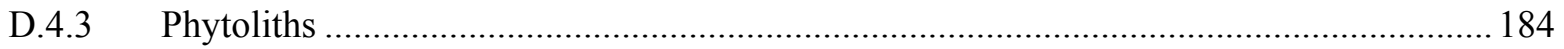

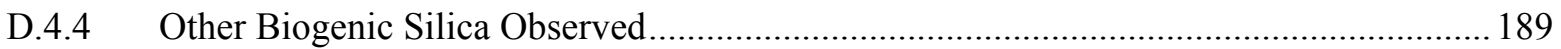

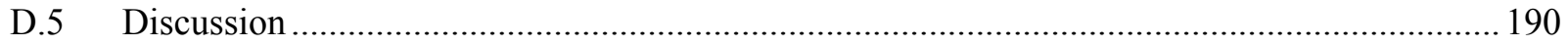

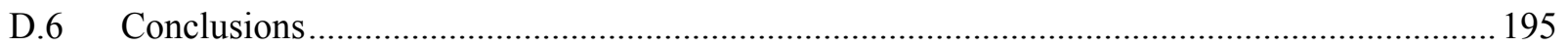

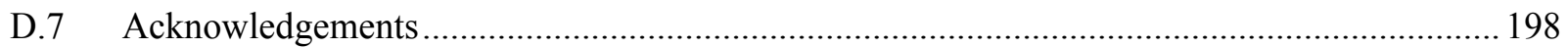

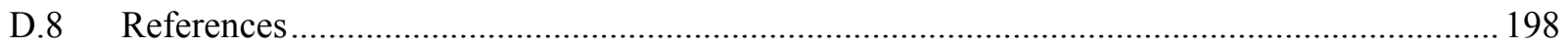

APPENDIX E: STARCH GRAIN ANALYSIS OF 26 SAMPLES FROM 41BL278 .........................201

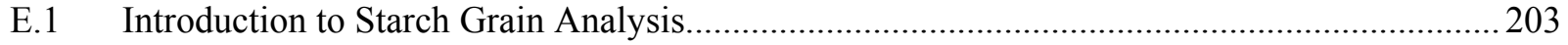

E.2 Understanding the Relationship Between Residues and Artifacts ........................................ 205

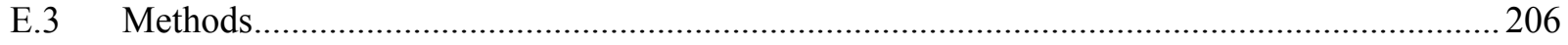

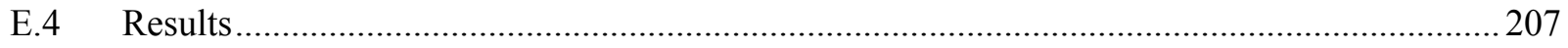

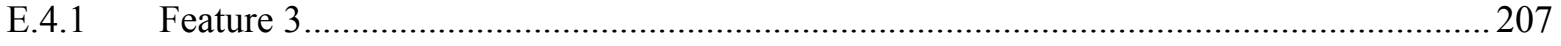

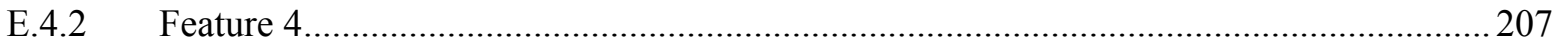

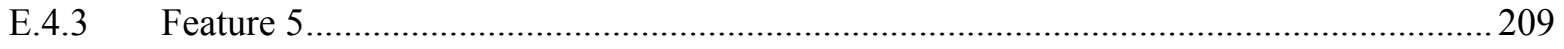

E.4.4 Feature 6

E.4.5 Feature 8

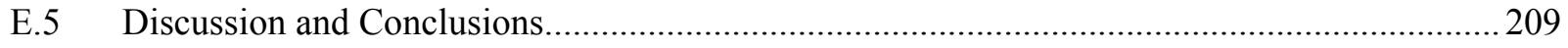

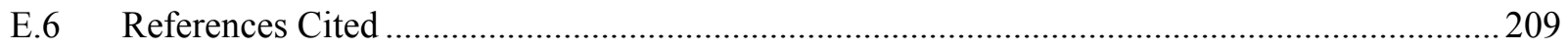




\section{APPENDIX F: ANALYSIS OF THE LIPID COMPOSITIONS OF ARCHEOLOGICAL BURNED}

ROCK RESIDUES FROM SITE 41BL278, CENTRAL TEXAS

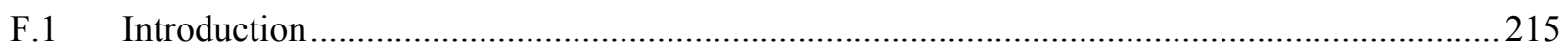

F.2 The Identification of Archeological Residues................................................................. 215

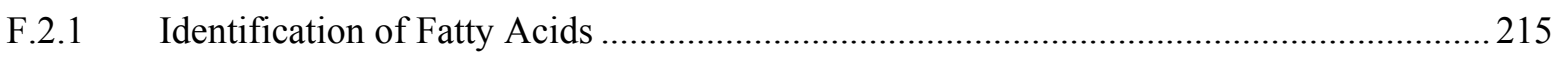

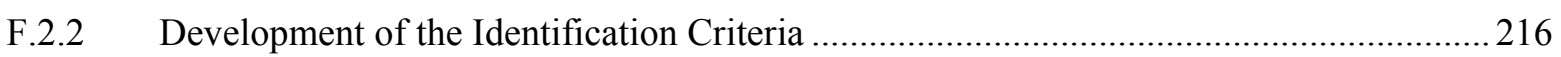

F.3 Using Lipid Distribution and Biomarkers to Identify Archeological Residues ......................2 217

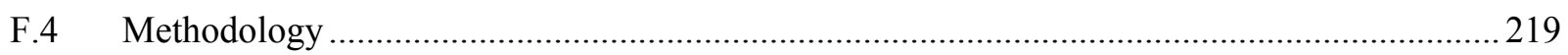

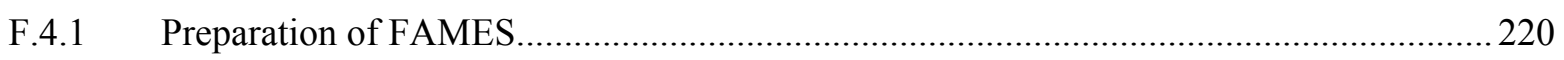

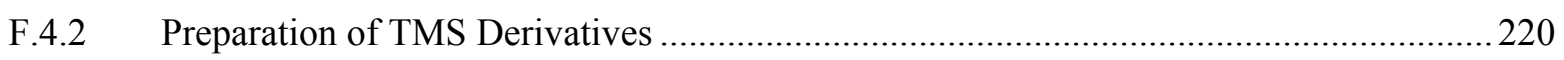

F.4.3 Gas Chromatography Analysis Parameters ................................................................ 221

F.4.4 High Temperature Gas Chromatography and Gas Chromatography with Mass

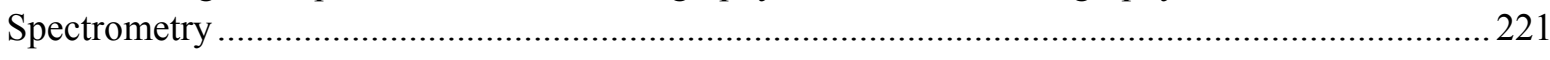

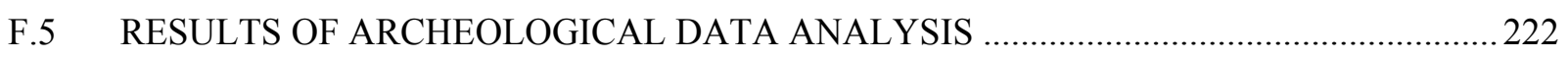

F.5.1 High Fat Content - Residues with High Levels of C18:1 Isomers ............................... 223

F.5.2 Borderline Moderate-High Fat and High Fat Content ................................................223

F.5.3 Medium Fat Content - Residues with Medium Levels of C18:1 Isomers ....................... 223

F.5.4 High Levels of C18:0 - Large Herbivore .............................................................. 226

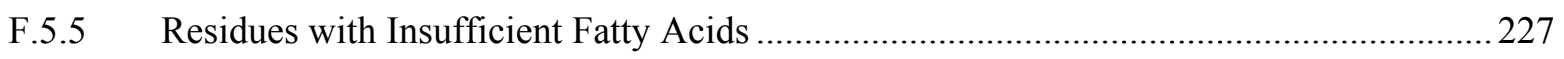

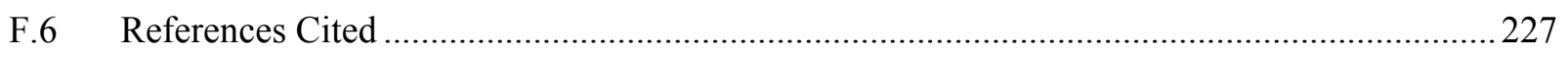

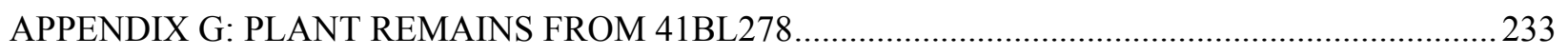

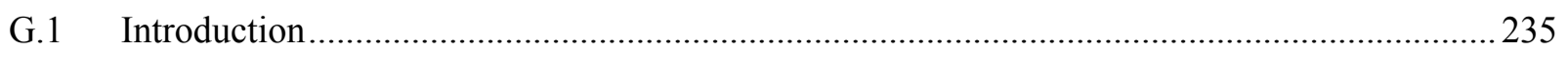

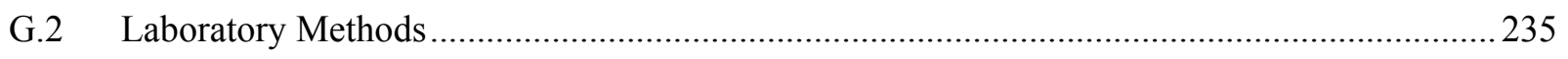

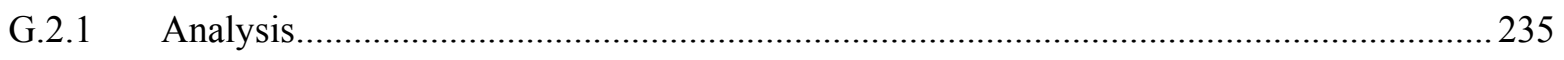

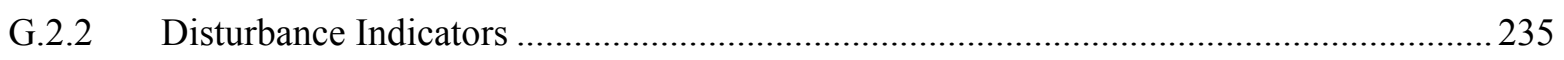

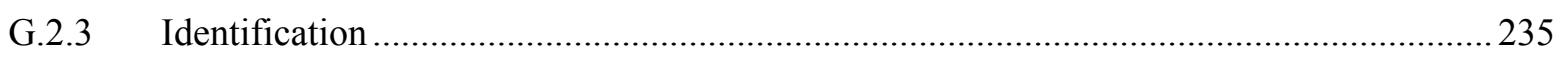

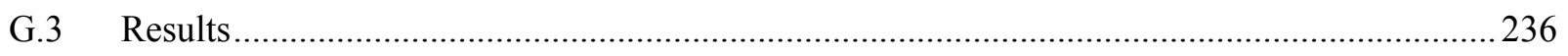

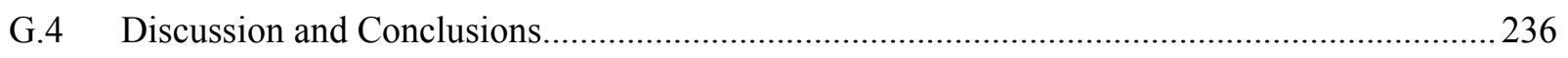

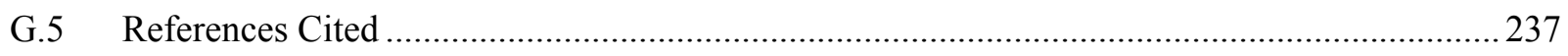

APPENDIX H: RESIDUE AND USE-WEAR ANALYSIS OF STONE ARTIFACTS FROM SITE

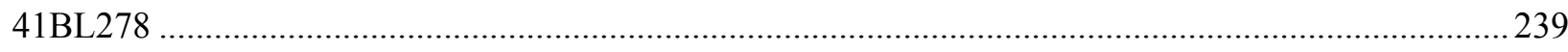

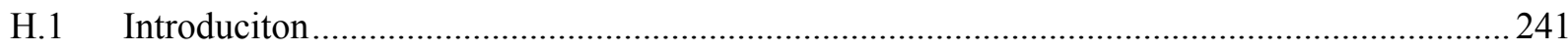

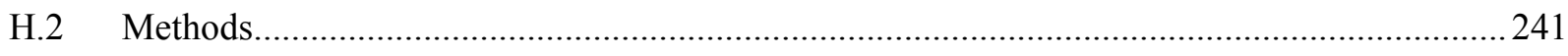

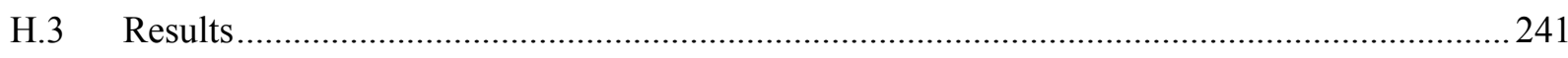

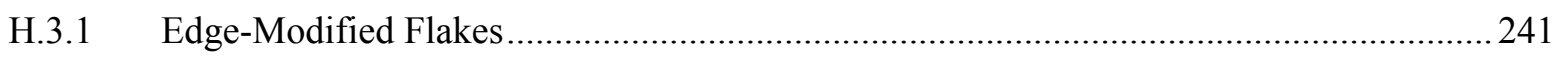




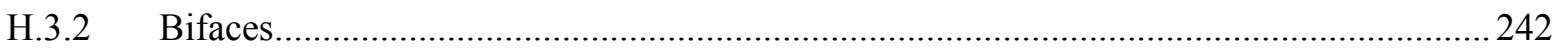

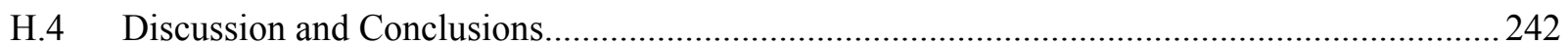

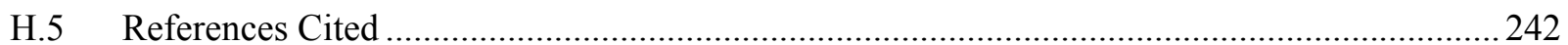
APPENDIX I: VERTICAL DISTRIBUTION OF ARTIFACTS RECOVERED DURING TESTING AT 41BL278, BELL COUNTY, TEXAS ...................................................................................... 249 


\section{LIST OF FIGURES}

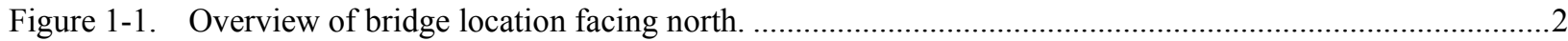

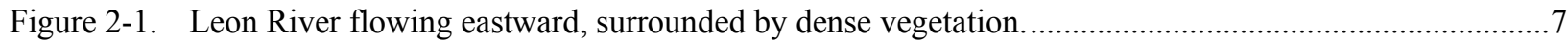

Figure 2-2. Regional average temperature for Bell County, Texas.......................................................................

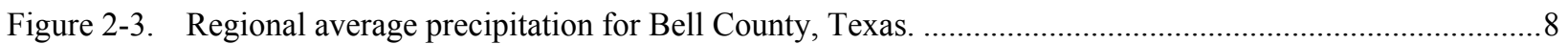

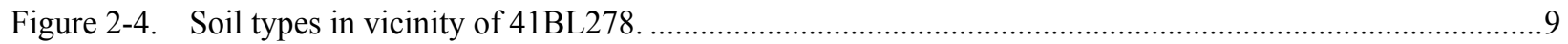

Figure 2-5. Pecan orchard on $\mathrm{T}_{1}$ terrace east of APE across 41BL278 (view east). ..............................................10

Figure 2-6. Examples of bulbs and tubers (bittertoot, biscuitroot, sego lily, and prairie onion), photography by M. Quigg.

Figure 2-7. Diverse water resources were likely utilized by prehistoric populations (photograph by M. Quigg).

Figure 2-8. Comparison of a few selected interpretations of changing environments in central Texas using

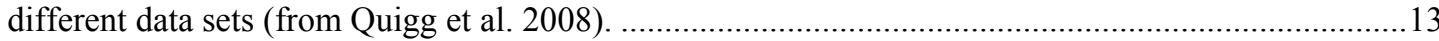

Figure 3-1. Central Texas chronology (adapted from Collins 2004:113, Figure 3.9a)........................................17

Figure 3-2. Comparisons of the old (Prewitt 1981) and new central Texas chronologies (Collins 2004)...............24

Figure 3-3. Selected Late Archaic sites in the vicinity of 41BL278 ...................................................................25

Figure 4-1. Electrical resistivity equipment employed in the geophysical study..................................................31

Figure 4-2. Setting resistivity probes at $1 \mathrm{~m}$ intervals in APE.

Figure 4-3. Numbered lines of resistivity and locations of anomalies across APE..............................................33

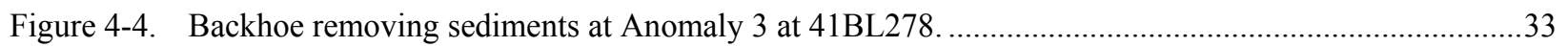

Figure 4-5. Plan map of APE at 41BL278 showing locations of backhoe trenches and hand-excavated units. ........34

Figure 4-6. Hand-excavation in test units at bottom of Backhoe Trench 14 .........................................................35

Figure 4-7. Overview of APE, with Backhoe Trench 12 in foreground, and Backhoe Trenches 8 and 13 in

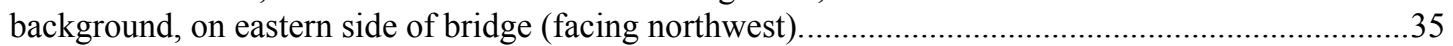

Figure 4-8. Backhoe Trench 11 and Test Unit 3 at Anomaly 1 filled with rainwater.............................................36

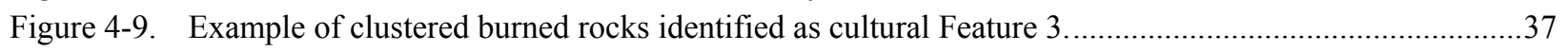

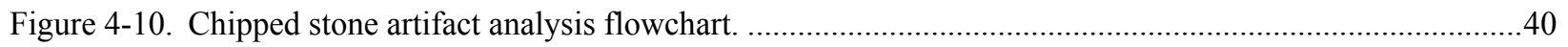

Figure 4-11. Examples of starch grains of wildrye grass recovered from burned rocks at archeological sites in Texas (photograph by L. Perry). .................................................................................................4

Figure 4-12. Technical equipment used in the lipid analysis (photograph provided by Dr. Malainey).....................45

Figure 5-1. Geophysical scan of Line 3 showing Anomaly 1 in lower panel on right.........................................48

Figure 5-2. Geophysical scan of Line 8 showing Anomaly 3 in lower panel on right..........................................49

Figure 5-3. Backhoe Trench 12 with rain water and one of the two large rocks thought to represent

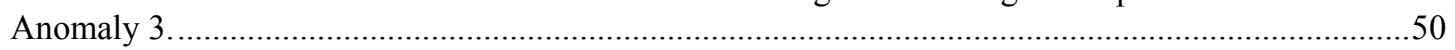

Figure 6-1. Schematic crossection of alluvial terrace sequence in TxDOT APE at 41BL278_...............................52

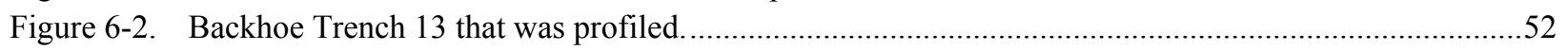

Figure 6-3. Profile of Bk horizon in Backhoe Trench 9 with cultural component visible near bottom...................56

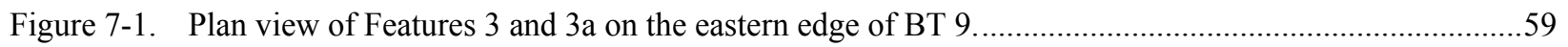

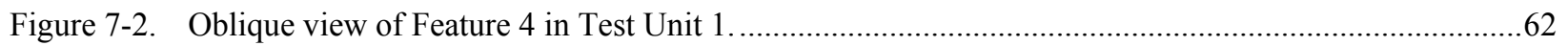

Figure 7-3. Plan View of Feature 4 in Test Unit 1 on eastern edge of Backhoe Trench 8.....................................63

Figure 7-4. Profile through the middle of Feature 5 in Test Unit 4. ......................................................................64

Figure 7-5. Plan view of Features 5 and 6 in Test Unit 4. .............................................................................64

Figure 7-6. Plan view of Features 7 and 8 in Test Units 6 and 7 on eastern side of Backhoe Trench 9.................65

Figure 7-7. Photograph of Features 7 and 8 in Test Units 6 and 7 on eastern side of Backhoe Trench 9...............66

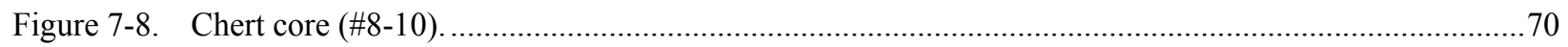

Figure 7-9. Unwashed biface (\#37-10) from $110 \mathrm{cmbs}$ in east wall of Backhoe Trench 14.................................72

Figure 7-10. Unwashed biface/preform (\#31-10) from $164 \mathrm{cmbs}$ in Test Unit 7 ...................................................72

Figure 7-11. Unwashed medial biface fragment (\#505-10) from $154 \mathrm{cmbs}$ in Feature 5 in Test Unit 4 ..................72 
Figure 7-12. Edge-modified flakes. Top left is \#25-10, top right is \#506-1, bottom left is \#40-1, bottom right is \#14-1.

Figure 7-13. The medial section of a beaver femur (\#10-2) from Test Unit 2 that was radiocarbon dated...............73

Figure 7-14. Examples of mussel shell types and conditions. .....................................................................74

Figure 7-15. Unit profile that exhibits cultural materials in massive Bk soil horizon. .......................................77

Figure 7-16. Vertical patterning of plotted materials across six excavation units. .............................................78

Figure 7-17. Graph of the radiocarbon dates obtained from APE in 41BL278. ...............................................80

Figure 10-1. Plan map of proposed location of data recovery excavation blocks.............................................96

Figure D-1. Oven dried soil samples before disaggregation (41BL278). A = Sample 6; B = Sample 7; C = Sample 8; and D = Sample 9 (Sample identities in Table D-1)....

Figure D- 2. Isolated sand fractions (41BL278). $\mathrm{A}=$ Sample 6; $\mathrm{B}=$ Sample 7; $\mathrm{C}=$ Sample 8; and D = Sample 9 (sample identities in Table D-1). [Jar internal diameters are 2.2 inches. The domed glass bottoms show in the center of the jars. The faint yellow marks in $\mathrm{C}$ and $\mathrm{D}$ are reflection of the camera flash.].

Figure D-3. Carbonates, snails, charcoal, and other particles present in the sand fractions (41BL278). A= Sample 6; B = Sample 7; C = Sample 8; and D = Sample 9 (Sample identities in Table D-1). Bar scales $1 \mathrm{~mm}$. .

Figure D- 4. Debris observed in the 41BL278 sand fractions (charcoal, bone, burned shell, and lithics). A = charcoal; B-D = bone, E-F = burned shell, and G-I = lithic material. Sample $6=\mathrm{A}-\mathrm{C}$; Sample $7=$ D-H; and Sample $9=$ I (Sample identities in Table D-1). Bar scales are $1 \mathrm{~mm}$.

Figure D-5. Snails recovered from the 41BL278 sand fractions shown in Figure D-2. A-D = Sample 6; E= Sample 7; F-H = Sample 8 [specimen F is visible in Figure D-2C at $\sim 1: 30$ near the jar wall; specimen $\mathrm{G}$ is also illustrated in Figure D-3C, bottom right corner], and I-K = Sample 9 (Sample identities in Table D-1). Bar scales are $1 \mathrm{~mm}$.

Figure D - 6. Silt sample fractions after clay known to be removal (41BL278). The top gray layer is due to the presence of residual water. The lower gray layer is quartz silt, and intermediate lighter layer is carbonate. $\mathrm{A}=$ Sample 6; $\mathrm{B}=$ Sample 7; $\mathrm{C}=$ Sample 8; and $\mathrm{D}=$ Sample 9 (sample identities in Table D-1).

Figure D-7. Carbonate removal from mination performed here, so that phytolith fractions in $8 \mathrm{ml}$ vials (41BL278). Difference may have adversely affected $A=$ dried sample phytolith fractions from the textural determination. Very low flotation. $\mathrm{B}=$ hydrochloric acid added to phytolith concentrations was present. Sample $6 . \mathrm{C}=$ hydrochloric acid added to all samples showing effervescence (sample identities in Table D-1).

Figure D-8. Sedimentation of decanted clay fractions (41BL278). A = Sample 6; B = Sample 9. (Sample identities in Table D-1).

Figure D-9. Short cell Poaceae phytoliths (41BL278). Sample 6= A-C, F, K-S, and Z-CC; Sample $7=$ D-E, G, T; Sample $8=\mathrm{H}$, and U-V; and Sample $9=\mathrm{I}-\mathrm{J}$ and W-Y. Pooids $=$ A-J; Panicoids $=\mathrm{K}-\mathrm{Y}$; Chloridoids $=A A-C C$. Image $Z$ is an Aristida lobate specimen. Images E, J, M, N, Q, R, V, $\mathrm{W}, \mathrm{Z}$, and $\mathrm{BB}$ show damage that appears to be from particle dissolution rather than from mechanical damage/breakage (sample identities in Table D-1). Bar scales are 10 microns.

Figure D-10. Chemical weathering of bulliform and elongate phytoliths (41BL278). A = Sample 6; B-D = Sample 7; E-L = Sample 8, and M-P = Sample 9 (Sample identities in Table D-1). Bar scales are 50 microns.

Figure D-11. Tree-related phytoliths (41BL278). Sample 6= A, B, E-M; Sample $7=$ C, N-P; Sample 8= D, Q; and Sample $9=\mathrm{R}$ (Sample identities in Table D-1). Bar scales as marked.

Figure D-12. Burned irregular "sheets" of amorphous silica (41BL278). Sample $6=$ A-E; Sample $7=$ F; and Sample $8=\mathrm{G}$ (Sample identities in Table D-1). Bar scales are 50 microns.

Figure D-13.Burned fused phytoliths (41BL278). The same amorphous silica specimen is illustrated in A and A', and appears likely to be comprised of elongate cell phytoliths. The difference between the two images is the focal plane of the microscope [A is focused on the bottom surface of the tabular particle, and $\mathrm{A}^{\prime}$ is focused on the top surface. Amorphous silica particles are clear--which is why one can view both sides of the particle; however, burning has darkened this particle]. (The specimen in $\mathrm{A} / \mathrm{A}^{\prime}$ is from Sample 9; sample identity is in Table D-1). 
Figure D-14. Unidentified phytolith forms observed in these samples (41BL278). Images A-P = Sample 6; images Q-T = Sample 7; images $\mathrm{U}-\mathrm{X}=$ Sample 8; and images Y-BB = Sample 9 (Sample identities in Table D-1). Bar scales are 25 microns.

Figure D-15. Sample 6 spicules (41BL278). The upper right specimen in B is a phytolith of similar size to the spicule that is pictured (Sample identities in Table D-1). Bar scales are 50 microns.

Figure D-16. Sample 7 and 8 spicules and similar particles (41BL278). A-E = Sample 7, F-J = Sample 8 (sample identities in Table D-1). All scale bars are 50 microns except for A which is 125 microns. Specimen $\mathrm{J}$ may not be a spicule; the identity of $\mathrm{C}$ and $\mathrm{I}$ is uncertain.

Figure D-17. Sample 9 spicules (41BL278) (Sample identities in Table D-1). Bar scale in B is 125 microns long [spicule photographed at 200x]; all other bar scales are 50 microns [spicules photographed at 500x]

Figure E-1. Starch grains recovered from 41BL278. The scale bar is 20 microns in length, and all photos are at equivalent size. $\mathrm{A}=$ a starch grain from a member of the Lily family from burned rock \#502-31a, Feature 3. B = a starch grain from a grass in the Triticeae from burned rock \#502-3-1a, Feature 3. $\mathrm{C}=$ a gelatinized starch mass from burned rock \#504-3-4, Feature 4.

Figure H-1. Visual summary of results........................................................................................245

Figure H-2. Specimen \#40-10, A) soft polish; B) photomosaic of feather barbule fragments.............................246

Figure H-3. Specimen \#31-10, A) collagen fragment; B) soft polish; C) striations parallel to long axis; D) plant fragments and bright polish related to haft. 


\section{LIST OF TABLES}

Table 1-1. Column Data off Backhoe Trenches from Ringstaff (2004)...........................................................

Table 3-1. Selected Intensively Investigated Sites in Bell and Adjacent Coryell and Williamson Counties. .........20

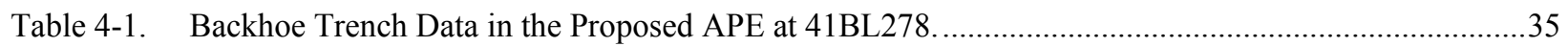

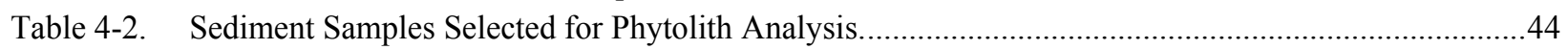

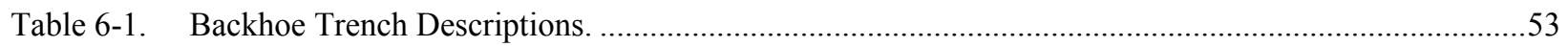

Table 7-1. Material Results from Heavy Fractions from Flotation of Sediments from Feature and Nonfeature

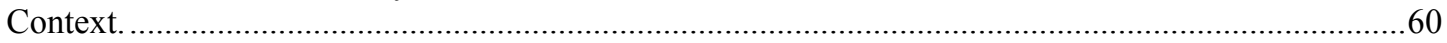

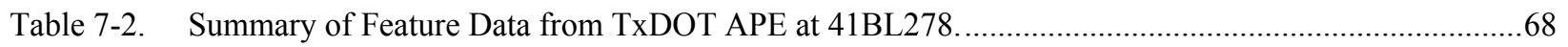

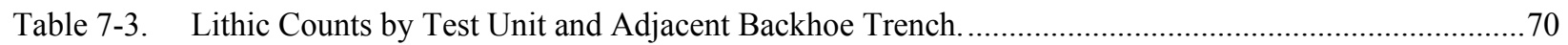

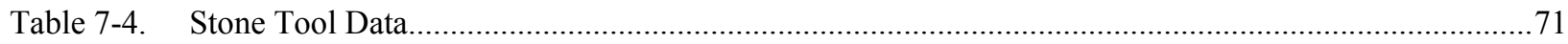

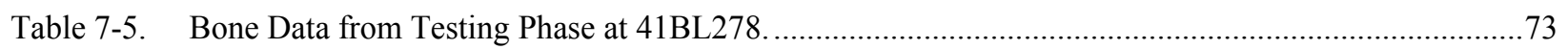

Table 7-6. Dering's Charcoal Identifications from Excavations at 41BL278 (see Appendix G). .........................75

Table 7-7. Burned Rock Counts and Weights by Test Unit and Adjacent Backhoe Trench. .................................75

Table 7-8. Cultural Material Summary by Unit for the Testing Phase. ..................................................................76

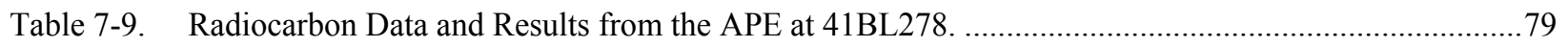

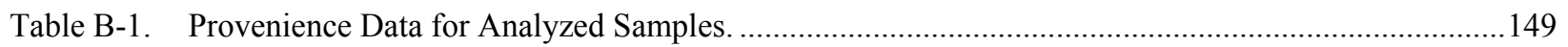

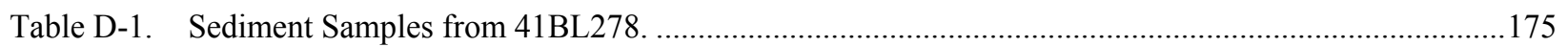

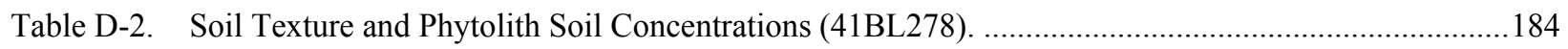

Table D-3. ca. 5100 B.P. Occupational Level Soil Phytolith Concentrations. .......................................................195

Table D-4. Site Soil Types and Carbonate Content (via USDA OSDs)..............................................................196

Table D-5. Biogenic Silica and Snail Frequency and Preservation at Study Sites. ..............................................197

Table E-1. Starch Grains Recovered from Site 41BL278. .............................................................................208

Table F-1. Summary of Average Fatty Acid Compositions of Modern Food Groups Generated by

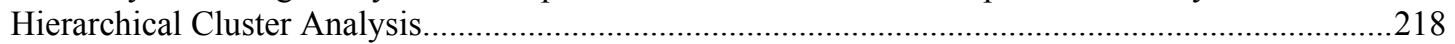

Table F-2. Criteria for the Identification of Archeological Residues Based on the Decomposition Patterns of Experimental Cooking Residues Prepared in Pottery Vessels. .........................................................219

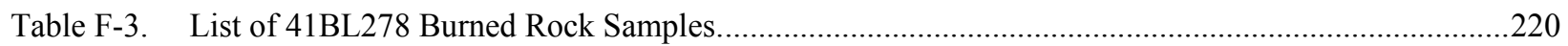

Table F-4. Known Food Sources for Different Types of Decomposed Residues................................................222

Table F-5. Lipid Compositions and Identifications of Residues from Site 41BL278........................................224

Table F-5. Lipid Compositions and Identifications of Residues from Site 41BL278 (continued). ......................225

Table F-6. Biomarker and TAG Distributions of Lipid Residues with Insufficient Fatty Acids..........................226

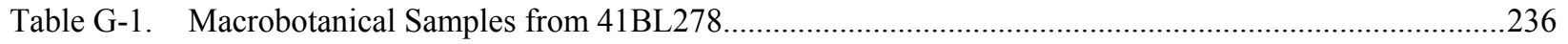

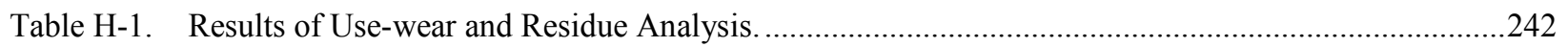

Table I-1. Vertical Provenience of Artifacts by Class and Test Unit...................................................................251 


\section{ACKNOWLEDGEMENTS}

Over the years many individuals from the TxDOT staff in the Environmental Affairs Division aided in the completion of the fieldwork, interim report, subsequent data analyses, and completion of this technical report. In 2004 Dr. Owen Lindauer was the Supervisor of the Archeological Studies Program and Mr. Jon Budd was and still is the TxDOT district archeologist, both of whom provided information and direction in getting Work Authorization 57-313SA006 in place for the 2004 fieldwork and subsequent interim report concerning the findings and recommendations. Thank you both for your efforts. Prior to actual fieldwork Dr. Lindauer and Mr. Budd accompanied Mr. Quigg of TRC Environmental Corporation (TRC) on a visit to site 41BL278 to observe first-hand and devise a strategy to assess the site. Subsequently in 2013 Dr. Scott Pletka, Supervisor of the Archeological Studies Program, managed the final Work Authorization 57-306SA004 under General Service Contract No. 57-3XXSA004 directed towards finalizing this project with the completion of the draft and final technical reports. Thank you Dr. Pletka for your direction in completing this project. Dr. James Abbott, TxDOT geoarcheologist, was instrumental in providing direction to and overseeing the multiple requests for and facilitating the submission of radiocarbon samples to the laboratories for dating provided by TxDOT. Coordination of the field activities and scheduling the backhoe was done with the aid of TxDOT Environmental Specialist Kerri Brown and Mike Roads from the TxDOT Waco District office.

The Antiquity Code of Texas permit application was completed by Principal Investigator J. Michael Quigg and submitted to the State, then to the Texas Historical Commission to conduct the field investigations. The TRC archeological staff is thanked for their excellent field energy in face extremely wet and sloppy conditions that made it difficult to excavate and screen the wet silty clay and even stand around the exposed trenches. The field crew was directed by J. M. Quigg, assisted by Jeffrey D. Owens and Senior Crew Chief Mercedes Cody, with field archeologists Charles Burton and Carl Welch. The geophysical investigations were conducted by Melanie Crisp, at the time a TRC geophysical scientist and geologist with the assistance of Shane Pritchard and Mike Quigg. Backhoe services were provided by independent contractor, Spangler Backhoe Service.

The 2004 laboratory procedures of washing, sorting, cataloging and database establishment were conducted by Laboratory Supervisor Ms. Cody. She was also instrumental in organization and preparation of the initial phytolith, charcoal, and radiocarbon samples submitted to outside laboratories, plus production of tables and feature drawings used in the interim and final reports. Thank you Mercedes for your organization and hard work in handling the many diverse tasks asked of you.

In 2013, 2014, and 2015 most laboratory tasks were conducted by Trisha-Ann Gonzales and Shannon Gray, TRC Laboratory Director. They proofed and fixed errors in the electronic database, and provided quality assessment and control over the field records and materials during various analyses. Shannon also completed figures, tables, and technical editing tasks of sections and chapters, and helped in many different ways. Thank you Shannon for your management of the database, table and figure creations, plus your editing skills. Trisha organized the multiple samples for technical analyses, crosschecked the database and shipped multiple samples to outside laboratories. Trisha also spent considerable time fixing database errors, and preparing the collections for curation. She also completed the tables in Appendix I. Meghan Bruckse picked the heavy fractions from the flotation results, and completed the appropriate 
forms. Ashleigh Knapp formatted, edited sections, produced the draft and final documents, and submitted final reports to institutions.

Dr. Charles Frederick of Dublin, Texas conducted the geoarcheological field investigations in wet and sloppy conditions. He provided advice and discussed the stratigraphy with me during the fieldwork. He also authored the geoarcheological chapter in this report and produced the figures and tables therein.

Dr. Linda Perry, Executive Director of The Foundation for Archaeobotanical Research in Microfossils, conducted the starch grain assessment on the initial suite of 10 samples for the interim report in 2004 and the subsequent detailed analysis on a suite of 26 burned rocks, artifacts, and sediment samples for this technical report (Appendix E). Thank you Linda for your scientific approach to handling the artifacts, your attention to detail, and continuous communication and interest in working with us on diverse and multiple artifact classes.
Dr. Phil Dering provided identifications of nine charcoal samples back in 2004 (Appendix G). He also performed the macrobotanical analysis on a selected suite of light fractions from the feature samples. Dr. Mary Malainey assisted by Timothy Figol provided lipid residue analysis on 18 burned rocks and wrote the technical report on the methods and results presented in Appendix F. Dr. Bruce Hardy conducted use-wear and residue analysis on a selected suite of chipped stone tools and wrote the technical report in Appendix H. Dr. Steven Bozarth performed the initial presence/absence for phytoliths on four samples for the interim report in 2004 (Appendix B). Dr. Byron Sudbury performed the full phytolith analysis on four samples and wrote the methods and results presented in Appendix D.

Thank you all for helping preserve part of Texas prehistory and contributing to a greater understanding of the past. Although the field effort was limited, the analyses provided important building blocks from which others may expand upon. Any problems in the presentation or errors in content are the responsibility of the project manager.

Mike Quigg

Project Manager 


\subsection{INTRODUCTION}

\section{J. Michael Quigg}

\subsection{INTRODUCTION}

This report describes the results of an archeological testing/evaluation program implemented at a portion of buried prehistoric site 41BL278 within the existing and proposed new right-of-way of State Highway (SH) 317 (CSJ:0396-04-059) where it crosses the Leon River in Bell County, Texas. The Texas Department of Transportation (TxDOT) is proposing to replace and expand the existing bridge over the Leon River (Figure 1-1). Previous cultural resource investigations conducted in the area of potential effect (APE) determined that buried cultural resources were present in the Holocene terrace deposits on the southern side of the Leon River that would be impacted by TxDOT's proposed undertaking (Ringstaff 2004). These buried cultural deposits have the potential to contribute to hunter-gather settlement patterns and subsistence knowledge in the region. The site was considered potentially eligible for listing on the National Register of Historic Places (NRHP) and as a State Antiquities Landmark (SAL), and recommended for further archeological assessment (Ringstaff 2004). The Texas Historical Commission (THC) concurred that site 41BL278 was potentially eligible for listing on the NRHP and as a SAL; and therefore, an evaluation program was initiated prior to any development.

Archeological testing/assessment of the portion of site 41BL278 within the proposed APE was conducted in 2004 to evaluate the eligibility per the requirements of Sections 106 and 110 of the National Historic Preservation Act (NHPA) and other related legislation. This assessment was conducted by archeologists from the Cultural Resources Section of the Planning, Permitting, and Licensing Practice of TRC Environmental
Corporation (TRC) Austin office under a TxDOT Scientific Services Contract No. 573XXSA006 (Work Authorization No. 57313SA006), and Texas Antiquities Committee Permit No. 3446 issued to J. Michael Quigg by the THC.. The analysis and reporting were conducted under Contract No. 573XXSA004 (Work Authorization 57-306SA004).

\subsection{GENERAL PROJECT LOCATION}

The TxDOT proposed project lies in central Texas at the eastern edge of the Balcones Escarpment and the eastern edge of the Lampasas Cut Plain physiographic provinces, with the Blackland Prairie just to the east. The project is one kilometer $(\mathrm{km})$ north of the City of Belton in Bell County, Texas, along SH 317 where it crosses the Leon River just downstream from Belton Reservoir. Cultural materials at the northwestern end of prehistoric site 41BL278 and within the APE are buried in a low alluvial terrace $\left(T_{1}\right)$ along the southern side (right bank) of the Leon River. The alluvial valley deposits are surrounded by limestone uplands composed of very shallow loamy to clayey soil over limestone bedrock. The regional topography is gently sloping to undulating with numerous rivers dissecting the region, flowing generally to the east and southeast.

\subsection{SITE BACKGROUND}

Site 41BL278 was originally recorded in 1984 (Texas Archeological Research Laboratory [TARL] files). The site form at TARL indicates that a deer bone and a flake were observed on the surface of a prominent levee along the south bank of the Leon River roughly 50 meters (m) southeast of the SH 317 bridge over the Leon River. The levee was covered with Bermuda grass (Cynodon dactylon). Although subsurface investigations were not conducted, the recorders speculated that the levee had been occupied in prehistoric times, and estimated site size was $20 \mathrm{~m}$ wide by $600 \mathrm{~m}$ long and generally parallels the river. 


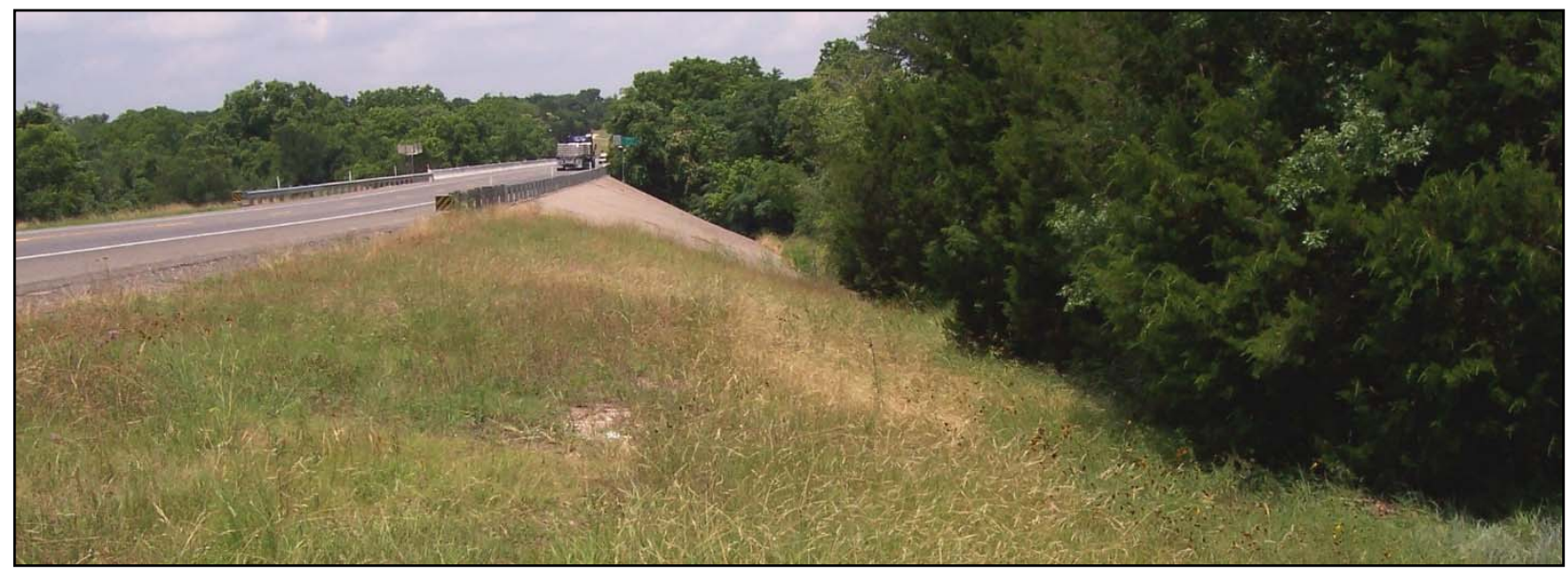

Figure 1-1. Overview of bridge location facing north.

In January 2004, archeologists from Blanton \& Associates, Inc., under contract with TxDOT, conducted an intensive cultural resource survey along roughly $1,800 \mathrm{~m}$ of TxDOT right-of-way where SH 317 crosses the Leon River (Ringstaff 2004). The existing roadway and bridge are about $12 \mathrm{~m}$ wide, and the roadway over the river terraces is elevated 10 to $11 \mathrm{~m}$ above the river terraces, with 12 concrete support pylons, each approximately 1 $\mathrm{m}$ wide, penetrating the alluvial deposits. The 100 percent pedestrian survey by Blanton \& Associates, Inc. archeologists encompassed 8.5 hectares (ha.) or 21.1 acres (ac.) and included the excavation of three shovel tests, ten backhoe trenches (BTs 1 through 10), and hand-excavation of five 25-by-25 centimeters $(\mathrm{cm})$ wide columns on the sides of five trenches.

As a result of this intensive survey, one new prehistoric archeological site, 41BL1218 in the colluvial toeslope and uplands south of the river (classified as an upland lithic procurement locale) was recorded in the proposed new right-of-way (Ringstaff 2004). Also the boundaries of previously recorded site 41BL278, in the river terrace to the southeast, were extended to the northwest to include the newly discovered cultural materials in the APE under the elevated SH 317 bridge. During the survey, significant quantities of coarse- to medium-grained opaque tan chert were observed eroding from bedrock in the project area (Ringstaff 2004).

During the 2004 survey, five backhoe trenches (BTs 4, 7, 8, 9, and 10) were excavated in the alluvial deposits in the first terrace $\left(T_{1}\right)$, on the eastern side of the existing bridge and within the APE. Backhoe Trench 4 was excavated in the $T_{1}$ alluvial deposits along the northwestern margin of the proposed right-of-way. Backhoe Trenches 7, 8, and 9 were excavated in a line along a levee at the front edge of $T_{1}$ terrace. Backhoe Trench 7 was at the eastern edge of the proposed right-of-way; Backhoe Trench 8 was roughly $16 \mathrm{~m}$ west and $4 \mathrm{~m}$ east of the existing overhead bridge, whereas BT 9 was immediately under the overhead bridge. Backhoe Trench 10 was excavated near the middle of the terrace some $5 \mathrm{~m}$ east of the eastern side of the elevated bridge, roughly $8 \mathrm{~m}$ south of BT 8 . Deeply buried cultural materials, between 105 and $170 \mathrm{~cm}$ below surface (bs) were recognized in BTs 4, 7, 8, 9, and 10 (Ringstaff 2004). Each trench profile was described and cultural materials observed were noted (Ringstaff 2004, Appendix B).

Subsequently, hand-excavation and screening of sediment from five 25 -by- $25 \mathrm{~cm}$ columns along the sides of those five trenches yielded cultural 
Table 1-1. Column Data off Backhoe Trenches from Ringstaff (2004).

\begin{tabular}{|c|c|}
\hline \multicolumn{2}{|c|}{ Backhoe Trench Column No. 4 } \\
\hline Depth (cmbs) & Material \\
\hline $0-20$ & None \\
\hline $20-40$ & None \\
\hline $40-60$ & None \\
\hline $60-80$ & None \\
\hline $80-100$ & None \\
\hline $100-120$ & None \\
\hline $120-140$ & Mussel Shells \\
\hline $140-150$ & Mussel Shells \\
\hline
\end{tabular}

\begin{tabular}{|c|c|}
\hline \multicolumn{2}{|c|}{ Backhoe Trench Column No. 7 } \\
\hline Depth (cmbs) & Material \\
\hline $0-20$ & None \\
\hline $20-40$ & None \\
\hline $40-60$ & None \\
\hline $60-80$ & None \\
\hline $80-100$ & None \\
\hline $100-120$ & None \\
\hline $120-140$ & 3 burned rocks \\
\hline $140-150$ & None \\
\hline
\end{tabular}

\begin{tabular}{|c|c|}
\hline \multicolumn{2}{|c|}{ Backhoe Trench Column No. 8 } \\
\hline Depth (cmbs) & Material \\
\hline $0-20$ & None \\
\hline $20-40$ & None \\
\hline $40-60$ & None \\
\hline $60-80$ & None \\
\hline $80-100$ & None \\
\hline $100-120$ & None \\
\hline $120-140$ & 1 mussel shell \\
\hline $140-150$ & None \\
\hline
\end{tabular}

\begin{tabular}{|c|c|}
\hline \multicolumn{2}{|c|}{ Backhoe Trench Column No. 9 } \\
\hline Depth (cmbs) & Material \\
\hline $0-20$ & None \\
\hline $20-40$ & None \\
\hline $40-60$ & None \\
\hline $60-80$ & None \\
\hline $80-100$ & None \\
\hline $100-120$ & 1 mussel shell \\
\hline $120-140$ & 1 burned rock \\
\hline $140-160$ & None \\
\hline
\end{tabular}

\begin{tabular}{|c|c|}
\hline \multicolumn{2}{|c|}{ Backhoe Trench Column No. $\mathbf{1 0}$} \\
\hline Depth (cmbs) & Material \\
\hline $0-20$ & None \\
\hline $20-40$ & None \\
\hline $40-60$ & None \\
\hline $60-80$ & None \\
\hline $80-100$ & None \\
\hline $100-120$ & None \\
\hline $120-140$ & None \\
\hline $140-180$ & 1 burned rock \\
\hline
\end{tabular}

materials from site 41BL278 (Table 1-1). The columns yielded buried cultural remains that included burned rocks, mussel shells, and chert flakes between 100 and 150 cmbs. The column excavations encountered three burned rock concentrations, which were designated as Features 1 through 3 . These features were not excavated at that time; rather, they were preserved intact and covered with backfill from the excavations and marked with flagging tape (Ringstaff 2004).

Feature 1 was encountered in the northern end of BT 7 at a depth of about $105 \mathrm{cmbs}$ (Ringstaff 2004, Appendix C). The feature was initially observed as a large piece of tabular limestone about $60 \mathrm{~cm}$ long,
$35 \mathrm{~cm}$ wide, and $20 \mathrm{~cm}$ thick, that weighed 90 kilograms $(\mathrm{kg})$. Beneath this natural-appearing rock was a cluster of 9 burned rocks and 14 whole and fragmented mussel shells. The feature extended across the entire $1.8 \mathrm{~m}$ wide trench. Beneath the burned rocks was a patch of burned clay that extended over a $30 \mathrm{~cm}$ diameter area. Feature 1 extended from about 105 to $155 \mathrm{cmbs}$. A carbon sample from the burned clay at about $140 \mathrm{cmbs}$ yielded a $\delta 13 \mathrm{C}(-24.3 \%)$ corrected age of $2490 \pm$ 50 B.P. (UGA-13280) (Ringstaff 2004, Appendix C). No lithic tools were observed, but two pieces of lithic debitage were in the trench wall near the feature. Feature 1 was not excavated but covered in dirt and flagging tape prior to being backfilled. 
Feature 2 was observed in the northern part of BT 8 between about 145 and $170 \mathrm{cmbs}$. It consisted of 16 pieces of tabular limestone and 7 whole and fragmented mussel shells that extended across the entire $1.8 \mathrm{~m}$ wide trench. It measured at least $225 \mathrm{~cm}$ in length along the trench and extended farther east and west. Again Feature 2 was not excavated but covered in dirt and flagging tape before backfilled (Ringstaff 2004, Appendix C).

Feature 3 was detected in the southern part of BT 9 between 125 and $140 \mathrm{cmbs}$. It consisted of a cluster of 12 tabular limestone pieces and 9 whole and fragmented mussel shells. Feature 3 extended across the entire $1.3 \mathrm{~m}$ wide trench and measured about $90 \mathrm{~cm}$ in length. Three pieces of lithic debitage were in association. Feature 3 was also covered in dirt and flagging tape prior to being backfilled (Ringstaff 2004, Appendix C).

Features 1, 2, and 3 were situated within a nearly 70 $\mathrm{cm}$ thick Bkb soil horizon. This sediment was described as brown (10YR 4/3) clay loam with weak to medium prismatic parting to moderate fine angular blocky structure, with 25 percent carbonate filaments (Ringstaff 2004). This Bkb soil horizon reflects similarities to West Range Alluvium, which dates between 4300 and 600 B.P. (Nordt 1992). The upper 75 to $100 \mathrm{~cm}$ of the profile was interpreted to be similar to the Ford Alluvium, which dates within the last ca. 600 years B.P. (Nordt 1992). The deposits extending southward from the levee-like ridge were interpreted as a recently created, broad paleochannel that grades to a gently sloping colluvial surface and eventually into the uplands.

Previously recorded site 41BL278 appeared to extend perpendicular to and through the TxDOT right-of-way and under the elevated two-lane bridge to at least the western margin of the proposed new right-of-way and parallel the river. Therefore, the original estimated boundary of 41LB278 was extended to include the newly discovered cultural materials.
Ringstaff (2004) recommended further archeological testing of that part of site 41BL278 within the APE if that area could not be avoided by planned bridge expansion. TxDOT and the THC concurred with that recommendation. That

determination by THC lead to the subsequent 2004 archeological testing program and NRHP and SAL eligibility assessment presented in this report.

\subsection{REPORT ORGANIZATION}

This report is divided into 12 chapters and 9 appendices. Following this introduction, Chapter 2.0 provides an overview of the environmental setting for this general project area, plus a brief review of the current understanding of the paleoenvironment for the general age of the cultural deposits encountered. Chapter 3.0 provides an archeological background and cultural history focused on the Late Archaic period for the general central Texas region. Chapter 4.0 discusses the field and laboratory methods, and analyses employed by TRC archeologists. The nondestructive geophysical investigation results are presented in Chapter 5.0, which is followed by Chapter 6.0 presenting the geoarcheological information obtained during this assessment phase. The archeological findings and results are presented in Chapter 7.0. A summary of the findings and conclusions are presented at Chapter 8.0. Chapter 9.0 provides TRC's recommendations concerning the cultural materials encountered in the APE at 41BL278 for listing on the NRHP and designation SAL. A proposed preliminary research design and data recovery plan for the proposed data recovery phase, which was written back in 2004 is presented in Chapter 10.0. This is followed by the references cited in Chapter 11.0. A glossary of technical and unusual terms is provided in Chapter 12.0.

Nine appendices provide detailed analytical methods and results from various technical analyses performed on diverse materials from this assessment. Radiocarbon laboratory procedures 
and results from multiple years are provided in Appendix A. This is followed by Dr. Steven Bozarth's 2004 assessment of the presence of phytoliths in four samples in Appendix B Appendix C provides line by line geophysical results from the electronic resistivity investigations conducted by Melanie Crisp in 2004. This is followed by detailed phytolith analysis and interpretations from 2014 provided by Dr. Byron Sudbury in Appendix D. Dr. Linda Perry's starch grain analysis from 2014 is presented in Appendix E. The results of the 2014 lipid residue analysis from Dr. Mary Malainey and Timothy Figol are in Appendix F. Appendix $G$ provides the identifications from the 2014 macrobotanical analysis by Dr. Phil Dering. The use-wear methods and results from 2014 are provided in Appendix H by Dr. Bruce Hardy. Appendix I presents the vertical provenience of the artifacts classes by test unit. 
This page intentionally left blank. 


\subsection{ENVIRONMENTAL SETTING}

\section{J. Michael Quigg}

\subsection{INTRODUCTION}

This section describes the modern environment for the general project area, just north of the city of Belton in Bell County in central Texas (see Figure 1-1). Modern vegetation and soils often affect site integrity. A baseline understanding of the modern environment provides clues to why prehistoric peoples occupied this location and what natural resources were potentially available to previous occupants. The TxDOT APE is on the right bank of the eastward flowing Leon River, and within the heavily vegetated valley itself (Figure 2-1). Here, the Leon River is deeply incised, with multiple Holocene terraces present $\left(T_{0}\right.$ and $\left.T_{1}\right)$, primarily on the southern bank of the valley. Prehistoric site 41BL278 is about $152 \mathrm{~m}$ above mean sea level and some 5 to $6 \mathrm{~m}$ above the river. The APE and the site is in the $T_{1}$ terrace and underlain by Holocene alluvium that fills the Leon River valley, which is quite narrow $(400 \mathrm{~m})$ at this point, before broadening out just downstream at Belton. The $\mathrm{T}_{0 \mathrm{a}}$ terrace is very narrow, less than $10 \mathrm{~m}$ wide and about $1 \mathrm{~m}$ above the river, whereas the $\mathrm{T}_{0 \mathrm{~b}}$ is about $25 \mathrm{~m}$ wide and about 2.5 to $3 \mathrm{~m}$ above the river. A major tributary to the Leon River is Cowhouse Creek that flows in from the west, where it crosses Fort Hood Military Reservation. The confluence of Leon River and Cowhouse Creek is about $1 \mathrm{~km}$ upstream from 41BL278, in Belton Reservoir. Both Cowhouse Creek and the Leon River have their headwaters in the Edwards Plateau further west, flowing eastward from the Lower Cretaceous limestones before entering the Blackland Prairie at the City of Belton. This river system is part of the much larger Brazos River Basin that drains much of central Texas and flows southeastward into the Gulf of Mexico.

Immediately on either side of the river valley is the Undivided Denton Clay, Fort Worth Limestone, and Duck Creek Limestone of the lower part of the Washita Group (mapped as Kdfdce) (Barnes 1970). Bordering the upland valley margins are Comanche Peak Limestone $(\mathrm{Kc})$ with hard, nodular gray and white limestone with numerous shale partings and filled burrows and marine megafossils (Barnes 1970).

\subsection{CLIMATE}

The climate of Bell County is characterized as humid, subtropical, with hot summers. Tropical maritime air controls the climate during the late

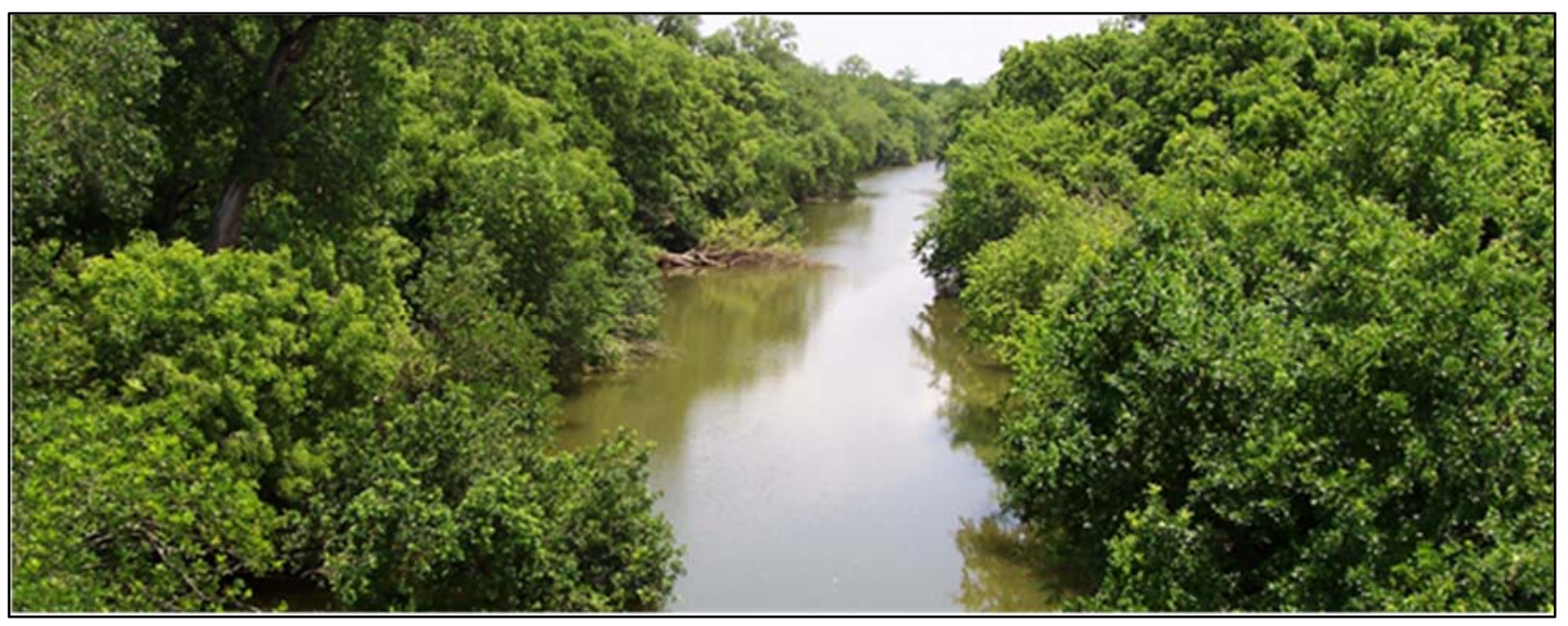

Figure 2-1. Leon River flowing eastward, surrounded by dense vegetation. 
spring, summer, and fall. In winter and early spring, surges of polar Canadian air causes sudden drops in temperature (Huckabee et al. 1977:72). These different air masses cause extremes in temperatures (Figure 2-2). The prevailing winds are southerly. The strongest persistent winds are in March and April. Winter temperatures are generally mild and cold spells are brief. Spring is generally a time of rapid and often abrupt weather changes. Summers are hot with high daytime temperatures. Fall is generally warm as well with increased precipitation in late September and into October dropping the temperatures (Huckabee et al. 1977:72). Annual precipitation averages $86 \mathrm{~cm}$ (33.87 in.). The driest months are January and July and the wettest month is generally May (Figure 2-3).

\subsection{SOILS}

Bosque clay loam (Be) soils (Mollisols) are immediately on either side of the Leon River and form narrow bands that parallel the river. On the southern side and next to the Bastrop soils (Alfisols) is a narrow band of Venus clay loam $(\mathrm{VeB})$ that parallels the Bosque band for a short distance (Figure 2-4). The very base of the southern valley wall has a band of Bastrop fine sandy loam (BaA). The upland above 41BL278 is characterized by Tarrant association (TAD) soils (Huckabee et al. 1977:8).

The Bosque series consists of deep, nearly level to gently sloping, loamy soils on the flood plain of the river. In a representative profile the surface layer is clay loam about $114 \mathrm{~cm}$ (45 in.) thick. It is a grayish-brown (10YR 5/2) in the upper $13 \mathrm{~cm}(5$ in.) and dark, grayish-brown (10YR 3/2) in the lower $100 \mathrm{~cm}$ (40 in.). These loamy alluvium are well-drained. Permeability is moderate, and available water capacity is high, with runoff slow to medium (Huckabee et al. 1977:8).

Venus clay loams are generally in 1 to 3 percent slopes on terraces. The surface layer is a dark, grayish- brown (10YR 4/2) clay loam $15 \mathrm{~cm}$ (6 in.)

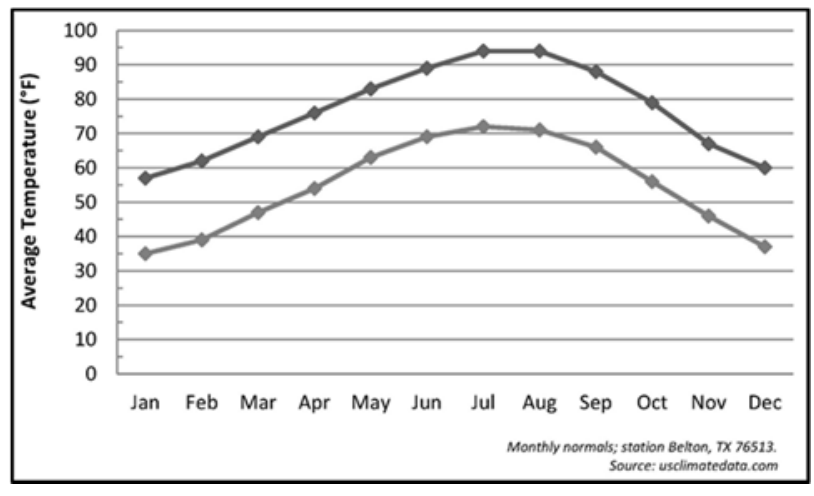

Figure 2-2. Regional average temperature for Bell County, Texas.

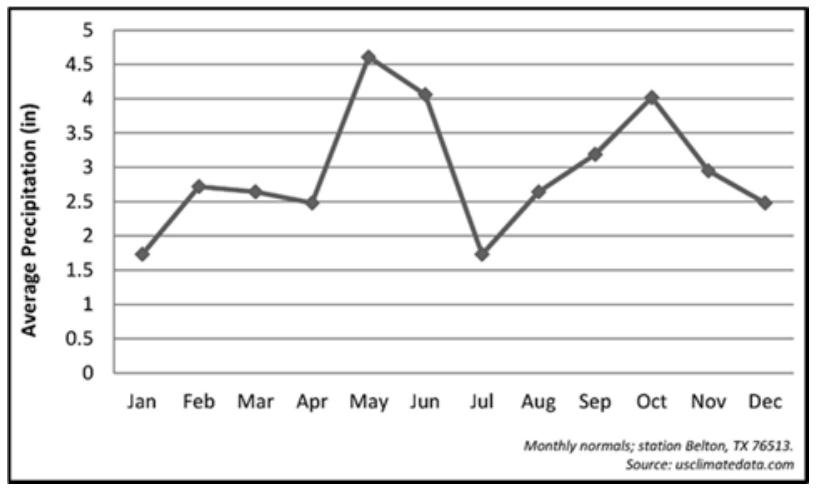

Figure 2-3. Regional average precipitation for Bell County, Texas.

thick. The next layer is very dark, grayish-brown (10YR 3/2) clay loam that reaches to a depth of 33 $\mathrm{cm}$ (13 in.). The next $36 \mathrm{~cm}$ (14 in.) is a brown (10YR 5/3) clay loam (Huckabee et al. 1977:33).

Bastrop fine sandy loam is nearly level on stream terraces. Most areas of this soil receive extra water and soil material from slopes above. In a representative profile, the surface layer is fine sandy loam about $41 \mathrm{~cm}$ (16 in.) thick. It is a dark brown (7.5YR 4/4) in the upper $15 \mathrm{~cm}$ (6 in.), and reddish-brown $(5 \mathrm{YR} 4 / 4)$ in the lower $25 \mathrm{~cm}(10$ in.). The next layer is sandy clay loam that extends to a depth of $183 \mathrm{~cm}$ (72 in.). It is red (2.5YR 5/6) in the upper $51 \mathrm{~cm}$ (20 in.) and yellowish-red (5YR5/6) in the lower $132 \mathrm{~cm}$ (52 in.) (Huckabee et al. 1977:8). 


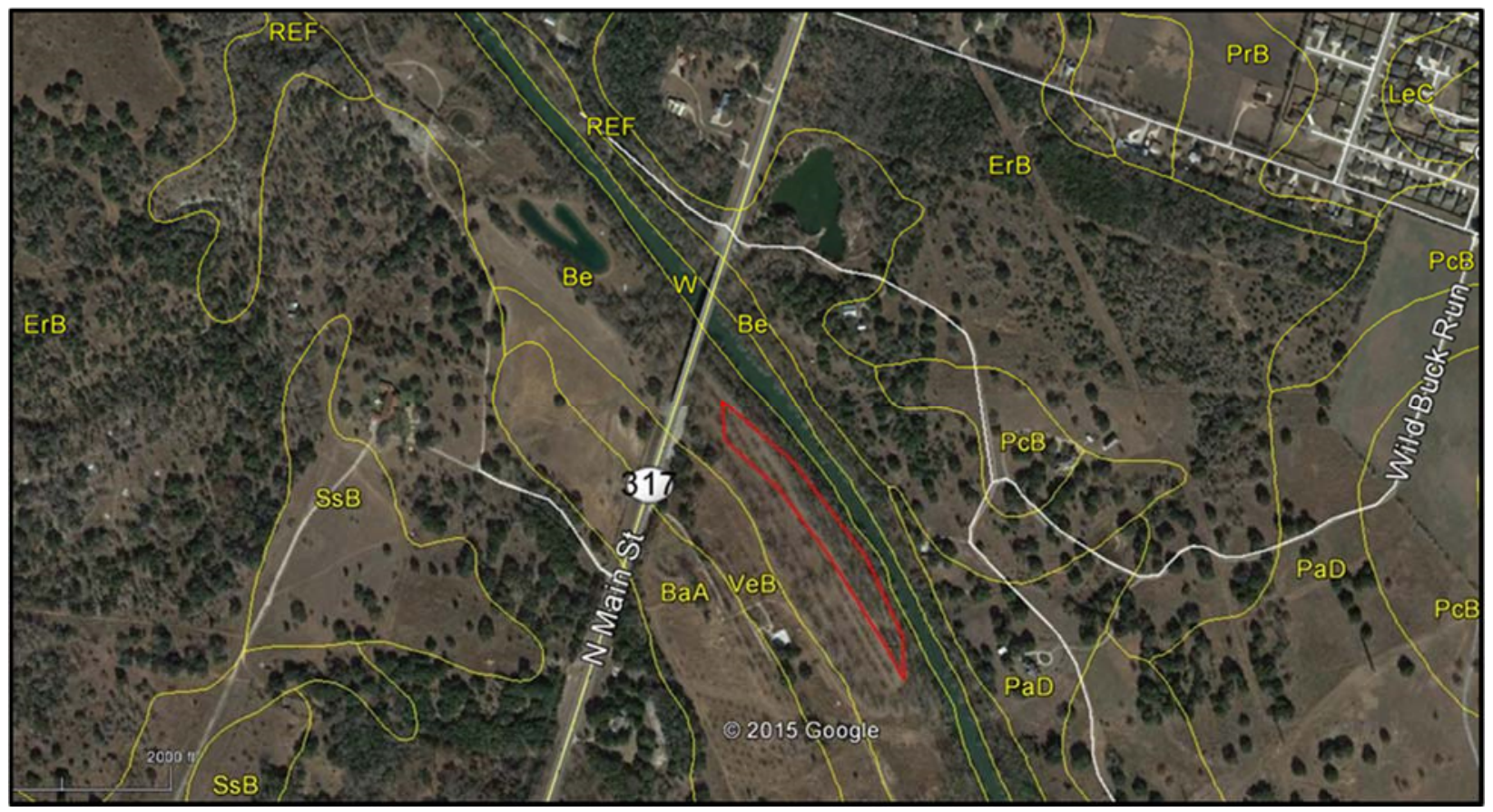

Figure 2-4. Soil types in vicinity of 41BL278.

Tarrant association (TAD) soils consist of very shallow to shallow, undulating to rolling, clayey soils in the uplands. These are noncalcareous soils formed in interbedded chalk, marl, and marly material, weathered mainly from limestones. Representative profile consists of a dark, grayishbrown (10YR 4/2) surface layer about $41 \mathrm{~cm}(16$ in.) thick. Large and small limestone rocks and gravel are on the surface and throughout the horizon, and make up about 40 percent of the upper part of this horizon. The lower part is about 80 percent rock over a hard limestone (Huckabee et al. 1977:31).

\subsection{VEGETATION}

Biotically, the region is a relatively small transition zone referred to as the Balconian biotic province (Blair 1950). This lies between much broader provinces. To the east lies the more mesic Texas province, whereas to the west lies the more xeric Chihuahuan province. South of the Edwards Plateau, or the Balconian province, lies the semiarid Tamaulipan province with extensive brush lands. To the north is the massive mesquite (Prosopis) grassland of the Kansan province. Thus, the region may contain a mixture of biota from the adjacent regions.

The regional vegetation is dominated by Mexican cedar (Juniperus mexicana) and Texas oak (Quercus texana) savanna across the uplands with some oak and hickory (Carya spp.) woodlands mixed with a variety of other trees and grasses (Blair 1950). Various oak species including stunted live oak (Quercus virginiana), post oak (Quercus stellata), and blackjack oak (Quercus marilandica) are in abundance along with other minor species such as Texas persimmon (Diospyros texana). The more common juniper (Juniperus mexicana), associated with much of the limestone region, is limited. Sotol (Dasylirion spp.), prickly pear (Opuntia spp.), and various yuccas occur across the southern part of the county and further west and south. Much of the region is a mosaic of vegetation communities.

Along the major rivers the arboreal species dominate although additional species may be present. These can include pecan (Carya 


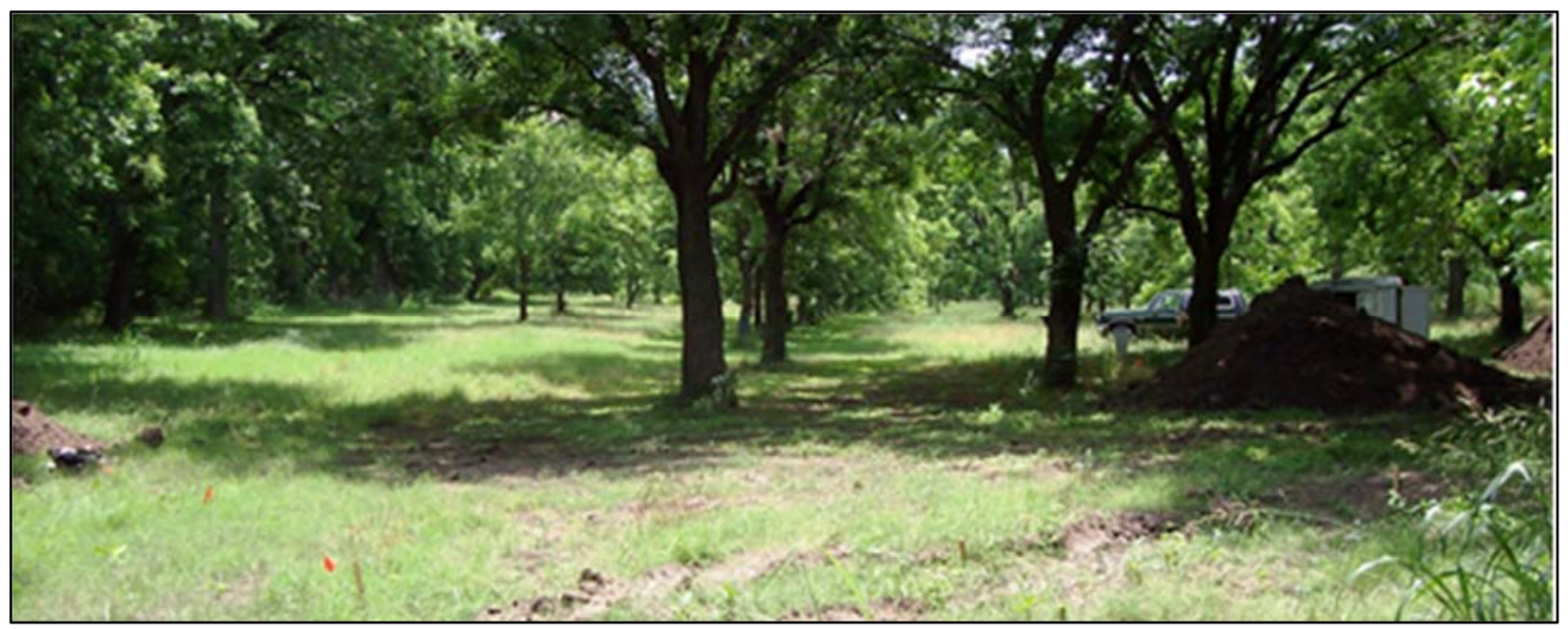

Figure 2-5. Pecan orchard on $T_{1}$ terrace east of APE across 41BL278 (view east).

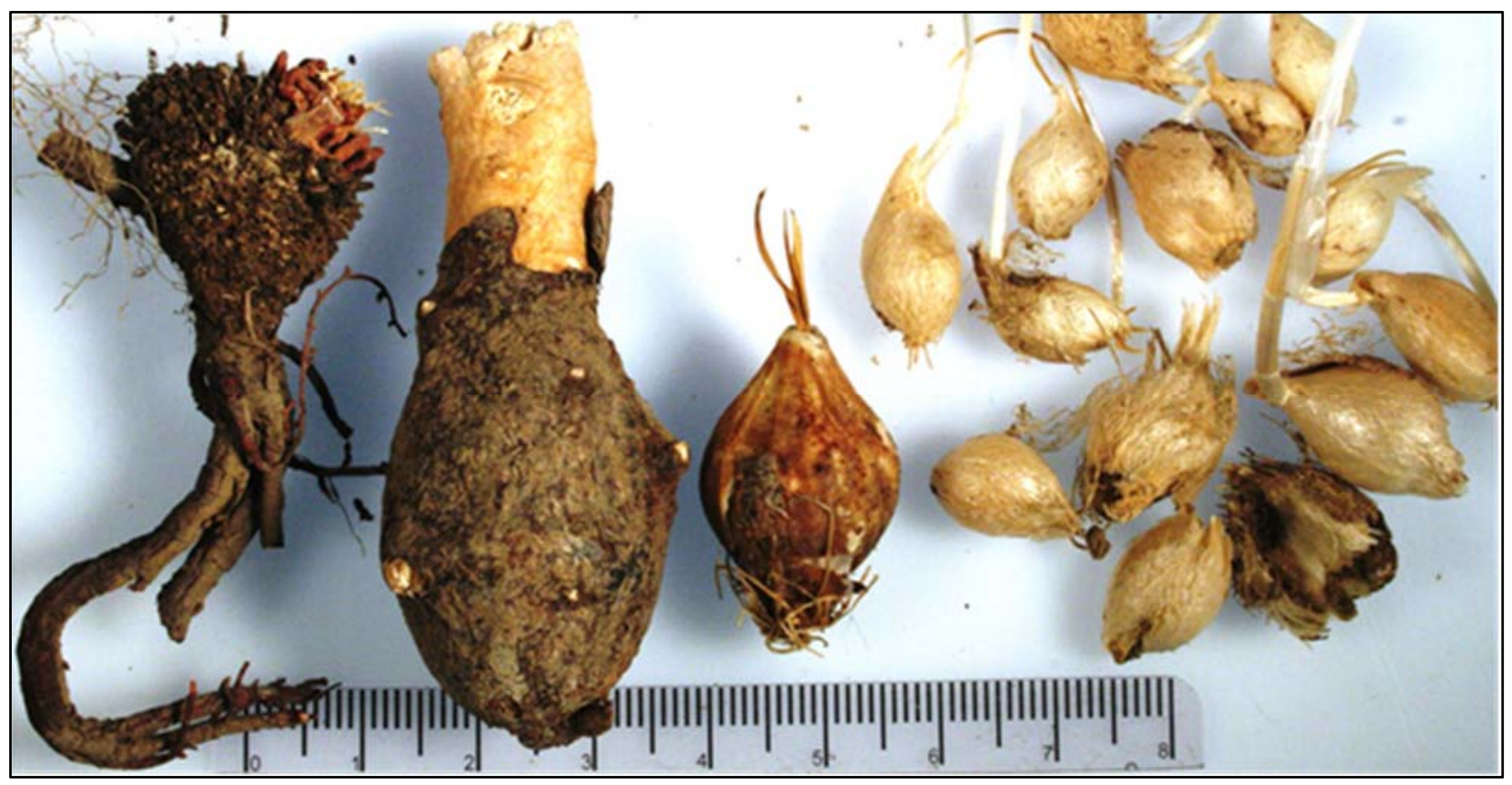

Figure 2-6. Examples of bulbs and tubers (bittertoot, biscuitroot, sego lily, and prairie onion), photography by M. Quigg.

illinoinensis) (Figure 2-5), American elm (Ulmus americana), and black willow (Salix nigra).

One plant resource that is increasingly identified in archeological assemblages in central Texas, specifically in burned rock features, are geophytes such as wild onions (Allium canadense), Eastern camas/wild hyacinth (Camassia scilloides), rain lily (Zephyranthes), Prairie celestial (Nemastylis geminiflora), winecup (Callirhoe involucrate), and others (Figure 2-6). These bulbs and tubers appear in the macrobotanical remains from excavated features in the Edwards Plateau and in the adjacent Blackland Prairie (i.e., Acuna 2010; Boyd et al. 2004a, 2004b; Dering 1998, 2003a, 2003b, 2004; Quigg, Lintz et al. 2011). 


\subsection{FAUNAL RESOURCES}

Blair (1950:101) considers this area part of the Balconian biotic province and lists 57 species of mammals in the widespread Balconian faunal assemblage of central Texas. This includes raccoon (Procyon lotor), rock squirrel (Spermophilus variegates), and nine banded armadillo (Dasypus novemcinctus). No species are totally restricted to this province, and most range into adjacent provinces, creating a transitional region for most mammals. At least 15 species of frogs and toads are known, some 36 species of snakes, one land turtle, and 16 species of lizards. Although Blair (1950) indicates the density of the mammals was usually lower than in the adjacent Tamaulipan province, a relatively greater diversity of plant and animal species, plus relatively abundant surface water and a range of mineral resources, may be what drew prehistoric human populations to this region.

Of considerable importance to prehistoric people were likely bison (Bison sp.), white-tailed deer (Odocoileus virginianus), pronghorn (Antilocapra americana), coyote (Canis latrans), black-tailed jackrabbit (Lepus californicus), fox squirrel (Sciurus niger), gray fox (Urocyon cinereoargenteus scotti), and eastern cottontail (Sylvilagus floridanus). Other than the gray fox and coyote, predators are relatively uncommon, although bobcat have been documented historically. Wild turkey (Meleagris gallopavo), and turtles (Terrapene sp.) are other potential meat resources.

\subsection{LITHIC RESOURCES}

The economic use of lithic resources by prehistoric people generally restricted to the acquisition of cherts to make stone tools, and limestone and other fossiliferous rocks to use in cooking. These two categories are briefly discussed below.

Local cherts are associated with the Fort Terrett and Segovia members of the Edwards Group formations and occur over a wide area of central Texas, especially south and west of the Llano Uplift region and along the Cretaceous limestone of the Balcones Escarpment (Frederick and Ringstaff 1994:140). Information obtained during previous systematic surveys across nearby Fort Hood has revealed several exposures that roughly coincide with the Edwards Group formation of the Manning surface buttes and mesas. The chert exposures are not continuous nor can they be correlated from one butte to the next. In some places, lenticular nodules of chert have eroded from softer limestone and mantle the ground surface. Elsewhere, bedded chert occurs in limestone and extends for distances as seam exposures, and amorphous nodules of chert erode from the limestone bedrock. Even though chert nodules occur in secondary lag gravels along streams across the military installation, vast areas of Fort Hood do not have quality cherts.

Considerable lateral variability is evident in the form, texture and color of cherts from various Edwards Group exposures. Initial attempts to characterize chert variability identified seven top quality cherts for knapping purposes (Dickens 1993). The next classification of cherts recognized some 17 varieties (Frederick and Ringstaff 1994). Further studies have expanded the chert types to 38 , but many of these additional types are not correlated to known exposures, nor are the detailed descriptions presently available (Mehalchick et al. 2002:17). As a means of ascertaining the sources of cherts, and perhaps the movements of people and/or trading networks, four chert source provinces have been identified on Fort Hood (Abbott and Trierweiler 1995). These consist of the west province, the southeastern province, the north province, and the Cowhouse Creek province (composed mostly of lag gravels). Given that Cowhouse Creek flows through Fort Hood and is capable of moving cobbles downstream, it is likely that many chert types identified in the Fort Hood region are further downstream in the gravels along the Leon River, and therefore potentially used at 41BL278. 
The limestone rocks that constitute many features on archeological sites were probably derived from locally available sources within a few hundred meters of sites. Limestone rocks used for thermal heating activities were readily available in uplands and in gravel bars along the river.

\subsection{AQUATIC RESOURCES}

Rivers, streams, and creeks provide multiple resources that may have been used by prehistoric populations. Besides the essential water, these environments provide fish, turtles, mussels, and aquatic plants. Although sparse, fish remains have been identified in a few archeological assemblages across central Texas (i.e., Yates 1982). Turtles are frequently identified, as they are easily recognized in faunal assemblages when preserved (Figure 2-7). In central Texas, sites with poor organic preservation, mussel shells are still often recovered and appear extensively utilized (i.e., Mahoney et al. 2003; Sorrow et al. 1967). These may represent one of the most important resources gathered, as they often occur in dense concentrations at sites.

\subsection{CENTRAL TEXAS PALEOENVIRONMENTS}

In central Texas, across the Edwards Plateau, the Blackland Prairie and along its eastern margins in the adjacent Post Oak Savanna region, multiple paleoclimate records are available for interpreting broad periods of paleoenvironment. These diverse datasets include pollen cores from bogs in the Post Oak Savanna (i.e., Bousman 1998; Bryant 1977; Frederick 2011; Holloway et al. 1987; Larson et al. 1972), data from geomorphic investigations of river valleys (i.e., Abbott 1994, 2003; Blum 1987; Blum and Valastro 1989; Hall 1982, 1990; Johnson and Goode 1994, 1995; Mear 1998; Nordt1992, 1993; Toomey 1993, Toomey et al. 1993; Waters and Nordt 1995), phytoliths (i.e., Bozarth and Woodburn 2011; Cummings 1994; Fredlund 1998; Yost and Cummings 2011), stable isotopes (i.e., Frederick 2011; Mauldin 2003, 2006; Tomka and Mauldin 2003), and cave deposits (Toomey 1993; Toomey et al. 1993). These provide diverse proxy data for reconstructing paleoenvironments, and have been summarized several times. Much of the

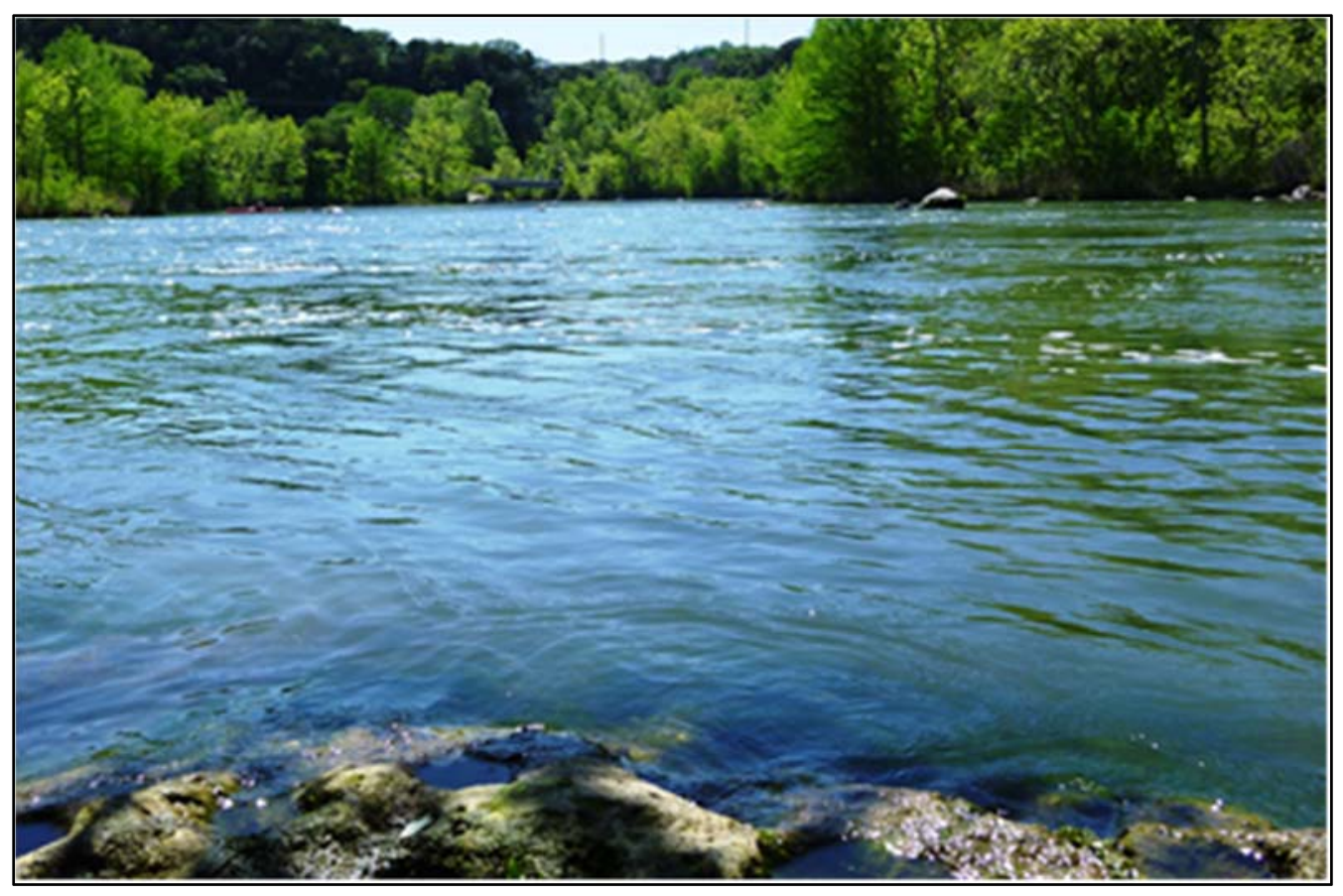

Figure 2-7. Diverse water resources were likely utilized by prehistoric populations (photograph by M. Quigg). 


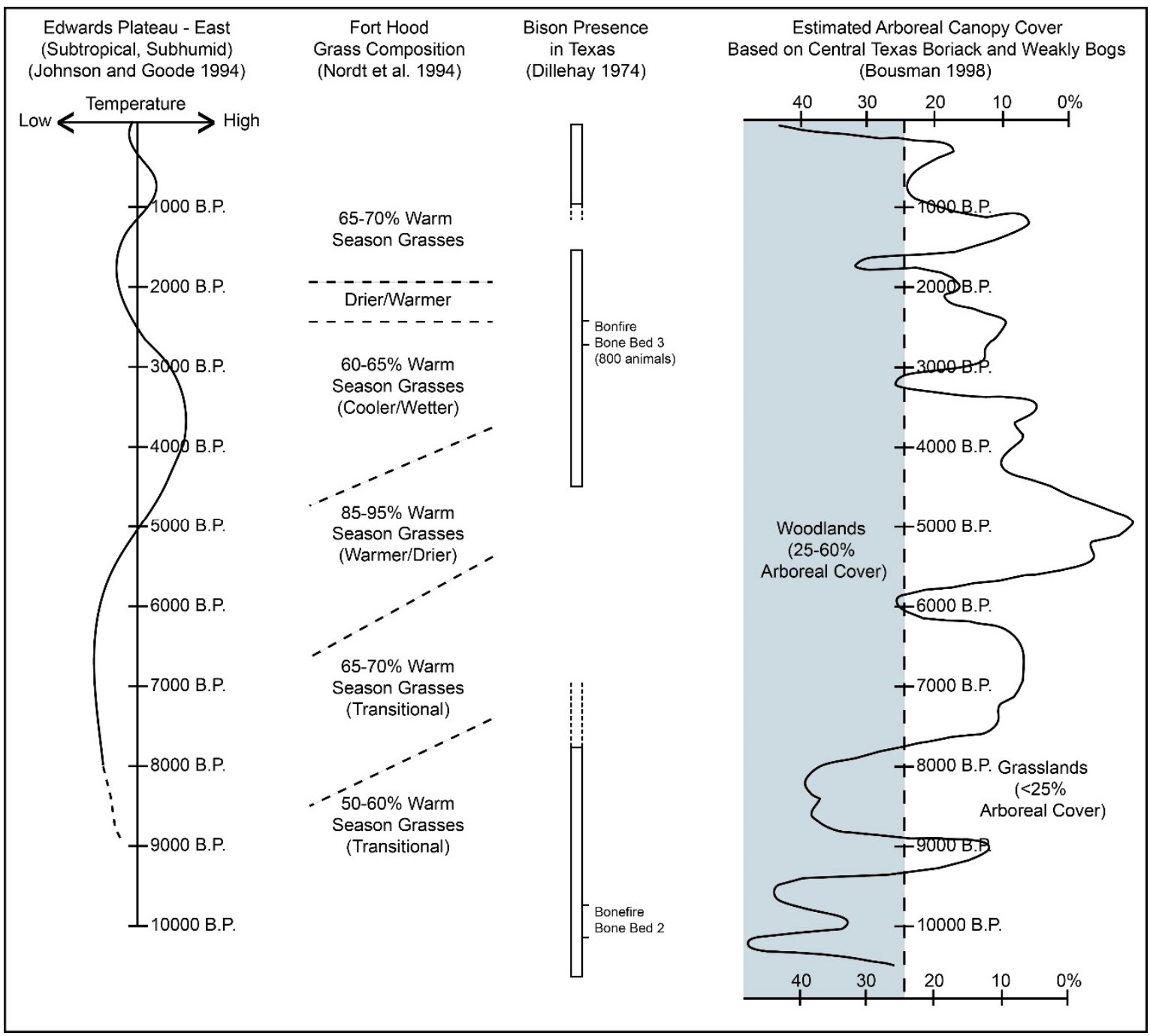

Figure 2-8. Comparison of a few selected interpretations of changing environments in central Texas using different data sets (from Quigg et al. 2008).

discussion that follows has been extracted from the overviews by Bryant and Holloway (1985), and the more specific trends observed by Bousman (1998).

Bousman (1998), using secondary counts, requantified the pollen results from Boriack and Weakly bogs just east of the Edwards Plateau in the Blackland Prairie. These two bogs provide a 16,000 year sequence of fluctuations between grass and arboreal pollen that indicate shifts between forest, woodland, and open plant communities (Figure 28). Bousman's interpretations of his recalculations indicate that open vegetative communities were present during the Late Glacial Maximum and between 13,000 and 12,000 B.P., 10,000 and 9000 B.P., and 8000 and 2500 B.P. (see Figure 28). A key factor in understanding these shifts in vegetation is that the mesic woody species invaded grasslands during moist climate intervals, but woody species died out during droughts (Coupland 1958). Apparently, between 8000 and 7000 B.P., the region became grassland. The phytolith data from the Wilson-Leonard site (41WM235) supports a grassland composition similar to today during the period from ca. 8700 to 6000 B.P. (Fredlund 1998). Along the Texas Gulf Coast, it appears that between approximately 6700 and 6000 B.P., the sea level was rising rapidly (Ricklis and Blum 1997). A two- 
phased, mid-Holocene dry interval occurred, with extremes recorded at 6500 B.P. and 5000 B.P. (Bousman 1998). Alternatively, Johnson and Goode (1994) see no long-lasting, dry hypsithermal (their term for the Altithermal) climate in the eastern Edwards Plateau; consequently, they project little change occurred in the climate between the Early and Middle Archaic cultural periods. Johnson and Goode (1994) do acknowledge, however, that some drying occurred in late Early Archaic times.

Southeast of Bell County along Little River in central Milam County, from a period roughly between 3000 and 2000 B.P., vertebrate faunal analysis indicates the presence of mammalian species such as beaver (Castor canadensis), raccoon, white-tailed deer, and cottontail rabbits (Sylvilagus sp.), plus reptiles such as turtle that preferred riverine/wooded habitats. Little River was also home to at least eight species of mussels. Snails and vertebrate faunal such as jackrabbits (Lepus californicus), and cotton rats (Sigmodon hispidus) indicate the riverine zone was likely bordered by an open grassland environment (Tomka and Mauldin 2003). Plant remains from sites along Little River indicate trees present included pecan (Carya illinoiensis), hickory (Carya sp.), honey locust (Gleditsia triacanthos), walnut (Juglans sp.), oak (Quercus sp.), willow/cottonwood (Salix/Populus sp.), elm (Ulmus sp.), holly (IIex sp.), box elder (Sambucus sp.), ash (Fraxinus sp.), and persimmon (Diospyros virginiana) (Bush 2006; Dering 2003b).

To the east, the geomorphic deposits along the Brazos River reveal the development of the Buffalo soil as the sediment load was reduced from around 4200 to 2500 B.P. (Waters and Nordt 1995). Based on the deposition, much of this period is interpreted to be cooler/wetter (Nordt et al. 1994, 2007; Waters and Nordt 1995). This general period is projected to have temperatures that dropped to slightly below modern July temperatures (Nordt et al. 2007).
Southwest of 41BL278, near the center part of the Edwards Plateau, the faunal record from Hall's Cave in Kerr County indicates conditions from ca. 5000 to 2500 B.P. that were dryer than modern (Toomey 1993; Toomey et al. 1993). About the time of this dry interval, the upland soil mantles in central Texas were being rapidly stripped (Toomey et al. 1993), as Nordt (1992) interpreted for the Fort Hood area. Fredlund (1998), using phytolith data from the Wilson-Leonard site in the Edwards Plateau, sees the overall vegetation composition of central Texas reach its modern balance of woodlands and grassland by about 4000 B.P. Between 4000 and 3200 B.P. was a period of rapid sea level rise (Ricklis and Blum 1997). Johnson and Goode (1994) propose that a dry Edwards Interval lasted from roughly 5000 to 3000 B.P., which is in direct contrast to that of the cooler/wetter climate proposed by Nordt et al. (1994, 2007; Waters and Nordt 1995).

For the last 3,000 years of the Weakly Bog sequence, grass and oak pollen are equally represented. Starting at roughly 3000 B.P., the pollen frequencies indicate that oak woodland was followed by oak-hickory woodland. Bousman (1998) interprets this change to indicate that the climate became progressively moister through the late Holocene. This is in direct contradiction to the interpretation previously offered by Holloway et al. (1987) on the same bog pollen. Toomey et al. (1993) also appear to differ in that they see drier conditions culminating between ca. 5000 and 2500 B.P. To date, research has not definitively established whether flood plain aggradation is related to dry periods or to moist conditions (Johnson and Goode 1994). Toomey et al. (1993) see more mesic conditions from about 2500 to 1000 B.P., with modern conditions predominating from 1000 B.P. to the present. The phytolith assemblage from the Wilson-Leonard site indicates that local conditions became less open after 2000 B.P. (Fredlund 1998). 
Two significant grass spikes occurred in the Weakly Bog data, one dated to 1500 B.P. and the other estimated at 500 to 400 B.P. (Bousman 1998). These grass spikes are linked to alluvial pedogenesis in floodplain deposits during these periods in Freestone and Leon counties to the northeast. This point is significant to the extent that grassy intervals may be associated with alluvial stability, but not all researchers agree on this issue. As an outgrowth of his Quaternary work in the upper Sabinal River valley along the southern Edwards Plateau, Mear (1998) believes that down cutting and deposition can occur simultaneously along a stream during both dry and humid climate regimes.

More recently, Frederick (2011) in discussing the late Holocene Unit Qa4 (ca. 3800 to 250 B.P.) from deposits along the lower Onion Creek valley (41TV410) in eastern Travis County, demonstrates a range of about 15 percent variation in the contribution of $\mathrm{C}_{4}$ plants in the stable carbon isotopic record for this time period. This isotopic record reveals more $\mathrm{C}_{4}$ plant input at the beginning and end of the period of around $-15.0 \%$, with values around $-18.0 \%$ during the middle part (Frederick 2011:94). During this depositional period (average rate of $0.166 \mathrm{~cm}$ per year) at least five buried soils are present, which indicate periods of stability within the depositional sequence (Mauldin et al. 2011:98). The phytolith record for this period at $41 \mathrm{TV} 410$ reveals grass phytoliths dominate the assemblage, with Chloridoids (short warm season grasses that prefer relatively warm and dry conditions) accounting for 60 to 95 percent $\mathrm{C}_{4}$ input. Late in this period one significant shift/spike is present, and reveals increased $\mathrm{C}_{3}$ cool season grasses. Overall, the phytolith record contrasts with the stable carbon isotope record (Mauldin et al. 2011:103). Bozarth and Woodburn (2011:220) interpret the temperature as relatively constant through the period, with one abrupt change to cooler temperatures sometime between 2870 and 1240 B.P. They also see the aridity index as relatively dry until the spike in moisture at the cooling period. The snail data from this late Holocene Unit Qa4 period indicates that our current understanding of the habitat conditions preferred by Rabdotus sp., Polygyra texasiana, and Helicina orbiculata may be far from complete (Mauldin et al. 2011:105).

Caran (1998) provides a cautionary note to interpretation of proxy data used in the reconstruction of paleoenvironments and reminds us that the data generally represent second, third, or higher-order extrapolations from the database. The different proxy data accounts for some different interpretations and limited or restricted dates from the different context contribute to unclear timing of events. Currently, it appears that Johnson and Goode's (1994) projection of temperature shifts is out-of-step with Bousman's (1998) canopy cover estimates and the phytolith assemblage at Morgan Playa (Fredlund et al. 1998) in the Rolling Plains to the north of the Edwards Plateau. Fredlund's (1998) results from the Wilson-Leonard site indicate that phytolith analyses for the Texas region are warranted. 
This page intentionally left blank. 


\subsection{ARCHEOLOGICAL BACKGROUND AND CULTURAL HISTORY}

J. Michael Quigg

\subsection{INTRODUCTION}

Excavations at 41BL278, at the extreme eastern edge of the Edwards Plateau along the Balcones Escarpment in east central Texas, revealed multiple occupations within a roughly a $50 \mathrm{~cm}$ thick zone located roughly between 130 and $180 \mathrm{cmbs}$. These occupations appear to represent a restricted time period. The majority of 12 radiocarbon results on diverse materials from these cultural occupations indicate the most likely use period was from approximately 2800 to 3200 B.P., during the Round Rock phase. Pedernales points were the diagnostic point, which are presently assigned to the Late Archaic period of central Texas (Collins 2004) (Figure 3-1). The following discussions provide a review of selected investigations in the immediate area, and a general overview of the central Texas Late Archaic as currently understood, with selected examples of investigated sites and data from specific sites for clarification.

\subsection{PREVIOUS ARCHEOLOGICAL INVESTIGATIONS IN THE REGION}

Major investigations in Bell County are few in number, even though over 1,370 cultural resource sites were documented in this county by 2014 . Most investigations in Bell and the adjacent Coryell Counties stemmed from investigations at Fort Hood beginning in the early 1980s. Those investigations focused primarily on conducting inventories with limited testing of sites, and very few intensive excavations (i.e., Abbott and Trierweiler 1995; Carlson 1993; Killian and Blake 2001; Kleinbach et al. 1999; Mehalchick et al. 1999, 2000; Quigg et al. 1996; Thoms 1993; Trierweiler 1994, 1996).

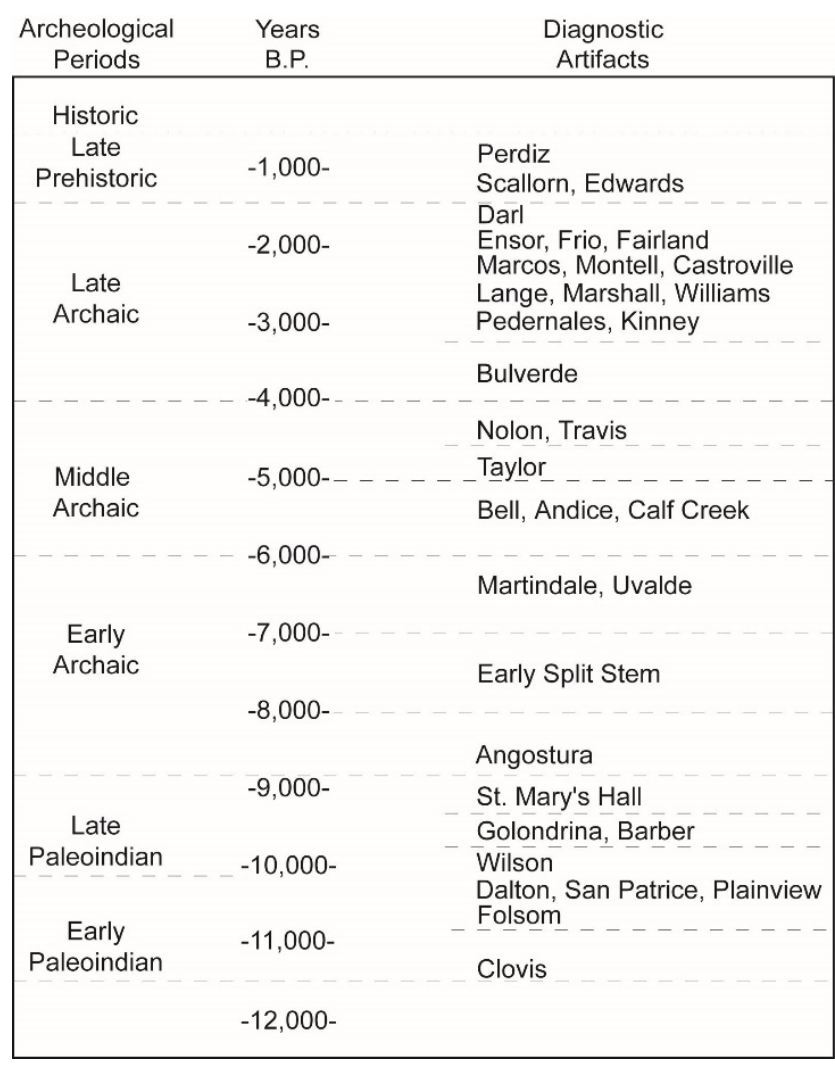

Figure 3-1. Central Texas chronology (adapted from Collins 2004:113, Figure 3.9a).

Investigations at Fort Hood, Texas, contribute information on the Late Archaic period. A few examples are discussed below. The Firebreak site (41CV595) in the Paluxy formation, a unique sandy outcrop limited in horizontal extent, is one of the more intensively investigated sites $\left(67 \mathrm{~m}^{2}\right)$ at Fort Hood. The cultural assemblage was dominated by materials primarily dating over the last 3,000 years, but no distinct, well-defined Pedernales occupation was identified (Mehalchick et al. 2004). However, at least 10 Pedernales points have been recovered from other Paluxy formation sites. The Paluxy environments present relatively poor settings for intact, well-separated, stratified human occupations, although over half the Paluxy sites are listed as eligible for the NRHP (Mehalchick et al. 2004:221). At least 17 Late Archaic components are present in the 38 Paluxy sites identified at Fort Hood. Plant remains include charred oak wood, wild onion, and camas bulb fragments from 
multiple rock oven features (Dering 2004). The fatty acid results on burned rocks from the rock ovens indicate that large herbivore products were absent and likely seed and/or animal fat were processed using the rocks (Malainey and Maliaza 2004).

Another investigated site $\left(35 \mathrm{~m}^{2}\right)$ at Fort Hood is the Cowdog Crossing site (41CV389) in $2.4 \mathrm{~m}$ of alluvial deposits. At least four stratified components are present, and most cultural materials reflect intermittent occupations from approximately 2,000 to 1,000 years ago (Carpenter et al. 2010). Although earlier components were present, only the end of the Archaic period and transitional components were targeted. Two ground stone artifacts were subjected to pollen and starch grain analyses. No starches were recovered from either artifact (Cummings and Varney 2010). Pollen was not well-preserved, and appeared to represent local plants rather than economic resources (Cummings and Varney 2010). Besides wood charcoal of several species from the different features, charred grass seeds were also recovered from Feature 8, along with an indeterminate tuber fragment (Acuna 2010).

A third example from Fort Hood is the Clear Creek Golf Course site (41CV413). Mitigation targeted a burned rock midden (Feature 2) through a $20 \mathrm{~m}^{2}$ $\left(24.5 \mathrm{~m}^{3}\right.$ ) block excavation (Quigg, Lintz et al. 2011). The $50 \mathrm{~cm}$ thick midden was in use for an approximately 1,200 year period between 2500 and 3700 B.P. during the Late Archaic. Two internally slab-lined basin hearth features, the remains of earth ovens, indicate cooking was conducted in this midden. Bones of deer and rabbit, and sparse charred bulb fragments indicate some subsistence resources processed. Pedernales points $(N=40)$ dominate the identifiable projectile points from the midden. Below the midden was a lower component radiocarbon dated to between 5100 and 4100 B.P., which included multiple Early Archaic point types (Quigg, Lintz et al. 2011). Ten artifacts revealed use-wear or use-related residues. Three exhibited plant residues, two had animal residues, one with possible bone/antler fragments, and one with degraded hair (Hardy 2011). Lipid residues from 10 analyzed burned rocks yielded fatty acids. These residues are most consistent with foods of high fat content such as seeds, nuts, or rendered mammal (other than large herbivore) fat (Malainey and Maliaza 2011).

Just southwest of 41BL278 in southern Bell County, and along the Lampasas River, east of the Balcones Escarpment, two sites were excavated during 1964 and 1966 in advance of construction of Stillhouse Hollow Reservoir (Sorrow et al. 1967). The Landslide site (41BL85) revealed stratified campsites in alluvial deposits. Six strata were identified in roughly $3.0+\mathrm{m}$ of alluvium in the roughly $31 \mathrm{~m}^{2}$ excavation. These strata were dominated by cultural mussel shells and burned rocks, with at least 11 well-defined features. Based on diagnostic projectile points, the cultural deposits date to the Early, Middle and Late Archaic periods. At least 14 Pedernales points, along with some Bulverde, Tortugas, and Travis points were recovered from Stratums II and IIIa. These Stratums were assigned to Occupational Phases 4 and 5. The latter included a burned rock midden dominated by Pedernales points. An apatite assay done on a single bison bone recovered from the top of Feature 2, a well-defined hearth, yielded a date of $>3520$ B.P. (Tx-289). This hearth and bone were assigned to the Occupational Phase 3 (Sorrow et al. 1967).

The second site, Evoe Terrace (41BL104), was excavated (ca. $29 \mathrm{~m}^{2}$ ) in a high sandy terrace on the southern side of the Lampasas River (Sorrow et al 1967). At least 10 Zones were identified, with some stratified cultural deposits in those zones. The cultural deposits contained at least 21 recognized features dominated by burned rocks. The diagnostic artifacts include arrow and dart points that represent six occupational phases that encompass major periods over an estimated 8,000 to 10,000 years. Occupational Phase 3 is represented by Pedernales 
points, scrapers, and bison bones (Sorrow et al. 1967).

To the south, in Williamson County, many prehistoric sites have been intensively investigated, many along the San Gabriel River and its tributaries, some in the Blackland Prairie and some along the Balcones Escarpment. Table 3-1 lists some of the more intensively investigated sites in Bell and adjacent Williamson and Coryell Counties. Selected sites are discussed below.

Wilson-Leonard (41WM235), a deeply stratified site with cultural occupations throughout the last 12,000 years, has made many significant contributions to regional prehistory through its 92 radiocarbon assays, vast array of special studies, and the intensive focus towards site formation processes. Unfortunately, the Late Archaic deposits were compressed and extensively intermixed with Middle Archaic and Late Prehistoric materials (Collins et al. 1998:245). Pedernales points were in low frequency in comparison to the other Late Archaic point types. The broad Late Archaic period deposits yielded 24 features that included; a cache of bifacial preforms, burned rock scatters, a burned rock basin, burned rock clusters, and one large burned rock accumulation. Faunal remains from the latter feature include large and medium mammals, rabbits, turtles, rodents, snakes, fish, birds, and river mussels (Collins et al. 1998:251).

One of the largest and the most extensive projects in Williamson County was the archeological investigations at North Fork Reservoir and Granger Lake, impoundments along the middle San Gabriel River, and the subsequent filling of Georgetown Reservoir and Granger Lake in 1980-81 (Hays 1982). North Fork is just west of the Balcones Escarpment, whereas Granger Lake is just east of the Escarpment in the Blackland Prairie. This multilocation United States Army Corps of Engineers (USACE) project was initiated in 1963 with reconnaissance surveys of the proposed reservoir basins (Shafer and Corbin 1965). Follow-up testing began in 1968, with three sites being investigated (Eddy 1973). More survey and testing occurred until late in 1978.

At North Fork, six prehistoric sites (41WM53, the Hawes site [41WM56], 41WM57, 41WM73, 41WM304, and 41WM328) were intensively excavated, and another eight sites were tested (Hays 1982). Occupations during the Round Rock phase (Prewitt 1981) were evident in numerous burned rock midden deposits at a four of the six excavated sites, and some 52 Pedernales points were recovered from 41WM57. Diverse cultural assemblages were documented, and include quantities of retouched lithics and bifaces, with limited quantities of scrapers and heavy chopping tools (Peter, Hays et al. 1982).

The Hawes site (41WM56), in North Fork Reservoir, revealed one of the largest deposits of cultural materials in the project (Peter, Prikryl et al. 1982). The Archaic period is well-represented and supported by three radiocarbon assays on charcoal of $3225 \pm 75$ B.P. (UGa-2480), $3615 \pm 60$ B.P. (UGa-2485), and $3750 \pm 90$ B.P. (UGa-2473) (Peter and Hays 1982). These three assays, from a $30 \mathrm{~cm}$ of deposits in a $20 \mathrm{~m}^{2}$ block in Area $\mathrm{C}$, were associated with Pedernales points for the youngest date and Bulverde, Travis, and Nolan points for the two older dates. Below these diagnostic points was a Martindale point of the San Geronimo phase. The Round Rock phase was not well-represented, which may be due to the limited volume excavated. Two burned rock features (Features 2 and 8) were assigned to the Round Rock phase, one a massive lens of burned rocks (Peter, Prikryl et al. 1982). The subsequent San Marcos and Twin Sisters phases were not represented in distinctive stratigraphic units.

At Granger Lake, 10 sites (41WM124, 41WM130, 41WM133, 41WM163, 41WM165, 41WM230, 41WM258, 41WM284, 41WM294, and 41WM267) were intensively excavated, and at least 
Table 3-1. Selected Intensively Investigated Sites in Bell and Adjacent Coryell and Williamson Counties.

\begin{tabular}{|c|c|c|}
\hline Site No. & Site Name & Reference \\
\hline 41BL85 & The Landslide & Sorrow et al. 1967 \\
\hline 41BL104 & Evoe Terrace & Sorrow et al. 1967 \\
\hline 41BL116 & Youngsport & Shafer 1963 \\
\hline 41BL670 & & Carlson 1993 \\
\hline $41 C V 389$ & Cowdog Crossing & Carpenter et al. 2010 \\
\hline $41 C \vee 413$ & $\begin{array}{l}\text { Clear Creek Golf } \\
\text { Course }\end{array}$ & $\begin{array}{l}\text { Mehalchick et al. } 2002 \\
\text { Quigg et al. } 2011\end{array}$ \\
\hline 41CV595 & Firebreak & Mehalchick et al. 2004 \\
\hline 41CV988 & & Mehalchick et al. 2004 \\
\hline 41CV1141 & & Mehalchick et al. 2004 \\
\hline 41CV1505 & $\begin{array}{l}\text { Leon Medicine } \\
\text { Wheel }\end{array}$ & Quigg et al. 1996 \\
\hline 41WM2 & Merrell & Campbell 1948 \\
\hline 41WM13 & Bessie Kruze & Johnson 2000 \\
\hline 41WM21 & Centerline & Moore 1978 \\
\hline 41WM40 & $\begin{array}{l}\text { Dobb's Hollow } \\
\text { Canyon }\end{array}$ & Schroeder 2000 \\
\hline 41WM49 & John Ischy & Sorrow 1969 \\
\hline 41WM53 & & Peter et al. 1982b \\
\hline 41WM73 & & Peter et al. 1982b \\
\hline 41WM56 & Hawes & Peter et al. 1982b \\
\hline 41WM124 & Bryan-Fox & Peter et al. 1982b \\
\hline 41WM130 & Hoxie Bridge & Bond 1978 \\
\hline 41WM133 & Loeve & Prewitt 1982 \\
\hline 41WM139 & Beaver Head & Clark 1964 \\
\hline 41WM163 & & Peter et al. 1982b \\
\hline 41WM165 & Tombstone Bluff & Prewitt 1982a, \\
\hline 41WM230 & Loeve-Fox & Prewitt 1974, 1982a, 1982b \\
\hline 41WM235 & Wilson-Leonard & Collins et al. 1998 \\
\hline 41WM258 & Bigon-Kubala & Peter et al. 1982b \\
\hline 41WM267 & Cervenka & Peter et al. 1982b \\
\hline 41WM284 & & Bond 1978 \\
\hline 41WM294 & & Bond 1978 \\
\hline 41WM304 & & Peter et al. 1982b \\
\hline 41WM328 & & Peter et al. 1982b \\
\hline 41WM437 & Rowe Valley & Prewitt 2012 \\
\hline 41WM632 & Blockhouse Creek & Keetley et al. 1999 \\
\hline 41WM815 & Rice's Crossing & Brownlow 2003 \\
\hline 41WM1010 & Shephard & Dixon and Rodgers 2006 \\
\hline 41WM1126 & Siren & Carpenter and Houk 2013 \\
\hline
\end{tabular}


12 other sites were tested (Bond 1978; Hays 1982; Prewitt 1982a). About 24 radiocarbon dates were obtained from Granger Lake sites, with 17 from Loeve-Fox (41WM230) (Prewitt 1982a, 1982b). Selected sites at Granger Lake with direct bearing on the data recovered from 41BL278 are presented. Testing and data recovery investigations at the Loeve-Fox site (41WM230) yielded significant information pertaining to the Late Archaic period (Prewitt 1974, 1982a, 1982b). The targeted deep alluvium $(3.6+\mathrm{m})$ revealed a stratified multicomponent site, dating back some 3,500 years, with features and high artifact frequencies in most occupational zones. Seventeen radiocarbon dates were obtained that delineate time ranges for three of phases, all less than 2,000 years old: Twin Sisters, Driftwood, and Austin (Prewitt 1981). Onehundred and thirty features were identified, with cooking features accounting for nearly 79 percent. The site contained a cemetery, associated with the Late Prehistoric Austin phase, with skeletons that contained Scallorn points as the probable cause of death. A separate human cremation associated with a conch columella bead was recovered from the San Marcos phase component. At least 27 interments and 10 cremations were present. Feature and artifact patterning in the Twin Sisters phase component revealed a circular encampment composed of smaller activity areas. The Austin phase component is one of the best defined that has been discovered and reported thus far, with 6 dates, 17 features, the cemetery, and nearly 3,200 artifacts. The Twin Sisters phase component (Ensor points dominated, mixed with Marcos and Montell points) represents the most intensive usage, with 60 features and nearly 21,000 artifacts (Prewitt 1974, 1982a, 1982b). Prewitt's Middle Archaic period zone, the lower portions of Stratum 6, did not yield any diagnostic artifacts (Prewitt 1982b:12). The horizontal distribution of features and artifacts appeared to represent specific zones of activity, possibly representative of small extended family groups. Subsistence, specifically in relative importance of hunting, appears to have changed through time (Prewitt 1982a).

For the Round Rock phase, from roughly 4000 to 2600 B.P. indicated by diagnostic Pedernales points, very few sites were identified in Granger Reservoir (Peter, Prikryl et al. 1982). Most Pedernales points occurred as isolated finds, or in very poor or mixed context. The context of the recovered Pedernales points also lacked radiocarbon dates (Peter, Prikryl et al. 1982). Few tools and cores were recovered for this time period, although bifaces, retouched flakes, and burins were all present. Occupational intensity for the Round Rock phase appears low in Granger Lake, which indicates this area was not a desired environment at that time (Peter, Prikryl et al. 1982:17-9). Peter, Prikryl et al. (1982:17-9) speculated that the carrying capacity of the Granger Reservoir was not sufficient to support a large population of huntergatherers during the Round Rock phase.

Pertinent to $41 \mathrm{BL} 278$ is the Bessie Kruze site (41WM13), which was in the upper $1.5 \mathrm{~m}$ of deep alluvium along Brushy Creek, a tributary to the San Gabriel River in Williamson County. This site was tested in 1988 and in 1989 further excavated (42 $\mathrm{m}^{2}$ ) by TxDOT archeologists. Johnson (2000) later conducted the analysis and completed the report. Though the Late Archaic deposits encountered were mixed and revealed no natural strata, three zones of cultural debris (from youngest to oldest: Zones I; II; and III) were organized and discussed, and supported by 10 radiocarbon dates. The most recent Zone I dated to 2310 B.P. by Rabdotus shells and 2280 B.P. by wood charcoal from Feature 7. This zone yielded five rock ovens (Features 3, 4, 5, 7, and 15) and a single scattered fireplace/hearth (Feature 28). A mixture of dart and arrow points, mostly broken, occurred in Zone I. Zone II yielded Pedernales points, seven rock-lined 'fireplaces', five rock clusters, a mussel shell heap (Feature 20), scattered mussel shells, and animal bones. A localized, single event, multi-individual secondary 
interment (Feature 13) was present, with comingled remains of at least three humans, associated with a radiocarbon date of 2440 B.P. by wood charcoal from Feature 6. This group of secondary interment was intentionally covered with white-tailed deer antlers and limestone cobbles. A Pedernales point and additional probable Pedernales points were in the grave and likely the cause of death. Zone III yielded two human cremations (Features 19 and 21), two earthen fire basins (Features 14 and 17), a cluster of rocks and chert knapping debris (Feature 22), and Pedernales points. A radiocarbon date on Rabdotus snails yielded an age of 4010 B.P.; however, wood charcoal provided a date of 3020 B.P. (Johnson 2000).

Further east, in north-central Milam County along Little River, out in the Blackland Prairie, eligibility testing was conducted at 41MM340 (Mahoney and Tomka 2000). This site is directly pertinent to 41BL278 as it contains a similar assemblage of mussel shells and burned rocks in alluvium, and representative of a similar time period as that identified at 41BL278. The site was determined eligible for listing on the NRHP, and data recovery excavations $\left(56 \mathrm{~m}^{2}\right)$ occurred in the densest part of 41MM340. These revealed 15 stratigraphic zones in deep alluvium, grouped into seven analytical units that spanned only about 1,000 years (from 3050 to 2060 B.P.) of the Late Archaic period (Mahoney et al. 2003). Twenty-four radiocarbon dates were obtained, 21 of which were on cultural charcoal. The analytical units (AUs) yielded varying quantities of burned rocks, lithic debitage, faunal remains, and cultural features. In addition to the standard analyses of the cultural materials, special analyses were conducted on Pedernales point style frequency and their distribution, gastropods, Carbon 13 and oxygen isotope analyses on mussel shells and Rabdotus, lipid residues on burned rocks, magnetic sediment susceptibility, and data for paleoenvironmental reconstruction. Analytical Units 2, 4, 5, and 6 yielded the greatest information. Of particular importance is AU 6 that yielded 1 Gary, 1 Marcos, 1 Woden, and 18 Pedernales points (Mahoney et al. 2003). The AU 6 cultural materials date to around 3000 B.P., and recovered at a depth of between 1.5 and $2 \mathrm{~m}$. These deposits were indicative of low-energy flood waters with clays settling from suspension (Nordt et al. 2003). The floodplain dynamics indicate rapid and frequent overbank flooding and long-term changes in stream flow. Depositional Unit 1, at roughly 9.3 $\mathrm{m}$ below surface, contained the bulk of the cultural materials, began to be deposited prior to 4390 B.P. and continued until near 1270 B.P. (Nordt et al. 2003). Nordt et al. (2003) noted a period of landscape stability and soil formation around 1000 B.P. along Little River and in adjacent river systems including the Lampasas and Leon rivers. Multiple research questions were addressed with the data. The site specific data has made significant contribution to the immediate area and surrounding region both in terms of the cultural aspects and the geomorphology.

Also in Milam County, eligibility assessment of the Barrett site (41MM382) yielded relevant radiocarbon dated components and a Pedernales point from stratified context in the valley of the San Gabriel River (Quigg et al. 2014). Excavation of four mechanical trenches (ca. 42 linear meters) plus $11.4 \mathrm{~m}^{3}$ of hand-excavations in nine test units (100by $-50 \mathrm{~cm})$, revealed multiple cultural events in a 60 $\mathrm{cm}$ thick alluvial zone from 100 to $160 \mathrm{cmbs}$. Twelve radiocarbon assays from noncultural materials (soil humates and Rabdotus snail shells) document a use period between 2500 and 3900 B.P. Mussel shells, burned chert cobbles, and lithic debitage dominated the cultural assemblages. Macrobotanical remains and animal bones were absent (Quigg et al. 2014).

Sites 41MM340 and 41MM382, both situated in the Blackland Prairie, yielded evidence of tool production, hunting, and cooking activities. However, due to the paucity of studied sites in this region during this period, patterns of seasonality, 
group mobility, and social interaction across this landscape are currently unclear.

Even though archeologists have made considerable strides towards understanding the Late Archaic period across parts of Texas, much of that period, especially between roughly 4000 and 2500 B.P., remains unknown and needs thorough documentation through more in depth excavations and diverse analyses of data sets. Johnson (2000:1) indicates that "sites with deposits dating to the Late Archaic I sub-period (as at Kruze) are not at all well-documented on the Blackland Prairie." One major area of relatively limited knowledge is the use of plant resources. Although the prehistoric occupants are often referred to as hunter-gatherers, we still have limited knowledge of the 'gathered', including plants utilized, processing techniques, and various uses. Nuts (specifically pecans, hickory, acorns, and walnut) and geophytes (onion, garlic, camas, etc.), have been documented as food resources, but are there others?

\subsection{THE LATE ARCHAIC PERIOD (400 TO 1300 B.P.) IN CENTRAL TEXAS}

In central Texas, the Late Archaic is currently divided into six intervals based on projectile point types (Collins 2004). Previously, Prewitt's (1976, 1981, 1985) original central Texas chronological sequence, used by the majority archeologists in most reports up to about 1995 consisted of three phases: Uvalde (Castroville, Marcos, and Montell points); Twin Sisters (Ensor points); and Driftwood (Mahomet [Darl] points). However, that general sequence as modified by Johnson and Goode (1994, 1995) and more recently by Collins (2004), is presently favored (Figure 3-2). As more sites are excavated and more radiocarbon dates obtained from good context, the actual timing of cultural events gradually becomes more secure and better defined (see Carpenter and Houk 2012, for an update on Late Archaic chronology).
The well-stratified Siren site (41WM1126), in Williamson County, contributes significant new radiocarbon dates for the end of the Late Archaic, the Transitional Archaic, and into the Late Prehistoric period (Figure 3-3). Unfortunately, as so often occurs, the early part of the Late Archaic (from ca. 4000 B.P. to 2500 B.P.) was not represented at that site. Many archeological sites that represent the latter part of the Late Archaic have been excavated, although few well-stratified components have been reported as represented, and even fewer have solid radiocarbon dates associated with robust cultural assemblages (Collins 1995, Table 2; Collins 2004, Figure 3.9a). Johnson and Goode (1994) provide a slightly different view by subdividing this period into early and late subperiods (Late Archaic I and Late Archaic II, respectively). The division is based on perceived changes in the archeological record. In the Late Archaic I, common dart point styles include Bulverde, Pedernales, Marshall, Montell, and Castroville. Marcos, Ensor, Frio, Darl, and Figueroa styles are common in Late Archaic II. Johnson and Goode (1994) indicate a time of about 2500 B.P. for the division of the two subperiods.

Although the projectile point sequence has not changed drastically from Prewitt's original work (1981, 1985), Johnson and Goode (1994) altered the projectile point chronology by placing the Bulverde, Pedernales, and Marshall points of Prewitt's Middle Archaic into their Late Archaic period. As a result, in order to prevent confusion, a researcher must qualify their use of general time period (i.e., Middle or Late Archaic) by specifying which chronology is being followed. The Johnson and Goode (1994) division, with the Marcos type occurring later than the Montell and Castroville, is also potentially problematic, as many researchers consider these points to be contemporaneous.

Two sites that possess good archeological context (i.e., radiocarbon dates and Uvalde phase projectiles [Marcos, Montell and Marshall types]) 


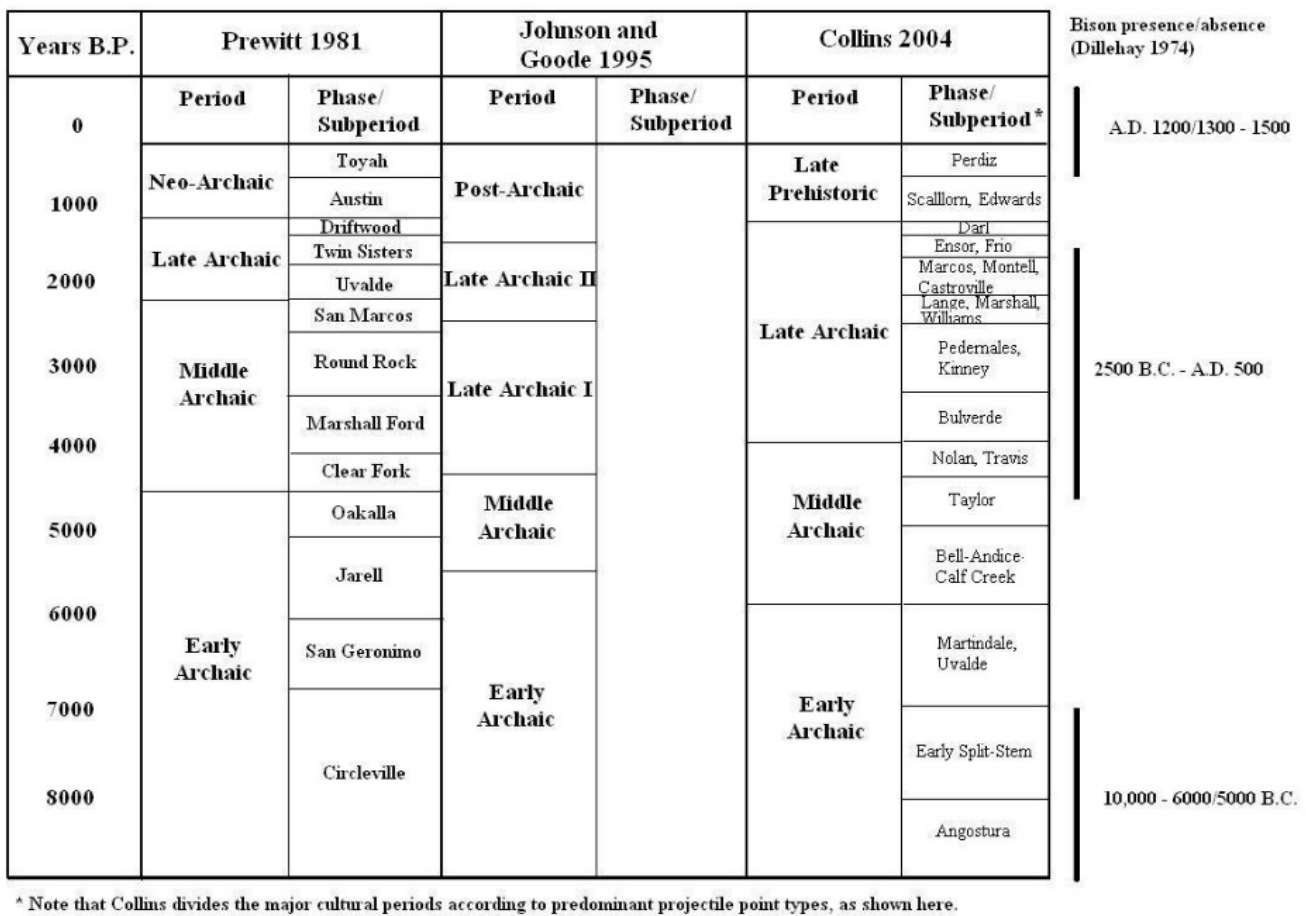

Figure 3-2. Comparisons of the old (Prewitt 1981) and new central Texas chronologies (Collins 2004).

are 41TG91, many kilometers west of 41BL278 in Tom Green County, and Culebra Creek site (41BX126) at the base of the Balcones Escarpment near San Antonio in Bexar County. At 41TG91 (East Levee), Marcos points are associated with three radiocarbon dates of $2910 \pm 270$ B.P. (Tx4764B), $2540 \pm 80$ B.P. (Tx-4764A), and $2480 \pm 60$ B.P. (Tx-4761) (Creel 1990). At Culebra Creek, three Montell points and one Marshall point came from a thin burned rock midden (Feature 2) associated with two charcoal dates of $2700 \pm 50$ B.P. (NSRL-3520) and $2780 \pm 50$ B.P. (NSRL-3519) (Nickels et al. 2001). These two sites document the age of Uvalde phase point types by associated radiocarbon dates and indicate these types can occur as separate entities.

Also at Culebra Creek, a rare and distinct Nolan component was present in Area B (Nickels et al. 2001). Three features (Features 7, 11, and 12) were identified in the component. Feature 7, referred to as an oven, yielded two Nolan points. A radiocarbon date on charcoal at the base of Feature 7 was $4940 \pm 50$ B.P. (NSRL-3697), with a second charcoal date of $4630 \pm 40$ B.P. (NSRL-3698) from the upper portion (Nickels et al. 2001). Other dart points in the component include one Tortugas, one Langtry, one Nolan-like, and three other Nolan points. Interestingly, fish otoliths were present and dated in Feature 7, but their dates were 1,750 to 3,060 years older than the associated charcoal dates (Nickels et al. 2001).

Pedernales points representative of the Collins (2004) Late Archaic scheme occur across much of central Texas, including the Blackland Prairie, as indicated by sites such as Bessie Kruze (Johnson 2000), 41MM340 (Mahoney et al. 2003), and 41MM382 (Quigg et al. 2014). Pedernales points are even found further east in the Post Oak Savanna at such sites as Bull Pen (41BP280) (Ensor and Mueller-Wille 1988) and Kennedy Bluffs (41BP19) (Bement 1989) in Bastrop County. Many sites in central Texas have yielded Pedernales points, 


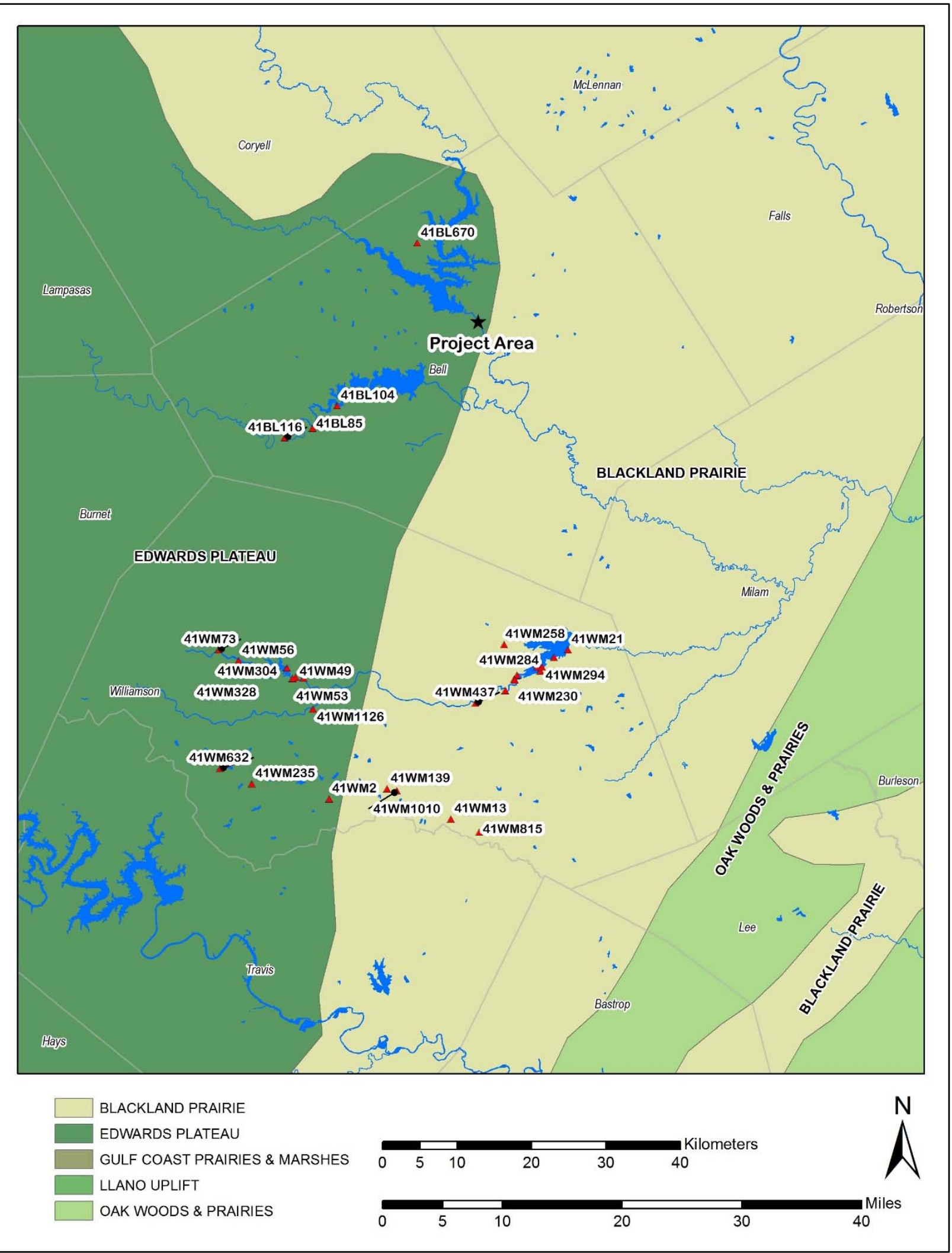

Figure 3-3. Selected Late Archaic sites in the vicinity of 41BL278. 


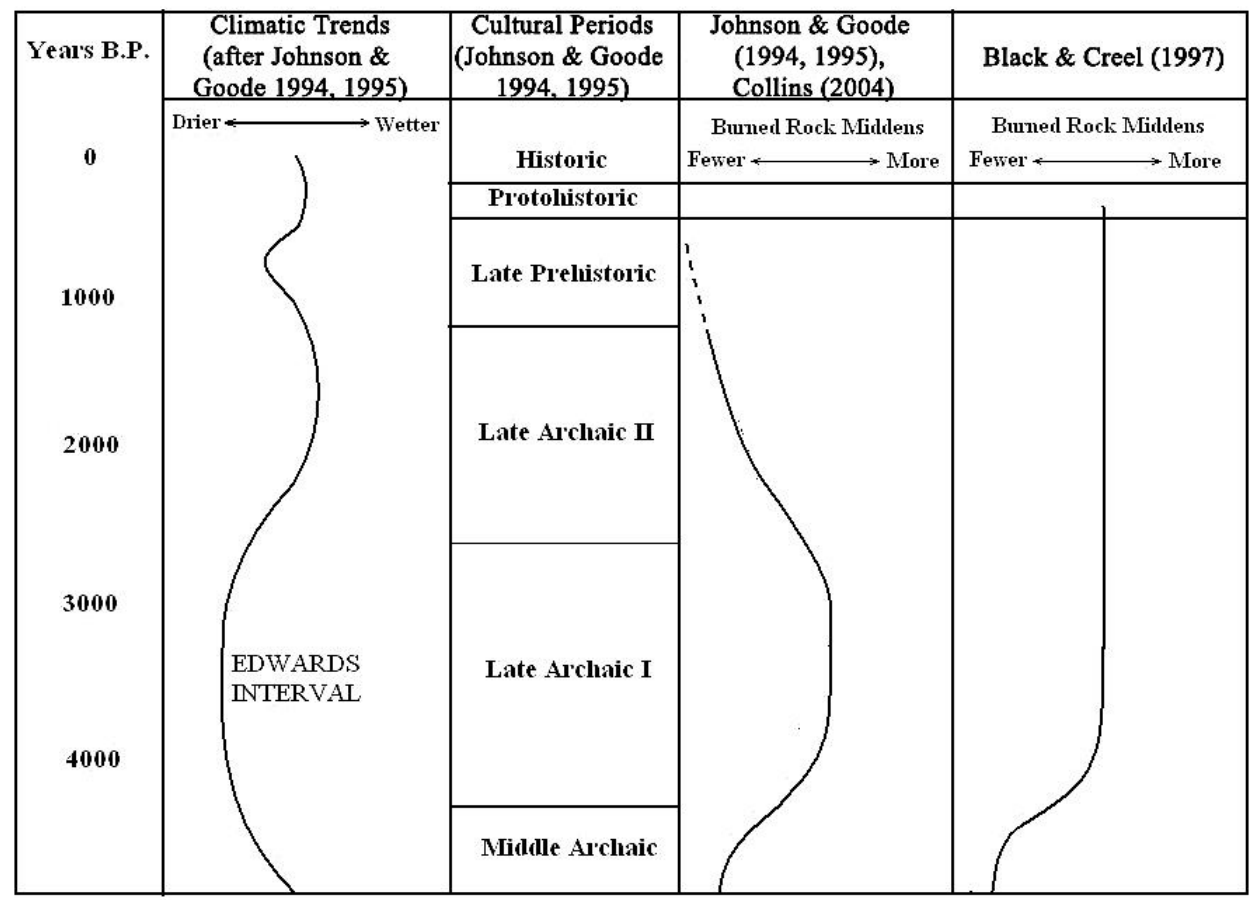

Figure 3-4. Schematic illustration of interpretations of intensity of burned rock midden formations through time.

including sites in Bell and Coryell Counties. The Round Rock phase is well-represented at Fort Hood (i.e., Quigg 1996). Pedernales points represent about 16 percent of all dart points from 571 sites at Fort Hood (Callister et al. 1994). A gap in the 35 radiocarbon dates from 56 tested sites in Fort Hood was detected between 3500 and 3200 B.P., during Prewitt's Round Rock phase. At least 19 Pedernales points were recovered from 27 tested sites prior to 1996 at Fort Hood (Quigg 1996:666).

Burned rock middens, thought to have debuted in the Middle Archaic period (Black and Creel 1997; Prewitt 1981; Weir 1976), continue through the Late Archaic period (Figure 3-4), some with welldefined central pit features or rock ovens (i.e., Black and Creel 1997; Mauldin et al. 2003; Ricklis and Collins 1994).

Collins (2004:121) states that the burned rock middens reached their peak use during this time, especially in the eastern parts of the area. Many researchers believe the rock ovens and large middens represent the cooking of bulk plant resources such as sotol or lechuguilla that require long periods of heating to make consumption a possibility. An older alternate hypothesis based on the strong co-occurrence of oak trees and burned rock middens is that these features were used to process acorns (Creel 1986, 1991, 1997). More recently it has been directly demonstrated by the identification of carbonized plant parts that geophytes (tubers, bulbs and roots) were cooked in burned rock ovens and middens (i.e., Dering 1997, 1998, 2003a; Mauldin et al. 2003; Mehalchick et al. 2004; Quigg, Lintz et al. 2011).

Cooking geophytes occurred in the Blackland Prairie region during the Late Archaic (i.e., at 41WM815 [Brownlow 2003]), and even in earlier periods, such as demonstrated at the Armstrong site (41CW54) (Schroeder and Oksanen 2002; Dering 2002), the Holt site (41HY341) (Brownlow 2004), and the Berdoll site (41TV2125) (Karbula et al. 2011). Chemical residue analysis on burned rocks from a large central cooking feature in a burned rock midden at Mustang Branch (41HY209) revealed animal residues present (Loy 1994). Other 
smaller burned rock dumps, scatters, basins, and flat hearths have been recognized at various sites during the Late Archaic. The function of most small features has never been demonstrated.

Burned rock midden distribution studies reveal the most intense concentration of middens is in southwestern Texas around the Del Rio region (Mauldin and Nickels 2003). Few counties east of the Edwards Plateau reveal many middens. No burned rock midden sites were reported in Bell County by Mauldin and Nickels (2003:225), although 22 percent of the recorded sites in Williamson County were burned rock middens. A potential reason for their limited numbers in the Blackland Prairie is the lack of rock for extensive cooking of the bulk resources such as bulbs and tubers. However, a few known sites in Blackland Prairie settings such as Rice's Crossing (41WM815) (Brownlow 2003), 41BL672 (Carpenter et al. 2006), the Holt site (41HY341) Brownlow 2004), and 41BL1214 (Griffith and Kibler 2005) all revealed large burned rock oven features that appeared to have cooked geophytes. At the Berdoll site, five radiocarbon dates on wood charcoal from Feature 11 date a $2.0 \mathrm{~m}$ diameter rock oven to a range of 7854 to 8103 B.P. (Karbula et al. 2011). Two radiocarbon dates, one of $4740 \pm 40$ B.P. (Beta-191422) on wood charcoal, and one of $5160 \pm 40$ B.P. (Beta-191738) on Rabdotus snails, date a $3.5 \mathrm{~m}$ diameter earth oven in Zone III at Holt (Brownlow 2004). Both these sites document the long-term usage of rock ovens in the Blackland Prairie and testify to resource availability over that long time span.

In addition to the exploitation of resources cooked with hot rocks, bison were also part of the subsistence base for certain periods within the Late Archaic, principally associated with Montell points (Mauldin et al. 2012). Mauldin and colleges (2012, Table 5.2) identified 18 'Initial Late Archaic' components (4450 to 2500 B.P.) from 77 sites investigated across central and south Texas, but only 39 percent had bison bones identified. The lack of identifiable bison bones may stem from the fact that much of the region has poor preservation of organic remains. Bison bones from the Barton site (41HY202), specifically Feature 17, yielded bone collagen radiocarbon dates of $1903 \pm 96$ B.P. (GX-15539) and $2169 \pm 95$ B.P. (GX-15540) (Collins 1994:186). This is the same period that bison were also present in the Lower Pecos region, as evidenced by the massive bison kill in Bone Bed 3 at Bonfire Shelter (41VV218), radiocarbon dated by two bone and two charcoal assays to between 2300 and 2850 B.P. and associated with Castroville and Montell points (Dibble and Lorrain 1967). Also this is the same time as northwest of here in Tom Green County at 41TG91 (East Levee) associated with Marcos points (Creel 1990). At the Landslide site (41BL85) in Bell County, a bison bone yielded an apatite date of $>3520$ B.P. (Tx-289) (Sorrow et al. 1967:41). Bison bones have also been recovered from Levels 6 and 7 at 41HY160 in San Marcos, and four were radiocarbon dated to between ca. 2475 and 3000 B.P. (Lohse 2013). Apparently, bison were widely distributed across much of Texas during the Late Archaic. However, few bison remains have been identified from excavated Late Archaic sites in the Blackland Prairie, where bison would have been expected (i.e., 41WM130 [Bond 1978]; 41WM230 [McDonald 1982]; 41WM13 [Johnson 2000]; 41WM815 [McClure 2003]; 41CW54 [Schroeder and Oksanen 2002]; 41MM340 [Meissner and Mahoney 2003]; 41WM1010 [Nash 2006]; 41TV540 [Meissner 2011]). As an example, only 1 of 31 features at 41WM130 yielded identifiable bison bones, which is from a nearly 4,000 piece assemblage (Bond 1978).

Deer were also a part of the utilized meat resources (i.e., Bond 1978; McClure 2003; McDonald 1982; Nash 2006; Sorrow et al. 1967:122;) as were riverine resources that included mussels (i.e., Gardner 2006; Howells 2003; Howells et al. 2003; Marie 2006; Sorrow et al. 1967). Both deer bones and mussel shells were directly associated with the Early Archaic features (ca. 7854 to 8066 B.P.) at the 
Berdoll site (Karbula et al. 2011). The latter example documents the long-term presence and exploitation of deer and mussels as two important food resources.

Plant subsistence evidence is generally sparse for many Late Archaic sites. However, a few investigated sites that represent multiple time periods such as; the Armstrong site (41CV54) (Dering 2002), Rice's Crossing (41WM815) (Dering 2003), 41TV540 (Dering 2011), the Shepherd site (41WM1010) (Dering 2006), the Toyah Bluff site (41TV441) (Karbula et al. 2001), and the Berdoll site (41TV2125) (Karbula et al. 2011) definitively document geophytes were available and often sought in this region. Nuts from various trees, such as oaks (Quercus sp.), pecans (Carya sp.), and walnut (Juglans sp.) were exploited and available throughout much of the Holocene. Bryan Fox (41WM124) and Loeve-Fox (41WM230) are two sites where wildrye grass (Elymus sp.) seeds and needlegrass (Stipa sp.) seeds have been documented (Crane 1982). Also at Loeve-Fox were charred grape seeds (Vitis sp.), dock seeds (Rumex sp.), sunflower seeds (Helianthus sp.), and pokeberry seeds (Phytolacca sp.), and possibly wildrice (Zizania sp.) (Crane 1982:15-7).

Lithic resources for the production of stone tools are common across the southern portions and eastern margins of the Edwards Plateau, and along the many rivers that cross the region (Frederick et al. 1994). Fort Hood Military Reservation, just upstream from this project, contains volumes of chert resources, especially Edwards chert, with an excess of over 32 varieties identified (e.g., Frederick and Ringstaff 1994; Mehalchick et al. 2004; Trierweiler 1994). Cowhouse Creek, the major tributary to the Leon River, with confluence just upstream from this project, cuts across the Fort Hood and the plentiful chert deposits. Quantities of chert cobbles have probable distribution throughout gravels all along the Leon River valley and likely in the adjacent uplands (i.e., 41BL1218 [Ringstaff 2004]).

Cemeteries were in use in central Texas during the Late Archaic, as demonstrated by sites such as the following examples. The Bessie Kruze site (41WM13) in Williamson County yielded a massive grave with three mingled skeletons in Zone II, dated to around 2440 B.P. (Beta-94000), which contained Pedernales points among the bones. Two human cremations were also in Zone III dated to around 3020 B.P. (Beta-94002) (Johnson 2000). At Olmos Dam (41BX1), in Bexar County far to the south (Lukowski 1988), at least some, if not all, 13 burials can be attributed to the Late Archaic period. At least two infant burials, one discovered flexed and associated with grave goods that included whitetail deer antlers, traces of ocher, and chert cobbles, associated with charcoal radiocarbon dates of $2200 \pm 70$ B.P. (Tx-3989), and $1920 \pm$ 160 B.P. (Tx-3993). Isolated burials are also present, as indicated by a semiflexed 35 to 45 year old male at 41LL356, buried $2.2 \mathrm{~m}$ deep in an alluvial terrace in Llano County (Bement 1993). This body was associated with a complete Ensor dart point near the dorsal side of the spine, opposite the lower thoracic vertebrae, which might indicate cause of death. Another example is the Carpenter Bend site (41TV2242) in Travis County, where an adult (aged greater than 50 years) male single burial was radiocarbon dated to 1350 B.P. This was a tightly flexed burial below several rock slabs (Malof and Taylor 2011). Another isolated burial, radiocarbon dated to 2015 B.P. (UCIAMS111181), was from Spring Lake (41HY160) (Lohse et al. 2013). There a single adult male was buried in a flexed position with no grave goods. Carbon isotope data from the latter two individuals (-18.3\%o and $-18.6 \%$ ) indicates these individuals were consuming inland plant and animal resources, as expected (Lohse et al. 2013; Malof and Taylor 2011).

The sporadic current evidence from the long Late Archaic period at various investigated sites in the Blackland Prairie and adjacent Edwards Plateau indicate small, highly mobile family groups utilized the region and employed a broad spectrum resource subsistence strategy. The Late Archaic is generally viewed as a continuation of a generalized collection 
adaptation strategy, with population densities increasing from the preceding period. In viewing the distribution pattern of 17 Castroville-MontellMarcos sites in Camp Bullis in Bexar County, Kibler and Scott (2000:184) believe these to represent campsites of specialized bison-hunting peoples, but discovered that 65 percent occurred in zones with little or no potential for bison.

Recently, Lohse (2013:141) stated that "Archaeologist working in Central Texas often lack a clear and detailed understanding of many Archaic-period sequences, developments, and adaptations." This mostly stems from limited projects that encounter these age sites, poor preservation, and/or palimpsest events that prevent extraction of a complete and detailed data that limit our understanding. We still need to address these shortcomings through larger and more focused data recovery projects, combined with more intensive analyses of diverse data sets.

\subsection{SUMMARY}

Although scattered excavations that represent most of the 14 Late Archaic time units (see Collins 2004) have occurred in the general central Texas region, few sites with extensive artifact assemblages, goodto-excellent context, with good preservation conditions, have been intensively excavated and thoroughly analyzed for the earlier part (2500 to 4500 B.P.) of the Late Archaic period. More extensive investigations and detailed analyses are needed to understand this little known 2,000 year time period in terms of subsistence and lithic resource procurement, trade, mobility, belief systems, and interactions with adjacent populations. Although limited excavations were conducted, a multidisciplinary approach with diverse technical analyses was employed to extract information concerning this component. As Collins (2004:122) stated, "Much remains to be learned about the hunter-gatherers of central Texas in Late Archaic times, and the questions prompted by the interpretations of Johnson and Goode (1994) will require thorough and comprehensive archeological investigations using data of the highest possible integrity." 
This page intentionally left blank. 


\subsection{METHODS}

J. Michael Quigg

\subsection{INTRODUCTION}

Dr. Owen Lindauer, Supervisor of the Archeological Studies Program of TxDOT's Environmental Affairs Division in 2004; Jon Budd, TxDOT district archeologist; and the senior author and Principal Investigator, visited the APE, which also contains part of site 41BL278 on April 26, 2004, to develop a strategy for the archeological assessment and testing program described in this report.

In the following sections, the general field methods for the project are presented. First, the agreed upon geophysical approach is explained, followed by the archeological field methods employed. Then the laboratory procedures that include the analytical methods, terminology, and technical analyses that document the findings are presented. Lastly, curation of materials and data is discussed.

\subsection{GEOPHYSICAL METHODS}

Prior to initiating the archeological fieldwork, two days of geophysical investigations were conducted on $840 \mathrm{~m}^{2}$ of TxDOT APE at the northwestern end of 41BL278. TRC proposed the use of an electrical resistivity study as a potentially useful, nondestructive approach to locate deeply buried cultural features that could guide the subsequent archeological testing. It was anticipated this technique would help determine the general depth, thickness, and horizontal location of potential burned rock features and/or other material concentrations buried in the top $2 \mathrm{~m}$ of alluvial deposits across the $\mathrm{T}_{1}$ terrace of the Leon River.

TxDOT granted TRC permission to implement this investigation strategy. Melanie Crisp, TRC Staff Geologist in 2004, aided by Shane Pritchard, TRC Environmental Scientist, and the senior author, conducted the geophysical fieldwork in May 2004

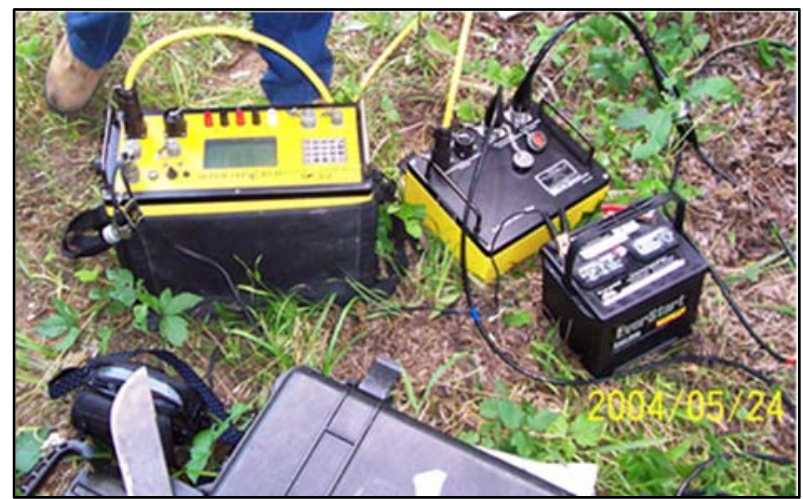

Figure 4-1. Electrical resistivity equipment employed in the geophysical study.

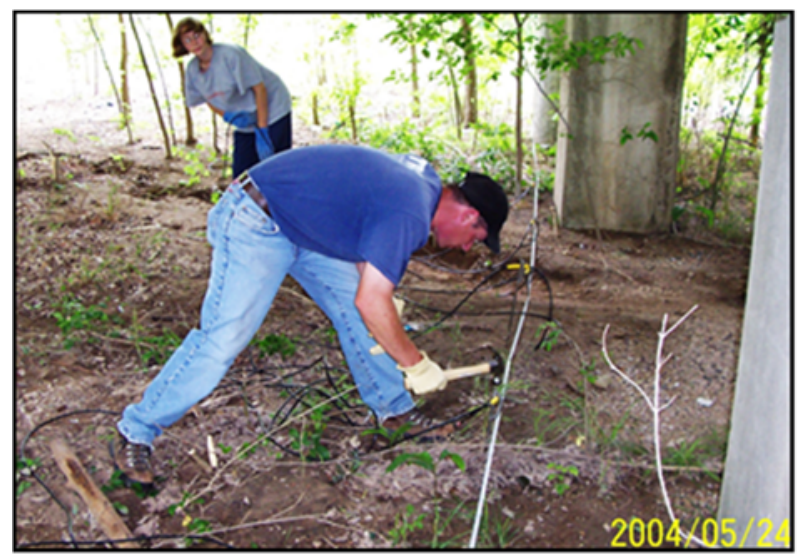

Figure 4-2. Setting resistivity probes at $1 \mathrm{~m}$ intervals in APE.

(Figures 4-1 and 4-2). The initial step was to clear the vegetation across the projected area for gridding the selected study area. No large trees had to be removed and only the poison ivy caused problems.

Once cleared, the projected 18 east-west lines were measured off and staked in $1 \mathrm{~m}$ increments starting from the southern end and working northward to about the southern edge of previously excavated BTs 7 and 8 (Figure 4-3). Line 19, which was about $26 \mathrm{~m}$ long, ran perpendicular to the other 18 survey lines through the approximate middle of the surveyed area as a cross-check. The first 13 survey lines were $50 \mathrm{~m}$ long, whereas the last 5 survey lines were $28 \mathrm{~m}$ long. Each survey line had electrical probes driven into the ground at $1 \mathrm{~m}$ intervals. The total area electrically probed at $1 \mathrm{~m}$ intervals 
covered $840 \mathrm{~m}^{2}$ across the southern three-quarters of the APE.

The resistivity investigations encompassed much of the broad, flat terrace under the eastern side of the bridge overpass within the existing and proposed new TxDOT right-of-way from the southern eastto-west oriented fence line under the elevated highway bridge near the foot of the highway embankment northward (see Figure 4-3). Individual east-west lines were the actual survey lines employed with identification transect numbers on the right side. The red diamonds are the approximate locations electronic anomalies that Crisp interpreted as potential cultural features. The two dark parallel lines to the left side represent the margins of the overhead bridge.

Following this electrical resistivity fieldwork, the recorded data was downloaded and processed by Crisp, who then provided TRC archeologists with 18 pages of vertically depicted line data (Appendix C). Each page of data displayed three vertical, scaled, colored graphics depicting the measured apparent resistivity pseudosection and calculated apparent resistivity pseudosection, followed by inverted, normalized resistivity section. Crisp interpreted the data and identified nine anomalies, five of which were considered low probability (Anomalies 2, 4, 5, 6, and 9), two of questionable probability (Anomalies 7 and 8), and two with high probability (Anomalies 1 and 3) of representing potential buried cultural materials near or within the 1 to $2 \mathrm{~m}$ deep target depth (see Figure 4-3). The approximate horizontal locations of the nine anomalies were provided on a scaled map prior to the archeological fieldwork. The two high potential anomalies (Anomalies 1 and 3) were subsequently targeted for verification through mechanical excavation.

During the following testing fieldwork, the horizontal positions of the two high potential anomalies were located on the ground and backhoe trenches were excavated to remove overburden at those two locations. Thin layers of sediment were carefully scraped away at each targeted location until evidence of the anomaly was encountered (Figure 4-4).

\subsection{ARCHEOLOGICAL FIELD METHODS}

Four new backhoe trenches (BTs 11 through 14) were excavated in the northern, central, and southern terrace deposits within the current and proposed new right-of-way under and east of the elevated bridge (Figure 4-5, Table 4-1).

Unfortunately, TxDOT had not received right-ofentry for the proposed expansion of new right-ofway west of the north-south fence line. Therefore, no archeological assessment was undertaken west of the existing bridge right-of-way. Backhoe Trenches 7, 8, and 9, excavated during the original archeological survey, were reopened to provide access to the buried cultural deposits and features previously discovered. Once reopened down to the top of the previously identified cultural zone and features, the overburden on one side of each trench and above the targeted cultural deposits was mechanically removed to just above the targeted zone (ca. $130 \mathrm{cmbs}$ ). This created linear platforms that varied from 3 to $7 \mathrm{~m}$ long by about 1 to $2 \mathrm{~m}$ wide parallel to the backhoe trenches. These roughly $130 \mathrm{~cm}$ deep platforms allowed for 1-by-1 $\mathrm{m}$ test units (TUs) to be established and then excavated, which facilitated access to the targeted cultural zone between 130 and $180 \mathrm{cmbs}$ (Figure 4$6)$.

Four new backhoe trenches (BTs 11 through 14), that totaled approximately 34 linear meters, were also excavated in the APE to locate additional cultural deposits and to investigate the two high probability geophysical anomalies identified during the resistivity study (see Figures 4-5 and 4-7). Backhoe Trenches 12 through 14 were profiled by TRC's geoarcheologist Charles Frederick. Backhoe Trenches 11 and 12 were excavated to uncover high potential geophysical Anomalies 1 and 3 (see 


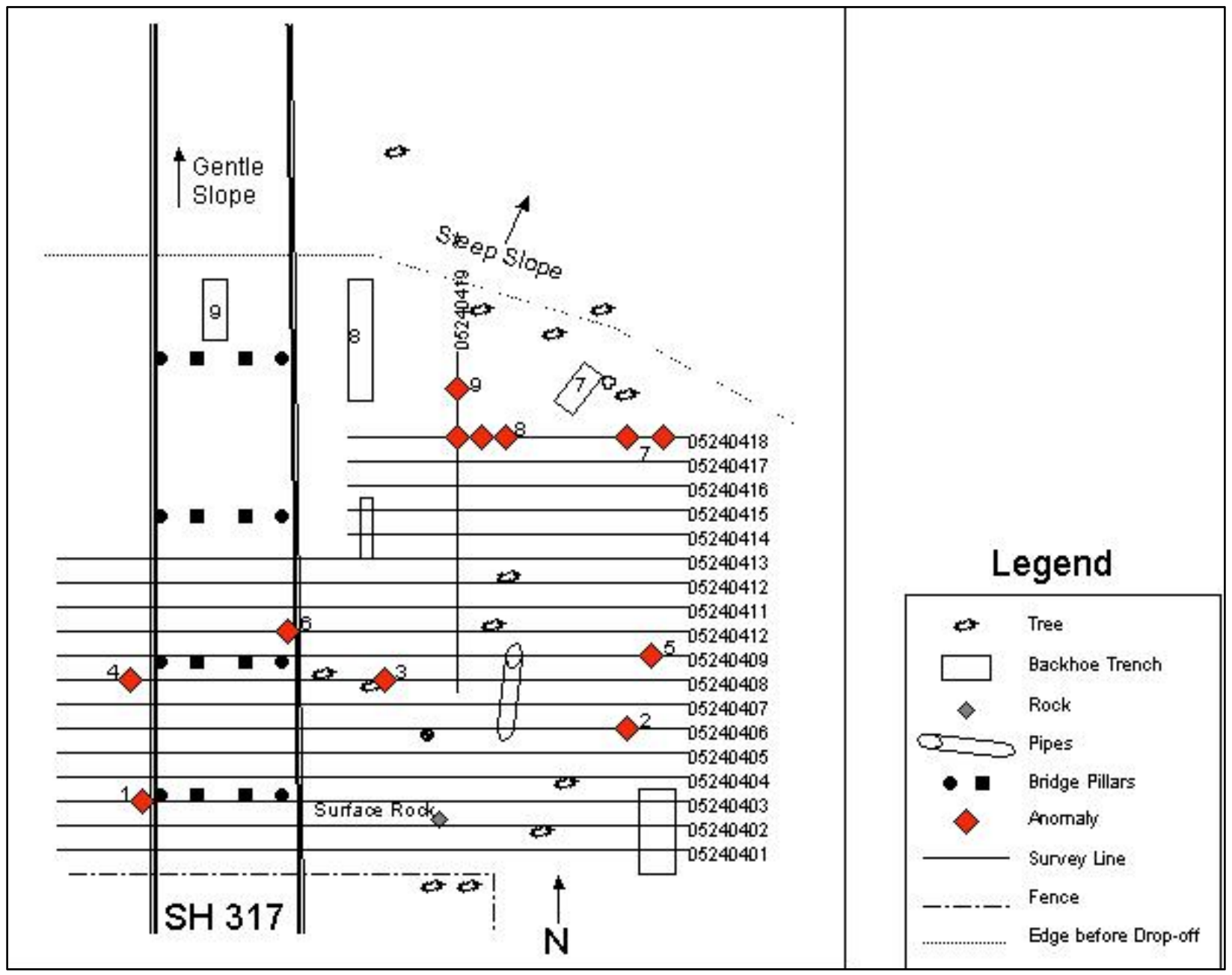

Figure 4-3. Numbered lines of resistivity and locations of anomalies across APE.

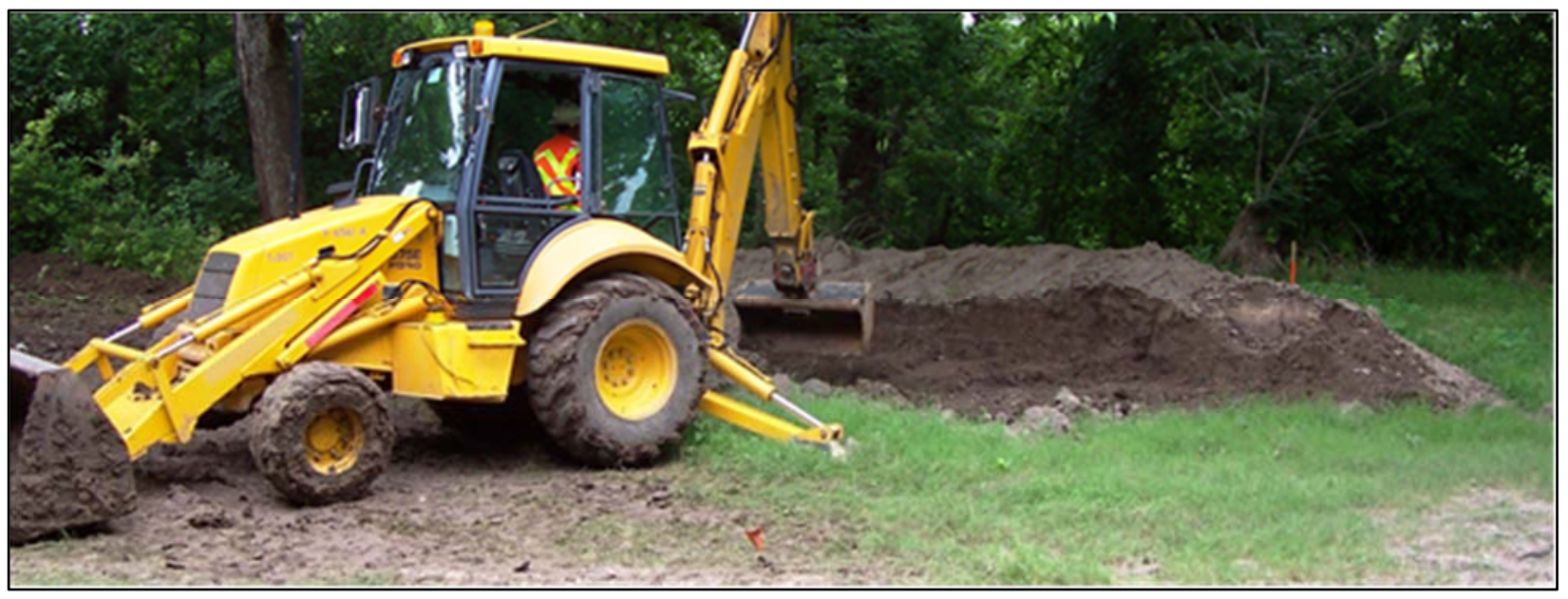

Figure 4-4. Backhoe removing sediments at Anomaly 3 at 41BL278. 


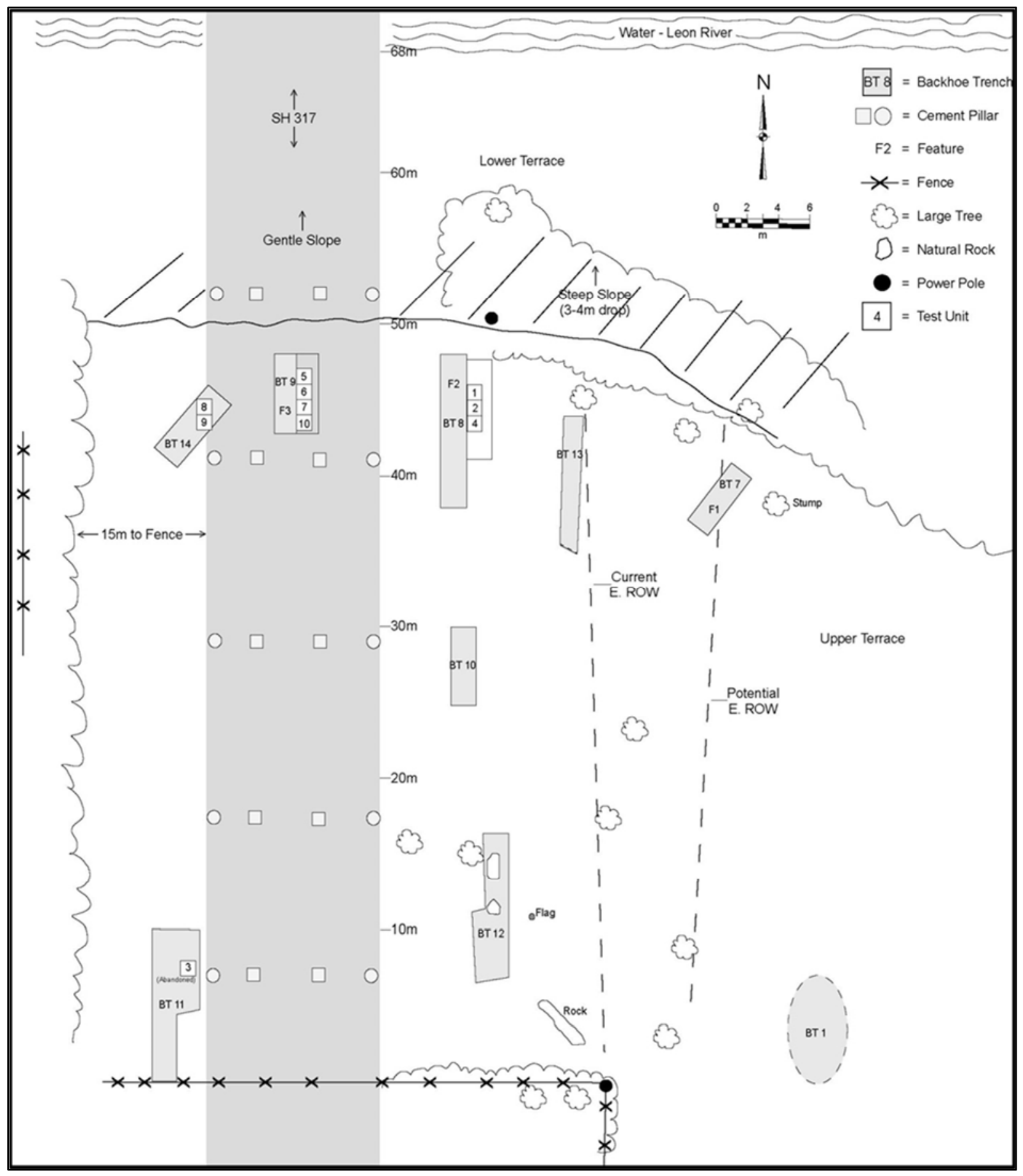

Figure 4-5. Plan map of APE at 41BL278 showing locations of backhoe trenches and handexcavated units. 
Table 4-1. Backhoe Trench Data in the Proposed APE at 41BL278.

\begin{tabular}{|c|c|c|c|c|c|c|}
\hline $\begin{array}{c}\text { Trench } \\
\text { No. }\end{array}$ & $\begin{array}{l}\text { Length } \\
\text { (m) }\end{array}$ & $\begin{array}{c}\text { Width } \\
\text { (m) }\end{array}$ & $\begin{array}{l}\text { Depth } \\
\text { (cm) }\end{array}$ & Location & Comments & Reference \\
\hline 1 & Unknown & 1.8 & 130 & Paleochannel & No cultural material observed & Ringstaff 2004 \\
\hline 4 & Unknown & 1.8 & 150 & Ridge on $\mathrm{T}_{1}$ & Quantities of mussel shells in Bkb soil & Ringstaff 2004 \\
\hline 7 & Unknown & 1.8 & 170 & Ridge on $T_{1}$ & Feature 1 between $105 \& 155 \mathrm{cmbs}$ in Bkb soil & Ringstaff 2004 \\
\hline 8 & Unknown & 1.8 & 170 & Ridge on $T_{1}$ & Feature 2 between $145 \& 170 \mathrm{cmbs}$ in Bkb soil & Ringstaff 2004 \\
\hline 9 & Unknown & 1.3 & 142 & Ridge on $T_{1}$ & Feature 3 between $125 \& 142 \mathrm{cmbs}$ in Bkb soil & Ringstaff 2004 \\
\hline 10 & Unknown & 3.5 & 175 & Ridge on $\mathrm{T}_{1}$ & Cultural material at $170 \mathrm{cmbs}$ & Ringstaff 2004 \\
\hline 11 & 10 & 1.8 & 250 & Paleochannel & No cultural material observed & this report \\
\hline 12 & 9 & 3 & 210 & Paleochannel & No cultural material observed, 2 large natural rocks & this report \\
\hline 13 & 9 & 1.8 & 150 & Ridge on $\mathrm{T}_{1}$ & No cultural material observed & this report \\
\hline 14 & 6 & 1.8 & 150 & Ridge on $\mathrm{T}_{1}$ & No cultural material observed & this report \\
\hline
\end{tabular}

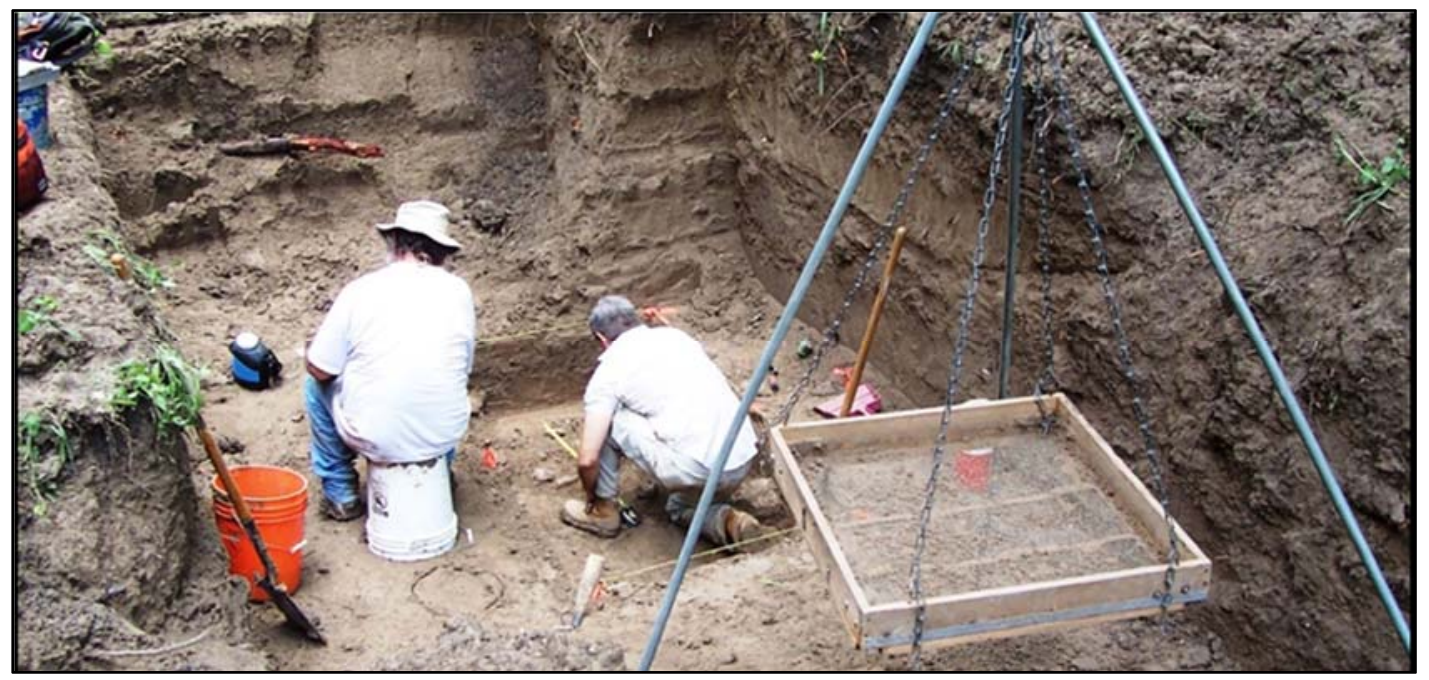

Figure 4-6. Hand-excavation in test units at bottom of Backhoe Trench 14.

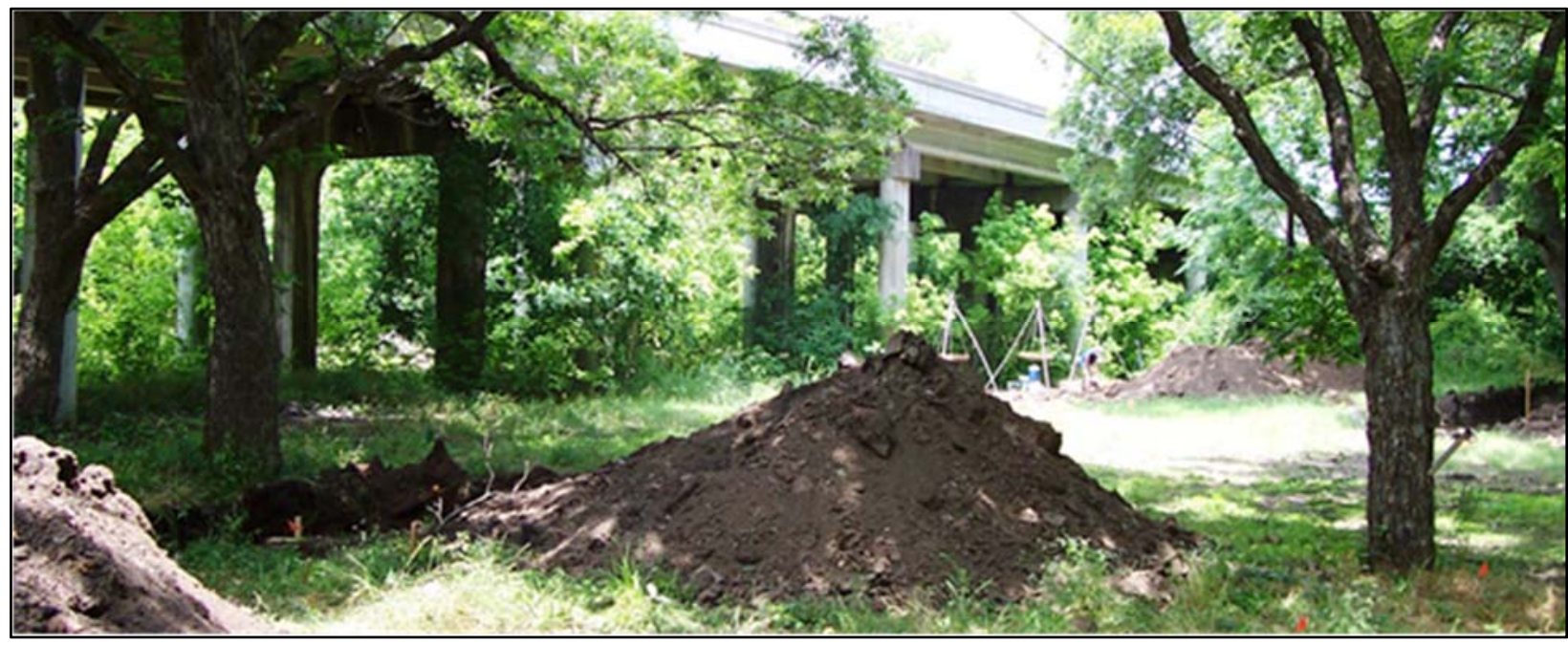

Figure 4-7. Overview of APE, with Backhoe Trench 12 in foreground, and Backhoe Trenches 8 and 13 in background, on eastern side of bridge (facing northwest). 
Figures 4-3 and 4-5). Backhoe Trench 11 was excavated near the southern edge of the $T_{1}$ terrace, under the southwestern edge of the overhead bridge, and targeted geophysical Anomaly 1. Test Unit 3 was initiated along the eastern side of BT 11 to further explore the nature of Anomaly 1. Backhoe Trench 12 near the southeastern side of the APE targeted geophysical Anomaly 3. Backhoe Trench 13 was excavated at the northern edge of the terrace from the top of the levee southward along the eastern edge of the existing right-of-way to obtain information about the interface between the presumed Ford Alluvium and the West Range Alluvium, and to document how they interfaced away from the levee crest. Backhoe Trench 14 was towards the northwestern end of the elevated bridge (see Figure 4-5) to determine if the cultural deposits continued along the levee-like feature that runs parallel to the river.

The fieldwork was hampered by two interrelated problems. The first dealt with backhoe and operator availability, while the second centered on the unusually intense June rainfall that occurred during the summer of 2004. Due to heavy rains and the road related clean-up that resulted, TxDOT was unable to provide a backhoe and operator for our needs. This delayed the initiation of handexcavations, as the backhoe was required to uncover the deeply buried cultural component. As a contingency, a private backhoe and operator was procured. However, it broke down after limited trenching had been accomplished. Eventually, this problem was resolved, but the delays and tight field schedule ultimately limited the number of backhoe trenches excavated.

The unusually heavy June rainfall in the project area during the archeological testing complicated and slowed the field investigations (Figure 4-8). Opened trenches and excavation units repeatedly filled with water, which in some cases had to be artificially drained to allow work to continue. Even when standing water was not in the units, the wet clay loam was difficult to dig and screen as short periods between rainstorms did not allow sediments to dry out. Water filled backhoe trenches tended to perform similarly to underground aquifers and leaked water slowly into adjacent open test units.

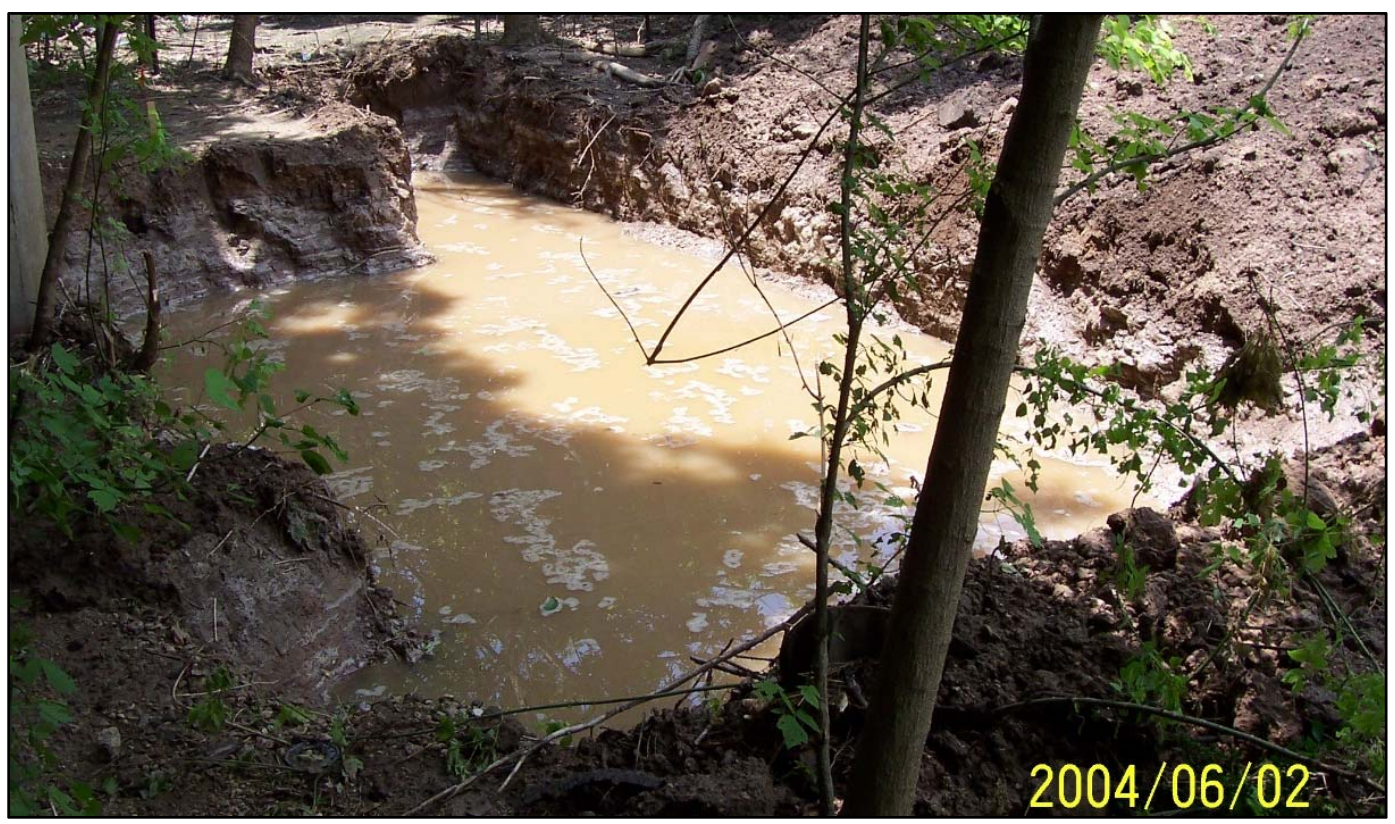

Figure 4-8. Backhoe Trench 11 and Test Unit 3 at Anomaly 1 filled with rainwater. 
A total of 10 1-by-1 $\mathrm{m}$ hand-excavation units were opened to sample the buried cultural component in the APE at the northwestern end of site 41BL278 (see Figure 4-5). These units were not handexcavated from the original surface, but started at various depths from roughly $130 \mathrm{~cm}$ deep platforms created by the backhoe adjacent to opened backhoe trenches. Vertical control was maintained through measurements from below surface (bs). Nine handexcavated units were positioned to target and sample the cultural zone identified during the survey phase in BTs 7, 8, and 9 (Ringstaff 2004). Test Unit 3 was placed adjacent to BT 11 to investigate geophysical Anomaly 1. However, after the excavation of only a single $10 \mathrm{~cm}$ level, both TU 3 and BT 11 filled with water during a heavy rainstorm and, despite attempts at pumping, never dried out (see Figure 4-8). No further excavations could be accomplished in that location. Test Units 1, 2, and 4 were established on the eastern edge of BT 8 next to Feature 2 (see Figure 4-5). Test Units $5,6,7$, and 10 were placed on the eastern edge of BT 9 in the vicinity of Feature 3. Test Units 8 and 9 were positioned in the bottom of BT 14.
Test units were hand-excavated in arbitrary $10 \mathrm{~cm}$ levels, and excavated sediment was screened through $6.4 \mathrm{~mm}$ (0.25 in.) hardware cloth. A TRC excavation level form was completed for each hand-excavated level. When sizable pieces of cultural materials or features were encountered in situ, items were piece plotted/point provenienced on TRC excavation level records and the bottom elevation of the object was recorded. Cultural materials (except for burned rocks) were bagged by unit and level in labeled, resealable plastic bags and returned to TRC's laboratory for processing and analysis. Burned rocks were generally sorted into preestablished size categories, counted, and weighed in the field, the data recorded on the level record forms, and then most rocks were discarded. Selected samples of burned rocks from both feature and nonfeature contexts were collected and transported to the laboratory for possible analyses.

Clusters of cultural materials recognized as features in the field were assigned specimen numbers and recorded on appropriate level records, and separate feature form was also completed for each (Figure 49). The portion of the feature within the test unit

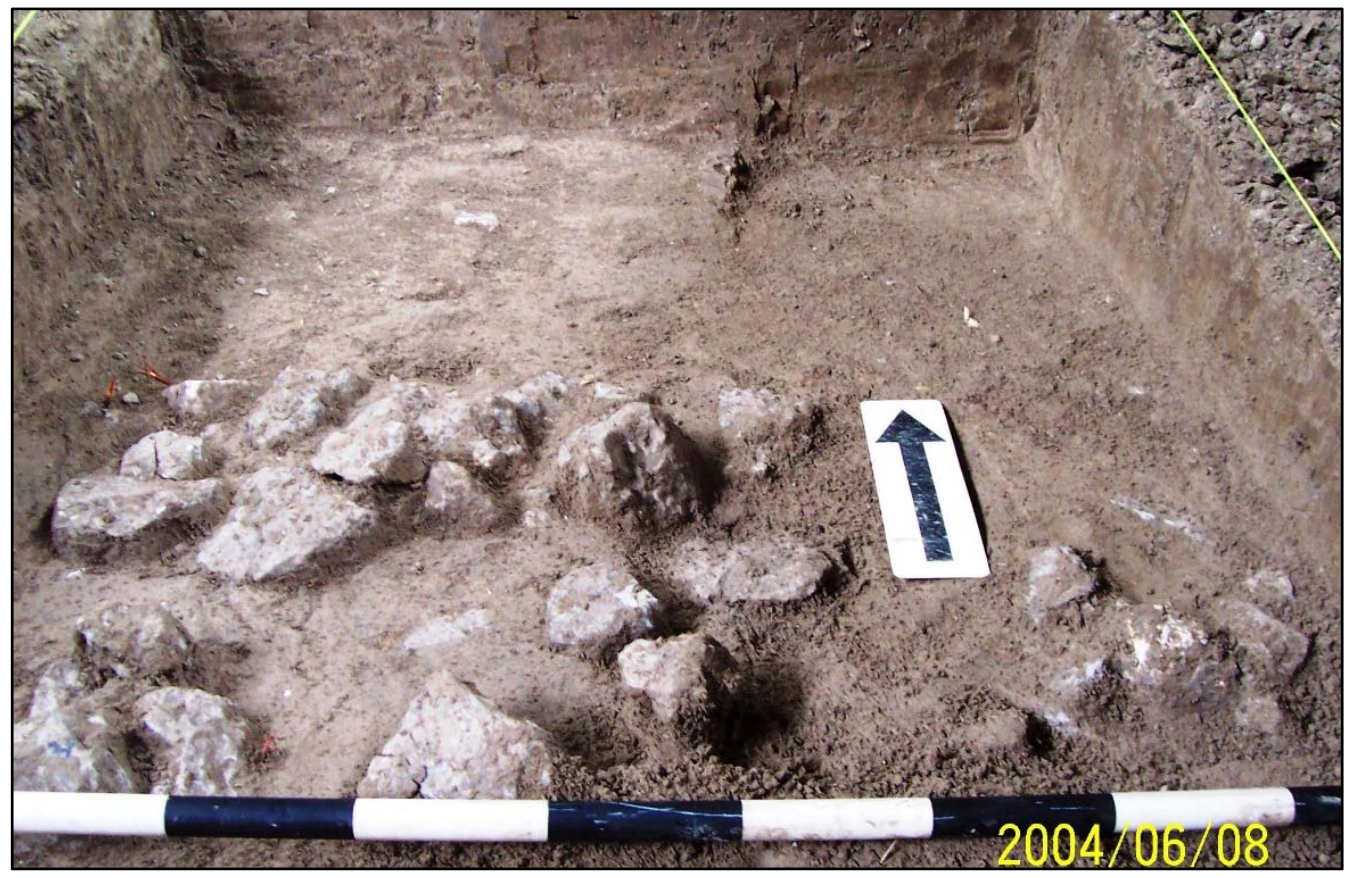

Figure 4-9. Example of clustered burned rocks identified as cultural Feature 3. 
was mapped, photographed, and artifact samples from the feature were collected.

Bulk sediment samples for macrobotanical, charcoal, flotation, fine screening, and other possible analyses were collected without screening and transported to the TRC laboratory in Austin for any further processing. These samples were judgmentally collected with the primary goals of placing the site deposits within a secure chronological framework and identifying data that may be pertinent to answering research questions. Technical analyses, such as testing for the presence/absence of phytoliths, identifying macrobotanical remains, radiocarbon dating, and identifying faunal bone, were anticipated to determine and refine data content of site deposits, assess the contextual integrity of these deposits, and address broad research questions about the chronology and nature of occupation(s) at the site.

Prior to backfilling, the west wall of BT 8 and the east wall of BT 9 were lined with long sheets of clear plastic. The west wall of BT 8 is $9.2 \mathrm{~m}$ from the east wall of BT9. These measures were intended to facilitate the relocation of our exact excavations.

\subsection{LABORATORY PROCEDURES AND TEHCNICAL ANALYSES}

Chipped and ground stone tools, lithic debitage, mussel shell, faunal bone, charcoal, and other cultural materials were washed (if appropriate), sorted, and counted following completion of the fieldwork. Initial field counts and an interim testing report with recommendations was completed and submitted to TxDOT (Quigg and Frederick 2004). The cultural materials and samples were temporarily curated at TRC's laboratory facilities in Austin, Texas from 2004 to 2015.

TRC artifact processing entailed the initial processing for use in the interim report. Prior to washing, all bags of lithic debitage were examined for formal and informal tools, including flakes with modified edges. All identified stone tools were bagged separately without washing or further handling. On unwashed specimens, a portion of one surface was cleaned so that an archivally stable ink label could be placed on the artifact. Nitrile gloves were used when handling these selected tools.

All cultural materials were assigned Provenience Numbers (PNUMs) and entered into an electronic database. These unique PNUMs were assigned to reflect separate excavation levels, as well as other proveniences. All provenience information available and pertinent data from the collection bags and level records were entered into a Microsoft Access format database.

TRC's cataloging system assigns strings of numbers to artifacts that encode information on provenience, artifact class, an unique identifier, and samples taken from the artifact or lot for specialized analyses. The PNUMs (e.g., \#155) were assigned to all artifacts such as lithic debitage, stone tools, and burned rocks. PNUMs are sequential numbers that designate the overall provenience unit (i.e., excavation unit, backhoe trench) and level, or depth, within that provenience unit and can be cross-referenced to a master list of PNUMs. Within each PNUM, various artifact classes were assigned a secondary designation, referred to as the artifact class or catalog number: lithic debitage (001), faunal bone (002), burned rock (003), soil (004), organic (005), shell (006), macrobotanical remains (007), ceramic sherds (008), and historic material (009). Individual tools and other unique items were assigned unique artifact numbers starting with the number 10 within the same unit and level designated by the PNUM. Thus, each specimen was assigned a PNUM and an artifact number (e.g., \#155-10, \#155-11, and \#155-12). The combination of PNUM and artifact class identifier creates the artifact catalog number.

About 1 in 10 items (10 percent) that occurred in bulk material classes (e.g., chert debitage) within specific provenience units (e.g., a level) were individually labeled as per Council of Texas 
Archeologists (CTA) standards. Specimen size was also a major consideration for labeling purposes, as many lithic pieces are less than $1 \mathrm{~cm}$ in diameter and were not labeled. Artifact labeling consisted of inscribing the State of Texas Archeological Site Trinomial (41BL278) and the artifact catalog number on designated artifacts using black indelible archival ink. After the ink was dry, the artifact labels were coated with clear Acryloid B-72 combined with reagent-grade acetone solvent to preserve the inscriptions.

Permanent paper tags were included with each individually bagged artifact or class of artifacts collected from a single provenience. These tags include the site trinomial, provenience information (unit and depth), the class or type of artifact(s), the date of excavation, the excavator's initials, and the quantity of items in the bag. These permanent tags were printed on acid free, $30.4 \mathrm{~kg}(67 \mathrm{lb}$.) cardstock and labeled with pencil.

\subsubsection{Analytical Methods}

Artifacts were subjected to different metric, nonmetric, typological, and specialized analyses, such as use-wear analysis. A set of predefined attributes for each material class were first encoded on paper, and then entered into TRC's electronic database management system utilizing Microsoft Access software, which constitutes the master database for the investigations in the APE at 41BL278. A copy of this database is provided on the $\mathrm{CD}$ attached to the back cover of this report. The specific data recorded for each class of artifact are presented below. Analytical methods pertinent to each data class and secondary suites of software used for specialized analyses are discussed in detail in the appropriate parts of this report.

\subsubsection{Chipped Stone Artifact Analysis}

A protocol for analysis of debitage and chipped stone tools has been developed by TxDOT archeological staff (TxDOT 2010) in an effort to standardize data collection and presentation in analytical and interpretive chapters of archeological reports sponsored by TxDOT. When possible, terminological and taxonomic uses follow those terms for this assemblage (Figure 4-10).

\section{Bifaces}

Bifacial tools, whether finely or crudely produced, appear to have completed the manufacturing process. This is evidenced by secondary retouch, edge straightening, hafting preparation, notching, and similar characteristics. Bifaces are defined predominantly on the basis of morphological characteristics, but they may also have functional associations (e.g., cutting, piercing, chopping, drilling). Bifacial tools exhibit purposeful, usually patterned, flake removals on both faces (ventral and dorsal). Most or all of both faces may be covered with flake scars, and in some cases one face may be completely modified, whereas the opposite face exhibits only partial modification. Bifaces may be fashioned either from large bifacial cores or from flakes. Included within this overall morphological category are diverse functional groups such as projectile points (see below).

\section{Projectile Points}

Projectile points are a functional subset of the biface class specifically designed to be hafted to the distal end of a shaft used in stabbing, throwing, or shooting. Projectile points are bifacial tools given their final form by means of fine secondary retouch, usually with basal modification in the form of notching, stemming, or thinning of the proximal end for purposes of hafting. Dart points, arrow points, and indeterminate dart/arrow points are all classes of projectile points. Dart points are those employed to tip hand-held darts or spears, arrow points are used to tip arrows, and indeterminate points are, as the name implies, of uncertain usage. Whereas dart points are usually manufactured from bifacial preforms, arrow points are often manufactured on thin flakes. 


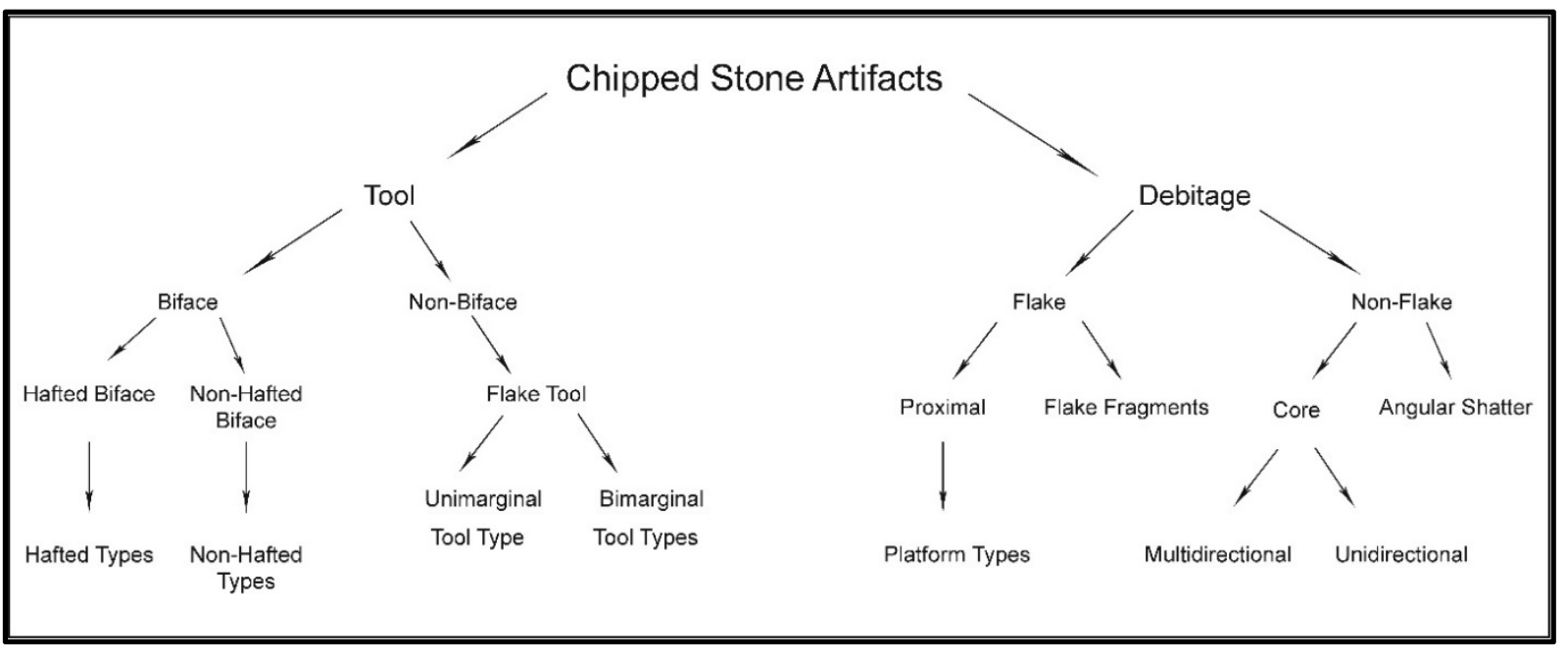

Figure 4-10. Chipped stone artifact analysis flowchart.

Projectile points were assigned to recognized typologies whenever possible. In traditional archeological literature, projectile points are normally referred to by their typological designation, which are usually based on a set of morphological characteristics, shared in common by groups of similar points, generally focusing on the hafting modification. Point classifications were conducted by TRC's personnel in reference to established point typologies in use in Texas archeology (Suhm and Jelks 1962; Turner et al. 2011).

\section{Scrapers}

Scrapers are a specific type of unifacial tool that have at least one intentionally modified working edge. In some instances, bifacial modification may be present, but in such cases the intentional retouch tends to be located on the dorsal flake surface, whereas the ventral surface tends to exhibit primarily use-related scars. Based upon the location of the primary working edge, scrapers are subdivided into end, side, or combination types. End scrapers are pieces with retouch, restricted primarily to either the distal or proximal end of the flake blank, generally producing a convex working edge. The opposing end of the piece may bear some minimal retouch, presumably to facilitate hafting. Side scrapers are pieces with retouch present on one or both lateral edges of the flake blank. Working edges may be convex, straight, or concave. On combination scrapers, marginal retouch may appear along the end as well as along one or more lateral edges of the blank. As implied by the name of this tool, the primary function of scrapers is presumed to relate to scraping relatively soft materials such as animal hides or vegetable matter, or slightly harder materials, such as wood or possibly antler or bone.

Twenty-eight metric and nonmetric attributes were recorded for scrapers. Many measurements relate to the number, location, and characteristics of the working edges on the tool. Metric measurements of length, width, thickness, and weight were recorded for each specimen even if it was broken.

\section{Unifaces}

Unifaces are those tools that exhibit flake scars on one face only. Like bifaces, unifaces are defined based predominantly on morphological characteristics, but they also tend to have functional associations (e.g., scraping, planing, cutting, engraving). Unifacial tools exhibit purposeful flaking across most or all of one face, whereas the opposite face most often remains flat and unmodified. Unifaces may be fashioned from cobbles or flakes and include such functionally diverse groups as scrapers, gouges, edge-modified 
flakes, gravers, and spokeshaves. One or more edges of a unifacial tool may exhibit manufacture and/or use-related flake removals that may be patterned or random. To some degree, unifacial tools form a continuum ranging from formal tools exhibiting intentional, patterned, and manufacturerelated edge flaking to informal, expedient tools that reveal only use-related edge scarring. The former tend to fall within the scraper and gouge categories, whereas the latter are generally classified as edge-modified flakes.

\section{Edge-Modified Flakes}

Edge-modified flakes are minimally modified flakes, flake fragments, or pieces of angular debris that are characterized by one or more areas of flake scarring along margins. The edge flaking may be patterned or unpatterned, continuous or discontinuous, and may result from use-related activities or from intentional pressure retouching to prepare an edge for use. Many edge-modified flake tools exhibit combinations of these characteristics, and many have more than one working edge. The modifications, however, usually are restricted to the edges and do not significantly alter the original flake form. Such edge modifications may be either unifacial or bifacial. Edge-modified flakes are usually considered 'expedient' tools, pieces of raw or minimally modified material that are utilized for a short time, and subsequently discarded soon after use.

\subsubsection{Lithic Debitage Analyses}

Chipped stone, or lithic debitage, is unmodified debris that resulted from stone tool manufacture and maintenance. During the analysis process, the laboratory technician uses macroscopic identification for flake or use scars indicating modification on each flake to separate any possible tools. All debitage was counted. Selected specimens were also examined under ultraviolet (UV) light to isolate any debitage inconsistent with Edwards formation chert.
The lithic debitage was first size graded as specified by screen manufacturer Gilson Company, Inc. into $6.4 \mathrm{~mm}$ (1/4 in.), $12.5 \mathrm{~mm}$ (1/2 in.), $19.0 \mathrm{~mm} \mathrm{(3/4}$ in.), and $26.5 \mathrm{~mm}$ ( $1 \mathrm{in}$.) size groups as specified by TxDOT protocol (TxDOT 2010). Each specimen was then sorted into platform bearing and nonplatform bearing groups. Non-platform bearing specimens were treated as shatter and weighed in bulk by provenience (specific to level and TU). Platform bearing specimens were examined individually and sorted into one of four classes: flat, multifaceted, crushed, and cortical. Other attributes documented include the presence/absence of heat alteration, cortex percentage (i.e., none, 1 to 25 percent, 26 to 50 percent, 51 to 75 percent, and 75 to 100 percent) and raw material type. Specimens were then weighed and findings entered into a database spreadsheet. Those that lacked a platform were grouped together on a single line, counted and weighed.

Lithic debitage lacks any macroscopic indications of use or modification. Pieces that exhibit any sign of use-wear or intentional modification are placed in the appropriate tool category.

\subsubsection{Mussel Shell Analysis}

The mussel shell was compared to TRCs extensive modern and prehistoric comparative collection that had individual specimens identified by Dr. R. G. Howells and then individually labeled. To confirm identifications, the specimen was also checked against modern pictures. Habitat data was obtained from literature sources (i.e., Howells et al. 1996).

\subsubsection{Analytical Techniques}

Six outsourced analytical techniques (radiocarbon dating, phytolith, starch grain analysis, lipid residue, macrobotanical, and use-wear analyses) were performed on selected suites of artifacts. These techniques were performed to gain greater insight and understanding of the ages and characteristics of the deposits and associated 
cultural materials, and provide insights such as what foods potentially were utilized by the populations represented.

The separate technical reports presented in the appendices provide details concerning methods, analytical results, and interpretations. The results are incorporated into the body of this report. The combined results are used to aid in the formulation of the research direction presented at the end.

\subsubsection{Radiocarbon Dating Analysis}

Charcoal, the preferred material for radiocarbon dating, was quite limited in frequency and size on site. The initial four samples submitted in 2004 were all tiny pieces of black material believed to be wood charcoal. These samples were submitted to TxDOT for approval and once approved, sent to University of Georgia (UGA), Center for Applied Isotope Studies in Athens for analysis. At the UGA laboratory, each sample was pretreated prior to dating. The obtained dates are reported as radiocarbon years before present (B.P.), with present being A.D. 1950, employing the same halflife as Beta. Each sample was also measured for $13 \mathrm{C} / 12 \mathrm{C}$ ratios, and again calculated relative to the internationally standard of Cretaceous Belemnite formation at Peedee, South Carolina (PDB or VPDB).

Late in 2013, seven more samples were selected for dating and submitted to TxDOT for approval. At that time other substances with the potential for organic content provided alternate means of potentially obtaining absolute dates were selected. An absolute date can be obtained from organic materials trapped in the sediments, shells and bone, though the obtained assay may not be as precise as might be obtained from charred seeds or wood. Direct dating of soil humates and Rabdotus snail shells have been accomplished previously with mixed results (see Frederick 2011 for comparisons and problems with dating these noncultural materials). Consequently, one must view the dates derived thusly as general ballpark dates, rather than a narrowly definable points in time. TRC archeologists selected seven more samples from cultural context; one on tiny charcoal flecks, three on multiple Rabdotus shells, two bulk sediment samples, and one tiny animal bone fragment, for direct radiocarbon dating and requested approval from TxDOT personnel. Once approved, TxDOT submitted these seven samples to Beta Analytical Inc., (Beta) in Miami, Florida.

Beta dates are reported as radiocarbon years before present (B.P.), with "present" being A.D. 1950 using the Libby ${ }^{14} \mathrm{C}$ half-life of 5,568 \pm 30 years. Each sample was measured for Carbon 13 verses Carbon 12 ratios $\left({ }^{13} \mathrm{C} /{ }^{12} \mathrm{C}\right)$ expressed as the delta 13 carbon $\left(\delta^{13} \mathrm{C}\right)$ and calculated relative to the internationally standard Cretaceous Belemnite formation at Peedee, South Carolina (PDB or VPDB). Beta's individual laboratory reports with specific details concerning each sample are presented in Appendix A. Individual sample results are also presented and discussed throughout the body of this report.

\subsubsection{Starch Grain Analysis}

Starch grain analysis is becoming more widely used in Texas archeology to identify plant resources utilized by the inhabitants (see Perry and Quigg 2011; Quigg 2011; Quigg, Frederick et al. 2010; Quigg, Matchen et al. 2011; Quigg, Matchen et al. 2013; Quigg, Ricklis et al. 2013). A brief introduction is provided here as background to this discipline for those that might not be familiar with this technique.

Starch grains are microscopic granules that serve as the principal food storage mechanism of plants (Figure 4-11). These grains are found in most plants that include roots and tubers (e.g., crow poison, rain lilies, false garlic, wine cup, and spring beauty), and in the seeds of legumes and grasses, where they are often produced in abundant numbers (Perry, personal communication 2008). Starch grains from 


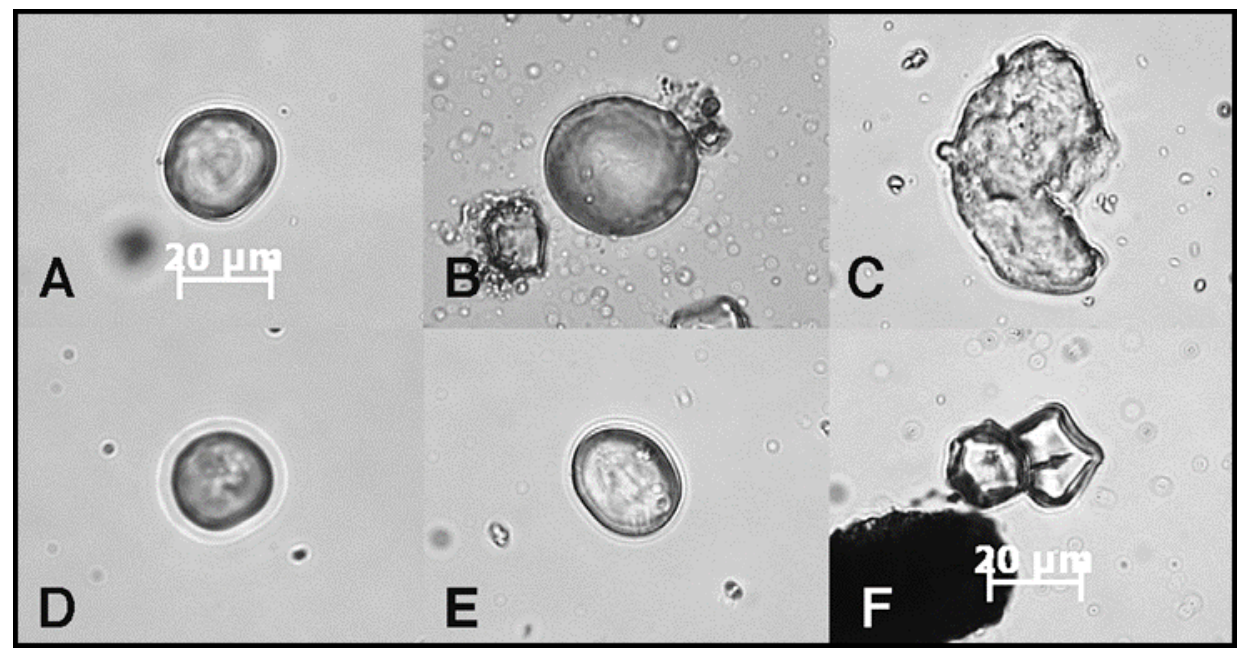

Figure 4-11. Examples of starch grains of wildrye grass recovered from burned rocks at archeological sites in Texas (photograph by L. Perry).

different plants possess a large variety of speciesspecific forms that have been recognized for some time.

Distinctive features of starch grains are genetically controlled, and when carefully observed, can be used to identify plant taxa. At least 300 species and varieties of important economic plants from around the world have been described and can be potentially preserved in archeological contexts (Piperno and Holst 1998; Piperno et al. 2000). Researchers around the world (particularly in the neotropics and in Australia) have been using these techniques with excellent results (Perry, personal communication 2007). Starch grain remains have significantly increased the knowledge of plant domestication and crop-plant dispersal in various regions (Perry et al. 2006:76-77). Researchers have employed starch grain analyses to study diet, plant processing, plant domestication and cultivation, tool use, and uses of ceramic vessels. Starch grains have been extracted from soil samples, ceramics, and chipped and ground stone tools to address questions of resource procurement and preparation of foods. Intact starch grains have been extracted from formal and informal chipped stone tools, both washed and unwashed (Perry, personal communication 2007). Heat alone does not destroy starches, as they are found in ceramic cooking vessels and in burned rocks (Perry and Quigg 2011; Quigg et al. 2010). When starch grains come in contact with heat and water the grain gelatinizes and creates a recognizable form. This allows information to implicate a cooking strategy.

A suite of burned rocks from across the site and from different cultural zones were selected for this initial analysis. The selection process was designed to sample various parts of the occupation and various levels of cultural materials to investigate the possible foods involved in the event(s) represented. Dr. Perry's methods, results, and interpretations are presented in Appendix E. Separate sample results are also presented and discussed in the body of this report.

\subsubsection{Phytolith Analysis}

Phytolith studies are important in reconstructing an approximate profile of grassland flora in settings and tracking possible changes through time, with the added potential for the discovery of plants used for foods by the prehistoric populations. Opal silicate bodies comprise the phytolith entity form within plant cells. The distinctiveness of various types of bodies varies according to cellulose structure. In grasses, phytoliths exhibit diversity 
and are distinctive by grass species. The presence of certain phytoliths (e.g., panicoid, festucoid, and chloridoid) in the paleoenvironmental record provides a record of general vegetative conditions, such as forested versus open grassland prairie, and the type of grasslands. Phytolith analysis was conducted to provide data for reconstructing the broad vegetative communities at this site at the times of the occupations.

Following the site assessment fieldwork, four sediment samples were selected that included samples from: TU 5, Feature 3 (S-2), \#501-4-2a; TU 1, Feature 4, 147-154, \#504-4A; TU 4, Feature 5, 150-160, \#505-4a; and TU 6, Feature 8 (S-2), 170, \#508-4-2a to determine if sufficient phytoliths were present to conduct further analyses. These initial samples were submitted to Dr. Steven Bozarth for assessment to determine if further phytolith analysis would be beneficial. $\mathrm{He}$ determined that "Phytoliths were well-preserved in all four samples. $\mathrm{C}_{3}$ and $\mathrm{C}_{4}$ grass phytoliths were in all four samples in addition to an arboreal phytolith in the TU 6 sample". "Phytolith analysis of these four samples would provide interpretable paleoenvironmental data at 41BL278" (Appendix B).

Given these assessment results and recommendations, TRC petitioned and was granted permission by TxDOT in 2013 to continue to pursue more intensive phytolith analysis from the APE. Four samples (three from cultural contexts and one control sample) were selected for complete phytolith analysis (Table 4-2). These were sent to Dr. Byron Sudbury in Oklahoma for analysis. Dr. Sudbury's extraction methods and procedures, counts, identifications, and interpretations are presented in Appendix D.

\subsubsection{Lipid Residue Analysis}

Previous research in Texas since about 2000 (Malainey 2000; Quigg and Cordova 2000), and other states using this chemical approach, has successfully demonstrated that organic residues are present and can be extracted and generally interpreted from burned rocks used by prehistoric peoples to process foodstuffs (cf. Quigg et al. 2000; Malainey 2000b, 2003; Malainey and Maliaza $2002,2008)$. Interpretations provide only a general indication of what is chemically represented rather than precise species or taxa. Since 2010, newer and more precise analysis was implemented and uses high temperature gas chromatography (HT-GC) and gas chromatography with mass spectrometry (HT-GC/MS) to identify biomarkers. This proxy line of investigation is critical when environmental conditions are not conducive to preservation of primary organic data, such as macrobotanical and faunal remains. The fatty acid analysis provides chemical results to help identify the types of general food resources (mostly plant versus animal residues) may have been cooked by burned rocks. This allows a general understanding of the function of the features and what food resources were available to cook within the burned rocks.

Selected from seven features, 18 chunks of burned rocks, weighing from 14 to $165 \mathrm{~g}$, were broken from the parent rocks for submission to Dr. Malainey in Winnipeg, Manitoba, for lipid residue analysis (Figure 4-12). The parent rock was retained and is curated for future reference.

Table 4-2. Sediment Samples Selected for Phytolith Analysis.

\begin{tabular}{|c|c|c|c|c|c|c|c|c|}
\hline BT & Unit & Level & $\begin{array}{c}\text { Depth } \\
\text { (cmbs) }\end{array}$ & $\begin{array}{c}\text { Feat. } \\
\text { No. }\end{array}$ & PNUM & Cat. No. & $\begin{array}{c}\text { Wt. } \\
\text { (g) }\end{array}$ & Comments \\
\hline 8 & 2 & 16 & $152-155$ & n/a & 8 & $4-1 b$ & 46 & Control \\
\hline 9 & 5 & 14 & 143 & $3 a$ & 503 & $4-1 a$ & 22 & S4; N13 E8 9 plotted; from under BR-4 \\
\hline 9 & 18 & 18 & 173 & 7 & 507 & $4-2 a$ & 30 & S2; N30 E5 1 plotted; from under BR-2 \\
\hline 9 & 17 & 17 & 165 & 8 & 508 & $4-1 a$ & 28 & S1; N35 E9 5 plotted; from under BR-1 \\
\hline
\end{tabular}




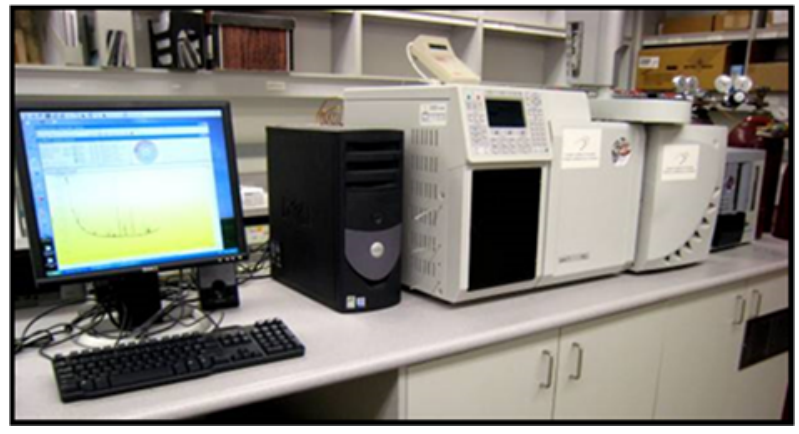

Figure 4-12. Technical equipment used in the lipid analysis (photograph provided by Dr. Malainey).

Dr. Malainey presents the background to identification of fatty acids, her detailed methods, results obtained on individual artifacts, and interpretations of the samples in Appendix F. Her results have been incorporated into the appropriate sections within the body of the text.

\subsubsection{Use-Wear and Residue Analyses}

The chipped stone tool assemblages from the identified cultural component were limited. Chipped stone tools from the component were selected for high-power, microscopic use-wear and residue analyses. Eight artifacts that included three bifaces, four edge-modified flakes, and one apparently nonutilized flake were sent to Dr. Bruce Hardy at Kenyon College (Gambier, Ohio) for usewear and residue analyses. Most tools selected were minimally handled in the field and not washed in the laboratory. In order to track individual items, a small spot on one face of the artifact was cleaned and a label applied with archival ink. Four edgemodified flakes were submitted as they presumably functioned in a variety of tasks and on a variety of materials. Therefore, it was thought that the greatest functional diversity would be apparent in the edgemodified flake tool class. The edge-modified flakes included a variety of edge shapes and sizes in hopes of identifying a wide range of functions such as cutting, graving, shaving, scraping, and whittling. The analytical methods and individual results of Dr. Hardy's findings are presented in Appendix H.

\subsubsection{Macrobotanical Analysis}

Sediment samples from separate features were collected for flotation in the laboratory. Handexcavations also yielded a few tiny chunks of charcoal or other macrobotanical remains. In 2004 nine samples were submitted to Dr. Phil Dering for wood identifications. Dr. Dering provided identifications where possible (Appendix G).

In the laboratory, seven selected bulk matrix samples from feature and nonfeature context with the potential to yield macrobotanical remains were subjected to flotation using a Dousman flotation system that allowed for the collection of separate light and heavy fractions. The collected heavy and light fractions were subjected to specific analyses.

Seven light fractions selected for macrobotanical analysis were sent to Dr. Phil Dering of Shumla Archeobotanical Services in Comstock, Texas for sorting and identification of organic materials. Dr. Dering's detailed technical report is presented in Appendix G.

Heavy fractions were carefully examined, picked and sorted in the laboratory for charcoal, burned seeds, bone, lithic debitage, burned rock fragments, and snail shells. These materials were then counted and weighed by material class, with results presented in the appropriate feature discussions within the body of the report.

\subsection{CURATION}

Artifacts collected from this assessment effort were temporarily curated at the offices of TRC in Austin, Texas. All stone tools, lithic debitage, burned rocks, field records, and photographs from this assessment are permanently curated at the Center for Archaeological Studies (CAS) in San Marcos, Texas. Individual artifacts and artifact lots, including all stone tools, lithic debitage, and burned rocks are curated in archival, clear, resealable four millimeter thick polyethylene bags according to artifact type and provenience. Each polyethylene 
bag contains an archival-quality, acid free curation tag that lists the site number, provenience data, date of excavation, excavator(s) name, artifact type, and quantity in pencil. Digital photographs were submitted on CDs and photo log placed in archival photo sleeves for curation. All original field records are on acid free paper and were placed in acid free archival file folders for curation. 


\subsection{GEOPHYSICAL RESULTS}

\section{J. Michael Quigg}

Nine localized electrical resistivity anomalies were identified in the $840 \mathrm{~m}^{2}$ area investigated covered during the geophysical study. Anomalies 1 through 6 were scattered across the southern half of the investigated area in the APE, south of survey Line 11 (see Figure 4-1; Appendix C). Three were at the very northern edge, with two along survey Line 18 and one along survey Line 19. Anomalies 1 and 3 were considered by TRC geophysical scientist Melanie Crisp to have greatest potential as they were the most defined on graphic depth sections and occur near the same depth as the cultural materials detected during the 2004 survey (Appendix C). Anomalies 7 and 8 were along survey Line 18 a few meters south of BT 7, in which Feature 1 was found at ca. $105 \mathrm{cmbs}$.

Anomalies 1 and 3 with high potential to represent or reflect cultural features were selected and targeted for verification through excavations. Anomaly 1 was beneath the southwestern edge of the existing overhead bridge, roughly $43 \mathrm{~m}$ along survey Line 3. On paper, this apparent anomaly appeared to measure roughly $2 \mathrm{~m}$ east-west and between 150 and $200 \mathrm{~cm}$ deep (Figure 5-1). BT 11 was excavated immediately adjacent to Anomaly 1. This trench was about $10 \mathrm{~m}$ long north-south, $3.5 \mathrm{~m}$ wide, and was excavated to a depth of $1.2 \mathrm{~m}$ over the anomaly and to about $2.5 \mathrm{~m}$ adjacent to the anomaly. A 1-by-1 m test unit (TU 3) was established over the projected anomaly, and handexcavation began at a depth of $120 \mathrm{cmbs}$; however, only one $10 \mathrm{~cm}$ thick level was excavated before the rains came. The entire backhoe trench and the test unit within the trench filled with water (see Figure 4-6). The trench was in an area that received runoff from around the bridge abutment, and this provided a greater water flow sufficient to fill the trench. The loamy clay did not drain and stayed inundated throughout the fieldwork. Despite an attempt to pump the water from this trench, subsequent rains immediately again filled the excavation and Anomaly 1 could not be reached for verification.

Anomaly 3 was near a large, $1 \mathrm{~m}$ diameter pecan tree at 20 to $22 \mathrm{~m}$ along survey Line 8 near the middle of the investigated terrace area (Figure 5-2). On paper, this anomaly appeared to measure roughly 1 to $2 \mathrm{~m}$ east-west and appeared between 170 to 300 cmbs. BT 12 was excavated in that vicinity to a length of $9 \mathrm{~m}$ north-south, $3 \mathrm{~m}$ in width, and $2 \mathrm{~m}$ in depth. The excavation was rapid to a depth of about $150 \mathrm{cmbs}$; at that point, it slowed to careful scraping with the backhoe bucket monitored by an archeologist. At roughly $180 \mathrm{cmbs}$, two large limestone boulders were encountered. The more northern rock was quite large (ca. $1 \mathrm{~m}$ in diameter by $40 \mathrm{~cm}$ thick) (Figure 5-3). About $180 \mathrm{~cm}$ south of the first rock, a second rock, roughly 40 to $50 \mathrm{~cm}$ in diameter and $35 \mathrm{~cm}$ thick appeared. The areas around the two natural rocks and trench walls were inspected for cultural materials. No cultural materials were observed in this trench. The two large natural limestone rocks are interpreted to account for Anomaly 3. The largest rock was positioned about $30 \mathrm{~cm}$ north of survey Line 8 at $21.9 \mathrm{~m}$ west. The second rock was positioned about $30 \mathrm{~cm}$ north of survey Line 6 at roughly $21.8 \mathrm{~m}$ west.

Groundtruthing of Anomalies 1 and 3 through backhoe trenching was only partially successful. Natural rocks were verified as Anomaly 3, whereas Anomaly 1 could not be verified because of the water filled trench. Limited field time prevented further groundtruthing of other anomalies. 


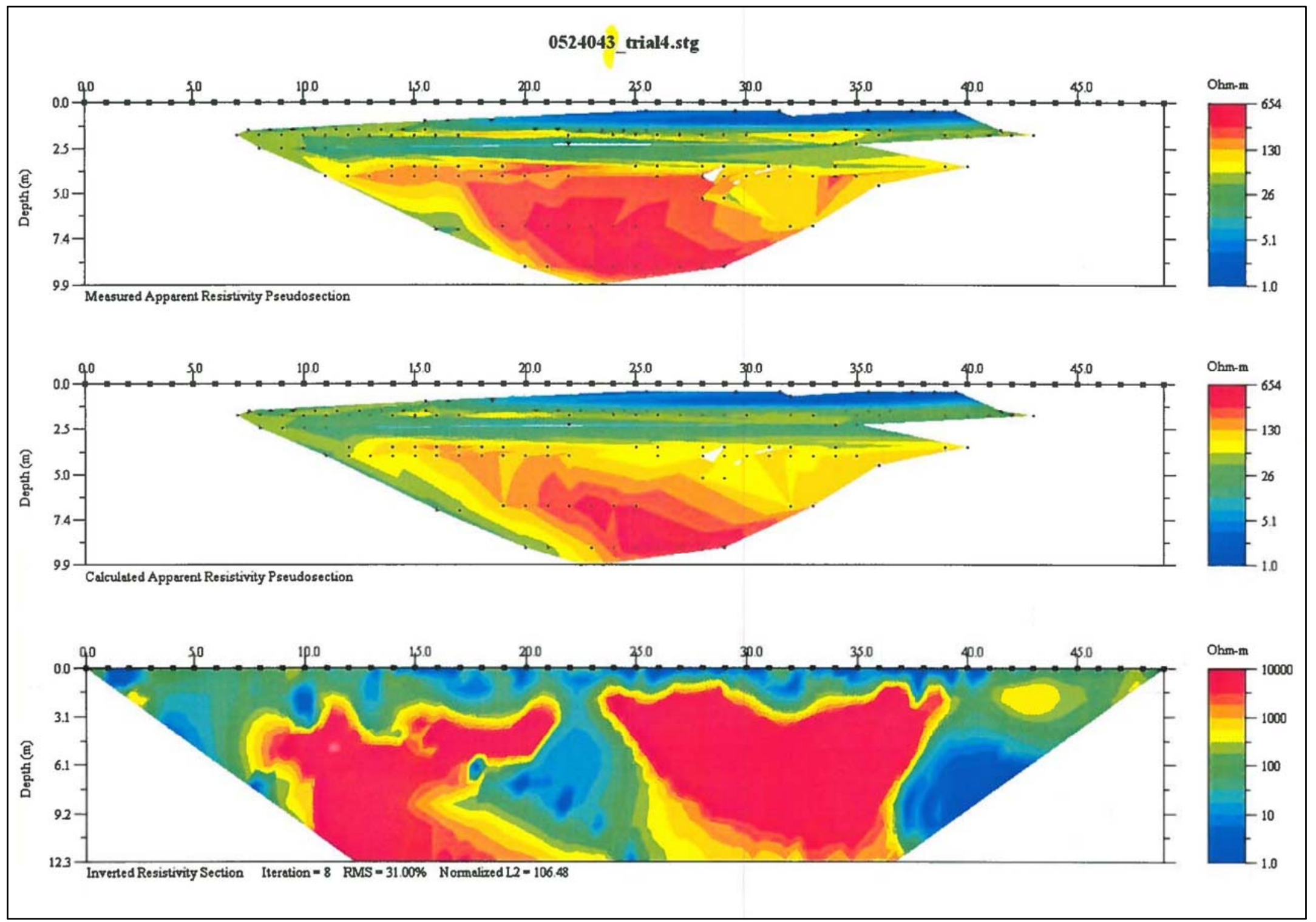

Figure 5-1. Geophysical scan of Line 3 showing Anomaly 1 in lower panel on right. 


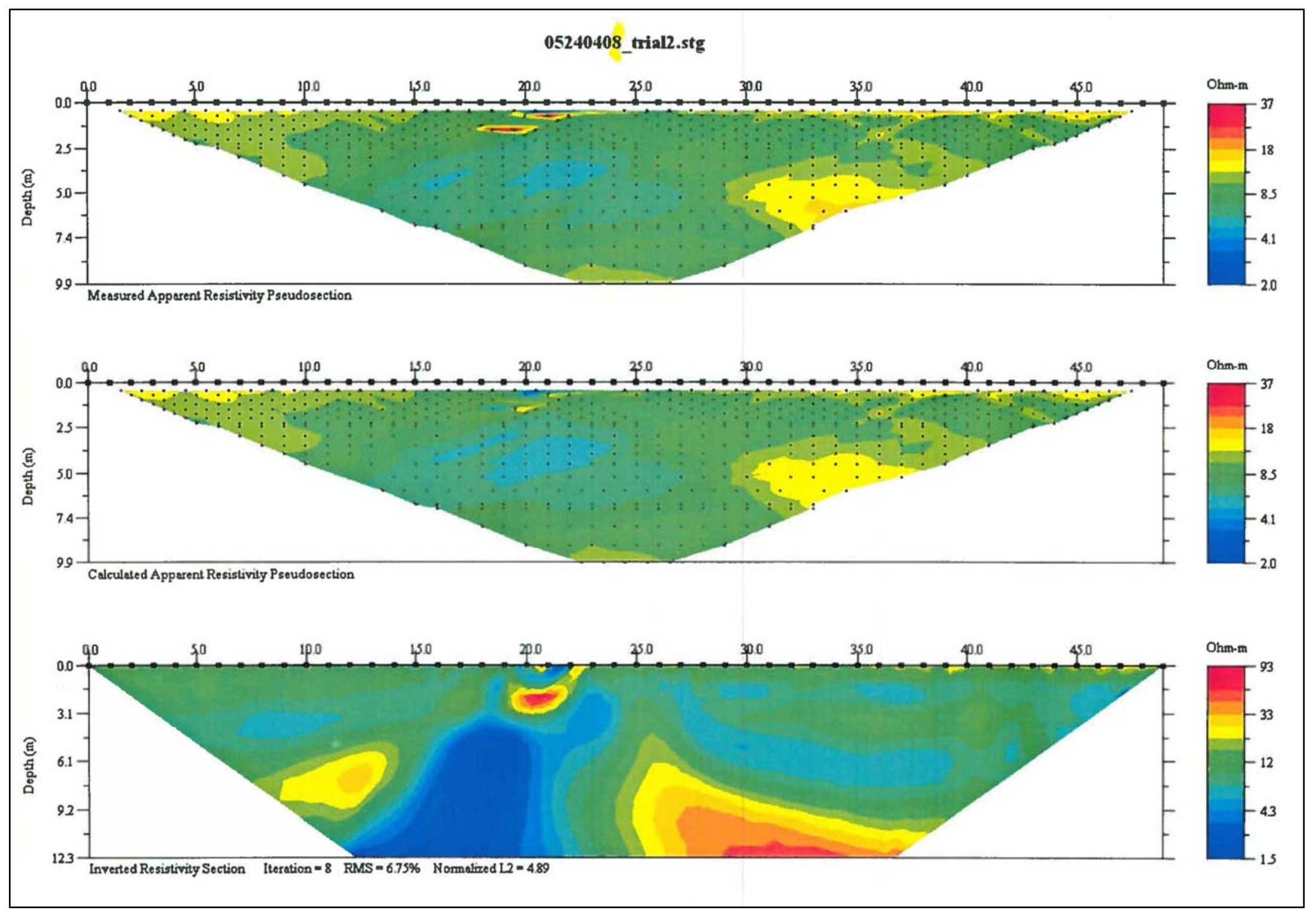

Figure 5-2. Geophysical scan of Line 8 showing Anomaly 3 in lower panel on right. 


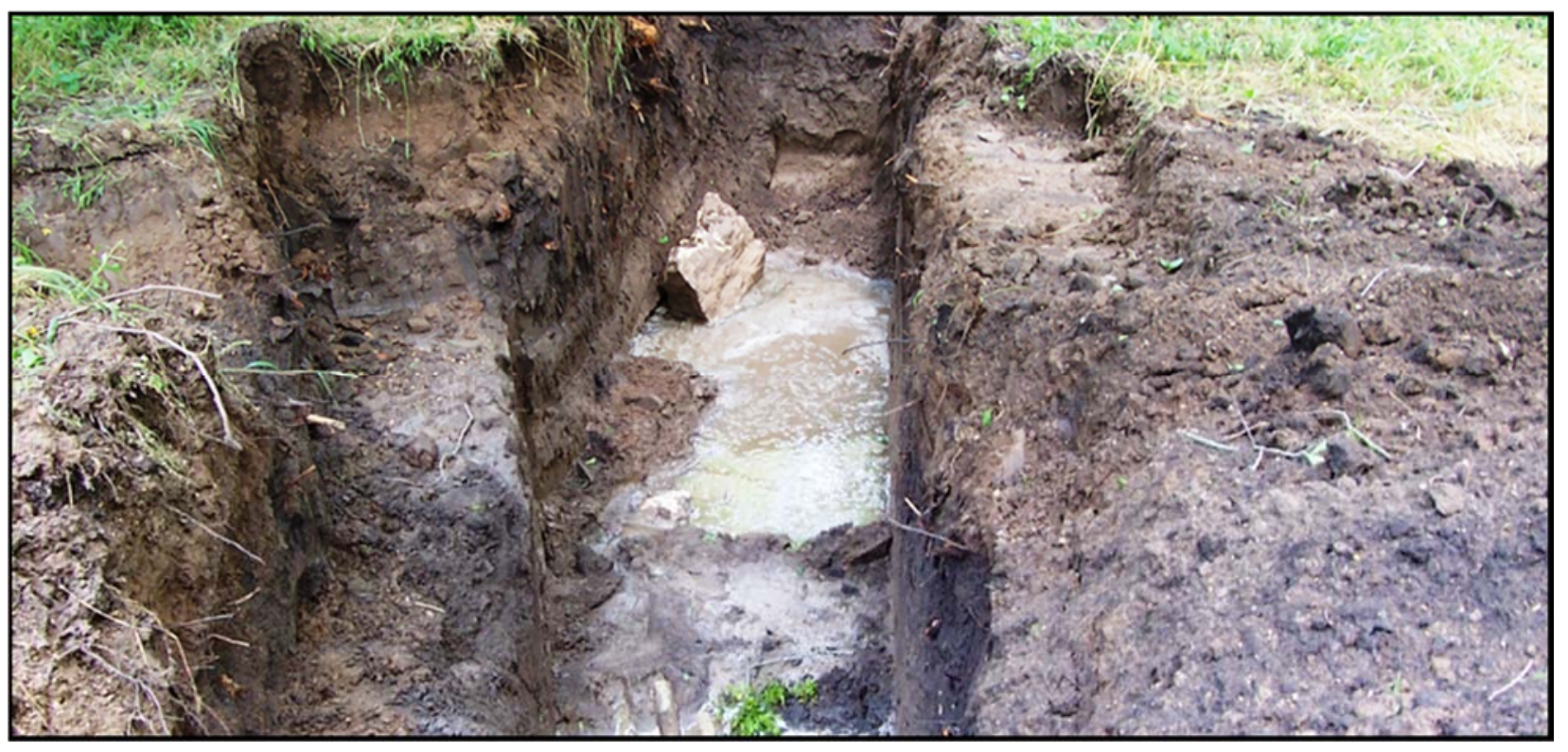

Figure 5-3. Backhoe Trench 12 with rain water and one of the two large rocks thought to represent Anomaly 3. 


\subsection{GEOARCHEOLOGICAL RESULTS}

Charles D. Frederick

\subsection{INTRODUCTION}

This chapter describes the geologic setting of prehistoric occupations in the APE at site 41BL278. The site is situated within an alluvial terrace adjacent to the right bank (south side) of the Leon River beneath and immediately east of the SH 317 bridge where it crosses the Leon River in Bell County, Texas. Three constructional alluvial surfaces (terraces) are present in proximity to the site $-\mathrm{T}_{0 \mathrm{a}}, \mathrm{T}_{0 \mathrm{~b}}$, and $\mathrm{T}_{1}$ (Figure 6-1). The $\mathrm{T}_{0 \mathrm{a}}$ surface is a low, narrow, discontinuous floodplain surface that immediately borders the Leon River channel and rises to an elevation of about $1 \mathrm{~m}$ above the water level. This surface is probably a lateral bar modified during flood events. The $\mathrm{T}_{0 \mathrm{~b}}$ surface is significantly larger and more geographically extensive than the $\mathrm{T}_{0 \mathrm{a}}$ surface. The tread of this floodplain surface is between approximately 2.5 and $3 \mathrm{~m}$ above the low water level in the Leon River channel, and is up to $25 \mathrm{~m}$ wide. It narrows downstream and is inset against the $\mathrm{T}_{1}$ surface. The latter lies 5 to $6 \mathrm{~m}$ above the stream and is a broadly concave surface that exhibits a prominent levee-like rise (of about $1 \mathrm{~m}$ ) adjacent to the leading edge of the $T_{1}$ surface where it overlooks the $T_{0 a}$ surface. The surface elevation decreases away from this linear ridge, and then rises again at the rear of the surface where it is inset against a bedrock outcrop. The slight depression in the center forms an ephemeral pond following rainfall and major flood events. Ringstaff (2004:3) identifies this surface depression as a "broad paleochannel (swale)."

\subsection{METHODS}

Multiple backhoe trenches were excavated during this archeological testing project, and several of the original trenches from the cultural resource survey conducted by Blanton \& Associates, Inc. (Ringstaff 2004), were reopened. Where old trenches were reopened, new profile descriptions were not recorded.

All but one of the new trenches were described (Figure 6-2). Backhoe Trench 11 was not described because it was situated in such a manner as to capture runoff from the bridge and keep it from flowing overland under the bridge and into open excavation units downslope and to the north. Unfortunately, it accomplished this task very effectively, filling with water before it could be described and retained this water for the duration of the testing phase.

Profiles were recorded in the field (Table 6-1) and descriptions generally (but not always) follow Schoeneberger et al. (2002). It should be noted that significant discrepancies in the amount of calcium carbonate filaments were observed in the field owing to the wet state of the soil during fieldwork, which decreased the visibility of the calcium carbonate filaments.

Trench excavations were designed to provide platforms for hand-excavated units in prehistoric occupation surfaces identified during the survey (Ringstaff 2004) at depths ranging from 120 to $170 \mathrm{cmbs}$. This series of occupation surfaces was observed in three trenches (BTs 7, 8 and 9) opened during the survey and in BT 14, which was excavated in line with and immediately west of BT 9. It is worth noting that it was not apparent until after most of the new trenches were opened that a younger, less obvious occupation surface was present in BTs 8, 9 and 14, at a depth of roughly 100 to $115 \mathrm{cmbs}$. Ringstaff (2004) did not detect or record this occupation. Unfortunately, this testing program was designed to target the lower component, therefore this slightly higher occupation surface was not sampled during the testing phase. 


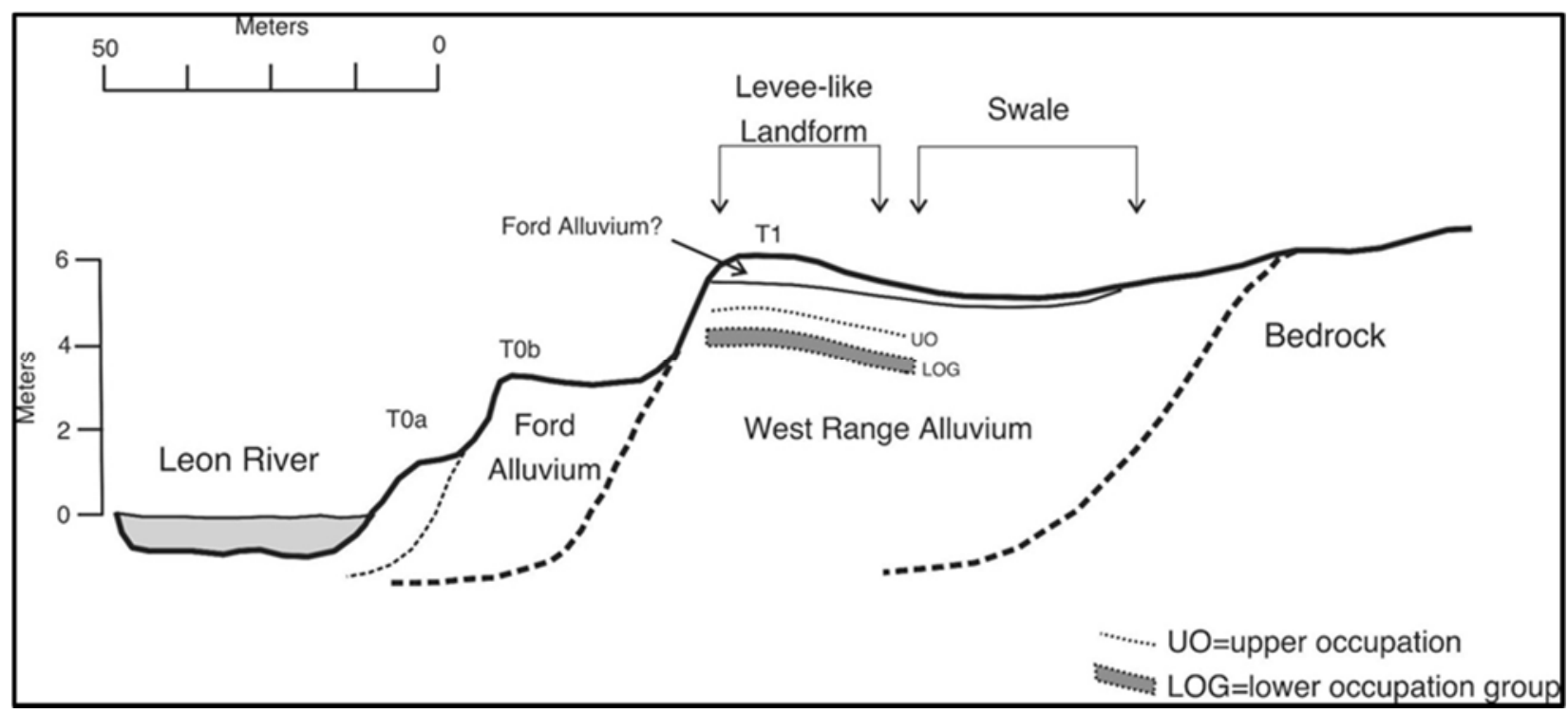

Figure 6-1. Schematic crossection of alluvial terrace sequence in TXDOT APE at 41BL278.

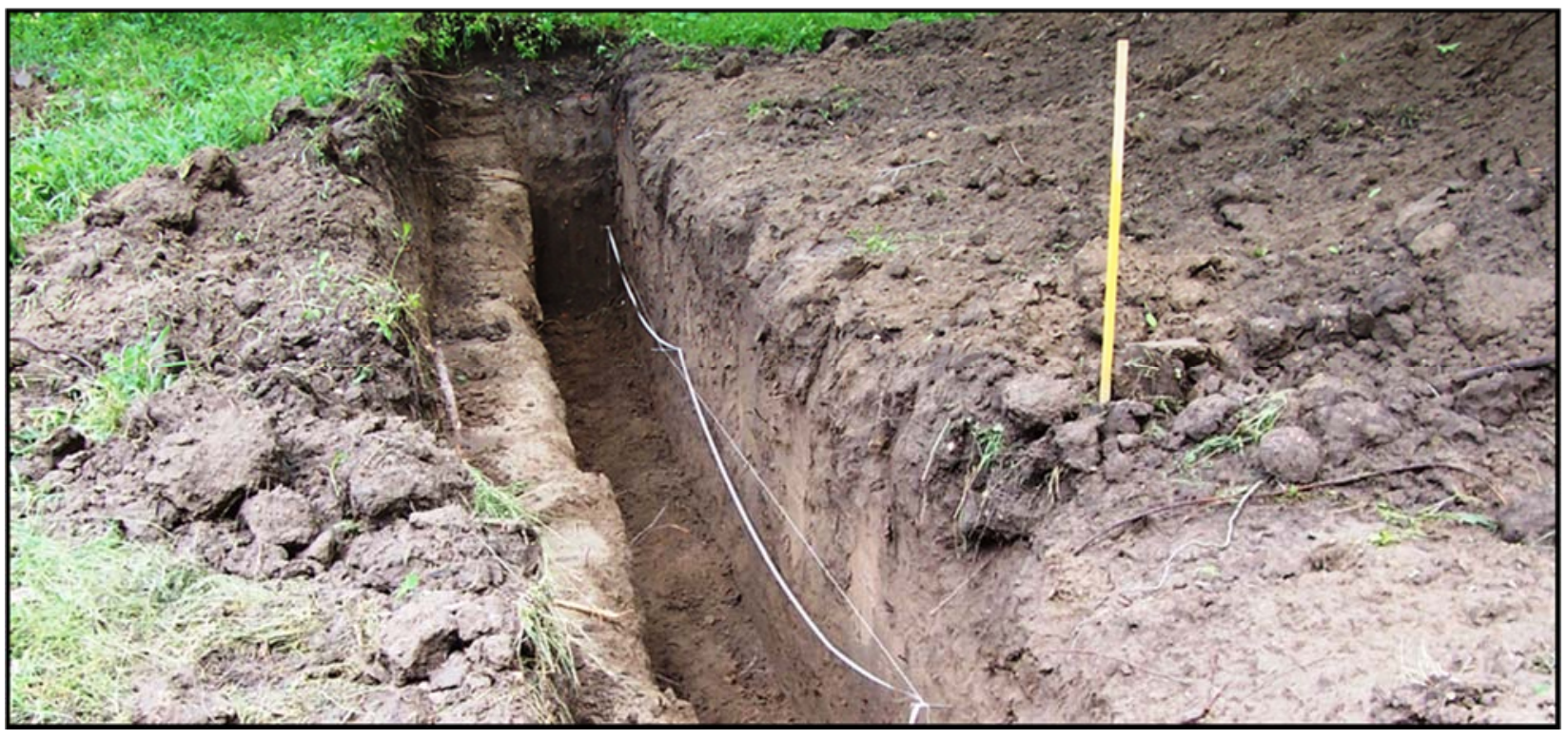

Figure 6-2. Backhoe Trench 13 that was profiled. 
Table 6-1. Backhoe Trench Descriptions.

\section{Trench 12}

Geologic Units: Recent road runoff over Ford Alluvium over West Range Alluvium

Cultural Material:

Comments:

None observed

This trench was sited here to explore a resistivity anomaly. The source of the anomaly is suspected to have been a couple of large boulders of limestone discovered at 190 to $230 \mathrm{cmbs}$. These boulders measured 120 by 90 by $40 \mathrm{~cm}$ and 50 by 40 by $30 \mathrm{~cm}$, respectively.

\begin{tabular}{|c|c|c|l|}
\hline Zone & Horizon & $\begin{array}{c}\text { Depth } \\
\text { (cmbs) }\end{array}$ & \multicolumn{1}{c|}{ Description } \\
\hline 1 & $\mathrm{C}$ & $0-18$ & $\begin{array}{l}\text { Very dark gray (10YR 3/1, moist), gravelly clay loam; friable, moderate, medium } \\
\text { subangular blocky structure; abrupt, smooth boundary; approximately 30 percent } \\
\text { coarse fragments; appears to be runoff from the highway }\end{array}$ \\
\hline 2 & Ap & $18-30$ & $\begin{array}{l}\text { Brown to dark brown (7.5YR 3.5/3, moist), slightly gravelly silty clay; firm, strong, } \\
\text { very coarse, angular blocky structure; abrupt, smooth boundary; one to three } \\
\text { percent coarse fragments; high apparent bulk density; probably compacted during } \\
\text { bridge construction }\end{array}$ \\
\hline 3 & $\mathrm{C}$ & $30-53$ & $\begin{array}{l}\text { Brown to dark brown (7.5YR 3.5/3, moist) clay; friable, strong, extremely coarse, } \\
\text { granular structure; abrupt, smooth boundary; same deposit as Zone 2 but not } \\
\text { compacted; has ca. 20 percent black (10YR 2/1) worm casts from Zone 4 }\end{array}$ \\
\hline 4 & $2 \mathrm{Ab}$ & $53-100$ & $\begin{array}{l}\text { Black (10YR 2/1, moist) clay; friable, strong, fine, granular structure; diffuse smooth } \\
\text { boundary, ca. one percent coarse fragments, 10 percent worm casts of Zone 3 } \\
\text { material decreasing in frequency with increasing depth; possibly some calcium } \\
\text { carbonate filaments, but if present obscured by elevated soil moisture }\end{array}$ \\
\hline 5 & $2 \mathrm{ABkb}$ & $100-135$ & $\begin{array}{l}\text { Very dark gray (10YR 3/1, moist) clay to silty clay; friable, strong, medium, } \\
\text { subangular blocky structure; clear, smooth boundary; seven percent calcium } \\
\text { carbonate filaments; common pressure faces }\end{array}$ \\
\hline 6 & $2 \mathrm{Bkb}$ & $\begin{array}{l}135- \\
230+\end{array}$ & $\begin{array}{l}\text { Dark grayish-brown (10YR 4/2, moist) silty clay; friable, strong, medium to coarse, } \\
\text { prismatic structure, one percent 1-to-3-mm-diameter, hard, calcium carbonate } \\
\text { nodules, at least 55 percent calcium carbonate filaments. Two large boulders } \\
\text { present, but basal contact could not be described owing to high water line following } \\
\text { rainfall }\end{array}$ \\
\hline
\end{tabular}




\section{Trench 13}

Geologic Units:

Cultural Material:

Comments:
Ford Alluvium (?) over West Range Alluvium

A few isolated fragments. A posthole, presumably from a fence line associated with the original bridge construction, was sectioned in the east wall, and the fill contained gravel and wire nails. This trench was created to examine the internal structure of the levee-like landform. It was terminated prematurely owing to insufficient time with the backhoe following mechanical problems. Given that the goal was to explore the presumed Ford-West Range interface, it was not excavated very deep.

\begin{tabular}{|c|c|c|c|}
\hline Zone & Horizon & $\begin{array}{c}\text { Depth } \\
\text { (cmbs) }\end{array}$ & \multicolumn{1}{c|}{ Description } \\
\hline 1 & A & $0-20$ & $\begin{array}{l}\text { Very dark gray to dark gray (10YR 3.5/1, moist) clay loam;, friable, weak to } \\
\text { moderate, coarse, subangular blocky structure parting to moderate, medium to } \\
\text { coarse, granular structure; clear, smooth boundary (presumably Ford Alluvium) }\end{array}$ \\
\hline 2 & Bw & $20-50$ & $\begin{array}{l}\text { Dark grayish-brown (10YR 4/2, moist) silt loam to silty clay loam; very friable, } \\
\text { weak, medium, prismatic structure parting to moderate, medium fine, subangular } \\
\text { blocky structure; abrupt to clear, smooth boundary; one to three percent calcium } \\
\text { carbonate filaments when moist, 15 to 20 percent calcium carbonate filaments } \\
\text { when dry (presumably Ford Alluvium) }\end{array}$ \\
\hline 3 & $2 \mathrm{Bk}$ & $50-90+$ & $\begin{array}{l}\text { Dark grayish-brown (10YR 4/2, moist) silt loam to silty clay loam; friable, moderate, } \\
\text { medium, prismatic, structure parting to moderate, medium, fine, subangular blocky } \\
\text { structure; 10 to 15 percent calcium carbonate filaments (presumed to be the West } \\
\text { Range Alluvium). This zone appeared darker than the overlying zone in weak, } \\
\text { diffuse sunlight }\end{array}$ \\
\hline
\end{tabular}

\section{Trench 14}

Geologic Units: Recent construction-related fills resting unconformably upon West Range Alluvium. Ab horizon (Zone 3) may be disturbed as well, but this was difficult to determine with certainty.

Cultural Material: $\quad$ An occupation was noted at 100 to $115 \mathrm{cmbs}$, and a thicker zone of cultural material was recognized between 160 and 190 cmbs.

Comment: Top two to three zones have been disturbed by construction.

\begin{tabular}{|c|c|c|c|}
\hline Zone & Horizon & $\begin{array}{c}\text { Depth } \\
\text { (cmbs) }\end{array}$ & \multicolumn{1}{c|}{ Description } \\
\hline 1 & Ap & $0-14$ & $\begin{array}{l}\text { Brown (10YR 4/3, moist) gravelly clay loam; friable, weak, medium, subangular } \\
\text { blocky structure; abrupt, smooth boundary; 30 to 40 percent coarse fragments; } \\
\text { probably post-construction runoff }\end{array}$ \\
\hline 2 & Ap & $14-35$ & $\begin{array}{l}\text { Black (10YR 3/1, moist) clay; firm to very firm, strong, fine, wedge to strong, fine, } \\
\text { angular blocky structure; abrupt, smooth boundary; very dense; some weakly } \\
\text { defined, contorted bedding apparent, clearly a construction fill of Zone 1 material }\end{array}$ \\
\hline 3 & $\begin{array}{c}2 \mathrm{Ab} \text { or } \\
\text { Ap }\end{array}$ & $35-67$ & $\begin{array}{l}\text { Black (10YR 3/1, moist) clay; friable, moderate, medium, subangular blocky } \\
\text { structure parting to moderate, fine, granular blocky structure; one percent } \\
\text { calcium carbonate filaments, 5 to 10 percent worm casts, one to two percent } \\
\text { coarse fragments of limestone and siliceous pebbles; possibly construction fill, } \\
\text { but does not have elevated bulk density or obvious contorted bedding }\end{array}$ \\
\hline 4 & $2 \mathrm{Bw}$ & $67-120$ & $\begin{array}{l}\text { Gray (10YR 5/1, moist) clay to clay loam; firm, moderate, medium, angular } \\
\text { blocky structure; gradual, smooth boundary; one to three percent calcium } \\
\text { carbonate filaments; prehistoric occupation located between 100 and 115 cmbs }\end{array}$ \\
\hline 5 & $2 \mathrm{Bk}$ & $120-200$ & $\begin{array}{l}\text { Grayish-brown (10YR 5/2, moist) clay; firm, strong, medium, angular blocky } \\
\text { structure; seven percent calcium carbonate filaments; few (one to three percent), } \\
\text { fine to coarse (3-to-10-mm-diameter), irregular, calcium carbonate nodules; } \\
\text { prehistoric occupations (multiple surfaces) between 160 and 190 cmbs }\end{array}$ \\
\hline
\end{tabular}




\subsection{ALLUVIAL STRATIGRAPHY}

Ringstaff (2004) recognized two alluvial deposits at the site - the Ford Alluvium and the West Range Alluvium. Both of these depositional units were first described at Fort Hood (Nordt 1992), and similarly aged deposits have recently been recognized downstream of 41BL278 along the Little River in Milam County (Nordt et al. 2003).

\subsubsection{Ford Alluvium}

Although the $\mathrm{T}_{0 \mathrm{a}}$ and $\mathrm{T}_{0 \mathrm{~b}}$ were not trenched during this study, their surfaces are undoubtedly underlain by the Ford Alluvium, which is the alluvial unit associated with the modern depositional regime. Ringstaff (2004) interpreted the upper part of the $T_{1}$ surface as being draped by the Ford Alluvium, but this interpretation is debatable. It was clear in the field what Ringstaff (2004) saw that made him want to distinguish this upper deposit (the upper 20 to $70 \mathrm{~cm}$ ) from the one at depth. However, the lack of any clear evidence of an unconformity between the units, especially in the form of a paleosol where the levee-like feature is thickest, and the absence of any vestiges of primary sedimentary stratigraphy (specifically thin-bedded deposits), which are common in most deposits of this age, the Ford Alluvium in particular and levees in general tend to cast a shadow of doubt on this interpretation. Ringstaff's (2004) interpretation has been retained for the moment, but there is some ambiguity concerning its veracity.

The Ford Alluvium, if present on the $T_{1}$ surface, appears to form the levee-like ridge on the leading edge of the surface. Beneath the ridge crest, the interface between the Ford and the West Range alluvium was denoted by a subtle color-texture change, but no clearly observable paleosol was observed in the older West Range Alluvium. In diffuse sunlight (i.e., with the sun behind a cloud), the top of the West Range Alluvium appeared to have a weak A horizon formed in it, but the color of this part of the deposit was indistinguishable (in Munsell terms) from the overlying deposit (what
Ringstaff [2004] termed the Bw horizon). For this reason, Ringstaff (2004: Appendix B, page 2) described the top of the West Range Alluvium as a Bkb horizon. Farther to the south, in BT 12, a prominent buried soil was present at the top of the West Range Alluvium. Ringstaff (2004) did not observe this in BT 10, located 9 to 10 m north of BT 12, which implies that the material burying the soil is recent runoff from the road encroaching on the $T_{1}$ surface from the south.

To check which deposit was responsible for burying the soil in BT 12 (Ford Alluvium originating in the channel to the north or road runoff originating from the south), BT 13 was excavated from the ridge crest to the south along the eastern edge of the right-of-way to reveal the interface between the presumed Ford Alluvium and the West Range Alluvium and to document how they changed away from the ridge crest (see Figure 6-2). Unfortunately, the trench was prematurely terminated after a short distance owing to mechanical problems with the backhoe. Over a distance of $8 \mathrm{~m}$, the drape of what is presumed to be Ford Alluvium decreased from 60 to $30 \mathrm{~cm}$ in thickness, and was only $20 \mathrm{~cm}$ thick in BT 12 . Furthermore, there was no depositional stratigraphy present in either deposit, an attribute more consistent with an older, West Range Alluvium age for this deposit.

The deposit presumed to be the Ford Alluvium consists of fine-grained sediment that ranges from silt loam to clay loam, within which an A-Bw soil profile has formed. The A horizon is very dark gray to dark gray (10YR 3.5/1) clay loam with no secondary carbonate filaments, and the Bw horizon is dark grayish-brown (10YR 4/2) silt loam to silty clay loam with numerous calcium carbonate filaments (15 to 20 percent when dry, one to three percent when wet). No radiocarbon dates were obtained for this depositional unit, and its identification should be considered tentative until confirmed by direct dating. 


\subsubsection{West Range Alluvium}

A floodbasin facies of the West Range Alluvium appears to form the core of the $T_{1}$ surface and consists of dark grayish-brown (10YR 4/2), finegrained alluvium, primarily clay, clay loam, or silty clay loam. Beneath the levee-like ridge of presumed Ford Alluvium, a Bk horizon has formed in this deposit, and away from the levee crest, an A-AB$\mathrm{Bk}$ profile is present. Under the levee-like deposit of Ford Alluvium, this deposit exhibited a Bw-Bk profile, where the $\mathrm{Bw}$ horizon exhibited one to three percent calcium carbonate filaments, and the Bk horizon exhibited about seven percent calcium carbonate filaments and one to three percent small ( 0.3 to $1.0 \mathrm{~cm}$ diameter), irregular-shaped, calcium carbonate nodules (Figure 6-3). The Bk horizon in BT 14 exhibited a similar morphology. Although this degree of carbonate development is normally associated with older deposits, Nordt et al. (2003:80) recently described a similar degree of calcium carbonate development for a clayey late Holocene alluvial deposit (Unit 1) on the Little River that he correlated to the West Range Alluvium at Fort Hood, and which was radiocarbon dated to the interval of approximately 3050 to 1270 B.P.

Scattered throughout the floodbasin facies in the APE at 41BL278 were occasional fine, limestone gravels. At a depth of about $220 \mathrm{cmbs}$ in BT 12, which was situated to investigate a buried resistivity Anomaly 3, several large boulders were observed suspended in a silty clay matrix (see Figure 5-3). These boulders measured 120-by-90by-40 $\mathrm{cm}$ and 50-by-40-by-30 cm, respectively. Their presence, together with the occasional fine gravels in the floodbasin facies, stand as evidence

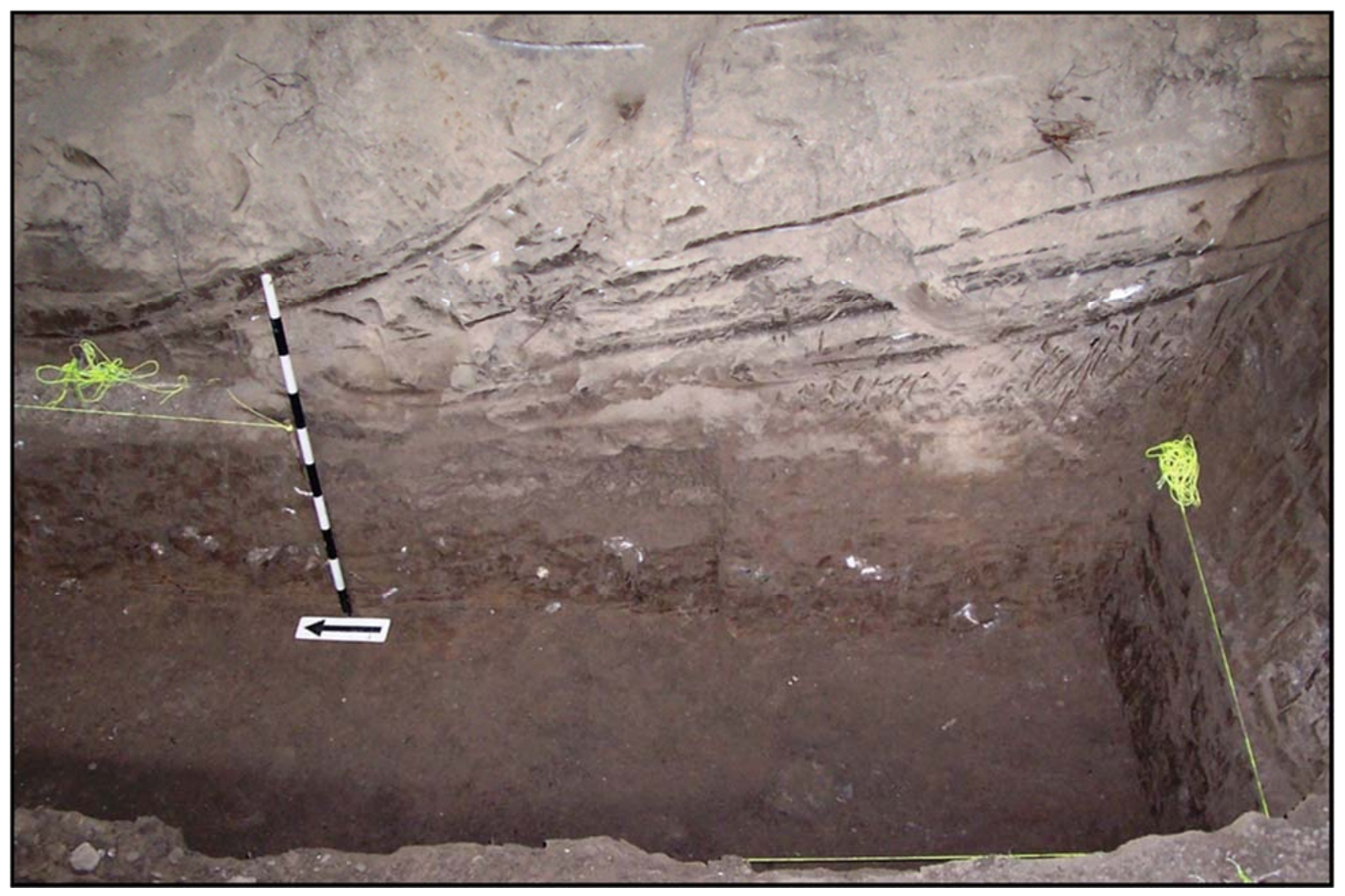

Figure 6-3. Profile of Bk horizon in Backhoe Trench 9 with cultural component visible near bottom. 
of occasional large magnitude to occasionally catastrophic flooding of the $T_{1}$ surface throughout its formation. It is possible that these boulders dislodged from an elevated (but now buried) bedrock outcrop and were not actually entrained bythe stream, but this could not be confirmed during the fieldwork. Flooding of this surface clearly continued into the last thousand years, as the levee-like ridge of Ford Alluvium implies, but gravel is not a common constituent of these deposits.

Ringstaff (2004) interpreted the swale that is present between the upland margin and the leveelike crest as a paleochannels (see Figure 6-1). These features appear on the United States Geological Survey (USGS) topographic maps downstream of the site through the Leon Valley Golf Course. Examination of the trench excavations yielded no substantial evidence supporting this hypothesis. There were no clear changes in the texture of the deposit from the riverside in BT 8 to the floodbasin in BT 12, as would be expected if this swale were a paleochannel. It was apparent following rainfall while working at the site that this swale is capable of ponding water from meteoric events, and would undoubtedly do so after inundation by floodwater should this surface be flooded. It is also likely that this feature would serve as an overflow channel during extreme flooding.

Recent work conducted along the Leon River by Kibler (2004) for a sewer line near the Leon Valley Golf Course immediately downstream noted the occasional presence of wetland-like deposits associated with a channel plug or swale-like feature within the West Range Alluvium. This deposit exhibited vertic properties, redoximorphic features, and aquatic snails (Kibler 2004:7). The existence of such deposits within the West Range Alluvium implies that the levee-like landform on site 41BL278 may have greater antiquity than Ringstaff (2004) presumed, and may have antecedents in the early phases of West Range Alluvium sedimentation.

\subsection{COMMENTS ON CONTEXTUAL INTEGRITY}

The cultural material revealed by test excavations comprised two groups of occupations - one at depths of approximately 130 to $180 \mathrm{cmbs}$ that was previously detected by Ringstaff (2004), and a second, younger, and stratigraphically shallower occupation around 95 to $115 \mathrm{cmbs}$ that may be represented by Feature 1. The depths of these occupations are broad ranges that reflect variations in the surface elevations (which vary with respect to where on the levee-like ridge the depth is measured from and the extent to which construction of the existing bridge altered the original ground surface elevation). The lowest occupation zone (termed the "lower occupation group" [LOG] in Figure 6-1) may represent two or three occupations, at least two of which are relatively easily separated by a thin deposit of sterile sediment. The upper occupation (termed the "upper occupation' [UO] in Figure 6-1) may be one represented by Feature 1 observed by Ringstaff (2004). The lower one was targeted by TRC's testing program, whereas the upper one appears limited, less pronounced, but likely a discrete, short-term occupation. None of the occupations appear to have been adversely affected by large magnitude flooding, they are encased in clayey floodbasin fines, and they lack significant quantities of gravel.

All of the occupations occur in the core of the West Range Alluvium well beneath the presumed surface of this fill. This stratigraphic position implies that they occurred in the portion of the deposit where the sedimentation rate was greatest, although the fine texture of the sediment implies a relatively slow rate of sedimentation.

The apparent spatial concentration of occupation remains in proximity to the modern channel and in approximately the same location as the presumably much later levee-like landform suggests that these occupations may have been sited on a similar feature/landform, although it was impossible to 
recognize it (if present) in the limited trench excavations. The texture of the deposit is more consistent with a floodbasin rather than a levee setting, but the occupation debris in TUs 1, 2 and 4 (adjacent to BT 8) and TUs 5, 6 and 7 (adjacent to BT 9) exhibited a downward slope, away from the river, of about $10 \mathrm{~cm}$ per $3 \mathrm{~m}$. A long profile drawn of BT 13, which extended from the crest of the levee-like ridge down into the floodbasin environment, depicts a 10 to $15 \mathrm{~cm}$ drop in elevation over a $3 \mathrm{~m}$ distance, with the greater slope occurring closer to the ridge crest and the lower gradient towards the floodplain. Hence, the modern ridge exhibits a similar slope to that observed in the lower occupations, which may support this hypothesis. This observation, in combination with other attributes of these deposits described above, imply that all of the deposits examined here (with the exception of the clearly modern ones contemporaneous with bridge construction and use) are of West Range Alluvium age and that the existing floodplain morphology originated prior to 3,200 years ago and persisted to the end of West Range Alluvium sedimentation. If additional work is performed at this APE, this hypothesis should be tested, and the presumed Ford Alluvium "levee" should be directly dated.

\subsection{SUMMARY}

At least three presumably short-term prehistoric occupations are present in the APE at 41BL278 buried within floodplain mud. The lower two were sampled during this testing phase, but the upper occupation, which was not targeted, was not discovered until most trenches had been excavated during the testing phase, and was not sampled during the test excavations.

All occupations appear within the West Range Alluvium. The lower occupations appear to date to around 2850 to 3250 B.P., an age that is consistent with their stratigraphic position. The upper part of the lower occupation returned radiocarbon dates of 940 B.P., a modern age, but it is difficult to envision a 2,000 year hiatus between these occupations; therefore, these two dates are considered potentially spurious. All occupations appear to form relatively short-term, sealed components, but there is some compression within the lower cultural "zone" that probably reflects more than one prehistoric visit to this location within the recurrence interval of flooding.

The lower occupations appear to cluster on the northern edge of the $T_{1}$ surface beneath the existing "levee-like" landform, and the slope of the artifact distributions indicates that they may have been situated on a much earlier, but morphologically similar, landform. Any future excavations should target this linear concentration, but should also look towards understanding how spatial arrangements changed toward the swale, away from the channel. 


\subsection{ARCHEOLOGICAL RESULTS}

\section{J. Michael Quigg}

\subsection{INTRODUCTION}

This chapter presents results of the 2004 archeological assessment and testing investigations within TxDOT's proposed APE at the northwestern end of 41BL278. The concentrations of cultural debris designated as cultural features are presented and discussed in Section 7.2. The classes and frequencies of recovered materials are presented in Section 7.3, followed by presentation of the vertical distributions of the cultural materials in Section 7.4. Finally, Section 7.5 provides the radiocarbon ages for the buried cultural component targeted during this assessment and testing phase.

\subsection{CULTURAL FEATURES}

Nine cultural features were identified, with Features 1, 2, and 3 encountered and recorded, but not excavated, during the survey phase conducted by Blanton \& Associates, Inc. (Ringstaff 2004), and seven (Features 3, 3a, 4, 5, 6, 7, and 8) excavated and documented during TRC's testing phase. As discussed in Section 1.3 above, Features 1 through 3 were detected in the bottoms of BTs 7, 8, and 9 , but were not excavated during the survey. Features $3 \mathrm{a}$ through 8 were hand-excavated during the testing phase and are described and addressed below. Features 1 and 2 were projected to be beyond TxDOT right-of-way and therefore not excavated.

\subsubsection{Feature 3}

This feature was originally discovered in the bottom of BT 9 during the survey phase. It was not excavated at that time, but rather left untouched, and reburied for subsequent investigation. Backhoe Trench 9 was reopened during the testing phase, and TUs 5, 6, 7, and 10 were aligned in a row along its eastern edge and hand-excavated through this cultural zone, which included previously identified Feature 3. A large quantity of burned rock was encountered at the bottom of Level 14 (130 to $140 \mathrm{cmbs}$ ) in TU 5. The southwestern part of TU 5 revealed a concentration of various sizes of burned limestone in a roughly $70 \mathrm{~cm}$ east-west by $50 \mathrm{~cm}$ north-south area, but this concentration likely extended westward into the excavated area of BT 9 and southward into TU 6 (Figure 7-1). The clustered burned rocks in the bottom of BT 9 is believed the same cluster of burned rocks encountered in the TUs 5 and 6 between 137 and $151 \mathrm{cmbs}$.

As observed in TU 5, the burned rocks were not in any well-defined or recognizable pattern. The 25 burned rocks $(6,800 \mathrm{~g})$ within the cluster varied

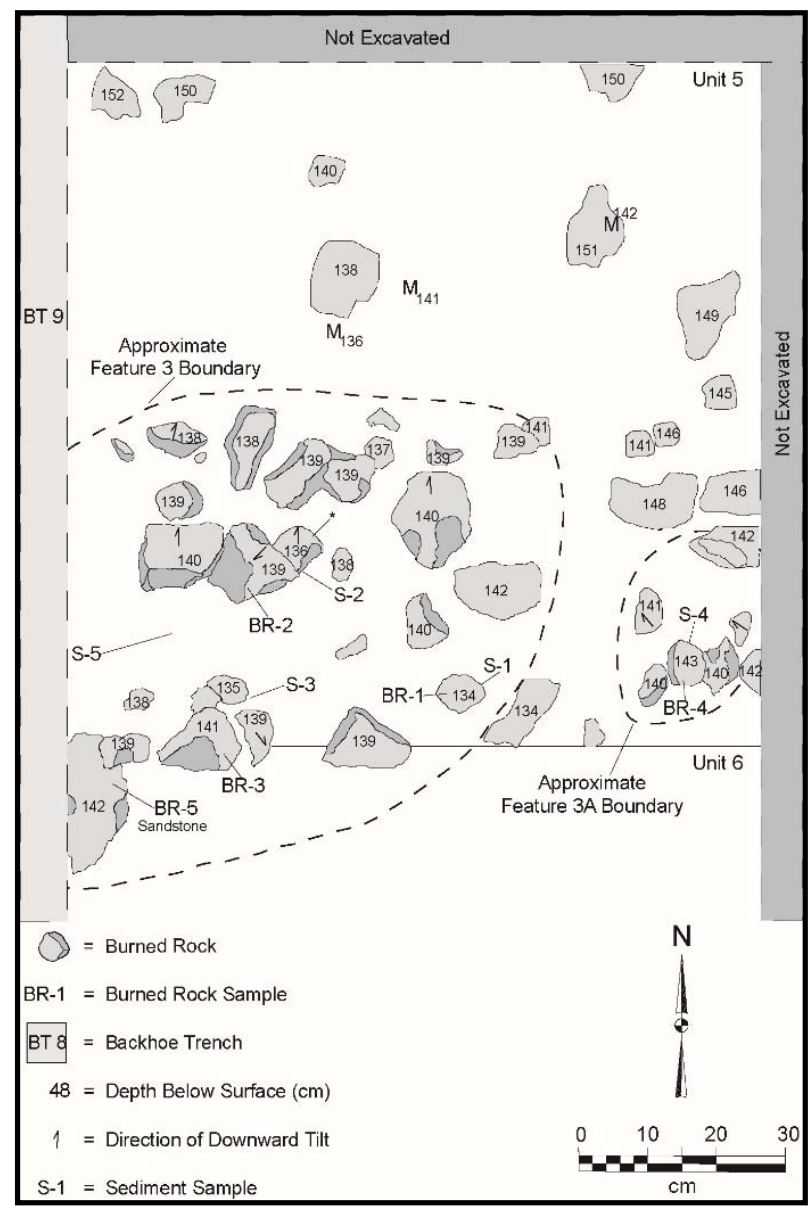

Figure 7-1. Plan view of Features 3 and $3 a$ on the eastern edge of BT 9. 
slightly in depth from 134 to $142 \mathrm{cmbs}$. The rocks varied in size from $2 \mathrm{~cm}$ to nearly $15 \mathrm{~cm}$ in diameter, with the smallest pieces (in the 0 to $4 \mathrm{~cm}$ size class) accounting for 60 percent. Five or six larger pieces slanted in one direction or another, but appeared to rest upon a single uneven surface. At least one sandstone burned rock was encountered, but most burned rocks were limestone. No basin or pit, charcoal staining, or oxidation rim was observed. The clay loam sediment outside the cluster appeared the same as inside the clustered burned rocks.

A bulk matrix sample (\#501-4) from directly under the major concentration of burned rocks was collected for possible flotation, plus four specifically numbered and marked burned rocks were collected for potential analyses. Small sediment samples from immediately below the collected burned rocks were also collected for possible phytolith analysis.
A small chunk of charcoal recovered from the screen was thought to be associated with this cluster. Dering identified the charcoal as cottonwood/willow. That charcoal piece was radiocarbon dated and yielded a $\delta^{13} \mathrm{C}(-25.0 \%)$ corrected accelerated mass spectrometer (AMS) date of $960 \pm 40$ B.P. (UGA-14097). This age is much too young for this depth and associated cultural materials and is therefore rejected (see Section 7.5 for further discussions).

The 3.0 liter bulk sediment sample (\#501-4) was floated and the heavy and light fractions collected. The light fraction weighed $1.4 \mathrm{~g}$, and the heavy fraction weighed $18.2 \mathrm{~g}$. The heavy fraction yielded only six tiny mussel shell fragments $(0.8 \mathrm{~g})$, one tiny unidentifiable bone fragment, and unidentifiable snail shell fragments (Table 7-1). The light fraction yielded one relatively large, complete snail shell and many tiny snail shells, plus three to four tiny charcoal flecks, and uncharred wood and root fragments.

Table 7-1. Material Results from Heavy Fractions from Flotation of Sediments from Feature and Nonfeature Context.

\begin{tabular}{|c|c|c|c|c|c|c|c|c|c|c|c|c|c|c|c|c|c|c|c|c|c|}
\hline PNUM No. & Unit & Feature & $\begin{array}{c}\text { Depth } \\
\text { (cmbs) }\end{array}$ & $\begin{array}{l}\text { Vol (L } \\
\text { wt (g) }\end{array}$ & & \multicolumn{2}{|c|}{\begin{tabular}{|c|} 
Mussel \\
Shell
\end{tabular}} & \multicolumn{2}{|c|}{$\begin{array}{l}\text { Burned } \\
\text { Rock }\end{array}$} & \multicolumn{2}{|c|}{ Debitage } & \multicolumn{2}{|c|}{ Charcoal } & \multicolumn{2}{|c|}{ Snail } & \multicolumn{2}{|c|}{ Macrobot } & \multicolumn{2}{|c|}{$\begin{array}{c}\text { Burned } \\
\text { Clay }\end{array}$} & \multicolumn{2}{|c|}{ Bone } \\
\hline \multicolumn{6}{|c|}{ Size } & $1 / 4$ & $<1 / 4$ & $1 / 4$ & $<1 / 4$ & $1 / 4$ & $<1 / 4$ & $1 / 4$ & $<1 / 4$ & $1 / 4$ & $<1 / 4$ & $1 / 4$ & $<1 / 4$ & $1 / 4$ & $<1 / 4$ & $1 / 4$ & $<1 / 4$ \\
\hline $507-4-6 \mathrm{~g}$ & 7 & Feature 7 & 173 & 2.0 & $N$ & 0 & 0 & 0 & 0 & 0 & 0 & 0 & 2 & 0 & 3 & 0 & 7 & 0 & 0 & 0 & 0 \\
\hline & & & & 33.6 & $\mathrm{Wt}$ & 0.0 & 0.0 & 0.0 & 0.0 & 0.0 & 0.0 & 0.0 & 0.1 & 0.0 & 1.3 & 0.0 & 0.1 & 0.0 & 0.0 & 0.0 & 0.0 \\
\hline $8-4-1 g$ & 2 & Nonfeature & $152-155$ & 3.8 & $N$ & 0 & 0 & 0 & 0 & 0 & 1 & 0 & 2 & 0 & 5 & 0 & 7 & 0 & 0 & 0 & 4 \\
\hline & & & & 12.5 & $\mathrm{Wt}$ & 0.0 & 0.0 & 0.0 & 0.0 & 0.0 & 0.1 & 0.0 & 0.1 & 0.0 & 1.9 & 0.0 & 0.1 & 0.0 & 0.0 & 0.0 & 0.1 \\
\hline 508-4-g & 6 & Feature 8 & $160-170$ & 2.0 & $N$ & 0 & 0 & 0 & 0 & 0 & 1 & 0 & 0 & 0 & 4 & 0 & 0 & 0 & 0 & 0 & 0 \\
\hline & & & & 16.8 & $\mathrm{Wt}$ & 0.0 & 0.0 & 0.0 & 0.0 & 0.0 & 0.1 & 0.0 & 0.0 & 0.0 & 1.3 & 0.0 & 0.0 & 0.0 & 0.0 & 0.0 & 0.0 \\
\hline $505-4-g$ & 4 & Feature 5 & $150-160$ & 12.5 & $N$ & 0 & 10 & 0 & 0 & 1 & 1 & 0 & 2 & 0 & 24 & 0 & 7 & 0 & 0 & 0 & 11 \\
\hline & & & & 113.5 & $\mathrm{Wt}$ & 0.0 & 0.5 & 0.0 & 0.0 & 12.9 & 0.7 & 0.0 & 0.1 & 0.0 & 5.7 & 0.0 & 0.1 & 0.0 & 0.0 & 0.0 & 0.1 \\
\hline $4-2 g$ & 2 & Nonf & $155-158$ & 3.5 & $N$ & 0 & 0 & 0 & 0 & 0 & 0 & 0 & 1 & 0 & 5 & 0 & 3 & 0 & 0 & 0 & 0 \\
\hline & & & & 47.7 & $\mathrm{Wt}$ & 0.0 & 0.0 & 0.0 & 0.0 & 0.0 & 0.0 & 0.0 & 0.1 & 0.0 & 1.3 & 0.0 & 0.1 & 0.0 & 0.0 & 0.0 & 0.0 \\
\hline $501-4-4 \mathrm{~g}$ & 5 & Feature 3 & $130-140$ & 3.0 & $N$ & 0 & 6 & 0 & 0 & 0 & 0 & 0 & 0 & 0 & 5 & 0 & 0 & 0 & 0 & 0 & 1 \\
\hline & & & & 18.2 & $\mathrm{Wt}$ & 0.0 & 0.8 & 0.0 & 0.0 & 0.0 & 0.0 & 0.0 & 0.0 & 0.0 & 2.3 & 0.0 & 0.0 & 0.0 & 0.0 & 0.0 & 0.1 \\
\hline 04-4-g & 1 & Feature 4 & $147-154$ & 7.0 & $N$ & 0 & 8 & 0 & 0 & 0 & 2 & 0 & 0 & 0 & 4 & 0 & 12 & 0 & 0 & 0 & 0 \\
\hline & & & & 83.8 & $\mathrm{Wt}$ & 0.0 & 0.7 & 0.0 & 0.0 & 0.0 & 0.2 & 0.0 & 0.0 & 0.0 & 1.4 & 0.0 & 0.1 & 0.0 & 0.0 & 0.0 & 0.0 \\
\hline
\end{tabular}


Small parts of three burned rocks (\#501-3-1a, \#5013-2a, and \#501-3-3a) were sent for lipid residue analysis that employed the newer and more precise analysis of HT-GC and HT-GC/MS to identify biomarkers. In general, lipid residue recoveries were poor, likely due to poor preservation (Appendix F). Only sample \#508-003-2a yielded sufficient residues to interpret and included both plant and animal residues. Conifer residues, likely from the heating of the rocks were also present. In this region, the conifer residues likely represent juniper or cypress wood. The other two samples yielded insufficient fatty acids for acceptable analysis but the biomarkers and triacylglycerols distributions of residues indicate both samples likely had plant and animal residues (Appendix F).

Parts of the same three burned rocks used for lipid residues (\#501-3-1b, \#501-3-2b, and $\# 501-3-3 b$ ), plus a fourth rock (\#502-3-1b), were subjected to starch analysis. A sediment sample (\#501-4-3a) was also subjected to starch analysis as a control for the burned rocks. Three rocks and the sediment samples failed to yield any starch grains (Appendix E). However, limestone burned rock \#502-3-1a, weighing 605 g, yielded 14 starch grains, the most recovered from any sample analyzed. This included a single lenticular starch grain from a grass in the Triticeae, the group that includes wildrye and little barley, four grains from the lily family, three grains derived from geophytes that do not appear in the lily family, four unidentified grass starch grains not in the Triticeae, a single unidentified starch grain, and a clump of unidentified starch grains. A damaged grain was also recovered, however, the damage was not distinctive enough to be identified (Appendix E).

Feature 3 is thus interpreted as discarded cooking rocks previously used in one or more adjacent cooking events. The absence of a basin, the random positions of the rocks, and lack of oxidation all support this interpretation.

\subsubsection{Feature 3A}

A second, smaller cluster of burned rocks detected along the eastern edge of TU 5 was designated Feature 3a, as it was unclear at first whether or not it warranted its own feature number. Slight elevation differences in the burned rocks across TU 5 made it unclear if all of the burned rocks represented the same event. This small rock cluster extended eastward beyond TU 5. This roughly 20 $\mathrm{cm}$ diameter cluster may or may not be an extension of Feature 3 (see Figure 7-1). The burned rocks varied in depth from 140 to $143 \mathrm{cmbs}$, were between 2 and $15 \mathrm{~cm}$ in diameter, and weighed a total of $850 \mathrm{~g}$. Again, no basin or pit, charcoal, or oxidation rim was observed below the rocks. No other cultural material was observed immediately around or among the rocks.

Parts of two burned rocks (\#503-3-1a and \#503-32) were sent for lipid residue analysis. Sample \#503-3-1a yielded a combination of plant and animal with conifer products also present (Appendix F). The other sample yielded insufficient fatty acids for acceptable analysis, although the biomarkers and triacylglycerols distributions of residues indicate both likely had plant and animal residues (Appendix F).

Parts of the same burned rock used for lipid residue analysis (\#503-3-1b) and a sediment sample (\#5034-2a) from under Burned Rock 4 (BR-4) were subjected to starch analysis as a control for the burned rocks. Neither sample yielded any starch grains (Appendix E).

A 22 g sediment sample (\#503-4-1a) from under BR-4 was sent for phytolith analysis. Overall phytolith preservation was very poor due to the basic $\mathrm{pH}$ environment of the Venus clay loam soil matrix which resulted in extensive phytolith chemical weathering (Appendix D). Short cell phytoliths were observed in very limited numbers, and the more abundant bulliform cells generally revealed extensive surface pitting from chemical 
weathering, which is readily attributed to the calcic soil environment. Only the sponge spicule and tree origin biogenic particles reveal good preservation. Not enough short cells were observed to reach minimum count required criteria.

Feature $3 \mathrm{a}$ is therefore interpreted as a small discard pile of burned rocks once used for cooking.

\subsubsection{Feature 4}

This burned rock feature was discovered towards the northern end of BT 8, near the center of TU 1 . This loose grouping was encountered near the central part of Level 15 (150 to $160 \mathrm{cmbs}$ ) and designated as Feature 4 (Figures 7-2 and 7-3). This grouping contained 21 rocks $(3,500 \mathrm{~g})$ between 147 and $155 \mathrm{cmbs}$. Nearly 65 percent of the rocks were less than $9 \mathrm{~cm}$ in diameter. No basin or pit, charcoal lens, or oxidation rim was observed below the rocks. A bulk sediment sample and selected burned rocks were collected for laboratory analyses.

The bulk sediment sample (\#504-4) of 7.0 liters was floated and heavy and light fractions collected. The light fraction weighed $1.6 \mathrm{~g}$, and the heavy fraction weighed $83.8 \mathrm{~g}$. The heavy fraction yielded two tiny lithic fragments $(0.2 \mathrm{~g})$, eight tiny mussel shell fragments $(0.7 \mathrm{~g})$, a variety of unidentifiable snail shells (including one burned gray fragment), and 12 unburned hackberry seed fragments (see Table 71). The light fraction yielded one complete and many tiny snail shells, plus three to four tiny charcoal flecks and uncharred wood and root fragments.

A few pieces of lithic debitage $(N=7)$, mussel shell $(N=4)$, tiny faunal bone fragments $(N=10)$, and scattered burned rocks were also recovered from the same level that surrounded Feature 4.

Parts of three burned rocks (\#504-3-1a, \#504-3-2a, and \#504-3-3a) were sent for lipid residue analysis. Sample \#504-3-1a yielded a combination of plant and large herbivore residues, with conifer products also present (Appendix F). Although the other two samples yielded insufficient fatty acids for acceptable analysis, the biomarkers and triacylglycerols distributions of residues indicate both likely had plant and animal residues (Appendix F).

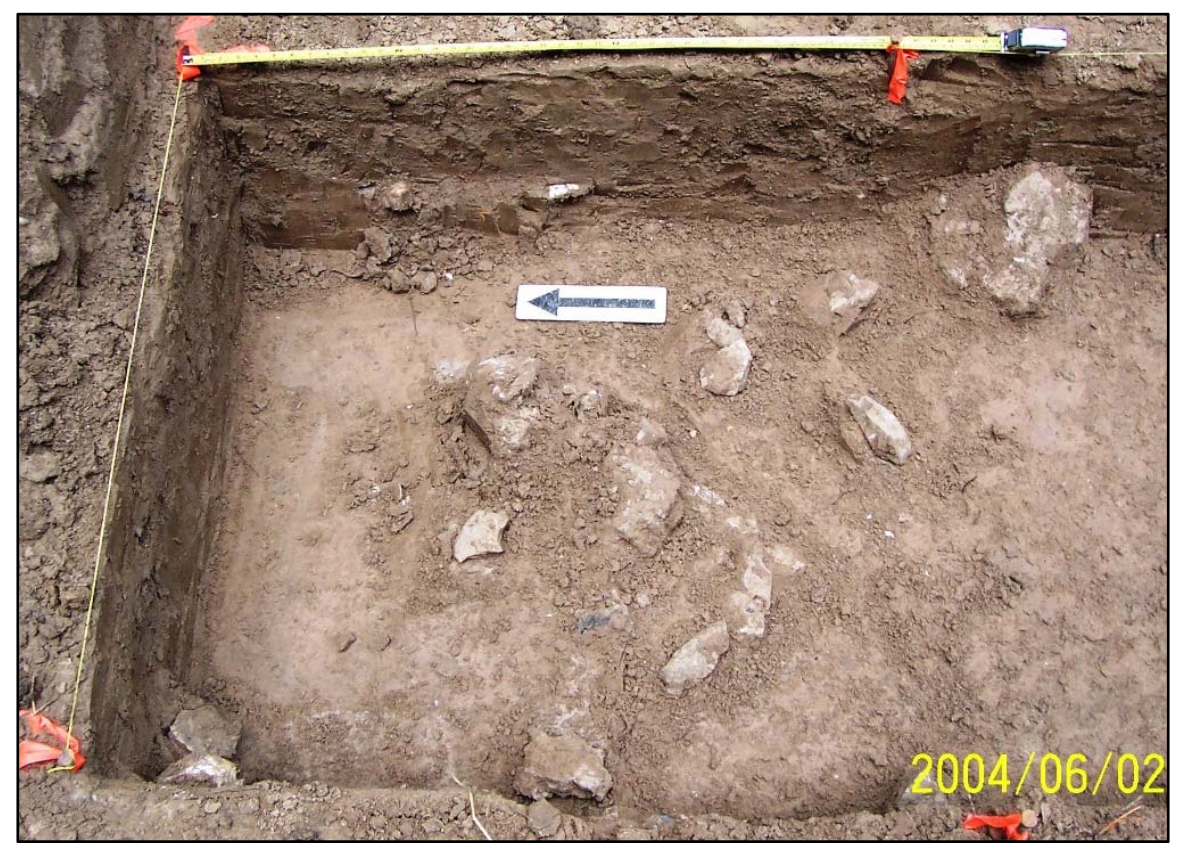

Figure 7-2. Oblique view of Feature 4 in Test Unit 1. 


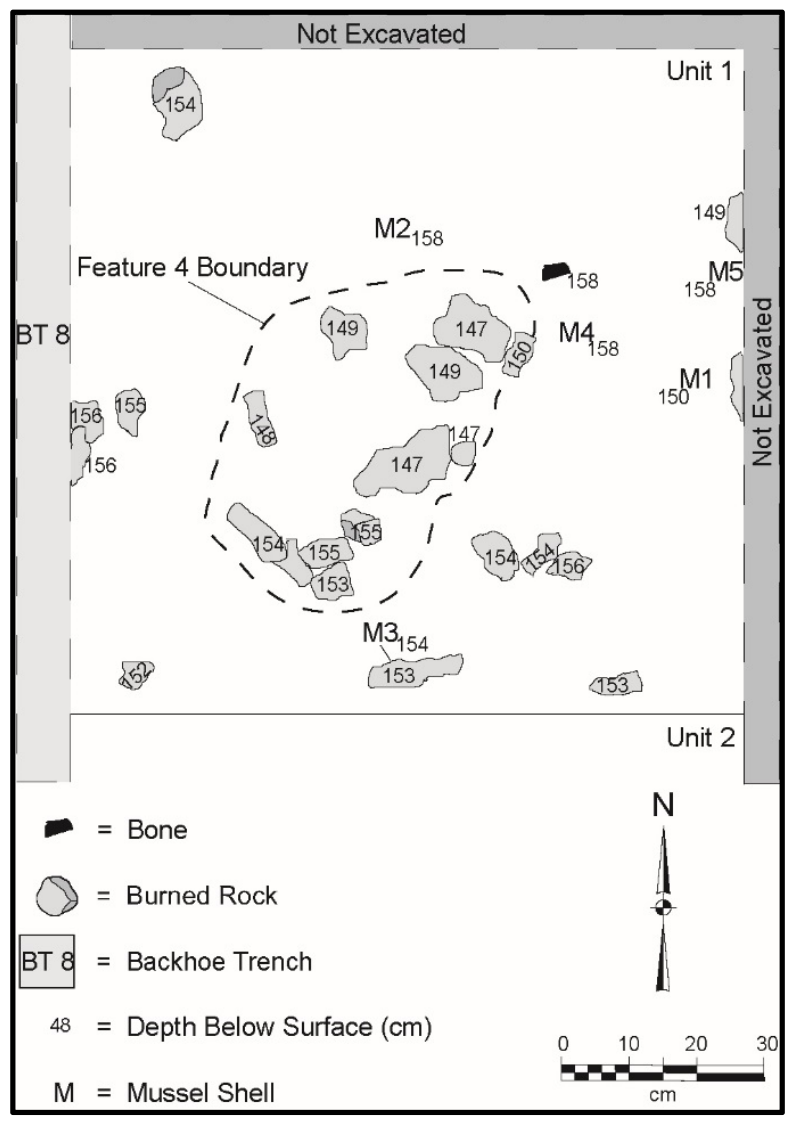

Figure 7-3. Plan View of Feature 4 in Test Unit 1 on eastern edge of Backhoe Trench 8.

Parts of the same three burned rocks used for lipid analysis, plus a fourth rock (\#504-3-4) were also subjected to starch analysis (\#504-3-1b, \#504-3-2b, and \#504-3-3b). All four samples failed to yield identifiable starch grains, but two contained gelatinized starches (Appendix E).

Feature 4 is interpreted as a burned rock discard pile as is revealed no basin, or oxidized sediment combined with random distribution of the rocks.

\subsubsection{Feature 5}

This roughly circular arrangement of burned rocks encountered between 150 and $160 \mathrm{cmbs}$ in TU 4 was also present along the eastern edge of BT 8 . Feature 5 was just over $1 \mathrm{~m}$ south of Feature 4 . The western and southern edges of Feature 5 extended beyond the margins of $\mathrm{TU} 4$; therefore, the excavated dimensions of nearly $80 \mathrm{~cm}$ in diameter are smaller than the projected overall dimensions (Figure 7-4). Relatively large limestone burned rocks formed an irregular, somewhat circular outline with scattered burned rocks within the interior of the outline. Only one burned rock along the northeastern margin was slanted.

The excavated portion of Feature 5 yielded 38 burned rocks that weighed a total of $20,780 \mathrm{~g}$, with an average rock weight of $547 \mathrm{~g}$. The feature was bisected, but no basin or pit, charcoal lens, or the burned rocks. A biface fragment (\#505-10) was discovered inside the circular arrangement on the oxidation rim was detected (Figure 7-5). A couple of tiny chunks of charcoal were discovered among southern edge, a few centimeters above the rocks. Five burned rocks (numbered 1 through 5) and a bulk sediment sample were collected for possible analyses.

A 12.5 liter bulk sediment sample (\#505-4) was floated and the heavy and light fractions collected. The light fraction weighed $2.4 \mathrm{~g}$, and the heavy fraction weighed $113.5 \mathrm{~g}$. The heavy fraction yielded multiple classes of cultural and noncultural materials that include two tiny pieces of wood charcoal and 11 tiny bone fragments, two of which are burned long bone shaft fragments of a very small animal (see Table 7-1). One fragment of a light colored chert pebble, over $6.4 \mathrm{~mm}$ long, is likely noncultural in origin as it lacks flake scars. The light fraction yielded one large complete and many tiny snail shells plus three to four tiny charcoal flecks and uncharred wood and root fragments.

Parts of four burned rocks (\#505-3-1a, \#505-3-2a, \#505-3-3a, and \#505-3-5a) were sent for lipid residue analysis. Sample \#505-3-1a yielded large herbivore and plant residues, whereas sample \#5053-2a had borderline moderate-high to high fat residue, interpreted to indicate both plant and animal products present. Although the other two samples yielded insufficient fatty acids for acceptable analysis, the biomarkers and 


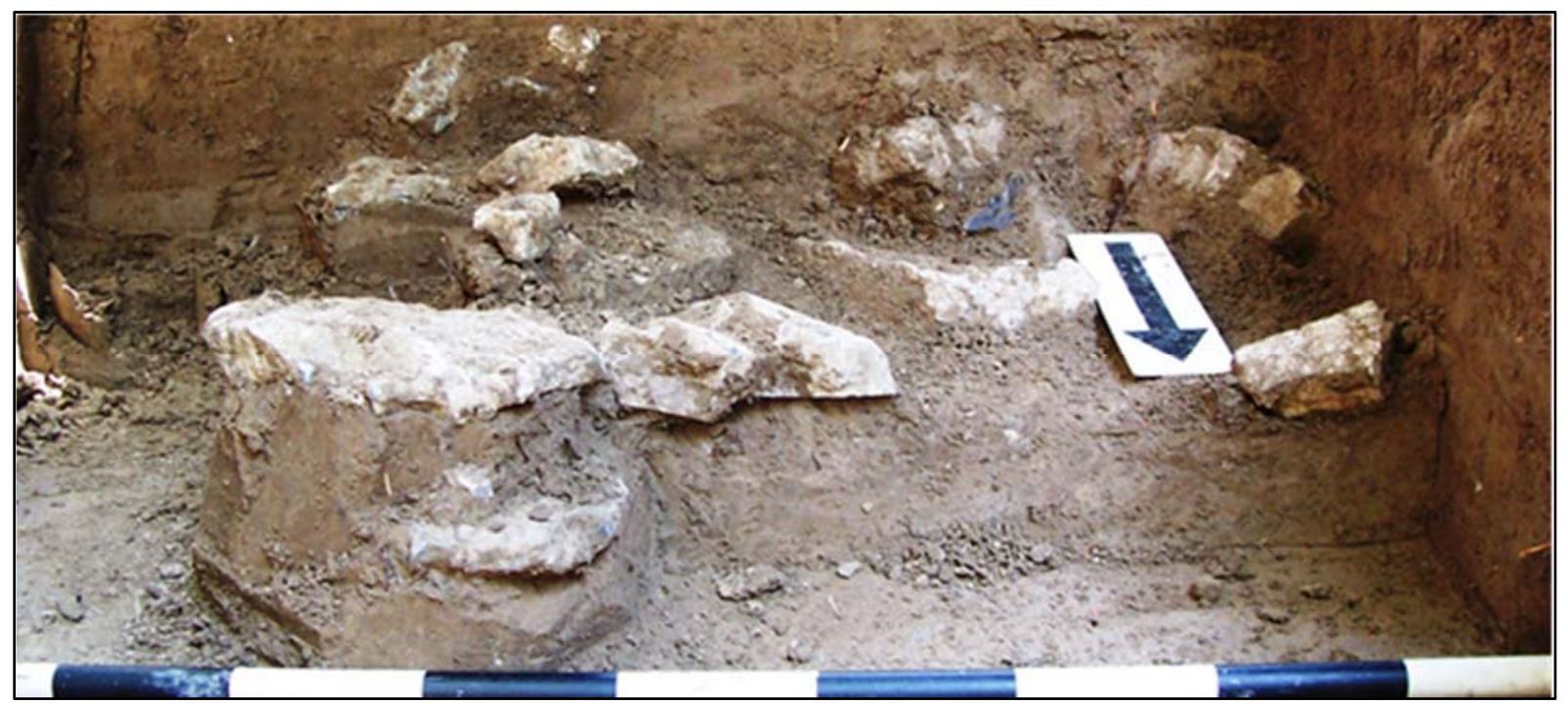

Figure 7-4. Profile through the middle of Feature 5 in Test Unit 4.

triacylglycerols distributions of residues indicate both likely had plant and animal residues (Appendix F). All samples appeared to have conifer residue present, indicating the wood types from heating the rocks.

Parts of the same four burned rocks used for lipid analysis (\#505-3-1b, \#505-3-2b, \#505-3-4a, and $\# 505-3-5 b$ ) plus one other (\#505-3-3b) were also subjected to starch analysis. Rock \#505-3-4a yielded a single starch grain from an unidentified geophyte, whereas rock \#505-3-5b yielded a gelatinized grain (Appendix E). Feature 5 is interpreted as part of a hearth/heating element with rocks used to cook plants and animal products. The rest of the level sediment immediately beyond this hearth yielded only three pieces of lithic debitage, one mussel shell, 11 snail shells, and 16 small burned rock pieces that weighed a total of $500 \mathrm{~g}$.

\subsubsection{Feature 6}

This small, dense concentration of diverse materials was on the northern edge of Feature 5 near the base of Level 16, and continued into Level 17 (158 to 166 cmbs) in TU 4 (see Figure 7-5). This short linear concentration of material covered an area about $15 \mathrm{~cm}$ wide by $30 \mathrm{~cm}$ long, and consisted of 1 chert flake, 3 nearly complete mussel shell valves,

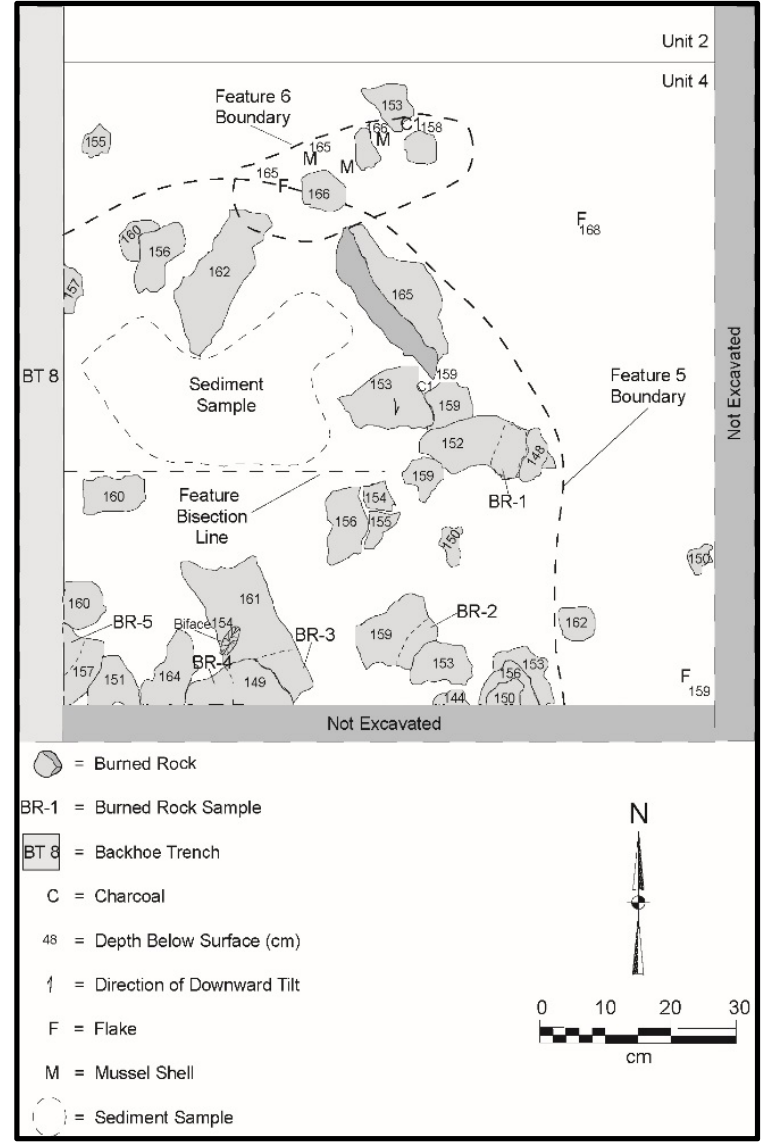

Figure 7-5. Plan view of Features 5 and 6 in Test Unit 4. 
29 Rabdotus snail shells, a couple of small charcoal chunks (assigned $\mathrm{C}_{1}$ on northern edge), and 13 small burned rocks. The burned rocks weighed a total of $199 \mathrm{~g}$, and were all in the 0 to $4 \mathrm{~cm}$ size class. One small, tabular burned rock was oriented vertically and found inside a mussel shell. The mussel shells were oriented both flat and vertically, which may indicate how they were discarded or minor displacement. All items were collected for possible analysis.

A soil humate sample (\#506-7-1) from $158 \mathrm{cmbs}$ within Feature 6 was radiocarbon and yielded a $\delta^{13} \mathrm{C}(-23.6 \%)$ corrected AMS date of $3430 \pm 30$ B.P. (Beta-370504). This age is acceptable for Feature 6 and the associated cultural component (see Section 7.9 below for more discussion).

One burned rock (\#506-3-2) was sent for lipid residue analysis. This sample yielded high fat, which may denote use with seeds or nuts and/or the rendered fats of certain mammals (other than large herbivores by definition), plus low fat content plants, such as roots, greens and some berries. Both plant and animal products are present along with conifer products (Appendix F).

Another rock (\#506-3-1) was submitted for starch analysis. This rock yielded an unidentifiable starch grain (Appendix E).

Feature 6 is interpreted as a concentration of discarded materials, probably associated with nearby hearth Feature 5.

\subsubsection{Feature 7}

Feature 7 consisted of a tight cluster of burned rocks and occasional chunk of charcoal near the center of TU 7, possibly extending westward into the excavated area of BT 9 (Figures 7-6 and 7-7). This cluster contained 16 burned rocks of 0 to $4 \mathrm{~cm}$ size class that weighed a total of 2,200 $\mathrm{g}$ and one mussel shell in an area about $40-$ by $-50 \mathrm{~cm}$ in diameter. The burned rocks varied in depth from

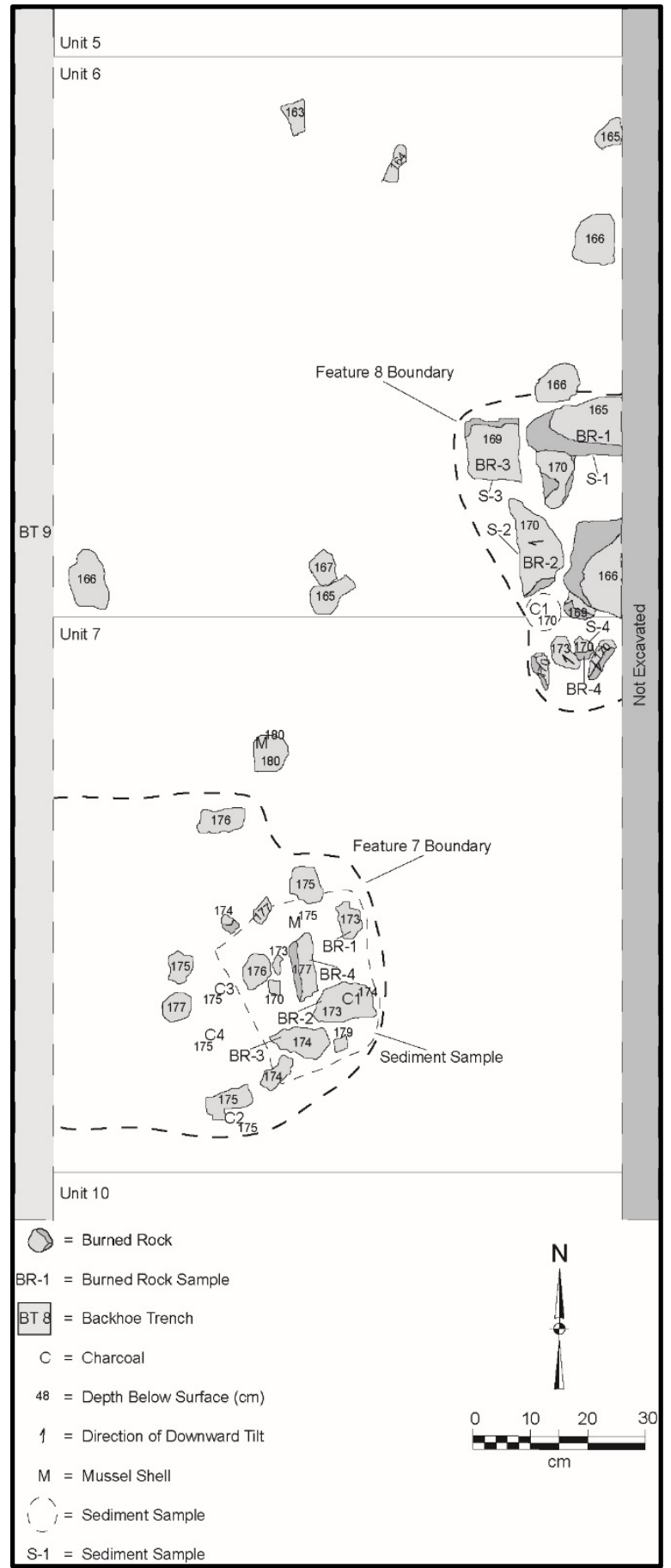

Figure 7-6. Plan view of Features 7 and 8 in Test Units 6 and 7 on eastern side of Backhoe Trench 9. 


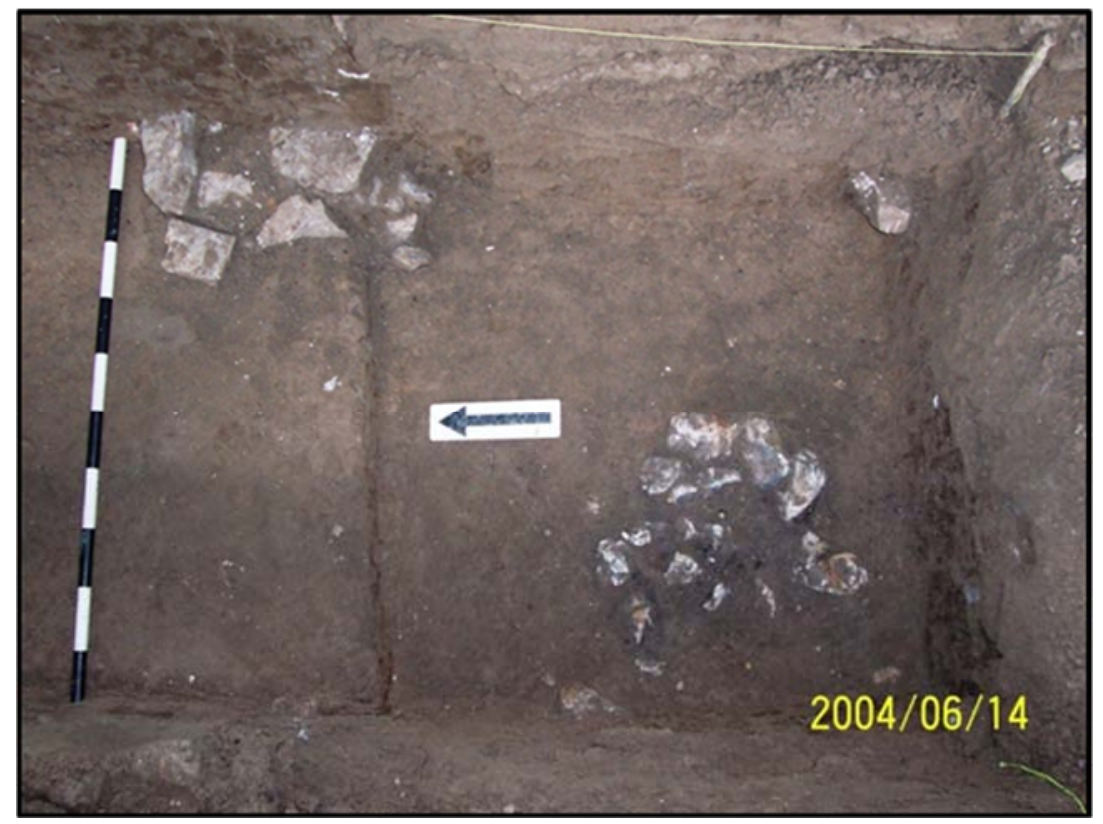

Figure 7-7. Photograph of Features 7 and 8 in Test Units 6 and 7 on eastern side of Backhoe Trench 9.

oxidation rim was observed under this cluster. Matrix between the rocks was the same brown color (10YR 4/3) as the rest of the level. A bulk sediment sample was collected from under and around the burned rocks. A second tight cluster of small burned rocks was detected in the northeastern corner of TU 7, and assigned Feature 8. The rest of the level outside the features yielded only two pieces of lithic debitage, one mussel shell adhering to a burned rock, and 21 small burned limestone rocks that weighed $1,900 \mathrm{~g}$.

A tiny chunk of wood charcoal (\#507-7-3a) from the western edge of Feature 7 was radiocarbon dated. This piece yielded a $\delta^{13} \mathrm{C}(-25.9 \%)$ corrected AMS date of $3120 \pm 40$ B.P. (UGA-14098). This age determination is accepted for Feature 7 and the associated cultural component (see Section 7.9 below for more discussion).

A 33.6 liter bulk sediment sample (\#507-4-6g) was floated and the heavy and light fractions collected. The light fraction weighed $1.2 \mathrm{~g}$, and the heavy fraction weighed $33.6 \mathrm{~g}$. The heavy fraction yielded two tiny pieces of wood charcoal $(0.1 \mathrm{~g})$ and unburned hackberry seed fragments (see Table 7-
1). The light fraction yielded many tiny snail shells plus uncharred wood and root fragments.

Two fragments of burned rocks (\#507-3-1a and \#507-3-2a) were sent for lipid residue analysis. Both samples yielded residues of medium fat content. This lipid residue is present in plant foods such as mesquite, corn and cholla (Opuntia sp.) and in animals including freshwater fish and Rabdotus snail meat (Appendix F). As with previous samples, conifer residues are also present.

Parts of the same two burned rocks sent for lipid analysis (\#507-3-1b and \#507-3-2b), plus one other rock (\#507-3-3) were subjected to starch analysis. A sediment sample (\#507-4-2b) from under Burned Rock 2 (BR-2) was also subjected to starch analysis as a control for the burned rocks (see Figure 7-6). None of the samples yielded starch grains (Appendix E).

A $30 \mathrm{~g}$ sediment sample (\#507-4-2a) from under BR-2 was also sent for phytolith analysis. Overall phytolith preservation was very poor due to the basic $\mathrm{pH}$ environment of the Venus clay loam soil matrix, which resulted in extensive phytolith 
chemical weathering (Appendix D). Short cell phytoliths were observed in very limited numbers, and the more abundant bulliform cells generally revealed extensive surface pitting from chemical weathering, which is readily attributed to the calcic soil environment. Only the sponge spicule and biogenic particles of tree origin reveal good preservation. Not enough short cells were observed to reach minimum count required for analysis.

Feature 7 is interpreted as a discard pile from a cooking event in which nonstarchy plants were cooked. Again, this cluster lacked a basin or oxidized sediment and the rocks appeared randomly orientated.

\subsubsection{Feature 8}

Feature 8 consisted of a tight cluster of burned rocks along the eastern edge of TUs 6 and 7, about $60 \mathrm{~cm}$ northeast of Feature 7 (see Figures 7-6 and 7-7). The excavated portion of Feature 8 covered an area about $55 \mathrm{~cm}$ north-south by $30 \mathrm{~cm}$ east-west, although more rocks extended eastward beyond the test units. The 12 burned rocks recovered from the feature weighed a total of $2,000 \mathrm{~g}$, ranged in size from 3 to slightly greater than $15 \mathrm{~cm}$, with about half in the 3 to $4 \mathrm{~cm}$ diameter size class. These burned rocks were between 165 and $173 \mathrm{cmbs}$. Four burned rocks, four small sediment samples from under those four collected burned rocks, a charcoal fleck concentration, and a bulk sediment sample from inside the concentration were collected for potential analyses.

The 2.0 liter bulk sediment sample (\#508-4-g) was floated and the heavy and light fractions collected. The light fraction weighed $0.2 \mathrm{~g}$, and the heavy fraction weighed $16.8 \mathrm{~g}$. Again, the heavy fraction yielded mostly tiny snail shells with one tiny lithic fragment (see Table 7-1). The light fraction also yielded a few tiny snail shells, plus uncharred wood and root fragments.

The rest of the $10 \mathrm{~cm}$ level between 160 and 170 cmbs in TU 6 yielded 2 pieces of lithic debitage, 1 mussel shell fragment, 4 Rabdotus snail shells, and 41 other burned rocks that weighed 4,200 g. Ninetythree percent of the latter burned rocks were in the 0 to $4 \mathrm{~cm}$ diameter size class.

Parts of three burned rocks (\#508-3-1a, \#508-3-2a, and \#508-3-3a) were sent for lipid residue analysis. Again, two samples yielded residues of medium fat content, with similar residues in plant foods such as mesquite, corn and cholla, whereas similar medium animal products include freshwater fish and Rabdotus snail meat (Appendix F). The third sample had possible traces of plant and animal products. Here again the samples from this feature revealed similar plant and animal products with conifer products in at least two of the three rocks (Appendix F).

Parts of the same three burned rocks used for lipid analysis (\#508-3-1b, \#508-3-2b, and \#508-3-3b), plus a control sediment sample (\#508-4-1b) were subjected to starch analysis. Rock \#508-3-1b yielded a single gelatinized starch grain (Appendix E).

A phytolith sample (\#508-4-1a) of $28 \mathrm{~g}$ from 165 cmbs under Burned Rock 1 yielded poor results (Appendix D). Overall phytolith preservation was very poor due to the basic $\mathrm{pH}$ environment of the Venus clay loam soil matrix, which resulted in extensive phytolith chemical weathering (Appendix D). Short cell phytoliths were observed in very limited numbers, and the more abundant bulliform cells generally revealed extensive surface pitting from chemical weathering, which is readily attributed to the calcic soil environment. Only the sponge spicule and tree origin biogenic particles reveal good preservation. Not enough short cells were observed to reach minimum count required.

Feature 8 is interpreted as a dump of expended cooking rocks, but potentially may represent the edge of a larger rock hearth/heating element. 
Table 7-2. Summary of Feature Data from TXDOT APE at 41BL278.

\begin{tabular}{|c|c|c|c|c|c|c|c|c|c|}
\hline & Feature $1^{1}$ & Feature $2^{1}$ & Feature $3^{1}$ & Feature $3 a$ & Feature 4 & Feature 5 & Feature 6 & Feature 7 & Feature 8 \\
\hline Backhoe Trench & 7 & 8 & 9 & 9 & 8 & 8 & 8 & 9 & 9 \\
\hline Unit & None & None & 5 & 5 & 1 & 4 & 4 & 7 & 7 and 8 \\
\hline $\begin{array}{l}\text { Depth Below Surface } \\
(\mathrm{cm})\end{array}$ & 105 & $145-170$ & $134-142$ & $140-143$ & $147-155$ & $149-165$ & $153-166$ & $173-179$ & $165-173$ \\
\hline Occupation Zone & Upper & Lower & Lower & Lower & Lower & Lower & Lower & Lower & Lower \\
\hline $\begin{array}{l}\text { Radiocarbon Age (B.P.) } \\
\text { of Cultural Zone }\end{array}$ & $2490 \pm 50$ & None & $960 \pm 40^{2}$ & None & None & None & $3430 \pm 30$ & $3120 \pm 40$ & None \\
\hline Feature Type & Hearth & Unrecorded & $\begin{array}{l}\text { Burned rock } \\
\text { dump }\end{array}$ & $\begin{array}{l}\text { Burned rock } \\
\text { dump }\end{array}$ & $\begin{array}{l}\text { Burned rock } \\
\text { dump }\end{array}$ & Hearth & $\begin{array}{c}\text { Burned } \\
\text { rock dump }\end{array}$ & $\begin{array}{c}\text { Burned rock } \\
\text { dump }\end{array}$ & $\begin{array}{c}\text { Burned rock } \\
\text { dump }\end{array}$ \\
\hline Shape & Unrecorded & Unrecorded & Irregular & Irregular & Irregular & Circular & Linear & Irregular & Irregular \\
\hline Profile & Unrecorded & Unrecorded & Irregular & Irregular & Irregular & Irregular & Irregular & Irregular & Irregular \\
\hline Length (cm) & Unrecorded & Unrecorded & 70 & 20 & 60 & 80 & 30 & 50 & 55 \\
\hline Width (cm) & Unrecorded & Unrecorded & 50 & 20 & 40 & 80 & 15 & 40 & 30 \\
\hline Thickness (cm) & Unrecorded & Unrecorded & 10 & 5 & 10 & 10 & 12 & 7 & 8 \\
\hline Mussel Shells & 14 & 7 & Tiny fragments & None & 8 tiny fragments & None & 3 & 1 & None \\
\hline Charcoal & Chunks & 0 & Flecks & None & Flecks & Tiny flecks & Tiny flecks & Chunks & Chunks \\
\hline Lithic debitage & 2 & 0 & None & None & 2 tiny & None & 1 & None & 1 \\
\hline Stone tools & None & 0 & None & None & None & 1 biface & None & None & None \\
\hline Burned Rock Count & 9 & 16 & 25 & 8 & 21 & 38 & 13 & 16 & 12 \\
\hline Burned Rock Weight (g) & Unrecorded & Unrecorded & 6,800 & 850 & 3,500 & 20,780 & 199 & 2,200 & 2,000 \\
\hline Burned Rock Type & Unrecorded & Unrecorded & Limestone & Limestone & Limestone & Limestone & Limestone & Limestone & Limestone \\
\hline Lipid analysis & None & None & 3 & 2 & 3 & 4 & 1 & 2 & 3 \\
\hline Starch analysis & None & None & 4 & 2 & 4 & 5 & 1 & 3 & 4 \\
\hline Phytolith analysis & None & None & None & 1 & None & None & None & 1 & 1 \\
\hline
\end{tabular}

1. = Features encountered and recorded, but not excavated by Blanton and Associates; $2 .=$ date rejected as to young. 


\subsubsection{Feature Discussion}

In summary, these seven cultural features documented during the eligibility assessment, plus the two additional features (Features 1 and 2) identified during the previous survey, were wellpreserved with good integrity. They indicate intense cultural activity and were horizontally concentrated on the northern edge of the $\mathrm{T}_{1}$ terrace. Feature 1 is potentially stratigraphically above (at roughly $105 \mathrm{cmbs}$ ) and younger (2495 B.P.) than the targeted component with the eight other features (at 130 to $180 \mathrm{cmbs}$ ), which were also older (Table 7-2). The lipid residue results reveal a remarkable consistency, which supports the cooking of similar food products, a combination of plants and animals in all features. This consistency may support a campsite occupied by the same group with all features employed to prepare similar products. These residue results also indicate that in the immediate environment conifer products, likely juniper and/or cypress was used to heat the rocks.

The microfossil results from starch grain analysis indicate grasses of the Triticeae, a tribe within the Pooideae subfamily that produce characteristic lenticular starch grains, as well as starches from the lily family, unidentified geophytes, unidentified grasses, and unidentified plant sources were some of the food resources cooked by the burned rocks in these features.

Although the phytolith record is poorly preserved, it does reveal aspects worthy of note. The three samples from three separate features (Features 3a, 7 and 8) did yield a sparse quantity of a variety of short cells (Pooids, Panicoids, and Chloridoids), undiagnostic bulliforms, well-preserved burned tree phytoliths, and well-preserved freshwater sponge spicules. The spicule presence in features is indicative of water use and may reflect stone boiling. The sand fraction of the phytolith process yielded a variety of snails as well as charcoal flecks, bone, burned shell (possibly snail), some lithic material, and other stone.
The encountered burned rock features that included dumps of discarded rocks and in situ cooking facilities indicate one principle activity. Cooking involved selected plant foods such as multiple grass types, lily bulbs, and other geophytes through small burned rock dominated facilities The cultural groups that used those features apparently were present a sufficient length of time to gather, prepare and cook varied plant and animal food resources and subsequently clean out and reuse primary cooking features and/or activity areas and discard unwanted materials. Evidence indicates the targeted lower component was occupied for a period(s) longer than an overnight stay, which highlights the potential for discerning recognizable activity areas and discovering a larger associated time-restricted assemblage. Features 2 through 8 and nearly all the cultural materials discussed below belong to the targeted lower component.

\subsection{MATERIAL CLASS AND FREQUENCIES}

This section presents the cultural material recovered from the testing program in the APE at the northwestern end of 41BL278 by classes and discusses their frequencies. This includes not only the counts but also the horizontal patterning and density of materials per cubic meter. Although all the material derives from one cultural component, two separate short-term events appear represented between 130 and $180 \mathrm{cmbs}$ (see Section 7.4 below).

\subsubsection{Lithic Debitage}

The $4.1 \mathrm{~m}^{3}$ hand-excavated area in the APE yielded 117 pieces of lithic debitage, for an average of 2.9 pieces per $10 \mathrm{~cm}$ level. However, the debitage was not evenly distributed across the three investigated areas (Table 7-3). Test Units 1, 2, and 4 adjacent to BT 8 yielded 24 percent of the total. Test Units 5, 6, 7, and 10 adjacent to BT 9 yielded about 75 percent. Test Units 8 and 9 adjacent to BT 14 yielded less than one percent. This uneven horizontal distribution indicates spatial patterning in the 
Table 7-3. Lithic Counts by Test Unit and Adjacent Backhoe Trench.

\begin{tabular}{|c|c|c|}
\hline $\begin{array}{c}\text { Backhoe } \\
\text { Trench No. }\end{array}$ & $\begin{array}{c}\text { Test Unit } \\
\text { No. }\end{array}$ & Counts \\
\hline \multirow{3}{*}{8} & 1 & 11 \\
\cline { 2 - 3 } & 2 & 10 \\
\cline { 2 - 3 } & 4 & 7 \\
\hline \multirow{3}{*}{9} & 5 & 30 \\
\cline { 2 - 3 } & 6 & 21 \\
\cline { 2 - 3 } & 7 & 14 \\
\cline { 2 - 3 } & 10 & 22 \\
\hline \multirow{2}{*}{14} & 8 & 2 \\
\cline { 2 - 3 } & 9 & 0 \\
\hline \multicolumn{2}{|c|}{ Total } & 117 \\
\hline
\end{tabular}

limited area investigated, and likely reflects specific intrasite activity areas. This also supports the integrity of the cultural event(s).

Ultraviolet (UV) fluorescence examination of the lithic debitage, revealed at least 87 percent Edwards chert and 13 percent non-Edwards chert. Based on the visible colors and patterns many pieces reflect chert types previously identified at Fort Hood. Types that appear represented include at least: Type 1, Heiner Lake Blue-light; Type 2, Cowhouse White; Type 6, Heiner Lake Tan; Type 8, Fort Hood Yellow; Type 13, East Range Flecked; and Type 15, Gray-Brown-Green (see Trierweiler 1994 for type descriptions and color photographs).

Multiple manufacturing stages are represented in this limited sample and include primary, secondary, and tertiary flakes, plus shatter and one multidirectional core (\#8-10). Both hammerstone and billet flakes are represented based on platform types, bulb sizes, and the presence of eraillure scars. General observations also indicate biface reduction occurred, as evidenced by well-established multifaceted platforms that have been intentionally ground on biface thinning flakes. Cobble reduction is represented as some larger pieces exhibit 30 percent or more cortex on primary and secondary flakes. At least two types of cortex are present, water smoothed and others much rougher. These two different types of cortex indicate procurement from both primary and secondary sources. Usable chert does not appear to be in short supply, as a relatively high proportion of the debitage is greater than $4 \mathrm{~cm}$ in length and about 5 percent are greater than $6 \mathrm{~cm}$. Only one piece has the appearance of possible patination. No pieces appear heat treated. No obviously nonlocal chert is present. All stages of lithic production, including cobble reduction, biface reduction and thinning, and tool resharpening occurred in this component.

A chert core (\#8-10) was recovered from $151 \mathrm{cmbs}$ in TU 2. It is mottled very pale brown (10YR 8/2) and white $(\mathrm{N} \mathrm{8.5/)}$ chert that weighs $136 \mathrm{~g}$ (Figure 7-8). This may also be a very early stage biface preform, as smooth cortex is only on one end and covers about five percent of the total surface area. The smooth cortex is reminiscent of a water worn exterior on a cobble. Flake scars are large, from multiple directions, and cover both faces. This piece measures $98.2 \mathrm{~mm}$ long, $72.5 \mathrm{~mm}$ wide, and $23.3 \mathrm{~mm}$ thick. It has a mottled orangish UV fluorescence with one small yellowish fluorescence area indicative of Edwards chert.

\subsubsection{Chipped Stone Tools}

Hand-excavations yielded eight chipped stone tools; four bifaces, and four edge-modified flakes. One large, complete chert biface (\#37-10) (Table 74, Figure 7-9) was collected from $110 \mathrm{cmbs}$ in the

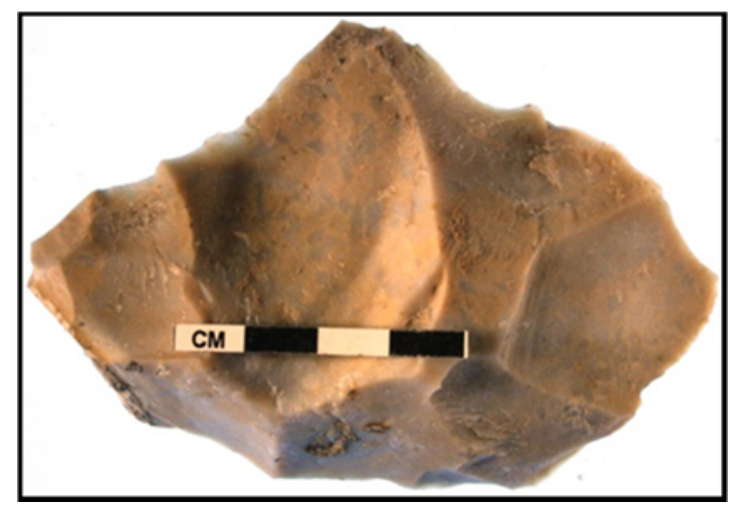

Figure 7-8. Chert core (\#8-10). 
Table 7-4. Stone Tool Data.

\begin{tabular}{|c|c|c|c|c|c|c|c|c|c|c|c|}
\hline PNUM & $\begin{array}{l}\text { Test } \\
\text { Unit }\end{array}$ & $\begin{array}{l}\text { Depth } \\
\text { (cmbs) }\end{array}$ & $\begin{array}{c}\text { Feature } \\
\text { No. }\end{array}$ & Tool Type & Portion & $\begin{array}{c}\text { Material } \\
\text { Type }\end{array}$ & $\begin{array}{c}\text { UV } \\
\text { Response }\end{array}$ & $\begin{array}{c}\text { Length } \\
(\mathrm{mm})\end{array}$ & $\begin{array}{l}\text { Width } \\
(\mathrm{mm})\end{array}$ & $\begin{array}{c}\text { Thickness } \\
(\mathrm{mm})\end{array}$ & $\begin{array}{l}\text { Wt. } \\
\text { (g) }\end{array}$ \\
\hline $14-10$ & 4 & $160-170$ & - & Edge-modified & Distal-medial & Chert & Orangish & 64.6 & 68.9 & 18.1 & 48.6 \\
\hline $21-10$ & 5 & $180-190$ & - & Biface & Medial & Chert & Yellowish & 27.3 & 57.6 & 12.2 & 21.6 \\
\hline $25-10$ & 6 & $150-160$ & - & Edge-modified & Complete & Chert & Orangish & 50.2 & 18 & 9.4 & 6 \\
\hline $31-10$ & 7 & 164 & - & Biface & Complete & Chert & Orangish & 69 & 34.9 & 11.3 & 24.6 \\
\hline $37-10$ & BT14 & 110 & - & Biface & Complete & Chert & Orangish & 104.8 & 53.8 & 17.5 & 84.8 \\
\hline $40-10$ & 10 & 155 & - & Edge-modified & Complete & Chert & Yellowish & 24.9 & 31.9 & 4.5 & 3.5 \\
\hline $505-10$ & 4 & 154 & 5 & Biface & Medial & Chert & Orangish & 44.2 & 66.8 & 24.6 & 63.8 \\
\hline $506-10$ & 4 & $158-166$ & 6 & Edge-modified & Medial & Chert & Orangish & 23.5 & 43.1 & 19.6 & 19.1 \\
\hline
\end{tabular}

east wall of BT 14. This vertical position was above the targeted component not documented in this report but possibly within the projected upper component.

This biface potentially correlates with Feature 1, at nearly $105 \mathrm{cmbs}$ in BT 7, discovered during the survey phase (Ringstaff 2004). Highpoweredmicrowear analysis indicates this biface was used for cutting soft materials by the presence of soft polish, but no microscopic residues were identified (Appendix H).

All remaining tools recovered are from the targeted lower component. The complete chert biface \#3110 is a relatively small, well-thinned late-stage or finished implement that may represent a projectile point preform (Figure 7-10). It is similar to Pedernales preforms at the Anthon site (Goode 2002). High-powered microwear analysis revealed plant fibers and collagen, coupled with soft polish on the distal end, hard/high silica polish and striae on the proximal end, with an overall general function likely related to cutting hides. It was definitely hafted (Appendix H). Another chert biface (\#505-10) is an early stage medial fragment recovered from inside Feature 5 (Figure 7-11). No use-wear or microresidues were observed during high-powered microwear analysis, thus function is unknown. A medial biface \#21-10 section revealed plant tissue and wood fragments, plus hard/high silica polish and striae and thus functioned in cutting wood (Appendix H).
The four edge-modified flakes reveal considerable differences in shape and size (Figure 7-12). These reveal minimal use/retouch along one edge. Highpowered microwear analysis was performed on all four specimens (Appendix H).

Specimen \#14-10 revealed hard/high silica polish with plant tissues residues to indicate cutting wood. It probably functioned in cutting hard unknown material. Specimen \#25-10 revealed collagen residues, soft polish and was likely used for cutting hide and butchering. Specimen \#40-10 revealed feather fragments, soft polish and used for butchering birds (Appendix H, Figure H-3). Specimen \#506-10 revealed hard/high silica polish used to cut hard material.

The three units (TUs 1, 2, and 4) excavated along BT 8 yielded three of the seven chipped stone tools from this component, or 43 percent, which includes the core, two edge-modified flakes, and a biface. The four test units (TUs 5, 6, 7, and 10) excavated along BT 9 also yielded three of the seven chipped stone tools. Chipped stone tool density is about one tool per every six $10 \mathrm{~cm}$ level excavated. Although few tools were recovered, this low density supports the idea this component is not a palimpsest of multiple events, but rather represents a relatively discrete component within a very restricted time with horizontally discrete activity areas. 


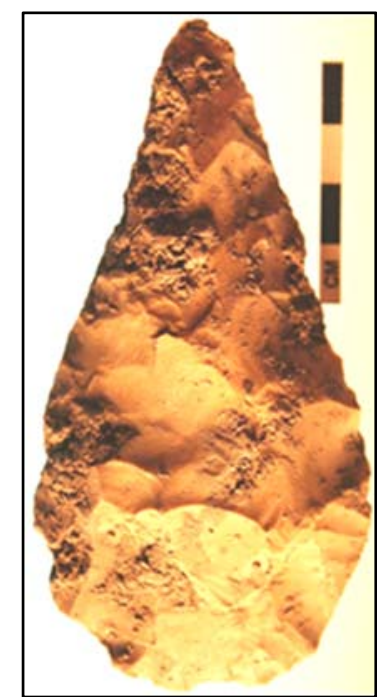

Figure 7-9. Unwashed biface (\#37-10) from $110 \mathrm{cmbs}$ in east wall of Backhoe Trench 14.

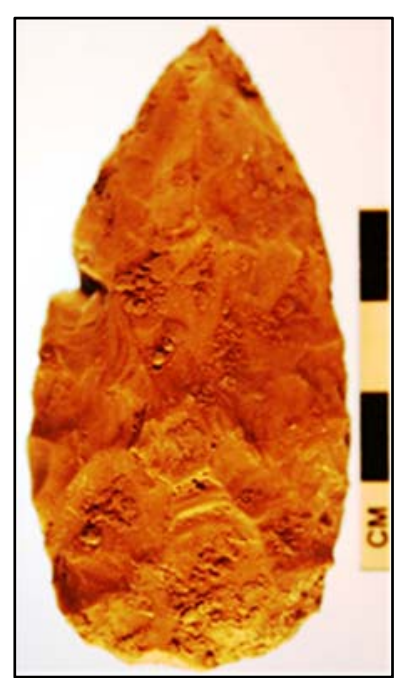

Figure 7-10. Unwashed biface/preform (\#3110) from $164 \mathrm{cmbs}$ in Test Unit 7.

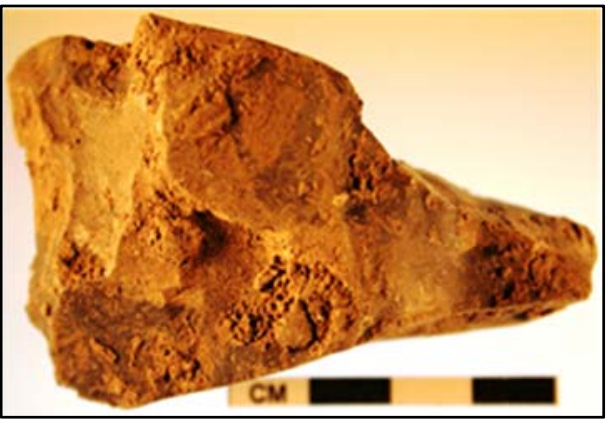

Figure 7-11. Unwashed medial biface fragment (\#505-10) from $154 \mathrm{cmbs}$ in Feature 5 in Test Unit 4.

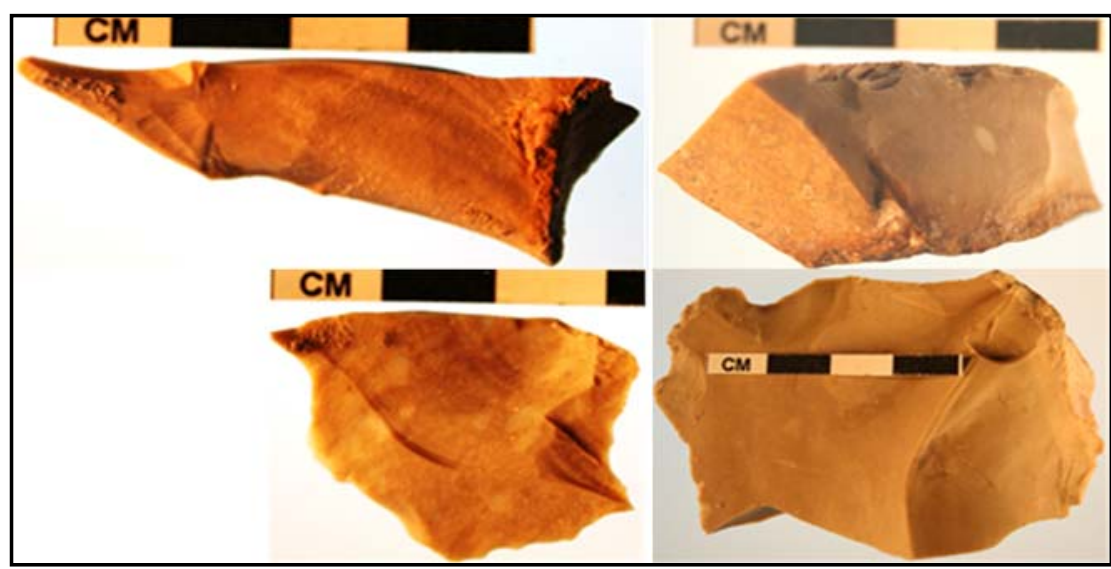

Figure 7-12. Edge-modified flakes. Top left is \#25-10, top right is \#506-1, bottom left is \#40-1, bottom right is \#14-1. 
Table 7-5. Bone Data from Testing Phase at 41BL278.

\begin{tabular}{|c|c|c|c|c|c|c|c|}
\hline PNUM & $\begin{array}{c}\text { Test } \\
\text { Unit }\end{array}$ & $\begin{array}{c}\text { Depth } \\
\text { (cmbs) }\end{array}$ & Identification & Element & Count & $\begin{array}{c}\text { Size } \\
(\mathbf{m m})\end{array}$ & Wt. (g) \\
\hline $3-002$ & 1 & $150-160$ & Unknown & Fragments & 2 & 1 & 0.3 \\
\hline $3-002$ & 1 & 158 & Unknown & Tooth & 8 & 3 & 2.4 \\
\hline $4-002$ & 1 & $160-170$ & Unknown & Fragments & 2 & 14.4 & 0.1 \\
\hline $9-002$ & 2 & 168 & Unknown & Fragments & 15 & 6.1 & 0.4 \\
\hline $9-002$ & 2 & 168 & Unknown & Fragments & 13 & 11.5 & 1.1 \\
\hline $10-002-1$ & 2 & $170-180$ & Beaver & Femur & 1 & 65 & 8.6 \\
\hline $12-002$ & 4 & $140-150$ & Unknown & Fragments & 2 & 16.1 & 0.4 \\
\hline $25-002$ & 6 & $150-160$ & Unknown & Fragments & 3 & 26.2 & 1.5 \\
\hline $31-002$ & 7 & $160-170$ & Unknown & Fragments & 1 & 11.7 & 0.1 \\
\hline
\end{tabular}

\subsubsection{Faunal Bone}

Test excavations yielded 47 small, animal bone fragments (14.9 g total) (Table 7-5). A medial section of a beaver femur (Castor canadensis) (\#10-2) was recovered from 170 to $180 \mathrm{cmbs}$ in TU 2 (Figure 7-13). This entire element was sent for radiocarbon dating and yielded a $\delta^{13} \mathrm{C}(-21.1 \%)$ corrected AMS date of $3490 \pm 30$ B.P. (Beta370500) (see Section 7.5 below). A deer-sized long bone fragment was present in TU 1. All the remaining bone is not identified to species. An unidentifiable small animal is represented by tiny burned bone fragments in the heavy fraction from Feature 5. A few bone fragments are potentially associated with the lower event, but the majority was associated with the upper event in this

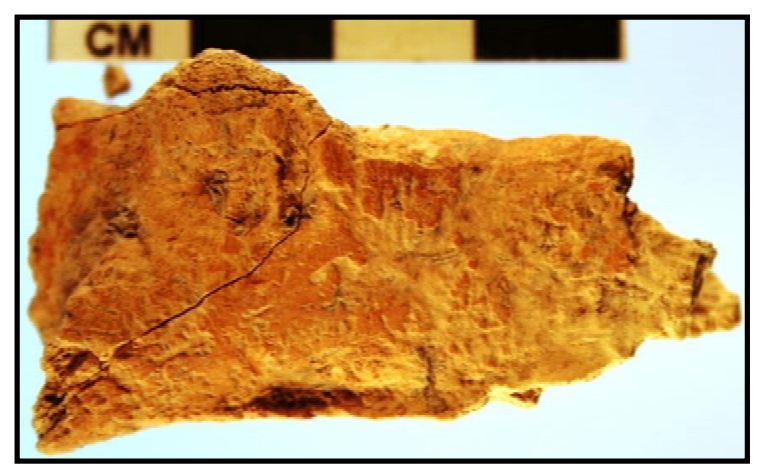

Figure 7-13. The medial section of a beaver femur (\#10-2) from Test Unit 2 that was radiocarbon dated. component. Nearly 87 percent of the fragments were from TUs 1, 2, and 4 adjacent to BT 9. This uneven horizontal distribution may reflect a specific animal processing/discard area.

\subsubsection{Mussel Shell}

The $4.1 \mathrm{~m}^{3}$ hand-excavations yielded 86 different mussel shell fragments, most with umbos still attached, but were generally crushed and poorly preserved (Figure 7-14).

Of those currently identifiable $(N=34), 62$ percent are Texas Pimpleback (Quadrula pentrina), roughly 15 percent are small Threeridge (Amblema plicata), 12 percent are Smooth Pimpleback (Quadrula houstonensis), with at least 9 percent Pistolgrip (Tritogonia verrucosa), and 3 percent Pink Mucket (Lampilis sp.). The identified species are common in the Leon River system (Howells et al. 1996). At least one shell fragment from 160 to $170 \mathrm{cmbs}$ in TU 2, and one small tooth section from $155 \mathrm{cmbs}$ in TU 10, are burned, based on their shiny gray color. This supports the likelihood that mussels were one food resource heated by the rocks. None appear fashioned into tools or ornaments. Shell sizes are small, ranging from about 20 to $75 \mathrm{~mm}$, with most in the smaller size range (see Figure 7-14). 


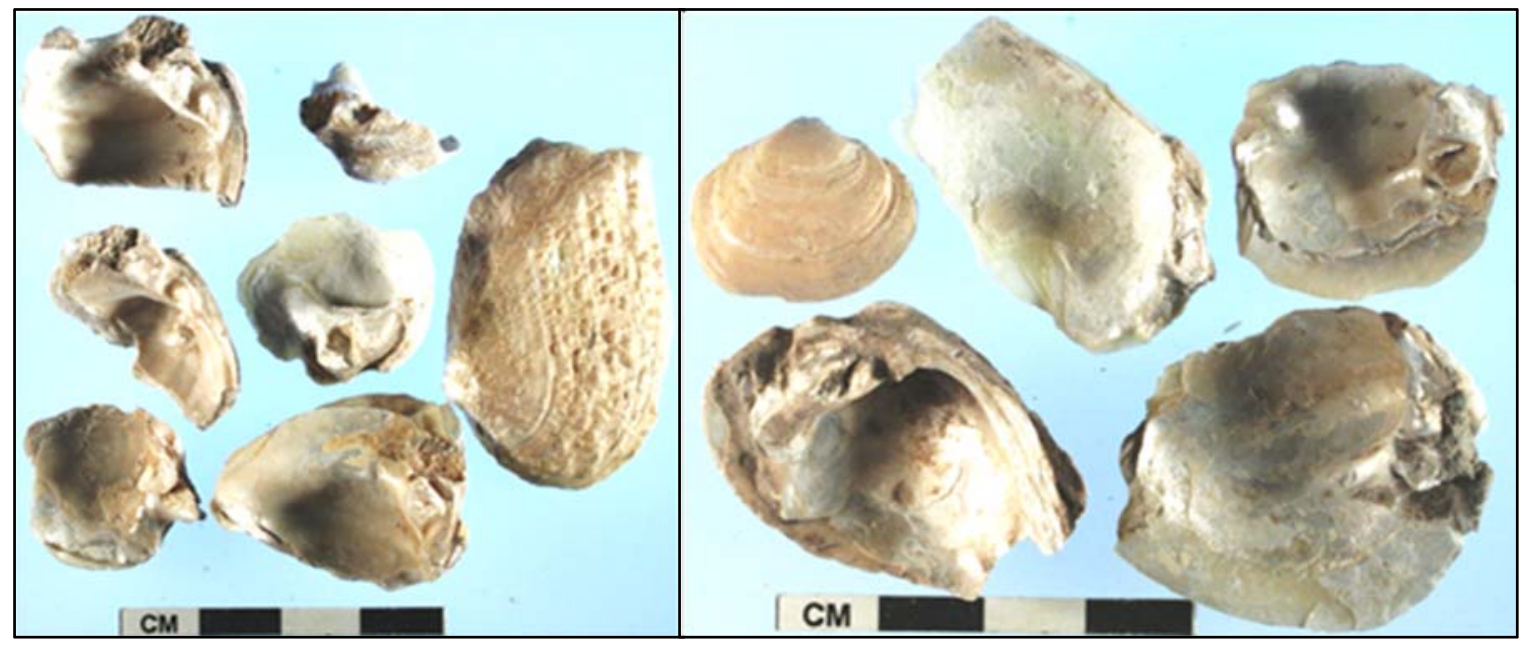

Figure 7-14. Examples of mussel shell types and conditions.

These shells, like the faunal bones, were unevenly distributed among the test units, with nearly 67 percent from TUs 5, 6, 7, and 10 along BT 9, nearly 27 percent from TUs 1,2 , and 4 adjacent to BT 8 , and only six percent from TUs 8 and 9 along BT 14. Mussel shells occurred throughout the component and appeared present in both the upper and lower events. Undoubtedly mussels were one food resource procured, heated/cooked, and consumed at this location.

\subsubsection{Charcoal}

Hand-excavations yielded 25 samples of what appeared as wood charcoal, weighing only $0.8 \mathrm{~g}$. Besides Feature 1 (which yielded charcoal and a radiocarbon date on charcoal), Features 3, 5, 6, 7, and 8 all yielded tiny pieces or flecks of charcoal (Table 7-6). Nine samples were submitted to Dr. Phil Dering for identification. Oak and cottonwood/willow are the two species identified however, most flecks were unidentifiable (Table 76; Appendix G). The charcoal was nearly equally distributed between units adjacent BT 8 .

\subsubsection{Ground Stone Tools}

Three possible ground stone manos were collected from TUs 5 and 6 adjacent BT 9. All three pieces were in the cultural zone between 170 and 180 cmbs. However, upon close examination in the laboratory, two appear naturally rounded water worn limestone cobbles with very questionable use indications. The third piece is a $6 \mathrm{~cm}$ long oblong quartzite fragment, with mostly rounded cortex and a broken area that probably reflects heat alteration to indicate this piece was recycled as a burned rock.

\subsubsection{Burned Clay}

Nine tiny (less than $1 \mathrm{~cm}$ diameter, $14.4 \mathrm{~g}$ total) pieces of rounded, burned clay were recovered from two units adjacent BT 8 . The four pieces (\#15-10) from TU 4 were slightly below Features 5 and 6. Their presence implies a relatively intense heating episode occurred at this location and supports the interpretation that Feature 5 functioned as a hearth and Feature 6 as a probable cleanout or discard pile from the hearth. The five pieces (\#10-101 and \#710) from TU 2 were from two different levels (140 to $150 \mathrm{cmbs}$ and 170 to $180 \mathrm{cmbs}$ ), rather than directly associated with any particular feature. No pieces revealed any type of impressions or other cultural modifications.

\subsubsection{Snail Shells}

Testing yielded at least 264 snail shells representing three or more types of snails. The vast majority of shells observed and collected are adult Rabdotus shells. Nearly 61 percent were from TUs 1,2 , and 4 along BT 8; 38 percent were from TUs 5, 6, 7, 
Table 7-6. Dering's Charcoal Identifications from Excavations at 41BL278 (see Appendix G).

\begin{tabular}{|c|c|c|c|c|c|c|c|c|}
\hline $\begin{array}{c}\text { PNUM } \\
\text { No. }\end{array}$ & Unit & $\begin{array}{c}\text { Depth } \\
\text { (cmbs) }\end{array}$ & $\begin{array}{c}\text { Feature } \\
\text { No. }\end{array}$ & Taxon & Common Name & Part & Count & $\begin{array}{c}\text { Weight } \\
\text { (g) }\end{array}$ \\
\hline $12-7$ & 8 & $140-150$ & -- & Quercus sp. & Oak & Wood & 3 & + \\
\hline $507-7-3$ & 9 & 175 & 7 & Indeterminate & NA & Flecks, soot, clay & -- & 4.7 \\
\hline $505-7$ & 8 & 159 & 5 & Indeterminate & NA & Flecks, soot, clay & -- & -- \\
\hline $15-7-1$ & 8 & 176 & -- & Indeterminate & NA & Flecks, soot, clay & -- & -- \\
\hline $18-7$ & 9 & $150-160$ & -- & Salicaceae & Cottonwood-willow & Wood & 2 & 0.1 \\
\hline $501-7$ & 9 & $130-140$ & -- & Salicaceae & Cottonwood-willow & Wood & 1 & 0.1 \\
\hline $8-7-3$ & 8 & 156 & -- & Indeterminate & NA & Flecks, soot, clay & -- & -- \\
\hline $8-7-4$ & 8 & 152 & -- & $\begin{array}{l}\text { Indeterminate } \\
\text { hardwood }\end{array}$ & NA & Wood & 7 & + \\
\hline $507-7-4$ & 9 & $173-179$ & -- & Indeterminate & NA & Flecks, soot, clay & -- & -- \\
\hline
\end{tabular}

and 10 along BT 9; and only one percent from TUs 8 and 9 along BT 14. Multiple Rabdotus shells recovered from three proveniences were selected for radiocarbon dating; 158 to $166 \mathrm{cmbs}$ in TU 4, 160 to $170 \mathrm{cmbs}$ in $\mathrm{TU} 7$, and 170 to $180 \mathrm{cmbs}$ in TU 4 (see Section 7.5 below for results).

\subsubsection{Burned Rocks}

Hand-excavations of $4.1 \mathrm{~m}^{3}$ yielded 1,123 burned rocks that weighed a total of $116,580 \mathrm{~g}$, for an average of $103.8 \mathrm{~g}$ per rock. All but one or two pieces appeared to be limestone. The pieces varied in size from about 2 to $15 \mathrm{~cm}$ in diameter, with smaller pieces within the 0 to $4 \mathrm{~cm}$ size class most common. About 13 percent were in recognizable features. The 145 burned rocks from features totaled $36,329 \mathrm{~g}$, for an average of about $250.5 \mathrm{~g}$ per rock. The nonfeature burned rocks account for 87 percent of the total, and weighed an average of $82 \mathrm{~g}$ each. Therefore, the burned rocks in features were three times as heavy as those scattered beyond the features. The small pieces beyond features reflect sizes no longer usable to transfer heat. With at least nine burned rock features identified, the burned rocks were unevenly distributed across the three investigated areas (Table 7-7). Test Units 1, 2, and 4 along BT 8 yielded about 38 percent of the total count, which included Features 2, 4, and 5. Test Units 5, 6, 7, and 10, adjacent to BT 9, yielded nearly 87 percent, and included Features 3, 3a, 7, and 8 . Test Units 8 and 9 along BT 14 yielded only 10 percent of the burned rock quantity and no identified features. The burned rocks were nearly equally distributed between the two apparent events in this component.

\subsubsection{Summary}

In summary, multiple and diverse material classes were present in this component, and their horizontal frequencies indicate nonrandom distributions (Table 7-8). The horizontal distribution patterns are indicative of a specific cultural activity area that focused on cooking various plant and animal resources which included heating mussels with the use of burned rocks and then discarding used rocks.

Table 7-7. Burned Rock Counts and Weights by Test Unit and Adjacent Backhoe Trench.

\begin{tabular}{|c|c|c|c|c|}
\hline $\begin{array}{c}\text { Backhoe } \\
\text { Trench No. }\end{array}$ & $\begin{array}{c}\text { Test Unit } \\
\text { No. }\end{array}$ & $\begin{array}{c}\text { Feature } \\
\text { No. }\end{array}$ & Counts & Weight (g) \\
\hline \multirow{3}{*}{8} & 1 & 4 & 157 & 9,600 \\
\cline { 2 - 5 } & 2 & & 80 & 5,600 \\
\cline { 2 - 5 } & 4 & $5 \& 6$ & 97 & 22,930 \\
\hline \multirow{3}{*}{9} & 5 & $3 \& 3 a$ & 211 & 21,400 \\
\cline { 2 - 5 } & 6 & 8 & 180 & 18,400 \\
\cline { 2 - 5 } & 7 & 7 & 229 & 20,500 \\
\cline { 2 - 5 } & 10 & & 92 & 10,350 \\
\hline \multirow{2}{*}{14} & 8 & & 65 & 7,400 \\
\cline { 2 - 5 } & 9 & & 12 & 400 \\
\hline \multicolumn{3}{|c|}{ Total burned rocks } & 1123 & 116,580 \\
\hline
\end{tabular}


Table 7-8. Cultural Material Summary by Unit for the Testing Phase.

\begin{tabular}{|l|c|c|c|c|c|c|c|c|c|c|c|}
\hline & \multicolumn{10}{|c|}{ Units } & Unit \\
\cline { 2 - 13 } \\
\hline Stone Tools & $\mathbf{1}$ & $\mathbf{2}$ & $\mathbf{3}$ & $\mathbf{4}$ & $\mathbf{5}$ & $\mathbf{6}$ & $\mathbf{7}$ & $\mathbf{8}$ & $\mathbf{9}$ & $\mathbf{1 0}$ & Totals \\
\hline Lithic Debitage & 11 & 10 & & 7 & 30 & 21 & 14 & 2 & & 22 & $\mathbf{1 1 7}$ \\
\hline Mussel Shells & 12 & 9 & & 6 & 17 & 15 & 20 & 6 & 1 & 14 & $\mathbf{1 0 0}$ \\
\hline Charcoal & & 6 & & 4 & 5 & 1 & 5 & & & & $\mathbf{2 1}$ \\
\hline Feature Nos. & 4 & & & $5 \& 6$ & $3 \& 3 a$ & 8 & 7 & & & & $\mathbf{7}$ \\
\hline Burned Rocks & 157 & 80 & & 97 & 211 & 180 & 229 & 65 & 12 & 92 & $\mathbf{1 1 2 3}$ \\
\hline Bone Fragments & 12 & 29 & & 2 & & 3 & 1 & & & & $\mathbf{4 7}$ \\
\hline Burned Clay & & 5 & & 4 & & & & & & & $\mathbf{9}$ \\
\hline Snail Shells & 24 & 55 & & 81 & 37 & 25 & 27 & 3 & & 12 & $\mathbf{2 6 4}$ \\
\hline Totals & $\mathbf{2 2 0}$ & $\mathbf{1 9 4}$ & & $\mathbf{2 0 3}$ & $\mathbf{3 0 0}$ & $\mathbf{2 5 3}$ & $\mathbf{3 0 4}$ & $\mathbf{7 6}$ & $\mathbf{1 3}$ & $\mathbf{1 4 0}$ & \\
\hline
\end{tabular}

Discrete, recognizable activity areas can lead to hypotheses concerning social and cultural phenomena not generally discernable at most archeological sites.

\subsection{VERTICAL MATERIAL DISTRIBUTIONS}

This section focuses on the vertical distributions of cultural material within the dark, grayish-brown (10YR 4/2) West Range Alluvium. No cultural events appear adversely affected by large magnitude flooding, as they are encased in clayey flood basin fines, and lack significant quantities of gravel (Figure 7-15). The cultural deposits are within a stratigraphic position that implies they occurred in the portion of the deposits where sedimentation rate was greatest, although the fine texture of the sediment implies a relatively slow rate of sedimentation (see Chapter 6.0 for more discussions). The deposit texture is more consistent with a flood basin rather than a levee setting, but the occupation debris in TUs 1,2 and 4 adjacent to BT 8, and TUs 5, 6 and 7 adjacent to BT 9, exhibited a downward slope, away from the river, of about $10 \mathrm{~cm}$ per $3 \mathrm{~m}$ to indicate a level setting.

The survey phase identified three concentrations of cultural materials, designated Features 1, 2, and 3, toward the bottoms of BTs 7,8 , and 9 , respectively (Ringstaff 2004). Those features were not investigated at that time, but were instead left as discovered in the bottoms of the trenches. The three features were identified at slightly different elevations in the three trenches, but the trenches are located along a slightly elevated ridge/levee-like deposit, and comparable depths below surface vary somewhat and may vary between trenches.

Feature 1, in BT 7, was identified at $105 \mathrm{cmbs}$, and consisted of one large limestone rock with burned clay at and below the rock. Feature 2, a cluster of burned rocks and mussel shells in BT 8, was recorded between 145 and $170 \mathrm{cmbs}$, and Feature 3 was documented between 125 and $140 \mathrm{cmbs}$. The materials that comprised those features vertically extended through a 15 to $50 \mathrm{~cm}$ thick zone. These cultural materials were within the upper part of a clay loam B horizon with pedogenic carbonates (Ringstaff 2004). The column excavations during the survey identified no cultural materials above that zone, and the alluvial deposits below that zone were not sampled. Backhoe Trench 4, near the northwestern edge of the proposed right-of-way, yielded significant quantities of mussel shell from the same B horizon and was considered part of the same cultural component (Ringstaff 2004). The previous survey results identified Feature 1 at a 


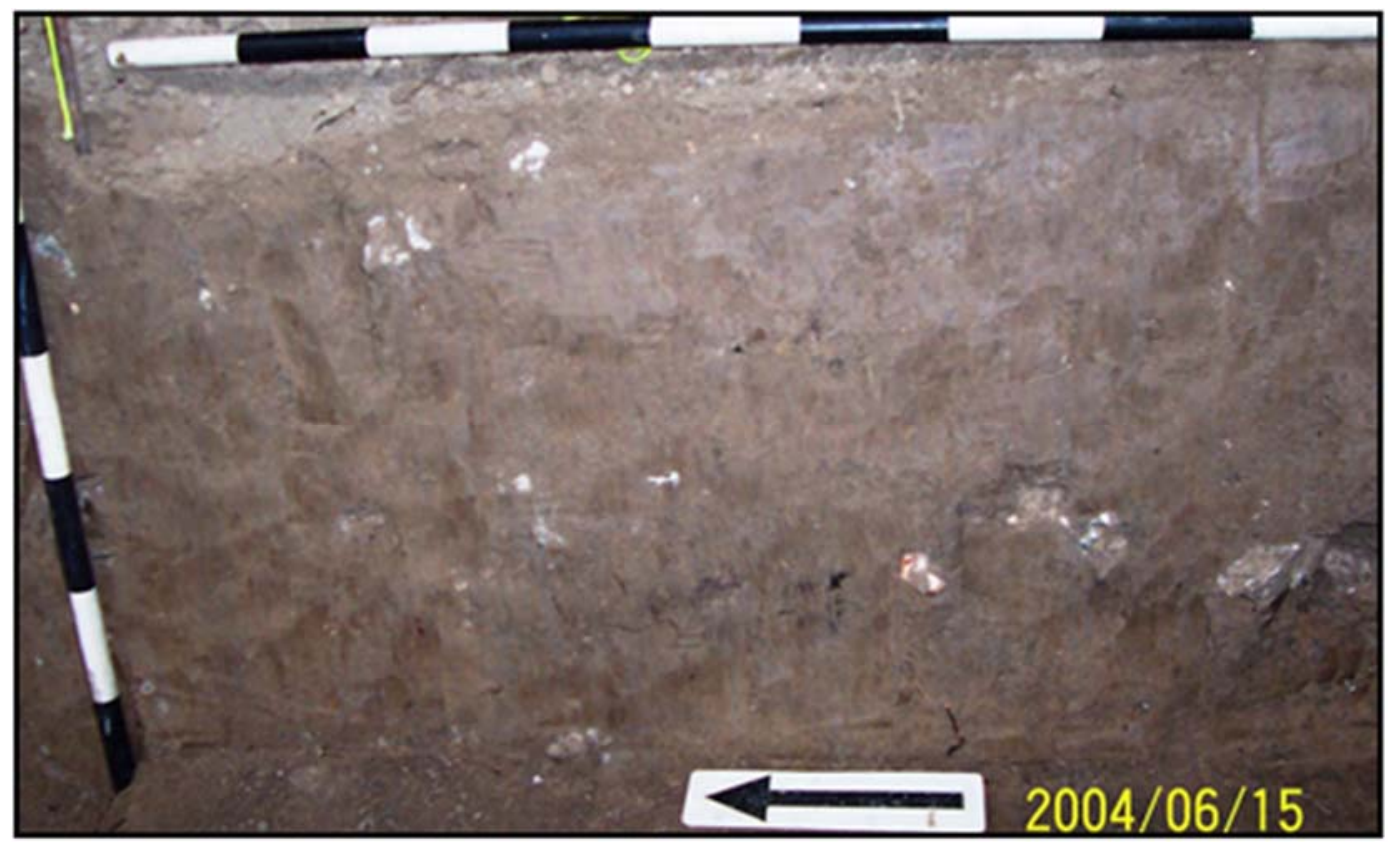

Figure 7-15. Unit profile that exhibits cultural materials in massive Bk soil horizon.

slightly higher elevation (105 cmbs) with little other material in association. Slightly deeper materials were buried between approximately 120 and $170 \mathrm{cmbs}$ and contained at least Features 2 and 3 , clusters of burned rocks and mussel shells, and a dense zone of mussel shell in all of the four trenches excavated along the front edge of the $\mathrm{T}_{1}$, or leveelike, formation.

TRC's testing phase targeted the previously identified cultural component between roughly 130 and $180 \mathrm{cmbs}$ for hand-excavations. The three primary areas of hand-excavated units, adjacent to BTs 8, 9, and 14, all revealed one zone of dense cultural materials at approximately the same depth as previously identified by Ringstaff (2004). During mechanical removal of deposits overlying the target zone in BT 8, and BT 14, very diffuse cultural materials were observed in trench wall profiles between roughly 90 and 110 cmbs. Although not targeted during the testing phase, a dispersed zone of cultural material, which might include Feature 1 and one large biface (\#37-10) above the more pronounced and targeted cultural zone may be present.
Backplots of the vertical distribution of in situ plotted cultural materials from the hand-excavated units along BTs 8 and 9 reveal one cultural occupation in TUs 1, 2, and 4 (Figure 7-16). Test Units 5, 6, 7, and 10 appear to contain two closely spaced short-term cultural events that represent one component, a sort time period (Figure 7-16). Backplots from TUs 8 and 9 reveal only one occupation that slopes downward towards the north.

In summary, one well-defined, isolated component lies roughly between 130 and $180 \mathrm{cmbs}$ in a B horizon developed in Holocene alluvium. This component contains one event in some places and two events in others. Where two events are discernable, they are separated by roughly $10 \mathrm{~cm}$ of sediment, and some slight displacement of cultural materials is apparent. Both events contain similar types of cultural materials and similar burned rock features, and are quite similar in radiocarbon age thus are considered part of the same component (see Section 7.5 below). 


\subsection{AGE OF CULTURAL DEPOSITS}

From the testing phase, five wood charcoal pieces, three Rabdotus snail shell samples, two bulk sediment/humate samples, and one animal bone were radiocarbon dated (Table 7-9, Figure 7-17). All were obtained from this single, targeted cultural component buried 130 to $180 \mathrm{cmbs}$ in a thick clay loam B horizon. At least two charcoal assays, the modern one and the 960 B.P. date, are much too young and probably not representative of the targeted cultural component. Therefore, these latter two assays are not accepted as representative of the age of this cultural component. Potentially the wood charcoal date of 2850 B.P. may also not represent the component. However, it is only a few hundred years younger than the next oldest charcoal date of 3120 B.P. If the date of 2850 B.P. is

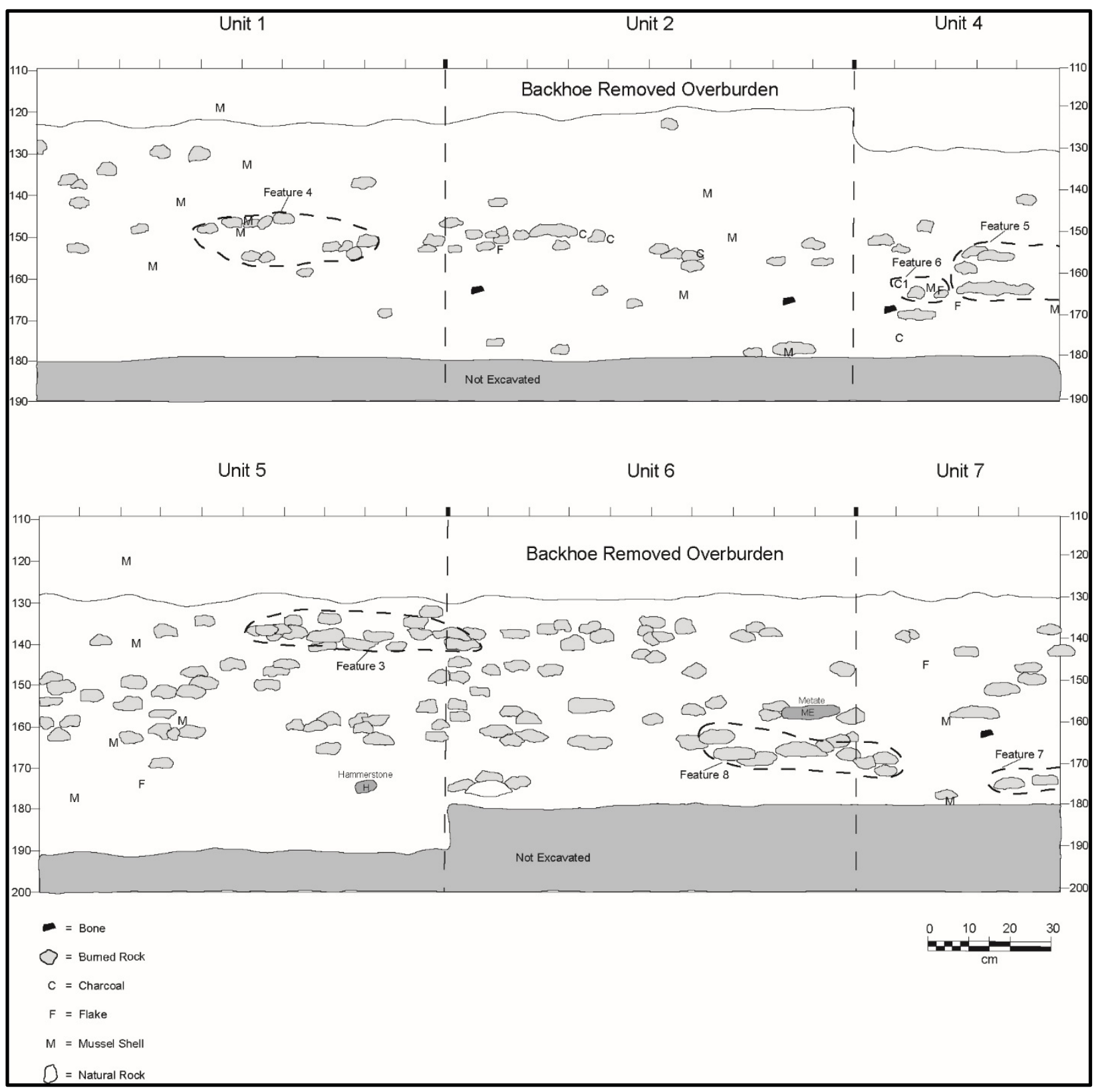

Figure 7-16. Vertical patterning of plotted materials across six excavation units. 
Table 7-9. Radiocarbon Data and Results from the APE at 41BL278.

\begin{tabular}{|c|c|c|c|c|c|c|c|c|c|c|}
\hline $\begin{array}{c}\text { PNUM } \\
\text { No. }\end{array}$ & $\begin{array}{c}\text { Unit } \\
\text { No. }\end{array}$ & $\begin{array}{c}\text { Depth } \\
(\mathbf{c m b s})\end{array}$ & $\begin{array}{c}\text { Feature } \\
\text { No. }\end{array}$ & $\begin{array}{c}\text { Material } \\
\text { Dated }\end{array}$ & $\begin{array}{c}\text { Weight } \\
\mathbf{( g )}\end{array}$ & Lab. No. & Measured Age & $\begin{array}{c}\mathbf{1 3 C / 1 2 C} \\
\text { Ratio (\%) }\end{array}$ & $\begin{array}{c}\text { Conventional } \\
\text { Age (B.P.) }\end{array}$ & $\begin{array}{c}\text { 2 Sigma Calibration } \\
\text { Range }\end{array}$ \\
\hline $8-7-4 a$ & 2 & 152 & & Charcoal & 0.1 & UGA-14095 & $3230 \pm 40$ & -24.5 & $3240 \pm 40$ & Cal 1620 to $1410 \mathrm{BC}$ \\
\hline $10-2-1$ & 2 & $170-180$ & & $\begin{array}{c}\text { Beaver } \\
\text { femur }\end{array}$ & 8.6 & Beta-370500 & $3430 \pm 30$ & -21.1 & $3490 \pm 30$ & Cal 1890 to $1740 \mathrm{BC}$ \\
\hline $12-7$ & 4 & $140-150$ & & Charcoal & 0.1 & Beta-370498 & $2850 \pm 30$ & -25.0 & $2850 \pm 30$ & Cal 1120 to $920 \mathrm{BC}$ \\
\hline $15-6$ & 4 & $170-180$ & & $\begin{array}{c}24 \\
\text { Rabdotus }\end{array}$ & & Beta-370502 & $3180 \pm 30$ & -10.0 & $3430 \pm 30$ & Cal 1870 to $1680 \mathrm{BC}$ \\
\hline $18-7 \mathrm{a}$ & 5 & $150-160$ & & Charcoal & 0.1 & UGA-14096 & $109.5 \pm .5 \mathrm{pMC}$ & -27.0 & NA & NA \\
\hline $31-6$ & 7 & $160-170$ & & $\begin{array}{c}10 \\
\text { Rabdotus }\end{array}$ & 6.0 & Beta-370501 & $3520 \pm 30$ & -9.4 & $3780 \pm 30$ & Cal 2290 to $2140 \mathrm{BC}$ \\
\hline $501-7 \mathrm{a}$ & 5 & $130-140$ & $3-a s h$ & Charcoal & 0.1 & UGA-14097 & $960 \pm 40$ & -25.0 & $960 \pm 40$ & Cal AD 990 to 1190 \\
\hline $506-6$ & 4 & $158-166$ & & $\begin{array}{c}6 \\
\text { Rabdotus }\end{array}$ & 5.7 & Beta-370503 & $3170 \pm 30$ & -4.4 & $3510 \pm 30$ & $\begin{array}{c}\text { Cal } 1950 \text { to } 1750 \\
\text { BC }\end{array}$ \\
\hline $506-7-1$ & 4 & 158 & 6 & Humates & 10.0 & Beta-370504 & $3410 \pm 30$ & -23.6 & $3430 \pm 30$ & Cal 1870 to 1680 \\
\hline $507-7-3 a$ & 7 & 175 & 7 & Charcoal & 0.1 & UGA-14098 & $3140 \pm 40$ & -25.9 & $3120 \pm 40$ & Cal 1460 to $1290 \mathrm{BC}$ \\
\hline $507-7-5$ & 7 & 174 & 7 & Humates & 8.6 & Beta-370499 & $3510 \pm 30$ & -25.1 & $3510 \pm 30$ & Cal 1920 to $1750 \mathrm{BC}$ \\
\hline
\end{tabular}

representative, then 9 of the 11 assays provide a reasonably good indication of the age of the targeted cultural zone and the cultural material within it.

These nine assays range from 2850 to 3780 B.P., or nearly 1,000 radiocarbon years. It is important to note that four different material types were dated and each may have its own problems in terms of providing the specific age of the cultural events. The different material types provide slightly different dates and are presented below under each material type.

Charcoal from Feature 1 at $138 \mathrm{cmbs}$ in BT 7 was collected and dated during the initial survey phase. It is not clear if this wood charcoal was collected from around the burned rocks detected in the bottom of the trench or from among the burned rocks encountered in the screened column along the side of the trench. The sample came from good context at $138 \mathrm{cmbs}$ in Feature 1. The wood charcoal yielded a $\delta^{13} \mathrm{C}(-24.3 \%)$ corrected AMS date of $2490 \pm 50$ B.P. (UGA-13280; Ringstaff 2004).
The cultural zone in which three burned rock features were identified during the survey phase became the target zone for the testing phase. The targeted cultural component between roughly 130 and $180 \mathrm{cmbs}$ in the hand-excavated units yielded sparse carbonized plant remains. Five wood charcoal samples from that zone were selected for radiocarbon dating. Each sample consisted of a single piece of wood charcoal and provided an AMS assay.

Two vertically dispersed pieces of wood charcoal from TU 5 were dated. Both pieces were recovered from the screen, but were from $10 \mathrm{~cm}$ thick levels that contained cultural materials and were at least separated by $10 \mathrm{~cm}$. A piece of cottonwood/willow charcoal (\#501-7a) from the vicinity of Feature 3 at a depth from 130 to $140 \mathrm{cmbs}$ yielded a corrected AMS date of $960 \pm 40$ B.P. A second piece of wood charcoal (\#18-7) from a depth of 150 to $160 \mathrm{cmbs}$ in TU 5 yielded a modern date of $109.8 \pm .5 \mathrm{pMC}$. These two results are also out of sequence as the modern obtained date came from below the older date. More than 1,400 years separate the 960 B.P. assay from the 2490 B.P. results obtained from 


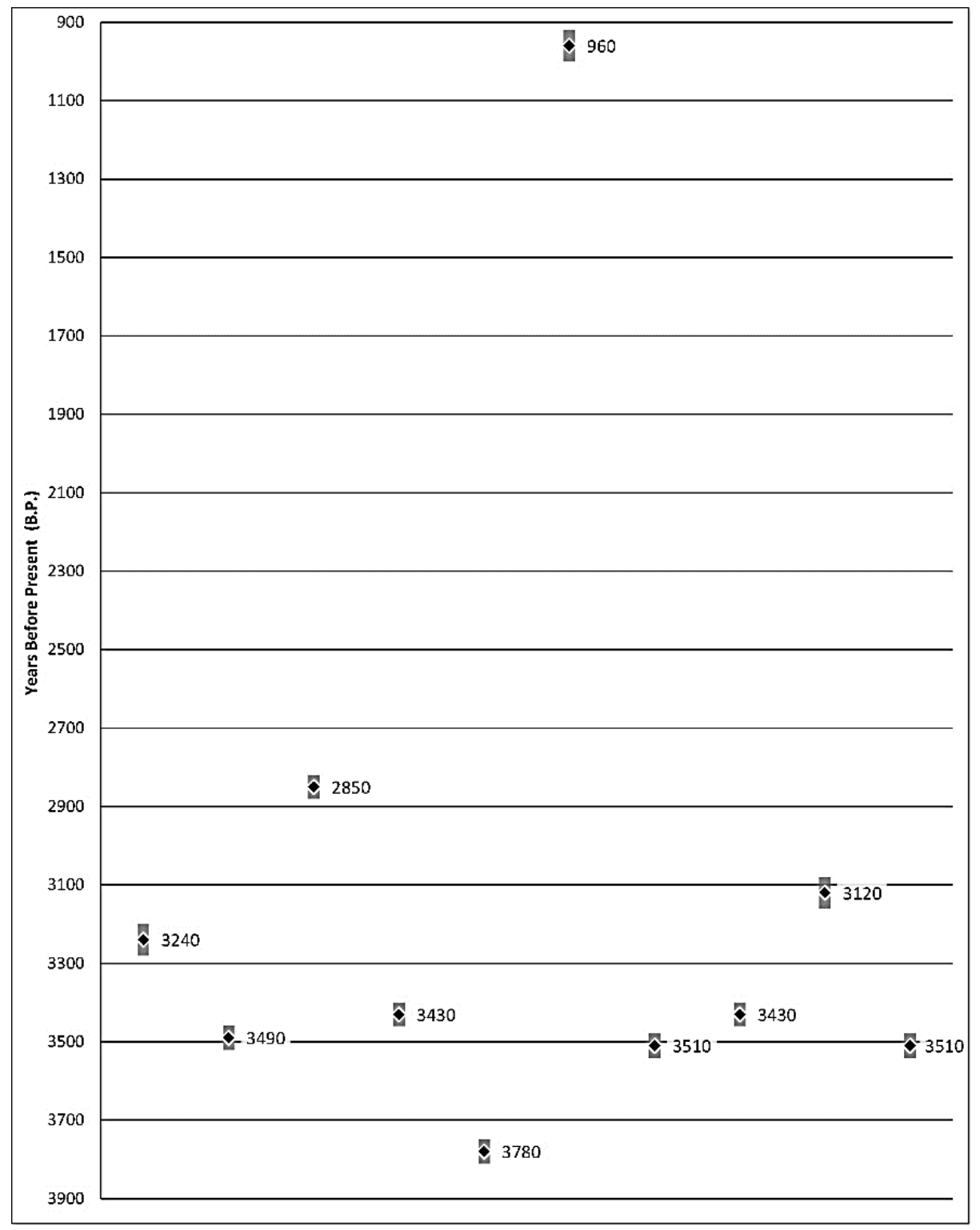

Figure 7-17. Graph of the radiocarbon dates obtained from APE in 41BL278.

Feature 1, which exhibits far better contextual integrity than the generalized matrix from which the preceding two samples were recovered. These two dates from TU 5 are rejected as too recent for this component. These two charcoal samples were probably displaced into the cultural zone by disturbances which were not detected.

Three other wood charcoal dates provide a much more acceptable time range for the component. A piece plotted wood charcoal chunk (\#507-7-3) from
$175 \mathrm{cmbs}$ in Feature 7 in TU 7 yielded a corrected AMS date of $3120 \pm 40$ B.P. Wood charcoal (\#8-7-4) plotted at $152 \mathrm{cmbs}$ in TU 2 yielded a corrected AMS date of $3240 \pm 40$ B.P. Wood charcoal (\#12-7), retrieved from between 140 and $150 \mathrm{cmbs}$ in TU 4, yielded a corrected AMS date of $2850 \pm 30$ B.P. These three dates are acceptable and indicate the two apparent cultural events from which these charcoal samples were extracted are relatively close in radiocarbon age. 
Three groups of multiple Rabdotus snail shells from TUs 4 and 7 were dated to provide support for the charcoal assays. They range in age from 3430 to 3780 B.P. All three dates are older than the wood charcoal dates by at least 200 years and as much as 540 years. Given that multiple shells were dated in each sample, it is possible that shells of different ages were part of each sample, and potentially the older shells skewed the results towards older times.

The two bulk sediment/humate assays from TUs 4 and 7, of 3430 and 3510 B.P., are very similar to each other, and similar to two of the three Rabdotus shell results. Again, these two dates are older than the three charcoal dates by at least 200 years.

The beaver femur yielded a collagen date of $3430 \pm$ 30 B.P. This is also some 200 years older than the charcoal dates from this same unit, but the charcoal date was some $20 \mathrm{~cm}$ above this bone. This bone date is similar to at least one Rabdotus shell assay and one humate result.

The four different materials dated provide similar ages, with the Rabdotus shells, humates, and bone results all older by at least 200 years than the three accepted wood charcoal dates. Frederick (2011) compares and discusses problems with Rabdotus shell and soil humate dates from alluvial context in the Onion Creek Valley in Travis County. If the three accepted wood charcoal dates are more representative of the actual age of the cultural events, then the best fit time range for this targeted component is roughly between 2850 and 3120 B.P., or sometime during a potential 730 year period. Unfortunately, no diagnostic artifacts were recovered to provide a relative chronological framework to indicate the cultural affiliation(s) for this identified period of occupation.

The charcoal date of $2490 \pm 50$ B.P. from Feature 1 appears beyond the age range obtained for the other charcoal dates, as it is at least 360 radiocarbon years younger. Therefore, it is likely this date may reflect a separate cultural event slightly above the targeted component. Alternatively, the wood charcoal dated from Feature 1 may not be in primary context, and Feature 1 is also associated with the rest of the features identified in the targeted zone, and the charcoal date is not representative of the cultural event. 
This page intentionally left blank. 


\subsection{SUMMARY, DUSCUSSION, AND CONCLUSION}

\section{J. Michael Quigg}

\subsection{INTRODUCTION}

In January 2004, an intensive cultural resource survey was conducted by archeologists from Blanton \& Associates, Inc., and targeted the TxDOT existing and proposed right-of-way (APE) for proposed roadway improvements and bridge replacement at the SH 317 Leon River crossing (CSJ: 0396-04-059). The 100 percent survey of 8.5 hectares (21.1 acres) was accompanied by the excavation of three shovel tests, ten backhoe trenches, and five 25 -by-25 cm hand-excavated columns at five of the trenches (Ringstaff 2004). Five backhoe trenches (BTs 4, 7 through 10) and the five screened trench columns were excavated in the alluvial terrace on the southern side of the Leon River, immediately east of the existing bridge. Four backhoe trenches (BTs 4, 7, 8 and 9), combined with positive results from three of the five handexcavated columns off those trenches demonstrated the presence of vertically isolated concentrations of cultural materials at depth. Three dense accumulations of burned rocks and mussel shell, designated as Features 1, 2, and 3, were identified at approximately the same depth below surface and appeared to represent a single, thick, relatively intact cultural component. Ringstaff (2004) reported no cultural materials above or below this one cultural zone. The cultural materials were within the upper part of a brown (10YR 4/3) B horizon with pedogenic carbonates in what appeared as West Range Alluvium. One wood charcoal sample from about $138 \mathrm{cmbs}$ in Feature 1 yielded a radiocarbon assay of 2490 B.P. (Ringstaff 2004).

Following that survey phase, the one identified deeply buried component appeared concentrated along the northern edge of the terrace deposits, whereas alluvial deposits farther south along the same terrace lacked signs of this cultural component. The part of site 41BL278 within the existing and proposed new TxDOT right-of-way planned for the bridge replacement work was recommended for further assessment (Ringstaff 2004). The THC concurred with that recommendation and furthered the subsequent assessment phase in the TxDOT APE.

\subsection{SUMMARY}

TRC archeologists conducted the assessment and testing phase in June 2004. The project was designed to assess the NRHP and SAL eligibility of the single, deeply buried component discovered during the previous intensive cultural survey phase within the existing and proposed new right-of-way (APE) for the TxDOT bridge replacement activity. The proposed western expansion of the existing right-of-way was not accessible at the time of the assessment and testing phase, as access had been denied. Therefore, the fieldwork conducted by TRC focused on the existing right-of-way under the elevated bridge and the proposed new right-of-way (APE) along the eastern side, south of the Leon River.

Prior to subsurface excavations, an $840 \mathrm{~m}^{2}$ area of the existing and proposed new right-of-way along the eastern side of the bridge was assessed through electrical resistivity to assist in detecting buried cultural deposits and features. Nine electrical anomalies were detected by this means, and two high probability anomalies (Anomalies 1 and 3) were selected and targeted for subsurface verification through excavations. Verification of Anomaly 3 through mechanical trenching revealed it consisted of two large, natural limestone boulders. Anomaly 1 was still underwater due to heavy rains at the close of our investigations and subsurface composition could not be verified.

Subsurface deposits in the APE were explored during the assessment and testing phase by means of eight additional backhoe trenches (totaling nearly 34 linear meters) and 10 hand-excavated 
1-by-1 m test units (totaling $4.1 \mathrm{~m}^{3}$ ) placed along the sides of three backhoe trenches. Backhoe Trenches 10, 11, and 12, placed more than $15 \mathrm{~m}$ south of the northern edge of the $T_{1}$ terrace, revealed only occasional pieces of cultural material. Therefore, hand-excavations focused on the dense accumulations of cultural materials within positive BTs 8, 9, and 14 along the northern edge of the terrace. At the time of the testing phase, BT 7 (previously excavated during the survey phase) was determined to be just beyound the APE and no further work was conducted in that area. Backhoe Trench 4 (also excavated during the survey phase) was in the far northwestern end of the proposed new right-of-way. That trench yielded quantities of mussel shell from the same depth as the targeted, deeply buried cultural component identified in the other units. However, at the time of the testing phase (June 2004), the western end of site 41BL278 was not accessible. All three sets of hand-excavated test units, located adjacent to BTs 8, 9, and 14, yielded in situ concentrations of cultural remains at approximately the same depths and are projected as part of a single vertically restrained cultural component.

The identified component is buried within the core of the West Range Alluvium in B horizon deposits in which the sedimentation rate was the greatest, although the fine texture of the sediment implies a relatively slow rate of sedimentation. Three acceptable wood charcoal dates document a use period between 2850 and 3120 B.P. However, dates from multiple Rabdotus shells, two soil humates, and one animal bone are all slightly older and may push the potential date of occupation back to about 3510 B.P. (see Table 7-7). This occupation period falls into Collins' (2004) Late Archaic period, which in Prewitt's $(1981,1985)$ chronology was part of the Middle Archaic. This well-defined component has good depositional integrity, but probably contains more than one cultural event at this specific location within the recurrence interval of flooding. This cultural component is encased in clayey floodbasin fines that lack significant quantities of gravel and obvious buried soils. Cultural materials cluster towards the northern edge of the $T_{1}$ surface beneath the existing "levee-like" landform. A slight slope was detected in the artifact distributions, which implies the materials may have been situated on a much earlier/older, but morphologically similar landform.

Within this component, nine clusters of cultural material were designated as features (Features 1, 2, 3, 3a, 4, 5, 6, 7, and 8) and documented to various degrees. Feature 1, at a depth between 105 and 138 cmbs, discovered in BT 7 during the previous survey phase, and radiocarbon dated by charcoal to 2490 B.P., was not further assessed as it was beyond the proposed APE. The association of Feature 1 with the sampled component from this testing phase is not clear but is considered just above the investigated component as the radiocarbon date obtained from Feature 1 is roughly 360 years younger. The remaining eight features were dominated by quantities of limestone burned rocks, some associated with sparse lithic debitage, chipped and ground stone tools, scattered mussel shells, and a few small animal bone fragments (see Table 7-8). These cultural materials indicate one or more intense events occurred in the encountered component, which reflects general cooking/food preparation activities, sometime between ca. 2850 and 3120 B.P. The feature types include at least one circular, rock-ringed hearth and various types of burned rock discard piles and dumps, some with only burned rocks, whereas some clusters were combined with other classes of cultural materials. Unfortunately, no diagnostic projectile points were recovered from this component.

Vertical plots of in situ cultural materials (mostly burned rocks) from hand-excavated units reveal one gently sloping cultural event in TUs 1,2 , and 4 excavated adjacent to BT 8 , two probable closely spaced events within TUs 5, 6, 7, and 10 along BT 9, and at least one cultural event in TUs 8 and 9 
along BT 14 within the targeted cultural component. Despite the possibility the identified component may include two discrete events, this single component is well-defined vertically in the middle of a thick B horizon that developed within accumulated alluvial fines. The component is covered by relatively thick and culturally sterile overburden, and lacks significant disruption from rodent activities. This component yielded organic remains in the form of animal bones, charcoal, mussel shells, and Rabdotus snail shells (Table 78 ), as well as multiple types of cultural features and multiple classes of cultural materials, that includes tool manufacturing debris, finished and broken bifaces, and expedient stone tools in the form of edge-modified flakes, from $4.1 \mathrm{~m}^{3}$ of handexcavated sediments.

In summary, the investigated portion of site 41BL278 within the TxDOT APE contains a welldefined cultural component in clay loam deeply buried between 130 and $180 \mathrm{cmbs}$. The component is defined by at least one, and potentially two, horizontal lenses of cultural materials dominated by scattered burned rocks and burned rock features. Relatively sterile overburden overlies and retains the depositional integrity of this component, and displacement through rodent activity has not significantly affected this deeply buried component. The component is radiocarbon dated based on wood charcoal to between ca. 2850 and 3120 B.P., within the Late Archaic period defined by Collins (2004). Dates derived from other material types may push this time back to about 3500 B.P.

High-powered use-wear results (Appendix H) provide specific functions for four formal and four informal tools. The four bifaces functioned as cutting tools on hard and soft materials, specifically hides. One medial fragment appears broken during manufacturing and lacks use-wear. The informal tools continue to provide the most diversity and unusual functions compared to other formal tools. The four edge-modified flakes were also used for cutting, such as wood, hides, hard materials, and one revealed evidence of processing birds, as feather fragments were present. The discovery of bird feathers on a stone tool is extremely rare, and supports the use of birds by those populations. The absence of bird bones in the limited faunal assemblage highlights the need for other technological methods of inquiry (such as microfossil identifications) to increase the data recovered, especially from areas of poor organic preservation, and therefore broaden our understanding of cultural systems.

Starch analysis (Appendix E) indicates at least two types of grasses, lily bulbs, and other geophytes were collected, processed and cooked in these features. Starches were recovered from eight burned rocks from five different burned rock features. The absence of starch grains in five sediment samples from these same features indicates those recovered from burned rocks are not environmental contaminants but rather definitively of cultural origin. The presence of gelatinized starches on nearly a fourth of the examined rocks is a good indicator stone boiling probably occurred as a means of cooking starchy plant foods. These two discoveries, when considered together, document multiple grass types and at least two types of starchy geophytes, one in the lily family, as food resources for the inhabitants. Starch grain analysis has significantly broadened our understanding of the resources employed at this component, which would have otherwise gone undetected. Mussels, beaver, and birds were also other resources employed, most likely for food. These combined data document a broad spectrum foraging population.

Identifiable charred wood was limited to oak and cottonwood/willow, both thought to be local woods used to heat the rocks and/or cook. Poor charcoal preservation hindered the identification of more wood types, but at least these two species were known to be present in the valley and utilized. The cutting of wood products is directly supported by at 
least three of the eight chipped stone tools analyzed during use-wear were employed to cut wood or other hard materials.

Lipid residue results (Appendix F) are remarkably similar, although recoveries were low and should be used with caution. Poor preservation probably accounts for the scarcity in the amount of lipids recovered and eight samples with insufficient lipids to interpret. However, the use of the high temperature gas chromatography (HT-GC) and gas chromatography with mass spectrometry (HTGC/MS) to identify lipid biomarkers provided useful information as to what was cooked with the burned rocks (Appendix E). Nearly all 18 burned rocks sampled had evidence of cooking plant and animal products with a high percentage documented with conifer residues, a by-product of heating rocks with juniper and/or cypress wood. The consistency in the results supports the use of these features by groups in a very narrow time frame and those features interpreted as discarded rocks probably came from cleaning of the apparently intact heating/cooking features.

Poor preservation again accounts for limited phytolith recovery. Samples from Features 3a, 7 and 8 yielded a variety of the important short cells (Pooids, Panicoids, and Chloridoids), but were not of sufficient quantity for meaningful counts or for interpreting the grassland composition. Also present were quantities of undiagnostic bulliforms, well-preserved burned tree phytoliths, and wellpreserved freshwater sponge spicules. Spicule presence in features is indicative of water use in association with the feature. Due to improved phytolith processing techniques, a variety of tiny snails as well as charcoal flecks, tiny bone fragments, burned shell (possibly snail), some lithic material, and other stone were present in the phytolith sand fractions.

Various and diverse technical results combined with poor vertebrate faunal remains and near absence of macrobotanical remains, indicate preservation is relatively poor. This was observed in the small assemblage of identifiable wood charcoal, few bone fragments, lower than normal recoveries of lipid residues, relatively limited starch grains and very poorly preserved phytoliths. The low recovery may have been partially influenced by the small area excavated and the restricted nature of the events at this one area of the site. Even though preservation was relatively poor, the analytical results still provide significant information important to understanding the prehistoric occupants of this component and contribute to our overall understanding of the central Texas prehistory.

\subsection{DISCUSSION}

A few Texas researchers suggest that Late Archaic populations increased throughout the period (i.e., Prewitt (1985). The climate appears to have fluctuated significantly during the Late Archaic period (i.e., Johnson and Goode 1994) with the climate around 3000 B.P. more mesic (Collins 2004:121) and/or cooler (Bousman 1998; Tomka and Mauldin 2003; Waters and Nordt 1995). Burned rock middens occurred during this time (i.e., Black and Creel 1997; Collins 2004; Johnson and Goode 1994; Prewitt 1981, 1985). Bison were also regionally available as evident in 7 of the 18 components across the region yielding bison bones for what Mauldin et al. (2012) termed the initial Late Archaic period, characterized by Pedernales, Bulverde, Kinney, Langtry, and Val Verde points. Evoe Terrace (41BL104), also in Bell County, yielded the most bison thus far documented for this general period (Sorrow et al. 1967). At Evoe Terrace, Levels 7, 8, and 9 in Area A lacked bison bones in association with Pedernales points, whereas Zone 5 in Area B, dominated by Pedernales points, yielded bison bones (Sorrow et al. 1967:121:Table 3). Apparently the utilization of both bison and burned rock middens occurred around 3000 B.P., although the specific climate at that time in central Texas is not well-understood. 
The investigated component at site 41BL278 is one of very few known, well-defined cultural components thus far assigned to this narrow time period (ca. 2850 to 3120 B.P.) in the central Texas region. Collins $(1995 ; 2004)$ in his review of the central Texas cultural history, lists only four excavated sites (the Anthon site [41UV60]; the Bull Pen site [41BP280]; the Loeve-Fox site [41WM230]; and the Youngsport site [41BL116]) from this time frame that have cultural materials with moderate $(N=2)$ to good $(N=2)$ contextual integrity. Most excavated sites with Late Archaic components reveal compressed stratigraphy or are mixed with multiple diagnostic projectile points (i.e., Wilson-Leonard in the adjacent Williamson County [Collins et al. 1998]). Most known sites assigned to this period have yielded Pedernales projectile points derived primarily from compressed/mixed contexts in burned rock middens, with few directly associated radiocarbon dates. An assessment of 42 prehistoric sites at Fort Hood indicates that Pedernales points are the dominant point type recovered from burned rock middens (Kleinbach et al. 1999, Table 93). For example, site 41CV1122 in adjacent Fort Hood revealed two thick burned rock middens that yielded one Castroville and three Pedernales points and two charcoal radiocarbon dates of ca. 3000 B.P. (Kleinbach et al. 1999). Of the 42 evaluated Fort Hood sites, 6 sites yielded 9 radiocarbon dates that range from ca. 2900 to 3520 B.P. that may correlate with the cultural component identified in the APE at 41BL278.

One site listed as having good integrity by Collins (1995) is the Loeve-Fox site (41WM230), just south of 41BL278 along the San Gabriel River in Williamson County (Prewitt 1982a, 1982b), which has good stratification and numerous cultural components. The Round Rock phase component (identified by Pedernales points), observed in Strata 14 through 16 in two excavation units, yielded 12 features that included basin hearths, burned clay and charcoal pits and lenses, and lithic debris concentrations. These diverse features were associated with at least five Pedernales points, seven other bifaces, a few scrapers, four edge-damaged flakes, a hammerstone, a uniface, quantities of lithic debitage, and scattered mussel shell. The features were horizontally distributed in sets/groups and interpreted to reflect specific small group activities (Prewitt 1982a). This Loeve-Fox component yielded evidence of two distinct use periods and was overlain by a nearly sterile stratum. The Loeve-Fox Round Rock phase assemblage lacked ornaments, shaped shell artifacts, and grinding instruments. In one instance, cultural debris was scattered in a zone a little more than $1 \mathrm{~m}$ in diameter around a hearth. The occupations were interpreted to reflect a balance of resource exploitation by small groups of people, possibly on a seasonal basis (Prewitt 1982b). Unfortunately, no radiocarbon dates are available for the Round Rock phase component at Loeve-Fox. The Round Rock phase occupation debris appears similar to that recovered from the investigated APE at the northwestern end of 41BL278. Even the stratigraphy is similar, with the nearly sterile Strata 15 separating two closely spaced events.

The second site that Collins (2004) identified as having good integrity is the Anthon site (41UV60) in Uvalde County, south of the Edwards Plateau. The Anthon site is a semistratified, multicomponent site with occupations spanning some 4,000 years (Goode 2002). Three wood charcoal dates of 3000 B.P. (TX-2381), 3120 B.P. (Tx-2385) and 3520 B.P. (Tx-2442) from near the bottom of the excavations are of similar age to the two oldest wood charcoal dates from 41BL278. The three Anthon site dates are associated with nearly equal numbers of Pedernales $(N=30)$ and Kenney points $(N=28)$. These two point types occurred in vertical association with at least two Marcos points within a $30 \mathrm{~cm}$ thick deposit (Goode 2002). The overlying 70 to $80 \mathrm{~cm}$ of deposits contained numerous younger point types. Although generally stratified, the Anthon site deposits did not include culturally sterile zones above or below any of the identified components, and multiple point types were often observed within single components or within one 15 $\mathrm{cm}$ (6 in.) thick excavation level. 
The Youngsport site (41BL116), along the Lampasas River in western Bell County, was assigned to a moderate integrity category by Collins (2004). It revealed multiple components generally stratified in $250 \mathrm{~cm}$ of alluvial deposits. Stratum 3B, a dense cultural zone with stone tools, lithic debitage, burned rocks, mussel and snail shells, and animal bone fragments, yielded 41 Pedernales points, 9 Castroville, 7 Marshall, 2 Lange, 1 Uvalde, and 1 Williams points (Shafer 1963). The Youngsport 3B component was not radiocarbon dated. The identified zones were not separated by sterile deposits.

More recently, mitigation excavations at the multicomponent and reasonably well-stratified site 41MM340, in Milam County roughly $50 \mathrm{~km}$ to the southeast, yielded a suite of 19 Pedernales, 1 Gary, and 1 Woden point from Zone 8 (Analytical Unit 6) in alluvial deposits. Two wood charcoal radiocarbon dates from Zone 8 are about 3000 to 3100 B.P. (Mahoney and Tomka 2000; Mahoney et al. 2003). Analysis of Pedernales stem forms indicates significant regional differences in stem forms. Those forms represented at 41MM340 clearly have differences in stem form that set it apart from nine other sites studied. Cultural features from AU 6 included both burned rock clusters and charcoal/burned clay concentrations. The tool assemblage includes a variety of tools such as choppers, celts, expedient scrapers, hammerstones, numerous bifaces, and four types of cores. The presence of celts, choppers and hammerstone indicates activities directed to woodworking. The faunal assemblage was dominated by fresh water mussels, represented by at least nine species, but dominated by Threeridge and Smooth Pimpleback (Mahoney et al. 2003). Other than the mussel shells, subsistence remains are dominated by animal bones, with deer, rabbit and turtle most prevalent (Meissner and Mahoney 2003:200). Analytical Unit (AU) 6 did not yield any bison bones and had a relatively narrow genus richness $(N=9)$ compared to later components. Lipid residue analysis revealed combinations of animal products (Malainey 2003). Macrobotanical results identified only pecan nuts from a single feature. This data indicates a diverse subsistence base.

These few sites discussed above provide some of the best data available for defining the timing of Pedernales events, associated cultural materials, and subsistence in central Texas. This brief background discussion reveals there remains considerably more to be understood about this general time period and the associated cultural lifeways of populations that employed Pedernales dart points or others of the same time.

The discovery that peoples that occupied this component processed birds with chipped stone tools, cooked multiple food resources, cleaned and discarded rocks form cooking features, with the remains in good context and horizontally patterned provides an excellent opportunity to gain insights into these prehistoric populations.

\subsection{CONCLUSIONS}

This document presents the field methods employed to evaluate the TxDOT APE at the SH 317 Leon River crossing, the analytical results on diverse cultural materials collected during fieldwork within the current and proposed TxDOT right-of-way (APE) within a portion of prehistoric site 41BL278, and makes recommendations to TxDOT and THC concerning further work at this location.

The deeply buried component identified and radiocarbon dated to between ca. 2850 and 3120 B.P. in that portion of site 41BL278 within the existing and proposed TxDOT right-of-way is similar in age to Pedernales-period sites in the region, although no diagnostic points were recovered. This deeply buried, clearly identifiable and intact cultural component, with high integrity, reflects a very restricted time period, represents a single use period, and the extracted data presents a strong case for yielding more meaningful data to address a variety of research issues and questions. 


\subsection{RECOMMENDATIONS}

\section{J. Michael Quigg}

\subsection{INTRODUCTION}

Cultural resource testing was conducted in June 2004 in the TxDOT defined APE for road and bridge replacement project (CSJ: 0396-04-059) in Belton County, Texas. Testing was also within the northwestern end of previously identified prehistoric site 41BL278 to comply with existing federal and state guidelines (Antiquities Code of Texas of 1977 [revised 1987], Title 9, Chapter 191, VACS, Art. 6145-9). This was done in order to assess the potential of the site to make contributions to the knowledge of Texas prehistory and eligibility for inclusion in the National Register of Historic Places (NRHP) and as a State Antiquities Landmark (SAL).

According to the National Historic Preservation Act of 1966 (Section 106), and Federal Regulations (36 CFR 60.4), a site's significance is evaluated based on criteria identified by the National Parks Service (1995:2). Cultural resources are eligible for listing on the NRHP and worthy of avoidance, protection, or mitigation through data recovery, if they are significant in American History, architecture, engineering, or cultural history. Significant properties are those that possess integrity of location, design, setting, materials, workmanship, feeling, and association and:

A. that are associated with events that have made a significant contribution to the broad patterns of our history; or

B. that are associated with the lives of persons significant in our past; or

C. that embody the distinctive characteristics of a type, period or method of construction, or that possess high artistic values, or that represent a significant and distinguishable entity whose components may lack individual distinction; or
D. that have yielded, or may be likely to yield, information important in prehistory or history.

Criterion D as defined above generally applies to prehistoric archeological sites.

The criteria for determining the eligibility of a prehistoric or historic cultural property for designation as an SAL are presented in Chapter 191, Subchapter D, Section 191.092 of the Antiquities Code of Texas. These criteria are similar to the criteria used in assessing the eligibility of a property for inclusion in the NRHP:

Sites, objects, buildings, artifacts, implements, and locations of historical, archeological, scientific, or educational interest including those pertaining to prehistoric and historical American Indians or aboriginal campsites, dwellings, and habitation sites, their artifacts and implements of culture, as well as archeological sites of every character that are located in, on, or under the surface of any land belonging to the State of Texas or to any county, city, or political subdivision of the state are state archeological landmarks and are eligible for designation (Section 191.092[a]).

The archeological field assessment of the portion of 41BL278 located within TxDOT's APE consisted of mechanical excavation of 8 backhoe trenches (totaling nearly 34 linear meters) and 10 handexcavated 1-by-1 meter units (totaling $4.1 \mathrm{~m}^{3}$ ) off the sides of the backhoe trenches. Assessment of features and artifacts present, as well as site context and integrity, indicates the presence of repeated short-term events that represent a single component limited time period, ca. 3100 B.P., in the Late Archaic I (see Collins 2004). Based on the data gathered during the archeological assessment (presented in the previous chapters), TRC finds the portion of 41BL278 in the TxDOT right-of-way has the potential to address a wide range of questions that pertain to behaviors of human groups during 
the occupations represented. Therefore, TRC recommends the portion of 41BL278 within the APE as eligible for NRHP listing under Criterion D, 36 CFR 60.4. Furthermore, this site is also recommended as eligible for SAL designation under Criteria 1 and 2 of the Rules of Practice and Procedures for the Antiquity Code of Texas, 13 TAC 26.8.

Because the site is recommended eligible, and has potential to yield information significant for understanding Texas prehistory, TRC recommends further examination of that portion of 41BL278 within the APE prior to any additional development impacts. A preliminary data recovery research design is therefore presented in the following section.

\subsection{DATA RECOVERY RECOMMENDATIONS}

Prehistoric site 41BL278 is an excellent candidate for data recovery due to potential to yield information important in local and regional Texas prehistory. The site can contribute additional data to address a variety of research issues and questions, especially as it contains cultural materials in good context pertaining to a temporally specific, period. Sites of this approximate age (ca. 2850 to 3120 B.P.) are not often encountered, intensively investigated, or reported with sufficient detail for central Texas. The component encountered here has the potential to contribute significantly to a better understanding of this heretofore poorly documented time period, use of local and nonlocal resources, regional land use patterns, and general paleoenvironmental conditions at that time for this region. An interdisciplinary approach is recommended in anticipation that varied aspects of human behavior may be linked to the surrounding environment. The proposed preliminary research design is presented in the subsequent chapter (Chapter 10.0) for an overview of potential research issues and specific questions that may be addressed through data recovery investigations. 


\subsection{DATA RECOVERY PLAN}

\section{J. Michael Quigg}

\subsection{INTRODUCTION}

If TxDOT and THC concur the investigated portion of 41BL278 in the TxDOT APE, which reveals a single, buried, time constrained component in the targeted zone, is eligible for the NRHP and listing as SAL, it is proposed the TxDOT APE that contains the deeply buried cultural component in the $T_{1}$ terrace, be targeted for data recovery prior to any construction activity.

The presence of multiple datasets (i.e., burned rocks, hearths, discard piles, stone tools, animal bones, mussel shells, and floral remains) within this single component provide a significant opportunity to investigate various aspects of this understudied and little known period, precisely characterize the artifacts employed by the inhabitance, and investigate and address numerous research issues and specific questions. A brief discussion of pertinent issues with some specific questions is presented below.

\subsection{SITE FUNCTION ISSUES}

Prewitt (1982a, 2012) implies that the type of small features represented at Loeve-Fox (41WM230) on the eastern edge of the Edwards Plateau reflect a site function different than the numerous burned rock midden sites across the Edwards Plateau. He also observed some intra-camp patterning to the discovered features and other material types and suggested that some social structure may be involved. Few sites in central Texas allow for detection of social or camp patterns, as most excavations are quite limited in aerial extent and often vertically oriented, and/or focused on one specific task area, i.e. burned rock middens that have very complex context.

- What are the specific functions of the various features?
- Are activity areas present that reflect separate and/or distinct tasks?

- Does this single component that contains diverse material categories reveal horizontal behavioral patterns or activity areas?

- Can group structure be interpreted from the cultural assemblage and/or site structure?

\subsection{PALEOENVIRONMENTAL ISSUES}

The age of this component (ca. 2850 to 3250 B.P.) falls within a broader period from roughly 4000 to 2200 B.P. that is thought of as generally having xeric conditions (Johnson and Goode 1994). The reconstructed data from Boriack and Weakly bogs by Bousman (1998) indicates that the arboreal canopy cover increased between 3500 and 3000 B.P. This canopy increase is generally thought to reflect an increase in effective moisture. Following that period from about 3000 to 2200 B.P. was a drying period with less moisture. However, phytolith analysis from the Granberg site (41BX17/271) in Bexar County revealed a fairly stable $\mathrm{C}_{4}$ grassland environment that indicates a predominance of a bluestem/grama (Andropogon/Bouteloua) grassland from roughly 4100 B.P. to 2000 B.P. (Yost and Cummings 2011:236).

- Does the environmental evidence from the APE at 41BL278 provide additional evidence to support the increased moisture or drying conditions?

- Did environmental conditions influence the availability bison and influence the subsistence pattern at 41BL278?

- Do the sediment packages and their structure evident at 41BL278 provide support for a stable or fluctuating environment? 


\subsection{CULTURAL HISTORIC ISSUES}

Johnson and Goode (1994) presented a revised chronological history for central Texas, which places the Marshall, Montell, and Castroville point styles at approximately 3000 to 3500 B.P. and the Pedernales points prior to that. Previously, Prewitt (1981, 1985) interpreted the Pedernales point type as the dominant point for that same period. Goode (2002) demonstrated the Kenney and Pedernales point types are contemporaneous at about 3000 to 3500 B.P. at the Anthon site (41UV60). Collins (2004) places the Pedernales and Kinney points around the 3000 B.P. period with the Bulverde point style earlier. The Pedernales points from Little River (41MM340), on the eastern edge of the Blackland Prairie, are also dated to about 3000 B.P. and are stylistic different from 10 other selected sites/components that yielded Pedernales points, which indicate some patterned regional variation in Pedernales stem forms. However, the Loeve-Fox site, which had good stratification, did not provide radiocarbon dates to establish the Pedernales point type in a specific chronological period (Prewitt 1982a).

- Can a collection of diagnostic artifacts from 41BL278 shed light on which of these point types actually dates to this very narrow time?

- Do the point forms or point attributes provide support for regional point type differences or time differences?

- Do point forms reflect trade and/or interaction with other populations in the region?

- Does the material type from which the point types were manufactured indicate movements across the region or trading patterns?

\subsection{SUBSISTENCE ISSUES}

The period around 3100 B.P. is considered a period of bison presence by Dillehay (1974) who indicated most sites in the central Texas region have yielded evidence of bison remains, whereas the adjacent regions lack this evidence. That perception has changed as recent research by Mauldin et al. (2012) documents minimal bison presence in central and south Texas during the period from around 4450 to 2500 B.P. In support of the latter, extensive excavations at $41 \mathrm{MM} 340$ along Little River on the eastern side of the Blackland Prairie yielded Pedernales points associated with radiocarbon dates around 3000 B.P. However, the recovered faunal assemblage yielded only a limited number of very large mammal bone fragments $(N=82)$ in the bison size range. The diverse vertebrate assemblage was dominated by large deer size $(N=544)$ mammals with moderate frequencies of small rabbit size mammals $(N=74)$, turtles $(N=102)$, and birds $(N$ $=$ 129) (Mahoney et al. 2003). No massive concentrations of burned rock, implying burned rock midden use, were documented at 41MM340.

The Pedernales point use period is best known for extensive burned rock middens (Collins 1995, 2004; Prewitt 1981), generally identified across much of the Edwards Plateau region, but small burned rock clusters, ovens, and hearths have also been attributed to this period (Johnson 2000; Mahoney et al. 2003; Prewitt 1981). The use of burned rock middens is often thought of as evidence for intensive processing a single, often restricted plant resource. Dering (2000), following many years of examining macrobotanical remains from across Texas, speculates the most likely plants cooked in small rock ovens are geophytes (bulbs, tubers, etc.), which existed across the eastern Edwards Plateau and the Blackland Prairies. Lipid residues from two burned rocks and two pieces of burned clay from burned rock concentration Feature 36 at $41 \mathrm{MM} 340$, indicate that low to medium fatty plants were mostly cooked (Malainey 2003). Starch grain analysis on rocks from small cooking features at 41BL278 indicates grasses and geophytes were among food resources along with mussel meat and possible beaver. These analytical results support Dering's interpretations and broadens the resources utilized during this period. 
The human skeleton remains from the Bessie Kruze site (41WM13) indicate human population did not consume large quantities of carbohydrates as evident by the lack of carries (Johnson 2000). Extensive wear on the teeth indicate to Johnson the food consumed contained quantities of grit from milling plants. However, no milling stones were recovered from the Bessie Kruze site component.

- Does faunal and/or floral data from 41BL278 represent a single season or multiple seasons of use?

- Does faunal and/or floral data provide a seasonal variation to the use of the more prevalent burned rock middens in the Edwards Plateau region or document the broader range of subsistence strategies for this particular group?

- Do subsistence resources at 41LB278 provide support for use of bison during this specific time? If not, does the subsistence documented at 41BL278 indicate a seasonal variation to the use of bison and/or middens?

- What percentage of the subsistence resources, the terrestrial fauna, flora, and fresh water mussels reflect the total diet?

- Does the subsistence assemblage reflect a stress related diet?

- Are plant resources the primary resources being cooked by the burned rocks?

\subsection{TECHNOLOGY ISSUES}

The Pedernales component at 41MM340, contained multiple events within roughly 15 to $30 \mathrm{~cm}$ of deposits, and revealed at least two visually different features - charcoal stained features and burned rock clusters. Mauldin and Tomka (2003) conducted several statistical tests and demonstrated these two types of features may in fact, represent different activities. Specific data sets for each of the 15 features at $41 \mathrm{MM} 340$ would have contributed to interpreting the function of those features. Multiple feature types that included small and medium sized basin hearths, burned clay/charcoal pits, charcoal lenses, and lithic concentrations were present in the Round Rock phase component at Loeve-Fox (41WM230) (Prewitt 1982a) and testify to a variety of activities and functions.

- Do various burned rock features at 41BL278 represent a diversified cooking technology or do the different features represent other various types of specific activities?

- Are animal resources cooked in the same manner as plant resources?

- Do differences in burned rock sizes and shapes reflect different types of cooking technologies?

- Does the type of cooking technology detected reflect a specific seasonal use and/or specific resource processing techniques?

Prewitt (1982a, Figure 35) depicts several Pedernales points from Loeve-Fox that exhibit slightly different stem configurations. A suite of 35 Pedernales points from the Fort Hood region also reveals point stem differences (Frederick et al. 1994). This is supported by a sample of 42 documented Pedernales points that exhibit extreme variability in the Pedernales group from Fort Hood (Callister et al. 1994:309). Tomka et al. (2003) discovered regional differences in the stem form for Pedernales points. Two stem forms (straight with indented base and contracting with rounded stem corners) were more common in central and east central Texas.

- If Pedernales points are present in the APE at 41BL278, do they fit the trend in stem forms observed at 41MM340?

- Do stem form variations reflect something besides regional population differences? 
- Does lithic debitage reflect a broad range of knapping activities such as core and biface reduction, tool production, and tool maintenance?

- Does lithic debitage reflect tool production through use of local gravels?

- Are cores and early stage bifaces dominated by local or nonlocal cherts?

\subsection{MOBILITY, TRADE, AND INTERACTIONS ISSUES}

Shafer et al. (1975) suggested that the utilization of the Blackland Prairie was intermittent with subsistence patterns being centered on ecotones along each side of the north-south Blackland Prairie corridor. This idea was expanded to include two alternative models. The first model, the "Prairie Centered Adaptation," was a subsistence pattern that reflected a larger territorial domain centered on a prairie population that ranged along the generally east-west riparian corridors crossing through the Blackland Prairie and their east-west movements to exploit the Edwards Plateau to the west and Post Oak Savanna to the east. The underlying assumption being no one narrow zone could provide sufficient resources to sustain a foraging population throughout the year. The second model, the "Prairie Ecotone Adaptation" was one in which the Edwards Plateau populations and Post Oak Savanna populations used the prairie ecotone (Shafer and Bryant 1976).

Prewitt (1982a) implies data from Loeve-Fox, situated on the eastern edge of the Edwards Plateau, may reflect seasonal use since it lacked evidence for the use of burned rock middens and revealed a more diversified subsistence economy. Johnson (2000:197) postulated Pedernales using groups that occupied Bessie Kruze (41WM13) in the Blackland Prairie were "home folk and not seasonal interlopers from afar", based on occurrence of tools made of local cherts from gravel deposits. He also implies these local groups interacted with nonlocal Pedernales point using populations as evident of individuals killed by somewhat different styles of Pedernales points than those documented in the Bessie Kruze assemblage. Death of individuals that employed Pedernales points by other groups that also employed Pedernales points indicates conflict between Pedernales point using groups.

A suite of 35 Pedernales points from Fort Hood, just a few kilometers upstream from 41BL278, have undergone instrumental neutron activation analysis (INAA) and at least half represent Edwards chert (Frederick et al. 1994). A Pedernales point from $41 \mathrm{CV} 1235$ at Fort Hood was manufactured from nonlocal, coarse-grained, olive-green (5Y 4/3) chert (Kleinbach et al. 1999:181). Visual comparisons of lithic debris from the Bessie Kruze site (41WM13) just east in the Blackland Prairie zone indicates most lithic materials from that site are Edwards chert, which probably came from local gravel bars since they are not recognized as any of the 16 identified chert types represented at Fort Hood (Kibler 2000). INAA results from the Varga site (41ED28) in Edwards County indicate chemical differences are present in various Edwards cherts from across the Edwards Plateau (Glascock and Speakman 2004). Further studies of INAA on cherts from central Texas, specifically from the Glen Rose formation in Gillespie County continue to support the existence of subtle differences between some chert types within the Edwards formation (Glascock and Speakman 2008). Also, INAA conducted in conjunction with the analysis of lithic materials from the Pavo Real site (41BX52) in Bexar County documented the local Leon Creek source samples were different from the nearby Camp Bullis source samples, and the Leon Creek source samples were differentiated from other Edwards limestone formation chert sources previously analyzed by MURR (Hudler 2003:289). Thus, INAA provides an important means of identifying chert source localities and movements of materials by populations. 
- What evidence exists for wide spread trade and interaction during this occupation that may be similar to many other slightly later Late Archaic sites?

- Does this valley setting and cultural materials support the use of the Leon River valley as an east-west transportation corridor between multiple east-west changing environmental settings?

- Are lithic resources (specifically Edwards chert) being transported away from the primary source areas in the Edwards Plateau through this river corridor?

- Are the anticipated Pedernales points indicative of local or nonlocal groups as indicated by the style of Pedernales point variations as Tomka et al. (2003) have documented?

- Are nonlocal lithic resources part of this assemblage and if so, where are these resources from and how are they arriving at this site direct procurement or trade?

\subsection{FIELD APPROACH}

To obtain the most useful data to address the above issues the following data recovery plan is presented. Data recovery should be in the form of large block excavations to allow researchers to address spatial patterning of artifacts and features, plus obtain a sizable assemblage of directly related artifacts and features. It is proposed that two blocks of different sizes totaling between 140 and $150 \mathrm{~m}^{2}$ be handexcavated on both sides of BT 8 with handexcavations targeting the previously identified cultural component between 130 and $170 \mathrm{cmbs}$ (Figure 10-1). This horizontal approach should include mechanically stripping the roughly 120 to $130 \mathrm{~cm}$ of sediments above the target component. This requires a deliberate and precise use of a backhoe/gradall with a straight blade to create a relatively flat surface from which to begin handexcavations. This stripping should be closely monitored by archeologists so as to prevent the backhoe from gouging the target component. Once the upper 120 to $130 \mathrm{~cm}$ has been removed, then a 1-by-1 m grid should be established across the stripped areas to provide the horizontal control over the targeted component. Hand-excavations should then remove and screen the sediments from the individual units.

It is proposed that $10 \mathrm{~cm}$ arbitrary levels be used to control the vertical recovery. It is anticipated that five to six levels should be excavated in each unit to ensure complete capture of the targeted cultural component. Level records should be completed for each hand-excavated level. Hand-excavated matrix should be screened through $6.4 \mathrm{~mm}$ (1/4 in.) mesh screens. Cultural debris, including lithic debitage, stone tools, bones, mussel shells, charcoal, and burned rocks, etc. should be collected and bagged according to the appropriate provenience. Although the vertical nature of the cultural materials is generally known, vertical depths of many of the larger burned rocks and other large specimens should be the focus for piece plotting during the hand-excavations. This selected piece plotting should permit detection of the number of occupations present and the slope of the event(s). Horizontal provenience of the larger pieces of lithic debitage, the recognized stone tools, and larger pieces of burned rocks should be mapped on individual level records to allow spatial patterning and associations to be investigated. This type of plotting should allow the development of broad horizontal maps to address site structure and behavioral issues.

When clusters of cultural material are encountered, these clusters should be designated as features and treated in greater detail. A feature form should be completed for each recognized feature and provide primary data concerning the nature of features construction and content. Following careful exposure by troweling and cleaning in and around the material concentration, the feature should be photographed, mapped in plan and profile views, 


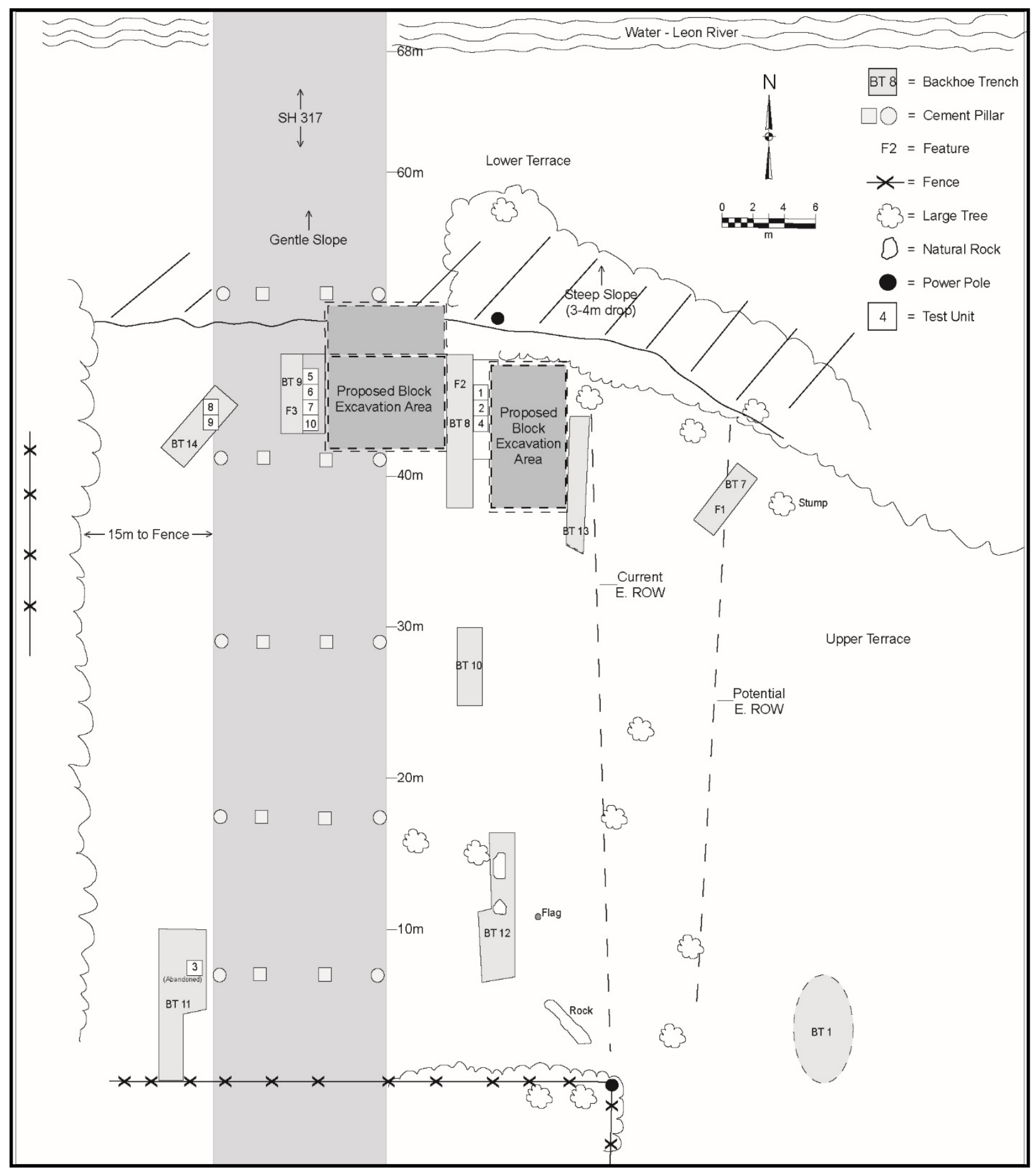

Figure 10-1. Plan map of proposed location of data recovery excavation blocks. 
metric measurements taken on the length, width, and depth of the clustered materials. Observations made on the context, integrity, and associations of burned rocks, and other cultural items should be documented. Artifacts and samples (i.e., burned rocks, bulk matrix, macrobotanical remains, and mussel shells) from within the features should be designated as such. Feature components (i.e. colored matrix and rocks, etc.) and sample localities should be plotted on the plan and/or profile views. Recovered cultural debris would be bagged and appropriately labeled separately from the materials collected from the general level. The exception should be burned rocks that will primarily be sorted into four size categories, counted and weighed by size category, and most discarded in the field. Selected burned rock samples from feature and nonfeature context should be retained for potential detailed analyses. Unscreened feature fill would be collected, bagged, and appropriately labeled for potential floating or fine screening in the laboratory.

One or two complete vertical columns of matrix samples from selected areas of the two blocks should be collected for potential analyses such as but not limited to; soil texture analysis, stable carbon and nitrogen isotope analyses, and phytolith analysis. The nature of the stratigraphy and the amount of turbation and other potential disturbances should influence the identification of the collection localities. Matrix samples would be collected from thin $(<4 \mathrm{~cm})$ horizontal zones/layers from above, through and below the cultural zone.

If possible, a sample of recognized stone tools should not be handled with bare hands upon discovery in the field. These selected tools should be carefully bagged and labeled so as not to contaminate them from handling in the laboratory and not be washed. A sample of selected tools should then undergo high-powered microscopic use-wear and residue analyses by a trained professional. These types of analyses should increase the information return and contribute to a broader understanding of the human behavior represented by the analyzed tools and allow specific tool function and activities to be determined.

From the cultural artifacts and samples collected from the target zone and control samples, a suite of technical analyses is proposed to maximize information return from this one cultural event. These are the same types of analyses that have been previously applied to other sites TRC has been involved in and approved by TxDOT. Not all artifacts will be subjected to various analyses but a suite of samples from good context should be selected and submitted to various technical experts. The technical analyses should include highpowered microscopic use-wear on stone tools, lipid residues on burned rocks, charcoal identification, instrumental neutron activation (INA), macrobotanical, and starch grain analyses. Given spotty results from previous analyses, initially only limited number of samples should be analyzed to reaffirm previous results. Based on those findings, decisions should be formulated as if further analyses should go forward.

Scattered burned rocks should be documented in the field with only a small percentage collected and returned to the laboratory for potential analyses, and from that sample only a smaller sample should be curated following analyses. It is anticipated that a suite of analyses on burned rocks (i.e., lipid residue and starch grain) should be conducted to address issues relating to cooking technology, feature function, and subsistence practices.

A sample of 20 or more natural cobbles, both chert and nonchert pieces, should be collected from exposed gravel lenses along and upstream on the Leon River and 20 or more from the upland lithic procurement area (41BL1218) above and immediately south of 41BL278. These natural rock samples should be used in INAA to compare and contrast to the cultural materials collected from the occupation zone. This information would 
contribute to addressing the lithic resource procurement exploitation, trade, and interaction issues.

The collected macrobotanical items should undergo specific identification by an archeobotanist to enable one to address various plant species present/used at the time of the occupation. This should also contribute to the understanding of the local environment, and the selection process for fuel woods and targeted plant subsistence resources. If sufficient mesquite wood is identified it should be advantageous to conduct wood structure analyses (ecologically diagnostic xylem analysis [EDXA]) to contribute to our understanding of the moisture conditions during the period of tree growth and general paleoenvironmental reconstruction. Identification of plant species should also help in assessing the seasonal use of this component.

The above approach should allow a sample of cultural materials to be recovered from one specific, limited period to use and address diverse research issues and questions presented above. It should also facilitate the recovery of a cultural assemblage that could be compared to other regional assemblages of this time period and other Late Archaic assemblages. 


\subsection{REFERENCES CITED}

Abbott, J. T.

1994 Geomorphic Context of the Barton Site (41HY202) and the Mustang Branch Site (41HY209). In Archaic and Late Prehistoric Human Ecology in the Middle Onion Creek Valley, Hays County, Texas, Volume 2, Topical Studies, by R. A. Ricklis and M. B. Collins, pp. 353-379. Studies in Archeology 19, Texas Archeological Research Laboratory, The University of Texas at Austin.

2003 Stratigraphic and Geomorphic Evaluation of Brushy Creek at FM973. In Archeological Investigations at 41WM815, A Blackland Prairie Site, Williamson County, Texas, by R. K. Brownlow, pp. 179-191. Studies in Archeology 36, Texas Archeological Research Laboratory, The University of Texas at Austin and Archeological Studies Program Report 23, Environmental Affairs Division, Texas Department of Transportation, Austin, Texas.

Abbott, J. T. and W. N. Trierweiler

1995 NRHP Significance Testing of 57 Prehistoric Archaeological Sites on Fort Hood, Texas. United States Army Fort Hood, Archeological Resource Management Series, Research Report No. 34.

Acuna, L. I.

2010 Plant Remains from Site 41CV389, Fort Hood, Coryell County, Texas. In Data Recovery Investigations on the Cowdog Crossing Site: A Study of the End of the Archaic, Fort Hood, Coryell County, Texas, by S. Carpenter, C. T. Hartnett, J. D. Lowe, and K. A. Miller, pp. 143-1154. United States Army Fort Hood,
Archeological Resource Management Series, Research Report No. 56.

Barnes, V. E.

1970 Geological Atlas of Texas, Waco Sheet. Lloyd William Stephenson Memorial Edition, Bureau of Economic Geology, The University of Texas at Austin.

Bement, L. C.

1989 Excavations at 41BP19, The Kennedy Bluffs Site, Bastrop County, Texas. Texas State Department of Highways and Public Transportation, Highway Design Division, Contract Reports in Archaeology, Report Number 5, Austin.

1993 A Flexed Burial from Llano County, Texas. Bulletin of the Texas Archeological Society 61:281-287.

Bender, M. M.

1971 Variations in the C13/C12 Ratios of Plants in Relation to the Pathway of Photosynthetic Carbon Dioxide Fixation. Phytochemistry 10:1239-1244.

Black, S. L. and D. G. Creel

1997 The Central Texas Burned Rock Midden Reconsidered. In Hot Rock Cooking on the Greater Edwards Plateau: Four Burned Rocks Midden Sites in West Central Texas. Volume I, by S. L. Black, L. W. Ellis, D. G. Creel, and G. L. Goode, pp. 269-305. Studies in Archeology 22, Texas Archeological Research Laboratory, The University of Texas at Austin and Archeological Studies Program, Report 2, Texas Department of Transportation, Environmental Affairs Department.

Blair, W. F.

1950 The Biotic Provinces of Texas. Texas Journal of Science 2(1):93-117. 
Blum, M. D.

1987 Late Quaternary Sedimentation by the Upper Pedernales River, Central Texas. Unpublished Master's Thesis, The University of Texas at Austin.

Blum, M. D. and S. Valastro, Jr.

1989 Response of the Pedernales River of Central Texas to Late Holocene Climate Change. Annals of the Association of American Geographers 79(3):435-456.

Bohrer, V.

1987 The Plant Remains from La Ciudad, A Hohokam Site in Phoenix. In Specialized Studies in the Economy, Environment and Culture of La Ciudad, edited by J. A. E. Kisselburg, G. E. Rice, and B. Spears, pp. 67-202. Office of Cultural Resource Management, Department of Anthropology, Arizona State University, Tempe.

Bond, C. L.

1978 Three Archeological Sites at Hoxie Bridge, Williamson County, Texas. Report Submitted to the Interagency Archeological Services-Denver, Report No. 43, Texas A\&M University.

Bousman, C. B.

1998 Paleoenvironmental Change in Central Texas: The Palynological Evidence. Plains Anthropologist 43(164):201-219.

Boyd, D. K., C. W. Ringstaff, and G. Mehalchick 2004a Analysis and Interpretations of the Cultural Occupations at the Firebreak Site. In Shifting Sands and Geophytes: Geoarcheological Investigations at Paluxy Sites on Fort Hood, Texas, by G. Mehalchick, D. K. Boyd, K. W. Kibler, and C. H. Ringstaff, pp. 129-198. United States
Army Fort Hood, Archeological Resource Management Series, Research Report No. 48.

Boyd, D. K., C. W. Ringstaff, and G. Mehalchick 2004b Rethinking Paluxy Site Archeology. In Shifting Sands and Geophytes: Geoarcheological Investigations at Paluxy Sites on Fort Hood, Texas, by G. Mehalchick, D. K. Boyd, K. W. Kibler, and C. H. Ringstaff, pp. 199-224. United States Army Fort Hood, Archeological Resource Management Series, Research Report No. 48.

Bozarth, S. and T. Woodburn

2011 Appendix F. Paleoenvironmental Reconstruction at 41TV410 (Area-3) based on Biosilicate, Charred Phytolith, and Particulate Charcoal Analysis. In Results of Archeological Significance Testing at 41TV410 and 41TV540 and Associated Geomorphological Investigations on a Segment of Onion Creek in Travis County, Texas, by A. Figueroa, R. Mauldin, C. Frederick, S. A. Tomka, and J. L. Thompson, pp. 211-225. Archaeological Report No. 420, Center for Archaeological Research, The University of Texas at San Antonio.

Brownlow, R. K.

2003 Archeological Investigations at 41WM815, A Backland Prairie Site, Williamson County, Texas. Studies in Archeology 36, Texas Archeological Research Laboratory, The University of Texas at Austin and Archeological Studies Program, Report 23, Environmental Affairs Division, Texas Department of Transportation, Austin.

2004 Data Recovery Investigations at the Holt Site (41YHY341), San Marcos, Hays County, Texas. HJN 040032 AR, Prepared 
for Fairfield Residential, LLC, by Horizon

Environmental Services, Inc., Austin.

Bryant, V. M., Jr.

1977 A 16,000 Year Old Pollen Record of Vegetation Change in Central Texas. Palynology 1:143-155.

Bryant, V. M., and R. G. Holloway

1985 A Late-Quaternary Paleoenvironmental Record of Texas: An Overview of the Pollen Evidence. In Pollen Records of the Late Quaternary North American Sediments, edited by V. M. Bryant and R. G. Holloway, pp. 39-70. American Association of Stratigraphic Palynologists Foundation, Dallas, Texas.

Bush, L. L.

2006 Appendix G: Analysis of Macrobotanical Remains from 41MM341. In Data Recovery Excavations at the J. B. White Site (41MM341), Milam County, Texas, by E. F. Gadus, R. C. Fields, and K. W. Kibler, pp. 173-298. Reports of Investigations, Number 145, Prewitt and Associates, Inc., Cultural Resources Services, Austin and Archeological Studies Program, Report No. 87, Texas Department of Transportation, Environmental Affairs Division, Austin.

Callister, K., J. Peck, and J. M. Quigg

1994 Analysis of and Variation in Fort Hood Projectile Points. In Archeological Investigations on 571 Prehistoric Sites at Fort Hood, Bell and Coryell Counties, Texas, edited by W. N. Trierweiler, pp. 294-318. United States Army Fort Hood, Archeological Resource Management Series, Research Report No. 31.
Caran, S. C.

1998 Quaternary Paleoenvironmental and Paleoclimate Reconstruction: A Discussion and Critique, with Examples from the Southern High Plains. Plains Anthropologist 43(164):111-124.

Carlson, D. L. (editor)

1993 Archaeological Investigations in Bull Branch: Results of the 1990 Summer Archaeological Field School. United States Army Fort Hood, Archaeological Resource Management Series, Research Report Number 19.

Carpenter, S. M. and B. A. Houk

2012 Siren Site Chronology: A Reconstruction of the Late Archaic to Late Prehistoric Temporal Sequence of Eastern Central Texas. Bulletin of the Texas Archeological Society 83:99-128

Carpenter, S., M. Chavez, K. Miller, and K. Lawrence

2006 The McKinney Roughs Site (41BP627): A Stratified Late Archaic II Site on the Colorado River Terraces, Bastrop County, Texas. SWCA Cultural Resources Report No. 02-313, Austin.

Carpenter, S., C. T. Hartnett, J. D. Lowe, and K. A. Miller

2010 Data Recovery Investigations on the Cowdog Crossing Site: A Study of the End of the Archaic, Fort Hood, Coryell County, Texas. United States Army Fort Hood, Archeological Resource Management Series, Research Report No. 56.

Collins, M. B

1994 Chapter 6: Late Archaic Evidence in the Project Area. In Archaic and Late Prehistoric Human Ecology in the Middle Onion Creek Valley, Hays County, Texas- 
Volume 1, Archeological Components by R. A. Ricklis and M. B. Collins, pp. 101189. Studies in Archeology, No. 19, Texas Archeological Research Laboratory, The University of Texas at Austin.

1995 Forty Years of Archeology in Central Texas. Bulletin of the Texas Archeological Society 66:361-400.

2004 Archeology in Central Texas. In The Prehistory of Texas, edited by T. K. Perttula, pp. 101-126. Texas A\&M University Press, College Station.

Collins, M. B., J. Guy, and S. W. Dial

1998 Chapter 9: The Archaic Period, 8800 to 1300 B.P. In Wilson-Leonard: An 11,000year Archeological Record of HunterGatherers in Central Texas. Volume I: Introduction, Background, and Synthesis, assembled and edited by M. B. Collins, pp. 211-270. Studies in Archeology 31, Texas Archeological Research Laboratory, The University of Texas at Austin and Archeology Studies Program, Report 10, Texas Department of Transportation, Environmental Affairs Division.

Coupland, R. T.

1958 The Effects of Fluctuations in Weather upon the Grasslands of the Great Plains. The Botanical Review 24(5):273-317.

Crane, C.

1982 Macrobotanical Analysis. In Archaeological Investigations at the San Gabriel Reservoir Districts, Central Texas, Volume 2, edited by T. R. Hays, pp. 15-5 through 15-12. Archaeology Program, Institute of Applied Sciences, North Texas State University, Denton.
Creel, D. G.

1986 A Study of Prehistoric Burned Rock Middens in West Central Texas. Unpublished Ph.D. Dissertation, Department of Anthropology, The University of Arizona, Tucson.

1990 Excavations at 41TG91, Tom Green County, Texas, 1978. Publications in Archaeology, Report No. 38, Texas Department of Transportation, Austin.

1991 Assessing the Relationship Between Burned Rock Midden Distribution and Archaic Subsistence in West Central Texas. In Burned Rock Middens of Texas: An Archeological Symposium, edited by T. R. Hester, pp. 33-43. Studies in Archeology No. 13. Texas Archeological Research Laboratory, The University of Texas at Austin.

1997 Chapter 5: Analysis of the Distribution of Burned Rock Midden Sites in the Study Area. In Burned Rock Middens of Texas: An Archeological Symposium, edited by T. R. Hester, pp. 89-98. Studies in Archeology No. 13. Texas Archeological Research Laboratory, The University of Texas at Austin.

Cummings, L. S.

1994 Pollen, Phytolith, Macrofloral, and Charcoal Analyses at the Mustang Branch Site (41HY209) and the Barton Site (41HY202). In Archaic and Late Prehistoric Human Ecology in the Middle Onion Creek Valley, Hays County, TexasVolume 2, by R. A. Ricklis and M. B. Collins, pp. 387-402. Studies in Archeology, No. 19, Texas Archeological Research Laboratory, The University of Texas at Austin. 
Cummings, L. S. and R. A. Varney

2010 Pollen and Starch Analysis of Samples from 41CV389, Fort Hood Texas. In Data Recovery Investigations on the Cowdog Crossing Site: A Study of the End of the Archaic, Fort Hood, Coryell County, Texas, by S. Carpenter, C. T. Hartnett, J. D. Lowe, and K. A. Miller, pp. 125-130. United States Army Fort Hood, Archeological Resource Management Series, Research Report No. 56.

Dering, J. P.

1997 Appendix D: Macrobotanical Remains. In Hot Rock Cooking on the Greater Edwards Plateau: Four Burned Rock Midden Sites in West Central Texas. Volume II, by S. L. Black, L. W. Ellis, D. G. Creel, and G. T. Goode, pp. 571-600. Texas Archeological Research Laboratory, The University of Texas at Austin, Studies in Archeology 22, and Texas Department of Transportation, Environmental Affairs Department, Archeology Studies Program, Report 2.

1998 Chapter 40: Carbonized Plant Remains. In Wilson-Leonard An 11,000-year Archeological Record of Hunter-Gatherers in Central Texas, assembled and edited by M. B. Collins, pp. 1609-1636, Volume V. Studies in Archeology 31, Texas Archeological Research Laboratory, The University of Texas at Austin, and Archeology Studies Program, Report 10, Texas Department of Transportation, Environmental Affairs Division, Austin.

2000 Appendix II: Macrobotanical Remains from Soil Flotation Samples from the Bessie Kruze Site, with Thoughts about the Blackland Prairie. In Life and Death at the Bessie Kruze Site (41WM13) on the Blackland Prairie of Williamson County, Texas, by L. Johnson, pp. 213-220. Texas
Department of Transportation,

Environmental Affairs Division,

Archeological Studies Program, Report 22.

2002 Appendix F: Plant Remains from the Armstrong Site, 41CV54. In Data Recovery at the Armstrong Site (41CV54), Caldwell County, Texas, Volume I: Background, Methods, and Site Contexts, by E. A. Schroeder and E. R. Oksanen, pp. 265-275. PPA Cultural Resources Report Number 0284, Prepared for GuadalupeBlanco River Authority by Paul Price Associates, Inc., Austin.

2003a Appendix C: Plant Remains from Rice's Crossing (41WM815). In Archeological Investigations at 41WM815, A Backland Prairie Site, Williamson County, Texas, by R. K. Brownlow, pp. 113-120. Studies in Archeology 36, Texas Archeological Research Laboratory, The University of Texas at Austin and Archeological Studies Program, Report 23, Environmental Affairs Division, Texas Department of Transportation, Austin.

2003b Appendix E: Macrobotanical Analysis. In Data Recovery Excavations at 41MM340: A Late Archaic Site along Little River in Milam County, Texas, by R. B. Mahoney, S. A. Tomka, R. P. Mauldin, H. J. Shafer, L. C. Nordt, R. D. Greaves, and R. R. Galdeano, pp. 223-233. Texas Department of Transportation, Environmental Affairs Division, Archeological Studies Program Report 54 and Center for Archaeological Research, The University of Texas at San Antonio, Archaeological Survey Report, No. 340 .

2004 Appendix B: Analysis of Macrobotanical Remains from Three Paluxy Sites on Fort Hood, Texas. In Shifting Sands and 
Geophytes: Geoarcheological Investigations at Paluxy Sites on Fort Hood, Texas, by G. Mehalchick, D. K. Boyd, K. W. Kibler, and C. H. Ringstaff, pp. 245-257. United States Army Fort Hood, Archeological Resource Management Series, Research Report No. 48.

2006 Plant Remains. In Prehistoric Encampments at the Shepherd Site: Testing and Data Recovery at 41WM1010, Williamson County, Texas, by D. Dickson and R. Rogers, pp. 153-156. Prepared for Texas Department of Transportation by PBS\&J, Austin.

2011 Appendix A: Plant Remains from 41TV410 and 41TV540. In Results of Archeological Significance Testing at $41 T V 410$ and 41TV540 and Associated Geomorphological Investigations on a Segment of Onion Creek in Travis County, Texas, by A. Figueroa, R. Mauldin, C. Frederick, S. A. Tomka, and J. L. Thompson, pp. 159-164. Archaeological Report No. 420, Center for Archaeological Research, The University of Texas at San Antonio.

Dibble, D. S., and D. Lorrain

1967 Bonfire Shelter: A Stratified Bison Kill Site, Val Verde County, Texas. Miscellaneous Papers, No. 1, Texas Memorial Museum, Austin.

Dickens, W. A.

1993 Lithic Analysis. In Archaeological Investigations in Bull Branch: Results of the 1990 Summer Archaeological Field School, edited by D. L. Carlson, pp. 75111. United States Army Fort Hood, Archeological Resource Management Series, Research Report Number 19.
Dillehay, T. D.

1974 Late Quaternary Bison Population Changes on the Southern Plains. Plains Anthropologist 19:180-196.

Eickmeier, W. G., and M. M. Bender

1976 Carbon Isotope Ratios of Crassulacean Acid Metabolism Species in Relation to Climate and Phytosociology. Ecologia 25:341-347.

Eddy, F. W.

1973 Salvage Archeology in the Laneport Reservoir District, Central Texas. Report submitted to the National Park Service by the Texas Archeological Survey, The University of Texas at Austin.

Ensor, H. B. and C. S. Mueller-Wille

1988 Excavations at the Bull Pen Site, 41BP280, Colorado River Drainage, Bastrop County, Texas. Contract Reports in Archaeology, No. 3. Texas State Department of Highways and Public Transportation, Highway Design Division, Austin.

Evershed, R. P.

2000 Biomolecular Analysis by Organic Mass Spectrometry. In Modern Analytical Methods in Art and Archeology, edited by E. Ciliberto and G. Spoto, pp. 177-239. Volume 155, Chemical Analysis. John Wiley \& Sons, New York.

Evershed, R. P., S. N. Dudd, M. J. Lockheart and S. Jim

2001 Lipids in Archeology. In Handbook of Archeological Sciences, edited by D. R. Brothwell and A. M. Pollard, pp. 331-349. John Wiley \& Sons, New York.

Frederick, C. D.

2011 Chapter 8: Late Quaternary Alluvial Stratigraphy of the Lower Onion Creek 
Valley. In Results of Archeological Significance Testing at 41 TV410 and 41TV540 and Associated Geomorphological Investigations on a Segment of Onion Creek in Travis County, Texas, by A. Figueroa, R. Mauldin, C. Frederick, S. A. Tomka, and J. L. Thompson, pp. 69-95. Archaeological Report No. 420, Center for Archaeological Research, The University of Texas at San Antonio.

Frederick, C. D. and C. Ringstaff

1994 Lithic Resources at Fort Hood: Further Investigations. In Archaeological Investigations on 571 Prehistoric Sites at Fort Hood, Bell, and Coryell Counties, Texas, edited by W. N. Trierweiler, pp. 125-181. United States Army Fort Hood, Archeological Resource Management Series, Research Report No. 31.

Frederick, C. D., M. D. Glascock, H. Neff, and C. M. Stevenson

1994 Evaluation of Chert Patination as a Dating Technique: A Case Study from Fort Hood, Texas. United States Army Fort Hood, Archeological Resource Management Series, Research Report No. 32.

Fredlund, G.

1998 Phytolith Analysis. In Wilson-Leonard An 11,000-year Archeological Record of Hunter-Gatherers in Central Texas, Volume V: Special Studies, assembled and edited by M. B. Collins, pp. 1637-1651. Studies in Archeology 31, Texas Archeological Research Laboratory, The University of Texas at Austin, and Archeology Studies Program, Report 10, Texas Department of Transportation, Environmental Affairs Division, Austin.
Fredlund, G. G., C. B. Bousman, and D. K. Boyd

1998 The Phytolith Record from Morgan Playa in the Rolling Plains of Texas. Plains Anthropologist 43(164):187-200.

Fullington, R. W. and W. L. Pratt, Jr.

1974 Bulletin 1. The Aquadic and Land Mollusca of Texas. Part Three: The Helicinidae, Carychiidae, Achatinidae, Bradybaenidae, Bulimulidae, Cionellidae, Haplotematidae, Helicidae, Oreohelicidae, Spiraxidae, Streaxidae, Streptaxidae, Strobiolosidae, Thysanophoridae, Valloniidae, (Gastropoda) in Texas. Dallas Museum of Natural History, Dallas.

Gardner, K. M.

2006 Appendix A: Analysis of Mussel Shells from 41MM341. In Data Recovery Excavations at the $J$. B. White Site (41MM341), Milam County, Texas, by E. F. Gadus, R. C. Fields, and K. W. Kibler, pp. 195-206. Reports of Investigations, Number 145, Prewitt and Associates, Inc., Cultural Resources Services, Austin and Archeological Studies Program, Report No. 87, Texas Department of Transportation, Environmental Affairs Division, Austin.

Glascock, M. D. and R. J. Speakman

2004 Appendix F: Instrumental Neutron Activation Analysis of Chert from the Varga Site (41ED28) in Southwest Texas. In The Varga Site: A Multicomponent, Stratified Campsite in the Canyonlands of Edwards County, Texas, by J. M. Quigg, J. D. Owens, P. M. Matchen, G. D. Smith, R. A. Ricklis, M. C. Cody, and C. D. Frederick, pp. 885-949. Texas Department of Transportation, Environmental Affairs Division, Archeological Studies Program, 
Report No. 110, and TRC Environmental Corporation, Technical Report No 35319, Austin.

2008 Appendix A: Instrumental Neutron Activation Analysis of Chert from Gillespie County in Central Texas - TRC Project 46843/0020. In Cultural Resource Survey and Testing of Properties at Boot Ranch, Gillespie County, Texas, by P. M. Matchen, J. M. Quigg, and A. Newman, pp. 89-109. Prepared for R. J. Brandes Company by TRC Environmental Corporation, Austin.

Goode, G. T.

2002 The Anthon Site: A Prehistoric Encampment in Southern Uvalde County, Texas. Texas Department of Transportation, Environmental Affairs Division, Archeological Studies Program, Report No. 38.

Griffith, T. B. and K. W. Kibler

2005 Test Excavations at 41BL1214, Bell County, Texas: State Highway 95 Bridge Replacement at the Little River. Technical Reports, Number 74, Texas Department of Transportation, Archeological Studies Program, Report 76.

Hall, S. A.

1982 Late Holocene Paleoecology of the Southern Plains. Quaternary Research 17:391-407.

1990 Channel Trenching and Climate Change in the Southern U.S. Great Plains. Geology 18:342-345.

Hardy, B. L.

2011 Results of Microscopic Use-Wear and Residue Analysis from Site 41CV413, Texas. In Cultural Resource Investigations to Offset Mechanical Impacts to the Clear Creek Golf Course Site (41CV413), Fort Hood, Texas, by J. M. Quigg, C. Lintz, G. Smith, D. DeMar and J. D. Owens, pp. 189202. United States Army Fort Hood, Archeological Resource Management Series, Resource Report No. 60.

Hays, T. R. (Compiler and Editor)

1982 Archaeological Investigations at the San Gabriel Reservoir Districts, Central Texas. Vols. I-IV. Archaeology Program, Institute of Applied Sciences, North Texas State University, Denton.

Holloway, R. G., L. M. Raab, and R. Stuckenrath 1987 Pollen Analysis of Late-Holocene Sediments from a Central Texas Bog. The Texas Journal of Science 39(1):71-79.

Howells, R. G.

2003 Appendix E: Freshwater Mussel (Bivalvia: Unionidae) Shell Remains Associated with the Rice's Crossing Site (41WM815). In Archeological Investigations at 41WM815, A Backland Prairie Site, Williamson County, Texas, by R. K. Brownlow, pp. 139-149. Studies in Archeology 36, Texas Archeological Research Laboratory, The University of Texas at Austin and Archeological Studies Program, Report 23, Environmental Affairs Division, Texas Department of Transportation, Austin.

Howells, R. G., R. W. Neck, and H. D. Murray

1996 Freshwater Mussels of Texas. Texas Parks and Wildlife Department Press, Austin.

Howells, R. G., J. Neel-Hartman, and S. A. Wagner 2003 Appendix G: Freshwater Mussel Shell from 41MM340. In Data Recovery Excavations at 41MM340: A Late Archaic Site along Little River in Milam County, Texas, by R. B. Mahoney, S. A. Tomka, R. 
P. Mauldin, H. J. Shafer, L. C. Nordt, R. D. Graves, and R. R. Galdeano, pp. 245-270. Texas Department of Transportation, Environmental Affairs Division, Archeological Studies Program, Report No. 54, Austin, and The University of Texas at San Antonio, Center for Archaeological Research, Archaeological Survey Report No. 340, San Antonio.

Huckabee, J. W. Jr., D. R. Thompson, J. C. Wyrick, and E. G. Pavlat

1977 Soil Survey of Bell County, Texas. United States Department of Agriculture, Soil Conservation Service, in cooperation with Texas Agricultural Experimental Station.

Hudler, D. B.

2003 Appendix 5: Instrumental Neutron Activation Analysis Results. In Pavo Real (41BX52): A Paleoindian and Archaic Camp and Workshop on the Balcones Escarpment, South-Central Texas, by M. B. Collins, D. B. Hudler, and S. L. Black, pp. 287-290. Studies in Archeology 41, Texas Archeological Research Laboratory, The University of Texas at Austin and Archeological Studies Program, Report 50, Environmental Affairs Division, Texas Department of Transportation, Austin.

Johnson, L.

2000 Life and Death as Seen at the Bessie Kruze Site (41WM13) on the Blackland Prairie of Williamson County, Texas. Texas Department of Transportation, Environmental Affairs Division, Archeological Studies Program, Report No. 22, Austin.

Johnson, L., and G. T. Goode

1994 A New Try at Dating and Characterizing Holocene Climates as Well as Archeological Periods on the Eastern
Edwards Plateau. Bulletin of the Texas Archeological Society 65:1-51.

1995 Cultures and Climates at the Jonas Terrace Site, 41ME29 of Medina County, Texas. Office of the State Archeologist Report 40. Texas Department of Transportation and Texas Historical Commission, Austin, Texas.

Karbula, J. W., R. Feit, and T. B. Griffith

2001 Changing Perspectives on the Toyah: Data Recovery Investigations of 41TV441, The Toyah Bluff Site, Travis County Texas. Archeology Series No. 84, Hicks \& Company, Austin.

Karbula, J. W., J. A. Campbell, and B. A. Jones

2011 The Berdoll Site: An Early Archaic Camp on Onion Creek, Travis County, Texas. Bulletin of the Texas Archeological Society 82:135-173.

Kibler, K. W.

2004 Archeological Survey of the Proposed Leon Valley Trunk Sewer Line, Bell County, Texas. Letter Report No. 627, Prewitt and Associates, Inc., Austin.

2000 Appendix I: The Bessie Kruze Site and Environs: Landforms, Alluvium, and Cherts. In Life and Death as Seen at the Bessie Kruze Site (41WM13) on the Blackland Prairie of Williamson County, Texas, by L. Johnson, pp. 207-212. Texas Department of Transportation, Environmental Affairs Division, Archeological Studies Program, Report No. 22, Austin, Texas.

Kibler, K. W. and A. M. Scott

2000 Archaic Hunters and Gatherers of the Balcones Canyonlands: Data Recovery at the Cibolo Crossing Site (41BX377), Bexar 
County, Texas. Reports of Investigations, Number 126, Prewitt and Associates, Inc., Austin.

Killian, K. and M. E. Blake

2001 Archeological Survey and Site Assessments in the Clabber Creek and Jack Mountain Ranges of the Live Fire Area, Fort Hood, Texas. United States Army Fort Hood, Archeological Resource Management Series, Research Report No. 45.

Klienbach, K., G. Mehalchick, D. K. Boyd, and K. W. Kibler

1999 National Register Testing of 42 Prehistoric Archeological Sites on Fort Hood, Texas: The 1996 Season. United States Army Fort Hood, Archeological Resource Management Series, Research Report No. 38.

Kwiatkowski, S.

1992 The Rye Creek Flotation and Macrobotanical Analyses. In The Rye Creek Project: Archaeology in the Upper Tonto Basin. Volume 2: Artifact and Specific Analyses, pp. 325-375. Anthropological Papers No. 11. Center for Desert Archeology, Tucson.

Larson, D. A., V. M. Bryant, and T. S. Patty

1972 Pollen Analysis of a Central Texas Bog. The American Midland Naturalist 88(2):358-367.

Lohse, J. C.

2013 Chapter 5: Radiocarbon Dates and Dating. In Data Recovery and Analysis at the Texas State University Ticket Kiosk Project Location at 41HY160, Spring Lake, Hays County, Texas, by J. C. Lohse, A. E. Reid, D. M. Yelacic, and C. L. Timperley, pp. 4352. Archaeological Studies Report No. 32,
Center for Archaeological Studies, Texas State University at San Marcos.

Lohse, J. C., A. E. Reid, D. M. Yelacic, and C. L. Timperley

2013 Data Recovery and Analysis at the Texas State University Ticket Kiosk Project Location at 41HY160, Spring Lake, Hays County, Texas. Archaeological Studies Report No. 32, Center for Archaeological Studies, Texas State University at San Marcos.

Loy, T. H.

1994 Residue Analysis of Artifacts and Burned Rock from the Mustang Branch and Barton Sites (41HY209 and 41HY202). In Archaic and Late Prehistoric Human Ecology in the Middle Onion Creek Valley, Hays County, Texas, by R. A. Ricklis and M. B. Collins, pp. 607-627. Studies in Archeology 19, Texas Archeological Research Laboratory, The University of Texas at Austin.

Lukowski, P. D.

1988 Archaeological Investigations at 41BX1, Bexar County, Texas. Center for Archaeological Research, The University of Texas at San Antonio, Archaeological Survey Report, No. 135.

Mahoney, R. B. and S. A. Tomka

2000 National Register of Eligibility Testing of 41MM340 and 41MM341 along Little River, Milam County, Texas. Center for Archaeological Research, The University of Texas at San Antonio, Archaeological Survey Report, No. 340. Draft.

Mahoney, R. B., S. A. Tomka, R. P. Mauldin, H. J. Shafer, L. C. Nordt, R. D. Graves, and R. R. Galdeano

2003 Data Recovery Excavations at 41MM340: A Late Archaic Site along Little River in 
Milam County, Texas. Texas Department of Transportation, Environmental Affairs Division, Archeological Studies Program, Report No. 54, Austin, and The University of Texas at San Antonio, Center for Archaeological Research, Archaeological Survey Report No. 340, San Antonio.

Malainey, M. E.

2000a Appendix K: Analysis of the Fatty Acid Compositions of Burned Rock Residues from Site 41ZP364, Zapata County, Texas. In Data Recovery at 41ZP364: An Upland Campsite at Falcon Reservoir, Zapata County, Texas, by J. M. Quigg and C. Cordova, pp. 331-352. Technical Report No. 22317, TRC Mariah Associates Inc., Austin.

2000b Appendix G: Analysis of the Fatty Acid Compositions of Burned rock and Ground Stone Tool Residues from the Lino Site, 41WB437, Webb County, Texas. In The Lino Site: A Stratified Late Archaic Campsite in a Terrace of the San Idelfonzo Creek, Webb County, Southern Texas, by J. M. Quigg, C. Lintz, G. Smith, and S. Wilcox, pp. 407-436. Technical Report No. 23756, TRC Mariah Associates Inc., and Texas Department of Transportation, Environmental Affairs Division, Archeological Studies Program, Report No. 20.

2003 Appendix F: Analysis of the Fatty Acid Compositions of Archeological Residues from 41MM340. In Data Recovery Excavations at 41MM340: A Late Archaic Site along Little River in Milam County, Texas, by R. B. Mahoney, S. A. Tomka, R. P. Mauldin, H. J. Shafer, L. C. Nordt, R. D. Graves, and R. R. Galdeano, pp. 235-244. Texas Department of Transportation, Environmental Affairs Division,
Archeological Studies Program, Report No. 54, Austin, and The University of Texas at San Antonio, Center for Archaeological Research, Archaeological Survey Report No. 340, San Antonio.

Malainey, M. E. and K. L. Maliaza

2002 Appendix G: Analysis of Fatty Acid Composition of Archaeological Residues from 41WB557. In The Boiler Site (41WB557): Utilization of an Upland Setting Over the Last 4200 Years, Webb County, Texas, by J. M. Quigg, S. Pritchard, and G. Smith, pp. G-1 through G-22. TRC Technical Report No. 27277 , TRC Environmental Corporation, Austin, Texas and Texas Department of Transportation, Environmental Affairs Division, Archeological Studies Program, Report No. 45, Austin.

2004 Appendix C: Analysis of Fatty Acid Compositions of Archeological Residues from 41CV595. In Shifting Sands and Geophytes: Geoarcheological Investigations at Paluxy Sites on Fort Hood, Texas, by G. Mehalchick, D. K. Boyd, K. W. Kibler, and C. H. Ringstaff, pp. 259-270. United States Army Fort Hood, Archeological Resource Management Series, Research Report No. 48.

2008 Appendix G: Analysis of the Fatty Acid Compositions of Archaeological Pottery and Rock Residues from the Varga Site (41ED28). In The Varga Site: A Multicomponent, Stratified Campsite in the Canyonlands of Edwards County, Texas Volume II, by J. M. Quigg, J. D. Owens, P. M. Matchen, G. D. Smith, R. A. Ricklis, M. C. Cody, and C. D. Frederick, pp. 951-983. Texas Department of Transportation Environmental Affairs Division, 
Archeological Studies Program Report No. 110 and TRC Environmental Corporation, Austin, Technical Report No. 35319.

2011 Analysis of the Fatty Acid Composition of Archeological Burned Rock Samples from 41CV413, Central Texas. In Cultural Resource Investigations to Offset Mechanical Impacts to the Clear Creek Golf Course Site (41CV413), Fort Hood, Texas, by J. M. Quigg, C. Lintz, G. Smith, D. DeMar and J. D. Owens, pp. 169-183. United States Army Fort Hood, Archeological Resource Management Series, Resource Report No. 60.

Malof, A. F. and M. S. Taylor

2011 A Terminal Archaic Burial from the Central Colorado River Basin, Travis County, Texas. Bulletin of the Texas Archeological Society 82:251-280.

Marie, R.

2006 Invertebrate Faunal Analysis. In Prehistoric Encampments at the Shepherd Site: Testing and Data Recovery at 41WM1010, Williamson County, Texas, by B. Dixon and R. Rogers, pp. 159-170. Prepared for Texas Department of Transportation by PBS\&J, Austin.

Mauldin, R.

2003 Appendix I: ${ }^{18} \mathrm{O}$ and ${ }^{13} \mathrm{C}$ Isotopes. In Data Recovery Excavations at 41MM340, A Late Archaic Site along Little River in Milam County, Texas, by R. B. Mahoney, S. A. Tomka, R. P. Mauldin, H. J. Shafer, L. C. Nordt, R. D. Greaves, and R. R. Galdeano, pp. 275-277. Environmental Affairs Division, Texas Department of Transportation, Archeology Studies Program, Report No. 54, and Center for Archaeological Research, The University of Texas at San Antonio, Report No. 340.
2006 Appendix D: Stable Carbon and Oxygen Isotopic Variability in Snail Shells from $41 \mathrm{MM} 340$ and 41MM341. In Data Recovery Excavations at the J. B. White Site (41MM341), Milam County, Texas, by E. F. Gadus, R. C. Fields, and K. W. Kibler, pp. 227-235. Reports of Investigations, Number 145, Prewitt and Associates, Inc., Cultural Resources Services, Austin and Archeological Studies Program, Report No. 87, Texas Department of Transportation, Environmental Affairs Division, Austin.

2011 Chapter 11: Summary. In Results of Archeological Significance Testing at 41TV410 and 41TV540 and Associated Geomorphological Investigations on a Segment of Onion Creek in Travis County, Texas, by A. Figueroa, R. Mauldin, C. Frederick, S. A. Tomka, and J. L. Thompson, pp. 137-139. Archaeological Report No. 420, Center for Archaeological Research, The University of Texas at San Antonio.

Mauldin, R. P. and D. L. Nickels

2003 Chapter 11: Burned Rock Middens in Texas. In Archaeological Testing to Determine the National Register Eligibility Status of Eighteen Prehistoric Sites on Camp Bowie, Brown County, Texas, by R. P. Mauldin, D. L. Nickels and C. J. Broehm, pp. 217-231. Volume 1. Center for Archaeological Research, The University of Texas at San Antonio, Archaeological Survey Report, No. 334.

Mauldin, R. P. and S. A. Tomka

2003 Chapter 11: Site Structural Issues. In Data Recovery Excavations at 41MM340: A Late Archaic Site along Little River in Milam County, Texas, by R. B. Mahoney, S. A. Tomka, R. P. Mauldin, H. J. Shafer, 
L. C. Nordt, R. D. Graves, and R. R. Galdeano, pp. 119-131. Texas Department of Transportation, Environmental Affairs Division, Archeological Studies Program, Report No. 54, Austin, and The University of Texas at San Antonio, Center for Archaeological Research, Archaeological Survey Report No. 340, San Antonio.

Mauldin, R., A. Figueroa, and S. Tomka

2011 Chapter 9: Attempts at Reconstruction of Paleoenvironmental Conditions and Resource Structure on the Onion Creek Floodplain. In Results of Archeological Significance Testing at 41 TV410 and 41TV540 and Associated Geomorphological Investigations on a Segment of Onion Creek in Travis County, Texas, by A. Figueroa, R. Mauldin, J. C. Fredrick, S. A. Tomka, and J. L. Thompson, pp. 97-108. Texas Department of Transportation, Environmental Affairs Division, Archeological Studies Program, Report No. 134, Austin and Center for Archaeological Research, The University of Texas at San Antonio, Archaeological Report No. 420.

Mauldin, R., J. Thompson, and L. Kemp

2012 Reconstructing the Role of Bison in the Terminal Late Prehistoric (Toyah) Period in Texas. In The Toyah Phase of Central Texas: Late Prehistoric Economic and Social Processes, edited by N. A. Kenmotsu and D. K. Boyd, pp. 90-110. Texas A\&M University Press, College Station.

McClure, W. L.

2003 The Vertebrates of the Rice's Crossing Site (41WM815). In Archeological Investigations at 41WM815, A Backland Prairie Site, Williamson County, Texas, by R. K. Brownlow, pp. 99-111. Studies in
Archeology 36, Texas Archeological Research Laboratory, The University of Texas at Austin and Archeological Studies Program, Report 23, Environmental Affairs Division, Texas Department of Transportation.

McDonald, J.

1982 Appendix II: Nonhuman Bones from the Loeve-Fox Site: A Preliminary Analysis. In Archeological Investigations at the Loeve-Fox Site, Williamson County, Texas, by E. R. Prewitt, pp. 117-120. Reprints in Archeology Number 1, Prewitt and Associates, Inc., Austin.

Mear, C. E.

1998 Terrace Deposits and Late Quaternary Climate, South-Central Edwards Plateau, Texas. Bulletin of the Texas Archeological Society 69:79-88.

Mehalchick, G., K. Killian, K. W. Kibler, and D. K. Boyd

1999 National Register Testing of 19 Prehistoric Archeological Sites at Fort Hood, Texas: The 1995 Season. United States Army Fort Hood, Archeological Resource Management Series, Research Report No. 37.

2002 Geoarcheological Investigations at the Clear Creek Golf Course Site (41CV413), Fort Hood, Texas. United States Army Fort Hood, Archeological Resource Management Series, Research Report No. 46.

Mehalchick, G., K. Kleinbach, D. K. Boyd, and K. W. Kibler

2000 Geoarcheological Investigations and National Register Testing of 52 Prehistoric Archeological Sites on Fort Hood, Texas: The 1997 Season. United States Army Fort 
Hood, Archeological Resource Management Series, Research Report No. 39.

Mehalchick, G., D. K. Boyd, K. W. Kibler, and C. H. Ringstaff

2004 Shifting Sands and Geophytes: Geoarcheological Investigations at Paluxy Sites on Fort Hood, Texas. United States Army Fort Hood, Archeological Resource Management Series, Research Report No. 48.

Meissner, B. A.

2011 Appendix N: Faunal Material from 41TV540. In Results of Archeological Significance Testing at $41 T \mathrm{~T} 410$ and $41 T V 540$ and Associated Geomorphological Investigations on a Segment of Onion Creek in Travis County, Texas, by A. Figueroa, R. Mauldin, C. Frederick, S. A. Tomka, and J. L. Thompson, pp. 357-362. Archaeological Report No. 420, Center for Archaeological Research, The University of Texas at San Antonio.

Meissner, B. A. and R. B. Mahoney

2003 Appendix B: Vertebrate Remains. In Data Recovery Excavations at 41MM340: A Late Archaic Site along Little River in Milam County, Texas, by R. B. Mahoney, S. A. Tomka, R. P. Mauldin, H. J. Shafer, L. C. Nordt, R. D. Greaves and R. R. Galdeano, pp. 197-206. Environmental Affairs Division, Texas Department of Transportation, Archeological Studies Program, Report No. 54 and Center for Archaeological Research, The University of Texas at San Antonio, Archaeological Survey Report No. 340.
Moore, G. L.

1978 Archeological Test Excavations at 41WM21 in Granger Reservoir, Williamson County, Texas. Report Submitted to the U.S. Army Corps of Engineers, Fort Worth District by Texas A\&M Research Foundation Project No. 3446, Report No. 37 (revised), Texas A\&M University.

Nash, M.

2006 Vertebrate Faunal Analysis. In Prehistoric Encampments at the Shepherd Site: Testing and Data Recovery at 41WM1010, Williamson County, Texas, by B. Dixon and R. Rogers, pp. 156-158. Prepared for Texas Department of Transportation, by PBS\&J, Austin.

National Parks Service

1995 How to Apply the National Register Criteria for Evaluation. National Register Bulletin 15. United States Department of the Interior, National Parks Service, National Register Division, Washington, D.C.

Nickels, D. L., C. B. Bousman, J. D. Leach, and D. A. Cargill

2001 Test Excavations at the Culebra Creek Site, 41BX126, Bexar County, Texas. Archaeological Survey Report No. 265, Center for Archaeological Research, The University of Texas at San Antonio and Archeology Studies Program, Report No. 3, Environmental Affairs Division, Texas Department of Transportation, Austin.

Nordt, L. C.

1992 Archaeological Geology of the Fort Hood Military Reservation, Fort Hood, Texas. United States Army Fort Hood, Archeological Resource Management Series, Research Report Number 25. 
1993

Additional

Geoarchaeological

Investigations at the Fort Hood Military

Reservation, Fort Hood, Texas. United

States Army Fort Hood, Archeological

Resource Management Series, Research

Report Number 28.

Nordt, L. C., R. D. Greaves, and S. A. Tomka

2003 Chapter 8: Floodplain Dynamics. In Data Recovery Excavations at 41MM340: A Late Archaic Site Along Little River in Milam County, Texas, by R. B. Mahoney, S. A. Tomka, R. P. Mauldin, H. J. Shafer, L. C. Nordt, R. D. Greaves, and R. R. Galdeano, pp. 75-94, and Appendix A-1, pp. 170-195. Texas Department of Transportation, Environmental Affairs Division, Archeological Studies Program, Report No. 54, Austin, and The University of Texas at San Antonio, Center for Archaeological Research, Archaeological Survey Report No 340, San Antonio.

Nordt, L. C., J. von Fisher, and L. Tieszen

2007 Late Quaternary Temperature Record from Buried Soils of the North American Great Plains. Geological Society of America 35(2):159-162.

Nordt, L. C., T. W. Boutton, C. T. Hallmark, and M. R. Waters

1994 Late Quaternary Vegetation and Climate Changes in Central Texas Based on the Isotopic Composition of Organic Carbon. Quaternary Research 41(1):109-120.

Perry, L., D. Sandweiss, D. R. Piperno, K. Rademaker, M. Malpass, A. Umire, and P. de la Vera

2006 Early Maize Agriculture and Interzonal Interaction in Southern Peru. Nature 440(2):76-78.
Perry, L. and J. M. Quigg

2011 Starch Remains and Stone Boiling in the Texas Panhandle, Part I: The Pipeline, Corral, and Pavilion Sites. Plains Anthropologist 56(218):95-107.

Peter, D. E. and T. R. Hays

1982 Chronological Framework for the San Gabriel Studies. In Archeological Investigations at the San Gabriel Reservoir Districts, Central Texas. Volume 1, compiled and edited by T. R. Hays, pp. 7-1 through 7-8. Archaeology Program, Institute of Applied Sciences, North Texas State University, Denton.

Peter, D. E., D. Prikryl, O. F. McCormick, and M. Demuynck

1982 Site Excavations Reports: Primary Contract. In Archeological Investigations at the San Gabriel Reservoir Districts, Central Texas. Volume 1, compiled and edited by T. R. Hays, pp. 8-1 through 8297. Archaeology Program, Institute of Applied Sciences, North Texas State University, Denton.

Peter, D. E., T. R. Hays, and M. Demuynck

1982 Synthesis: The Archaeology of the San Gabriel Reservoir Districts. In Archeological Investigations at the San Gabriel Reservoir Districts, Central Texas. Volume 2, compiled and edited by T. R. Hays, pp. 16-1 through 16-30. Archaeology Program, Institute of Applied Sciences, North Texas State University, Denton.

Piperno D. R. and I. Holst

1998 The Presence of Starch Grains on Prehistoric Stone Tools from the Humid Neotropics: Indications of Early Tuber Use and Agricultural in Panama. Journal of Archeological Science 25:765-776. 
Piperno, D. R., A. J. Ranere, I. Holst, and P. Hansell

2000 Starch Grains Reveal Early Root Crop Horticulture in the Panamanian Tropical Forest. Nature 407:894-897.

Prewitt, E.

1974 Archeological Investigations at the LoeveFox Site, Williamson County, Texas. Research Report 49. Texas Archeological Survey, The University of Texas at Austin.

1976 Late Archaic Occupations at the LoeveFox Site: The San Marcos and Twin Sisters Phases. In The Texas Archaic: A Symposium, T. R. Hester editor, pp. 67-77. Center for Archaeological Research Special Report 2, The University of Texas at Austin.

1981 Cultural Chronology in Central Texas. Bulletin of the Texas Archeological Society 52:65-90.

1982a Archeological Investigations at the LoeveFox, Loeve, and Tombstone Bluff Sites in the Granger Lake District of Central Texas. In Archaeological Investigations at the San Gabriel Reservoir Districts, Central Texas, Volume 4, edited by T. R. Hays. Institute of Applied Sciences, North Texas State University, Denton.

1982b Archeological Investigations at the LoeveFox Site, Williamson County, Texas. Reprints in Archeology Number 1, Prewitt and Associates, Inc., Austin.

1985 From Circleville to Toyah: Comments on Central Texas Archeology. Bulletin of the Texas Archeological Society 54:201-238.

1995 Distribution of Typed Projectile Points in Texas. Bulletin of the Texas Archeological Society 66:83-173.
2012 Toyah: Reflections on Evolving Perceptions. In The Toyah Phase of Central Texas: Late Prehistoric Economic and Social Processes, edited by N. A. Kenmotsu and D. K. Boyd, pp. 181-203. Texas A\&M University Press, College Station.

Quigg, J. M.

1996 Chapter 11: Overall Summary and Interpretations. In Archeological Testing at Fort Hood: 1994-1995, Volume II, edited by W. N. Trierweiler, pp. 653-705. United States Army Fort Hood, Archeological Resource Management Series, Research Report No. 35.

2011 Use-Wear and Starch Residue Analyses on an In Situ Corner-Tang Knife from the Texas Panhandle: Towards and Understanding of Function. Plains Anthropologist 56(217):37-44.

Quigg, J. M. and C. Cordova

2000 Data Recovery at 41ZP364: An Upland Campsite at Falcon Reservoir, Zapata County, Texas. Technical Report No. 22317, TRC Mariah Associates Inc., Austin.

Quigg, J. M. and C. D. Frederick

2004 Archeological Testing of TxDOT Right-ofWay Through Site 41BL278, Bell County, Texas: Interim Report No. 42568 (Draft). Manuscript submitted to Department of Transportation, Environmental Affairs Division, Archeological Studies Program. On file at TRC Environmental Corporation, Austin.

Quigg, J. M., C. D. Frederick, and D. Lippert

1996 Archeology and Native American Religion at the Leon River Medicine Wheel. United States Army Fort Hood, Archeological 
Resource Management Series, Resource Report No. 33.

Quigg, J. M., C. Lintz, G. Smith, and S. Wilcox 2000 The Lino Site: A Stratified Late Archaic Campsite in a Terrace of the San Idelfonzo Creek, Webb County, Southern Texas. Technical Report No. 23756, TRC Mariah Associates Inc., and Texas Department of Transportation, Environmental Affairs Division, Archeological Studies Program, Report No. 20.

Quigg, J. M., C. D. Frederick, P. M. Matchen, and K. DuBois

2010 Landis Property: Data Recovery at Three Prehistoric Sites (41PT185, 41PT186, and 41PT245) in Potter County, Texas. TRC Technical Report No. 150832. Manuscript on file at TRC Environmental Corporation, Austin and Bureau of Land Management, Santa Fe.

Quigg, J. M., P. M. Matchen, C. D. Frederick and R. A. Ricklis

2011 Root-Be-Gone (41YN452): Data Recovery of Late Archaic Components in Young County, Texas. Texas Department of Transportation, Environmental Affairs Division, Archeological Studies Program Report 135 and TRC Environmental Corporation, Technical Report Nos. 50907 and 171219, Austin.

Quigg, J. M., R. A. Ricklis, P. M. Matchen, and J. T. Abbott

2013 Data Recovery at 41MI96 in Mills County, Texas. Texas Department of Transportation, Environmental Affairs Division, Archeological Studies Program Report 150 and TRC Environmental Corporation, Technical Report No. 192832, Austin.
Quigg, J. M., C. Lintz, G. Smith, D. DeMar and J. D. Owens

2011 Cultural Resource Investigations to Offset Mechanical Impacts to the Clear Creek Golf Course Site (41CV413), Fort Hood, Texas. United States Army Fort Hood, Archeological Resource Management Series, Resource Report No. 60.

Quigg, J. M., P. M. Matchen, C. D. Frederick, B. Gregory and R. A. Ricklis

2014 Assessment of the Barrett Site (41MM382); Milam County (CSJ: 0590-05-027), Texas. Texas Department of Transportation, Environmental Affairs Division, Archeological Studies Program Report No. 163, and TRC Environmental Corporation, Technical Report No. 192919 and 211462, Austin.

Quigg, J. M., P. M. Matchen, C. D. Frederick, R. A. Ricklis, B. Gregory, D. Maki and M. Bateman

2013 Long View (41RB112): Data Recovery of Two Plains Village Components in Roberts County, Texas, Volumes I and II. Texas Department of Transportation, Environmental Affairs Division, Archeological Studies Program Report 147 and TRC Environmental Corporation, Technical Report Nos. 50907 and 171219, Austin.

Ricklis, R. A. and M. B. Collins

1994 Archaic and Late Prehistoric Human Ecology in the Middle Onion Creek Valley, Hays County, Texas-Volume 1, Archeological Components. Studies in Archeology, No. 19, Texas Archeological Research Laboratory, The University of Texas at Austin.

Ricklis, R. A. and M. D. Blum

1997 The Geoarchaeological Record of Holocene Sea Level Change and Human 
Occupation of the Texas Gulf Coast. Geoarchaeology: An International Journal 12(4):287-314.

Ringstaff, C.

2004 Interim Report: Archeological Survey of SH 317 at Leon River, Bell County, Texas. Blanton \& Associates, Inc., Austin, Texas. Letter Report Submitted to Texas Department of Transportation, Environmental Affairs Division, Archeological Studies Program, Austin.

Schoeneberger, P. J., D. A. Wysocki, E. C. Benham, and W. D. Broderson (editors)

2002 Field Book for Describing and Sampling Soils. Version 2.0. Natural Resources Conservation Service, National Soil Survey Center, Lincoln, Nebraska.

Schroeder, E.

2000 Archeological Investigations along the Williamson Drive Wastewater Interceptor and Data Recovery at the Dobb's Hollow Canyon Site (41WM40): A Prehistoric Site, City of Georgetown Williamson County, Texas. Prepared for the City of Georgetown by Paul Price Associates, Inc., Austin.

Schroeder, E. A. and E. R. Oksanen

2002 Data Recovery at the Armstrong Site (41CW54), Caldwell County, Texas. Prepared for Guadalupe-Blanco River Authority by Paul Price Associates, Inc., Austin.

Shafer, H. J.

1963 Test Excavations at the Youngsport Site: A Stratified Terrace Site in Bell County, Texas. Bulletin of the Texas Archeological Society 34:57-81.
Shafer, H. J. and J. E. Corbin

1965 An Appraisal of the Archeological Resources of North Fork, South Fork and Laneport Reservoirs, Williamson County, Texas. Report submitted to the National Park Service by the Texas Archeological Salvage Project, The University of Texas at Austin.

Shafer, H. J. and V. M. Bryant, Jr.

1976 A Preliminary Assessment of the Cultural Resources in the North Fork and Granger Reservoir, Williamson County, Texas. Supplemental Report to An Archeological Survey of Granger and North Fork Reservoir, Preliminary Report. Anthropology Research Laboratory, Texas A\&M University, College Station.

Shafer, H. J., P. Dering, and S. P. Baxter

1975 Richland Creek Watershed, Hill County, Texas: Archeological Surveys of Floodwater Retarding Structure Site Nos. 70, 71A, 77A, 84, 85, 91A, 92A, 92B, 97, 130, and 136. Anthropology Research Laboratory, Texas A\&M University, College Station.

Smith, B. N. and W. V. Brown

1973 The Kranz Syndrome in the Gramineae as Indicated by Carbon Isotope Ratios. American Journal of Botany 60:505-513.

Sorrow, W. M., H. J. Shafer, and R. E. Ross

1967 Excavations at Stillhouse Hollow Reservoir. Papers of the Texas Archeological Salvage Project, No. 11, Austin.

Suhm, D. A. and E. B. Jelks

1962 Handbook of Texas Archeology: Type Descriptions. The Texas Archeological Society, Special Publication Number One 
and The Texas Memorial Museum Bulletin

Number Four, Texas

Texas Department of Transportation (TxDOT)

2010 TxDOT Lithic Protocol Version 2.1, Chipped Stone Analytical Protocol, TxDOT Archeological Studies Program, On File with Environmental Affairs Division, Texas Department of Transportation, Austin.

Thoms, A. V. (Editor)

1993 Archaeological Survey at Fort Hood, Texas, Fiscal Years 1991 and 1992. The Cantonment and Belton Lake Periphery Areas. United States Army Fort Hood, Archaeological Resource Management Series, Research Report No 27.

Tomka, S. A. and R. P. Mauldin

2003 Chapter 9: Paleoenvironmental Reconstruction. In Data Recovery Excavations at 41MM340: A Late Archaic Site along Little River in Milam County, Texas, by R. B. Mahoney, S. A. Tomka, R. P. Mauldin, H. J. Shafer, L. C. Nordt, R. D. Greaves, and R. R. Galdeano, pp. 95-108. Texas Department of Transportation, Environmental Affairs Division, Archeological Studies Program, Report No. 54, Austin, and The University of Texas at San Antonio, Center for Archaeological Research, Archaeological Survey Report No. 340, San Antonio.

Tomka, S. A., H. J. Shafer, and R. P. Mauldin

2003 Lithic Technology at 41MM340. In Data Recovery Excavations at 41MM340: A Late Archaic Site Along Little River in Milam County, Texas, by R. B. Mahoney, S. A. Tomka, R. P. Mauldin, H. J. Shafer, L. C. Nordt, R. D. Greaves, and R. R. Galdeano, pp. 133-154. Texas Department of Transportation, Environmental Affairs
Division, Archeological Studies Program, Report No. 54, Austin, and The University of Texas at San Antonio, Center for Archaeological Research, Archaeological Survey Report No. 340, San Antonio.

Toomey, R. S., III

1993 Late Pleistocene and Holocene Faunal Changes at Hall's Cave, Kerr County, Texas. Unpublished Ph.D. Dissertation, Department of Geology, The University of Texas at Austin.

Toomey, R. S., III, M. D. Blum, and S. Valastro, Jr. 1993 Late Quaternary Climates and Environments of Edwards Plateau, Texas. Global and Planetary Change 7:299-320.

Trierweiler, W. N., (editor)

1994 Archeological Investigations on 571 Prehistoric Archeological Sites at Fort Hood, Bell and Coryell Counties, Texas. United States Army Fort Hood, Archeological Resource Management Series, Research Report No. 31.

1996 Archeological Testing at Fort Hood: 19941995. United States Army Fort Hood, Archeological Resource Management Report Series, Research Report No. 35.

Turner, E. S., T. R. Hester, and R. McReynolds 2011 Stone Artifacts of Texas Indians. Third Edition. Taylor Trade Publishing, London, New York.

Waters, M. R. and L. C. Nordt

1995 Late Quaternary Floodplain History of the Brazos River in East-Central Texas. Quaternary Research 43:311-319. 
Weir, F. A.

1976 The Central Texas Archaic. Unpublished Ph.D. Dissertation, Washington State University, Pullman, Washington.

Yates, B. C.

1982 Chapter 15: Vertebrate Faunal Remains. In Archeological Investigations at the San Gabriel Reservoir District, Central Texas, Volume 2, compiled and edited by T. R. Hays, pp. 15-57 to 15-227. Archaeology Program, Institute of Applied Sciences, North Texas State University, Denton.
Yost, C. and L. S. Cummings

2011 Appendix D: Phytolith Analysis of Feature and Stratigraphic Samples from the Granberg Site, 41BX17, Bexar County, Texas. In Archeological Significance Testing at 41BX17/271, The Granberg Site: A Multicomponent Site along the Salado Creek in Bexar County, Texas, by C. M. Munoz, R. P. Mauldin, J. L. Thompson, and S. C. Caran, pp. 229-238. Texas Department of Transportation, Environmental Affairs Division, Archeological Studies Program, Report No. 140, Austin, and Center for Archaeological Research, The University of Texas at San Antonio, Archaeological Survey Report No. 393, San Antonio. 


\subsection{GLOSSARY OF TECHNICAL TERMS}

A Horizon: The near surface horizon of a natural soil. This is a carbon rich soil horizon characterized by an accumulation of partially decomposed to decomposed organic matter and eluvial loss of constituents such as clays and carbonates, which tend to accumulate in the deeper B horizon. The A horizon represents the upper solum of a soil. Lower case letters with the upper case letter A indicate specific characteristics of that A horizon. An Ab designation indicates the A horizon is buried. An Ap designation indicates a disturbed or anthropically modified soil such as in a plow zone.

\section{Accelerated Mass Spectrometry (AMS):} Laboratory technique that separates and identifies ions based on their mass to charge ratios. This technique is used in radiocarbon dating tiny particles of carbon in organic remains and residues.

Acidic: Containing acid bearing pollutants.

Acryloid B-72: This is a conservation material used to stabilize or glue artifacts together. It is an ethyl methacrylate copolymer.

A.D.: Anno domini in Latin. "In the year of our Lord." For example, A.D. 1000 is 1,000 years after Christ. This is generally used when a B.P. radiocarbon date is calibrated to the tree ring results with a calibration formula.

Agavaceae: A plant family name that refers to fiber, vascular bundle, or the central stem sections that cannot be specifically identified as agave (Agave), yucca (Yucca) or sotol (Dasylirion).

Alfisols: These are a soil order in United States Department of Agriculture soil taxonomy. They form in semiarid to humid areas, typically under a hardwood forest cover, but also under grass savanna. Alfisols are moderately leached soils that have relatively high native fertility.
Allostratigraphic Unit: Depositional unit made up of sediments dating to a similar period of deposition.

Alluvium: Clastic sediments, such as sand, silt, or clay deposited by a flowing stream, either in or beyond the channel during overbank flooding.

Anomaly: Here this term is used with the electrical resistivity survey. It refers to a detectable difference in the resistivity of something below the surface.

Antiquities Code of Texas: This is the state law passed in 1977 to protect and preserve prehistoric and historic cultural resources on lands owned by the State and its political subdivisions (i.e., cities and counties).

Arboreal: This word comes from the Latin arboreus, which means "pertaining to trees." It refers not just to animals that live in trees, but also to anything that resembles the branching form of a tree - like a chandelier or a family geology drawn out. It even can be used to describe, as its Latin root suggests, something pertaining to trees.

Argillins: These are clay coatings on ped- or pore surfaces.

Atlatl: This is a stick, roughly 40 to $60 \mathrm{~cm}$ long, with a handle on one end and a groove or peg at the other end, used for throwing a dart shaft or light spear. This stick adds length to the arm to provide much greater leverage and force to the throw the dart shaft. This is the primary instrument used to propel projectiles before the bow and arrow.

Azelaic Acid: This is a chemical biomarker in lipid residue analysis and a short chain dicarboxylic acid associated with the oxidation of unsaturated fatty acids. Its presence may indicate plant seed processing.

B.C.: The abbreviation for Before Christ, in contrast to After Christ (A.D.). 
Biface or Bifacial: A stone tool that has two distinct sides or faces, both of which have been substantially worked and/or flaked. The biface may take the form of many shapes and sizes and used in diverse activities.

B Horizon: The lower solum of a natural soil. A $\mathrm{B}$ horizon is a mineral soil horizon characterized by an accumulation of constituents such as clays, carbonates or salts, or organic complexes that have been translocated from the A horizon. Common subordinates include lowercase letters such as $t$ as Bt, which indicates accumulation of alluvial clays. The lowercase $\mathrm{k}(\mathrm{Bk})$ indicates accumulation of carbonate. The lower case $\mathrm{w}$ indicates structural or color changes with no significant accumulations of alluvial material.

Biomarker: This is in lipid residue analysis, a molecular associated with a narrow range of substances, or the presence and distribution of certain types of lipids that enables a residue to be identified with a high degree of precision.

Biosilicates: This is a general term to include various tiny hard bodies that contain silicon and are developed in plants such as phytoliths, diatoms, algal statospores, and sponge spicules.

Bioturbation: The churning and mixing of sediments by living organisms, including burrowing rodents, insects, worms, and plant roots.

B.P.: An abbreviation for before present, which in radiocarbon dating is referenced to the standard year A.D. 1950, which is considered "present". Generally B.P. dates have not been tree ring corrected using one of the calibration formulas.

$\boldsymbol{\beta}$-sitosterol and Stigmasterol: These are sterols associated with plant products, which can be detected during lipid analysis. Its presence indicates plant residues.

Burned Rock Dump: A loose cluster of previously heated rocks that exhibits no horizontal patterning to the positions of the rocks and lacks indications of in situ heating/burning, such as a prepared basin, lenses of charcoal or ash, and/or the absence of an oxidation rim. Scattered charcoal or other cultural items may be present between or around the burned rocks.

Burned Rock Midden: An accumulation of a large quantity of discarded burned rocks previously employed in multiple cooking activities. These accumulations were the results of long extensive cooking episodes generally in association with rock ovens.

$\mathbf{C}_{3}$ Plants: A photosynthetic pathway that most trees and flowering bushes use to assimilate carbon dioxide into their systems. The average carbon isotope of $\mathrm{C}_{3}$ plant matter is $-26.5 \%$ with a range from about $-19.0 \%$ o to $-34.0 \%$.

$\mathbf{C}_{4}$ Plants: A photosynthetic pathway used by most arid (xeric) grasses and maize (corn) to assimilate carbon dioxide into their systems. The average carbon isotope of $\mathrm{C}_{4}$ plant matter is $-12.5 \%$ with a range of $-6 \%$ to $-19 \%$. These plants are more resistant to stress due to lack of water, but more susceptible to cold temperatures.

C Horizon: Weathered, but relatively unaltered parent material at the base of a soil profile, generally below the B horizon. This term is roughly synonymous with subsoil, although the latter term is often used to encompass the lower B horizon.

Calcareous: Rocks, minerals, or sediment containing calcium carbonates.

Calcite: A mineral consisting only or mainly of calcium, the principal mineral of limestone and marble.

Calcium: A chemical element with the symbol $\mathrm{Ca}$ and atomic number 20. Calcium is a soft gray alkaline earth metal, and is the fifth most abundant element by mass in the Earth's crust. Calcium is also the fifth most abundant dissolved ion in seawater by 
both molarity and mass, after sodium, chloride, magnesium, and sulfate.

Caliche: A more or less cemented deposit of calcium carbonate in soils of warm temperate, subhumid to arid areas. Caliche, normally white, occurs as soft, thin layers in the soil or as hard, thick beds just beneath the solum, or it is exposed at the surface by erosion.

CAM Plants: A photosynthetic pathway for assimilating carbon dioxide into plants that can change from $\mathrm{C}_{3}$-like to $\mathrm{C}_{4}$-like pathways depending on the diurnal (day or night) cycle. Most succulent plants such as cactus have crassulacean acid metabolism (CAM) pathways. The carbon isotope values of most CAM plants in Texas such as Agave lechuguilla and Opuntia englmannii are similar to the values in $\mathrm{C}_{4}$ plants (see Eickmeier and Bender 1976).

Campesterol: This along with stigmasterol and sitosterol are sterols found in plant tissue, which can be detected during lipid analysis. Its presence indicates that plants were processed.

Carbonates: These are rock or mineral classes that include limestone, calcite, ooids, and bioclasts. White carbonate filaments are often observed in $\mathrm{C}$ horizons of soils.

Chalcedony: A cryptocrystalline variety of quartz or chert. Chalcedony is often a component of other cherts. It may be translucent or semitranslucent, has a wax-like luster, and generally is white, pale blue, gray, blown, or black in color.

Cheno-am: A term used in botanical classification that includes the plant family of Chenopodiaceae (goosefoot) and the genus Amaranthus (pigweed), with tiny charred seeds that are indistinguishable from each other.

Chloridoid: These are short cell phytoliths that are squat and tall saddle-shaped, and occur dominantly in $\mathrm{C}_{4}$ grasses such as grama grass (Bouteloua sp.) and buffalo grasses (Bouchloe sp.). These plants thrive in warm, arid to semiarid regions in which the available soil moisture is very low, thus thrive in the shortgrass prairies during the hot summers.

Cholesterol: This is the major sterol in animal tissue, which can be detected during lipid analysis. Its presence indicates animal residues.

Clast: Any detrital particle of sediment created by the weathering and disintegration of a larger rock mass and transported by water, wind, or ice. Clasts also include discrete particulates created and deposited by volcanic action.

Clay: This is mineral sediment particles less than 0.002 millimeters in diameter. As a soil textural class, soil mineral that is 40 percent or more clay, less than 45 percent sand, and less than 40 percent silt.

Collagen: This is a group of naturally occurring proteins found in animals, especially in the flesh and connective tissues of vertebrates. It is the main abundant protein in mammals, making up about 25 percent to 35 percent of the whole-body protein content. Collagen, in the form of elongated fibrils, is mostly found in fibrous tissues such as tendon, ligament and skin, and is also abundant in cornea, cartilage, bone, blood vessels, the gut, and intervertebral disc. The fibroblast is the most common cell which creates collagen. In muscle tissue, it serves as a major component of the endomysium. Collagen constitutes 1 to 2 percent of muscle tissue, and accounts for 6 percent of the weight of strong, tendinous muscles. It is converted into gelatin by boiling, which is irreversibly hydrolyzed. Collagen is the preferred material used in dating bones.

Colluvium: Soil material, rock fragments, or both, moved by creep, slide, or local wash that is deposited at the base of steep slopes.

Complex: A group of archeological sites that date to the same time period and that contain similar artifacts. This term expresses a relationship of 
common cultural or technological traits in assemblages within widespread geographic area.

Component: An archeological site or portion of a site that is spatially and chronologically discrete from other accumulations of artifacts. These can be horizontally or vertically differentiated.

Conifers: Any member of the order Pinales, woody plants that bear their seeds and pollen on separate, cone-shaped structures. They constitute the largest division of gymnosperms, with more than 550 species. Most are evergreen, upright trees and shrubs. They grow throughout North American and prefer temperate climate zones. Conifers include the pines (Pinus), junipers (Juniperus), spruces (Picea), hemlocks (Tsuga), firs (Abies), larches (Larix), yews (Taxus), cypresses (Cupressus), bald cypresses (Taxodium), Douglas firs (Pseudotsuga), and related groups. The trees are the source of resins, volatile oils, turpentine, tars, and pharmaceuticals.

Context: The association and position of artifacts, materials, and cultural features that are used by archeologists to interpret space, time, and culture.

Cumlic Haplustolls: These soils have a thick mollic epipedon and are on flood plains and alluvial fans where fresh sediments have accumulated slowly enough to have become incorporated in the mollic epipedon. The mollic epipedon may be very thick, or there may be a series of thin buried epipedons. Consequently, there may not be either a cambic horizon or an accumulation of secondary carbonates in the soils. The natural vegetation is mostly grass and widely spaced trees.

Dehydroabietic Acid: This is a biomarker that indicates the presence of conifer products, which may have been introduced from firewood, resins or other conifer products. This acid can be detected in lipid residue analysis.
Dendrite: An oxide of manganese that has crystallized in a branching pattern as in the dark inclusions in moss agate.

Deposition: The accumulation of sediments or gravels laid down by natural agencies such as moving water, or artificial agencies such as dumping.

Diatoms: These are single-celled algae whose cellular contents are enclosed between two valves of silica that are preserved when the organism dies. Often diatoms are preserved in ponds and streams and important to stream ecology. Different taxa have different tolerances for extremes of temperature, salinity, water depth, water clarity, and nutrient concentrations and respond rapidly to changes in the environment. These are useful in reconstructing aquatic paleoenvironments.

Electrical Resistivity (ER): This is a geophysical technique for imaging subsurface structures from electrical resistivity measurements made at the surface, or by electrodes in one or more boreholes. If the electrodes are suspended in the boreholes, deeper sections can be investigated. ERT is essentially a direct current method. Resistivity surveys measure variations in the electrical resistivity of the ground, by applying small electric currents across arrays of ground electrodes. The survey data is processed to produce graphic depth sections of the thickness and resistivity of subsurface electrical layers. The resistivity sections are correlated with ground interfaces such as soil and fill layers or soil-bedrock interfaces, to provide information on subsurface ground conditions.

Eraillure Scar: A small enigmatic flake scar formed on the surface between the bulb of force and the bulbar scar. This scar is generally formed through the use of hard hammer percussion.

Erosional Unconformity: A significant break or gap in the geological or depositional record, indicative of removal of the older unit prior to renewed deposition. 
Ester: This is an organic compound that contains a carbonyl group linked to an alkyl group through an oxygen atom; organic compounds synthesized from a carboxylic acid and an alcohol in the presence of water.

Facies: A definable subdivision of a formal or informal stratigraphic unit.

FAMES: This is an abbreviation for fatty acid methyl esters (FAMES) and is prepared by treating the dry lipid with $3 \mathrm{~mL}$ of $0.5 \mathrm{~N}$ anhydrous hydrochloric acid in methanol $\left(68^{\circ} \mathrm{C} ; 60 \mathrm{~min}\right)$. This is part of the lipid residue analysis.

Fatty Acids: The major constituents of fats and oils (lipids) that occur in nature in plants and animals. They are insolubility in water and relatively abundant compared to other classes of lipids. Fatty acids may be absorbed into porous archeological materials during cooking, including heated rocks and ceramics, or ground into manos, metates, or mortar holes. Some of the major fatty acids are referred to as C12:0, C14:0, C15:0, C16:0, C16:1, C17:0, C18:0, C18:1w9, C18:1w11, C18:2.

Floodplain: A nearly level alluvial plain that borders a stream or river and is subject to periodic flooding.

Fungal mycelia: Mycelium is the vegetative part of a fungus, consisting of a mass of branching, thread-like hyphae. The mass of hyphae is sometimes called shiro, especially within the fairy ring fungi. Fungal colonies composed of mycelium are found in and on soil and many other substrates. A typical single spore germinates into a homokaryotic mycelium, which cannot reproduce sexually. A mycelium may be minute, forming a colony that is too small to see, or it may be extensive:

Gas Chromatography (GC): This highly technical measuring instrument separates and measures the amount of elemental components of a specific sample by the measurement of light passed through gas at regulated temperatures, which allows the detection of fatty acids at the nonogram $\left(\begin{array}{llll}1 & X & 10^{-9} & \text { g}\end{array}\right)$ level. High temperature gas chromatography is used to separate and assess a wide range of lipid components, including fatty acids, long chain alcohols and hydrocarbons, sterols, waxes, terpenoids and triacylglycerols (Evershed et al. 2001). The molecular structure of separated components is elucidated by mass spectrometry (Evershed 2000).

Gas Chromatography-Mass Spectrometry (GCMS): This is an analytical technique that enables the mass analysis and identification of components separated from a sample by gas chromatography; an analytical technique that combines gas chromatography with mass spectrometry.

Gastropod: Commonly known as snails and slugs, are a large taxonomic class within the phylum Mollusca. The class Gastropoda includes snails and slugs of all kinds and all sizes from microscopic to large. There are many thousands of species of sea snails and sea slugs, as well as freshwater snails, freshwater limpets, land snails and land slugs.

Gelatinization: In regards to starch grains this is a morphological change, a distortion of the original shape in the grain caused by the exposure to heat and water when starches are cooked.

Geomorphology: That part of geography concerned with the form and development of the landscape.

Geophytes: These are plants with underground storage organ such as bulbs (i.e., onions, camas, and false garlic), tubers, roots, and rhizomes that are a reserve of carbohydrates, nutrients, and water. These storage organs can be collected, cooked, and eaten as part of the human diet. The study of these geophytes from an archeological site aids in determining the diet of the past occupants. 
Glume: Pertains to small dry membranous chaffy bract found at the base of a grass spikelet or each flower in a sedge or related plant.

Graticule: A device used in the microscope to measure the size of items under magnification.

Hard/High Silica Polish: This is a residue that comes from material that a stone tool came in contact with. This type of polish is generally produced when processing soft plants with high silica content in the plant tissues such as grasses, wood, reeds, bone/antler, and potentially soil. This polish was detected during high-powered microscopic use-wear studies conducted during stone tool analysis.

HCl: Hydrochloric acid, which is the solution of hydrogen chloride $(\mathrm{HCl})$ in water. It is a highly corrosive, strong mineral acid and has major industrial uses.

Heating Element: This is an intentional, intact and localized spot were a human created a fire in an archeological site or component. This is generally evidenced by quantities of wood charcoal, prepared basin, lenses of charcoal or ash, and possibly an oxidation rim often accompanied by intentionally placed rocks, either lining the margins or directly amongst the charcoal. The function of this fire may reflect many different things, such as for heat to warm a person, to cook on, or to heat rocks for other uses. The specific contents may provide clues as to a more specific function or length of use.

High-powered Microscopic Use-wear: This is the examination of the artifacts employing microscopes using 100 to 500 power for the presence of residues and wear related to use.

High Temperature Gas Chromatography (HTGC): This instrument is used to separate and assess a wide range of lipid components, including fatty acids, long chain alcohols and hydrocarbons, sterols, waxes, terpenoids and triacylglycerols (Evershed et al. 2001). This is used with mass spectrometry (MS) to elucidate the molecular structure of separated components. Triacylglycerols, diacylglycerols and sterols can be used to distinguish animal derived residues, which contain cholesterol and significant levels of both triacylglycerols, from plantderived residues, indicated by plant sterols, such as $\beta$-sitosterol, stigmasterol and campesterol, and only traces of triacylglycerols.

Hilum: The scar on a seed, such as a bean, indicating the point of attachment to the funiculus. The nucleus of a starch grain.

Holocene: Geological time period spanning roughly the last 10,000 years before present. The Holocene is roughly equivalent to the Post-glacial period, and often referred to as the "Recent" period in geology. Many investigations consider the Holocene to be an interstadial in the ongoing Pleistocene epoch.

Horizon: A discrete, relatively uniform layer in a soil profile that is typically parallel with the surface and formed as the result of pedogenic process.

Humates: These are substances formed from the biological and chemical breakdown of animal and plant life over time. Humates are made up of compounds and materials that plant life on earth absolutely needs for growth. Humates contain a mixture of organic acids, including humic acids, fulvic acids, macromolecules of amino acids, amino sugars, and peptides. The chemistry of humate is so complex it cannot really be broken down.

Humus: A dark, organic-rich substance consisting of decomposed organic material (animal or vegetable) and is found in the soil.

In Situ: An artifact in its original position that was placed or deposited within the landscape.

Integrity: This refers to the degree of intactness of archeological deposits, components, features, or artifacts. 


\section{Instrumental Neutron Activation Analysis} (INAA): This is a method to determine the elemental composition of a sample (pottery or lithic) through the exposure of samples to a neutron flux from a nuclear reactor without the use of chemical separation. The exposure to neutrons produces several short- and long-lived radioactive isotopes that emit characteristic gamma rays. The energy of the emitted gamma rays provides information to identify the constituent elements, while the intensity of the emitted radiation is proportional to the amount of the element present in the sample. Gamma-ray spectroscopy is performed at different levels after irradiation to measure isotopes with different half-lives. The method is particularly sensitive to a large number of trace elements, including the rare-earth elements, transition metals and others.

Inulin: This is a carbohydrate, a fructan is not digestible via acid hydrolysis, the typical way we digest carbohydrates such as starch.

Isomers: These are compounds with the same molecular formula that differ with respect to how the atoms are joined. Structural isomers differ with respect to the order in which atoms are joined. Stereoisomers differ with respect to the arrangement of atoms in space but the order in which the atoms are attached is identical.

Isotope: An atom of an element. One of two or more forms of a chemical element, differentiated by the number of neutrons contained in the nucleus.

Jasper: A dense, cryptocrystalline, opaque to slightly translucent variety of chert associated with iron oxide impurities that give the rock various colors. Most often red, but can be yellow, green, grayish-blue, brown, or black.

Knapping: A term used to describe the manufacturing of prehistoric chipped stone tools using different techniques, such as pressure and/or percussion methods, to chip/flake a target mass of material to form a useful tool.
Krotovina: A discrete, anomalous area visible in plan or profile in a soil resulting from the infilling of a void (e.g. a burrow or root) with dissimilar sediment. Some investigators prefer to limit the term to animal burrows, preferring the term "root trace" for filling related to decayed roots. Some krotovina are obvious, whereas others are tiny and may only be identified in thin sections.

Legume: A plant that produces a bean or seedpod in various forms consisting of one cell and/or two valves. Common legume plants across Texas include such plants as; mesquite, Texas ebony, various acacia, retama, Dalea sp., mimosa, and rattlebush.

Levee: This is a dike, embankment, floodbank or stopbank. It is generally an elongated naturally occurring ridge or artificially constructed fill or wall, which regulates water levels. It is usually earthen and often parallel to the course of a river in its floodplain or along low-lying coastlines.

Lily: These are herbaceous flowering plants growing from bulbs, all with large prominent flowers. Lilies are in the genus Lilium (members of which are true lilies) and are important in culture and literature in much of the world. The term "lily" has been applied to numerous flowering plants, often with only superficial resemblance to the true lily, including lotus, ranunculus, tulip, iris, anemone, agapanthus, zantedeschia, daylily, and others. Most species are native to the temperate northern hemisphere, though their range extends into the northern subtropics. They are commonly adapted to either woodland habitats, often montane, or sometimes to grassland habitats. A few can survive in marshland and epiphytes are known in tropical southeast Asia. In general they prefer moderately acidic or lime-free soils.

Lipids: These are hydrophobic constituents of living tissues including fatty acids, alcohols, triacylglycerols, sterols, bile acids, and waxes. Lipids are present in tissues of all living organisms in varying proportions. These are insoluble in 
water, relatively easy to extract, and are readily amenable to separation and characterization.

Lithic: Means "of stone". This term is used by archeologists to refer to stone artifacts and the debris that result from the manufacture of stone artifacts.

Lithology: The scientific study and description of rocks, especially at the macroscopic level, in terms of their color, texture, and composition. The gross physical character of a rock or rock formation.

Little Barley: This is a short winter annual bunch grass with a scientific name of Hordeum pusillum in the Poaceae grass family. It has a rapid growth period with a brown seed that develops after spring and is available in the early summer. The seed head consists of flattened spikes. It is considered low in protein and is intolerant to shade. This grass has a low drought tolerance but can grow with only 10 inches of rain per year. It is considered a $\mathrm{C}_{3}$ grass (26.7\% ; Smith and Brown 1973) adapted to fine and medium soil (http://plants.usda.gov 2011).

Loam: This is soil composed of sand, silt, and clay in relatively even concentration (about 40-40-20\% concentration respectively). Loam soils generally contain more nutrients and humus than sandy soils, have better drainage and infiltration of water and air than silty soils, and are easier to till than clay soils.

Macrobotanical: These are remains of plant tissues, such as wood, charcoal, and seeds that one can see with the naked eye. These remains are generally collected in the field and subsequently sent to a specialist-botanist for identification.

Maize (Zea mays): The scientific name for corn, which is a water efficient $\mathrm{C}_{4}$ plant with a shallow root system. The corn cob is also known as a rachis, which have alignments of cupules that are weakly jointed. The term Indian corn presently refers specifically to multi-colored "field corn" (flint corn) cultivars. There are many forms of maize, such as flint corn, popcorn, Dent corn, sweet corn (modern), and others.

Mano: This is a hand-held stone, usually sandstone or quartzite, used to grind plants such as corn, nuts, seeds, or other vegetable matter and sometimes other rocks. It is used in conjunction with a stone metate that plants are placed on to perform the grinding.

Manuport: An object, usually a rock, transported by humans to the place it was recovered, but its macroscopic appearance does not indicate it had been artificially altered to form a specific tool or other kind of artifact.

Mass Spectrometer (MS): This is an instrument used to produce molecular and elemental ions, sort them according to mass and detect abundances to establish the composition, determine molecular structure or measure isotopic ratios of specific elements.

Matrix: Refers to the sediments in which the artifacts at an archeological site are encased, or surrounds.

Melanize: This is too darken by incorporating humus and is used in describing soils.

Mesic Condition: A relatively moist interval of time generally used in the context of climatic conditions.

Metate: A slab of rock in which vegetable matter is placed upon for the purpose of grinding. The natural surface becomes polished and a concave depression forms on the metate surface from continued grinding. The grinding stone used with the metate is called a mano.

Microdebitage: Any stone or lithic material from the manufacture of stone tools that is less than 4.0 $\mathrm{mm}$ in diameter. Microdebitage is often recovered in sieving or floating sediments from archeological deposits. 
Microfauna: Any bone material from the fracturing of bones that is less than $4.0 \mathrm{~mm}$ in diameter. Microfauna is most often recovered in sieving or floating sediments from archeological deposits.

Microfossils: These include a variety of very tiny residues including such things as starch grains, diatoms, phytoliths, pollen, and organic remains that are only detectable and visible under highpowered microscopes.

Midden: This is somewhat of a catch-all term. It generally refers to an accumulation of cultural material such as a zone of burned rocks, and it is often used to refer to a thick accumulation of mixed cultural material in a vertical zone.

Mollisols: These are soils that form in semiarid to semihumid areas under grasslands. They are characterized by a thick, dark surface horizon.

Mussel Shells: This is the outer shell that protects a meaty soft mussel on the interior. The shell is composed of inorganic and organic components. Three major layers combine to make up the shell and include the thin outermost layer that is called the periostracum or epidermis. Underlying the epidermis is the prismatic layer made of calcium carbonate (calcite). The third layer is the innermost and is the nacre or mother-of-pearl layer, which is also composed of calcium carbonate in the form of calcite, aragonite, or both in alternating layers.

National Historic Preservation Act: This is the federal law passed in 1966 that establishes a program for the preservation of significant historic properties throughout the United States.

National Register of Historic Places: This is the federal list of significant historic properties maintained by the National Parks Service.

Organic: Compounds that contain carbon and are associated with living organisms. Materials or objects that contain organic carbon can be radiocarbon dated.
Ostracods: These are a class of the Crustacea (class Ostracoda), sometimes known as seed shrimp. They are small crustaceans, typically around $1 \mathrm{~mm}$ (0.039 in) in size, but varying from 0.2 to $30 \mathrm{~mm}$ (0.0079 to $1.2 \mathrm{in})$. Their tiny bodies are flattened from side to side and protected by a bivalve-like, chitinous or calcareous valve or "shell". The hinge of the two valves is in the upper (dorsal) region of the body.

Overbank Deposits: The deposition of fine silts and clay particles that are left on terrace tops and banks when water in creeks exceeds the capacity of the channel and drops the suspended sediments in the lower energy environment. Overbank depositional processes usually cause minimal movement to large objects on the terrace top.

Oxidation: A chemical process wherein oxygen is added to minerals or other compounds; weathering oxidizes minerals; burning wood and rusting metal are types of oxidation.

Paleochannel: This is a remnant of an inactive river or stream channel that has been either filled or buried by younger sediment. The sediments that the ancient channel is either cut into or buried by can be either unconsolidated, semi-consolidated, consolidated, or lithified. The word paleochannel is formed from the words "palaeo" or 'old', and channel; i.e.; a paleochannel is an old channel. This may be synonymous with paleovalley and paleoriver.

Paleoenvironment: Ancient or past environments.

Paleosol: Generally refers to a soil that developed an A horizon and was subsequently buried by younger deposits.

Palimpsest: Archeologically, refers to the inability to distinguish and separate material remains from repeated occupations by a succession of cultural events of different ages due to their deposition and intermixing over time on relatively stable surfaces. 
Some palimpsest assemblages are buried following a long period of exposure.

Panicoid: A group of short cell grass phytoliths that result from tall $\mathrm{C}_{4}$ grasses and are taxonomically diagnostic of switch grass (Panicum), big and little bluestem (Andropogon sp.), and Indian grass (Sorghostrum). These grasses do well in warm, moist environments and are a major species in the tallgrass prairies. These include basic morphotypes that include simple lobate, panicoid-type, cross, and other lobate forms.

Parenchyma: This is the bulk of a substance. In animals, a parenchyma comprises the functional parts of an organ and in plants parenchyma is the ground tissue of nonwoody structures.

Ped: A unit of soil structure such as an aggregate, crumb, prism, block, or granule, formed by natural processes.

Pedogenesis: The dynamic process of soil formation and development, which typically leads to the formation of a darkened, organic-rich A horizon at or near the surface, and the downward movement of fine clays into, and/or the formation of carbonate nodules within, the underlying B horizons.

Pedoturbation: A general term used to describe soil that has been mixed.

Pee Dee Belmnite: A limestone found in Southern Carolina used as the international standard for various compositional (carbon and oxygen isotopic and elemental) analyses.

pH: The standard numerical designation of acidity and alkalinity commonly used in reference to soils. A neutral $\mathrm{pH}$ value (as in distilled water) is 7.0. Lower and higher values are acidic and base, respectively.

Phase: A group of related archeological traits (e.g., artifacts, features) that contain similar cultural material and date to one relatively narrow time period within a limited region.

Phytoliths: These are microscopic, inorganic siliceous bodies/residues that form in plant cells and frequent mirror parent cell shape. They are produced in multiple shapes and sizes. After the plant dies, the silica bodies become part of the mineral component of soils. A single plant may produce many different phytolith forms. A single phytolith form may be produced by several plant taxa. Phytoliths may survive for thousands of years and provide evidence of past plants.

Platform: The specific location where a flake was struck to remove it from the core.

Pleistocene: The first epoch, which along with the Holocene Epoch constitutes the Quaternary period, spanning the time between roughly 2.0 or 1.65 million years ago and 10,000 years ago. Characterized by repeated continental glaciations, the Pleistocene witnessed the evolution of modern humans.

Poaceae: This, also called Gramineae or true grasses, are a large and nearly ubiquitous family of monocotyledonous flowering plants. There are more than 10,000 domesticated and wild species, the Poaceae represent the fifth-largest plant family. The three Poaceae subfamilies include Pooids, Panicoids, and Chloridoids.

Polyunsaturated Fatty Acids: Pertaining to long chain carbon compounds (e.g., C18:2) like fats with multiple double bonds. These fats are very unstable and degrade very rapidly over time. These are detected in archeological samples during lipid residue analysis.

Pooids: A group of phytoliths from mostly coolmoist $\mathrm{C}_{3}$ grasses such as fescue (Festuca sp.), Canadian wildrye (Elymus sp.), Foxtail barley (Hordeum sp.), and western wheatgrass (Agropyron sp.). These grasses often grow in shaded areas and in riparian environments. Basic morphotypes for 
Pooids include keeled, conical, pryramidal, and crenate forms.

Pressure Flaking: A method used to shape stone tools through the application of force applied by pushing rather than striking. This is generally part of the final stages of finishing a stone tool.

Profile: A cross-sectional exposure of the sequence of horizons that make up a soil or a sequence of sedimentary deposits. It can be the result of either natural erosional down cutting or an artificial excavation.

Provenience: The specific vertical and horizontal location of where an object is found.

Quaternary: The second period, which along with the Tertiary Period, make up the Cenozoic Era, encompassing the Pleistocene and Holocene epochs; roughly the last 2.0 or 1.65 million years.

Rabdotus sp.: These are gastropods of the family of Bulimulidae. These are primarily open grassland to sparsely wooded area species (Fullington and Pratt 1974).

Radiocarbon Dating: The process of determining the age of a sample based on the amount of radioactive carbon (carbon 14) retained in that object.

Radoximorphic Features: These are features associated with wetness, which result from alternating periods of reduction and oxidation of iron $(\mathrm{Fe})$ and manganese $(\mathrm{Mn})$ compounds in soils.

Raphides: Needle-shaped crystals in a plant cell, typically of calcium oxalate. These are small (30 to $500 \mu \mathrm{m})$ crystals, generally with points on the ends and of similar lengths. They are often found in plants of the Agavaceae family such as sotol, yucca, agave, and lechuguilla. They are not diagnostic of any particular plant. Bohrer (1987) and Kwiatkowski (1992) believe that only agave contain these crystals. In contrast, Dering (2003b) believes raphides occur in a variety of Agavaceae including sotol, yucca, agave, and beargrass.

Rel\%: This abbreviation is used in the lipid analysis and appears in the individual sample analysis table. The abbreviation represents the "relative percentage" of the fatty acid with respect to the total fatty acids in the sample.

Retouch: A technique of chipped stone artifact manufacture in which pressure flaking is used to detach small flakes to sharpen or otherwise modify the edge of a stone tool.

Saturated Fatty Acids: Each carbon in the chain is connected to its neighboring carbon by a single bond, which makes them relatively stable. The most abundant saturated fatty acids have chain-lengths of either, 14, 16, or 18 carbons. Mammal fats consist primarily of saturated fatty acids and are solid at room temperature. These are detected in archeological samples during lipid residue analysis.

Section 106 Process: This is the federal process to assess whether or not a project will have effects on historic properties. The basic steps include establishing the parameters of the development/undertaking, identifying the historic properties within the undertaking, if historic properties are affected then assess the effects, and resolve the adverse effects. The assessing is generally done in terms of evaluating/testing, whereas the resolving the adverse effects is through avoidance or data recovery/mitigation.

Silt: A particle size that has a range from $0.06 \mathrm{~mm}$ to $0.002 \mathrm{~mm}$. These are smaller than sand grains and larger than clay particles.

Siliceous: Pertaining to silica, as in silicon dioxide, the most common chemical constituent on earth, and the dominant component of chert and quartz.

Site Structure: The spatial distribution of features, artifacts, and debris across a single occupation (or within a component) of an archeological site that is used to reconstruct manufacturing, maintenance, 
processing, production, and disposal activities at specific loci, and the spatial ways prehistoric groups organized their space at a site.

Slackwater: Water that is essentially still/unstressed or with no movement either way.

Soft Polish: This is a residue left on stone tools and comes from the material that a stone tool used on. This type of polish is generally produced when processing animal skins, meat, muscle or soft plants. This polish was detected during highpowered microscopic use-wear studies conducted during stone tools analysis.

Soil Horizon: A layer of soil, approximately parallel to the surface, having distinct characteristics produced by soil forming processes. In the identification of soil horizons an upper case letter (i.e., A, B, C, R, and O) represents the major horizons with $\mathrm{A}$ at the top. Lower case letters that follow the upper case letters represent subdivisions of the major horizons.

Sponge Spicules: Spicules are structural elements found in most sponges. They provide structural support and deter predators. Large spicules that are visible to the naked eye are referred to as megascleres, while smaller, microscopic ones are termed microscleres. Megascleres are large spicules measuring from $60-2000 \mu \mathrm{m}$. Spicules are found in a range of symmetry types. Sponges can be calcareous, siliceous, or composed of organic substance called spongin. The composition, size, and shape of spicules is one of the largest determining factors in sponge taxonomy.

Sponge Gemmoscleres: Gemmoscleres are important for sponge species survival. They are part of the sponge's reproductive mechanism. Gemmules--which are spheres with the axially aligned gemmoscleres forming the outer "wall" of the gemmule as a layer or shell protecting the sponge larvae inside--are released from adult sponges to establish new sponge colonies.
Stable Isotope: An isotope is not subjected to radioactive decay, it is stable. This contrasts with radioactive isotopes such as carbon $\left(\mathrm{C}^{13}\right)$, oxygen $\mathrm{O}^{18}$, or nitrogen $\left(\mathrm{N}^{15}\right)$ isotopes that decay over time.

Starch Granules: Starch is produced by all green plants for energy storage and is a major food source for humans. Starch granules differ morphologically between plants and their distinctive characteristics can allow identification to the level of genus or species in archeological samples. Pure starch is a white, tasteless and odorless powder that is insoluble in cold water or alcohol. Starch can be used as a thickening, stiffening or gluing agent when dissolved in warm water, giving, for example, wheat paste. In photosynthesis, plants use light energy to produce glucose from carbon dioxide. The glucose is stored mainly in the form of starch granules. Toward the end of the growing season, starch accumulates in twigs of trees near the buds. Fruit, seeds, rhizomes, and tubers store starch to prepare for the next growing season. The successful identification of starch granules relies upon the viewing of each granule in three dimensions to gain an accurate assessment of its morphological features.

State Antiquities Landmark (SAL): This is any archeological site on county or municipal property, according to the Antiquities Code of Texas (Texas National Resources Code of 1977, Title 9, Chapter 191 as amended). State Antiquities Landmarks with high research potential may be designated by the Texas Historical Commission.

Sterols: These are structural lipids that are present in cell membranes and contain the perhydrocyclopentanophenanthrene ring system. Sterols are a special king of alcohol that serve as precursors to a wide variety of products known as steroids. The cholesterol is the major sterol in animal tissue. Campesterol, stigmasterol and sitosterol are sterols found in plant tissue.

Stigmasterol: This and sitosterol are sterols found in plant tissue and can be detected in lipid analysis. 
Stipa: Stipa is a genus of around 300 large perennial hermaphroditic grasses (Poaceae) collectively known as feather grass, needle grass, and spear grass. They are placed in the subfamily Pooideae and the tribe Stipeae.

Stratigraphy: The study of layering in rocks and/or sediments, and how the layers correlate to each other.

Striae: These are tiny, thin, narrow grooves, channels, or lines, often called striations. Here, they were observed during high-powered microscopic use-wear analysis on stone tools and are an indication of the direction of the movement of the tools during their use. They were observed under high magnification in the residues left on the tools.

Terrace: In geologic terms this is an old alluvial plain that is generally flat and borders a river, stream, lake, or sea. Terraces are recognized by different elevations and generally labeled $\mathrm{T}_{0}, \mathrm{~T}_{1}$ and $\mathrm{T}_{2}$ from lowest to highest.

Thalweg: This is the line of lowest elevation within a valley or watercourse.

TMS: This is the abbreviation for trimethylsilyl and is a functional group in organic chemistry. This group consists of three methyl groups bonded to a silicon atom $\left[-\mathrm{Si}\left(\mathrm{CH}_{3}\right)_{3}\right]$, which is in turn bonded to the rest of a molecule. This structural group is characterized by chemical inertness and a large molecular volume which makes them useful in several applications.

Tracheids: These are elongated cells in the xylem of vascular plants that serve in the transport of water and mineral salts. Tracheids are one of two types of tracheary elements, vessel elements being the other. Tracheids, unlike vessel elements, do not have perforations. The presence of tracheary elements is the defining characteristic of vascular plants to differentiate them from nonvascular plants.
Triacylglycerol (TAGs): This is a glycerol molecule to which three fatty acids are bounded through ester linkages. The presence and abundance of TAGs varies with the material of origin. These can be detected in lipid analysis and is useful for distinguishing plant residues, animal residue, and plant/animal combinations.

Triglycerides: A triglyceride (TG) is an ester derived from glycerol and three fatty acids. As a blood lipid, it helps enable the bidirectional transference of adipose fat and blood glucose from the liver. There are many triglycerides: depending on the oil source, some are highly unsaturated, some less so. Unsaturated fats have a lower melting point and are more likely to be liquid. Saturated fats have a higher melting point and are more likely to be solid at room temperature.

Triticeae: This is a tribe within the Pooideae subfamily of grasses that includes genera with many domesticated species. Major crop genera are found in this tribe and includes wheat, barley, and rye; crops in other genera include some for human consumption and others used for animal feed or rangeland protection. Seed storage proteins in Triticeae are implicated in various food allergies and intolerances.

Turbation: Disturbance to natural matrix deposits generally caused by biological agents (burrowing rodents, insects, worms, and plant roots) and natural (soil creep, desiccation crack displacement, frost heaving, landslides, etc.) processes. These actions tend to move cultural objects in the ground.

Tuber: This is the thick, fleshy underground stem of a plant. This stem serves as the primary storage organ of nutrients that stores food over winter and produces new growth in spring.

Type: This is a group of similar items (ceramic sherds or projectile points) all of which are more or less the same. 
Ultraviolet Light: The wave length of light above that is usually detected by the human eye and that fluorescence various kinds of minerals and emits distinctive colors. Here, a multiband light source (UV light 254/366 nm Model UVGI-58) was used to investigate the visual fluorescence of culturally modified stones to help in identifying their source and detect new/recent scars from old flake scars.

Unconformity: Stratigraphic term for a boundary or break created by a depositional hiatus. This boundary separates younger strata from older strata. An unconformity is usually caused by erosion and therefore deposits are missing.

Unsaturated Fatty Acids: These types of fatty acids contain at least one carbon-carbon double bond or point of unsaturation. That point of unsaturation is susceptible to additional reactions. Unsaturated fatty acids are the primary constituents of plant and fish oils and tend to be in liquid-state at room temperature. Their chain-lengths vary with a minimum of 12 carbons but most common ones contain at least 18 carbons.

Use-wear: The high-powered microscopic evidence on a stone tool created from sustained use. The wear may appear as striations, tiny nicks, abrasive particles, polish, rounding, soluble inorganic residues, etc. The accompanying usewear study used magnification between 100x and $500 \mathrm{x}$ to observe wear and edge-modification on artifacts. This detailed analysis contributes to our understanding of tool function and potentially substances tools were used on.

Vertisols: These are deep, mature clay-rich soils that shrink and swell as their moisture content changes. This natural process can cause artifacts to be displaced.

Vertic Properties: These are soils that have 30 percent or more clay throughout a thickness of 15 $\mathrm{cm}$ or more and one or both of the following: slickensides or wedge-shaped aggregates cracks that open and close periodically and are $1 \mathrm{~cm}$ or more wide.

Waxes: These are long chain fatty acids and long chain alcohols that form protective coatings on skin, fur, feathers, leaves and fruit, also resist decay. These can be detected in lipid analysis.

Wildrye (Elymus sp.): A common grass throughout the Plains of the United States, from Mexico to Canada and all across Texas. The seeds of this genus are large and possess large distinctive starch grains. This is a cool season $\mathrm{C}_{3}$ grass (ca. $27.6 \%$, $-27.1 \%$, Bender 1971) that produces short cell phytoliths. The seeds are available during the summer and fall.

Xeric Condition: A dry or relatively arid condition often in reference to climatic conditions.

Xerophic Plants: These are plants that have adapted to survive in an environment that lacks water, such as a desert. These include cactus, sotol, yucca, agave, lechuguilla, and others.

Xylem: This is one of the two types of transport tissue in vascular plants (phloem is the other). The word xylem is derived from the Greek word $\xi u ́ \lambda o v$ (xylon), meaning "wood"; the best known xylem tissue is wood, though it is found throughout the plant. Its basic function is to transport water, but it also transports some nutrients. 


\title{
APPENDIX A: RADIOCARBON ASSAY RESULTS
}

\author{
Prepared for:

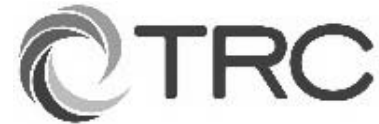 \\ TRC Environmental Corporation \\ 505 East Huntland Drive, Suite 250 \\ Austin, Texas 78752
}

Prepared by:

Darden Hood

Beta Analytic Inc.

4985 S.W. 74 Court

Miami, Florida 33155 
This page intentionally left blank. 


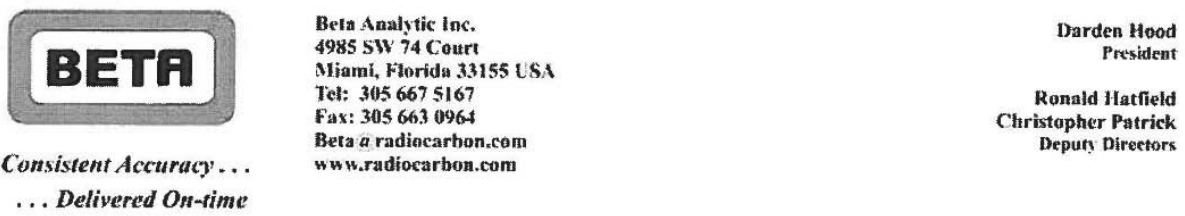

January 31,2014

Dr. James Abbott

Texas Department of Transportation

Cultural Resource Management

Environmental Affairs Division

125 East 11 th Street

Austin, TX 78701

USA

RE: Radiocarbon Dating Results For Samples MS69-512-4-b, MS69-511-7-1h, MS69-37-7-3a, MS69-417, MS69-505-7-1h, MS69-505-4-1d, BL278-12-7, BL278-507-7-5, BL278-10-2-1, BL278-31-6, BL27815-6, BL278-506-6, BL278-506-7-1

Dear Dr. Abbott:

Enclosed are the radiocarbon dating results for 13 samples recently sent to us. They each provided plenty of carbon for accurate measurements and all the analyses proceeded normally. As usual, the method of analysis is listed on the report with the results and calibration data is provided where applicable.

The web directory containing the table of results and PDF download also contains pictures including, most importantly the portion actually analyzed. These can be saved by opening them and right clicking. Also a cvs spreadsheet download option is available and a quality assurance report is posted for each set of results. This report contains expected versus measured values for 3-5 working standards analyzed simultaneously with your samples.

All results reported are accredited to ISO-17025 standards and all analyses were performed entirely here in our laboratories. Since Beta is not a teaching laboratory, only graduates trained in accordance with the strict protocols of the ISO-17025 program participated in the analyses. When interpreting the results, please consider any communications you may have had with us regarding the samples.

Our invoice has been sent separately. Thank you for your prior efforts in arranging payment. As always, if you have any questions or would like to discuss the results, don't hesitate to contact me.

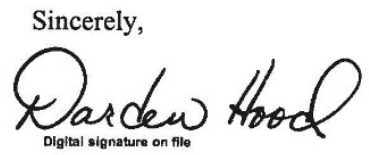

Page 1 of 18 


\section{BETR \\ BETA ANALY TIC INC.}

DR. M.A. TAMERS and MR. D.G. HOOD
4985 S.W. 74 COURT

MIAMI, FLORIDA, USA 33155

PH: 305-667-5167 FAX:305-663-0964

beta@radiocarbon.com

\section{REPORT OF RADIOCARBON DATING ANALYSES}

\section{Sample Data}

Measured
Radiocarbon Age

$13 C / 12 C$
Ratio

Ratio
Conventional

Radiocarbon Age $\left(^{*}\right)$

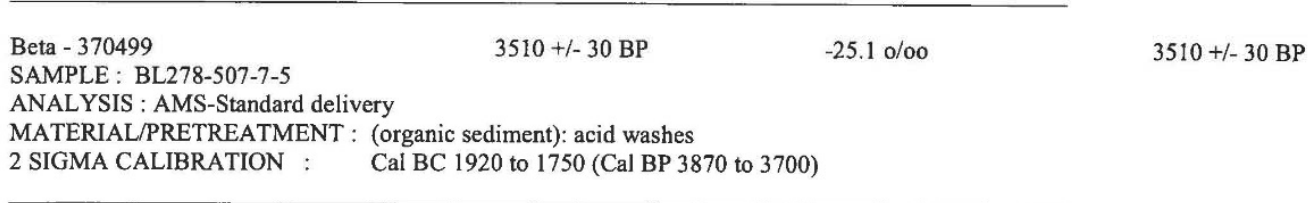

Dates are reported as RCYBP (radiocarbon years before present, "present" = AD 1950). By international convention, the modern reference standard was $95 \%$ the $14 \mathrm{C}$ activity of the National institute of Standards and Technology (NIST) Oxalic Acid (SRM 4990C) and calculated using the Libby $14 \mathrm{C}$ half-life (5568 years). Quoted errors represent 1 relative standard deviation statistics $\langle 68 \%$ probability counting errors based on the combined measurements of the sample background, and modern reference standards. Measured $13 \mathrm{C} / 12 \mathrm{C}$ ratios (delta $13 \mathrm{C}$ ) were calculated relative to the PDB-1 standard.
The Conventional Radiocarbon Age represents the Measured Radiocarbon Age corrected for isotopic fractionation, calculated using the delta $13 \mathrm{C}$. On rare occasion where the Conventional Radiocarbon Age was calculated using an assumed delta $13 \mathrm{C}$ the ratio and the Conventional Radiocarbon Age will be followed by " $\approx n$ " The Conventional Radiocarbon Age is not calendar calibrated When available, the Calendar Calibrated result is calculated from the Conventional Radiocarbon Age and is listed as the "Two Sigma Calibrated Result" for each sample. is listed as the 


\section{BETR}

BETAANALYTIC INC.

DR. M.A. TAMERS and MR. D.G. HOOD
4985 S.W. 74 COURT

MIAMI, FLORIDA, USA 33155

PH: 305-667-5167 FAX:305-663-0964

beta@radiocarbon.com

\section{REPORT OF RADIOCARBON DATING ANALYSES}

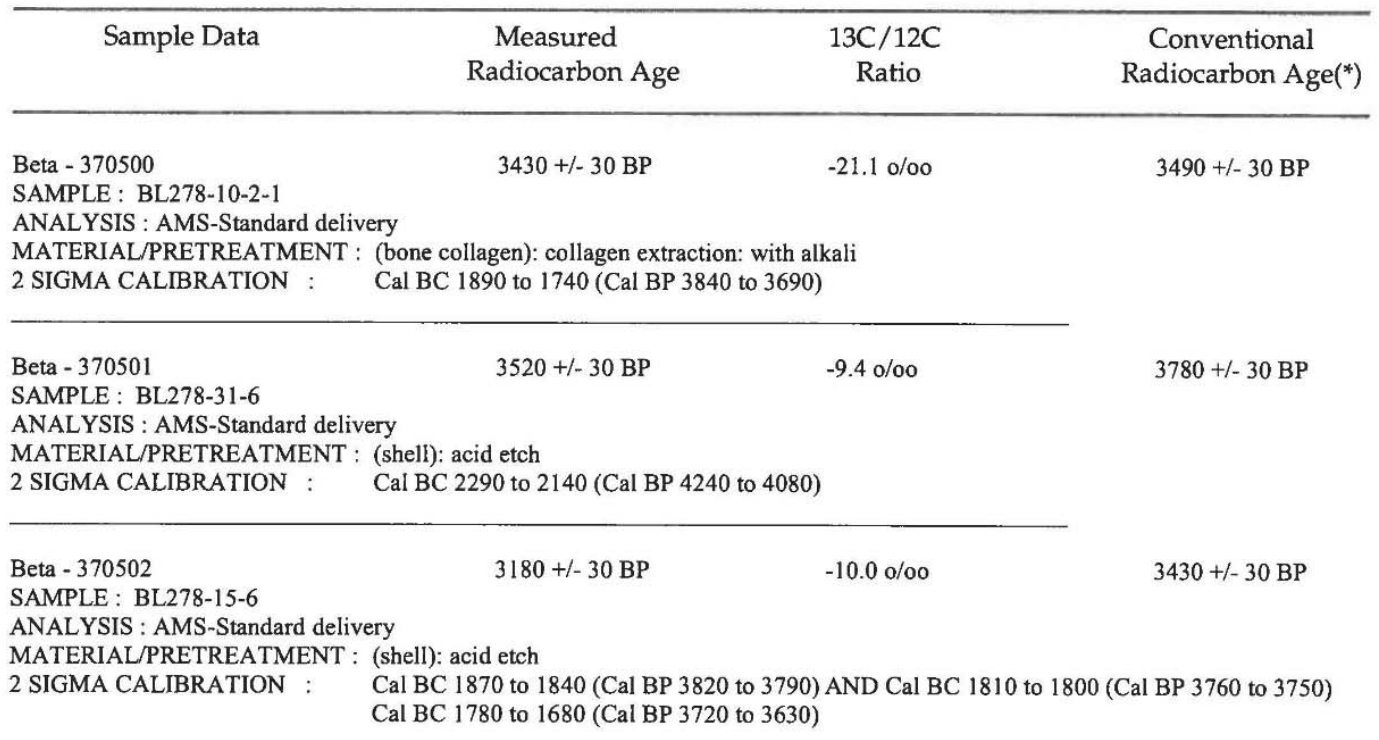

$\begin{array}{llll}\text { Beta }-370503 & 3170+/-30 \mathrm{BP} & -4.4 \mathrm{o} / \mathrm{oo} & 3510+/-30 \mathrm{BP}\end{array}$

SAMPLE : BL278-506-6

$3170+/-30 \mathrm{BP}$

ANALYSIS : AMS-Standard delivery

MATERIAL/PRETREATMENT : (shell): acid etch

2 SIGMA CALIBRATION : $\quad$ Cal BC 1920 to 1750 (Cal BP 3870 to 3700)

Dates are reported as RCYBP (radiocarbon years before present, "present" = AD 1950). By international convention, the modern reference standard was $95 \%$ the $14 \mathrm{C}$ activity of the National Institute of Standards and Technology (NIST) Oxalic Acid (SRM 4990C) and calculated using the Libby $14 \mathrm{C}$ half-life (5568 years). Quoted errors represent 1 relative standard deviation statistics (68\% probability) counting errors based on the combined measurements of the sample background, and modern reference standards. Measured $13 \mathrm{C} / 12 \mathrm{C}$ ratios (delta 13C) were calculated relative to the PDB-1 standard.
The Conventional Radiocarbon Age represents the Measured Radiocarbon Age corrected for isotopic fractionation, calculated using the delta $13 \mathrm{C}$. On rare occasion where the Conventional Radiocarbon Age was caiculated using an assumed delta $13 \mathrm{C}$ the ratio and the Conventional Radiocarbon Age will be followed by "*s" The Conventional Radiocarbon Age is not calendar calibrated. When available, the Calendar Calibrated result is calculated from the Conventional Radiocarbon Age and is listed as the "Two Sigma Calibrated Result" for each sample.

Page 4 of 18 


\section{BETR \\ BETA ANALYTIC INC}

DR. M.A. TAMERS and MR. D.G. HOOD
4985 S.W. 74 COURT

MIAMI, FLORIDA, USA 33155

PH: 305-667-5167 FAX:305-663-0964

beta@radiocarbon.com

\section{REPORT OF RADIOCARBON DATING ANALYSES}

\begin{tabular}{lccc}
\hline \multicolumn{1}{c}{ Sample Data } & $\begin{array}{c}\text { Measured } \\
\text { Radiocarbon Age }\end{array}$ & $\begin{array}{c}13 \mathrm{C} / 12 \mathrm{C} \\
\text { Ratio }\end{array}$ & $\begin{array}{c}\text { Conventional } \\
\text { Radiocarbon Age( }\end{array}$ \\
\hline $\begin{array}{l}\text { Beta - 370504 } \\
\text { SAMPLE : BL278-506-7-1 }\end{array}$ & $3410+/-30 \mathrm{BP}$ & $-23.6 \mathrm{o} / \mathrm{oo}$ \\
$\begin{array}{l}\text { ANALYSIS : AMS-Standard delivery } \\
\text { MATERIAL/PRETREATMENT : (charred material): acid/alkali/acid } \\
\text { 2 SIGMA CALIBRATION : }\end{array}$ & $\begin{array}{l}\text { Cal BC } 1870 \text { to } 1840 \text { (Cal BP 3820 to 3790) AND Cal BC } 1810 \text { to } 1800 \text { (Cal BP } 3760 \text { to 3750) } \\
\text { Cal BC 1780 to } 1680 \text { (Cal BP } 3720 \text { to 3630) }\end{array}$
\end{tabular}

Dates are reported as RCYBP (radiocarbon years before present present $=A D$ 1950). By international convention, the modern reference standard was $95 \%$ the $14 \mathrm{C}$ activity of the National institute of Standards and Technology (NIST) Oxalic Acid (SRM 4990C) and calculated using the Libby $14 \mathrm{C}$ half-life (5568 years). Quoted errors represent 1 relative standard deviation statistics $(68 \%$ probability) counting errors based on the combined measurements of the sample background, and modern reference standards. Measured $13 \mathrm{C} / 12 \mathrm{C}$ ratios (delta 13C) were calculated relative to the PDB-1 standard.
The Conventional Radiocarbon Age represents the Measured Radiocarbon Age corrected for isotopic fractionation, calculated using the delta $13 \mathrm{C}$. On rare occasion where the Conventional Radiocarbon Age was calculated using an assumed delta $13 \mathrm{C}$ the ratio and the Conventional Radiocarbon Age will be followed by "**" The Conventional Radiocarbon Age is not calendar calibrated. When available, the Calendar Calibrated result is calculated from the Conventional Radiocarbon Age and is listed as the 'Two Sigma Calibrated Result' for each sample.

Page 5 of 18 


\section{CALIBRATION OF RADIOCARBON AGE TO CALENDAR YEARS}

(Variables: C $13 / \mathrm{C} 12=-25: \mathrm{lab}$. mult $=1$ )

Laboratory number: Beta-370498

Conventional radiocarbon age: $2850 \pm 30$ BP

2 Sigma calibrated result: Cal BC 1120 to 920 (Cal BP 3070 to 2870)

( $95 \%$ probability)

Intercept data

Intercept of radiocarbon age with calibration curve:

Cal BC 1010 (Cal BP 2960)

1 Sigma calibrated result: (68\% probability)

Cal BC 1050 to 980 (Cal BP 3000 to 2920)

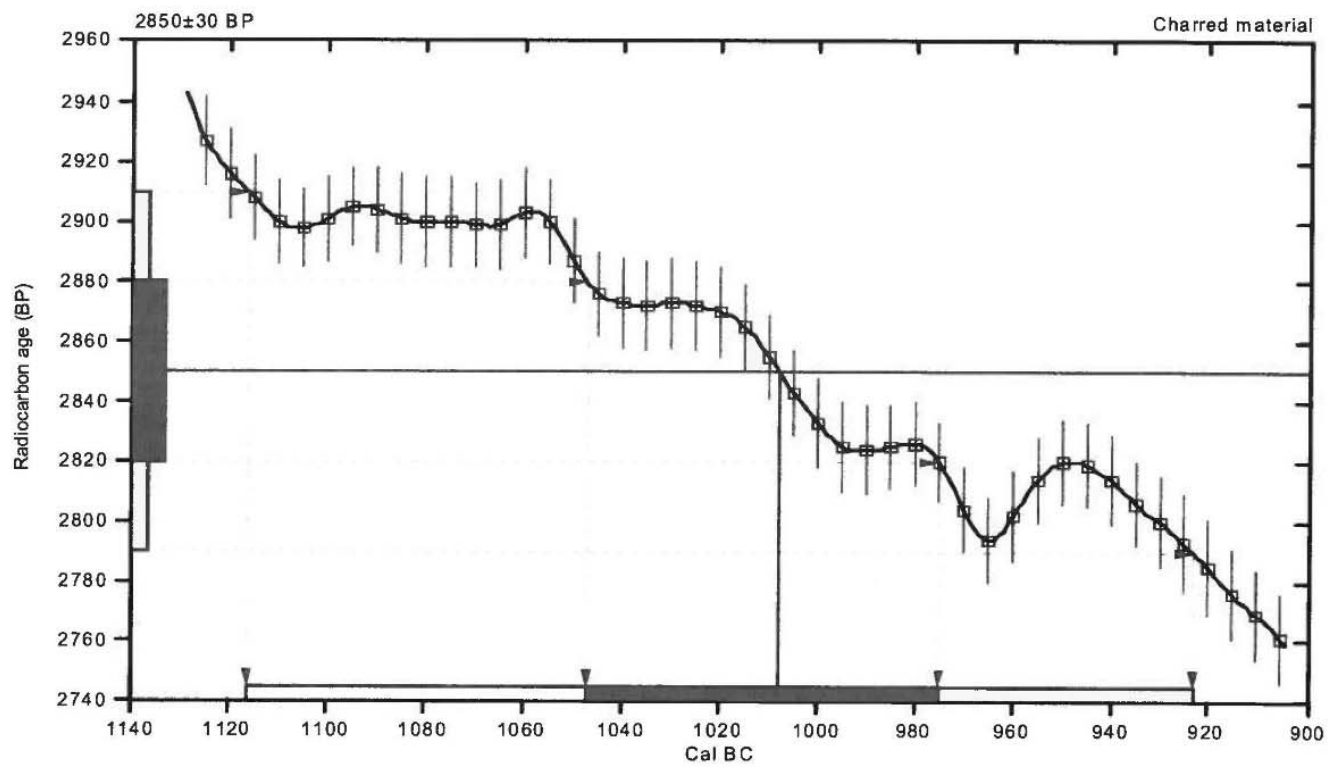

References:

Database used

INTCALO9

References to INTCALO9 database

Heaton, et.al.,2009, Radiocarbon 51(4):1151-1164, Reimer,et.al, 2009, Radiocarbon 51(4):1111-1150, Stuiver,et.al,1993, Radiocarbon 35(I):137-189, Oeschger,et.al.,1975, Tellus 27:168-192

Mathematics used for calibration scenario

A Simplified Approach to Calibrating C14 Dates

Talma, A. S., Vogel, J. C., 1993, Radiocarbon 35(2):317-322

Beta Analytic Radiocarbon Dating Laboratory

4985 S.W.74th Court, Miami, Florida 33155·Tel:(305)667-5167·Fax: (305)663-0964·E-Mail: beta@ radiucarbon.com

Page 12 of 18 


\section{CALIBRATION OF RADIOCARBON AGE TO CALENDAR YEARS}

(Variables: C $13 / \mathrm{C} 12=-25 \cdot 1:$ lab. mult $=1$ )

Laboratory number: Beta-370499

Conventional radiocarbon age: $3510 \pm 30$ B P

2 Sigma calibrated result: Cal BC 1920 to 1750 (Cal BP 3870 to 3700 )

( $95 \%$ probability)

Intercept data

Intercepts of radiocarbon age

with calibration curve: CaI BC 1880 (Cal BP 3830) and

Cal BC 1840 (Cal BP 3790) and

Cal BC 1830 (Cal BP 3780)

1 Sigma calibrated results: CaI BC 1890 to 1860 (C al BP 3840 to 3810 ) and

(68\% probability) Cal BC 1850 to 1770 (Cal BP 3800 to 3720 )

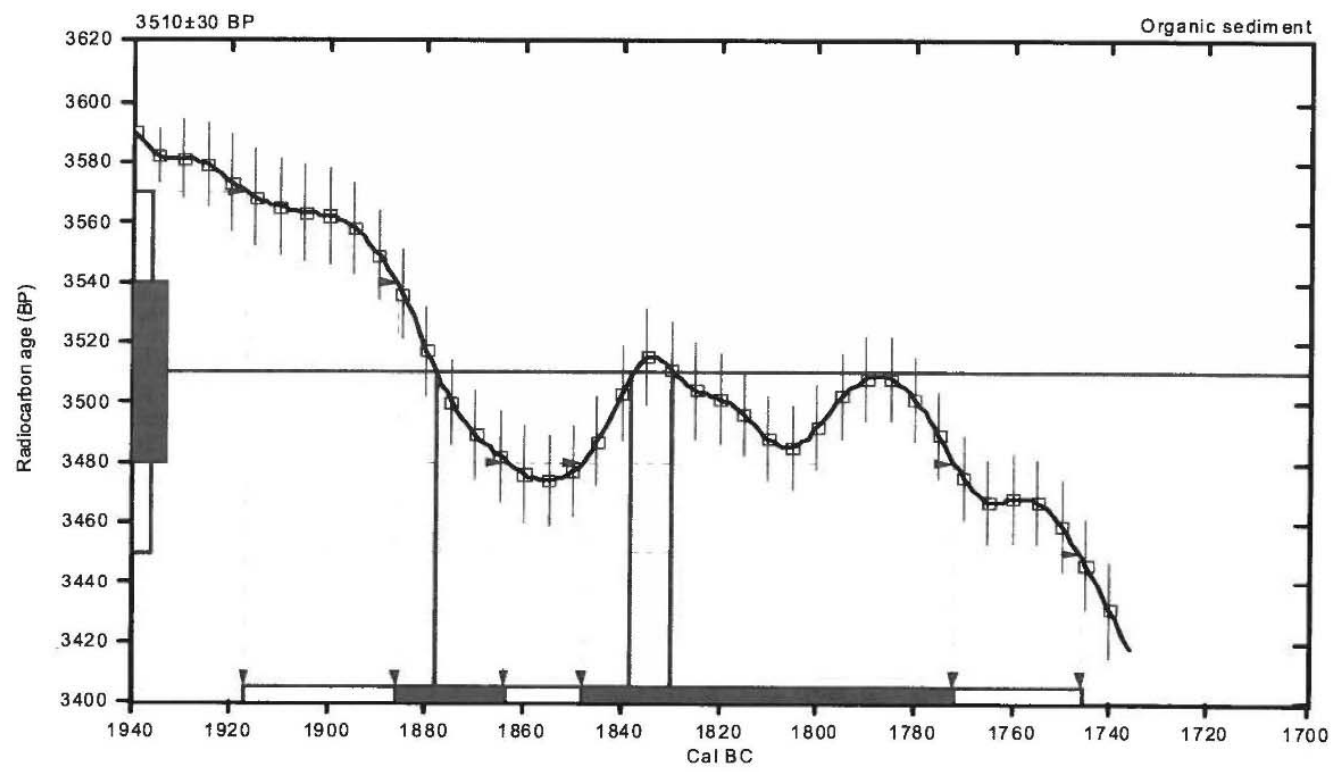

References:

Database used

INTCALO9

References to INTCALO9 database

Heaton, et.al,.2009, Radiocarbon 51(4):1151-1164, Reimer,et.al, 2009, Radiocarbon 51(4):1111-1150. Stuiver, et.al,1993, Radiocarbon 35(1):1-244, Oeschger, et.al., 1975, Tellus 27:168-192

Mathematics used for calibration scenario

A Simplified Approach to Calibrating C14 Dates

Talm a, A.S., Vogel, J. C., 1993, Radiocarbon 35(2):317-322

\section{Beta Analytic Radiocarbon Dating Laboratory}

4985 S.W. 74th Court, Miami, Florida $33155 \cdot$ Tel: (305)667-5167 · Fax: (305)663-0964 - E-Mail: beta@radiocarbon.com 


\section{CALIBRATION OF RADIOCARBON AGE TO CALENDAR YEARS}

(Variables: $\mathrm{C} 13 / \mathrm{C} 12=-21.1: \mathrm{lab} . \mathrm{mult}=1$ )

Laboratory number: Beta-370500

Conventional radiocarbon age: $3490 \pm 30 \mathrm{BP}$

2 Sigma calibrated result: Cal BC 1890 to 1740 (Cal BP 3840 to 3690 )

( $95 \%$ probability)

Intercept data

Intercepts of radiocarbon age

with calibration curve: Cal BC 1870 (Cal BP 3820) and

$\mathrm{Cal} \mathrm{BC} 1840$ (Cal BP 3790) and

Cal BC 1810 (Cal BP 3760) and

Cal BC 1800 (Cal BP 3750) and

Cal BC 1780 (Cal BP 3720)

1 Sigma calibrated result: Cal BC 1880 to 1750 (Cal BP 3830 to 3700 ) (68\% probability)

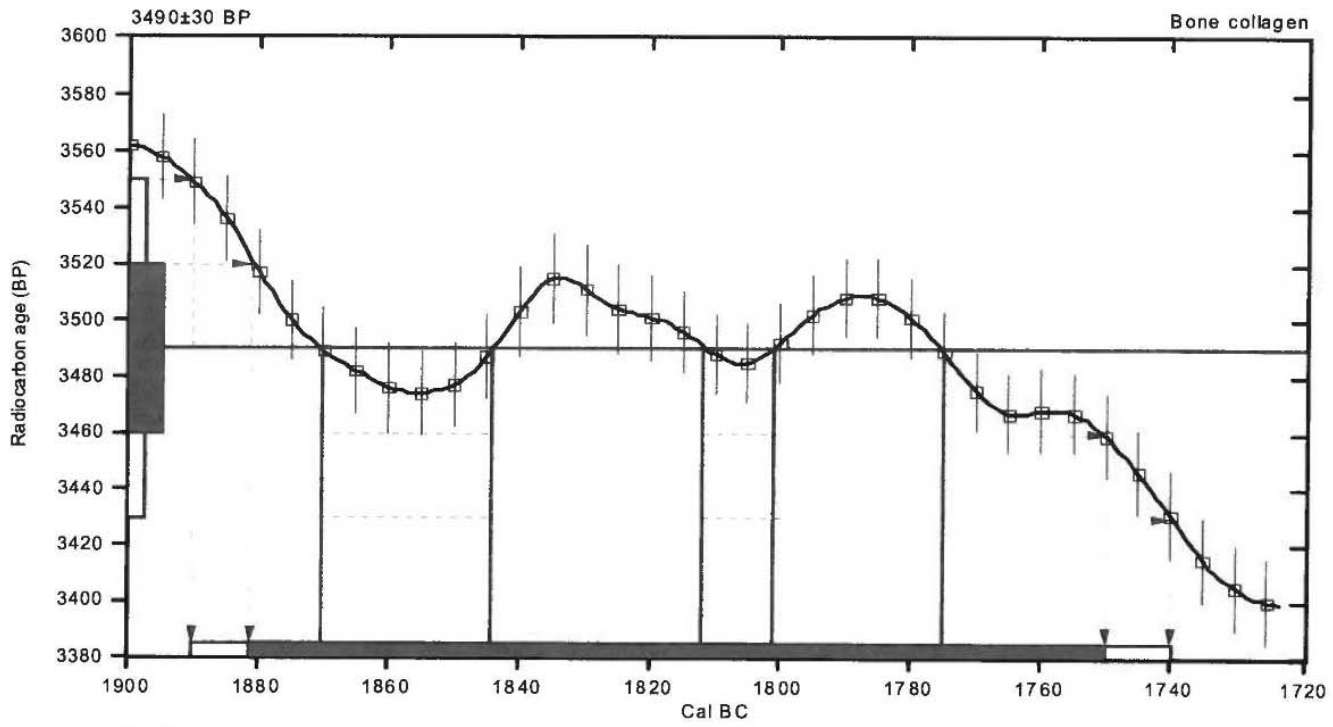

References:

Database used

$$
\text { INTCALO9 }
$$

References to INTCALO9 database

Heaton,et.al,2009, Radiocarbon 51(4):1151-1164, Reimer,et.al, 2009, Radiocarbon 51(4):1111-1150, Stuiver,et.al, 1993, Radiocarbon 35(1):1-244, Oeschger,et.al.,1975, Tellus 27:168-192

Mathematics used for calib ration scenario

A Simplified Approach to Calibrating C14 Dates

Talma, A. S., Vogel, J. C., 1993, Radiocarbon 35(2):317-322

Beta Analytic Radiocarbon Dating Laboratory

4985 S.W.74th Court, Miami, Florida 33155·Tel: (305)667-5167·Fax:(305)663-0964·E-Mail: beta@ radiocarbon.com

Page 14 of 18 


\section{CALIBRATION OF RADIOCARBON AGE TO CALENDAR YEARS}

(Variables: C $13 / \mathrm{C} 12=-9.4:$ lab. mult $=1$ )

Laboratory number: Beta-370501

Conventional radiocarbon age: $3780 \pm 30 \mathrm{BP}$

2 Sigma calibrated result: Cal BC 2290 to 2140 (Cal BP 4240 to 4080) ( $95 \%$ probability)

Intercept data

Intercept of radiocarbon age

with calibration curve: Cal BC 2200 (Cal BP 4150)

1 Sigma calibrated results: Cal BC 2280 to 2250 (Cal BP 4230 to 4200 ) and (68\% probability) Cal BC 2230 to $2220(\mathrm{Cal} \mathrm{BP} 4180$ to 4170$)$ and Cal BC 2210 to 2190 (Cal BP 4160 to 4140 ) and $\mathrm{Cal} \mathrm{BC} 2180$ to 2140 (Cal BP 4130 to 4090 )

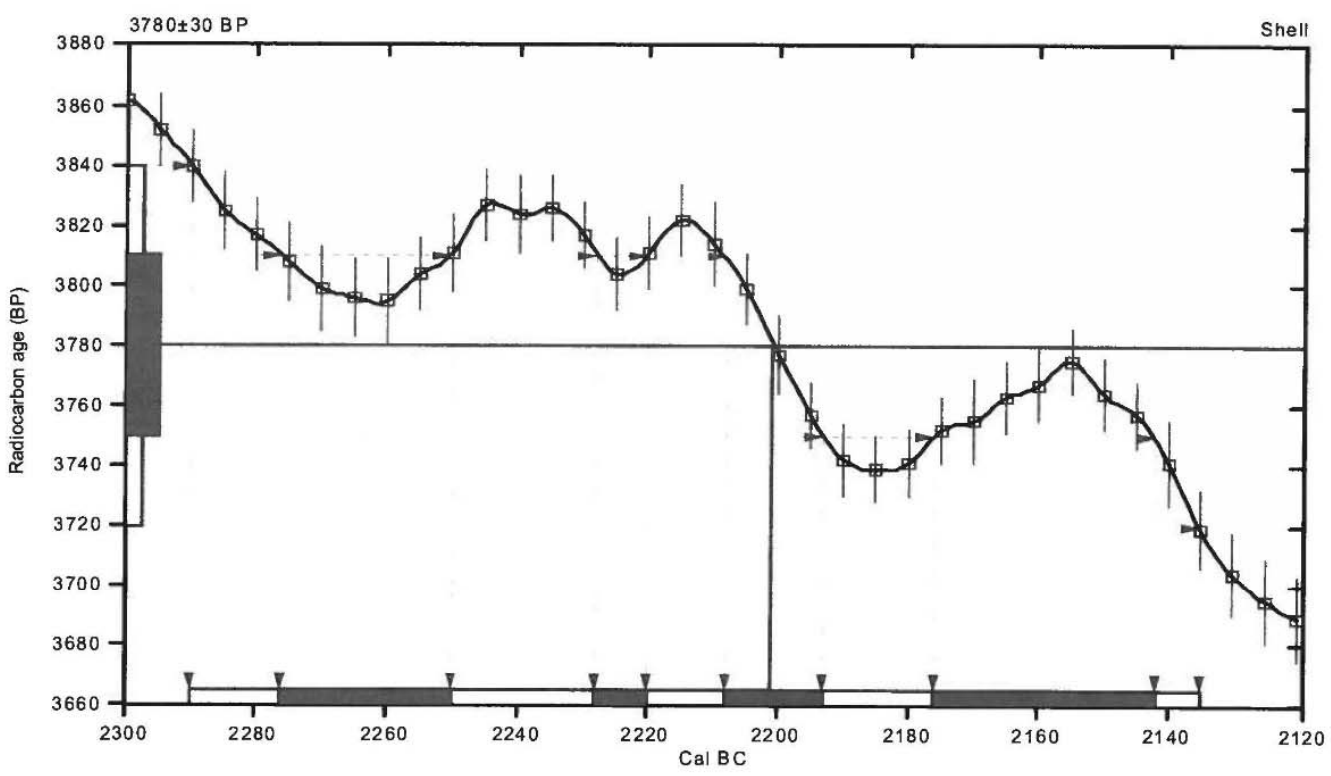

References:

Database used INTCALO9

References to INTCALO9 database

Heaton,et.al.,2009, Radiocarbon 51(4):1151-1164, Reimer,et.al, 2009, Radiocarbon 51(4):1111-1150, Stuiver, et.al,1993, Radiocarbon 35(1):137-189, Oeschger, et.al.,1975, Tellus 27:168-192

Mathematics used for calibration scenario

A Simplified Approach to Calibrating C14 Dates

Talma, A. S., Vogel, J. C.. 1993, Radiocarbon 35(2):317-322

\section{Beta Analytic Radiocarbon Dating Laboratory}

4985 S.W. 74th Court, Miami, Florida 33155 - Tel: (305)667-5167 - Fax: (305)663-0964 - E-Mail: beta@ radiocarbon.com

Page 15 of 18 


\section{CALIBRATION OF RADIOCARBON AGE TO CALENDAR YEARS}

(Variables: $\mathrm{C} 13 / \mathrm{C} 12=-10: 1 \mathrm{ab} . \mathrm{mult}=1)$

Laboratory number: Beta-370502

Conventional radiocarbon age: $3430 \pm 30 \mathrm{BP}$

2 Sigma calibrated results: Cal BC 1870 to 1840 (Cal BP 3820 to 3790) and

(95\% probability) Cal BC 1810 to 1800 (Cal BP 3760 to 3750) and

Cal BC 1780 to 1680 (Cal B P 3720 to 3630 )

Intercept data

Intercept of radiocarbon age with calibration curve:

1 Sigma calibrated results: Cal BC 1750 to 1720 (Cal BP 3700 to 3680 ) and

(68\% probability) Cal BC 1720 to 1690 (Cal BP 3670 to 3640 )

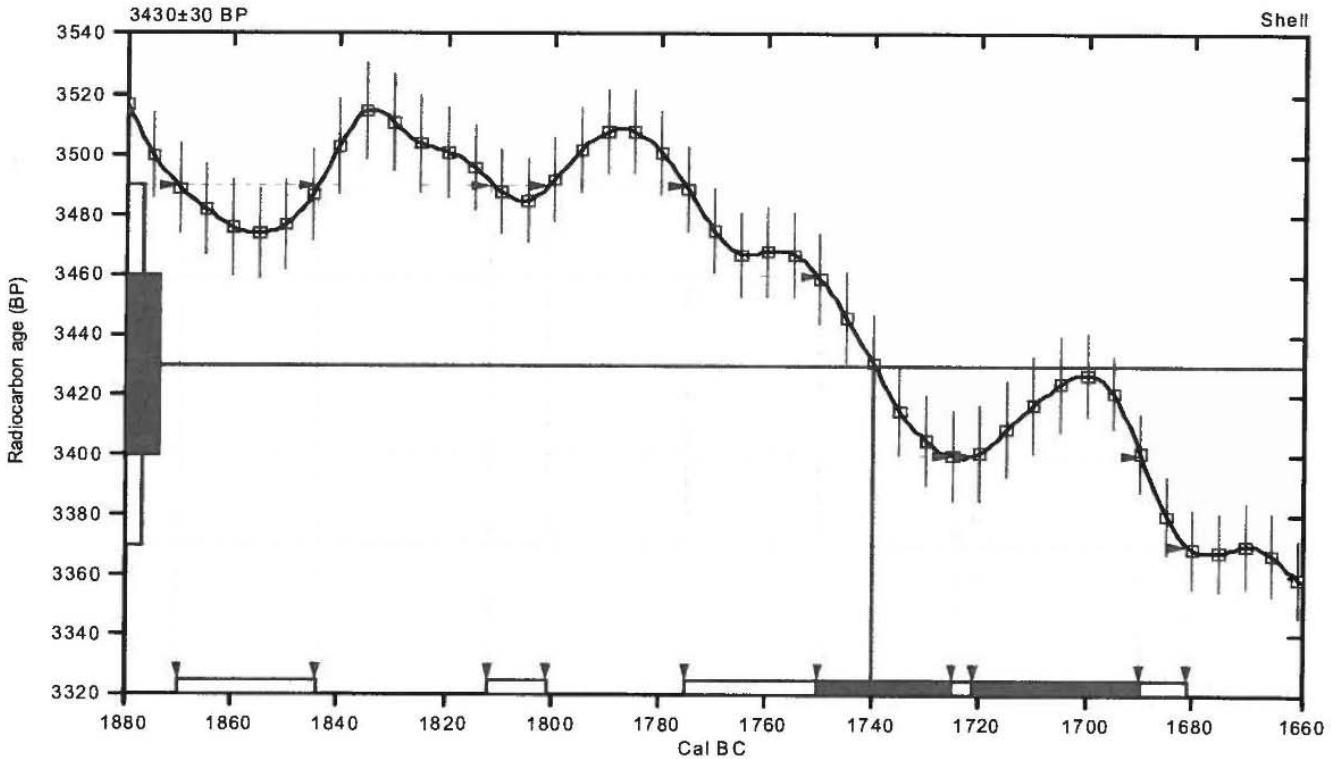

References:

Database used

INTCALO9

References to INTCALO9 database

Heaton,et.al.2009, Radiocarbon 51(4):1151-1164, Reimer,et.al, 2009, Radiocarbon 51(4):1111-1150. Stuiver, et.al,1993, Radiocarbon 35(1):137-189, Oeschger,et.al.,1975, Tellus 27:168-192

Mathematics used for calibration scenario

A Simplified Approach to Calibrating C14 Dates

Talma, A. S., Vogel, J. C., 1993, Radiocarbon 35(2):317-322

Beta Analytic Radiocarbon Dating Laboratory

4985 S.W.74th Court, Miami, Florida 33155 - Tel: (305)667-5167 - Fax: (305)663-0964 - E-Mail: beta@radiocarbon.com

Page 16 of 18 


\section{CALIBRATION OF RADIOCARBON AGE TO CALENDAR YEARS}

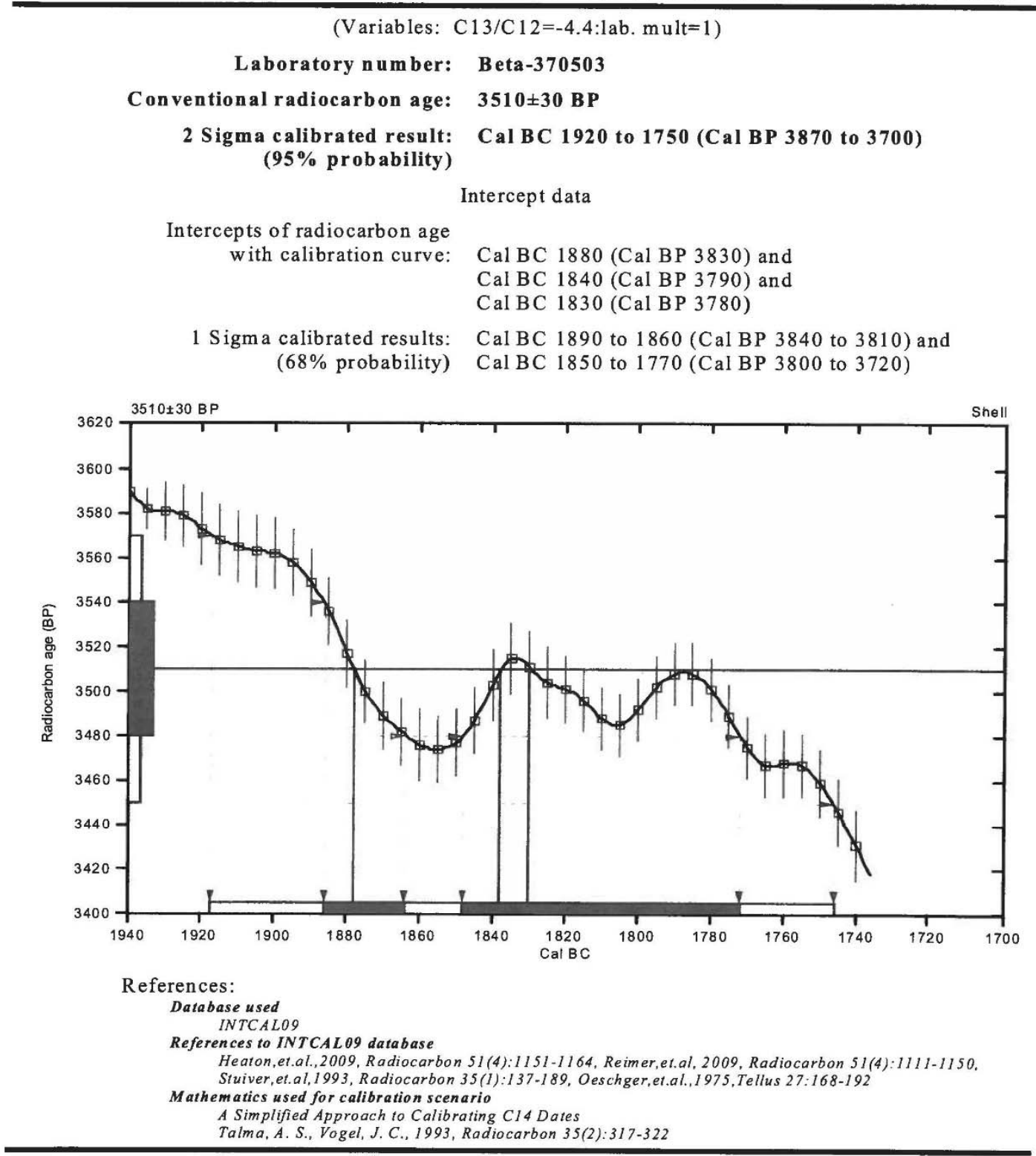

Beta Analytic Radiocarbon Dating Laboratory

4985 S.W. 74 th Court. Miami, Florida 33155 Tel: (305)667-5167·Fax: (305)663-0964·E-Mail: beta@radiocarbon.com

Page 17 of 18 


\section{CALIBRATION OF RADIOCARBON AGE TO CALENDAR YEARS}

(Variables: C $13 / \mathrm{C} 12=-23.6$ : lab. mult $=1$ )

Laboratory number: Beta-370504

Conventional radiocarbon age: $3430 \pm 30$ B P

2 Sigma calibrated results: Cal BC 1870 to 1840 (Cal BP 3820 to 3790 ) and

(95\% probability) Cal BC 1810 to 1800 (Cal BP 3760 to 3750) and

Cal BC 1780 to 1680 (Cal BP 3720 to 3630 )

Intercept data

Intercept of radiocarbon age

with calibration curve: Cal BC 1740 (Cal BP 3690)

1 Sigma calibrated results: Cal BC 1750 to 1720 (C al BP 3700 to 3680 ) and

(68\% probability) Cal BC 1720 to 1690 (C al BP 3670 to 3640 )

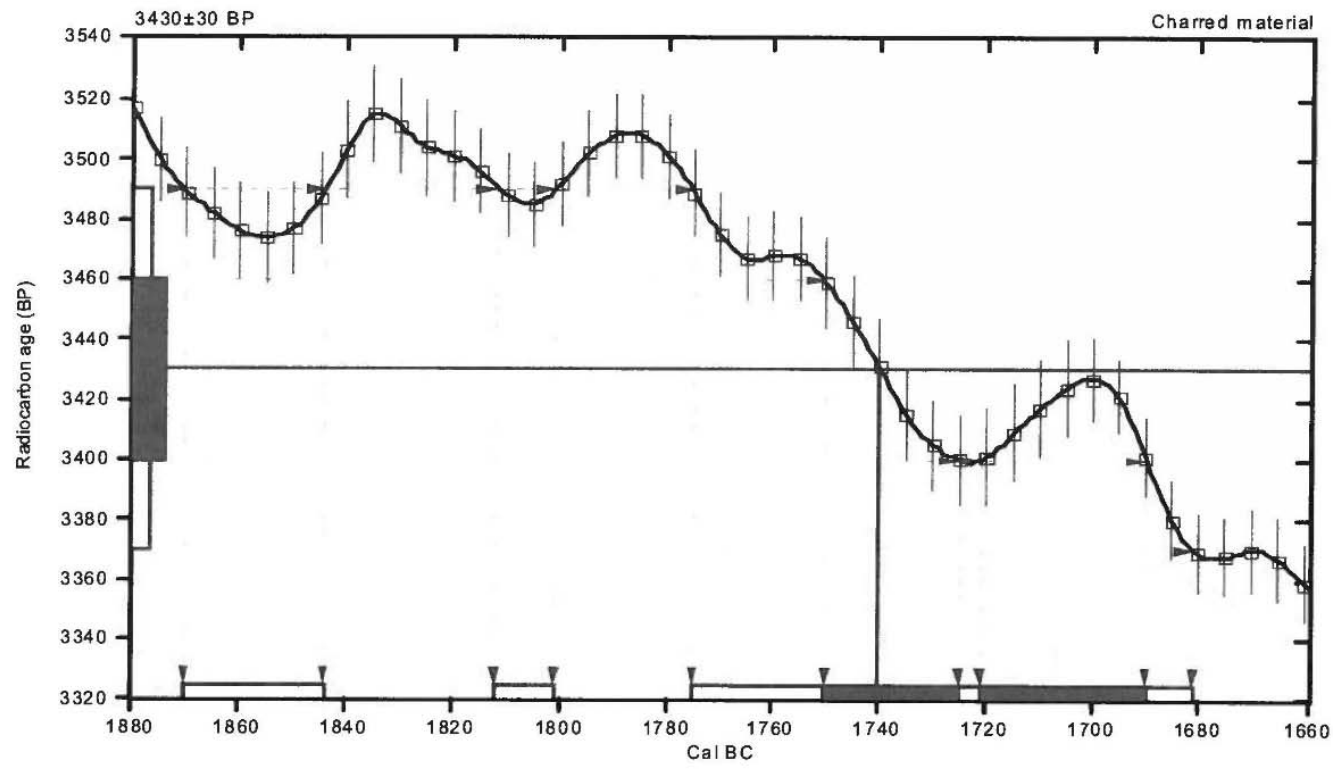

References:

Database used

INTCALO9

References to INTCALO9 database

Heaton, et.al.,2009, Radiocarbon 51(4):1151-1164, Reim er,et.al, 2009, Radiocarbon 51(4):1111-1150,

Stuiver,et.al,1993, Radiocarbon 35(I):1-244, Oeschger,et.al.,1975, Tellus 27:168-192

Mathematics used for calibration scenario

A Simplified Approach to Calibrating C14 Dates

Talma, A.S., Vogel, J. C., 1993, Radiocarbon 35(2):317-322

Beta Analytic Radiocarbon Dating Laboratory

4985 S.W. 74th Court, Miami, Florida 33 155 Tel: (305)667-5167·Fax: (305)663-0964·E-Mail: beta@radiocarbon.com

Page 18 of 18 
This page intentionally left blank. 


\title{
APPENDIX B: \\ ASSESSMENT OF PHYTOLITH PRESERVATION AT 41BL278
}

\author{
Prepared for:

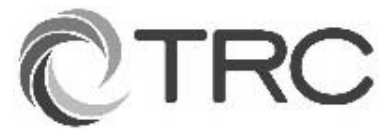 \\ TRC Environmental Corporation \\ 505 East Huntland Drive, Suite 250 \\ Austin, Texas 78752
}

Prepared by:

Steven Bozarth, Ph.D.

University of Kansas Palynology Laboratory

Department of Geography

Lawrence, Kansas 66045 
This page intentionally left blank. 
APPENDIX B: ASSESSMENT OF PHYTOLITH PRESERVATION AT

\section{BL278}

Steve Bozarth, Ph.D.

\section{B.1 INTRODUCTION}

The following four sediment samples were processed for phytoliths: \#501-4-2a, \#504-4A, \#505-4a, and \#508-4-2a (Table B-1).

\section{B.2 METHODS}

Phytoliths were isolated from 5-gram samples using a procedure based on heavy-liquid (zinc bromide) flotation and centrifugation. This procedure consists of five basic steps: 1) removal of carbonates with dilute hydrochloric acid; 2) removal of colloidal organics, clays, and very fine silts by deflocculation with sodium pyrophosphate, centrifugation, and decantation through a $7-\mu$ filter; 3) oxidation of sample to remove organics; 4) heavy-liquid flotation of phytoliths from the heavier clastic mineral fraction using zinc bromide concentrated to a specific gravity of $2.3 ; 5$ ) washing and dehydration of phytoliths with butanol; and 6) dry storage in 1-dram vials.
A representative portion of each phytolith isolate was mounted on a microscope slide in immersion oil under a 22-by-40 mm cover glass and sealed with clear nail lacquer. Each slide was then scanned with a petrographic Zeiss microscope at a magnification of $625 \mathrm{X}$.

\section{B.3 RESULTS}

Phytoliths were well preserved in all four samples. $\mathrm{C}_{3}$ and $\mathrm{C}_{4}$ grass phytoliths were found in all four samples in addition to an arboreal phytolith in the Unit 6 sample. Phytolith analysis of these four samples would provide interpretable paleoenvironmental data at 41BL278.

Table B-1. Provenience Data for Analyzed Samples.

\begin{tabular}{|c|c|c|c|}
\hline Cat. No. & \multicolumn{1}{c}{ Unit } & \multicolumn{1}{c|}{ Depth } & Comments \\
\hline $501-4-2 a$ & 5 & & Feature 3 \\
\hline $504-4 a$ & 1 & $147-154$ & Feature 4 \\
\hline $505-4 a$ & 4 & $150-160$ & Feature 5 \\
\hline $508-4-2 a$ & 6 & 170 & Feature 8 \\
\hline
\end{tabular}


This page intentionally left blank. 


\section{APPENDIX C: \\ GEOPHYSICAL RESULTS FROM 41BL278 \\ IN BELL COUNTY, TEXAS}

Prepared by:

Melanie Crisp

Staff Geologist

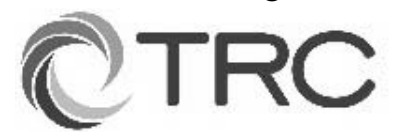

TRC Environmental Corporation

505 East Huntland Drive, Suite 250

Austin, Texas 78752 
This page intentionally left blank. 

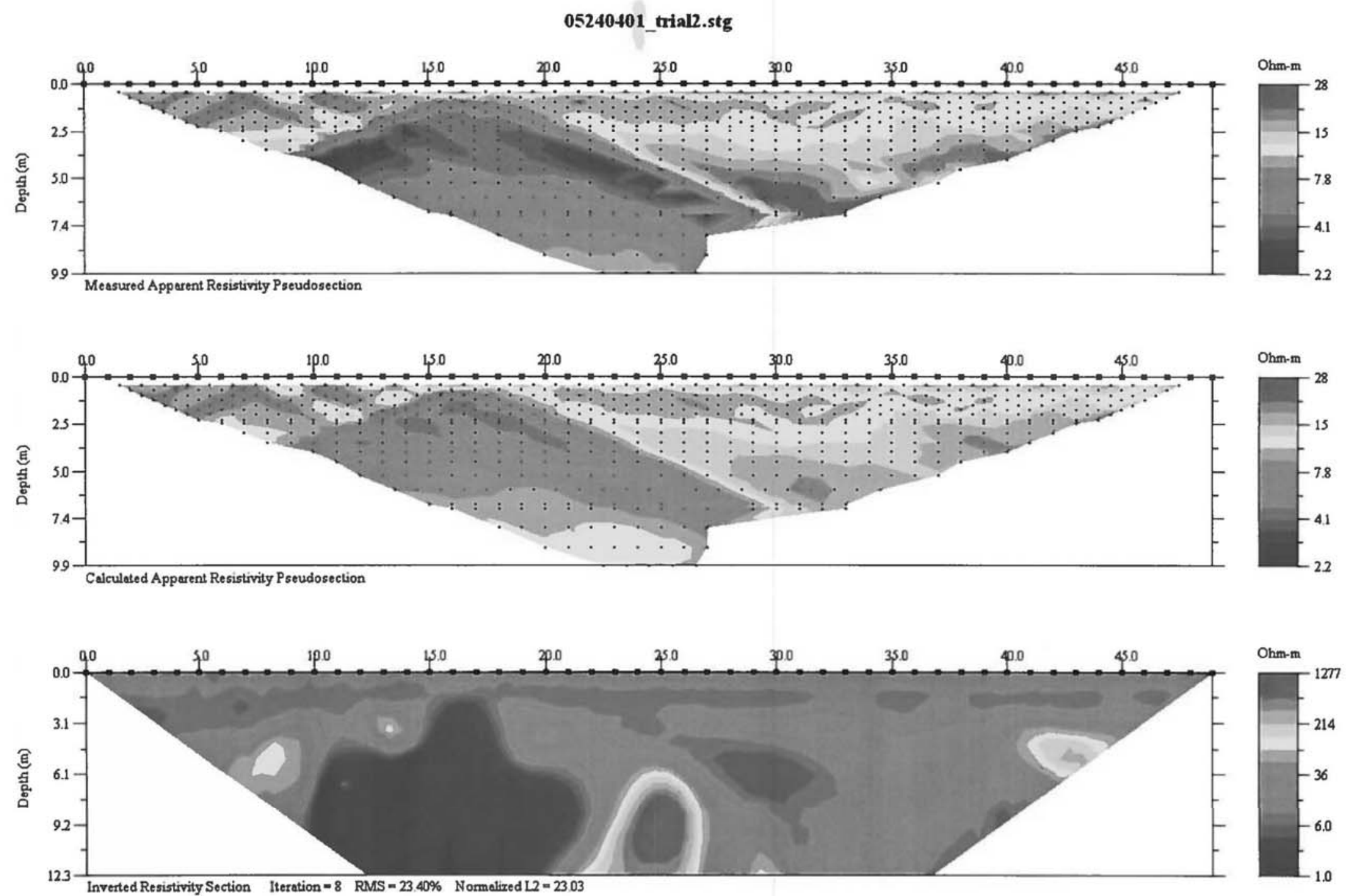

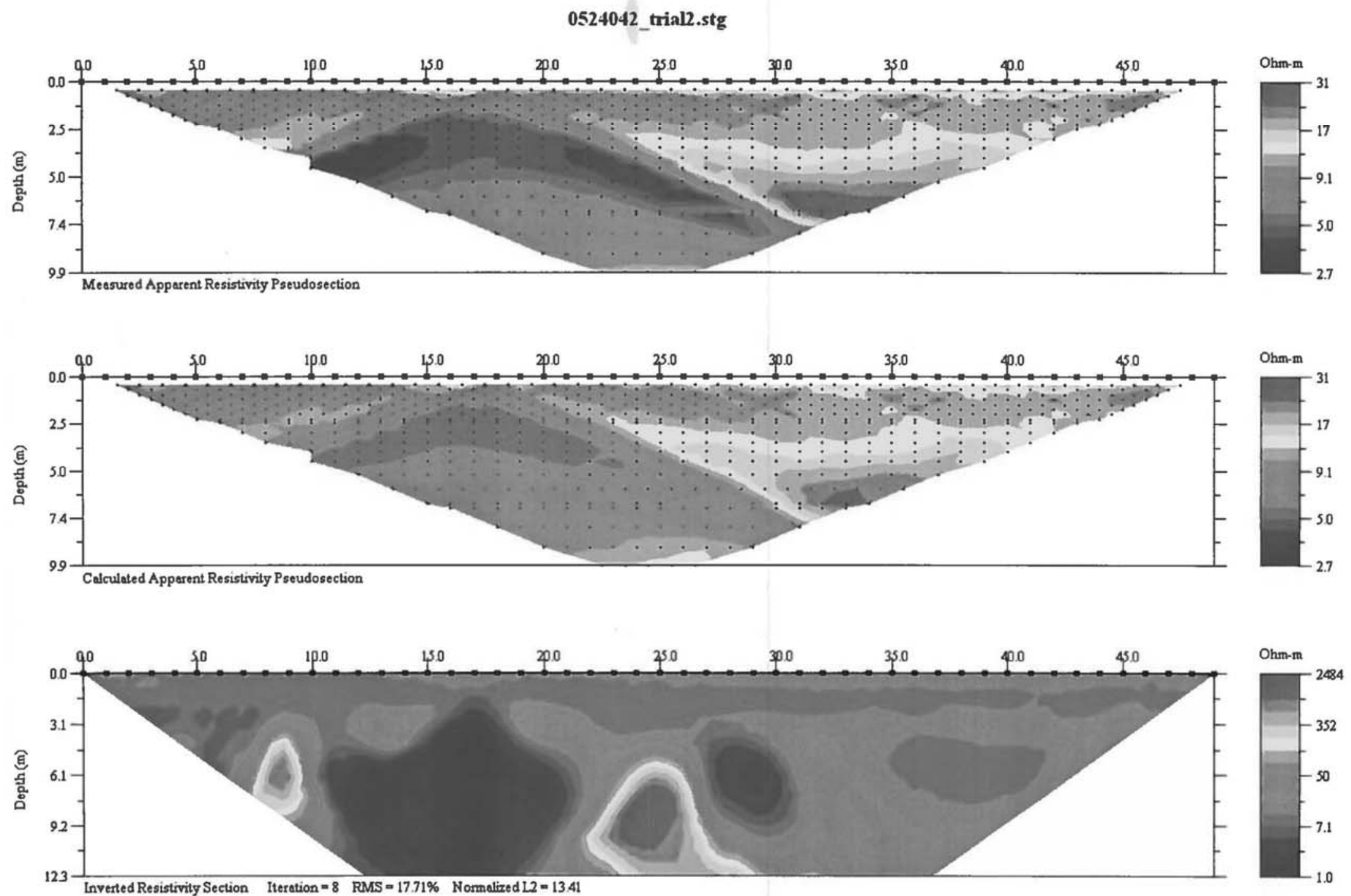

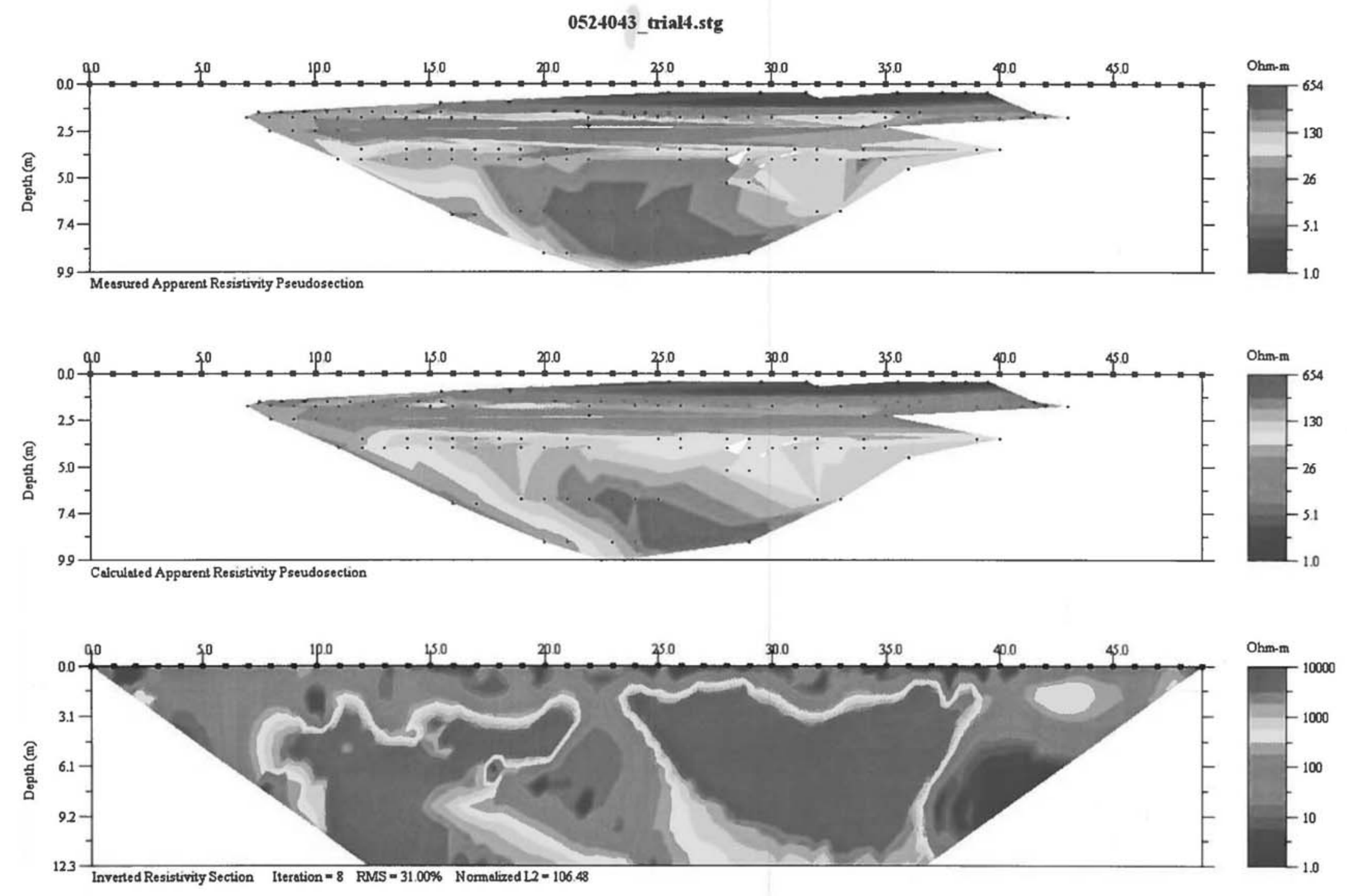

CTRC Technical Report Nos. 42568 (106760) and 211462 

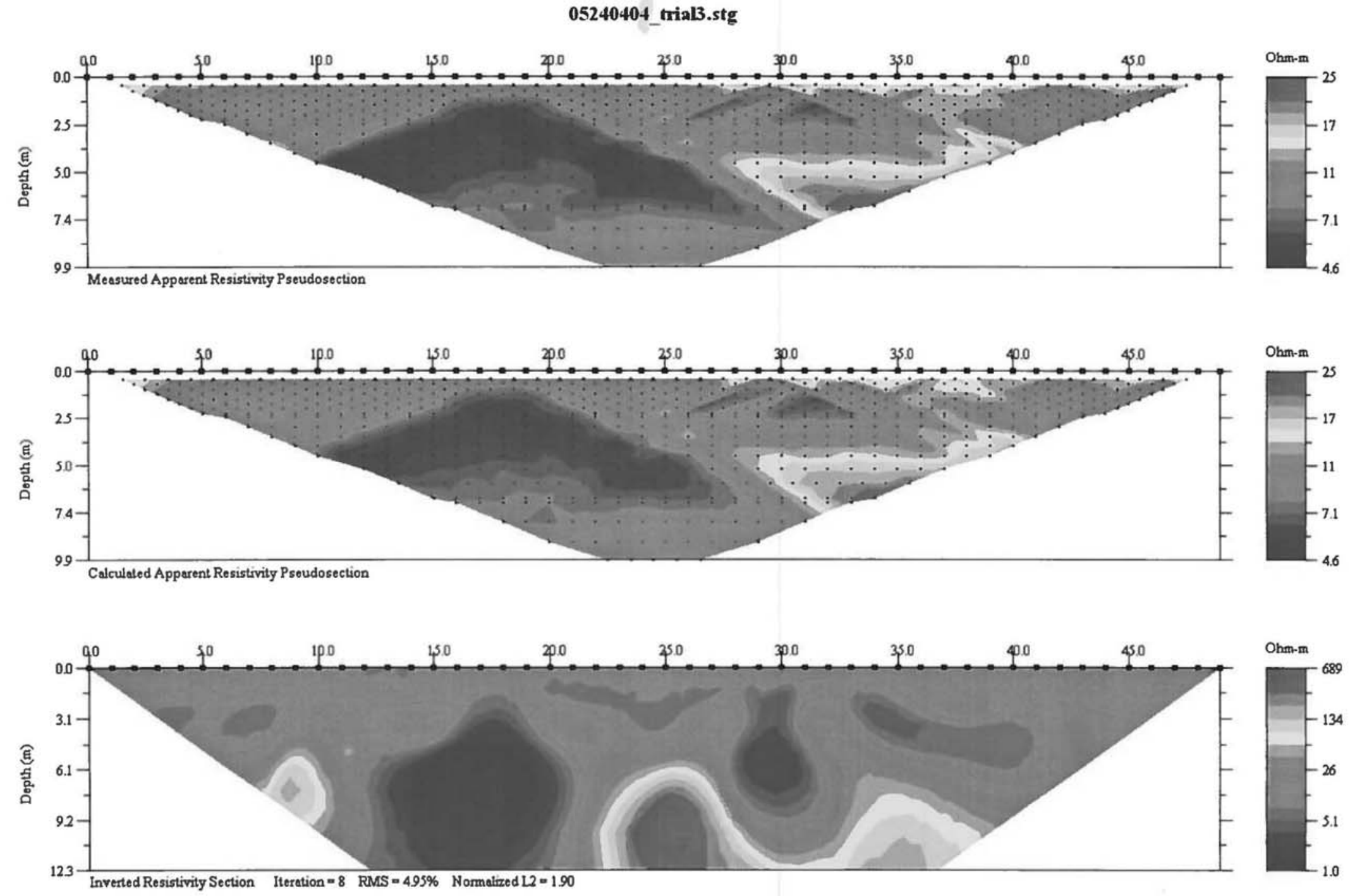

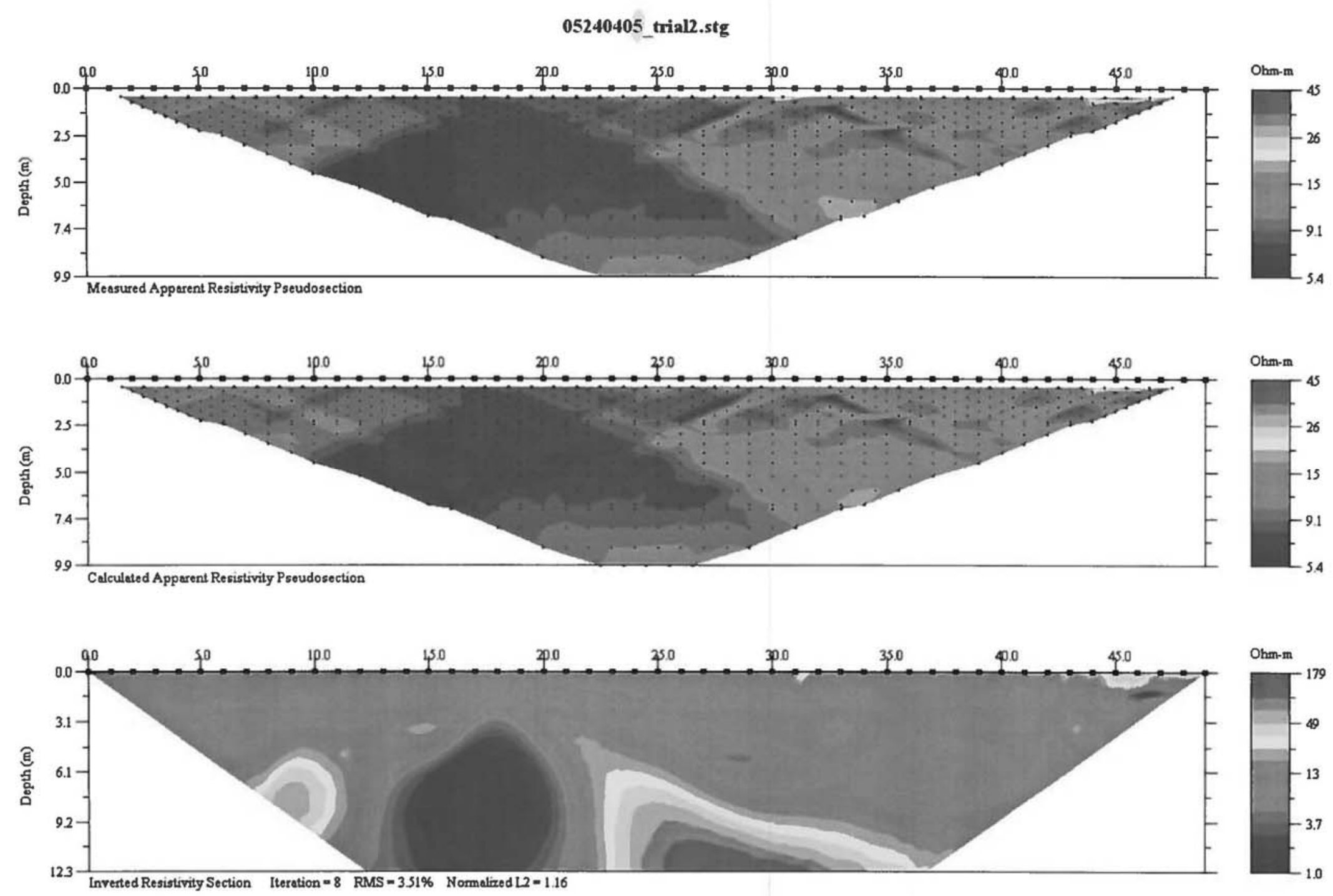

CTR Technical Report Nos. 42568 (106760) and 211462 

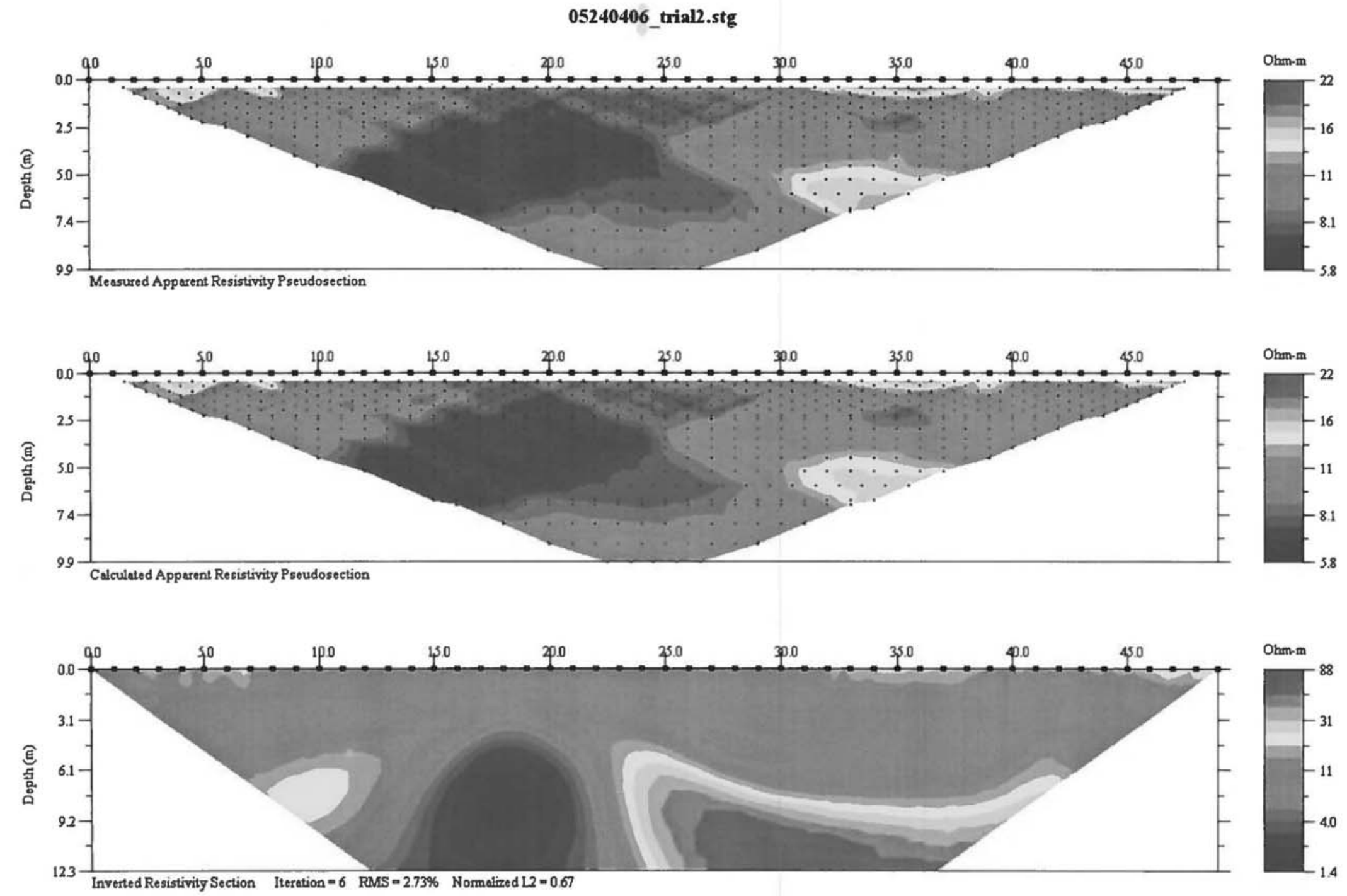

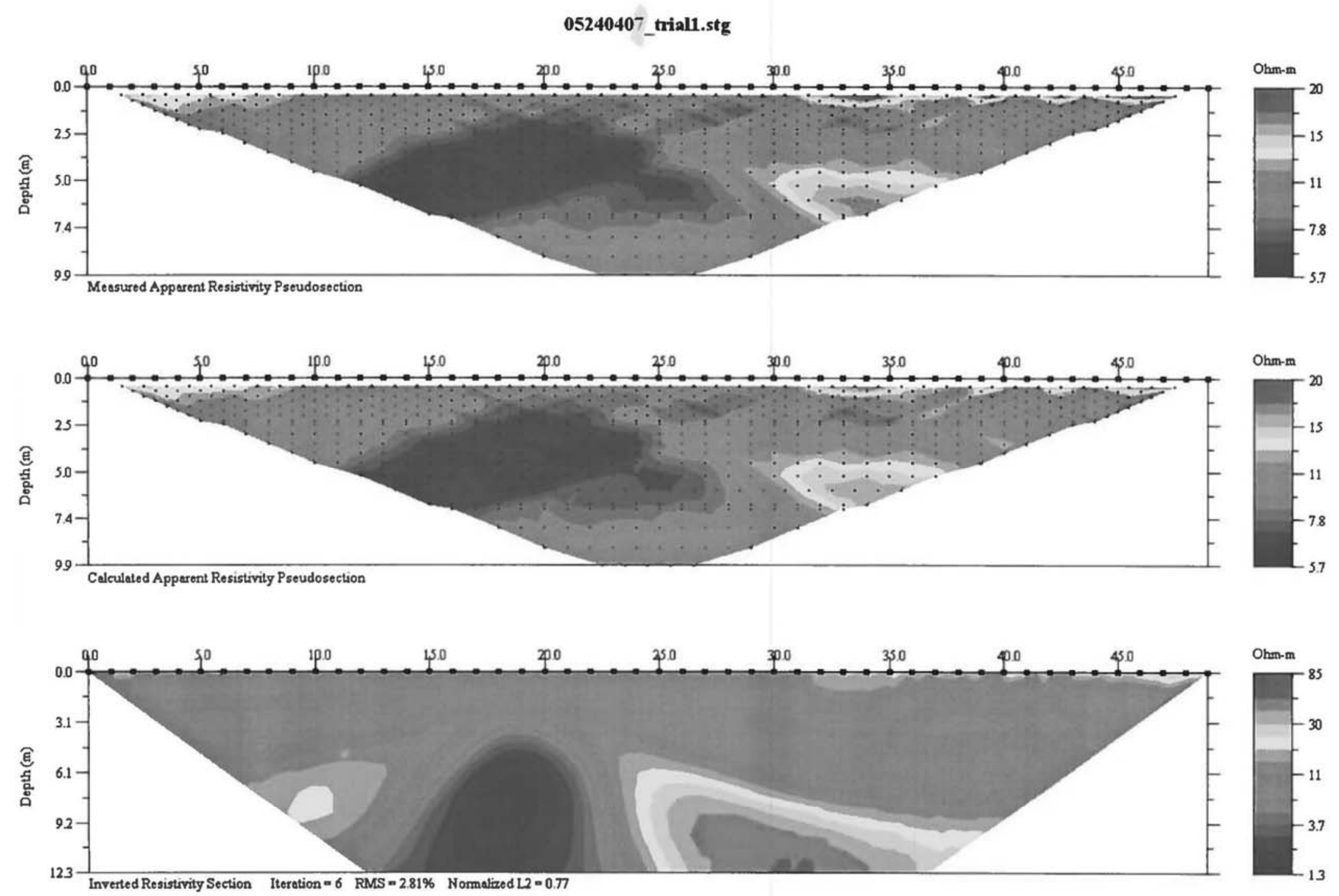

CTR Technical Report Nos. 42568 (106760) and 211462 

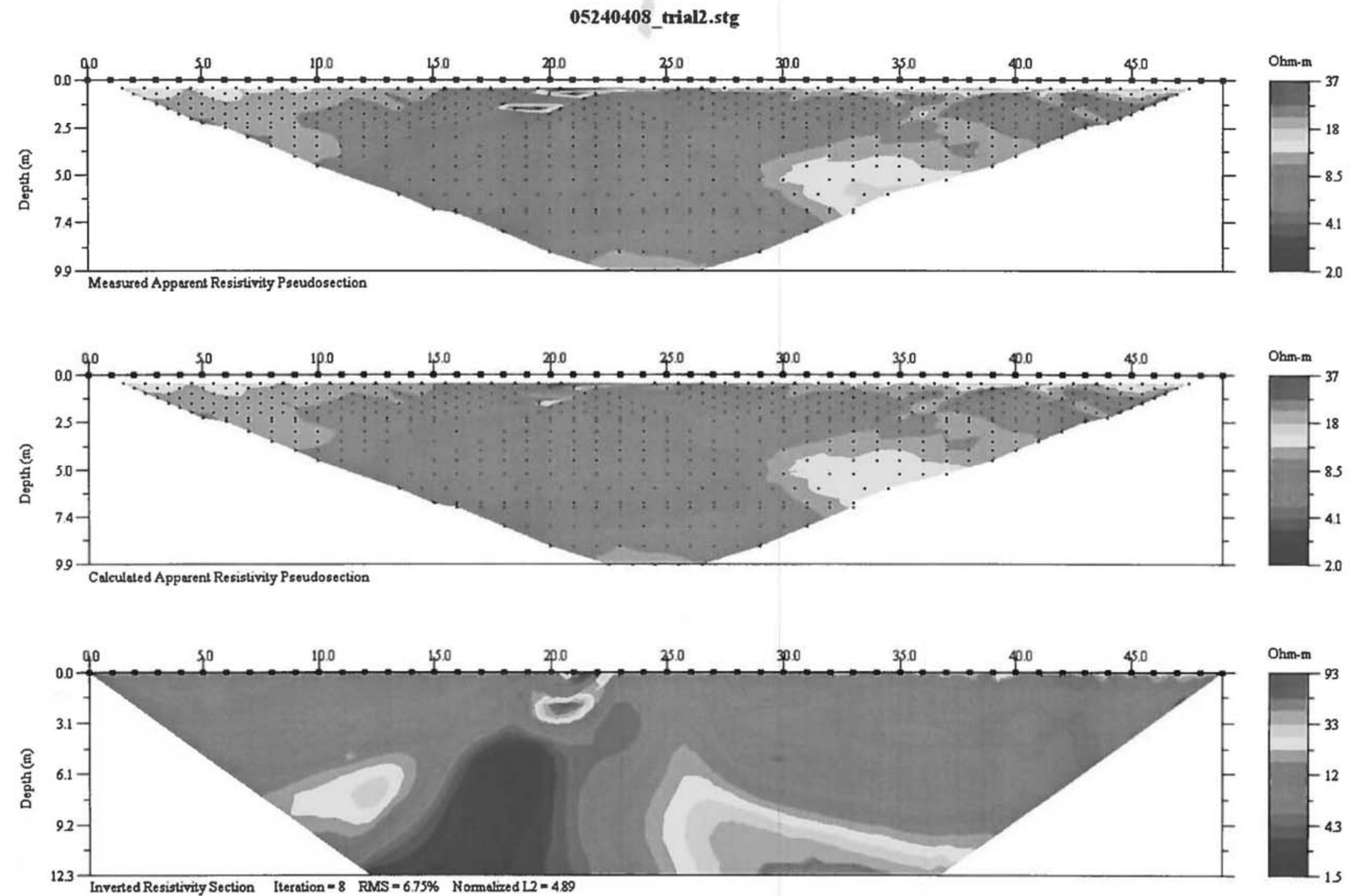

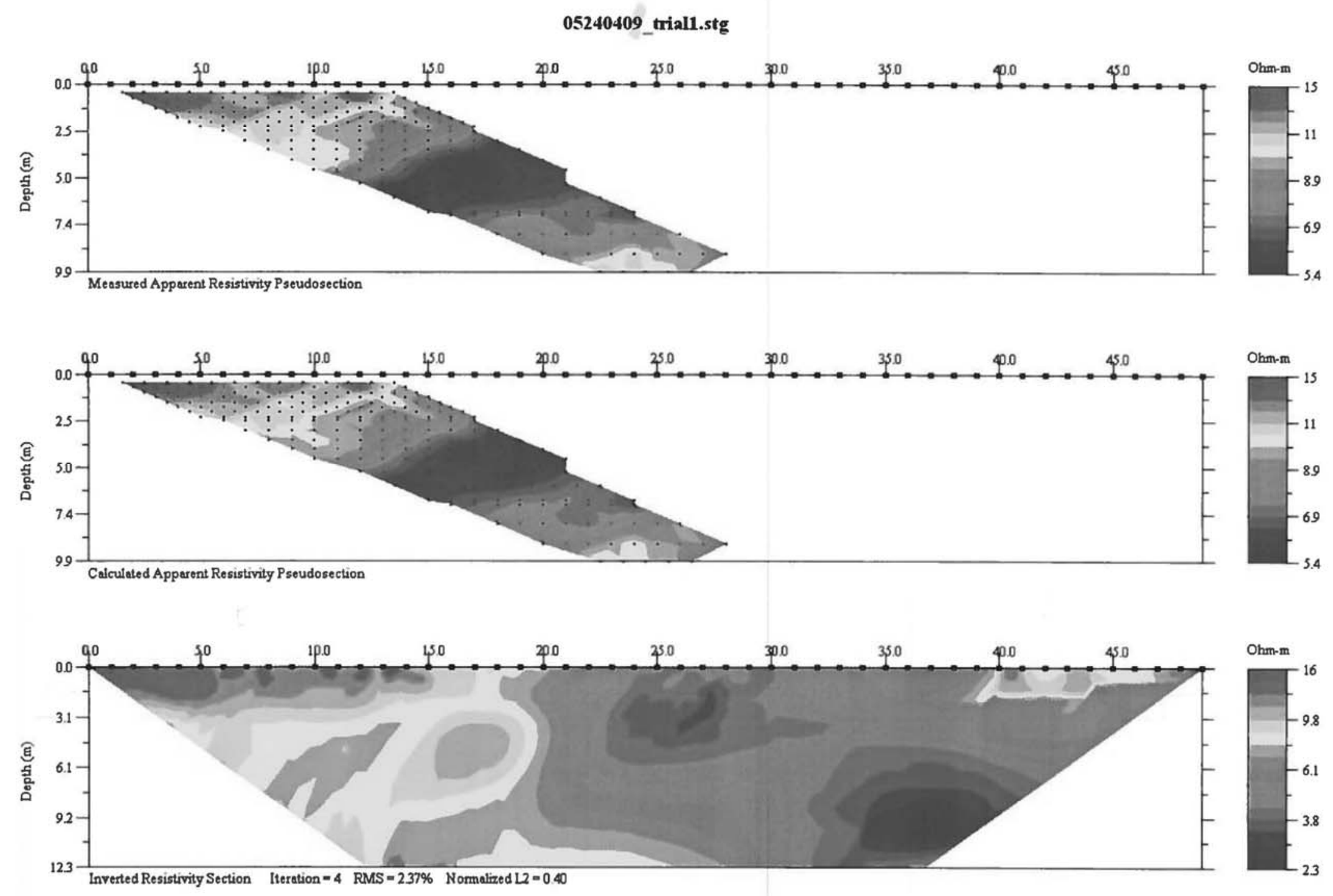

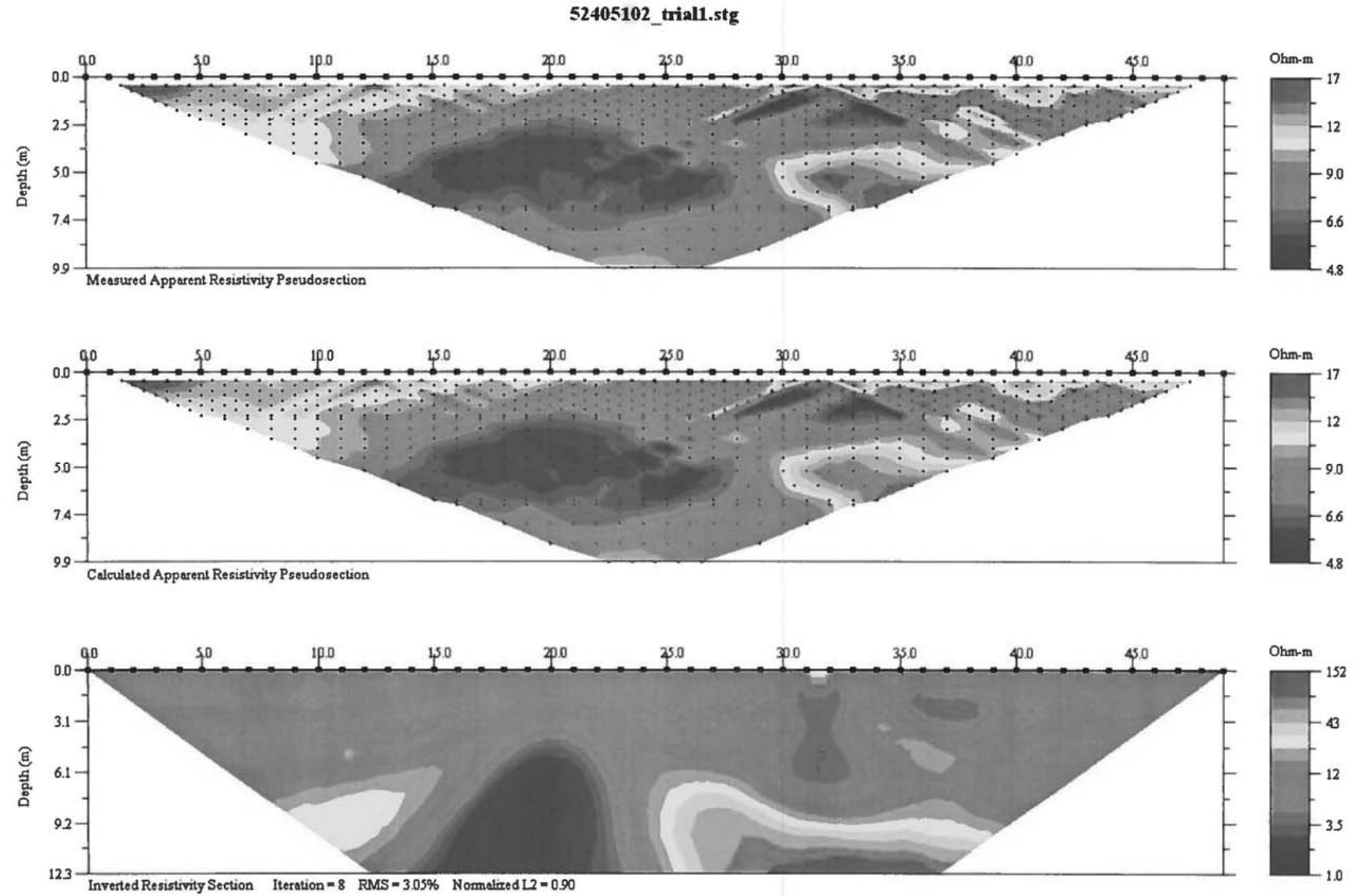

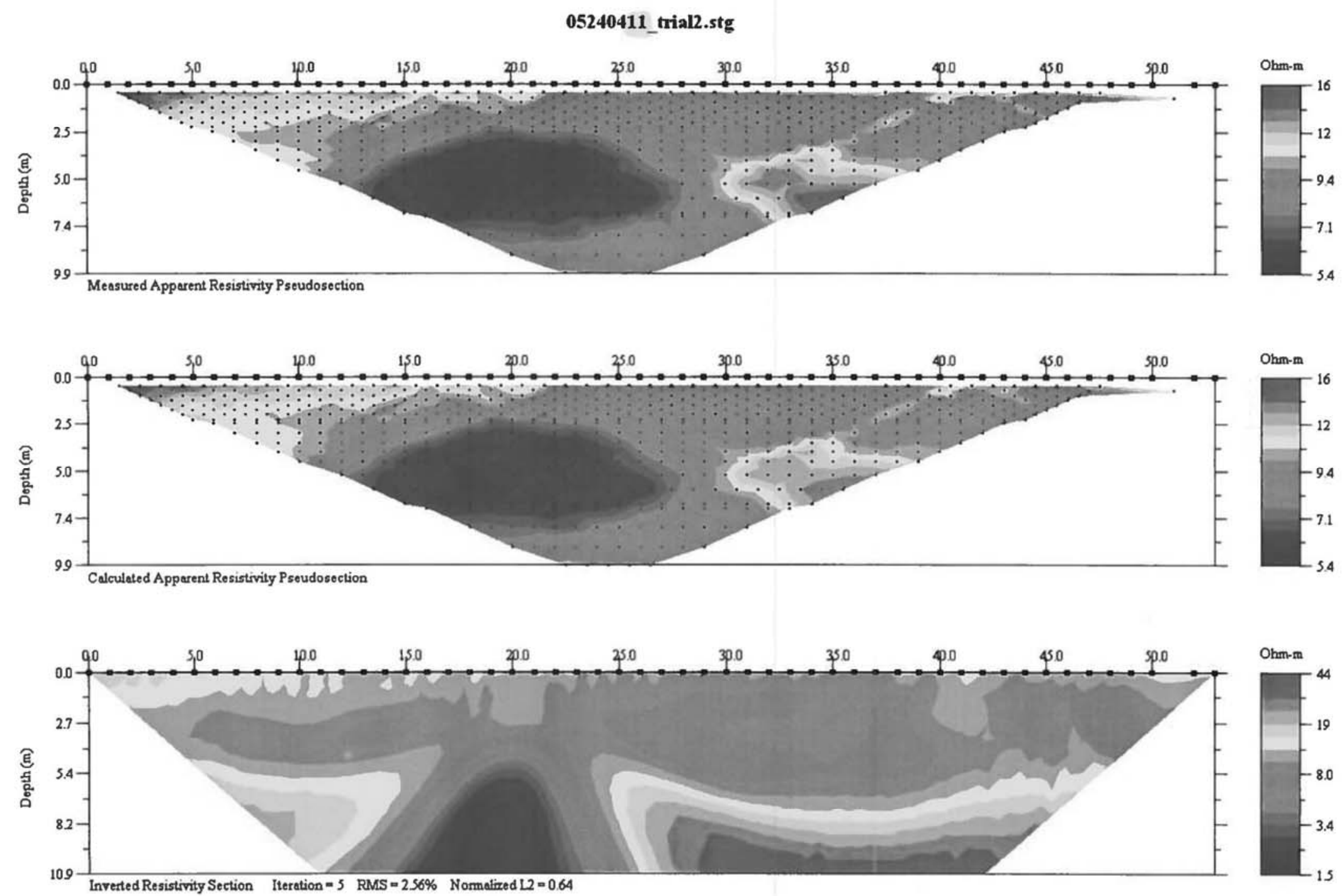

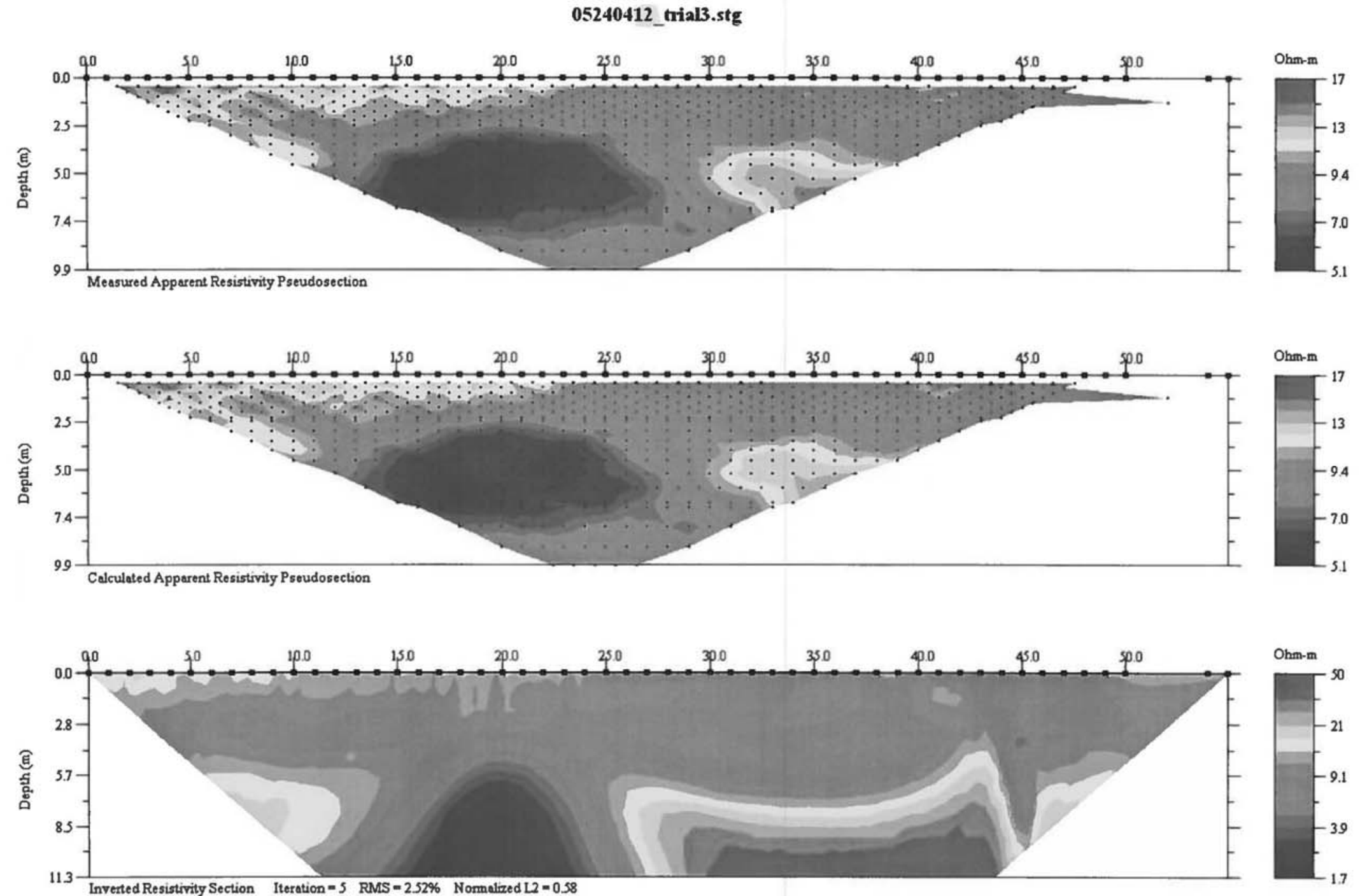

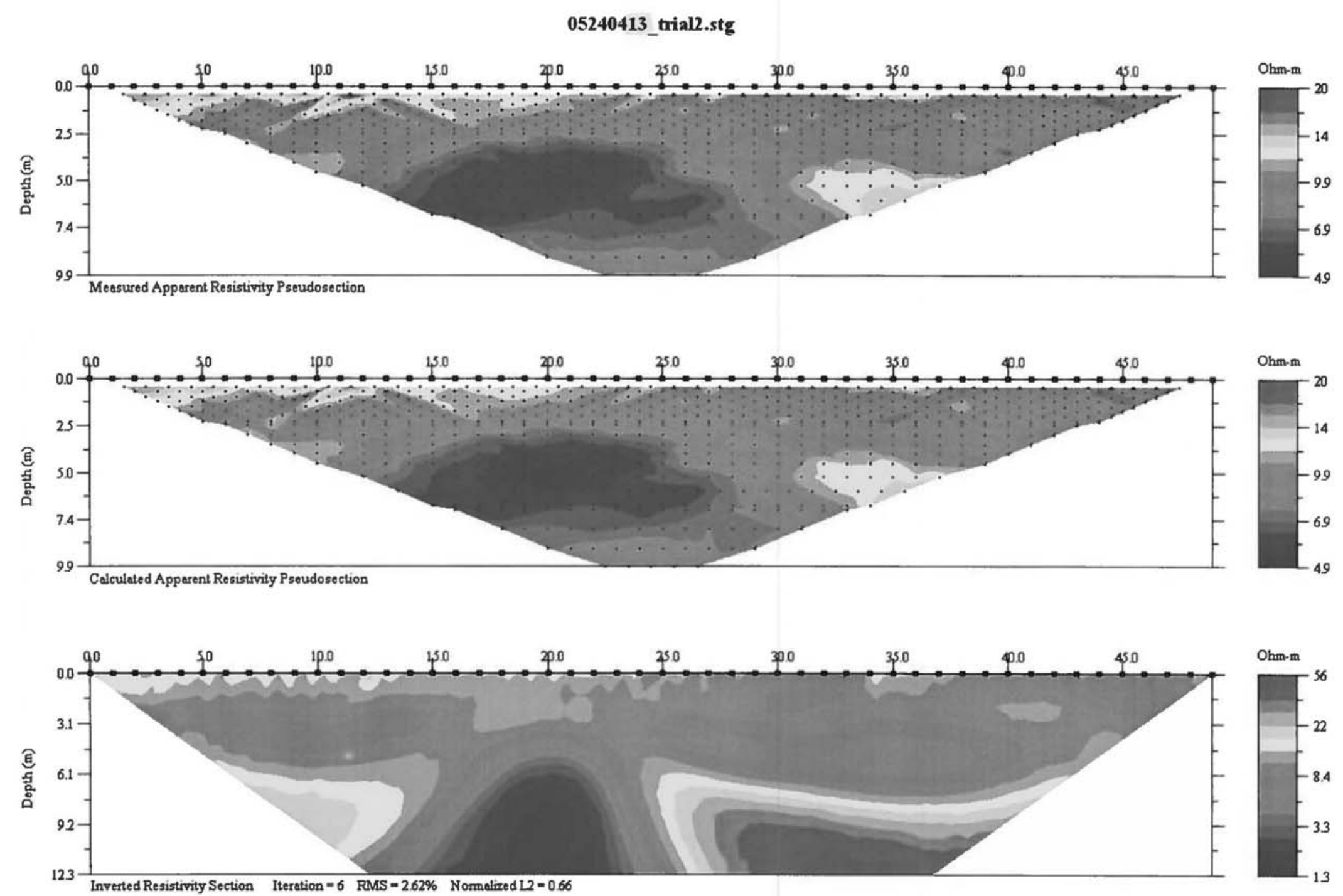

CTR Technical Report Nos. 42568 (106760) and 211462 

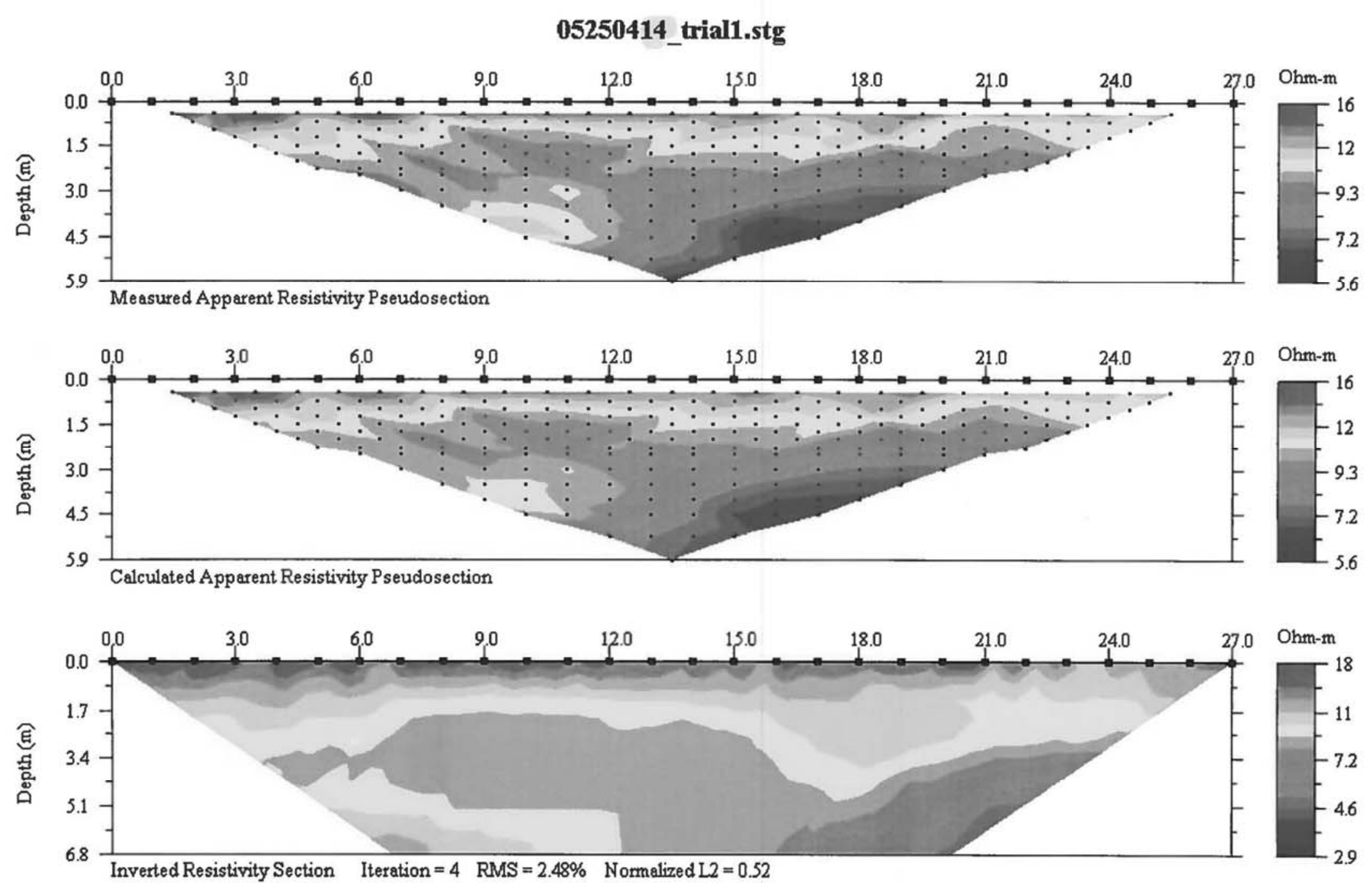

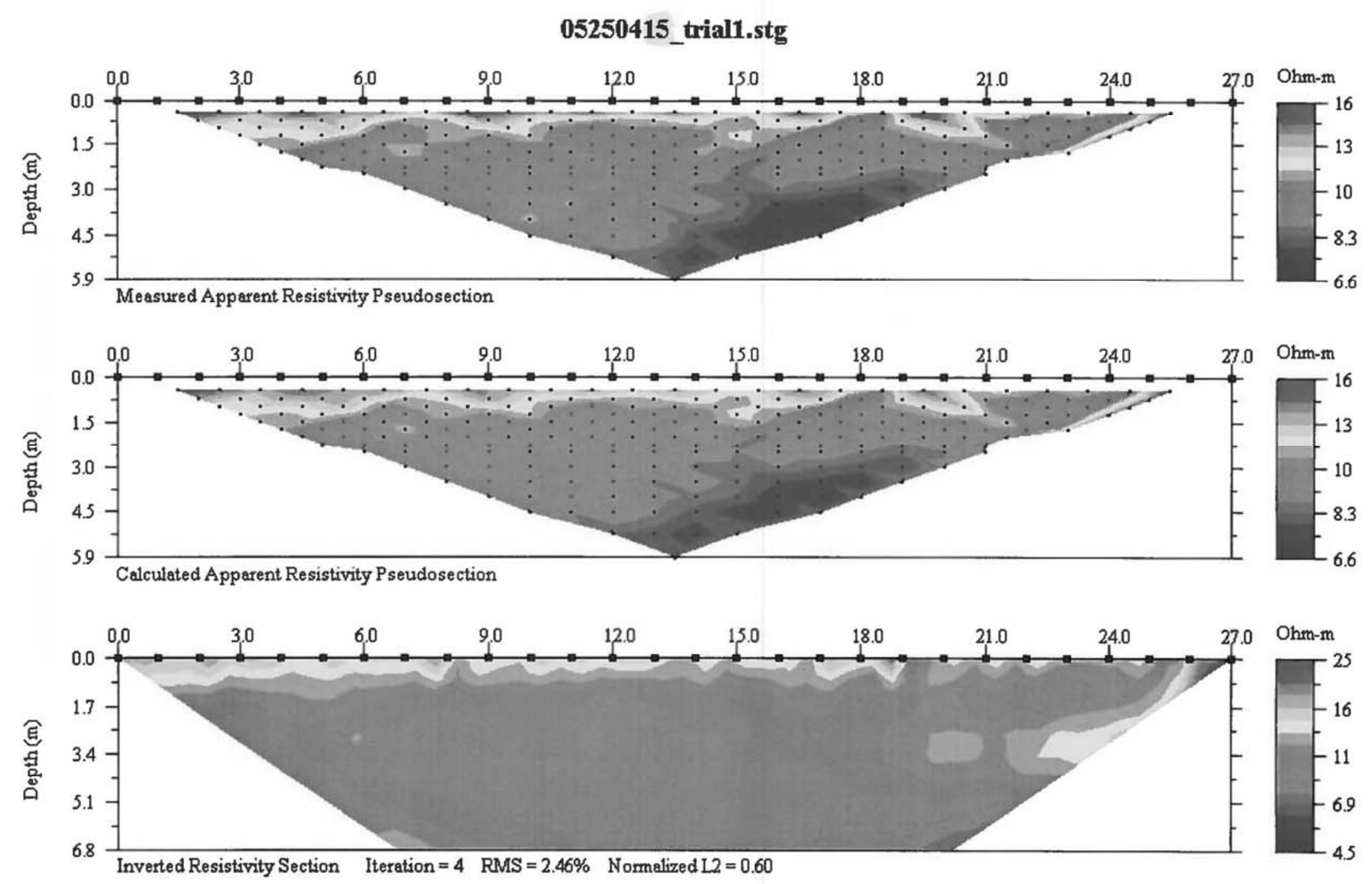

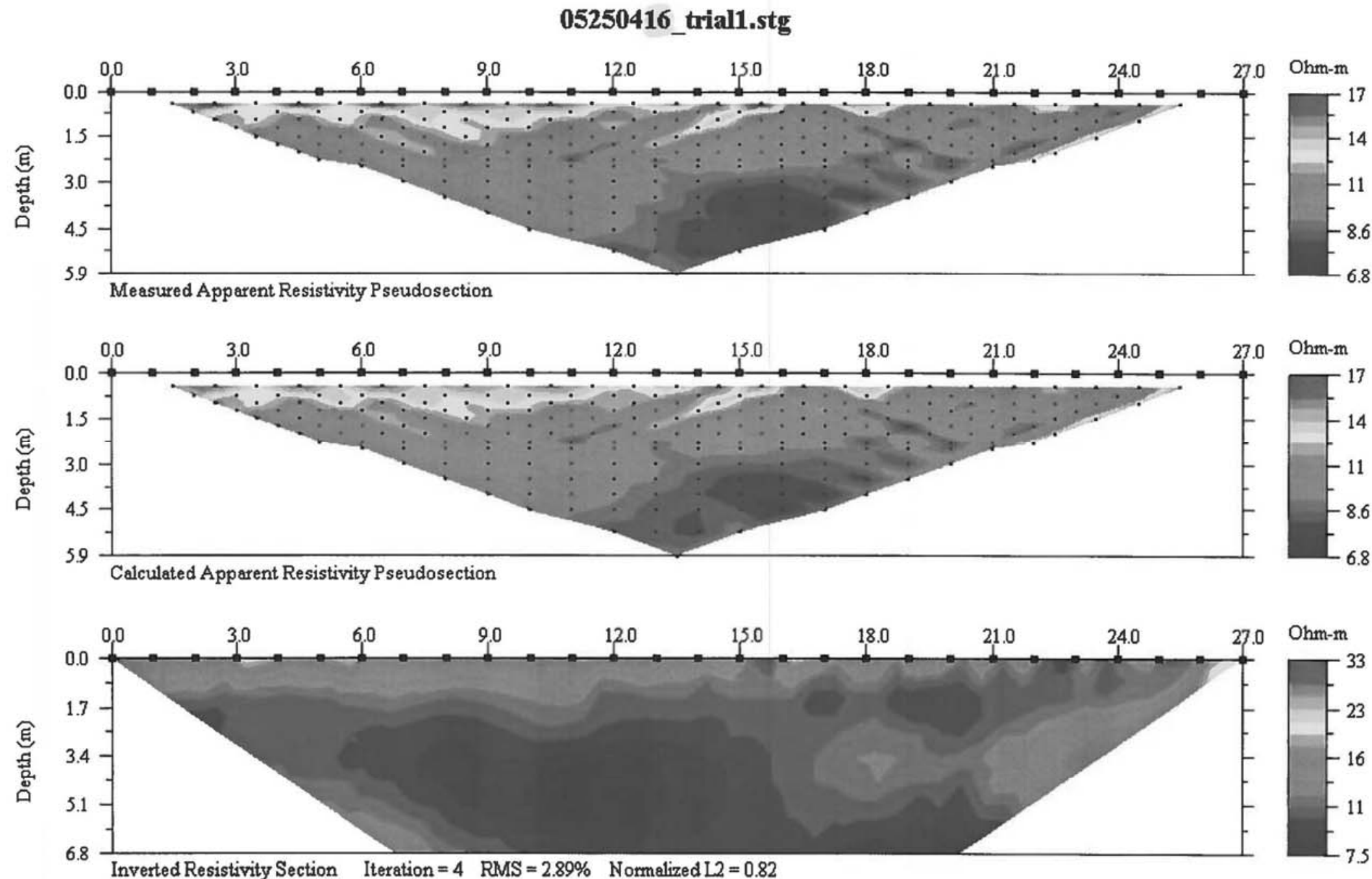

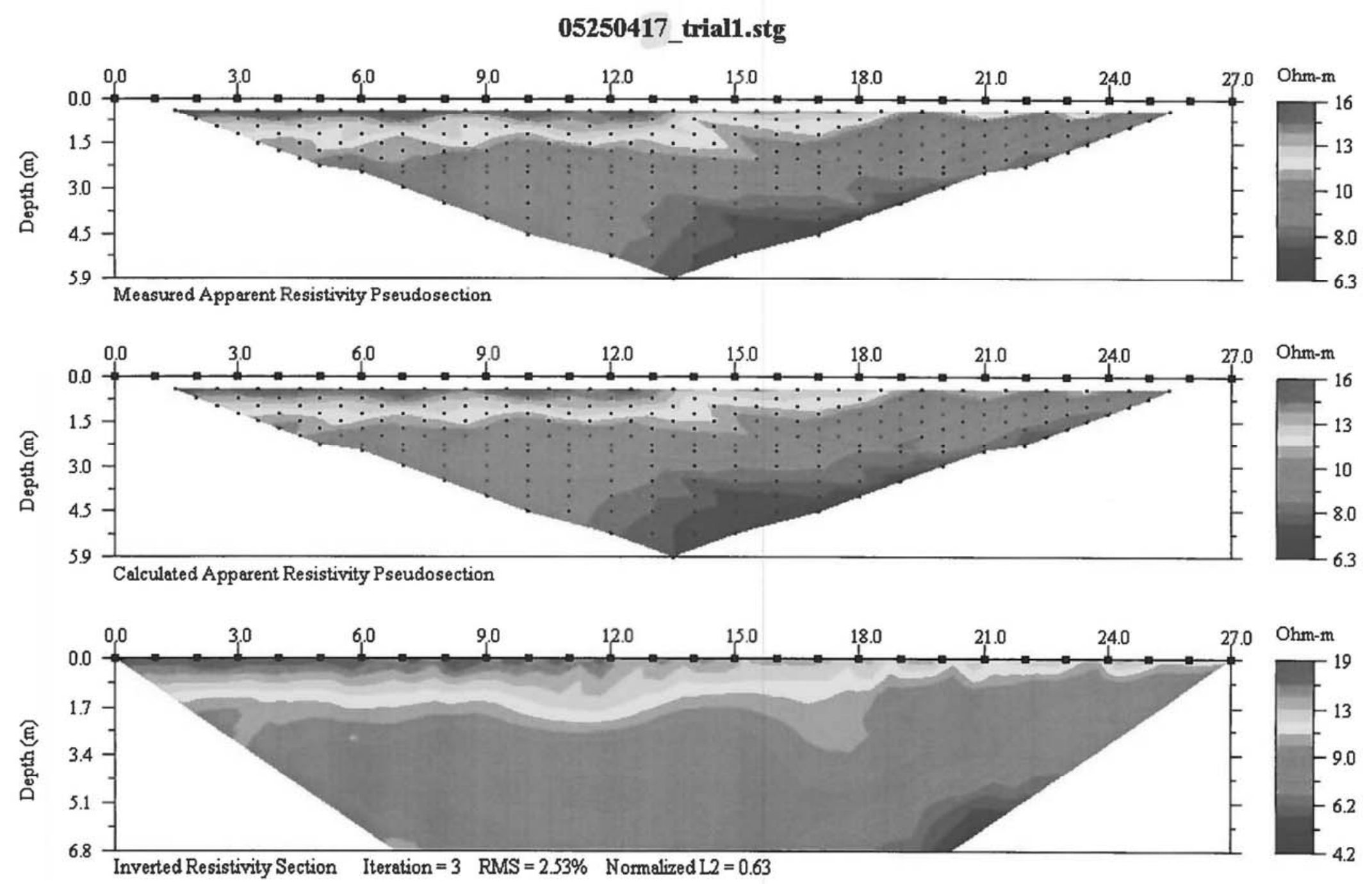

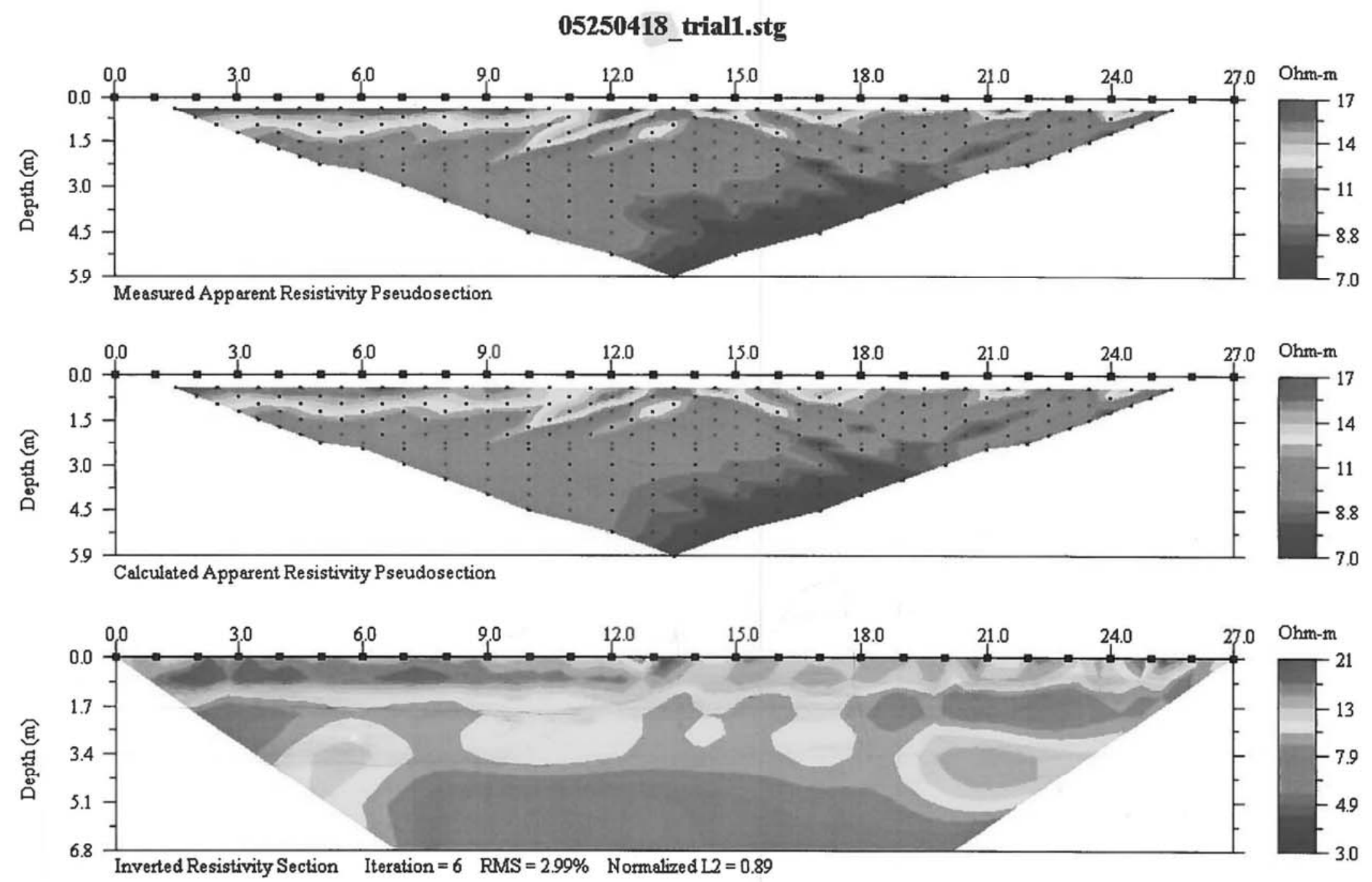


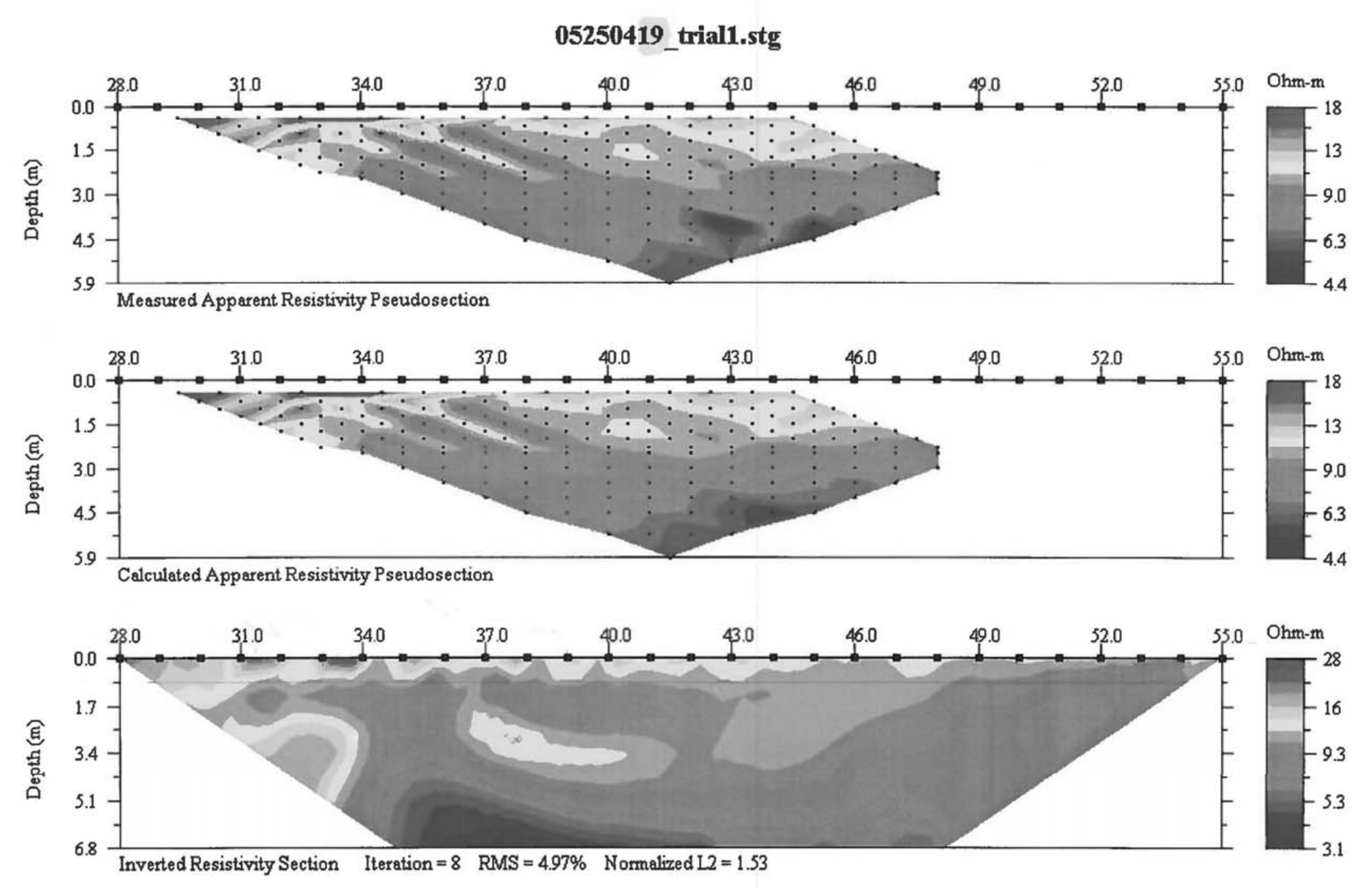

CTRC Technical Report Nos. 42568 (106760) and 211462 
This page intentionally left blank. 


\title{
APPENDIX D: \\ PHYTOLITH AND BIOGENIC SILICA ASSESSMENT OF SELECT SEDIMENT SAMPLES FROM 41BL278
}

\author{
Prepared for:

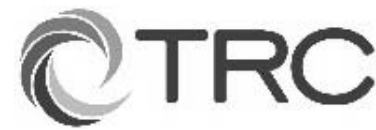 \\ TRC Environmental Corporation \\ 505 East Huntland Drive, Suite 250 \\ Austin, Texas 78752 \\ Prepared by: \\ J. Byron Sudbury, Ph.D. \\ J.S. Enterprises, Inc. \\ Ponca City, Oklahoma 74602 \\ jschemistry@hotmail.com
}


This page intentionally left blank. 
APPENDIX D: PHYTOLITH AND BIOGENIC SILICA ASSESSMENT OF SELECT SEDIMENT SAMPLES FROM 41BL278

\author{
J. Byron Sudbury, Ph.D.
}

\section{D.1 SUMMARY}

Four sediment samples were processed for phytolith recovery and analysis. Overall phytolith preservation was very poor due to the basic $\mathrm{pH}$ environment of the Venus clay loam soil matrix which resulted in extensive phytolith chemical weathering with apparent preferential dissolution of the smaller but very important Poaceae short cell phytoliths. Bulliform cell phytoliths did survive, but generally were very weathered. No diatoms or statospores were observed, although sponge spicules were recovered from all four samples. Carbonate deposits containing root impressions were present in the sand fraction, emphasizing the calcic nature of the soil. The calcic soil preserved snail specimens which were recovered.

\section{D.2 INTRODUCTION TO PHYTOLITHS AND BIOGENIC SILICA}

Phytoliths form as a byproduct of plant water transport. When soil pore water is absorbed by plant roots, silicon along with other dissolved ions also enter and are distributed throughout the plant. As water is lost via evapotranspiration from the leaves, silicon becomes trapped in the plant cells. As silicon accumulates in the cells, it gradually solidifies and in many cases is preserved in the shape of the plant cell in which it formed. When the plant dies and decays, the inorganic silicon--in the form of $\mathrm{SiO}_{2} \bullet n \mathrm{H}_{2} \mathrm{O}$--becomes a mineral component of the soil's silt fraction. Thus, the assemblage of siliceous plant cell casts, or phytoliths, become a microfossil record of the plant community living in that location at that time. (Pearsall 2000; Piperno 1988, 2006).

The same precipitated silicon species also occurs in several other organism types which--when recovered in soil are generally referred in aggregate as biogenic silica. Besides phytoliths, of the other forms (i.e., siliceous sponge spicules, statospores, diatoms, and radiolarians)--only sponge spicules were recovered from 41BL278.

Although the various forms of biogenic silica are chemically the same, they may vary in their water content (which is denoted by the " $n$ " in the above formula). This matrix water variation in turn leads to variation in particle density, with a density range from about 1.50 to $.30 \mathrm{~g} / \mathrm{cm}^{3}$ (Piperno 2006:15). This particle density difference does not affect biogenic particulate recovery as the heavy liquid solvent used to recover the phytoliths and other biogenic silicas is $2.35 \mathrm{~g} / \mathrm{cm}^{3}$, so the entire range of lighter particle densities are recovered together in a single fraction. However, variation in phytolith density is extremely important in soil particle stability as different density particles dissolve at different rates when incorporated in a caustic pH environment (Iler 1979:46-47; Sudbury 2014a). It turns out this pH sensitivity is very important in the sediment samples examined from 41BL278.

\section{D.3 SAMPLE PREPARATION}

The samples (Table D - 1) were transferred to 250 milliliter glass jars (Figure D-1), oven dried, and dry soil weights obtained. The samples were then shaken vigorously in a sodium hexametaphosphate solution [a discontinued Calgon ${ }^{\circledR}$ formulation] for 24 hours. The samples were allowed to settle and come to room temperature, and then the initial mixture of suspended silt and clay was removed by decanting into a settling columns. Then, using settling times calculated via Stoke's Law, each sand-containing 
Table D-1. $\quad$ Sediment Samples from 41BL278.

\begin{tabular}{|c|c|c|l|l|l|l|l|l|l|l|}
\hline $\begin{array}{c}\text { JSE Lab } \\
\text { Sample } \\
\text { Number }\end{array}$ & $\begin{array}{c}\text { MQ's } \\
\text { Sample } \\
\text { No. }\end{array}$ & Block & Unit & Level & $\begin{array}{c}\text { Depth } \\
\text { (cmbs) }\end{array}$ & $\begin{array}{c}\text { Feat. } \\
\text { No. }\end{array}$ & PNUM & $\begin{array}{c}\text { Cat. } \\
\text { No. }\end{array}$ & $\begin{array}{c}\text { Ext. } \\
\text { No. }\end{array}$ & Comment \\
\hline MQ14-6 & 1 & BT 8 & 2 & 16 & $152-155$ & & 0008 & 004 & 1 b & control \\
\hline MQ14-7 & 2 & BT 9 & 5 & 14 & 143 & 3 A & 0503 & 004 & $1 a$ & S4; N13 E89; from under BR4 \\
\hline MQ14-8 & 3 & BT 9 & 7 & 18 & 173 & 7 & 0507 & 004 & $2 a$ & S2, N30 E51; from under BR2 \\
\hline MQ14-9 & 4 & BT 9 & 6 & 17 & 165 & 8 & 0508 & 004 & 1 a & S1; N35, E95; from under BR1 \\
\hline
\end{tabular}

sample fraction was repeatedly remixed, allowed to settle, and decanted until all of the silt and clay components were decanted and pooled in settling columns. The clean sand fractions were then oven dried, weighed, and photographed (Figure D-2) and transferred to glass Petri dishes for later examination (Figures D-5).

After three days initial settling, $\sim 80 \%$ of each suspended clay fraction in the silt/clay mixture was decanted into another settling vessel. The residual clay/silt from the bottom $20 \%$ of each mixture was then quantitatively transferred to a 250 glass jar for the remaining particle separation steps. Again using particle settling times based on Stoke's Law, regular remixing and decants of the suspended clay $(\sim 80 \%$ of the mixture volume) were removed and pooled for later retrieval and examination. After the liquid phase over the settled silt fraction was clear, the final liquid removal was performed by aspiration in order to remove as much water as possible without disturbing the sediment bed (Figure D-6). A white upper layer of variable thickness-- presumed to contain carbonate-was visible in all settled sample silt fractions. Rather than dissolving the carbonate at this stage of preparation, the samples were oven dried, weighed, transferred to crucibles for organic constituent removal, and treated in a muffle furnace at $535^{\circ} \mathrm{C}$ overnight to remove organic materials.

Next, the ashed silt fractions were transferred to $50 \mathrm{ml}$ plastic centrifuge tubes. The lower density phytolith fractions were separated from the quartz-based silt matrix using a $2.35 \mathrm{~g} / \mathrm{cm}^{3}$ zinc bromide solution. The recovered lower density particulate fraction was pooled for each sample, and once sequential flotations of the parent silt sample did not produce any more particulate material, water was added to the isolates to dilute the liquid density to below $1.50 \mathrm{~g} / \mathrm{cm}^{3}$, and the particulate was recovered via centrifugation. The centrifuge pellets were rinsed multiple times to remove residual zinc bromide, and then oven dried and weighed. Hydrochloric acid (10\%) was used to test for carbonate carryover into the isolated phytolith fraction (Figure D-7) Carbonate was present, so all sample phytolith fractions were acid treated, remixed, centrifuged, and the clear acid phase removed via Pasteur pipet until no more microscope slides of the phytolith isolates were prepared mounting 1-2 mg of sample phytolith/biogenic silica isolate in Canada Balsam as illustrated elsewhere (Sudbury 2011a:5053). The slides were cured in a $35^{\circ} \mathrm{C}$ incubator for several weeks, at which time the balsam at the cover slip edges had set sealing the slides. The slides were then scanned at 500x while counting particles and rolling particles as needed for clearer discernment. Due to low phytolith counts and obvious poor particle preservation (Table D-2), the slides were also rescanned entirely at $100 \mathrm{x}$ to search for significant specimens that may have been overlooked if they had been between $500 \mathrm{x}$ scan transects. A number of sponge spicules and spicule sections were noted during the $100 x$ scans. 


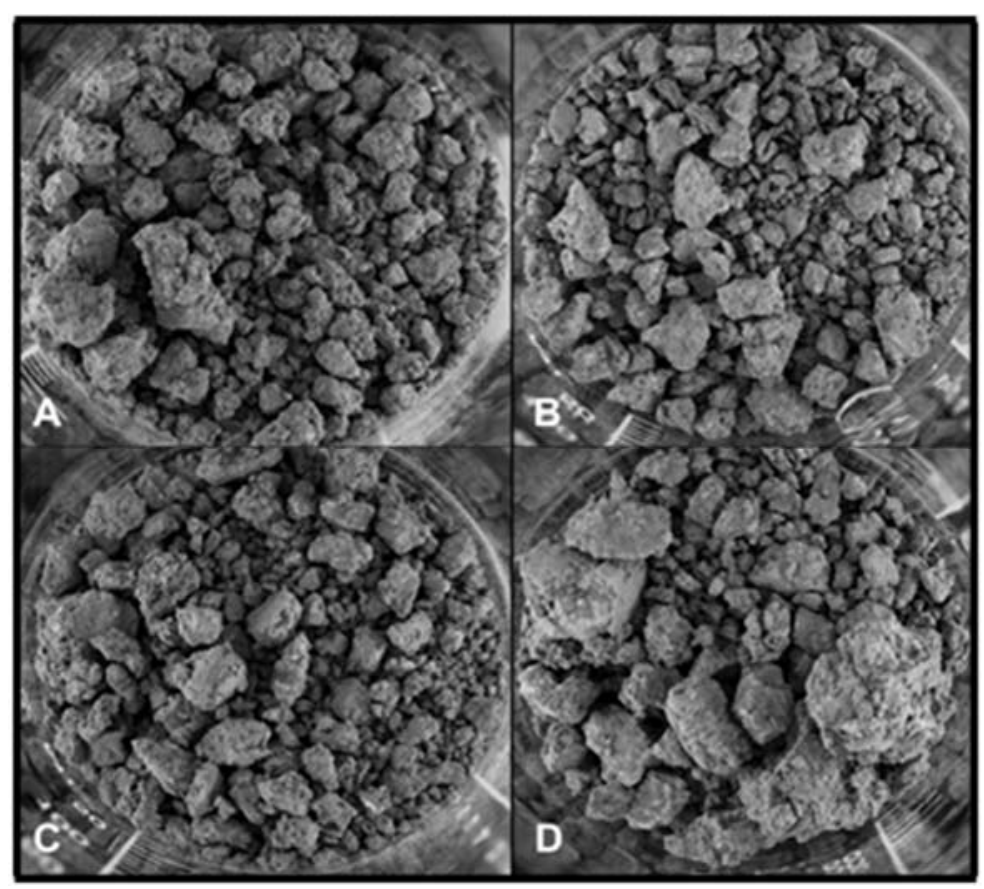

Figure D-1. Oven dried soil samples before disaggregation (41BL278). A = Sample 6; $B=$ Sample 7; C = Sample 8; and D = Sample 9 (Sample identities in Table D-1).

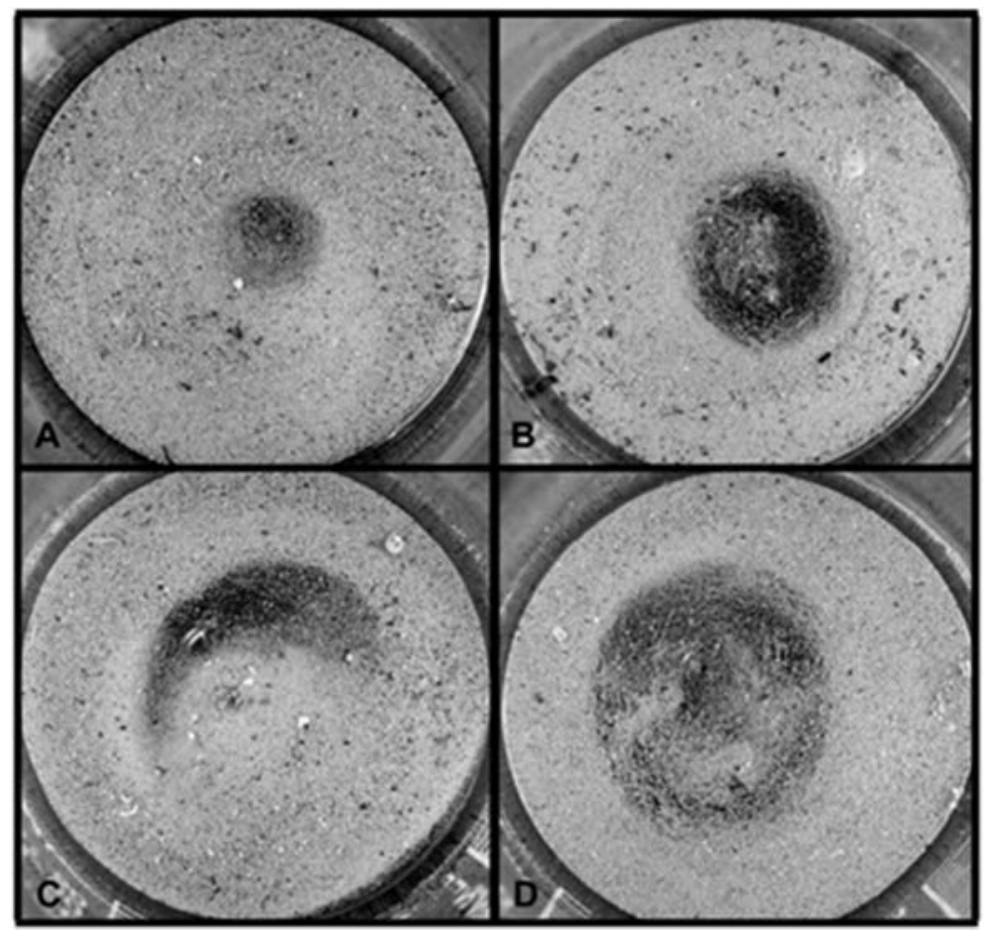

Figure D- 2. Isolated sand fractions (41BL278). A = Sample 6; B = Sample 7; C = Sample 8; and D = Sample 9 (sample identities in Table D-1). [Jar internal diameters are 2.2 inches. The domed glass bottoms show in the center of the jars. The faint yellow marks in $C$ and $D$ are reflection of the camera flash.] 


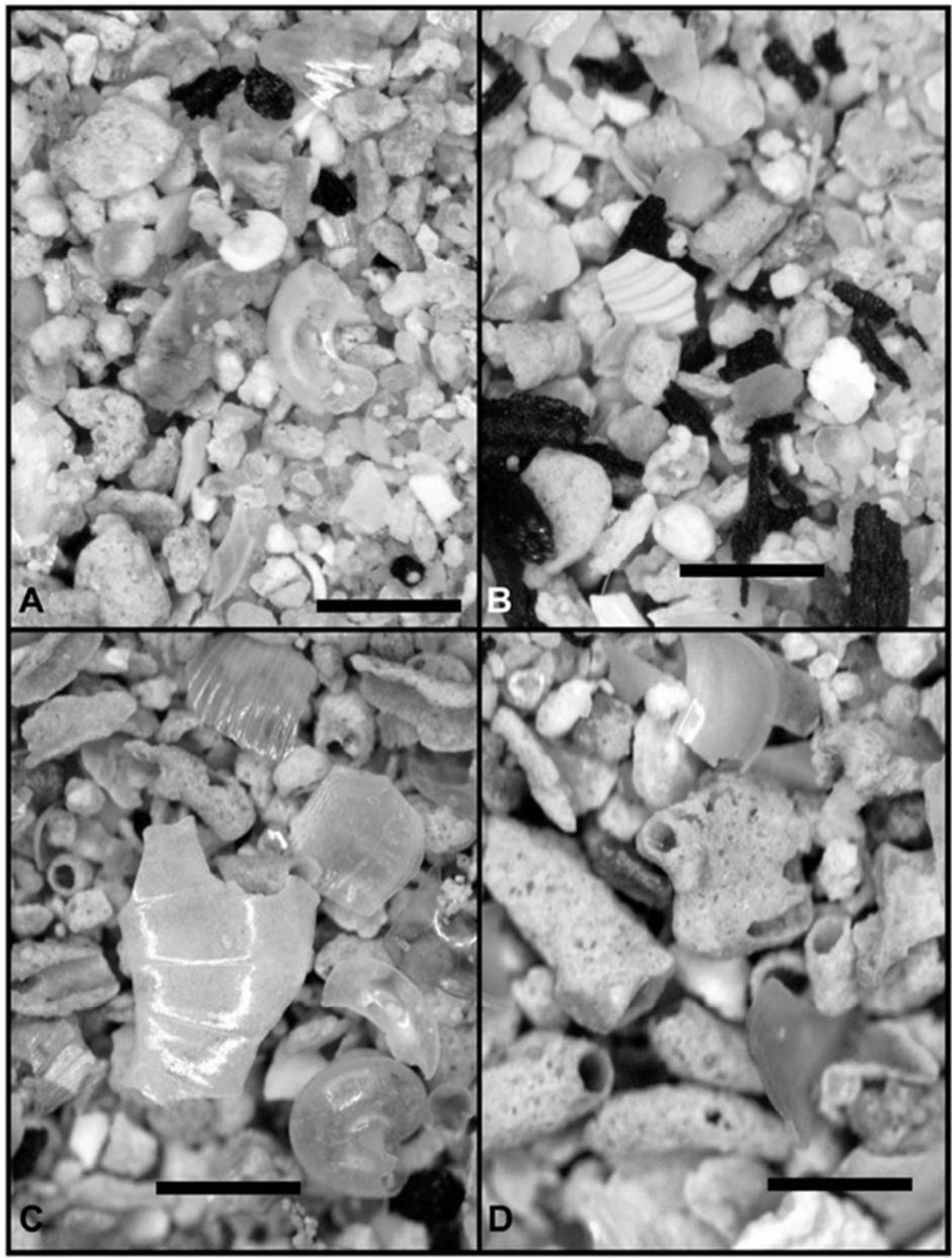

Figure D-3. Carbonates, snails, charcoal, and other particles present in the sand fractions (41BL278). A = Sample 6; B = Sample 7; C = Sample 8; and D = Sample 9 (Sample identities in Table D-1). Bar scales $1 \mathrm{~mm}$. 


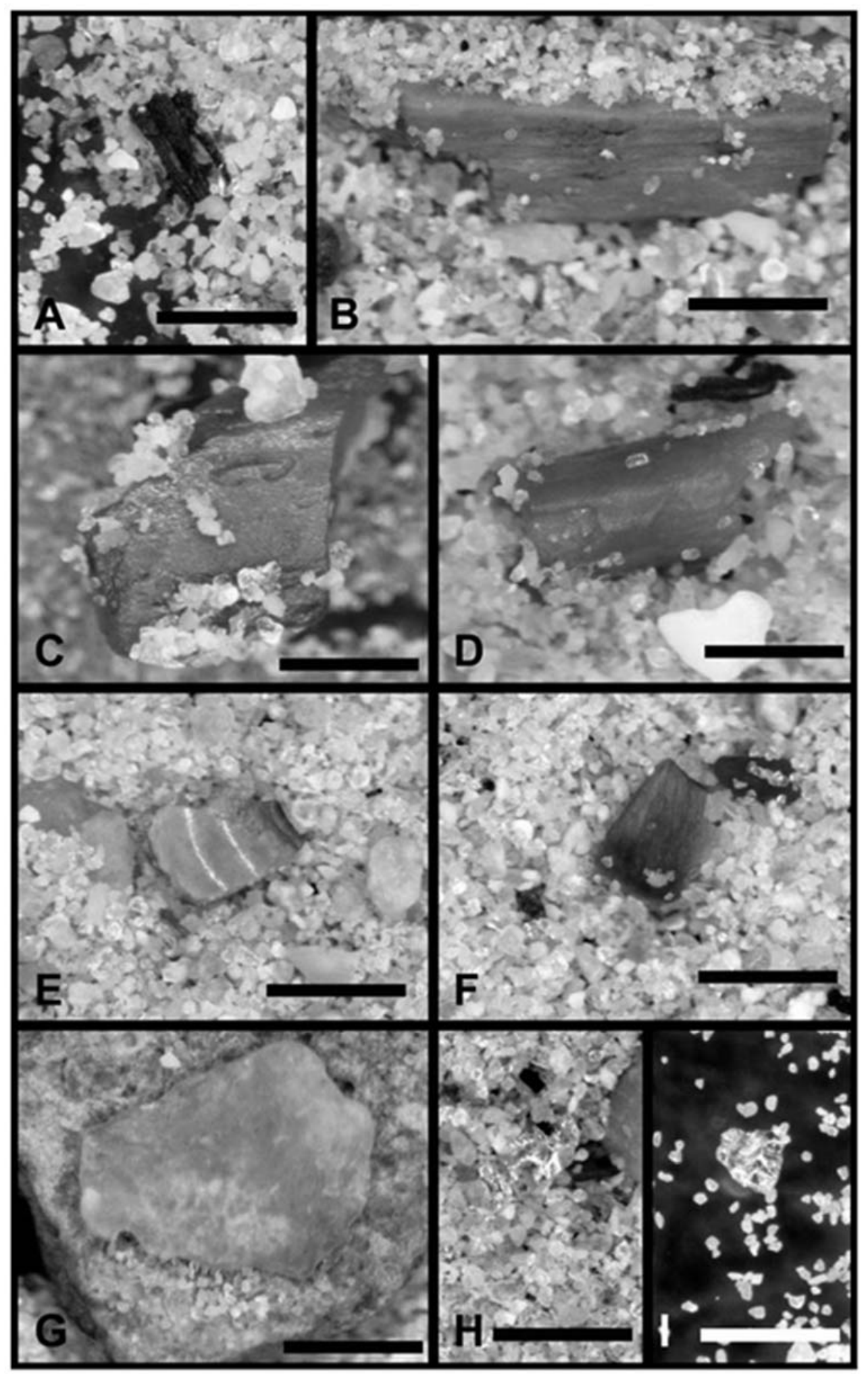

Figure D- 4. Debris observed in the 41BL278 sand fractions (charcoal, bone, burned shell, and lithics). A = charcoal; B-D = bone, E-F = burned shell, and G-I = lithic material. Sample $6=\mathrm{A}-\mathrm{C}$;

Sample 7 = D-H; and Sample 9 = I (Sample identities in Table D-1). Bar scales are 1 mm. 


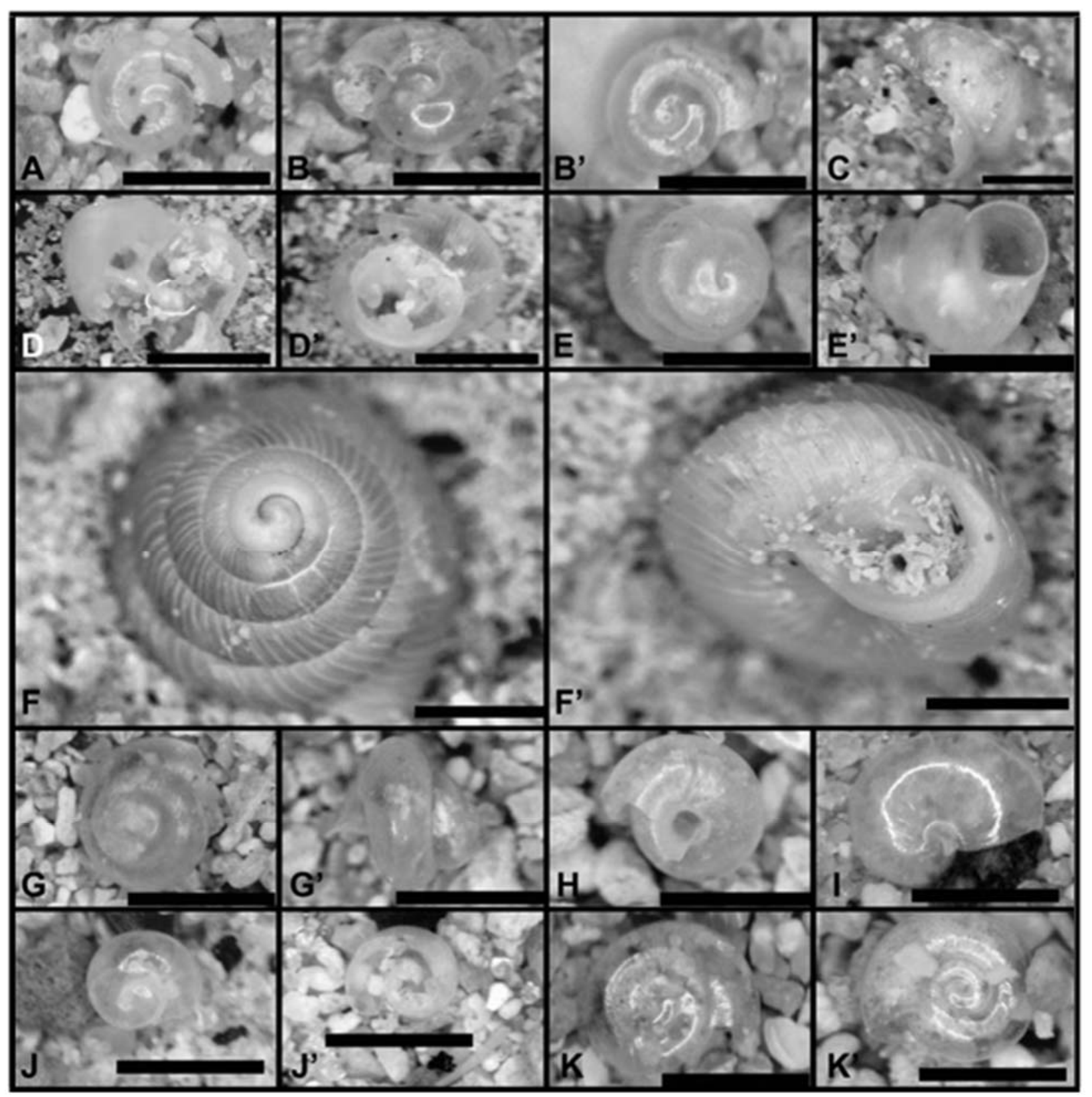

Figure D-5. Snails recovered from the 41BL278 sand fractions shown in Figure D-2. A-D = Sample 6; E = Sample 7; F-H = Sample 8 [specimen F is visible in Figure D-2C at $\sim 1: 30$ near the jar wall; specimen $G$ is also illustrated in Figure D-3C, bottom right corner], and I-K = Sample 9

(Sample identities in Table D-1). Bar scales are $1 \mathrm{~mm}$. 


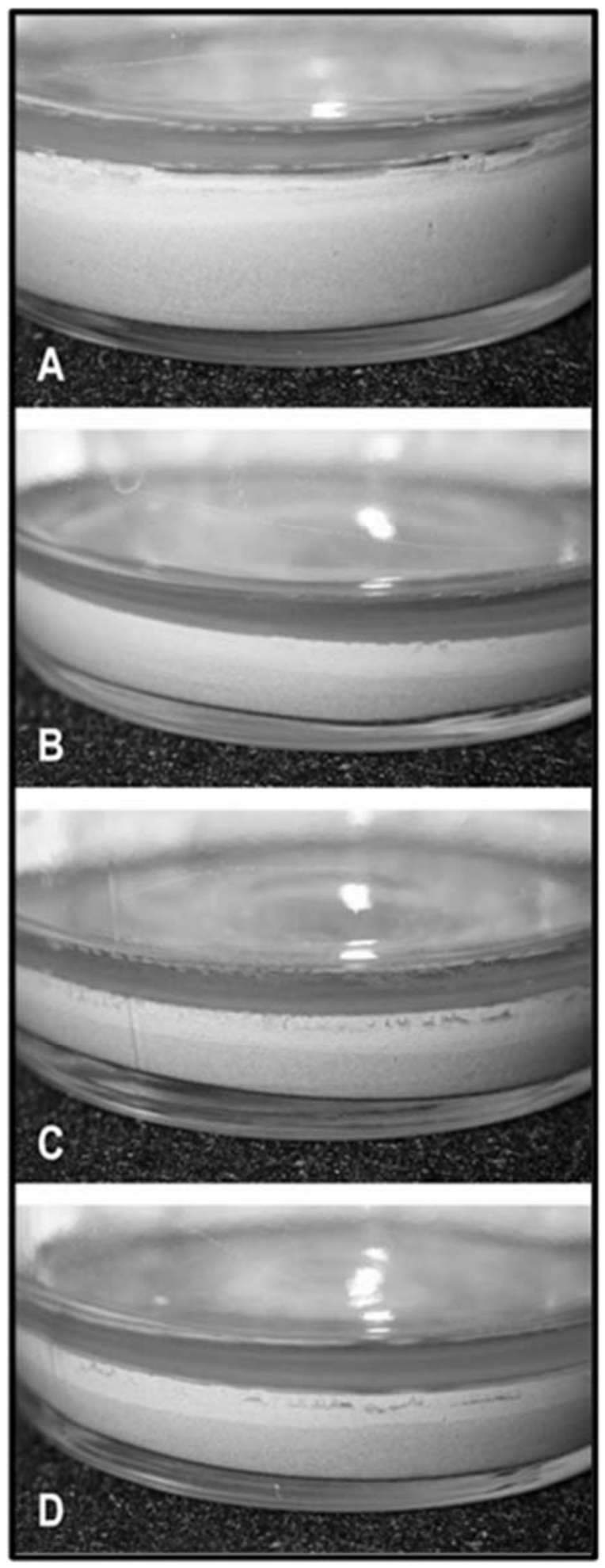

Figure D - 6. Silt sample fractions after clay known to be removal (41BL278). The top gray layer is due to the presence of residual water. The lower gray layer is quartz silt, and intermediate lighter layer is carbonate. $A=$ Sample 6; B = Sample 7; C = Sample 8; and D = Sample 9 (sample identities in Table D-1). 


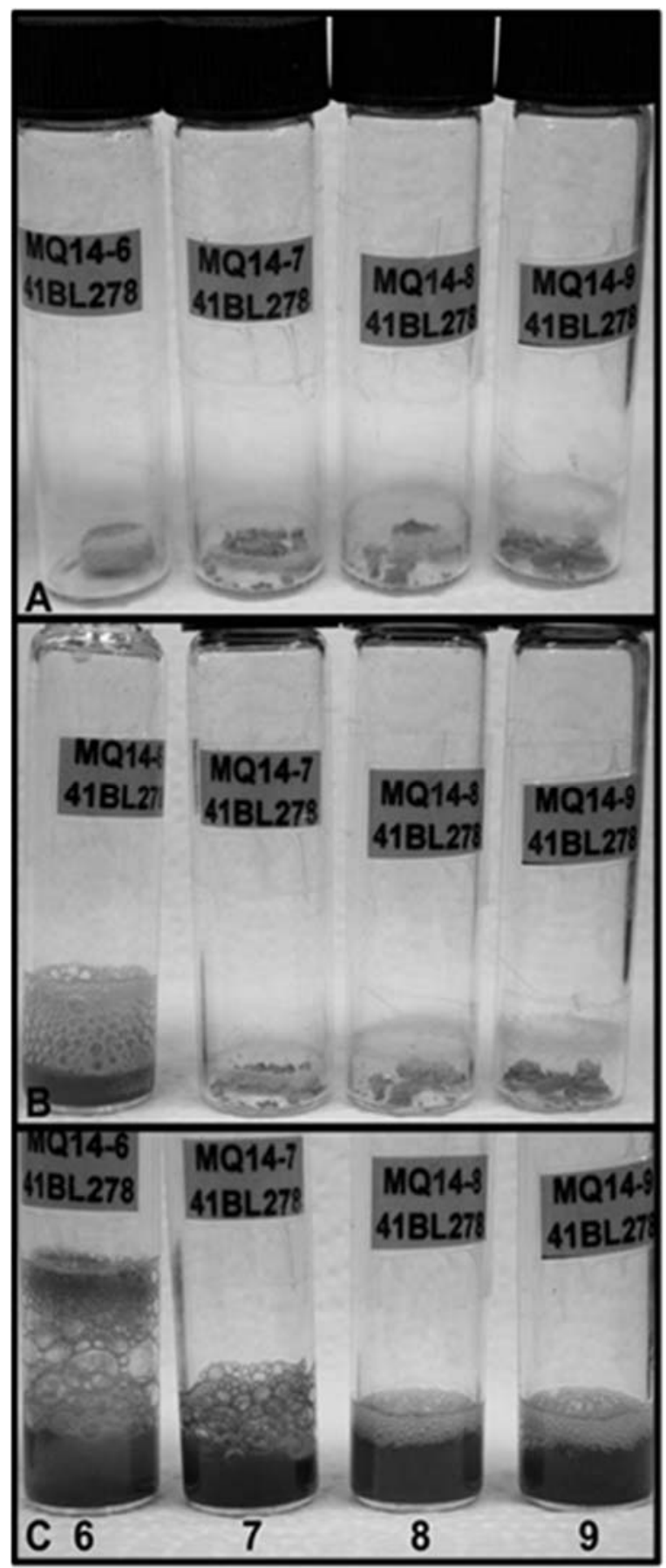

Figure D-7. Carbonate removal from mination performed here, so that phytolith fractions in 8 $\mathrm{ml}$ vials (41BL278). Difference may have adversely affected $A=$ dried sample phytolith fractions from the textural determination. Very low flotation. $B=$ hydrochloric acid added to phytolith concentrations was present. Sample 6. $C=$ hydrochloric acid added to all samples showing effervescence (sample identities in Table D-1). 


\section{D.4 RESULTS}

\section{D.4.1 Sand Fractions}

The four sample over-view shots in Figure D 3 show the general range of sand-size particle types observed in these samples. After quartz sand, the most abundant component appeared to carbonate. In all samples, evidence of at least a portion of the carbonate deposits having formed around roots was apparent (most readily seen in Figure D-3D). There were also abundant shell (most likely all from snails) and charcoal, as well as some burned shell and bone fragments, as well as lithic debris (Figure D-4) and whole snail specimens (Figure D-5).

Figure D-4 shows examples of some of the cultural debris observed in the sand fractions: charcoal (Figure D-4A), bone fragments (Figure D-4B-D), burned shell fragments (Figure D-E-F), lithic material and other stone (Figure D-G), and possible quartz microflakes (Figure D-4H-I). Although some of the apparent pieces of quartz present in the samples looked like shatter (angular pieces of variable thickness), these micro-specimens appeared to have bulbs of percussion on them. Due to clarity and small size, the quartz flakes are very difficult to locate, examine, and to photograph.

\section{D.4.2 Silt Fractions}

After the clay was removed from the silt by decanting and aspiration, the remaining silt had two strata beneath the residual water (Figure D-6 [color variation may possibly be due to camera settings]). In all cases, there is a lower darker colored layer (grayish), with an upper light colored near-white layer. Although both layers are components of the silt fraction--which is a definition based on particle size--the darker bottom portion is quartz-based silt, and the upper lighter portion [likely finer particles so they settle more slowly in the silt fraction] is predominantly carbonate. This carbonate is the "fine" version of the same abundant material noted in the nodular carbonate fragments observed in the sand fractions (Figure D-2). Although calcium carbonate $(2.83 \mathrm{~g} / \mathrm{cm} 3)$ is denser than quartz-based sand (2.65 $\mathrm{g} / \mathrm{cm} 3$ ), the carbonate [and possibly other minerals] settled on top of the quartz-based silt as the carbonate is smaller size particles. [Stoke's Law settling calculations are based on the nonrealistic assumptions of sphericity and uniform density--both assumptions which are not $100 \%$ correct in this application]. It is probable that there are also larger carbonate particles present in the darker gray zone, but this was not tested.

The most important ramification of these observed layers is that both isolated textural fractions--the sand and silt-- contain a high carbonate content. This -along with the accompanying basic $\mathrm{pH}-$ - deleterious to good phyto- survival in a basic $\mathrm{pH}$ matrix (Iler 1979:41-47; Piperno 2006:22; Sudbury 2014a).

Carbonate removal was performed on the entire silt fraction in a recent sample suite (Sudbury 2014a), which took a very prolonged time to successfully execute. In processing this current sample batch, the silt fraction--including carbonate-- remained intact following thermal organic removal. The resulting isolates are shown following flotation, phytolith fraction isolation, recovery, and drying (Figure D-7A). Ten percent hydrochloric acid was added to Sample 6 (Figure D-7B) which resulted in effervescence indicative of carbonates having been recovered along with the phytoliths. Thus, the remaining three samples were also acid treated (Figure D-7C). The samples were reacted, centrifuged, the clear spent $\mathrm{HCl}$ removed and replaced with fresh $\mathrm{HCl}$, and the sample remixed. These acidification and clean-up steps were repeated until no effervescence resulted. Then the remaining solids were rinsed with distilled water and centrifuged five times to remove any residual acid. Based on weight loss, more than two- thirds of the original isolated "phytolith" fraction weight turned out to be carbonate (Table D-2). 
Table D-2. Soil Texture and Phytolith Soil Concentrations (41BL278).

\begin{tabular}{|c|c|c|c|c|c|c|c|}
\hline \multirow{2}{*}{$\begin{array}{l}\text { JSE Lab } \\
\text { Sample No. }\end{array}$} & \multirow{2}{*}{$\begin{array}{l}\text { Depth } \\
\text { (cmbs) }\end{array}$} & \multirow{2}{*}{$\begin{array}{c}\text { Feature } \\
\text { No. }\end{array}$} & \multirow{2}{*}{$\begin{array}{l}\text { Sample } \\
\text { wt. (g) }\end{array}$} & \multirow{2}{*}{$\underset{\%}{\operatorname{Sand}}$ wt. } & \multirow{2}{*}{ Silt wt. \% } & \multicolumn{2}{|c|}{ Phytolith Fraction (wt. \% of soil) } \\
\hline & & & & & & with CO present & with CO removed \\
\hline MQ14-6 & $152-155$ & control & 47.88 & 10.2 & 54.2 & 0.23 & 0.07 \\
\hline MQ14-7 & 143 & $3 \mathrm{~A}$ & 20.64 & 11.9 & 54.2 & 0.22 & 0.04 \\
\hline MQ14-8 & 173 & 7 & 28.68 & 11.6 & 51.9 & 0.14 & 0.03 \\
\hline MQ14-9 & 165 & 8 & 27.18 & 11.7 & 52.8 & 0.08 & 0.04 \\
\hline
\end{tabular}

Since the carbonate was never removed from the sand fractions, the intact silt and sand fraction weights were recorded as the textural component weights. Gravi-metrically, all four samples are classified as silty clay loams--which is a slightly higher silt content than anticipated based on USDA soil data. However, USDA soil textural analysis is based on hydrometer measurements vs. the gravimetric deter-

All decanted clay fractions were recovered and examined before storage. Three clay fractions were collected based on the settling procedure and container volumes used. The original decant from the two liter bottle containing the original silt/clay mixture decanted from the sand was kept separate from the later decants performed during final removal of the clay from the silt. The material that initially settled from the original decant was also kept separate from the larger volume of the first clay solution. Two of these "settled" clay fractions are illustrated in Figure D-8 due to their strikingly different appearance. The amount of soil sample 6 that was processed was $76 \%$ larger soil sample than Sample 9; however, the difference between the Sample 6 clay volume fraction and Sample 9 clay fraction is larger than that difference (Figure D-8). Even more striking are the additional banding of strata present in Sample 6 that are not visible in Sample 9. The cause of this difference has not been determined, but as the total percent clay content of the parent samples is approximately the same, the observed differences are almost certainly at least in part a reflection of differences in clay particle size and/or composition between the two samples. The slight difference in phytolith recovery (preservation status?) between these samples suggests that the samples may also contain different carbonate levels (or at least a different effective soil $\mathrm{pH}$ ), and/or possible differences in water flow or soil permeability.

\section{D.4.3 Phytoliths}

Phytolith recovery was very low (Table D-2), with short cells in particular being in very short supply in all samples [the sample counts were each less than 50 short cells; the bulliform counts were 3-20x higher in each sample]. Not enough

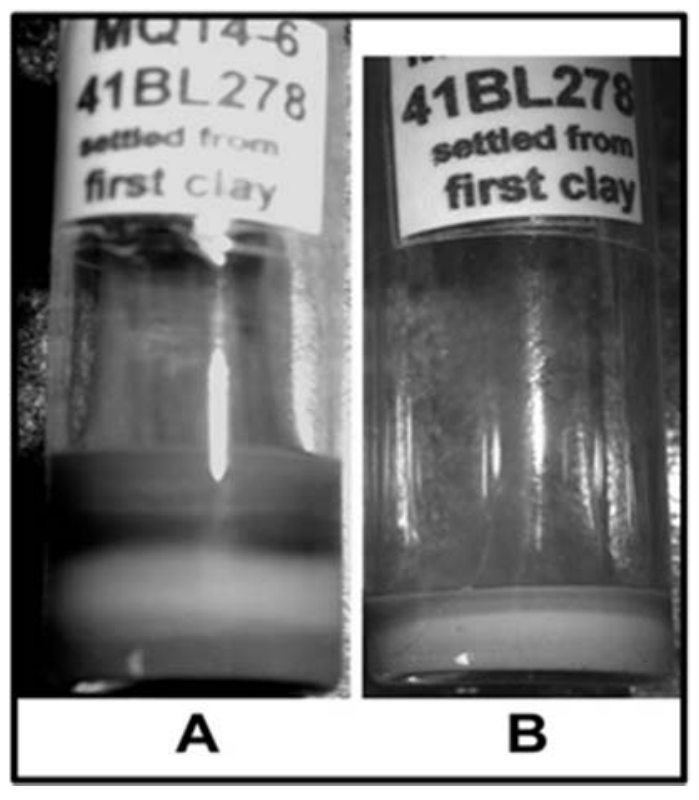

Figure D-8. Sedimentation of decanted clay fractions (41BL278). A = Sample 6; B = Sample 9. (Sample identities in Table D-1). 
short cells were observed to reach minimum count required criteria (Strömberg 2009). "Classic" form short cell phytoliths are shown in Figure D-9. The larger crenate forms show some evidence of surface damage that is likely attributable to chemical weathering due to the basic soil environment; this is most noticeable in Figures D-9C, E, and HJ (Sudbury2014a). The smaller panicoid forms with apparent weathering do no show surface pitting nearly as much as what appears to be complete dissolution of parts of the particles (c.f., Figures D-9L-N, P-R, V, and W). Many of the very uncommon Aristida lobate (Figure D-9Z) and saddle phytoliths (Figure D-9BB) also show evidence of what is likely partial particle dissolution.

Although a number of elongate forms were present (Figure D-10D and M), by far the most abundant phytolith form present in the samples were the bulliform cells (Figure D-10). Although some particles were in fairly good state of preservation, most bulliform and elongate cells showed varying degrees of particle damage--again most likely attributable to partial dissolution due to the basic $\mathrm{pH}$ environment in the calcic soil. Looking at the specimen in Figure D-10I, it is not hard to envision a root growing adjacent to the particle, and the more basic $\mathrm{pH}$ environment immediately surrounding the root contributing to dissolution of the portion of the phytolith that it was in contact with.

Phytoliths generally attributed to trees were in much better condition (Figure D-11). Tracheid elements (Figure D-11A through D), spiny spheroids (Figure D-11E through G), and angular phytoliths (Figure D-11H through R) were all in a good state of preservation. Some of the angular phytoliths show some surface pitting from weathering (Figure D-11I, O, and Q), but overall the tree origin phytoliths are in better shape than the short cell and the bulliform cell phytoliths.
Some of the very large biogenic silica fragments recovered at 41BL278 are more sheet- like and, based on their darkened appearance, show evidence of being burned (Figure D-12); these are likely derived from molten or semi-molten biogenic silica from grass and/or tree origin. Most of these particles (all except Figure D-12G) show more evidence of surface pitting than the specimens in Figure D-11. This enhanced surface pitting is presumably due to chemical weathering in the soil environment; it is more severe in the overheated specimens (Figure D-12) than in any of the tree angular forms (Figure D-11H trough $\mathrm{R}$ ), but significantly less that observed in the bulliform and elongate cells (Figure D-10A through P). Heating would tend to drive off residual water within the phytolith matrix, increasing its particle density. Thus, this proposed "heating correlates with more chemical weathering" observation based on empirical evidence is in full agreement with the prior observation that higher biogenic particle density is correlated with more rapid particle dissolution in a basic $\mathrm{pH}$ solution (Iler 1979:46-47; see also Sudbury 2014a). This effect likely correlates with particle hydration and thus particle density (ibid.). Natural grassland fires do not generally burn hot enough to melt phytoliths, so a hearth or some other cultural burn is more likely to be the cause of this disfigurement.

The specimen in Figure D-13 is even more exciting--although darkly discolored, the outlines of the presumed plant elongate cells are still clearly visible. They are on the lower side of the particle as mounted on the slide (in focus in Figure D-13A). The weathering process appears to have been more severe on the upper side (Figure D-13A') where clear evidence of the cellular structure are no longer visible except as vague hints. If this mass was against the ground when exposed to heat, the ground side would have likely have been cooler than the side exposed to the heat source. The difference in residual visible 


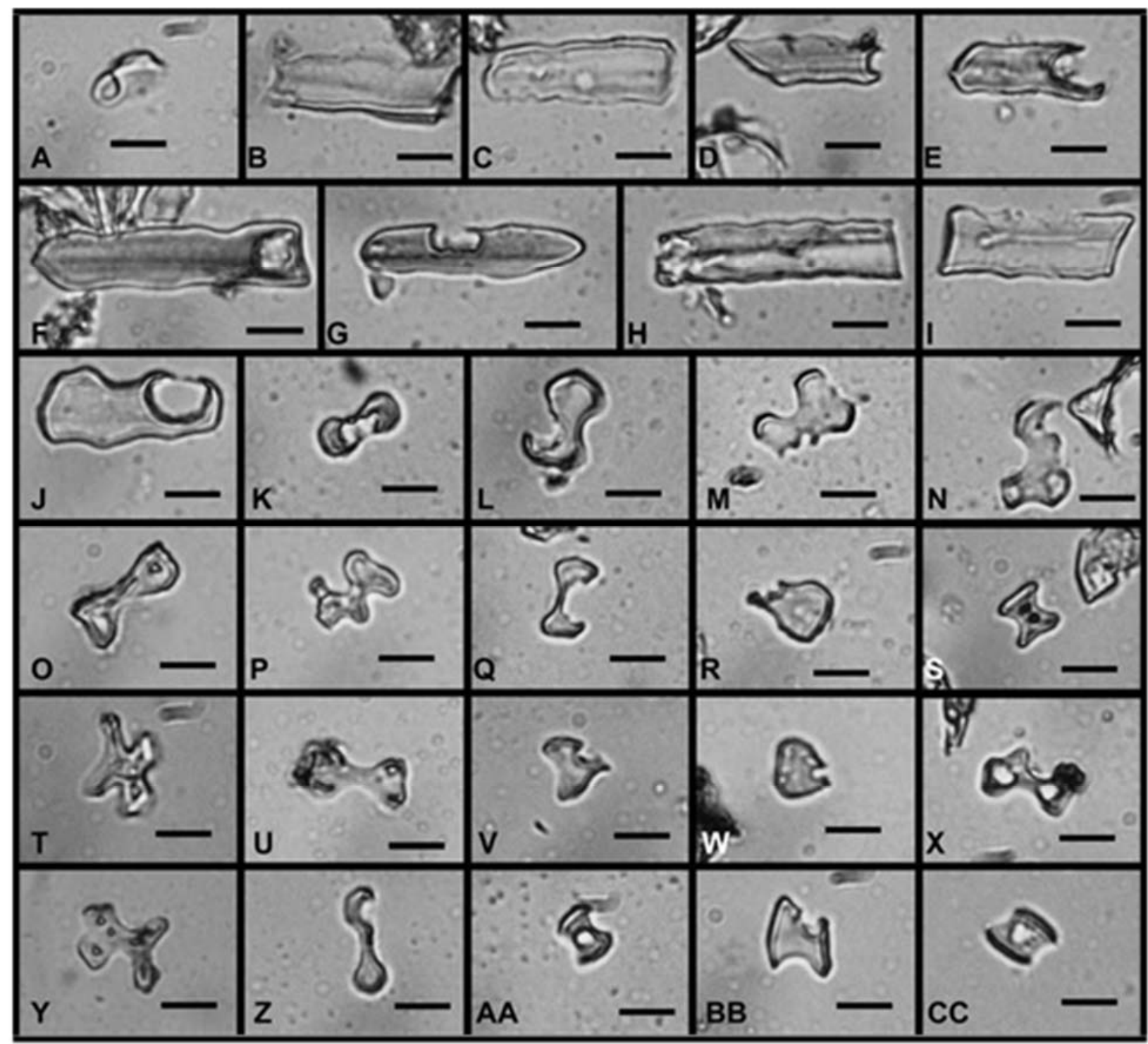

Figure D-9. Short cell Poaceae phytoliths (41BL278). Sample $6=\mathrm{A}-\mathrm{C}, \mathrm{F}, \mathrm{K}-\mathrm{S}$, and Z-CC;

Sample 7 = D-E, G, T; Sample $8=\mathrm{H}$, and U-V; and Sample $9=\mathrm{I}-\mathrm{J}$ and W-Y. Pooids = A-J;

Panicoids = K-Y; Chloridoids = AA-CC. Image $Z$ is an Aristida lobate specimen. Image s E, J, M, $\mathrm{N}, \mathrm{Q}, \mathrm{R}, \mathrm{V}, \mathrm{W}, \mathrm{Z}$, and $\mathrm{BB}$ show damage that appears to be from particle dissolution rather than from mechanical damage/breakage (sample identities in Table D-1). Bar scales are 10 microns. 


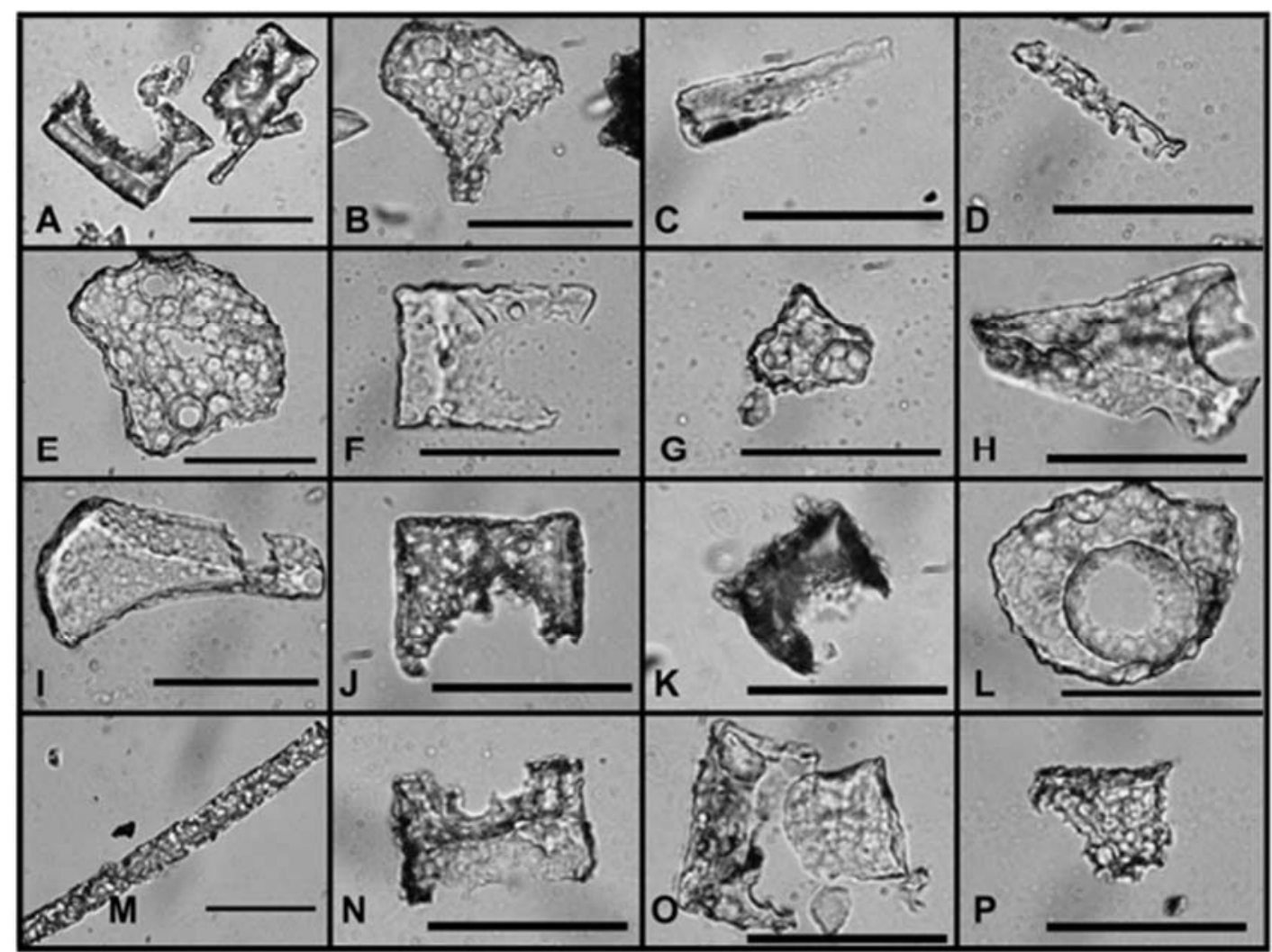

Figure D-10. Chemical weathering of bulliform and elongate phytoliths (41BL278). A = Sample 6; B-D = Sample 7; E-L = Sample 8, and M-P = Sample 9 (Sample identities in Table D-1). Bar scales are 50 microns.

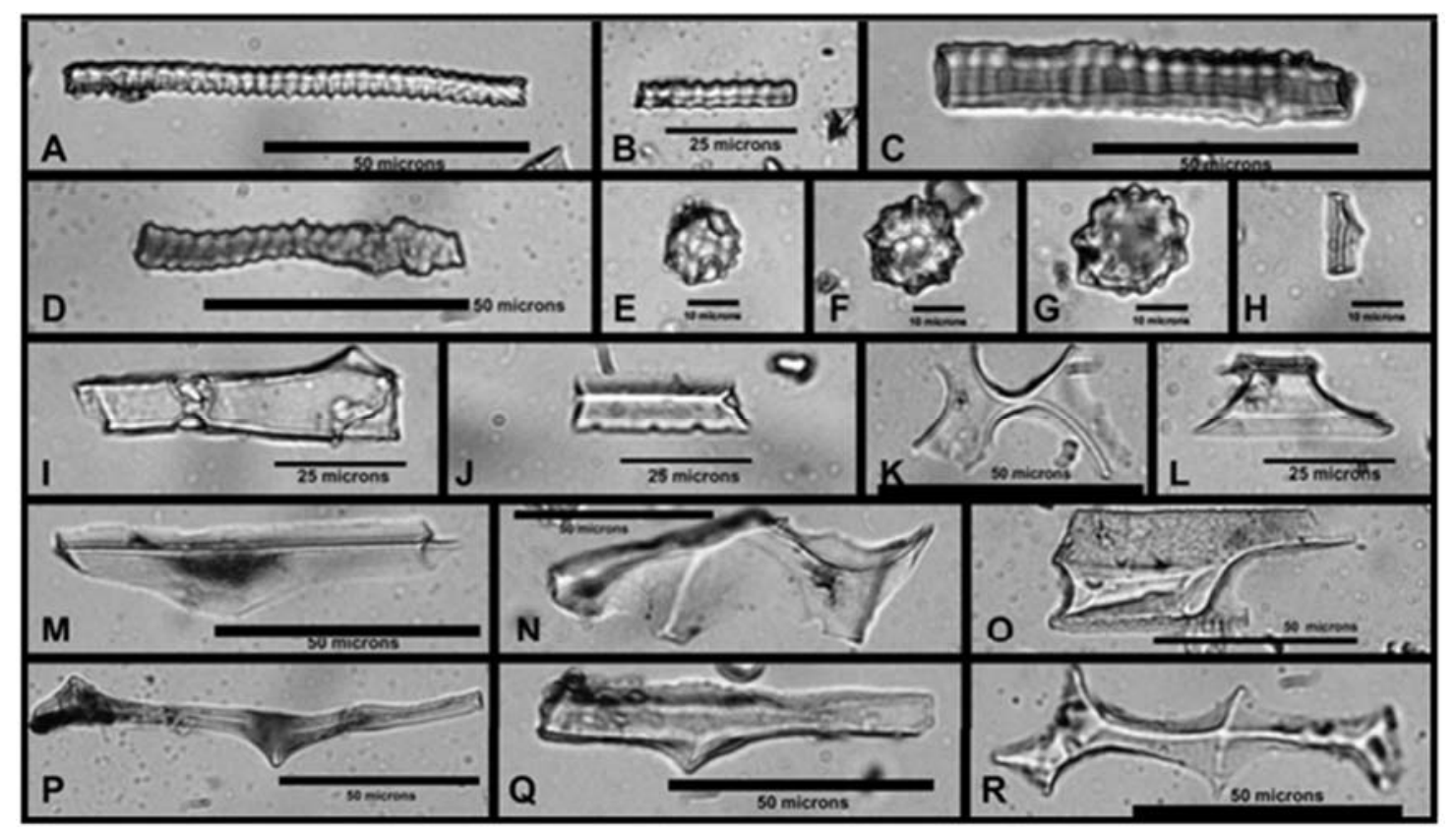

Figure D-11. Tree-related phytoliths (41BL278). Sample $6=$ A, B, E-M; Sample $7=$ C, N-P; Sample 8 = D, Q; and Sample 9 = R (Sample identities in Table D-1). Bar scales as marked. 


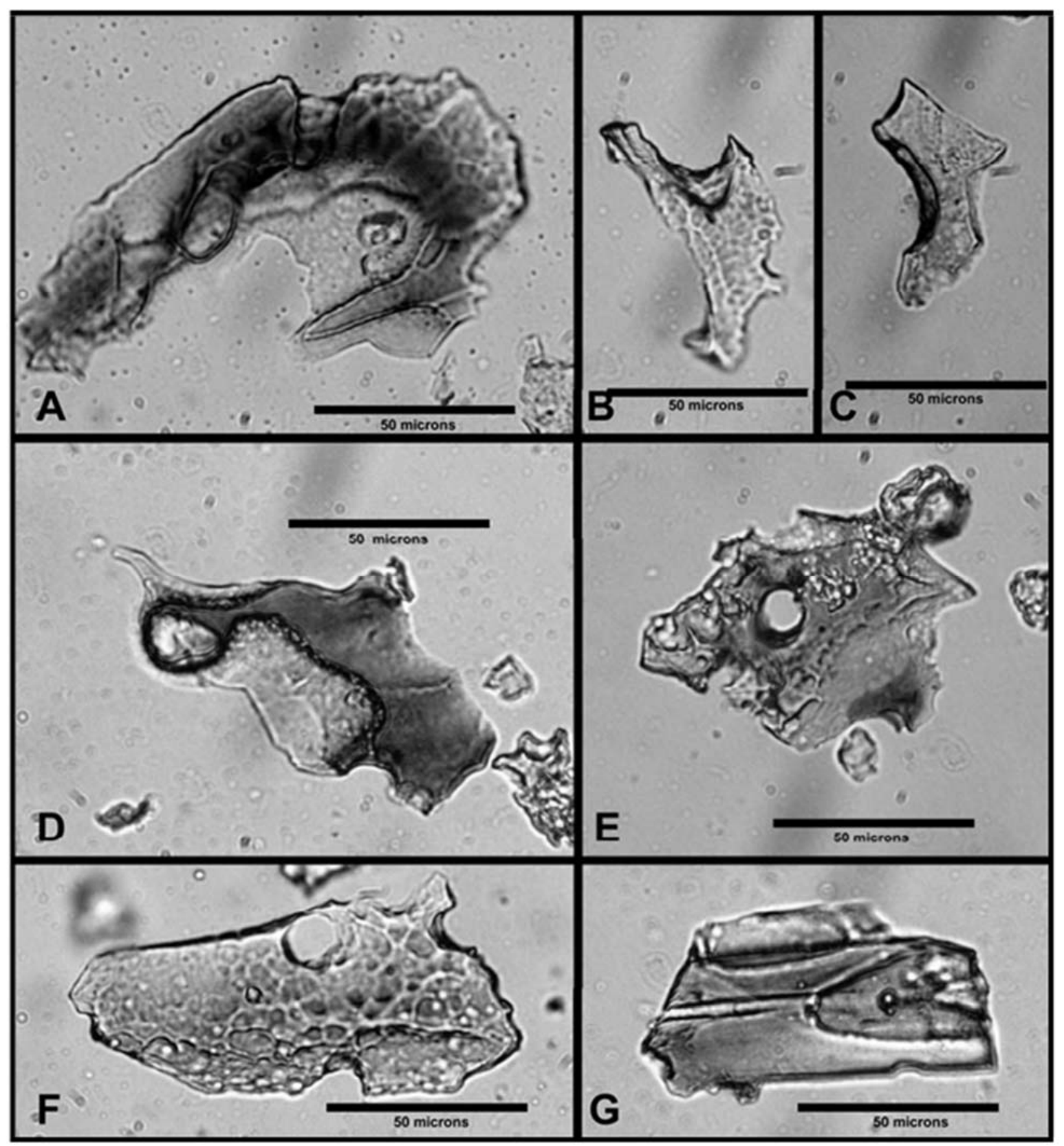

Figure D-12. Burned irregular "sheets" of amorphous silica (41BL278). Sample 6 = A-E; Sample 7 = F; and Sample 8 = G (Sample identities in Table D-1). Bar scales are 50 microns. 


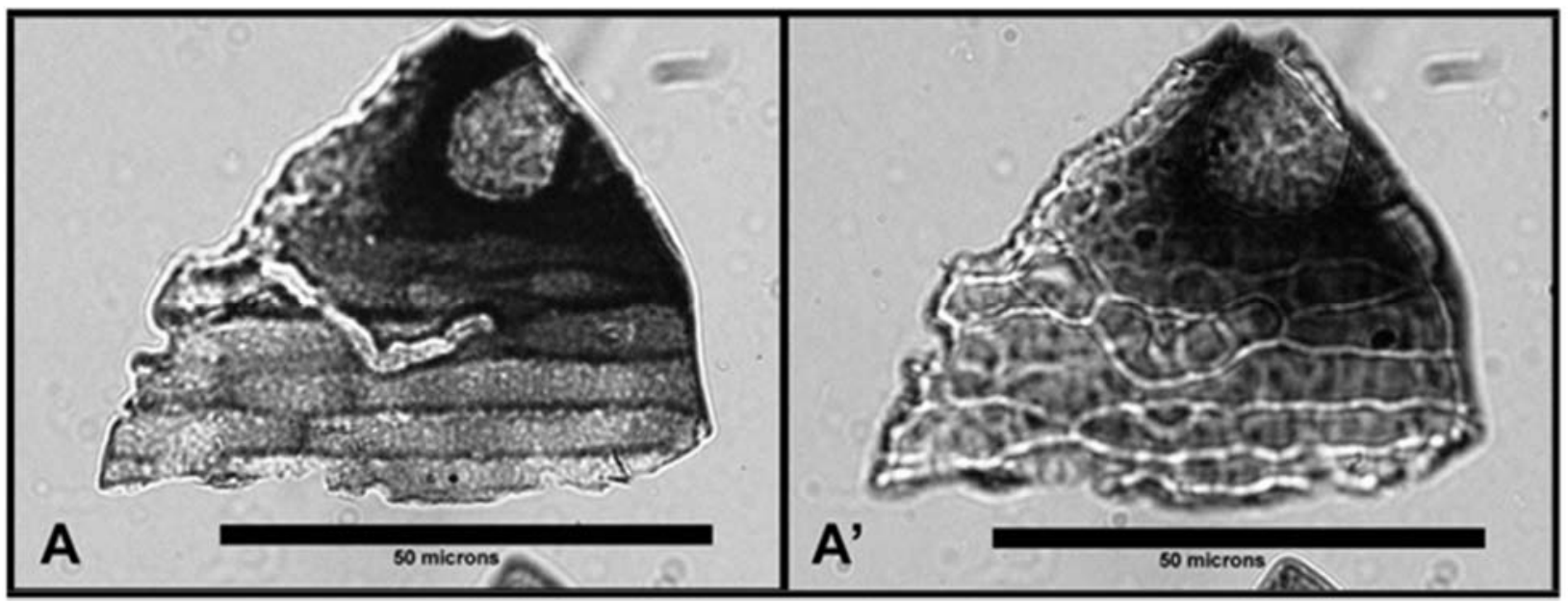

Figure D-13. Burned fused phytoliths (41BL278). The same amorphous silica specimen is illustrated in $A$ and $A^{\prime}$, and appears likely to be comprised of elongate cell phytoliths. The difference between the two images is the focal plane of the microscope [A is focused on the bottom surface of the tabular particle, and $A^{\prime}$ is focused on the top surface. Amorphous silica particles are clear--which is why one can view both sides of the particle; however, burning has darkened this particle]. (The specimen in A/A' is from Sample 9; sample identity is in Table D-1).

cellular structure on the two particle faces seems to support this interpretation. A somewhat similar specimen was reported previously--the cells were fused, but their structure was not obscured on either side, the melting was not as extensive, nor was the particle as severely discolored (Sudbury 2014a: Figure 35A and $\left.A^{\prime}\right)$.

Some of the various unidentified phytolith specimens observed during the course of this study are illustrated in Figure D-14 for future reference.

\section{D.4.4 Other Biogenic Silica Observed}

Fresh water siliceous sponge spicules were present in all four samples (Figures D-15 through 17). No gemmoscleres (reproductive spicules) were recovered. Other biogenic silica forms (i.e., diatoms and statospores) were not observed in any of the 41BL278 soil samples.

Complete spicules were recovered from all samples (Figure D-15A, D-16A, B, F, and D-17A and B). None of the complete specimens were weathered suggesting an available local water supply which supported a freshwater sponge population. Weathered specimen sections are present, suggesting movement caused abrasion and/or soil induced chemical weathering (Figure D-15B, G, and $\mathrm{H}$; Figure $\mathrm{D}-16 \mathrm{H}$; and $17 \mathrm{C}, \mathrm{D}$, and $\mathrm{E}$ ). The other fragmentary specimens not specified do not show evidence of significant surface weathering.

Several of these illustrations are of particles of uncertain identity. The overall appearance of the specimen in Figure D-16D is reminiscent of a spicule, but the internal morphology is somewhat aberrant. More importantly, the rounded closed end does not occur in modern freshwater sponges in North America--all modern specimens are bipointed with orifices at each end. Marine glass sponges do occur with a single orifice and a rounded second end--so specimen Figure D-16D may be a fossiliferous spicule. The sharp angular projection on the specimen shown in Figure D$16 \mathrm{~J}$ suggests it is not a spicule, but may be some other amorphous particle type. Specimen in Figure 
D-16J makes one wonder whether or not other large bore thin-walled specimen sections are spicules [Figures D-15E and F; D-16C and I]--either from an aberrant thin-walled version of modern species or an unknown species. The thin-walled specimen reported from 41TV2161 showed the classic enlarged area which housed the sclerocyte--which positively confirmed its identity a spicule (Sudbury 2014a: Figure 28K). This morphologic feature was not present in any of the 41BL278 thinwalled specimens [in the current sample, this feature is most clearly visible in the specimen Figure D-16A; the specimen in Figure D-15A has a thickened outer wall in the center of the spicule, but does not have the enlarged area in the axial canal]. As both the thin-walled and single orifice/round-based specimens are now known from two sites of similar age in the same general geographic area, there is the possibility that they represent new mid-Holocene sponge species.

Another possible explanation for the two aforementioned odd morphologic forms is that they are atypical spicules formed by sponges in response to environmental stresses. The specimen in Figure D-16B almost certainly fits in this category; with its bulbous appearance, it looks more like a serological pipet than a spicule--this is not a typical fresh water spicule morphology. Evaluation of additional sponge spicule samples from this and similar age sites is clearly needed to clarify these issues.

For additional background information about freshwater sponge spicules, consult Reiswig, Frost, Ricciardi (2010), Harrison (1974), or Sudbury (2011c).

\section{D.5 DISCUSSION}

Biogenic silica preservation at 41BL278 was poor-no diatoms or statospores were present, short cell phytoliths were observed in very limited numbers, and the more abundant bulliform cells generally showed extensive surface pitting from chemical weathering which is readily attributed to the calcic soil environment. Only the sponge spicule and tree origin biogenic particles showed good preservation.

Phytoliths have been processed at JSE labs from four different Calf Creek affiliated sites in the past four years; a summary of the occupation zone phytolith concentrations is presented in Table D3. All four sites were located on or very near active water ways when occupied (34WO69 may have been on more of a spring, seep, or marshy area (Barbara Winsborough, personal communication). The two Texas sites are located in central Texas, whereas 34W069 is near the Oklahoma Panhandle, and 34NW132 is in far northeastern Oklahoma. The Texas sites had calcic or cambic soil soils with high carbonate content, whereas the Oklahoma sites were slightly acidic to near neutral. As can be seen in Table D-3, the total phytolith recovery from the two Texas sites was very low ( $<0.10$ wt. $\%$ of soil once the carbonates were removed--and the vast majority of that weight is attributable to the much larger and much more abundant bulliform cells and spicules). In contrast, the soil phytolith concentration was much higher on the Oklahoma sites, both in the cultural zone of interest (Table D-3) and throughout the overall profile. The actual average soil profile phytolith concentration at $34 \mathrm{WO} 69$ was $2.58 \mathrm{wt} . \%$, and at $34 \mathrm{NW} 132$ was 1.62 wt. $\%$ of soil, and no detrimental particle preservation issues encountered at either site. Note that, with a much deeper profile, soil aggradation at 34NW132 in an active flood plain was much more rapid than at 34W069 which likely accounts for the lower relative phytolith concentration at 34NW132.

The biogenic assemblage (phytoliths, diatoms, sponge spicules, and statospores) from the Opossum Creek Site (34NW132) was reported in detail (Sudbury 2011b). Below the surface control/plow zone interval at Opossum Creek, the profile samples were collected based on visible 


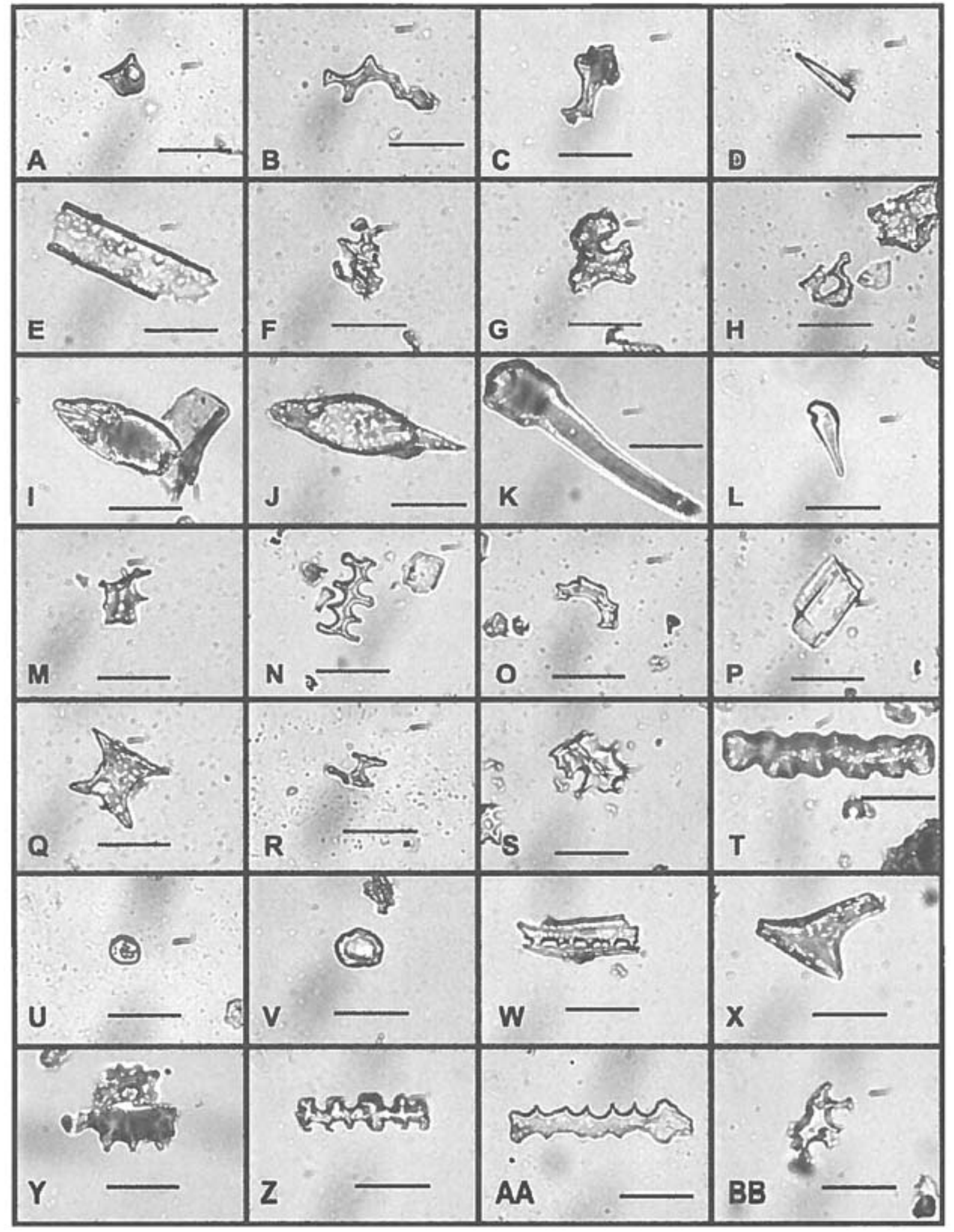

Figure D-14. Unidentified phytolith forms observed in these samples (41BL278). Images A-P = Sample 6; images Q-T = Sample 7; images U-X = Sample 8; and images Y-BB = Sample 9 (Sample identities in Table D-1). Bar scales are 25 microns. 


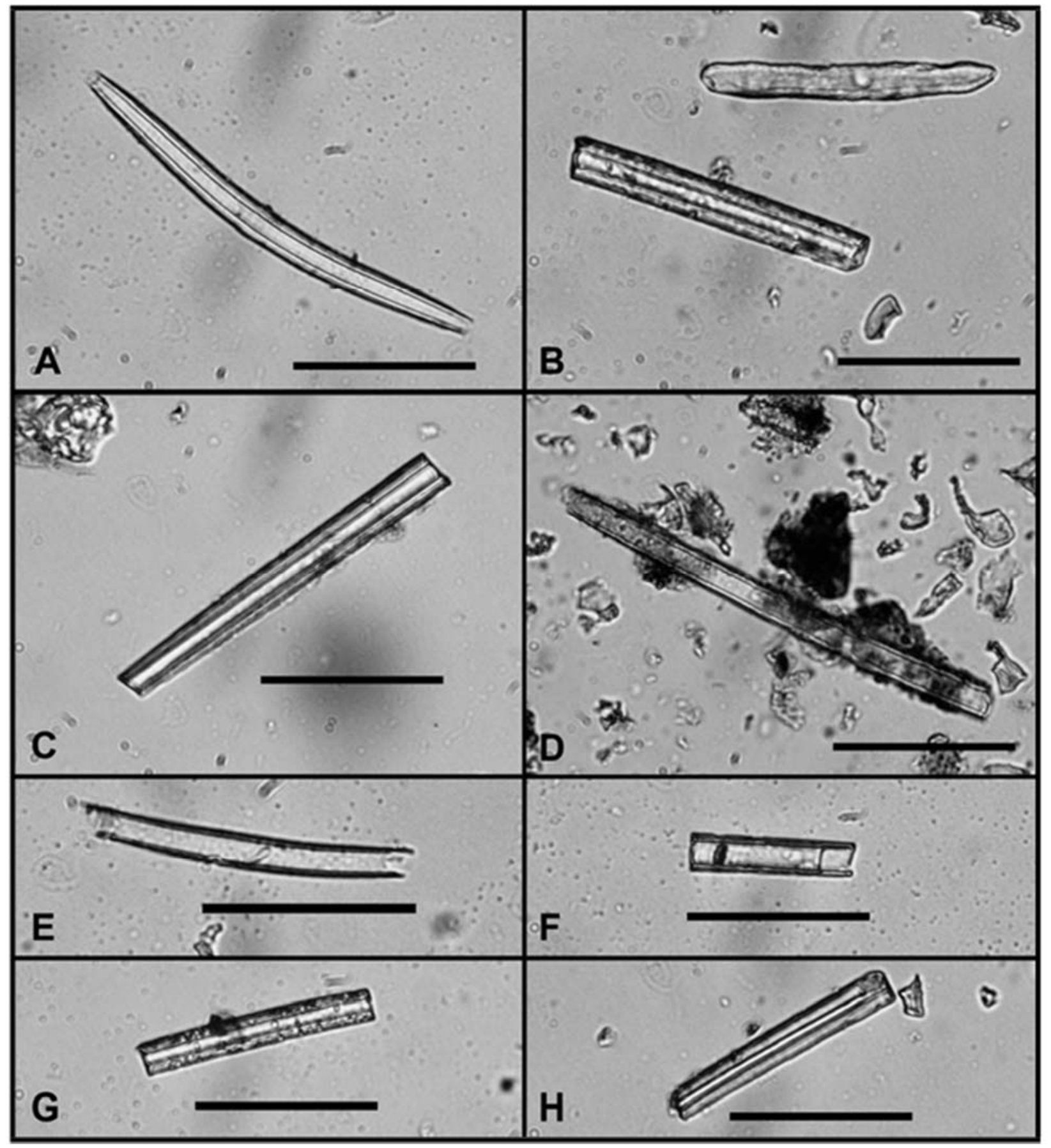

Figure D-15. Sample 6 spicules (41BL278). The upper right specimen in B is a phytolith of similar size to the spicule that is pictured (Sample identities in Table D-1). Bar scales are 50 microns. 


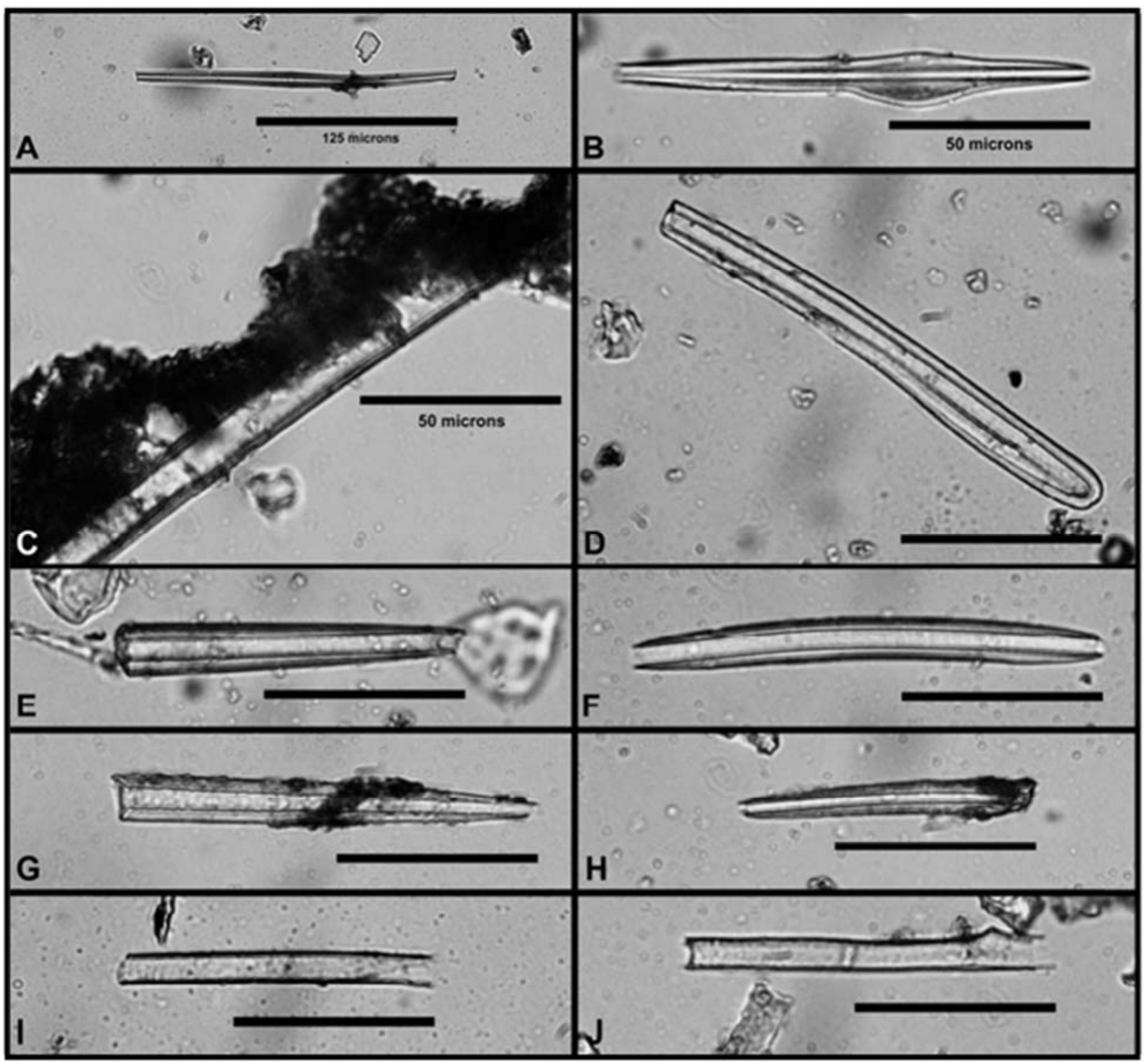

Figure D-16. Sample 7 and 8 spicules and similar particles (41BL278). A-E = Sample 7, F-J = Sample 8 (sample identities in Table D-1). All scale bars are 50 microns except for A which is 125 microns. Specimen $\mathrm{J}$ may not be a spicule; the identity of $C$ and $I$ is uncertain. 


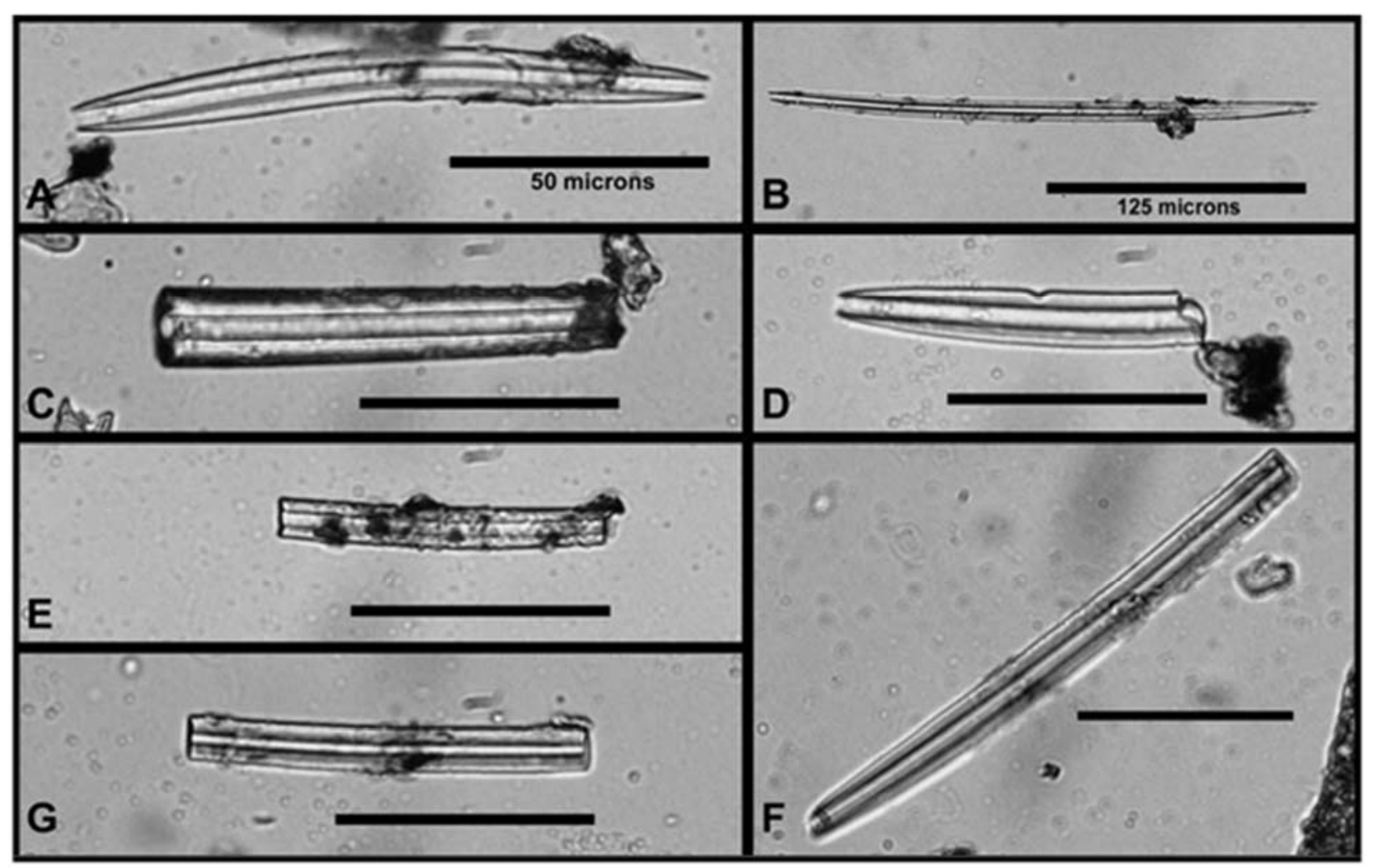

Figure D-17. Sample 9 spicules (41BL278) (Sample identities in Table D-1). Bar scale in B is 125 microns long [spicule photographed at 200x]; all other bar scales are $\mathbf{5 0}$ microns [spicules photographed at 500x].

strata so they were of variable thickness although the total profile was much thicker than at the Burnham Site. Work to date on 34WO69 has been summarized (Sudbury 2014b) and will be reported more fully in the future; that profile was sampled in $4 \mathrm{~cm}$ intervals to a depth of 1 meter (the $8 \mathrm{~cm}$ plow zone was pooled as one sample).

The samples analyzed from the Texas sites honed in on specific occupation features rather than complete soil profiles. A draft report documenting abundant snails and poor phytolith preservation at the Big Hole Site (41TV2161) has been prepared (Sudbury 2014a), and 41BL278--which also produced well preserved snails and poorly preserved phytoliths--is the topic of this current report. The samples from 41TV2161 were processed in sets of 12; the high carbonate content in the first two sets was neutralized in the $50 \mathrm{ml}$ centrifuge tubes which turned out to be an extremely time consuming- strategy. As a result, the carbonates were not removed from the third 41TV2161 sample set and carbonate contamination of the phytolith isolates occurred (thus explaining the higher $[0.18 \%]$ recovery for sample set 3 (Table D-3). To expedite laboratory processing, the biogenic silica isolates [instead of the whole silt fractions] from 41BL278 were acid treated to remove the carbonate contamination (Figure D7) which resulted in a very low phytolith recovery of 0.05 weight percent in soil from 41BL278.

The previous carbonate issue encountered at 41TV2161 led to some literature investigation to understand the possible mechanism involved. The silica "bible" prepared by Iler (1979) was consulted, and a number of pertinent comments from that volume are documented in the Big Hole report (Sudbury 2014a). In summary the basic 
Table D-3. ca. 5100 B.P. Occupational Level Soil Phytolith Concentrations.

\begin{tabular}{|c|c|c|c|c|}
\hline $\begin{array}{l}\text { Site } \\
\text { Number }\end{array}$ & $\begin{array}{l}\text { Phytoliths, } \\
\text { wt. \% in Soil }\end{array}$ & $\begin{array}{l}\text { \# Samples } \\
\text { Averaged }\end{array}$ & $\begin{array}{l}\text { Phytolith, wt. \% Range in } \\
\text { the Samples/Profile }\end{array}$ & $\begin{array}{l}\text { Site Name/Comment [TX site's } \\
\text { carbonate removal status] }\end{array}$ \\
\hline $41 \mathrm{MS} 69$ & $0.04 \%$ & 5 & $0.03-0.05 \%(n=5)$ & Spl 1-5, same age $\left(\right.$ no $\left.\mathrm{CO}_{3}\right)$ \\
\hline \multirow{3}{*}{ 41TV2161 } & $0.09 \%$ & 12 & $0.04-0.14 \%(n=12)$ & Spl 1-12; soil column (no $\mathrm{CO}_{3}$ ) \\
\hline & $0.10 \%$ & 12 & $0.08-0.16 \%(n=12)$ & Spl 13-24; samples (no $\mathrm{CO}_{3}$ ) \\
\hline & $0.18 \%$ & 12 & $0.07-0.53 \%(n=12)$ & Spl 25-36; samples ( $\mathrm{CO}_{3}$ remains) \\
\hline 34W069 & $2.09 \%$ & 3 & $0.80-4.11 \%(n=24)$ & Burnham 1 meter profile @ 4 cm \\
\hline 34NW132 & $1.10 \%$ & 1 & $0.46-4.60 \%(n=25)$ & Opossum Creek profile, by strata \\
\hline
\end{tabular}

issue was the caustic soil $\mathrm{pH}$ accelerated biogenic silica dissolution in the soil profile. This process can be accelerated by more water movement in the profile, and there are possible mechanisms whereby charcoal [and thus wood ash] and the action of other cations than calcium may also contribute to an accelerated dissolution rate.

The USDA soil type descriptions in the Official Series Descriptions (OSDs) were consulted for these four sites, and the significant soil information is summarized in Table D-4. The average carbonate equivalent range is the summary data provided on the USDA soil web site. The average carbonate range is the value given for the entire USDA testedprofile; the maximum range [which was only provided for 41BL278] lists the minimum and maximum values for the profile. The parent material and location relative to waterways is also noted. The modern day climate of the two Texas sites is similar, whereas both Oklahoma sites are slightly cooler. 34WO69 is significantly drier and 34NW132 is significantly wetter than the Texas sites. Both Texas sites clearly have calcic soils; the Oklahoma sites do not (although there was a trace of carbonate visible in the lower portions of the type profile cited as the type profile for St. Paul silt loam).

Table D-5 addresses the relative quality of snail and biogenic silica preservation at these same four sites. Clearly from this tabular summation, the basic calcic soils at the Texas sites provide excellent preservation for snails, but poor phytolith and biogenic silica preservation--with the apparent exception of siliceous sponge spicules. Conversely, no snails were recovered from the non-calcic Oklahoma sites, but the Oklahoma sites had exceptionally good phytolith and biogenic silica preservation--both in quantity and in apparent chemical weathering status. The sole trace microfossil difference between the two Oklahoma sites was in statospore abundance; this is interpreted as being due to 34NW132 being regularly wet, whereas prehistorically 34WO69 apparently dried out frequently which induces statospore formation (i.e., it had an intermittent water source, such as a spring, seep, or marshy area). The biogenic silica preservation improved in Table D-5 moving left to right as the soil carbonate content decreased. The point at which biogenic preservation deteriorates is bracketed in this data set, but the exact tipping point is not known--and may be somewhat variable due to specific localized conditions.

\section{D.6 CONCLUSIONS}

At 41BL278, there were abundant poorly preserved bulliform phytolith cells, and a relative dearth of short cell phytoliths recovered from the soil samples. The poor Poaceae phytolith preservation is felt to be due to dissolution caused by the calcic soil matrix. The phytolith evidence from 
Table D-4. Site Soil Types and Carbonate Content (via USDA OSDs).

\begin{tabular}{|c|c|c|c|c|}
\hline & 41BL278 & 41TV2161 & $34 W 069$ & 34NW132 \\
\hline $\begin{array}{l}\text { Soil Name (typical soil } \\
\text { texture) }\end{array}$ & Venus $^{2}$ (loam) & Lewisville $^{3}$ (silty clay) & St. Paul ${ }^{4}$ (silt loam) & Radley $^{5}$ (silt loam) \\
\hline $\begin{array}{l}\text { Soil Classification } \\
\text { (Taxonomic Class) }\end{array}$ & $\begin{array}{l}\text { Fine-loamy, mixed, } \\
\text { superactive, thermic } \\
\text { (Udic Calciustolls) }\end{array}$ & $\begin{array}{l}\text { Fine-silty, mixed, } \\
\text { active, thermic } \\
\text { (Udic Calciustolls) }\end{array}$ & $\begin{array}{l}\text { Fine-silty, mixed, } \\
\text { superactive, thermic } \\
\text { (Pachic Argiustolls) }\end{array}$ & $\begin{array}{c}\text { Fine-silty, mixed, } \\
\text { active, thermic } \\
\text { (Fluventic Hapludolls) }\end{array}$ \\
\hline Average $\mathrm{CO}_{3}$ Equivalent & $15-40 \%$ & $20-40 \%$ [at 10-40"] & $\begin{array}{c}0-1 \% \text { visible } \mathrm{CO}_{3} \\
\text { below } \mathrm{B}[\text { in } \mathrm{BC} \& \mathrm{C}]\end{array}$ & 0 \\
\hline $\mathrm{CO}_{3}$ Equivalent Range & $0-60 \%$ & \# not provided & \# not provided & 0 \\
\hline $\begin{array}{l}\text { Calcic Horizon } \\
\left(>15 \% \mathrm{CO}_{3}\right)\end{array}$ & 14-60" (Bk or K) & 16-62" (Bk) & none & none \\
\hline $\begin{array}{l}\text { Parent Materiall } \\
\text { Base Residuum }\end{array}$ & $\begin{array}{l}\text { Formed in loamy } \\
\text { calcareous alluvial } \\
\text { sediments of } \\
\text { Pleistocene age }\end{array}$ & $\begin{array}{c}\text { Formed in ancient } \\
\text { loamy and calcareous } \\
\text { sediments }\end{array}$ & $\begin{array}{c}\text { Formed in silty } \\
\text { Pleistocene alluvium } \\
\text { over residuum of } \\
\text { weathered Permian } \\
\text { siltstone/sandstone }\end{array}$ & $\begin{array}{l}\text { Formed in stratified } \\
\text { silty alluvium }\end{array}$ \\
\hline Flood Plain & $\begin{array}{l}\text { Stream terraces and } \\
\text { footslopes of valleys }\end{array}$ & Upland & Alluvial plain remnant & Nearly level flood plain \\
\hline Comment & $\mathrm{PZ}$ also contains $\mathrm{CO}_{3}$ & $\mathrm{PZ}$ also contains $\mathrm{CO}_{3}$ & currently upland & frequently flooded \\
\hline $\begin{array}{l}\text { Soil Type Location } \\
\text { Average Rainfall; } \\
\text { Mean Temperature }\end{array}$ & $28-40^{\prime \prime} ; 62-69^{\circ} \mathrm{F}$ & 28-36"; 66º & $21-28^{\prime \prime}, 57-64^{\circ} \mathrm{F}$ & $38-47^{\prime \prime}, 57-64^{\circ} \mathrm{F}$ \\
\hline $\begin{array}{l}\text { Thornwaite Annual P-E } \\
\text { index }\end{array}$ & $44-64$ & $44-66$ & $32-44$ & $64-82$ \\
\hline
\end{tabular}

41BL278 does show clear but non-species specific tree and fire data. No sedge phytoliths, statospores, or diatoms were observed in the sample biogenic isolates. The sponge spicules were well preserved-some fragments were weathered and/or abraded whereas many appeared to be pristine; some spicules were also complete, suggestive of enough available water available to pool and flow. Spicule presence in the feature is suggestive of water use in association with the feature. No reproductive spicules (i.e., gemmoscleres) were recovered.

A variety of snails were present in the sand fractions, as well as charcoal flecks, bone, burned shell (possibly snail), some lithic material, and other stone. Several sub- millimeter microflakes which looked like clear crystalline quartz that appeared to have platforms were observed (i.e., possible retouch flakes). Some slightly larger blocky apparent quartz debris was also noted in the sand.
The main component of the sand fraction--after quartz sand grains--appeared to be carbonate, some in chunks and shards, while other fragments appear to have definitely formed around roots when the roots were alive and/or recently decaying. The calcium concentration in the rhizosphere increases when the plants take up water; when $\mathrm{CO}_{2}$ is given off in the root zone--either by bacteria or decaying roots--the calcium and the $\mathrm{CO}_{2}$ form calcium carbonate (Bohn et al. 1979:131, 279-280; Birkeland 1984:139-140; Bouchardt 2002:714$715)$. Thus, the root traces in the carbonate seem to suggest that the carbonate in the rhizosphere was likely formed at or immediately after the time that the site was occupied. Samples 7 through 9 were collected from under limestone rocks in an effort to determine the environment at the time of occupation. Although some of the calcium and carbonate could have been derived from the soil parent material or the overlaying rocks, the general consensus in the literature is that the majority of 
Table D-5. Biogenic Silica and Snail Frequency and Preservation at Study Sites.

\begin{tabular}{|c|c|c|c|c|c|c|c|c|c|c|c|c|}
\hline & \multicolumn{12}{|c|}{ Site Number } \\
\hline & \multicolumn{3}{|c|}{ 41BL278 } & \multicolumn{3}{|c|}{ 41TV2161 } & \multicolumn{3}{|c|}{$34 W 069$} & \multicolumn{3}{|c|}{ 34NW132 } \\
\hline & $\mathbf{P}^{6}$ & A & Condition & $\mathbf{P}$ & A & Condition & $\mathbf{P}$ & A & Condition & $\mathbf{P}$ & A & Condition \\
\hline Phytoliths & $\mathrm{X}$ & & Poor, rare & $\mathrm{X}$ & & Poor, rare & $\mathrm{x}$ & & $\mathrm{XL}$, abund & $\mathrm{X}$ & & $\mathrm{XL}$, abund \\
\hline Diatoms & & $\mathrm{X}$ & Absent & $\mathrm{x}$ & & Poor, v rare & $\mathrm{x}$ & & $\mathrm{XL}$, abund & $x$ & & $\mathrm{XL}$, abund \\
\hline Sponge Spicules & $x$ & & $X \mathrm{XL}$ & $\mathrm{x}$ & & $X \mathrm{~L}$ & $\mathrm{x}$ & & $\mathrm{XL}$, abund & $\mathrm{x}$ & & $\mathrm{XL}$, abund \\
\hline Gemmoscleres & & $x$ & Absent & $\mathrm{X}$ & & $\mathrm{XL}$, scarce & $\mathrm{x}$ & & $\mathrm{XL}$, abund & $x$ & & $\mathrm{XL}$, abund \\
\hline Statospores & & $x$ & Absent & $x$ & & Poor, v rare & $\mathrm{X}$ & & $\mathrm{XL}, \mathrm{V}$ abund & $\mathrm{X}$ & & $\mathrm{XL}$, rare \\
\hline Snails & $x$ & & $\mathrm{XL}$, abund & $x$ & & $\mathrm{XL}$, abund & & $x$ & Absent & & $x$ & Absent \\
\hline Phytoliths, wt. \% & \multicolumn{3}{|c|}{$0.05 \%$} & \multicolumn{3}{|c|}{$0.10 \%$} & \multicolumn{3}{|c|}{$2.09 \%$} & \multicolumn{3}{|c|}{$1.10 \%$} \\
\hline $\begin{array}{l}\text { Soil Subgroup } \\
\text { Great Group }\end{array}$ & \multicolumn{3}{|c|}{ Udic Calciustolls } & \multicolumn{3}{|c|}{ Udic Calciustolls } & \multicolumn{3}{|c|}{ Pachic Argiustolls } & \multicolumn{3}{|c|}{ Fluventic Hapludolls } \\
\hline Carbonate Content & \multicolumn{3}{|c|}{$0-60 \%$} & \multicolumn{3}{|c|}{$20-40 \%$} & \multicolumn{3}{|c|}{$0-1 \%$} & \multicolumn{3}{|r|}{0} \\
\hline
\end{tabular}

2 https://soilseries.sc.egov.usda.gov/OSD_Docs/VIVENUS.html (accessed 8-3-14)

3 https://soilseries.sc.egov.usda.gov/OSD_Docs/L/LEWISVILLE.html (accessed 8-3-14)

$4 \quad$ https://soilseries.sc.egov.usda.gov/OSD_Docs/S/ST._PAUL.html (accessed 8-3-14)

5 https://soilseries.sc.egov.usda.gov/OSD_Docs/R/RADLEY.html (accessed 8-3-14)

$6 \quad$ "P" denotes presence; "A" denotes absence; "Condition" refers to weathering or preservation; "XL" denotes excellent condition; " $v$ " as in v rare means "very" rare; "abund" means abundant. Gemmoscleres are reproductive sponge spicules

calcium present in soil is deposited at sites via aeolian deposition, or by dust settled by precipitation (Birkeland 1984:140-141; Goldberg and Macphail 2006:141-144). A significant carbonate content was also observed in the soil sample silt fractions.

The reason for the additional clay components present in the control soil (Sample 6) clay fraction (Figure D-8) is uncertain. One potential caution could be due to the samples collected. The other three samples were collected under rocks to evaluate the living surface, and thus were cut off from further aeolian deposition. The control sample remained exposed to normal soil aggradation, and thus may contain components that were added via post-occupation environmental deposition. The limestone rocks may have contributed to detrimental soil preservation of the three samples-but even the control sample sans rocks had poor phytolith preservation.
The abundance of well-preserved snails in high carbonate content soils presents an opportunity to harvest environmental information from that resource. In the future the sample preparation method could be optimized (i.e., gentler initial disaggregation) to enhance complete snail specimen recovery, and the recovered snails and/or snail images provided to a specialist for identification and environmental assessment.

In a very significant observation, it has been reported that diatoms--absent in the general site soil matrix at 41TV2161--were congregating at the root surfaces (presumably feeding) and were encapsulated and preserved in the carbonate nodules that formed in the rhizosphere (and also found preserved in carbonate nodules adjacent to bone) (Winsborough 2014). Thus, encapsulation by carbonate apparently shielded the diatoms from dissolution via basic $\mathrm{pH}$ coupled with migrating 
soil pore water, and the carbonate may have maintained the local environment $\mathrm{pH}$ in the 8.2 to 8.5 range.

There are several potential issues that the archived soil carbonate-containing samples from 41BL278 could address.

1. Although soil phytoliths were not alive and actively feeding in the root zone, any phytoliths that were incidentally present in the carbonate encapsulated soil zone may be preserved in the carbonate nodules as the diatoms were. No sand origin carbonate nodules were dissolved to test this theory, but that does remain an option.

2. In the absence of good short cell phytolith samples, soil carbonate can be analyzed to determine the $\delta 13 \mathrm{C}$ value of the soil, and thus provide an indication of the $\mathrm{C} 3$ vs. $\mathrm{C} 4$ plant community distribution that contributed the carbon at or very near the living surface (Schaetzl and Anderson 2005:648-649).

3. The carbonate can also be used to potentially determine the source of the carbonate at the site (i.e. aeolian vs. marine vs. pedogenic) (ibid.). This information can also be pertinent to the question addressed in point 2 in unraveling the ultimate source of the carbon in the carbonate. The sand fractions (and all soil fractions) have been curated at the J.S. Enterprise laboratory, and are available for any additional analysis if and when needed.

\section{D.7 ACKNOWLEDGEMENTS}

I gratefully acknowledge the contributions of Barbara Winsborough and Mike Quigg in the completion of this report.

\section{D.8 REFERENCES}

Birkeland, P. W.

1984 Soils and Geomorphology. Oxford University Press, Oxford.

Bohn, H., B. McNeal, and G. O'Connor

1979 Soil Chemistry. John Wiley \& Sons, Inc., New York.

Borchardt, G.

2002 Mineralogy and Soil Tectonics. In Soil Mineralogy with Environmental Applications, pages 711-736. Dixon, J. B., and D. G. Schulze (Eds.). Number 7 in the Soil Science Society of America Book Series. Soil Science Society of America, Inc., Madison, Wisconsin.

Doner, H. E. and P. R. Grossl

2002 Carbonates and Evaporites. In Soil Mineralogy with Environmental Applications, pages 199-228. Dixon, J. B., and D. G. Schulze (Eds.) Number 7 in the Soil Science Society of America Book Series. Soil Science Society of America, Inc., Madison, Wisconsin.

Goldberg, P. and R. I. Macphail

2006 Practical and Theoretical Geoarchaeology. Blackwell Publishing, Malden, MA.

Harrison, F. W.

1974 Sponges (Porifera Spongillidae). In Pollution Ecology of Freshwater Invertebrates, pp. 29-66. Hart, C. W., Jr. and S. L. H. Fuller (Eds.) Academic Press, New York.

Iler, R. K.

1979 The Chemistry of Silica. John Wiley \& Sons: New York. 
Pearsall, D. M.

2000 Paleoethnobotany: A Handbook of Procedures. 2nd Edition. Academic Press, San Diego.

Piperno, D. R.

1988 Phytolith Analysis: An Archaeological and Geological Perspective. Academic Press, San Diego.

2006 Phytoliths: A Comprehensive Guide for Archaeologists and Paleoecologists. AltaMira Press, New York.

Reiswig, H. M., T. M. Frost, and A. Ricciardi

2010 Porifera. In Ecology and Classification of North American Freshwater Invertebrates, pp. 91-123. J.H.Thorp and A. P. Covich (Eds.) Academic Press, New York.

Schaetzl, R., and S. Anderson

2005 Soils Genesis and Geomorphology. Cambridge University Press, Cambridge.

Strömberg, C. A. E.

2009 Methodological concerns for analysis of phytolith assemblages: Does count size matter? Perspectives on Phytolith Research: $6^{\text {th }}$ International Meeting on Phytolith Research. Quaternary International 193:124-140.
Sudbury, J. B.

2014a Biogenic Silica Assessment of Sediment Samples from the Soil Profile and Select Cultural Features at 41TV2161. (In press, MS submitted to TRC [6-10-14])

2014b Phytolith Insights into the mid-Holocene Calf Creek Paleoenvironment. Presentation at the Society of American Archeologist Annual meeting, Austin (April 26).

2011a Quantitative Phytolith Analysis-A Working Example from Modern Prairie Soils and Buried Holocene A Horizons. Phytolith Press, Ponca City, Oklahoma. $288 \mathrm{p}$.

2011b Biogenic Silica from an Opossum Creek Soil. Phytolith Press, Ponca City, Oklahoma. $107 \mathrm{p}$.

2011c "Sponge Spicules in the Opossum Creek Soil Profile, Nowata County, Northeastern Oklahoma". Biogenic Silica from an Opossum Creek Soil Profile, Nowata County, Oklahoma USA, pp. 75-101. J. B. Sudbury, Phytolith Press, Ponca City, Oklahoma.

Winsborough, B. M.

2014 Diatom Paleoenvironmental Analysis of Sediments from Archaeological Site 41TV2161, Travis County, Texas. (In Press, submitted May 2014). 
This page intentionally left blank. 


\title{
APPENDIX E: \\ STARCH GRAIN ANALYSIS OF 26 SAMPLES FROM 41BL278
}

\author{
Prepared for:

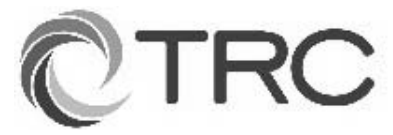 \\ TRC Environmental Corporation \\ 505 East Huntland Drive, Suite 250 \\ Austin, Texas 78752
}

Prepared by:

Linda Perry, Ph.D.

Executive Director

The Foundation for Archeobotanical Research in Microfossils

Fairfax, Virginia 22038 
This page intentionally left blank. 
APPENDIX E: STARCH GRAIN ANALYSIS OF 26 SAMPLES FROM 41BL278

Linda Perry, Ph.D.

\section{E.1 INTRODUCTION TO STARCH GRAIN ANALYSIS}

Archaeobotanical investigators are constantly seeking new methods by which previously unobtainable data can be recovered. Among archeologists who work in regions characterized by the poor preservation of organic remains, the analyses of starch granules have proven particularly useful in accessing the residues of starchy root and tuber crops that have previously been invisible in the archeological record (Bryant 2003; Coil et al. 2003; Fullagar et al. 1998; Hall et al. 1989; Iriarté et al. 2004; Loy et al. 1992; Pearsall et al. 2004; Perry 2001, 2002, 2004, 2005, 2007; Perry and Quigg 2011a, 2011b; Perry et al. 2006, 2007, 2010; Piperno and Holst 1998; Piperno et al. 2000). These residues have proven to be tenacious survivors in harsh climates, and their preservation on the surfaces of lithic tools that were used in the processing of starch-bearing plants occurs consistently in archaeobotanical investigations (Iriarté et al. 2004; Pearsall et al. 2004; Perry 2001, 2002, 2004, 2005, 2007, 2010; Perry and Quigg 2011a, 2011b; Perry et al. 2006, 2007; Piperno and Holst 1998; Piperno et al. 2000).

Investigations of the starchy remains of plant foods on the surfaces of archeological lithic tools began with simple analyses using chemical reagents that identified the residues in question as plant-derived storage starch (Bruier 1976) rather than animal tissue. Within the last fifteen years, however, archeologists have been successfully employing morphological criteria to identify plant taxa. The methods are almost identical to those used in the analysis of phytolith microfossils.
Just as different plants produce characteristically shaped leaves, flowers, and seeds, different genera and species make starch grains that are distinctive to and diagnostic for each taxon. The anatomical features that distinguish the starch of one species of plant from another have been noted by botanists (e.g., Denniston 1904; MacMasters 1964; Reichert 1913), and their methods have been expanded by archaeobotanists who are now able even to distinguish wild from domesticated species in some plant families (Iriarté et al. 2004; Pearsall et al. 2004; Perry 2001, 2002, 2004; Piperno et al. 2000). Basic physical features that are comparable between modern reference specimens and archeological samples can be viewed using a light microscope and include gross morphological features such as shape and faceting, the location of and appearance of the hilum, and presence and patterning of lamellae (Iriarté et al. 2004; Loy 1994; Pearsall 2004; Perry 2004; Piperno and Holst 1998; Piperno et al. 2000). Fissuring and other internal patterning have also proven to be useful criteria for identification. The successful identification of starch granules relies upon the viewing of each granule in three dimensions to gain an accurate assessment of its morphological features.

Because starch granules differ morphologically between plants, their distinctive characteristics can often allow identification to the level of genus or species in archeological samples (e.g., Iriarté et al. 2004; Pearsall et al. 2004; Perry 2001, 2002, 2004, 2005, 2007; Perry et al. 2006, 2007; Perry and Quigg 2011b; Piperno and Holst 1998; Piperno et al. 2000). The method has proven particularly useful in identifying the remains of plant tissues that would not usually be preserved as macroremains, such as the remnants of root and tuber crops (Bryant 2003; Coil et al. 2003; Fullagar et al. 1998; Hall et al. 1989; Iriarté et al. 2004; Loy et al. 1992; Pearsall et al. 2004; Perry 2001, 2002, 2004, 2005; Piperno and Holst 1998; Piperno et al. 2000). This role of starch analysis as a tool for revealing the significance of plant foods in the 
archaeobotanical record also adds to our understanding of the pre-contact significance of starchy seed crops like maize (Zea mays).

In a citation of preliminary results from an ongoing study, the archeological remains of maize starch have been extracted from 2000 year old obsidian artifacts from the Honduran site of Copán (Haslam 2003, 2004). The starchy residues of maize were also successfully recovered and identified from a migmatite milling stone from Cueva de los Corrales 1 in Argentina (Babot and Apella 2003). In this case, the grinding stone was found to have multiple purposes, including the grinding of burned bone, presumable for a non-food purpose. Starch analyses of ground stone artifacts from Real Alto have supported previously published phytolith studies that indicate the great antiquity of maize in Ecuador, and its role in subsistence during the Formative period (Pearsall et al. 2004). Seventeen examined artifacts from Real Alto yielded concentrations of maize starch granules ranging from one to more than ten granules per sampled tool. Other Neotropical studies have resulted in the recovery of more complex assemblages of starches.

Archeologists have recovered starch granules from maize, beans (Phaseolus sp.), and Canna from the Los Ajos mound complex in Uruguay (Iriarté et al. 2004). Maize starch granules were reported from three ground stone tools including one mano and two milling stone bases. Concentrations of maize starches ranged from two to eleven granules on tools from contexts dating from 3600 years before present to about 500 years before present (Iriarté et al. 2004: supplementary information). The starch data were combined with phytolith evidence and, together, these results introduce compelling evidence for the early development of a mixed subsistence economy in this region of South America. In other regions of the Neotropics, starch analysis has been an essential tool in defining similar subsistence patterns that included the exploitation of root and tuberous food plants.
Starch granules of maize, manioc (Manihot esculenta), both wild type and domesticated yams (Dioscorea spp.), and arrowroot (Maranta arundinacea) have been recovered from edge ground cobbles and grinding stone bases collected from the Aguadulce rock shelter as well as the sites of Monagrillo, La Mula, and Cerro Juan Diaz in Panama (Piperno and Holst 1998; Piperno et al. 2000). Edge ground cobbles are characterized by faceting that is hypothesized to have resulted from the processing of root crops against larger grinding stone bases (Ranere 1975), and the analyses of the residual remains of plant tissues supports this hypothesis. However, the use of the milling stones does appear to have been more complex than previously believed. Maize remains were recovered from all twelve artifacts that bore starch (Piperno et al. 2000). The numbers of starch granules of maize per artifact ranged from one to twenty-five per artifact. Two starch granules of arrowroot occurred on a single artifact, manioc starch granules were recovered from three artifacts (one, five, and eight granules), and yam starch granules were found on the surfaces of three of the artifacts (two, three, and sixteen granules) (Piperno et al. 2000). These investigations resulted in the recovery of the oldest evidence for root and tuber crop cultivation in the Neotropics, with radiocarbon dates spanning from 5,000 to 7,000 years before present.

Starch granules of maize, yams, and arrowroot have also been recovered from twelve flake and three ground stone tools collected from Pozo Azul Norte 1 and Los Mangos del Parguaza in Venezuela (Perry 2001, 2002, 2004, 2005). These sites date from the middle first century A.D. to contact. As in the above-cited set of studies, maize remains were recovered from every examined artifact and ranged in number from two to fifty-one per artifact. Additionally, four granules of yam starch were recovered from two flake tools, four flake tools yielded four granules of guapo (Myrosma sp.) starch, and seven starch granules from arrowroot were collected from five tools, one of which was a 
ground stone artifact. These findings were significant in that five of the examined artifacts were chosen for study due to their hypothetical function as microlithic grater flakes from a manioc specific grater board. The evidence indicated a more complex function of these tools that did not include the processing of manioc.

More recent investigations have led to the recovery of direct evidence for contact between the highland Peruvian Andes and the lowland tropical forest to the east (Perry et al. 2006). This contact and interaction had been a significant component of Andean theory for decades, but direct evidence had been elusive until starch microfossils of arrowroot were collected from both sediment samples and lithic tools at the mid-elevation site of Waynuna (Perry et al. 2006). Further, the discovery and cataloging of a microfossil will allow for the recovery and understanding of the origins and subsequent dispersals of chili peppers (Perry et al. 2007), plants whose histories are poorly understood due to the lack of preservation of macroremains in the archaeobotanical record. Remains of these plants have been successfully recovered throughout the Americas from ceramic sherds, lithic tools, and sediment samples dating from 6250 B.P. to European contact.

\section{E.2 UNDERSTANDING THE RELATIONSHIP BETWEEN RESIDUES AND ARTIFACTS}

Early work on starch remains from Panamanian sites used stepwise analysis to support the direct association between starchy residues on tools and the tools' use (Piperno et al. 2000). These studies demonstrated that starch grains were not present in sediments adhering to stone tools or on unused parts of the lithics, but they did occur in the cracks and crevices of the tools on used surfaces, thus indicating that the residues were the result of the tools' use and not environmental contamination. Similar experiments have been undertaken independently by other researchers, and the results were equivalent.

In a study of obsidian artifacts recovered from an open air site in Papua New Guinea, the frequency of starch granules recovered from stone artifacts was compared to that present in the soil matrix immediate to the tool (Barton et al. 1998). The frequency of starch granules was found to be much higher on used artifacts than in the surrounding soil. Thus, the conclusion was drawn that the tools were not contaminated by environmental starch sources. Further, use-wear analyses were used in combination with the soil and starch analyses to assess the degree of association of starchy residues with the used surfaces of tools (Barton et al. 1998). The researchers found that, indeed, the occurrence of starch granules was highly correlated with obsidian tools that bore use-wear and was not correlated with unused tools.

In a study of starch residues occurring on stone pounding tools from the Jimmium site in north central Australia, the starch forms in soil samples were compared to those extracted from the artifacts (Atchison and Fullagar 1998). It was found that, although starch granules did occur in the soil matrices surrounding the tools, they were of different size and shape than those present on the pounding stones, and, therefore, are probably not from the same plant source. This result was interpreted as evidence that the tools had not been contaminated by soil-borne starches.

Another method for assessing whether or not starch residues are culturally deposited involves the analysis of control samples from non-cultural contexts surrounding a site. If different types of starches, or different concentrations of starches, or no plant residue whatsoever are recovered from the control samples than are recovered from the artifacts undergoing testing, then one can be more secure that the residues are the remains of prehistoric food processing (Brieur 1976). 
In addition to the study of association of microfossils with tool use, experimentation with processing methods has also been undertaken. In Argentina, a researcher replicated ancient Andean methods of food processing and found that each different process resulted in diagnostic damage to starch granules in plant tissues including potato tubers (Solanum tuberosum) and quinoa seeds (Chenopodium spp.) (Babot 2003). Modern plant materials were subjected to freeze-drying, dehydration, roasting, charring, desaponification (a process particular to the preparation of quinoa), and grinding. It was found that fragments of starches that would probably otherwise be identified as unknowns or non-starches are actually damaged starches. Further, with careful analysis, researchers can link damage patterns with processing techniques (Babot 2003). Experimentation with various cooking techniques has resulted in similar conclusions: cooked starches are identifiable as such, and different cooking techniques yield different patterns of damage (Henry et al. 2009).

Recent work at the Pipeline, Pavilion, and Corral sites in Texas have demonstrated the utility of starch grain analysis in understanding the function of burned rocks in archeological contexts (Perry 2010). Here, the analysis of burned rocks yielded starch grains that bore clear damage from boiling and secured the function of many burned rocks as boiling stones used for the cooking of wildrye. The analysis of other artifacts from the sites yielded wildrye starches bearing damage from grinding, thus indicating that the grain was probably milled into flour prior to cooking (Perry 2010; Perry and Quigg 2011a, 2011b).

Archaeobotanists have focused their energies upon honing their methods toward the effective recovery of and identification of residual starch granules to understand plant use and processing. Studies have resulted in an impressive assemblage of various suites of starchy food plants, both wild and domesticated, raw and cooked. At this juncture in time, more studies are being undertaken and starch remains are being successfully recovered. What we now lack are baseline data as to how and why different plant materials may or may not adhere to stone tools. Thus, we are not yet able to understand issues such as intensity of use based upon numbers of recovered grains, or the history of a tool based upon the numbers of species of plants recovered from its surface. Linda Perry has obtained funding and will be performing experiments over the next year in the hopes of gaining an understanding of these issues.

\section{E.3 METHODS}

Twenty-six samples from the site were selected for analysis. These samples included 21 burned rocks and five sediment samples. All artifacts were collected and bagged separately without washing. Washing is a traditional step in the collection and curation of artifacts, but it will remove some of the residues that are of interest to archeologists.

The methods used in the extraction of starch remains have been developed over a period of more than fifteen years of study by the author, and are typical of those used throughout the discipline. Detailed methods are available at www.fossilfarm.org.

All artifacts were placed in clean, metal beakers and were covered with filtered water. The beakers were then set aside for ten minutes to soak in the hope that this step would loosen the microfossils and allow for a better extraction. At this point, the beakers were placed in a sonic bath for fifteen minutes to shake the microfossils loose from the artifacts. The artifacts were removed from the beakers and the surfaces were rinsed with filtered water that was collected in the same effluent vessel.

The effluent from the cleaning was allowed to settle overnight, then the settled material was centrifuged for ten minutes at 1000 RPM to pellet out the solids. The solid materials were then subject to a heavyliquid flotation using cesium chloride $(\mathrm{CsCl})$ at a 


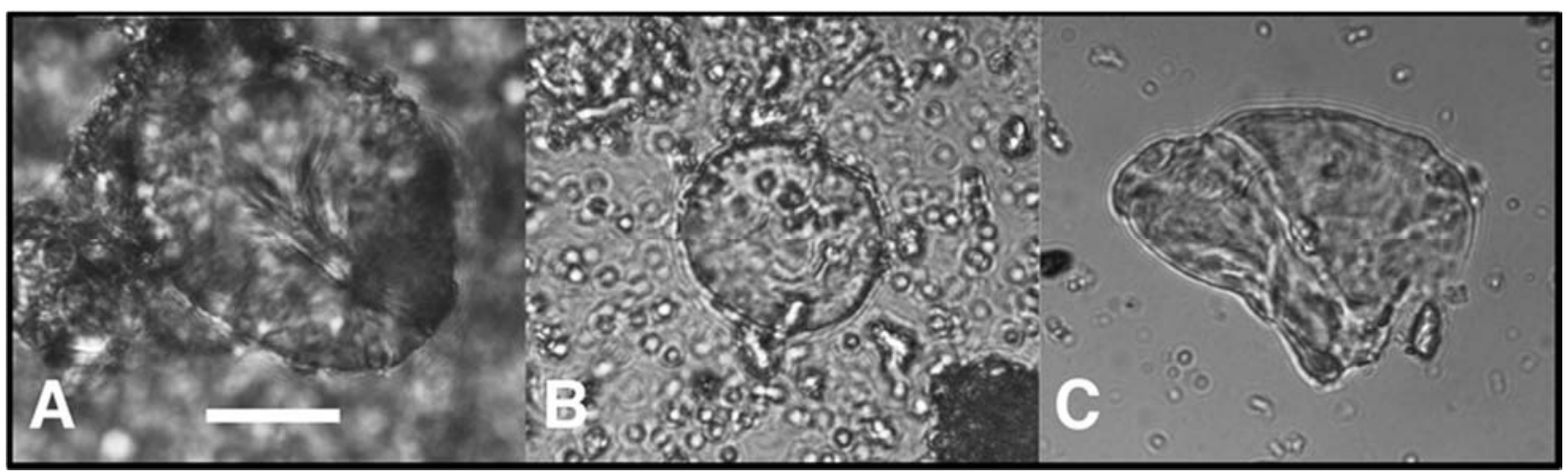

Figure E-1. Starch grains recovered from 41BL278. The scale bar is 20 microns in length, and all photos are at equivalent size. $A=a$ starch grain from a member of the Lily family from burned rock \#502-3-1a, Feature 3. $B=$ a starch grain from a grass in the Triticeae from burned rock \#5023-1a, Feature 3. $C$ = a gelatinized starch mass from burned rock \#504-3-4, Feature 4.

density of $1.8 \mathrm{~g} / \mathrm{cm}^{3}$ to separate the starch grains from the sediment matrix.

Sediment samples were deflocculated with a combination of baking soda and deionized water for a period of three days. The samples were then centrifuged and the baking soda/water was discarded. The sediments were then subjected to a heavy-liquid flotation, after which the steps are identical to those used in artifact processing.

The material collected from the flotation was rinsed and centrifuged three times with filtered water to ensure that the $\mathrm{CsCl}$ was completely removed from the solution. At this point, the pellet from the final centrifugation was placed on a clean glass slide with a small amount of water/glycerin solution.

Slides were scanned with a Zeiss Universal compound microscope for polarized light at $200 \times$, and identifications were made at $400 \times$ using standard methods. Digital images were captured at 800× magnification using a Micropublisher 3.3 camera and software.

\section{E.4 RESULTS}

A total of sixteen intact starch grains were recovered from three of the examined burned rocks (Table E-1). Types of starches include those derived from grasses of the Triticeae that produce characteristic lenticular starch grains, starches from the lily family, unidentified geophytes, unidentified grasses, and unidentified plant sources (Figure E1). Damaged starch was also observed, with the predominant type of damage being gelatinization, or heating in the presence of liquid water.

Starch grains were recovered from artifacts collected from each examined feature except for Feature 7. None of the sediment samples contained any starch grains.

\section{E.4.1 Feature 3}

Burned Rock \#502-3-1a: This burned rock yielded the most starch I have ever recovered from a burned rock. The remains included a single lenticular starch grain from a grass in the Triticeae, the group that includes wildrye and little barley, four grains from the lily family, three grains that are derived from geophytes that do not appear to be in the lily family, four unidentified grass starch grains that are not in the Triticeae, a single unidentified starch grain, and a clump of unidentified starch grains. A damaged grain was also recovered however, the damage was not distinctive enough to be identified.

\section{E.4.2 Feature 4}

Burned Rock \#504-3-4 and \#504-3-1b: These burned rocks contained gelatinized starches. 
Table E-1. $\quad$ Starch Grains Recovered from Site 41BL278.

\begin{tabular}{|c|c|c|c|c|c|c|c|c|c|c|}
\hline 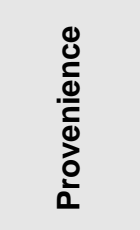 & 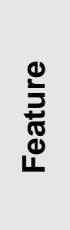 & 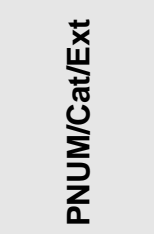 & 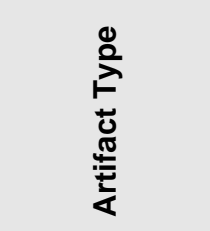 & 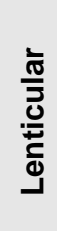 & 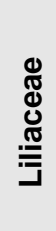 & 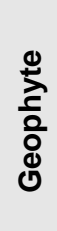 & 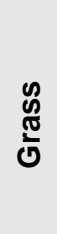 & 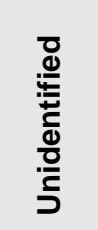 & 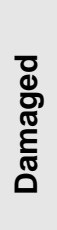 & 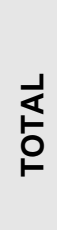 \\
\hline BT9 514 & 3 & $501-3-1$ & Burned Rock & & & & & & & 0 \\
\hline BT9 514 & 3 & $501-3-2 b$ & Burned Rock & & & & & & & 0 \\
\hline BT9 514 & 3 & $501-3-3 b$ & Burned Rock & & & & & & & 0 \\
\hline BT9 614 & 3 & $502-3-1 a$ & Burned Rock & 1 & 4 & 3 & 4 & $1,1 \mathrm{c}$ & $x$ & 14 \\
\hline BT9 514 & $3 A$ & $503-3-1 b$ & Burned Rock & & & & & & & 0 \\
\hline BT8 116 & 4 & $504-3-4$ & Burned Rock & & & & & & $G$ & $x$ \\
\hline BT8 116 & 4 & $504-3-2 b$ & Burned Rock & & & & & & & 0 \\
\hline BT8 116 & 4 & $504-3-3 b$ & Burned Rock & & & & & & & 0 \\
\hline BT8 116 & 4 & $504-3-1 b$ & Burned Rock & & & & & & $\mathrm{G}$ & $x$ \\
\hline BT8 416 & 5 & $505-3-3 b$ & Burned Rock & & & & & & & 0 \\
\hline BT8 416 & 5 & $505-3-1 b$ & Burned Rock & & & & & & G & $x$ \\
\hline BT8 416 & 5 & $505-3-4 a$ & Burned Rock & & & 1 & & & & 1 \\
\hline BT8 416 & 5 & $505-3-2$ & Burned Rock & & & & & & & 0 \\
\hline BT8 416 & 5 & $505-3-5 b$ & Burned Rock & & & & & & $\mathrm{G}$ & $x$ \\
\hline BT8 417 & 6 & $506-3-1$ & Burned Rock & & & & & 1 & & 1 \\
\hline BT9 718 & 7 & $507-3-3$ & Burned Rock & & & & & & & 0 \\
\hline BT9 718 & 7 & $507-3-2 b$ & Burned Rock & & & & & & & 0 \\
\hline BT9 718 & 7 & $507-3-1 b$ & Burned Rock & & & & & & & 0 \\
\hline BT9 617 & 8 & $508-3-1 b$ & Burned Rock & & & & & & $\mathrm{G}$ & $x$ \\
\hline BT9 617 & 8 & $508-3-3 b$ & Burned Rock & & & & & & & 0 \\
\hline BT9 617 & 8 & $508-3-2$ & Burned Rock & & & & & & & 0 \\
\hline BT8 216 & & $8-4-1 a$ & Sediment & & & & & & & 0 \\
\hline BT9 514 & 3 & $501-4-3 a$ & Sediment & & & & & & & 0 \\
\hline BT9 514 & $3 A$ & $503-4-2 a$ & Sediment & & & & & & & 0 \\
\hline BT9 718 & 7 & $507-4-2 b$ & Sediment & & & & & & & 0 \\
\hline BT9 617 & 8 & $508-4-1 b$ & Sediment & & & & & & & 0 \\
\hline \multicolumn{3}{|c|}{ TOTAL } & 26 & 1 & 4 & 4 & 4 & 3 & $X$ & 16 \\
\hline
\end{tabular}

Note: "G" indicates gelatinization damage, while " $X$ " in the same column designates unidentifiable damage. The " $C$ " indicates a clump of starch grains. 


\section{E.4.3 Feature 5}

Burned Rock \#505-3-4a: This burned rock yielded a single starch grain from an unidentified geophyte. Burned Rocks \#505-3-1b and \#505-3-5b: These two burned rocks contained gelatinized starches.

\section{E.4.4 Feature 6}

Burned Rock \#506-3-1: This burned rock yielded a single, unidentified starch grain.

\section{E.4.5 Feature 8}

Burned Rock \#508-3-1b: This rock contained gelatinized starch.

\section{E.5 DISCUSSION AND CONCLUSIONS}

The results from this starch study indicate that grasses from at least two groups, lily bulbs, and other geophytes were present at the site. The presence of gelatinized starches on nearly a quarter of the examined rocks is a good indicator that there was stone boiling occurring at the site as a means of cooking starchy plant foods. These two items, when considered together, are fairly good indicators that these types of plant foods, both grass seeds and starchy geophytes, were probably food resources for the inhabitants of 41BL278.

Of particular interest is burned rock \#502-3-1a from Feature 3, which yielded more starch grains than I have ever recovered from this type of artifact. The numbers of taxa are equally as impressive, and, therefore, I suggest a careful analysis of the context of this artifact with the intention of understanding why it was such a treasure-trove of information. This analysis could very well help us maximize future recovery of starch microfossils.

\section{E.6 REFERENCES CITED}

Atchison, J. and R. Fullagar,

1998 Starch residues on pounding implements from Jinmium rock-shelter. In: A Closer Look: Recent Studies of Australian Stone Tools, edited by R. Fullagar. Sydney University Archaeological Methods Series 6, Archaeological Computing Laboratory, School of Archaeology, University of Sydney, Sydney.

Babot, M. del Pilar

2003 Starch grain damage as an indicator of food processing. Phytolith and Starch Research in the Australian-Pacific-Asian Regions: The State of the Art, edited by D. M. Hart, L. A. Wallis, pp. 69-81. Papers from a conference held at the ANU, August 2001, Canberra, Australia. Pandanus Books.

Babot, M. del Pilar and M.C. Apella

2003 Maize and bone: Residues of grinding in northwestern Argentina. Archaeometry 45:121 -132.

Barton, H., Torrence, R., and R. Fullagar.

1998 Clues to Stone Tool Function Reexamined: Comparing Starch Grain Frequencies on Used and Unused Obsidian Artefacts. Journal of Archaeological Science 25:1231-1238.

Briuer, F. L.

1976 New Clues to Stone Tool Function: Plant and Animal Residues. American Antiquity 41(4):478-484.

Bryant, V. M.

2003 Invisible clues to new world plant domestication. Science 299:1029-1030.

Coil, J., M. A. Korstanje, S. Archer, and C. A. Hastorf

2003 Laboratory goals and considerations for multiple microfossil extraction in Archaeology. Journal of Archaeological Science 30:991-1008. 
Crawford, G. W. and D. G. Smith

2003 Paleoethnobotany in the Northeast. In People and Plants in Ancient Eastern North America, edited by P. E. Minnis, pp. 172-257. Smithsonian Books, Washington DC.

Denniston, R. H.

1904 The Growth and Organization of the Starch Grain. Ph.D. dissertation. University of Wisconsin, Madison, Wisconsin.

Fullagar, R., T. Loy, and S. Cox,

1998 Starch grains, sediments and stone tool function: evidence from Bitokara, Papua New Guinea. In: A Closer Look: Recent Australian Studies of Stone Tools, edited by R. Fullagar, pp. 49-58. Archaeological Computing Laboratory, University of Sydney.

Green W. and C. Tolmie

2004 Analysis of Plant Remains from Blood Run. Plains Anthropologist 49(192):525542.

Hall, J., S. Higgins, and R. Fullagar

1989 Plant Residues on Stone Tools. Tempus 1:136-155.

Haslam, M.

2003 Evidence for maize processing on 2000 year old obsidian artefacts from Copán, Honduras. In: Phytolith and Starch Research in the Australian-Pacific-Asian Regions: The State of the Art, edited by D. M. Hart, L. A. Wallis, pp. 153-161. Papers from a conference held at the ANU, August 2001, Canberra, Australia. Pandanus Books.

2004 The decomposition of starch grains in soils: Implications for archaeological residue analyses. Journal of Archaeological Science 31:1715-1734.

Henry A. G., H. F. Hudson, and D. R. Piperno

2009 Changes in starch grain morphologies from cooking. Journal of Archaeological Science 36:915-922.
Iriarté, J., I. Holst, O. Marozzi, C. Listopad, E. Alonso, A. Rinderknecht, and J. Montaña

2004 Evidence for cultivar adoption and emerging complexity during the midHolocene in the La Plata Basin. Nature 432:614-617.

Loendorf, L. L.

1985 A Possible Explanation for the Association between Wild Rye Grass (Elymus spp.) and Formerly Occupied Cave Sites in the Pryor Mountains, Montana. Plains Anthropologist 30(108):137-144.

Loy, T. H.

1994 Methods in the Analysis of Starch Residues on Prehistoric Stone Tools. In: Tropical Archaeobotany: Applications and New Developments, edited by J. G. Hather Routledge, pp. 86-113.

Loy, T. H., M. Spriggs, and S. Wickler

1992 Direct evidence for human use of plants 28,000 years ago: starch residues on stone artifacts from the northern Solomon Islands. Antiquity 66:898-912.

MacMasters, M. M.

1964 Microscopic Techniques for Determining Starch Granule Properties. In: Methods in Carbohydrate Chemistry, edited by R. L. Whistler, pp. 233-240. Academic Press.

Pearsall, D. M., K. Chandler-Ezell, and J. A. Zeidler

2004 Maize in ancient Ecuador: results of residue analysis of stone tools from the Real Alto site. Journal of Archaeological Science 31:423-442.

Perry, L.

2001 Prehispanic subsistence in the middle Orinoco basin: starch analyses yield new evidence. Doctoral dissertation, Southern Illinois University Carbondale, Illinois.

2002 Starch analyses indicate multiple functions of quartz "manioc" grater flakes from the Orinoco basin, Venezuela. Interciencia 27(11):635-639. 
2004 Starch analyses reveal the relationship between tool type and function: an example from the Orinoco valley of Venezuela. Journal of Archaeological Science 31(8):1069-1081.

2005 Reassessing the traditional interpretation of "manioc" artifacts in the Orinoco valley of Venezuela. Latin American Antiquity.

2007 Starch grains, preservation biases, and plant histories. In: Rethinking Agriculture: Archaeological and Ethnographic Perspectives, edited by T. Denham, L. Vrydaghs and J. Iriarté. One World Archaeology, Left Coast Press.

2010 Starch Analyses from the BLM Landis Property. In Landis Property: Data Recovery at Three Prehistoric Sites (41PT185, 41PT186, and 41PT245) in Potter County, Texas, by J. M. Quigg, C. D. Frederick, P. M. Matchen, and K. G. DeBois, pp. 767-785. TRC Technical Report 150832, TRC Environmental Corporation, Austin.

Perry L. and J. M. Quigg

2011a Starch remains and stone boiling in the Texas panhandle part 1: The Pipeline, Corral, and Pavilion sites. Plains Anthropologist 56:95-108.

$2011 \mathrm{~b}$ Starch remains and stone boiling in the Texas panhandle part 2: Identifying wildrye (Elymus spp.). Plains Anthropologist 56:109-120.
Perry, L., D. Sandweiss, D. Piperno, K. Rademaker, M. Malpass, A. Umire, and P. de la Vera.

2006 Early Maize Agriculture and Interzonal Interaction in Southern Peru. Nature 440:76-79.

Perry, L. R. Dickau, S. Zarrillo, I. Holst, D. Pearsall, D. Piperno, M. Berman, R. Cooke, K. Rademaker, A. Ranere, J. Raymond, D. Sandweiss, F. Scaramelli, K. Tarble, and J. Zeidler.

2007 Starch fossils and the domestication and dispersal of chili peppers (Capsicum spp. L.) in the Americas. Science 315:986-988. With accompanying Perspective, Knapp, S. Some Like it Hot. Science 315: 946-947.

Piperno, D. R. and I. Holst

1998 The presence of starch grains on prehistoric stone tools from the humid Neotropics: Indications of early tuber use and agriculture in Panama. Journal of Archaeological Science 25:765-776.

Piperno, D. R., A. J. Ranere, I. Holst, and P. Hansell 2000 Starch grains reveal early root crop horticulture in the Panamanian tropical forest. Nature 407:894-897.

Ranere, A. J.

1975 Toolmaking and tool use among the preceramic peoples of Panama. In: Lithic Technology, edited by E. H. Swanson, pp. 173-210. Mouton.

Reichert, E. T.

1913 The Differentiation and Specificity of Starches in Relation to Genera, Species, Etc. In two parts. Carnegie Institution of Washington. 
This page intentionally left blank. 


\title{
APPENDIX F: \\ ANALYSIS OF THE LIPID COMPOSITIONS OF ARCHEOLOGICAL BURNED ROCK RESIDUES FROM SITE 41BL278, CENTRAL TEXAS
}

\author{
Prepared for:

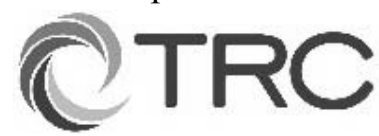 \\ TRC Environmental Corporation \\ 505 East Huntland Drive, Suite 250 \\ Austin, Texas 78752
}

Prepared by:

M. E. Malainey, Ph.D. and Timothy Figol

Department of Anthropology

Brandon University

Brandon, Manitoba Canada 
This page intentionally left blank. 
APPENDIX F: ANALYSIS OF THE LIPID COMPOSITIONS OF ARCHEOLOGICAL BURNED ROCK RESIDUES FROM SITE 41BL278, CENTRAL TEXAS

\author{
M. E. Malainey, Ph.D. and Timothy Figol
}

\section{F.1 INTRODUCTION}

Eighteen burned rocks were submitted for analysis. Exterior surfaces were ground off to remove any contaminants and samples were crushed. Absorbed lipid residues were extracted with organic solvents. Derivatives prepared from lipid extracts were analyzed using gas chromatography (GC), high temperature GC (HT-GC) and high temperature gas chromatography with mass spectrometry (HTGC/MS). Residues were identified using criteria developed from the decomposition patterns of experimental residues. The first section of this report outlines the development of the identification criteria. Following this, analytical procedures and results are presented.

\section{F.2 THE IDENTIFICATION OF ARCHEOLOGICAL RESIDUES}

\section{F.2.1 Identification of Fatty Acids}

Fatty acids are the major constituents of fats and oils (lipids) and occur in nature as triglycerides, consisting of three fatty acids attached to a glycerol molecule by ester-linkages. The shorthand convention for designating fatty acids, Cx:y $\omega z$, contains three components. The " $\mathrm{Cx}$ " refers to a fatty acid with a carbon chain length of $x$ number of atoms. The "y" represents the number of double bonds or points of unsaturation, and the " $\omega z$ " indicates the location of the most distal double bond on the carbon chain, i.e. closest to the methyl end. Thus, the fatty acid expressed as C18:1 $\omega 9$, refers to a mono-unsaturated isomer with a chain length of 18 carbon atoms with a single double bond located nine carbons from the methyl end of the chain. Similarly, the shorthand designation, C16:0, refers to a saturated fatty acid with a chain length of 16 carbons.

Their insolubility in water and relative abundance compared to other classes of lipids, such as sterols and waxes, make fatty acids suitable for residue analysis. Since employed by Condamin et al. (1976), gas chromatography has been used extensively to analyze the fatty acid component of absorbed archeological residues. The composition of uncooked plants and animals provides important baseline information, but it is not possible to directly compare modern uncooked plants and animals with highly degraded archeological residues. Unsaturated fatty acids, which are found widely in fish and plants, decompose more readily than saturated fatty acids, sterols or waxes. In the course of decomposition, simple addition reactions might occur at points of unsaturation (Solomons 1980) or peroxidation might lead to the formation of a variety of volatile and non-volatile products which continue to degrade (Frankel 1991). Peroxidation occurs most readily in fatty acids with more than one point of unsaturation.

Attempts have been made to identify archeological residues using criteria that discriminate uncooked foods (Loy 1994; Marchbanks 1989; Skibo 1992). The major drawback of the distinguishing ratios proposed by Loy (1994), Marchbanks (1989), and Skibo (1992) is they have never been empirically tested. The proposed ratios are based on criteria that discriminate food classes on the basis of their original fatty acid composition. The resistance of these criteria to the effects of decompositional changes has not been demonstrated. Rather, Skibo (1992) found his fatty acid ratio criteria could not be used to identify highly decomposed archeological samples.

In order to identify a fatty acid ratio unaffected by degradation processes, Patrick et al. (1985) simulated the long term decomposition of one 
sample and monitored the resulting changes. An experimental cooking residue of seal was prepared and degraded in order to identify a stable fatty acid ratio. Patrick et al. (1985) found that the ratio of two C18:1 isomers, oleic and vaccenic, did not change with decomposition; this fatty acid ratio was then used to identify an archeological vessel residue as seal. While the fatty acid composition of uncooked foods must be known, Patrick et al. (1985) showed that the effects of cooking and decomposition over long periods of time on the fatty acids must also be understood.

\section{F.2.2 Development of the Identification Criteria}

As the first stage in developing the identification criteria used herein, the fatty acid compositions of more than 130 uncooked Native food plants and animals from Western Canada were determined using gas chromatography (Malainey 1997; Malainey et al. 1999a). When the fatty acid compositions of modern food plants and animals were subject to cluster and principal component analyses, the resultant groupings generally corresponded to divisions that exist in nature (Table F-1). Clear differences in the fatty acid composition of large mammal fat, large herbivore meat, fish, plant roots, greens and berries/seeds/nuts were detected, but the fatty acid composition of meat from medium-sized mammals resembles berries/seeds/nuts.

Samples in cluster A, the large mammal and fish cluster had elevated levels of C16:0 and C18:1 (Table 1). Divisions within this cluster stemmed from the very high level of $\mathrm{C} 18: 1$ isomers in fat, high levels of C18:0 in bison and deer meat and high levels of very long chain unsaturated fatty acids (VLCU) in fish. Differences in the fatty acid composition of plant roots, greens and berries/seeds/nuts reflect the amounts of C18:2 and C18:3 $\omega 3$ present. The berry, seed, nut and small mammal meat samples appearing in cluster B have very high levels of $\mathrm{C} 18: 2$, ranging from $35 \%$ to
$64 \%$ (Table F-1). Samples in subclusters V, VI and VII have levels of C18:1 isomers from $29 \%$ to $51 \%$, as well. Plant roots, plant greens and some berries appear in cluster C. All cluster C samples have moderately high levels of $\mathrm{C} 18: 2$; except for the berries in subcluster XII, levels of C16:0 are also elevated. Higher levels of C18:3 13 and/or very long chain saturated fatty acids (VLCS) are also common except in the roots which form subcluster $\mathrm{XV}$.

Secondly, the effects of cooking and degradation over time on fatty acid compositions were examined. Originally, 19 modern residues of plants and animals from the plains, parkland and forests of Western Canada were prepared by cooking samples of meats, fish and plants, alone or combined, in replica vessels over an open fire (Malainey 1997; Malainey et al. 1999b). After four days at room temperature, the vessels were broken and a set of sherds analysed to determine changes after a short term of decomposition. A second set of sherds remained at room temperature for 80 days, then placed in an oven at $75^{\circ} \mathrm{C}$ for a period of 30 days in order to simulate the processes of long term decomposition. The relative percentages were calculated on the basis of the ten fatty acids (C12:0, C14:0, C15:0, C16:0, C16:1, C17:0, C18:0, C18:1w9, C18:1w11, C18:2) that regularly appeared in Precontact period vessel residues from Western Canada. Observed changes in fatty acid composition of the experimental cooking residues enabled the development of a method for identifying the archeological residues (Table F-2).

It was determined that levels of medium chain fatty acids (C12:0, C14:0 and C15:0), C18:0 and C18:1 isomers in the sample could be used to distinguish degraded experimental cooking residues (Malainey 1997; Malainey et al. 1999b). Higher levels of medium chain fatty acids, combined with low levels of C18:0 and C18:1 isomers, were detected in the decomposed experimental residues of plants, such as roots, greens and most berries. High levels of C18:0 indicated the presence of large herbivores. 
Moderate levels of C18:1 isomers, with low levels of C18:0, indicated the presence of either fish or foods similar in composition to corn. High levels of C18:1 isomers with low levels of C18:0, were found in residues of beaver or foods of similar fatty acid composition. The criteria for identifying six types of residues were established experimentally; the seventh type, plant with large herbivore, was inferred (Table F-2). These criteria were applied to residues extracted from more than 200 pottery cooking vessels from 18 Western Canadian sites (Malainey 1997; Malainey et al. 1999c; 2001b). The identifications were found to be consistent with the evidence from faunal and tool assemblages for each site.

Work has continued to understand the decomposition patterns of various foods and food combinations (Malainey et al. 2000a, 2000b, 2000c; Malainey, Malisza et al. 2001; Quigg et al. 2001). The collection of modern foods has expanded to include plants from the Southern Plains. The fatty acid compositions of mesquite beans (Prosopis glandulosa), Texas ebony seeds (Pithecellobium ebano Berlandier), tasajillo berry (Opuntia leptocaulis), prickly pear fruit and pads (Opuntia engelmannii), Spanish dagger pods (Yucca treculeana), cooked sotol (Dasylirion wheeler), agave (Agave lechuguilla), cholla (Opuntia imbricata), piñon (Pinus edulis) and Texas mountain laurel (or mescal) seed (Sophora secundiflora) have been determined. Experimental residues of many of these plants, alone or in combination with deer meat, have been prepared by boiling foods in clay cylinders or using sandstone for either stone boiling (Quigg et al. 2000) or as a griddle. In order to accelerate the processes of oxidative degradation that naturally occur at a slow rate with the passage of time, the rock or clay tile containing the experimental residue was placed in an oven at $75^{\circ} \mathrm{C}$. After either 30 or 68 days, residues were extracted and analysed using gas chromatography. The results of these decomposition studies enabled refinement of the identification criteria (Malainey 2007).

\section{F.3 USING LIPID DISTRIBUTION AND BIOMARKERS TO IDENTIFY ARCHEOLOGICAL RESIDUES}

Archeological scientists working in the United Kingdom have had tremendous success using high temperature gas chromatography (HT-GC) and gas chromatography with mass spectrometry (HTGC/MS) to identify biomarkers. High temperature gas chromatography is used to separate and assess a wide range of lipid components, including fatty acids, long chain alcohols and hydrocarbons, sterols, waxes, terpenoids and triacylglycerols (Evershed et al. 2001). The molecular structure of separated components is elucidated by mass spectrometry (Evershed 2000).

Triacylglycerols, diacylglycerols and sterols can be used to distinguish animal-derived residues, which contain cholesterol and significant levels of both triacylglycerols, from plant-derived residues, indicated by plant sterols, such as $\beta$-sitosterol, stigmasterol and campesterol, and only traces of triacylglycerols (Evershed 1993; Evershed, Mottram et al. 1997; Dudd and Evershed 1998). Barnard et al. (2007), however, have recently suggested that microorganisms living off residues can introduce $\beta$-sitosterol into residues resulting from the preparation of animal products. Waxes, which are long chain fatty acids and long chain alcohols that form protective coatings on skin, fur, feathers, leaves and fruit, also resist decay. Evershed et al. (1991) found epicuticular leaf waxes from plants of the genus Brassica in vessel residues from a Late Saxon/Medieval settlement. Cooking experiments later confirmed the utility of nonacosane, nonacosan-15-one and 
Table F-1. Summary of Average Fatty Acid Compositions of Modern Food Groups Generated by Hierarchical Cluster Analysis.

\begin{tabular}{|c|c|c|c|c|c|c|c|c|c|c|c|c|c|c|c|}
\hline Cluster & \multicolumn{4}{|c|}{ A } & \multicolumn{6}{|c|}{ B } & \multicolumn{5}{|c|}{ C } \\
\hline Subcluster & I & II & III & IV & $\mathbf{V}$ & VI & VII & VIII & IX & $\mathrm{X}$ & $\mathbf{X I}$ & XII & XIII & XIV & $\mathbf{X V}$ \\
\hline Type & $\begin{array}{l}\text { Mammal } \\
\text { Fat and } \\
\text { Marrow }\end{array}$ & $\begin{array}{c}\text { Large } \\
\text { Herbivore } \\
\text { Meat }\end{array}$ & Fish & Fish & $\begin{array}{c}\text { Berries } \\
\text { and } \\
\text { Nuts }\end{array}$ & Mixed & $\begin{array}{c}\text { Seeds } \\
\text { and } \\
\text { Berries }\end{array}$ & Roots & Seeds & Mixed & Greens & Berries & Roots & Greens & Roots \\
\hline C16:0 & 19.90 & 19.39 & 16.07 & 14.10 & 3.75 & 12.06 & 7.48 & 19.98 & 7.52 & 10.33 & 18.71 & 3.47 & 22.68 & 24.19 & 18.71 \\
\hline C18:0 & 7.06 & 20.35 & 3.87 & 2.78 & 1.47 & 2.36 & 2.58 & 2.59 & 3.55 & 2.43 & 2.48 & 1.34 & 3.15 & 3.66 & 5.94 \\
\hline C18:1 & 56.77 & 35.79 & 18.28 & 31.96 & 51.14 & 35.29 & 29.12 & 6.55 & 10.02 & 15.62 & 5.03 & 14.95 & 12.12 & 4.05 & 3.34 \\
\hline C18:2 & 7.01 & 8.93 & 2.91 & 4.04 & 41.44 & 35.83 & 54.69 & 48.74 & 64.14 & 39.24 & 18.82 & 29.08 & 26.24 & 16.15 & 15.61 \\
\hline C18:3 & 0.68 & 2.61 & 4.39 & 3.83 & 1.05 & 3.66 & 1.51 & 7.24 & 5.49 & 19.77 & 35.08 & 39.75 & 9.64 & 17.88 & 3.42 \\
\hline VLCS & 0.16 & 0.32 & 0.23 & 0.15 & 0.76 & 4.46 & 2.98 & 8.50 & 5.19 & 3.73 & 6.77 & 9.10 & 15.32 & 18.68 & 43.36 \\
\hline VLCU & 0.77 & 4.29 & 39.92 & 24.11 & 0.25 & 2.70 & 1.00 & 2.23 & 0.99 & 2.65 & 1.13 & 0.95 & 2.06 & 0.72 & 1.10 \\
\hline
\end{tabular}

VLCS- Very Long Chain (C20, C22 and C24) Saturated Fatty Acids VLCU - Very Long Chain (C20, C22 and C24) Unsaturated Fatty Acids 
Table F-2. Criteria for the Identification of Archeological Residues Based on the Decomposition Patterns of Experimental Cooking Residues Prepared in Pottery Vessels.

\begin{tabular}{|c|c|c|c|}
\hline Identification & Medium Chain & C18:0 & C18:1 isomers \\
\hline Large herbivore & $\leq 15 \%$ & $\geq 27.5 \%$ & $\leq 15 \%$ \\
\hline $\begin{array}{c}\text { Large herbivore with plant } \\
\text { or Bone marrow }\end{array}$ & Low & $\geq 25 \%$ & $15 \% \leq X \leq 25 \%$ \\
\hline Plant with large herbivore & $\geq 15 \%$ & $\geq 25 \%$ & no data \\
\hline Beaver & Low & Low & $\geq 25 \%$ \\
\hline Fish or Corn & Low & $\leq 25 \%$ & $15 \% \leq X \leq 27.5 \%$ \\
\hline Fish or Corn with Plant & $\geq 15 \%$ & $\leq 25 \%$ & $15 \% \leq X \leq 27.5 \%$ \\
\hline Plant (except corn) & $\geq 10 \%$ & $\leq 27.5 \%$ & $\leq 15 \%$ \\
\hline
\end{tabular}

nonacosan-15-ol to indicate the preparation of leafy vegetables, such as turnip or cabbage (Charters et al. 1997). Reber et al. (2004) recently suggested ndotriacontanol could serve as an effective biomarker for maize in vessel residues from sites located in Midwestern and Eastern North America. Beeswax can be identified by the presence and distribution of n-alkanes with carbon chains 23 to 33 atoms in length and palmitic acid wax esters with chains between 40 and 52 carbons in length (Heron et al. 1994; Evershed, Vaugh et al. 1997).

Terpenoid compounds, or terpenes, are long chain alkenes that occur in the tars and pitches of higher plants. The use of GC and GC/MS to detect the diterpenoid, dehydroabietic acid, from conifer products in ogical residues extends over a span of 25 years (Heron and Pollard 1988; Shackley 1982). Lupeol, $\alpha^{-}$and $\beta$-amarcheolyrin and their derivatives indicate the presence of plant materials (Regert 2007). Eerkens (2002) used the predominance of the diterpenoid, $\Delta-8(9)$ isopimaric acid, in a vessel residue from the western Great Basin to argue it contained piñyon resins. Other analytical techniques have also been used to identify terpenoid compounds. Sauter et al. (1987) detected the triterpenoid, betulin, in Iron Age tar using both $1 \mathrm{H}$ and $13 \mathrm{C}$ nuclear magnetic resonance spectroscopy (NMR), confirming the tar was produced from birch.

\section{F.4 METHODOLOGY}

Descriptions of samples analyzed are presented in Table F-3. Possible contaminants were removed by grinding off exterior surfaces with a Dremel ${ }^{\circledR}$ tool fitted with a silicon carbide bit. Immediately thereafter, the sample was crushed with a hammer mortar and pestle and the powder transferred to an Erlenmeyer flask. Lipids were extracted using a variation of the method developed by Folch et al. (1957). The powdered sample was mixed with a $2: 1$ mixture, by volume, of chloroform and methanol (2 $\times 25 \mathrm{~mL}$ ) using ultrasonication $(2 \times 10 \mathrm{~min})$. Solids were removed by filtering the solvent mixture into a separatory funnel. The lipid/solvent filtrate was washed with $13.3 \mathrm{~mL}$ of ultrapure water. Once separation into two phases was complete, the lower chloroform-lipid phase was transferred to a roundbottomed flask and the chloroform removed by rotary evaporation. Any remaining water was removed by evaporation with benzene $(1.5 \mathrm{~mL}) ; 1.5$ $\mathrm{mL}$ of chloroform-methanol $(2: 1, \mathrm{v} / \mathrm{v})$ was used to transfer the dry total lipid extract to a screw-top glass vial with a Teflon ${ }^{\circledR}$-lined cap. The sample was flushed with nitrogen and stored in a $-20^{\circ} \mathrm{C}$ freezer. 
Table F-3. List of 41BL278 Burned Rock Samples.

\begin{tabular}{|c|c|c|c|c|}
\hline Lab No. & PNUM-CAT-EXT & Block & Feature & $\begin{array}{c}\text { Sample Size } \\
\text { (g) }\end{array}$ \\
\hline 14MQ 1 & 0501-003-3a & BT 9 & 3 & 17.597 \\
\hline 14MQ 2 & $0501-003-2 a$ & BT 9 & 3 & 26.581 \\
\hline 14MQ 3 & 0501-003-1a & BT 9 & 3 & 24.395 \\
\hline $14 \mathrm{MQ} 4$ & 0503-003-1a & BT 9 & $3 a$ & 37.467 \\
\hline 14MQ 5 & 0503-003-2 & BT 9 & $3 a$ & 36.917 \\
\hline 14MQ 6 & 0504-003-1a & BT 8 & 4 & 36.321 \\
\hline $14 \mathrm{MQ} 7$ & 0504-003-2a & BT 8 & 4 & 30.858 \\
\hline $14 \mathrm{MQ} 8$ & 0504-003-3a & BT 8 & 4 & 36.367 \\
\hline $14 \mathrm{MQ} 9$ & 0505-003-5a & BT 8 & 5 & 29.999 \\
\hline $14 \mathrm{MQ} 10$ & $0505-003-3 a$ & BT 8 & 5 & 30.663 \\
\hline $14 \mathrm{MQ} 11$ & 0505-003-1a & BT 8 & 5 & 13.929 \\
\hline 14MQ 12 & $0505-003-2 a$ & BT 8 & 5 & 35.208 \\
\hline $14 \mathrm{MQ} 13$ & 0506-003-2 & BT 8 & 6 & 20.578 \\
\hline $14 \mathrm{MQ} 14$ & 0507-003-2a & BT 9 & 7 & 35.444 \\
\hline $14 \mathrm{MQ} 15$ & 0507-003-1a & BT 9 & 7 & 31.598 \\
\hline $14 \mathrm{MQ} 16$ & 0508-003-1a & BT 9 & 8 & 25.004 \\
\hline $14 \mathrm{MQ} 17$ & $0508-003-2 a$ & BT 9 & 8 & 34.826 \\
\hline $14 \mathrm{MQ} 18$ & 0508-003-3a & BT 9 & 8 & 38.399 \\
\hline
\end{tabular}

\section{F.4.1 Preparation of FAMES}

A $400 \mu \mathrm{L}$ aliquot of the total lipid extract solution was placed in a screw-top test tube and dried in a heating block under nitrogen. Fatty acid methyl esters (FAMES) were prepared by treating the dry lipid with 5 or $3 \mathrm{~mL}$ of $0.5 \mathrm{~N}$ anhydrous hydrochloric acid in methanol $\left(68^{\circ} \mathrm{C} ; 60 \mathrm{~min}\right)$. Fatty acids that occur in the sample as di- or triglycerides are detached from the glycerol molecule and converted to methyl esters. In 2007, after cooling to room temperature, $3.4 \mathrm{~mL}$ of ultrapure water was added. FAMES were recovered with petroleum ether $(2.5 \mathrm{~mL})$ and transferred to a vial. In 2013, after cooling to room temperature, $2.0 \mathrm{~mL}$ of ultrapure water was added. FAMES were recovered with petroleum ether $(2 \times 1.5 \mathrm{~mL})$ and transferred to a vial. The solvent was removed by heat under a gentle stream of nitrogen; the FAMES were dissolved in $75 \mu \mathrm{L}$ of iso-octane then transferred to a GC vial with a conical glass insert.

\section{F.4.2 Preparation of TMS Derivatives}

A $200 \mu \mathrm{L}$ aliquot of the total lipid extract solution was placed in a screw-top vial and dried under nitrogen. Trimethylsilyl (TMS) derivatives were prepared by treating the lipid with $70 \mu \mathrm{L}$ of $N, O-$ bis(trimethylsilyl)trifluoroacetamide (BSTFA) containing $1 \%$ trimethylchlorosilane, by volume $\left(70^{\circ} \mathrm{C} ; 30 \mathrm{~min}\right)$. The sample was then dried under nitrogen and the TMS derivatives were redissolved in $100 \mu \mathrm{L}$ of hexane.

Solvents and chemicals were checked for purity by running a sample blank. Traces of fatty acid 
contamination were subtracted from sample chromatograms. The relative percentage composition was calculated by dividing the integrated peak area of each fatty acid by the total area of fatty acids present in the sample. In order to identify the residue on the basis of fatty acid composition, the relative percentage composition was determined first with respect to all fatty acids present in the sample (including very long chain fatty acids) and second with respect to the ten fatty acids utilized in the development of the identification criteria (C12:0, C14:0, C15:0, C16:0, C16:1, C17:0, C18:0, C18:1w9, C18:1w11 and C18:2) (not shown). The second step is necessary for the application of the identification criteria presented in Table F-2. It must be understood that the identifications given do not necessarily mean that those particular foods were actually prepared because different foods of similar fatty acid composition and lipid content would produce similar residues (see Table F-4). It is possible only to say that the material of origin for the residue was similar in composition to the food(s) indicated. High temperature gas chromatography and high temperature gas chromatography with mass spectrometry is used to further clarify the identifications.

\section{F.4.3 Gas Chromatography Analysis Parameters}

The GC analysis was performed on a Varian 3800 gas chromatograph fitted with a flame ionization detector connected to a personal computer. Samples were separated using a VF-23 fused silica capillary column (30 m × 0.25 mm I.D; Varian; Palo Alto, CA). An autosampler injected the sample using a split/splitless injection system. Hydrogen was used as the carrier gas with a column flow of 1.0 $\mathrm{mL} / \mathrm{min}$. Column temperature was increased from $80^{\circ} \mathrm{C}$ to $140^{\circ} \mathrm{C}$ at a rate of $20^{\circ} \mathrm{C}$ per minute then increased to $185^{\circ} \mathrm{C}$ at a rate of $4^{\circ} \mathrm{C}$ per minute. After a 4.0 minute hold, the temperature was further increased to $250^{\circ} \mathrm{C}$ at $10^{\circ} \mathrm{C}$ per minute and held for 2 minutes. Chromatogram peaks were integrated using Varian MS Workstation ${ }^{\circledR}$ software and identified through comparisons with external qualitative standards (NuCheck Prep; Elysian, $\mathrm{MN})$.

\section{F.4.4 High Temperature Gas Chromatography and Gas Chromatography with Mass Spectrometry}

Both HT-GC and H-GC/MS analyses were performed on a Varian 3800 gas chromatograph fitted with a flame ionization detector and a Varian 4000 mass spectrometer connected to a personal computer. For HT-GC analysis, the sample was injected onto a DB-1HT fused silica capillary column (15 m × 0.32 mm I.D.; Agilent J\&W; Santa Clara, CA) connected to the flame ionization detector, using hydrogen as the carrier gas. The column temperature was held at $50 \mathrm{oC}$ for 1 minute then increased to $350 \mathrm{oC}$ at a rate of $15 \mathrm{oC}$ per minute and held for 26 minutes. For HT-GC/MS analysis, samples were injected onto a DB-5HT fused silica capillary column $(30 \mathrm{~m} \times 0.25 \mathrm{~mm}$ I.D.; Agilent J\&W; Santa Clara, CA) connected to the ion trap mass spectrometer in an external ionization configuration using helium as the carrier gas. After a 1 minute hold at $50 \mathrm{oC}$, the column temperature was increased to $180 \mathrm{oC}$ at a rate of $40 \mathrm{oC}$ per minute then ramped up to $230 \mathrm{oC}$ at a rate of $5 \mathrm{oC}$ per minute and finally increased to $350 \mathrm{oC}$ at a rate of $15 \mathrm{oC}$ per minute and held for 27.75 minutes. The Varian 4000 mass spectrometer was operated in electronimpact ionization mode scanning from $\mathrm{m} / \mathrm{z}$ 50-700. Chromatogram peaks and MS spectra were processed using Varian MS Workstation ${ }^{\circledR}$ software and identified through comparisons with external qualitative standards (Sigma Aldrich; St. Louis, MO and NuCheck Prep; Elysian, MN), reference samples and the National Institute of Standards and Technology (NIST) database. 
Table F-4. Known Food Sources for Different Types of Decomposed Residues.

\begin{tabular}{|c|c|c|}
\hline $\begin{array}{c}\text { Decomposed Residue } \\
\text { Identification }\end{array}$ & $\begin{array}{c}\text { Plant Foods Known to } \\
\text { Produce Similar Residues }\end{array}$ & $\begin{array}{c}\text { Animal Foods Known To Produce } \\
\text { Similar Residues }\end{array}$ \\
\hline $\begin{array}{c}\text { Large herbivore } \\
\text { OR Bone marrow }\end{array}$ & $\begin{array}{c}\text { Tropical seed oils, including } \\
\text { sotol seeds }\end{array}$ & $\begin{array}{c}\text { Bison, deer, moose, fall-early winter } \\
\text { fatty elk meat, Javelina meat }\end{array}$ \\
\hline $\begin{array}{c}\text { Low Fat Content Plant } \\
\text { (Plant greens, roots, berries) }\end{array}$ & $\begin{array}{c}\text { Jicama tuber, buffalo gourd, } \\
\text { yopan leaves, biscuit root, millet }\end{array}$ & Cooked Camel's milk \\
\hline $\begin{array}{c}\text { Medium-Low Fat Content Plant } \\
\text { Prickly pear, Spanish dagger } \\
\text { (Fish or Corn) }\end{array}$ & $\begin{array}{c}\text { Corn, mesquite beans, cholla } \\
\text { Medium Fat Content } \\
\text { (Beaver) }\end{array}$ & $\begin{array}{c}\text { Freshwater fish, Rabdotus snail, } \\
\text { terrapin, late winter fat-depleted elk }\end{array}$ \\
\hline $\begin{array}{c}\text { Moderate-High Fat Content } \\
\text { High Fat Content }\end{array}$ & $\begin{array}{c}\text { High fat nuts and seeds, } \\
\text { including acorn and pecan }\end{array}$ & $\begin{array}{c}\text { Rendered animal fat (other than large } \\
\text { otherbivore), including bear fat }\end{array}$ \\
\hline $\begin{array}{c}\text { Very high fat nuts and seeds, } \\
\text { including pine nuts }\end{array}$ & $\begin{array}{c}\text { Freshly rendered animal fat (other than } \\
\text { large herbivore) }\end{array}$ \\
\hline
\end{tabular}

\section{F.5 RESULTS OF ARCHEOLOGICAL DATA ANALYSIS}

The full lipid compositions of 10 residues are presented in Table F-5. The term, Area, represents the area under the chromatographic peak of a given fatty acid, as calculated by the Varian MS Workstation ${ }^{\circledR}$ software minus the solvent blank. The term, Rel\%, represents the relative percentage of the fatty acid with respect to the total fatty acids in the sample. Hydroxide or peroxide degradation products can interfere with the integration of the C22:0 and C22:1peaks; these fatty acids were excluded from the analysis. Results of the HT-G and HT-GC/MS analyses of eight residues with insufficient fatty acids to attempt identification are presented in Table F-6. Lipid recoveries from many site 41BL278 samples were poor. In order to characterize more residues, the cut-off for "sufficient fatty acids" was reduced by one-half (i.e., from total area counts of 200,000 to 100,000 ); these residue identifications should be treated with caution.
Residues were analysed for the presence of lipid biomarkers and triacylglycerols (TAGs) using HTGC and HT-GC/MS. The data obtained is useful for distinguishing plant residues, animal residues and plant/animal combinations. The sterol cholesterol is associated with animal products; $\beta$-sitosterol, stigmasterol and campesterol are associated with plant products. The presence and abundance of TAGs varies with the material of origin. When present, amounts of TAGs tend to decrease with increasing numbers of carbon atoms in plant residues (Malainey et al. 2010; Malainey, Álvarez et al. 2014; Malainey, Innes et al. 2014). The peak arising from C48 TAGs is largest and peak size (and area) progressively decreases with the C54 TAG peak being the smallest. A line drawn to connect the tops of the C48, C50, C52 and C54 TAG peaks slopes down to the right. In animal residues, amounts of TAGs tend to increase with carbon numbers, with the C52 or C54 TAG peaks being the largest (Malainey et al. 2010). A line drawn to connect the tops of the C48, C50, C52 and C54 TAG peaks either resembles a hill or the line slopes up to the right. A parabola-like pattern, such 
as the shape of a "normal distribution," can also occur in the residues of oil seeds that contain high levels of C18:1 isomers (Malainey et al. 2010; Malainey, Álvarez et al. 2014; Malainey, Innes et al. 2014).

\section{F.5.1 High Fat Content - Residues with High Levels of C18:1 Isomers}

Levels of C18:1 isomers in three residues, 0501003-2a (14MQ 2), 0503-003-1a (14MQ 4) and 0506-003-2 (14MQ 13), are high, ranging from $39.92 \%$ to $43.76 \%$. Foods known to produce high fat content residues include high fat content seeds or nuts and the rendered fats of certain mammals (other than large herbivores). Levels of medium chain saturated fatty acids in all three residues exceed $10 \%$, which strongly indicates the presence of low fat content plants, such as roots, greens and some berries.

Analyses of these residues using HT-GC and HTGC/MS shows these residues likely represent combinations of plant and animal products. The animal sterol cholesterol occurs in residue 0506003-2 (14MQ 13); it probably occurs in 0503-0031a (14MQ 4) and it may occur in 0501-003-2a (14MQ 2). The plant $\beta$-sitosterol may occur in residue 0501-003-2a (14MQ 2). Dehydroabietic acid occurs in residue 0501-003-2a (14MQ 2) and 0506-003-2 (14MQ 13) and probably occurs in 0503-003-1a (14MQ 4). This biomarker indicates the presence of conifer products, which may have been introduced from pine nuts, firewood, resins or other conifer products.

The C48 TAG peak is predominant in residue 0503003-1a (14MQ 4); plant material may be dominant but plant sterols are absent so it is identified as a plant and animal combination. The C48 and C50 TAG peaks are predominant in residues 0501-0032a (14MQ 2) and 0506-003-2 (14MQ 13), which suggests a plant and animal combination; because cholesterol was the only sterol detected in the latter, animal products may be dominant.

\section{F.5.2 Borderline Moderate-High Fat and High Fat Content}

The level of C18:1 isomers in residue 0505-003-2a (14 MQ 12) falls on the border between high fat content and moderate-high fat content foods. Decomposed residues of high fat content seeds or nuts and the rendered fats of certain mammals (other than large herbivores) are of high fat content. Foods known to produce moderate-high fat content residues include Texas ebony seeds and the fatty meat of medium-sized mammals, such as beaver. The level of medium chain saturated fatty acids is over $9 \%$ so some low fat content plant material is present. The animal sterol cholesterol is probably present and the plant sterol $\beta$-sitosterol may occur. Dehydroabietic acid, the biomarker for conifer products, is present. The C48 and C50 TAG peaks are predominant, which suggests a plant and animal combination.

\section{F.5.3 Medium Fat Content - Residues with Medium Levels of C18:1 Isomers}

Levels of C18:1 isomers in four residues are medium fat content, ranging between $18.10 \%$ and 25.72\%: 0507-003-2a (14MQ 14), 0507-003-1a (14MQ 15), 0508-003-1a (14MQ 16) and 0508003-2a (14MQ 17). Residues with similar levels of C18:1 isomers result from the preparation of medium fat content foods. Examples of medium fat content plant foods include mesquite, corn and cholla. Freshwater fish, terrapin, Rabdotus snail and late winter, fat-depleted elk are examples of medium fat content animal foods. The level of medium chain saturated fatty acids exceeds $10 \%$ in 0507-003-2a (14MQ 14), 0507-003-1a (14MQ 15) and 0508-003-2a (14MQ 17), which indicates the presence of low fat content plant material, such as greens, roots and certain berries. The level of medium chain saturated fatty acids is over $7 \%$ in residue 0508-003-1a (14MQ 16), so some low fat content plant material is present. Levels of the fatty acid C18:0 are somewhat elevated in all of these residues. 
Table F-5. Lipid Compositions and Identifications of Residues from Site 41BL278.

\begin{tabular}{|c|c|c|c|c|c|c|c|c|c|c|}
\hline \multirow{2}{*}{ Fatty acid } & \multicolumn{2}{|c|}{ 14MQ 2, 501-003-2a } & \multicolumn{2}{|c|}{ 14MQ 4, 503-003-1a } & \multicolumn{2}{|c|}{ 14MQ 6, 504-003-1a } & \multicolumn{2}{|c|}{ 14MQ 11, 505-003-1a } & \multicolumn{2}{|c|}{ 14MQ 12, 505-003-2a } \\
\hline & Area & Rel\% & Area & Rel\% & Area & Rel\% & Area & Rel\% & Area & Rel\% \\
\hline C12:0 & 7160 & 4.62 & 3834 & 3.05 & 0 & 0.00 & 0 & 0.00 & 2083 & 1.58 \\
\hline C14:0 & 9269 & 5.98 & 10545 & 8.38 & 885 & 0.78 & 3447 & 2.48 & 7392 & 5.61 \\
\hline C14:1 & 0 & 0.00 & 0 & 0.00 & 0 & 0.00 & 0 & 0.00 & 0 & 0.00 \\
\hline C15:0 & 4759 & 3.07 & 2542 & 2.02 & 1155 & 1.02 & 1499 & 1.08 & 2773 & 2.10 \\
\hline C16:0 & 42173 & 27.21 & 32737 & 26.02 & 35797 & 31.53 & 36082 & 25.93 & 46066 & 34.94 \\
\hline C16:1 & 3964 & 2.56 & 5205 & 4.14 & 0 & 0.00 & 1339 & 0.96 & 3307 & 2.51 \\
\hline C17:0 & 4558 & 2.94 & 3443 & 2.74 & 1903 & 1.68 & 2628 & 1.89 & 3597 & 2.73 \\
\hline C17:0 & 0 & 0.00 & 0 & 0.00 & 0 & 0.00 & 0 & 0.00 & 0 & 0.00 \\
\hline C18:0 & 15125 & 9.76 & 11764 & 9.35 & 54564 & 48.06 & 76047 & 54.65 & 10517 & 7.98 \\
\hline C18:1s & 61856 & 39.92 & 51982 & 41.31 & 14794 & 13.03 & 14112 & 10.14 & 49222 & 37.33 \\
\hline C18:2 & 1650 & 1.06 & 1358 & 1.08 & 1693 & 1.49 & 1139 & 0.82 & 3879 & 2.94 \\
\hline C18:3w3 & 0 & 0.00 & 0 & 0.00 & 0 & 0.00 & 0 & 0.00 & 0 & 0.00 \\
\hline C20:0 & 3156 & 2.04 & 2410 & 1.92 & 2743 & 2.42 & 2859 & 2.05 & 3003 & 2.28 \\
\hline C20:1 & 1294 & 0.84 & 0 & 0.00 & 0 & 0.00 & 0 & 0.00 & 0 & 0.00 \\
\hline C24:0 & 0 & 0.00 & 0 & 0.00 & 0 & 0.00 & 0 & 0.00 & 0 & 0.00 \\
\hline Total & 154964 & 100.00 & 125820 & 100.00 & 113533 & 100.00 & 139152 & 100.00 & 131839 & 100.00 \\
\hline Biomarkers & \multicolumn{2}{|c|}{$\begin{array}{l}\text { Possibly } \beta \text {-sitosterol; } \\
\text { possibly Cholesterol; } \\
\text { Dehydroabietic acid }\end{array}$} & \multicolumn{2}{|c|}{$\begin{array}{c}\text { Probably Cholesterol; } \\
\text { probably Dehydroabietic } \\
\text { acid }\end{array}$} & \multicolumn{2}{|c|}{$\begin{array}{l}\text { Possibly Cholesterol; } \\
\text { possibly } \beta \text {-sitosterol; } \\
\text { Dehydroabietic acid }\end{array}$} & \multicolumn{2}{|c|}{$\begin{array}{c}\text { Possibly Cholesterol; } \\
\text { probably Dehydroabietic } \\
\text { acid }\end{array}$} & \multicolumn{2}{|c|}{$\begin{array}{l}\text { Probably Cholesterol; } \\
\text { Possibly } \beta \text {-sitosterol; } \\
\text { Dehydroabietic acid }\end{array}$} \\
\hline$\underline{\text { Triacylglycerols }}$ & \multicolumn{2}{|c|}{$\begin{array}{c}\text { Possibly C48 \& C50 } \\
\text { TAGs and traces of } \\
\text { others; Possible Plant } \\
\text { and Animal combination }\end{array}$} & \multicolumn{2}{|c|}{$\begin{array}{l}\text { Possibly C48 TAG \& } \\
\text { traces of others; Plant } \\
\text { material may dominate }\end{array}$} & \multicolumn{2}{|c|}{$\begin{array}{l}\text { Possibly C48 \& C50 } \\
\text { TAGs and traces of } \\
\text { others; Possible Plant } \\
\text { and Animal combination }\end{array}$} & \multicolumn{2}{|c|}{$\begin{array}{c}\text { Probably C48 TAG \& } \\
\text { possible traces of others; } \\
\text { Plant material probably } \\
\text { dominate }\end{array}$} & \multicolumn{2}{|c|}{$\begin{array}{c}\text { Possibly C48 \& C50 } \\
\text { TAGs and traces of } \\
\text { others; Possible Plant } \\
\text { and Animal combination }\end{array}$} \\
\hline Identification & \multicolumn{2}{|c|}{$\begin{array}{l}\text { High fat content and Low } \\
\text { Fat Content Plant; } \\
\text { Probable plant and } \\
\text { animal combination; } \\
\text { conifer products occur }\end{array}$} & \multicolumn{2}{|c|}{$\begin{array}{l}\text { High fat content and Low } \\
\text { Fat Content Plant; Probable } \\
\text { plant and animal } \\
\text { combination; conifer } \\
\text { products may occur } \\
\end{array}$} & \multicolumn{2}{|c|}{$\begin{array}{l}\text { Large Herbivore and } \\
\text { Plant; conifer products } \\
\text { occur }\end{array}$} & \multicolumn{2}{|c|}{$\begin{array}{l}\text { Large Herbivore and } \\
\text { Plant; conifer products } \\
\text { probably occur }\end{array}$} & \multicolumn{2}{|c|}{$\begin{array}{l}\text { Borderline Moderate high- } \\
\text { High fat content, some Low } \\
\text { Fat Content Plant; plant } \\
\text { and animal combination; } \\
\text { conifer products present }\end{array}$} \\
\hline Catalogue No. & \multicolumn{2}{|c|}{$0501-003-2 a$} & \multicolumn{2}{|c|}{$0503-003-1 a$} & \multicolumn{2}{|c|}{ 0504-003-1a } & \multicolumn{2}{|c|}{$0505-003-1 a$} & \multicolumn{2}{|c|}{$0505-003-2 a$} \\
\hline
\end{tabular}


Archeological Testing of TxDOT Right-of-Way through site 41BL278, Bell County, Texas Texas Department of Transportation

Table F-5. Lipid Compositions and Identifications of Residues from Site 41BL278 (continued).

\begin{tabular}{|c|c|c|c|c|c|c|c|c|c|c|}
\hline \multirow{2}{*}{ Fatty acid } & \multicolumn{2}{|c|}{$14 \mathrm{MQ} 13,506-003-2$} & \multicolumn{2}{|c|}{$14 \mathrm{MQ} 14,507-003-2 a$} & \multicolumn{2}{|c|}{$14 \mathrm{MQ} 15,507-003-1 \mathrm{a}$} & \multicolumn{2}{|c|}{$14 \mathrm{MQ} 16,508-003-1 \mathrm{a}$} & \multicolumn{2}{|c|}{ 14MQ 17, 508-003-2a } \\
\hline & Area & Rel\% & Area & Rel\% & Area & Rel\% & Area & Rel\% & Area & Rel\% \\
\hline C12:0 & 4181 & 1.90 & 2005 & 1.86 & 8812 & 5.59 & 0 & 0.00 & 1912 & 1.10 \\
\hline C14:0 & 19445 & 8.85 & 7090 & 6.59 & 15797 & 10.02 & 6178 & 4.87 & 14890 & 8.58 \\
\hline C14:1 & 0 & 0.00 & 0 & 0.00 & 0 & 0.00 & 0 & 0.00 & 0 & 0.00 \\
\hline C15:0 & 5390 & 2.45 & 3530 & 3.28 & 4276 & 2.71 & 3019 & 2.38 & 4402 & 2.54 \\
\hline C16:0 & 63150 & 28.74 & 44639 & 41.50 & 56454 & 35.82 & 57932 & 45.71 & 70266 & 40.47 \\
\hline C16:1 & 6027 & 2.74 & 1729 & 1.61 & 2032 & 1.29 & 1377 & 1.09 & 1350 & 0.78 \\
\hline C17:0 & 5654 & 2.57 & 3819 & 3.55 & 6326 & 4.01 & 5795 & 4.57 & 7208 & 4.15 \\
\hline C17:1 & 0 & 0.00 & 0 & 0.00 & 0 & 0.00 & 0 & 0.00 & 0 & 0.00 \\
\hline C18:0 & 14214 & 6.47 & 14083 & 13.09 & 27971 & 17.75 & 24219 & 19.11 & 24350 & 14.02 \\
\hline C18:1s & 96161 & 43.76 & 26169 & 24.33 & 30404 & 19.29 & 22935 & 18.10 & 44662 & 25.72 \\
\hline C18:2 & 2784 & 1.27 & 1641 & 1.53 & 2044 & 1.30 & 1242 & 0.98 & 0 & 0.00 \\
\hline C18:3w3 & 0 & 0.00 & 0 & 0.00 & 0 & 0.00 & 0 & 0.00 & 0 & 0.00 \\
\hline C20:0 & 2742 & 1.25 & 2870 & 2.67 & 3497 & 2.22 & 4045 & 3.19 & 4590 & 2.64 \\
\hline C20:1 & 0 & 0.00 & 0 & 0.00 & 0 & 0.00 & 0 & 0.00 & 0 & 0.00 \\
\hline C24:0 & 0 & 0.00 & 0 & 0.00 & 0 & 0.00 & 0 & 0.00 & 0 & 0.00 \\
\hline Total & 219748 & 100.00 & 107575 & 100.00 & 157613 & 100.00 & 126742 & 100.00 & 173631 & 100.00 \\
\hline Biomarkers & \multicolumn{2}{|c|}{$\begin{array}{c}\text { Cholesterol; Dehydroabietic } \\
\text { acid }\end{array}$} & \multicolumn{2}{|c|}{$\begin{array}{c}\text { Possibly Cholesterol; } \\
\text { probably Dehydroabietic acid }\end{array}$} & \multicolumn{2}{|c|}{$\begin{array}{c}\text { Probably Dehydroabietic } \\
\text { acid } \\
\end{array}$} & \multicolumn{2}{|c|}{ Possibly Cholesterol } & \multicolumn{2}{|c|}{$\begin{array}{c}\text { Possibly Cholesterol; } \\
\text { possibly Dehydroabietic acid }\end{array}$} \\
\hline Triacylglcerols & \multicolumn{2}{|c|}{$\begin{array}{l}\text { Possibly C48 \& C50 TAGs } \\
\text { and traces of others; } \\
\text { Possible Plant and Animal } \\
\text { combination }\end{array}$} & \multicolumn{2}{|c|}{$\begin{array}{c}\text { Possibly C48, C50 \& C52 } \\
\text { TAGs; Possible Plant and } \\
\text { Animal combination, animal } \\
\text { material dominant }\end{array}$} & \multicolumn{2}{|c|}{$\begin{array}{c}\text { Probably C50 TAG, possibly } \\
\text { C48 \& C54 TAGs; Possible } \\
\text { Plant and Animal } \\
\text { combination; animal material } \\
\text { dominant }\end{array}$} & \multicolumn{2}{|c|}{ Possible traces of TAGs } & \multicolumn{2}{|c|}{$\begin{array}{l}\text { Possibly C48 \& C50 TAGs } \\
\text { and traces of others; } \\
\text { Possible Plant and Animal } \\
\text { combination }\end{array}$} \\
\hline Identification & \multicolumn{2}{|c|}{$\begin{array}{l}\text { High fat content and Low Fat } \\
\text { Content Plant; Probable } \\
\text { plant and animal } \\
\text { combination, animal may be } \\
\text { dominant; conifer products } \\
\text { occur } \\
\end{array}$} & \multicolumn{2}{|c|}{$\begin{array}{l}\text { Medium fat content and Low } \\
\text { Fat Content Plant; Possible } \\
\text { Plant and animal } \\
\text { combination, dominated by } \\
\text { animal; conifer products } \\
\text { probably occur } \\
\end{array}$} & \multicolumn{2}{|c|}{$\begin{array}{l}\text { Medium fat content and Low } \\
\text { Fat Content Plant; Possible } \\
\text { Plant and animal } \\
\text { combination, dominated by } \\
\text { animal; conifer products } \\
\text { probably occur }\end{array}$} & \multicolumn{2}{|c|}{$\begin{array}{c}\text { Medium fat content, some } \\
\text { Low Fat Content Plant; } \\
\text { Possible Plant and animal } \\
\text { combination, dominated by } \\
\text { animal }\end{array}$} & \multicolumn{2}{|c|}{$\begin{array}{l}\text { Medium fat content and Low } \\
\text { Fat Content Plant; Possible } \\
\text { Plant and animal } \\
\text { combination, dominated by } \\
\text { animal; conifer products may } \\
\text { occur } \\
\end{array}$} \\
\hline Catalogue No. & \multicolumn{2}{|c|}{ 0506-003-2 } & \multicolumn{2}{|c|}{$0507-003-2 a$} & \multicolumn{2}{|c|}{$0507-003-1 a$} & \multicolumn{2}{|c|}{$0508-003-1 a$} & \multicolumn{2}{|c|}{$0508-003-2 a$} \\
\hline
\end{tabular}


Table F-6. Biomarker and TAG Distributions of Lipid Residues with Insufficient Fatty Acids.

\begin{tabular}{|c|c|c|c|}
\hline $\begin{array}{l}\text { Lab No.I } \\
\text { Cat. No. }\end{array}$ & Biomarkers Detected & $\begin{array}{c}\text { Occurrence of } \\
\text { Triacylglycerols (TAGs) }\end{array}$ & Identification \\
\hline $\begin{array}{c}14 \mathrm{MQ} 1 \\
0501-003-3 a\end{array}$ & $\begin{array}{c}\text { Probably Cholesterol; } \\
\text { possibly } \\
\beta \text {-sitosterol }\end{array}$ & $\begin{array}{l}\text { Possibly C48 TAG \& } \\
\text { traces of others; Plant } \\
\text { material may dominate }\end{array}$ & $\begin{array}{l}\text { Plant and animal } \\
\text { combination }\end{array}$ \\
\hline $\begin{array}{c}14 \mathrm{MQ} 3 \\
0501-003-1 \mathrm{a}\end{array}$ & $\begin{array}{l}\text { Probably Cholesterol; } \\
\text { Dehydroabietic acid }\end{array}$ & $\begin{array}{l}\text { Possibly C48 \& C50 TAGs } \\
\text { and traces of others; } \\
\text { Possible Plant and Animal } \\
\text { combination }\end{array}$ & $\begin{array}{c}\text { Plant and Animal material, } \\
\text { animal dominant }\end{array}$ \\
\hline $\begin{array}{c}\text { 14MQ } 5 \\
0503-003-2\end{array}$ & $\begin{array}{c}\text { Probably Cholesterol; } \\
\text { possibly } \\
\beta \text {-sitosterol; } \\
\text { Dehydroabietic acid }\end{array}$ & $\begin{array}{l}\text { Possibly C48 TAG \& } \\
\text { traces of others; Plant } \\
\text { material may dominate }\end{array}$ & $\begin{array}{l}\text { Plant and Animal } \\
\text { combination; conifer } \\
\text { products present }\end{array}$ \\
\hline $\begin{array}{c}14 \mathrm{MQ} 7 \\
0504-003-2 a\end{array}$ & $\begin{array}{l}\text { Cholesterol; possibly } \\
\quad \beta \text {-sitosterol; }\end{array}$ & $\begin{array}{l}\text { Possibly C48 TAG \& } \\
\text { traces of others; Plant } \\
\text { material may dominate }\end{array}$ & Animal and Plant material \\
\hline $\begin{array}{c}14 \mathrm{MQ} 8 \\
0504-003-3 a\end{array}$ & $\begin{array}{c}\text { Possibly Cholesterol; } \\
\text { possibly Dehydroabietic } \\
\text { acid }\end{array}$ & $\begin{array}{c}\text { Possibly C48 TAG \& } \\
\text { traces of others; Plant } \\
\text { material may dominate }\end{array}$ & $\begin{array}{c}\text { Plant and Animal } \\
\text { combination; conifer } \\
\text { products present }\end{array}$ \\
\hline $\begin{array}{c}14 \mathrm{MQ} 9 \\
0505-003-5 a\end{array}$ & $\begin{array}{l}\text { Probably Cholesterol; } \\
\text { Dehydroabietic acid }\end{array}$ & $\begin{array}{l}\text { Probably C48 TAG \& } \\
\text { traces of others; Plant } \\
\text { material probably } \\
\text { dominate }\end{array}$ & $\begin{array}{l}\text { Plant and Animal } \\
\text { combination; conifer } \\
\text { products present }\end{array}$ \\
\hline $\begin{array}{c}14 \mathrm{MQ} 10 \\
0505-003-3 a\end{array}$ & $\begin{array}{l}\text { Probably Cholesterol; } \\
\text { Dehydroabietic acid }\end{array}$ & $\begin{array}{l}\text { Possibly C48 \& C50 TAGs } \\
\text { and traces of others; } \\
\text { Possible Plant and Animal } \\
\text { combination }\end{array}$ & $\begin{array}{c}\text { Plant and Animal } \\
\text { combination, animal } \\
\text { dominant; conifer products } \\
\text { present } \\
\end{array}$ \\
\hline $\begin{array}{c}14 \mathrm{MQ} 18 \\
0508-003-3 a\end{array}$ & $\begin{array}{c}\text { Possibly Cholesterol; } \\
\text { possibly Dehydroabietic } \\
\text { acid }\end{array}$ & $\begin{array}{c}\text { Possibly C48 TAG \& } \\
\text { traces of others; Plant } \\
\text { material may dominate }\end{array}$ & $\begin{array}{c}\text { Plant and Animal } \\
\text { combination; conifer } \\
\text { products may occur }\end{array}$ \\
\hline
\end{tabular}

The animal sterol cholesterol may occur in all residues, except 0507-003-1a (14MQ 15); no plant sterols were detected. Dehydroabietic acid probably occurs in residues 0507-003-2a (14MQ 14) and 0507-003-1a (14MQ 15) and may occur in 0508-003-2a (14MQ 17). Only possible traces of TAGs occur in 0508-003-1a (14MQ 16); they provide little information about the residue. The C48 and C50 TAG peaks are predominant in residue 0508-003-2a (14MQ 17), which suggests a plant and animal combination. The C48, C50 and C52 TAG peaks may occur in residue 0507-003-2a (14MQ 14), which suggests a plant and animal combination dominated by animal products. The C50 TAG peak probably occurs and the C48 and
C54 TAGs peaks may occur in residue 0507-0031a (14MQ 15), which also suggests a plant and animal combination dominated by animal products.

\section{F.5.4 High Levels of C18:0 - Large Herbivore}

The fatty acid compositions of two residues, 0504003-1a (14MQ 6) and 0505-003-1a (14MQ 11), are consistent with the preparation of large herbivore products, likely in combination with plant material. Large herbivore residues result from the preparation of bison, deer, moose, fat elk meat or other bovines or cervids; but javelina meat and tropical oil seeds also produce residues high in 
C18:0 and must be considered as potential sources where available.

The animal sterol cholesterol may occur in both residues; the plant sterol $\beta$-sitosterol may occur in 0504-003-1a (14MQ 6). Dehydroabietic acid occurs in residue 0504-003-1a (14MQ 6) and probably occurs in 0505-003-1a (14MQ 11). The C48 and C50 TAG peaks are predominant in residue 0504-003-1a (14MQ 6), which suggests a plant and animal combination. The C48 TAG peak is predominant in residue 0505-003-1a (14MQ 11); plant material may be dominant but because plant sterols are absent it is identified as a plant and animal combination.

\section{F.5.5 Residues with Insufficient Fatty Acids}

Eight residues had insufficient fatty acids to attempt identification: 0501-003-3a (14MQ 1), 0501-0031a (14MQ 3), 0503-003-2 (14MQ 5), 0504-003-2a (14MQ 7), 0504-003-3a (14MQ 8), 0505-003-5a (14MQ9), 0505-003-3a (14MQ 10) and 0508-0033a (14MQ 18). Analysis of these residues using HT-GC and HT-GC/MS shows that animal and plant products may have been present in all of them. The animal sterol cholesterol occurs in residue 0504-003-2a (14MQ 7) and probably or possibly occurs in all others. The plant sterol $\beta$-sitosterol may occur in residues 0501-003-3a (14MQ 1), 0503-003-2 (14MQ 5) and 0504-003-2a (14MQ 7). The presence of dehydroabietic acid, the biomarker for conifer products, was confirmed in residues 0501-003-1a (14MQ 3), 0503-003-2 (14MQ 5), 0505-003-5a (14MQ9) and 0505-003-3a (14MQ 10 ); it may occur in 0504-003-3a (14MQ 8) and 0508-003-3a (14MQ 18). The C48 TAG peak is predominant in residues 0501-003-3a (14MQ 1), 0503-003-2 (14MQ 5), 0504-003-2a (14MQ 7), 0504-003-3a (14MQ 8), 0505-003-5a (14MQ9) and 0508-003-3a (14MQ 18), which may suggest that plant material is dominant. In all cases, plant sterols are absent or the presence of the animal sterol cholesterol is stronger; all these residues are simply identified plant and animal combinations. The $\mathrm{C} 48$ and C50 TAG peaks are predominant in residues 0501-003-1a (14MQ 3) and 0505-003-3a (14MQ 10), which suggests a plant and animal combination; because cholesterol was the only sterol detected, animal products may be dominant.

\section{F.6 REFERENCES CITED}

Barnard, H., A. N. Dooley and K. F. Faull

2007 Chapter 5: An Introduction to Archaeological Lipid Analysis by GC/MS. In Theory and Practice of Archaeological Residue Analysis, edited by H. Barnard and J. W. Eerkens, pp.42-60. British Archaeological Reports International Series 1650. Oxford, UK.

Charters, S., R. P. Evershed, A. Quye, P. W. Blinkhorn and V. Denham

1997 Simulation Experiments for Determining the Use of Ancient Pottery Vessels: The Behaviour of Epicuticular Leaf Wax during Boiling of a Leafy Vegetable. Journal of Archaeological Science 24: 1-7.

Collins M. B., B. Ellis and C. Dodt-Ellis

1990 Excavations at the Camp Pearl Wheat Site (41KR243): An Early Archaic Campsite on Town Creek, Kerr County, Texas. Studies in Archaeology 6. Texas Archaeological Research Laboratory, The University of Texas at Austin.

Condamin, J., F. Formenti, M. O. Metais, M. Michel, and P. Blond

1976 The Application of Gas Chromatography to the Tracing of Oil in Ancient Amphorae. Archaeometry 18(2):195-201. 
Dudd, S. N. and R. P. Evershed

1998 Direct demonstration of milk as an element of archaeological economies. Science 282: 1478-1481.

Eerkens, J. W.

2002 The Preservation and Identification of Pinon Resins by GC-MS in Pottery from the Western Great Basin. Archaeometry 44(1):95-105.

Evershed, R. P.

1993 Biomolecular Archaeology and Lipids. World Archaeology 25(1):74-93.

2000 Biomolecular Analysis by Organic Mass Spectrometry. In Modern Analytical Methods in Art and Archaeology, edited by E. Ciliberto and G. Spoto, pp. 177-239. Volume 155, Chemical Analysis. John Wiley \& Sons, New York.

Evershed, R. P., C. Heron and L. J. Goad

1990 Analysis of Organic Residues of Archaeological Origin by High Temperature Gas Chromatography and Gas Chromatography-Mass Spectroscopy. Analyst 115:1339-1342.

Evershed, R.P., C. Heron and L.J. Goad

1991 Epicuticular Wax Components Preserved in Potsherds as Chemical Indicators of Leafy Vegetables in Ancient Diets. Antiquity 65:540-544.

Evershed, R. P., H. R. Mottram, S. N. Dudd, S. Charters, A. W. Stott, G. J. Lawrence, A. M. Gibson, A. Conner, P. W. Blinkhorn and V. Reeves 1997 New Criteria for the Identification of Animal Fats in Archaeological Pottery. Naturwissenschaften 84: 402-406.
Evershed, R. P., S. J. Vaugh, S. N. Dudd and J. S. Soles

1997 Fuel for Thought? Beeswax in Lamps and Conical Cups from Late Minoan Crete. Antiquity 71: 979-985.

Evershed, R. P., S. N. Dudd, M. J. Lockheart and S. Jim

2001 Lipids in Archaeology. In Handbook of Archaeological Sciences, edited by D. R. Brothwell and A. M. Pollard, pp. 331-349. John Wiley \& Sons, New York.

Folch, J., M. Lees and G. H. Sloane-Stanley

1957 A simple method for the isolation and purification of lipid extracts from brain tissue. Journal of Biological Chemistry 191:833.

Frankel, E. N.

1991 Recent Advances in Lipid Oxidation. Journal of the Science of Food and Agriculture 54:465-511.

Heron, C. and A. M. Pollard

1988 The Analysis of Natural Resinous Materials from Roman Amphoras. In Science and Archaeology Glasgow 1987. Proceedings of a Conference on the Application of Scientific Techniques to Archaeology, Glasgow, 1987, edited by E.

A. Slater and J. O. Tate, pp. 429-447. BAR British Series 196 (ii), Oxford.

Heron, C., N. Nemcek, K. M. Bonfield, J. Dixon and B. S. Ottaway

1994 The Chemistry of Neolithic Beeswax. Naturwissenschaften 81: 266-269.

Loy, T.

1994 Residue Analysis of Artifacts and Burned Rock from the Mustang Branch and Barton Sites (41HY209 and 41HY202). In: Archaic and Late Prehistoric Human 
Ecology in the Middle Onion Creek Valley, Hays County, Texas. Volume 2: Topical Studies, by R. A. Ricklis and M. B. Collins, pp. 607- 627. Studies in Archeology 19, Texas Archaeological Research Laboratory, The University of Texas at Austin.

Malainey, M. E.

1997 The Reconstruction and Testing of Subsistence and Settlement Strategies for the Plains, Parkland and Southern boreal forest. Unpublished Ph.D. thesis, University of Manitoba.

Malainey, M. E.

2007 Chapter 7: Fatty Acid Analysis of Archaeological Residues: Procedures and Possibilities. In Theory and Practice of Archaeological Residue Analysis, edited by H. Barnard and J. W. Eerkens, pp.77-89. British Archaeological Reports International Series 1650. Oxford, UK.

Malainey, M. E., M. Álvarez, I. Briz i Godino, D. Zurro, E. Verdún i Castelló and T. Figol

2014 The Use of Shells as Tools by HunterGatherers in the Beagle Channel (Tierra del Fuego, South America): An Ethnoarchaeological Experiment. Archaeological and Anthropological Sciences. DOI: 10.1007/s12520-014-01881.

Malainey, M. E., P. J. Innes and T. J. Figol

2010 Taking a Second Look: Results of the Reanalysis of Archaeological Lipid Residues from North America and Beyond, Paper presented at the $75^{\text {nd }}$ Annual Meeting of the Society for American Archaeology, St. Louis, MO.
Malainey, M. E., P. J. Innes and T. J. Figol

2014 Taking a Second Look: A Functional Analysis of Burned Rock Features from Eight Sites in Texas and Arizona. Chapter prepared for a volume edited by $\mathrm{H}$. Hoekman-Sites and M. Raviele to be published by the University of Colorado Press (40 pages).

Malainey, M. E., K. L. Malisza, R. Przybylski and G. Monks

2001 The Key to Identifying Archaeological Fatty Acid Residues. Paper presented at the $34^{\text {th }}$ Annual Meeting of the Canadian Archaeological Association, Banff, Alberta, May 2001.

Malainey, M. E., R. Przybylski and B. L. Sherriff

1999a The Fatty Acid Composition of Native Food Plants and Animals of Western Canada. Journal of Archaeological Science 26:83-94

1999b The Effects of Thermal and Oxidative Decomposition on the Fatty Acid Composition of Food Plants and Animals of Western Canada: Implications for the Identification of archaeological vessel residues. Journal of Archaeological Science 26:95-103.

1999c Identifying the former contents of Late Precontact Period pottery vessels from Western Canada using gas chromatography. Journal of Archaeological Science 26(4): 425-438.

2001 One Person's Food: How and Why Fish Avoidance May Affect the Settlement and Subsistence Patterns of Hunter-Gatherers. American Antiquity 66(1): 141-161.

Malainey, M. E., R. Przybylski and G. Monks

2000a The identification of archaeological residues using gas chromatography and 
applications to archaeological problems in Canada, United States and Africa. Paper presented at The $11^{\text {th }}$ Annual Workshops in Archaeometry, State University of New York at Buffalo, February 2000.

$2000 \mathrm{~b}$ Refining and testing the criteria for identifying archaeological lipid residues using gas chromatography. Paper presented at the $33^{r d}$ Annual Meeting of the Canadian Archaeological Association, Ottawa, May 2000.

2000c Developing a General Method for Identifying Archaeological Lipid Residues on the Basis of Fatty Acid Composition. Paper presented at the Joint Midwest Archaeological \& Plains Anthropological Conference, Minneapolis, Minnesota, November 2000.

Marchbanks, M. L.

1989 Lipid Analysis in Archaeology: An Initial Study of Ceramics and Subsistence at the George C. Davis Site. Unpublished M.A. thesis, The University of Texas at Austin.

Marchbanks, M. L. and J. M. Quigg

1990 Appendix G: Organic Residue and Phytolith Analysis. In: Phase II Investigations at Prehistoric and Rock Art Sites, Justiceburg Reservoir, Garza and Kent Counties, Texas, Volume II, by D. K. Boyd, J. T. Abbott, W. A. Bryan, C. M. Garvey, S. A. Tomka and R. C. Fields. pp. 496-519. Reports of Investigations No. 71. Prewitt and Associates, Inc., Austin.

Patrick, M., A. J. de Konig and A. B. Smith

1985 Gas Liquid Chromatographic Analysis of Fatty Acids in Food Residues from Ceramics Found in the Southwestern Cape, South Africa. Archaeometry 27(2): 231236.
Quigg, J. M., C. Lintz, S. Smith and S. Wilcox

2000 The Lino Site: A Stratified Late Archaic Campsite in a Terrace of the San Idelfonzo Creek, Webb County, Southern Texas. Technical Report No. 23765, TRC Mariah Associates Inc., Austin. Texas Department of Transportation, Environmental Affairs Division, Archaeological Studies Program Report 20, Austin.

Quigg, J. M., M. E. Malainey, R. Przybylski and G. Monks

2001 No bones about it: using lipid analysis of burned rock and groundstone residues to examine Late Archaic subsistence practices in South Texas. Plains Anthropologist 46(177): 283-303.

Reber, E. A., S. N. Dudd, N. J. van der Merwe and R. P. Evershed

2004 Direct detection of maize in pottery residue via compound specific stable carbon isotope analysis. Antiquity 78: 682-691.

Regert, M., H. A. Bland, S. N. Dudd, P. F. van Bergen and R. P. Evershed

1998 Free and Bound Fatty Acid Oxidation Products in Archaeological Ceramic Vessels. Philosophical Transactions of the Royal Society of London, B 265 (1409):2027-2032.

Regert, $\mathrm{M}$.

2007 Chapter 6: Elucidating Pottery Function using a Multi-step Analytical Methodology combining Infrared Spectroscopy, Chromatographic Procedures and Mass Spectrometry. In Theory and Practice of Archaeological Residue Analysis, edited by H. Barnard and J. W. Eerkens, pp.61-76. British Archaeological Reports International Series 1650. Oxford, UK. 
Sauter, F., E. W. H. Hayek, W. Moche and U. Jordis 1987 Betulin aus archäologischem Schwelteer. Z. für Naturforsch 42c (11-12):1151-1152.

Shackley, M.

1982 Gas Chromatographic Identification of a Resinous Deposit from a 6th Century Storage Jar and Its Possible Identification. Journal of Archaeological Science 9:305306.
Skibo, J. M.

1992 Pottery Function: A Use-Alteration Perspective. Plenum Press, New York.

Solomons, T. W. G.

1980 Organic Chemistry. John Wiley \& Sons, Toronto. 
This page intentionally left blank. 


\title{
APPENDIX G: \\ PLANT REMAINS FROM 41BL278
}

\author{
Prepared for:

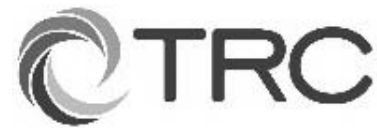 \\ TRC Environmental Corporation \\ 505 East Huntland Drive, Suite 250 \\ Austin, Texas 78752 \\ Prepared by: \\ Phil Dering, Ph.D. \\ Shumla Archeobotanical Services \\ Comstock, Texas 78837
}


This page intentionally left blank. 


\section{APPENDIX G: PLANT REMAINS FROM 41BL278}

Phil Dering, Ph.D.

\section{G.1 INTRODUCTION}

Michael Quigg of TRC Environmental Corporation submitted nine macrobotanical samples from 41BL278 for identification. These samples were recovered from Features 5 and 7 as well as several non-feature contexts. This report presents the identification of the samples as well as an assessment of the information they contain.

\section{G.2 LABORATORY METHODS}

\section{G.2.1 Analysis}

The analysis follows standard archeobotanical laboratory procedures. The light fraction of each flotation sample is passed through a nested set of screens of $4 \mathrm{~mm}, 2 \mathrm{~mm}, 1 \mathrm{~mm}$, and $0.350 \mathrm{~mm}$ mesh and examined for charred material that is separated for identification. The heavy fraction is also scanned for charcoal, which is set aside for identification. The results are combined with identifications from each corresponding light fraction. Only charred plant material is included in the analysis, because uncarbonized material is consumed by insects, fungi and bacteria and does not survive more than a few years in open deposits. Carbonized plant material is sorted into two categories -woody fragments, and seed/fruit fragments including maize (Zea mays) or agave (Agavaceae) parts when present.

Carbonized wood from the $4 \mathrm{~mm}$ and $2 \mathrm{~mm}$ screens (smaller pieces are seldom identifiable) is separated in a 25-piece grab sample and identified. Care is taken to select representative materials from both levels (cf. Diehl 2003:213; Huckell 2002:645; Miksicek 1994:243). When a sample contains more than 25 wood fragments, the additional material is scanned and sorted into wood charcoal types. For each type with more than 25 fragments, the volume of each type is measured in milliliters and reported along with its weight.

Charred material caught on all of the sieve levels, including the bottom pan, is scanned for floral parts, fruits, seeds, and other potentially edible plant parts such as agave or maize fragments, and these plant parts are counted and examined for identification.

\section{G.2.2 Disturbance Indicators}

Sample content may be affected by various biological disturbance factors, including insect or small mammal activity, and plant root growth. In an effort to assess this impact, the amounts of insect parts, termite pellets, rodent/rabbit pellets, gastropods, and modern uncharred seeds are estimated for each flotation sample. These amounts are reported on a scale of 1-25(+), 25-50 (++), and over $50(+++)$. In the current study, roots, insect parts, and gastropod remains were noted in the light fractions. There was no material other than a few small, unsorted gravels in the heavy fractions.

\section{G.2.3 Identification}

Identification of carbonized wood is accomplished by using the snap technique, and examining the transverse, radial, and tangential surfaces at 7.5 to 75 power with a binocular dissecting microscope, and comparing the material to reference specimens in the Shumla Archeobotanical Services reference collection. Seeds, fruit fragments, and Agavaceae type (agave, sotol, yucca, etc.) are identified using seed manuals and reference specimens.

When I could distinguish vessels imbedded in fibers and parenchyma, I classified the wood as a hardwood (not a conifer). If the wood sample contained sufficient diagnostic features, I assigned it to a more restrictive category, such as woodylegume type or live-oak type. I did not observe wood consisting primarily of tracheids (e.g., conifer wood/juniper) in this assemblage. 
The wood of mesquite, acacia, and other members of the legume family (Fabaceae), is difficult to separate beyond the family level (Fabaceae). Mesquite can be separated from other woody members of that family, but in cases where the charcoal fragments are too small or the gross anatomy does not include diagnostic features, the material is assigned to the Fabaceae-type (woodylegume type). Willow family wood, including cottonwood and willow, are also difficult to distinguish, and these are placed in the Salicaceaetype (willow family-type).

\section{G.3 RESULTS}

Table G-1 presents the identifications of the macrobotanical samples. Oak and willow family wood, recovered from general contexts, were the only identified wood types. Most of the macrobotanical samples in this assemblage consist of carbonized plant tissue imbedded in a silt or sandy silt matrix. Much of the carbonized material is too decomposed to be able to identify or even determine if it was wood (xylem and associated tissue). This indistinguishable material I describe as carbonized plant tissue. Some of the material is so minute and powdery it is labeled soot. At first inspection many specimens appeared to be wood charcoal, but actually consisted of silt matrix covered in black sooty material or decomposed plant material. In many cases, when material appearing to be wood charcoal is snapped into two pieces to examine the cross-section, it reveals a silt matrix core.

Most of the charred plant material in the samples was decomposed and very delicate. As I tried to pick or dislodge the carbonized material from the silt matrix, much of it would disintegrate when moved or when snapped in two for examination of a cross-section. After picking out the larger pieces, I attempted to extract more charred material by soaking the matrix in water. The charcoal was so decomposed that once separated from the matrix by water, it disintegrated into tiny particles. This likely explains the poor flotation results.

\section{G.4 DISCUSSION AND CONCLUSIONS}

The results indicate that plant preservation is poor at 41BL278. Wood charcoal content consists of oak and willow family-types. Most of the charred plant material has been reduced to small flecks and sootlike powder. No seeds were identified in the samples.

Table G-1. Macrobotanical Samples from 41BL278.

\begin{tabular}{|c|c|c|c|c|c|c|}
\hline Cat \# & Feature & Taxon & Common & Part & Count & Wt. (g) \\
\hline $12-007$ & -- & Quercus sp. & Oak & Wood & 3 & + \\
\hline $507-007-3$ & 7 & Indeterminate & NA & Flecks, soot, clay & -- & 4.7 \\
\hline $505-007$ & 5 & Indeterminate & NA & Flecks, soot, clay & -- & -- \\
\hline $15-007-1$ & -- & Indeterminate & NA & Flecks, soot, clay & -- & -- \\
\hline $18-007$ & -- & Salicaceae & $\begin{array}{c}\text { Cottonwood- } \\
\text { willow }\end{array}$ & Wood & 2 & 0.1 \\
\hline $501-007$ & -- & Salicaceae & $\begin{array}{c}\text { Cottonwood- } \\
\text { willow }\end{array}$ & Wood & 1 & 0.1 \\
\hline $8-007-3$ & -- & Indeterminate & NA & Flecks, soot, clay & -- & -- \\
\hline $8-007-4$ & -- & $\begin{array}{c}\text { Indeterminate } \\
\text { hardwood }\end{array}$ & NA & Wood & 7 & + \\
\hline $507-007-4$ & -- & Indeterminate & NA & Flecks, soot, clay & -- & -- \\
\hline
\end{tabular}


It is difficult to predict when and where archeologists will encounter botanical remains, due primarily to the stochastic nature of botanical preservation. Recovery from open site deposits depends on carbonization of the plant fragments, and carbonization is usually a byproduct of plant processing or food preparation accidents, waste disposal, burning of structures after abandonment, or in the best case scenario, catastrophic burning of an occupied structure. In the case of temporary encampments of foragers, one can expect low recovery rates, especially from shallowly buried and briefly occupied archeological sites located on stable landforms.

Other factors of poor preservation include the fine texture and alkalinity of the archeological deposits in the region. Woody plant materials do not preserve well in alkaline soils, and the fine-textured soils absorb and hold moisture, providing a medium for plant growth as well as fungal and bacterial activity. Some of the samples contained rootlets or fungal mycelia growing through the pores of the wood charcoal. If the samples in the current analysis are an accurate indication, 41BL278 does not have good potential to yield botanical information.

\section{G.5 REFERENCES CITED}

Diehl, M.

2003 Prehistoric Subsistence Strategies and the Macrobotanical Assemblage. In Hohokam Farming on the Salt River Floodplain, edited by T. Kathleen Henderson, pp. 211-230. Anthropological Papers No. 42, Center for Desert Archaeology. Tucson. Anthropological Papers No. 9. Pueblo Grande Museum. Phoenix.

Huckell, L.

2002 Paleoethnobotany. In Tonto Creek Archaeological Project Artifact and Environmental Analyses. Volume 2: Stone Tool and Subsistence Studies, edited Jeffery J. Clark, pp. 643-709. Anthropological Papers No. 23. Center for Desert Archaeology. Tucson.

Miksicek, C.

1994 Deceptive Barrenness: Archaeobotanical Material from the Schuk Toak Project Area. In Archaeological Studies of the Avra Valley, Arizona: Excavations in the Schuk Toak District. Vol 2. Scientific Studies and Interpretations, edited by Allen Dart, pp. 243-266. Anthropological Papers No. 16. Center for Desert Archaeology. Tucson. 
This page intentionally left blank. 


\title{
APPENDIX H: \\ RESIDUE AND USE-WEAR ANALYSIS OF STONE ARTIFACTS FROM SITE 41BL278
}

\author{
Prepared for:

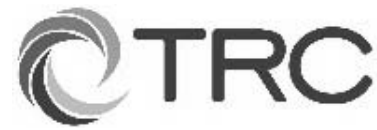 \\ TRC Environmental Corporation \\ 505 East Huntland Drive, Suite 250 \\ Austin, Texas 78752
}

Prepared by:

Bruce L. Hardy, Ph.D.

Department of Anthropology

Kenyon College

Gambier, Ohio 43022 
This page intentionally left blank. 
APPENDIX H: RESIDUE AND USE-WEAR ANALYSIS OF STONE ARTIFACTS FROM SITE 41BL278

Bruce L. Hardy, Ph.D.

\section{H.1 INTRODUCITON}

A total of 8 artifacts were examined for use-wear and residue analysis from this Late Archaic (ca. 3100-3300 B.P.) component associated with multiple burned rock features. The sample included 4 edge-modified flakes and 4 bifaces (or biface fragments).

\section{H.2 METHODS}

Artifacts were examined under bright-field incident light using an Olympus BH30 microscope (magnification 50-500x). Images were recorded using a Motic 5 digital camera and Motic Images Plus 2.0 software. All residues observed were photographed and their location noted on a line drawing of each artifact. Identification of residues was based on comparison with a large modern reference collection and with published sources (Anderson-Gerfaud 1990; Beyries 1988; Brom 1986; Brunner and Coman 1974; Catling and Grayson 1982; Crowther 2009; Dove et al. 2005; Fullagar 1991, 2006; Genten et al. 2009; Hather 1993; Hardy 1994; Hardy and Garufi 1998; Haslam 2004; Hoadley 1990; Kardulias and Pearsall 2000; Teerink 1991; Warren 2009; Williamson 1996; Yerkes 1996. Huffman et al. 2008). Identifiable residue categories include wood, bark, plant fibers, starch grains, calcium oxalate crystals, plant tissue, resin, hair, feathers, fish scales, skin, and bone (Hardy and Moncel 2011). Starch grains can potentially be mistaken for fungal spores or other materials and identification under reflected light is therefore considered preliminary (Haslam 2006; Loy 2006). For all identifications, a suite or related residues (e.g. hair fragments, collagen, bone or plant cells, starch grains, plant fibers) strengthened the confidence of the identification (Lombard and Wadley 2007). Calcium oxalate crystals (raphides) can be mistaken for rod-shaped calcite crystals (Crowther 2009). Treatment of putative raphides with acetic acid is necessary to confirm their identification.

Use-wear analysis to identify the relative hardness of the use-material and the use-action included the identification of striations, edge rounding and microflake scars (Mansur-Franchomme 1986; Odell and Odell-Vereecken 1980). Due to the potential overlap of polishes from different worked materials, polishes were identified as either "soft" (animal skin, muscle or soft plants) or "hard/high silica" (bone, antler, wood, or plants with high silica content) (Fullagar 1991; Hardy 2004; Hardy, Bolus et al. 2008; Hardy, Kay et al. 2001). Högberg et al. (2009) have described one other category of polish characterized by linear streaks of dull, greasy polish with bright spots that develops during fish processing. Striations and polish on the proximal $1 / 3$ to $1 / 2$ of an artifact are sometimes indicative of hafting (Lombard and Wadley 2007). Residue distribution and co-occurrence of wear patterns were used to help determine if residues were userelated.

\section{H.3 RESULTS}

Seven of the eight artifacts showed some type of functional evidence. One biface fragments showed no evidence of use. See Table H-1 and Figure H-1 for summaries.

\section{H.3.1 Edge-Modified Flakes}

All five edge-modified flakes showed signs of use. Of these, two had no residues preserved but had wear patterns indicative of use on hard or high silica materials. One artifact (\#14-10) had plant tissue in association with hard/high silica polish 
Table H-1. Results of Use-wear and Residue Analysis.

\begin{tabular}{|c|c|c|c|c|}
\hline Cat. No. & Type & Residue & Use-wear & Function \\
\hline $14-10$ & Edge-modified flake & $\begin{array}{c}\text { Plant tissue, } \\
\text { wood }\end{array}$ & $\begin{array}{c}\text { Hard/high silica polish, } \\
\text { striae }\end{array}$ & Cutting wood \\
\hline $21-10$ & Biface & ---- & Hard/high silica polish & Cutting hard material \\
\hline $25-10$ & Edge-modified flake & Collagen & Soft polish & Cutting hide/butchery \\
\hline $31-10$ & Biface & $\begin{array}{c}\text { Plant fragments, } \\
\text { collagen }\end{array}$ & $\begin{array}{c}\text { Soft polish distal, } \\
\text { hard/high silica polish } \\
\text { and striae proximal }\end{array}$ & Hafted, cutting hide \\
\hline $37-10$ & Biface & ---- & Soft polish & Cutting soft material \\
\hline $40-10$ & Edge-modified flake & $\begin{array}{c}\text { Feather } \\
\text { fragments }\end{array}$ & Soft polish & Cutting feathers/bird \\
\hline $505-10$ & Biface & ---- & ---- & Unknown/unused \\
\hline $506-10$ & Edge-modified flake & --- & Hard/high silica polish & Cutting hard material \\
\hline
\end{tabular}

and striations. The anatomy of the plant tissue suggests that the tool was used for cutting wood (Hardy and Garufi 1998).

The final flake had soft polish associated with two fragments of feather barbules (Figure H-2). If the feather fragments are use-related, the tool could have been used in processing birds for food, as adornment, or for the preparation of fletching. While it is possible to identify feathers to the Order level (Brom 1986), there was insufficient diagnostic anatomy available in this instance.

\section{H.3.2 Bifaces}

One large biface (\#37-10) has scattered areas of soft polish but no residues were found. A second biface (\#31-10) has two distinct zones of wear (Figure H3). Soft polish and collagen fragments at the distal end suggest it was used to cut hide or in butchery tasks. On the proximal third, striations, polish, and plant tissue suggest that the tool was hafted. The final biface showed no evidence of use.

\section{H.4 DISCUSSION AND CONCLUSIONS}

Although the sample size is small, functional analyses point to wood working, butchery or hide processing, and possibly use of avian resources.

\section{H.5 REFERENCES CITED}

Anderson-Gerfaud, $\mathrm{P}$.

1990 Aspects of behavior in the Middle Paleolithic: Functional analysis of stone tools from southwest France. In: The Emergence of Modern Humans: An Archaeological Perspective, edited by $\mathrm{P}$. Mellars, pp. 389-418. Cornell University Press, Ithaca.

Beyries, S.

1988 Industries Lithiques: Traçeologie et Technologie. British Archaeological Reports International Series, London.

Brom, T.

1986 Microscopic identification of feathers and feather fragments of palearctic birds. Bijdragen Tot De Dierkunde 56:181-204. 
Brunner, H. and B. J. Coman

1974 The Identification of Mammalian Hair. Inkata Press, Melbourne.

Catling, D. and J. Grayson

1982 Identification of Vegetable Fibres. Chapman and Hall, New York.

Chandler, A. C.

1916 A study of feathers, with reference to their taxonomic significance. University of California, Publication Zoology 13:243446.

Crowther, A.

2009 Morphometric analysis of calcium oxalate raphides and assessment of their taxonomic value for archaeological microfossil studies. Archaeological Science under a Microscope [Electronic Resource]: Studies in Residue and Ancient DNA Analysis in Honour of Thomas H. Loy, edited by Michael Haslam [et al.]. Terra Australis 30:102-128.

Dickson, W. C.

2000 Integrative Plant Anatomy. San Diego: Harcourt.

Dove, C. J., P. G. Hare and M. Heacker

2005 Identification of ancient feather fragments found in melting alpine ice patches in southern Yukon. Arctic 58:38-43.

Fullagar, R.

1991 The role of silica in polish formation. Journal of Archaeological Science 18:124.

2006 Starch on Artifacts. In Ancient Starch Research, edited by $\mathrm{R}$. Torrence and $\mathrm{H}$. Barton, pp. 177-204. Walnut Creek: Left Coast Press.

Genten, F., E. Terwinghe and A. Danguy

2009 Atlas of Fish Histology. Enfield, New Hampshire: Science Publishers.
Hardy, B. L.

1994 Investigations of stone tool function through use-wear, residue and DNA analyses at the Middle Paleolithic site of La Quina, France. Unpublished Ph.D. dissertation, Indiana University.

2004 Neanderthal behaviour and stone tool function at the Middle Paleolithic site of $\mathrm{La}$ Quina, France. Antiquity 78:547-565.

Hardy, B. L. and G. T. Garufi

1998 Identification of woodworking on stone tools through residue and use-wear analyses: Experimental results. Journal of Archaeological Science 25:177-184.

Hardy, B. L., M. Kay, A. E. Marks, and K. Monigal 2001 Stone tool function at the Paleolithic sites of Starosele and Buran Kaya III, Crimea: Behavioral implications. Proceedings of the National Academy of Sciences, U.S.A. 98:10972-10977.

Hardy, B. L. and M. H. Moncel

2011 Neanderthal use of fish, mammals, birds, starchy plants and wood 125-250,000 Years Ago. PloS One, 6(8), e23768.

Hardy, B. L., M. Bolus, and N. J. Conard

2008 Hammer or crescent wrench? Stone-tool form and function in the Aurignacian of southwest Germany. Journal of Human Evolution 54: 648-662.

Haslam, M.

2004 The decomposition of starch grains in soils: Implications for archaeological residue analyses. Journal of Archaeological Science 31:1715-1734.

2006 Potential misidentification of in situ archaeological tool-residues: starch and conidia. Journal of Archaeological Science 33:114-121. 
Hather, J.

1993 An Archaeobotanical Guide to Root and Tuber Identification, Vol. I: Europe and South West Asia. Oxbow Books, Oxford.

Hoadley, R.

1990 Identifying Wood: Accurate Results with Simple Tools. Taunton Press, Newtown.

Huffman, D., L. Tiffany, G. Knaphus, and R. Healy 2008 Mushrooms and Other Fungi of Midcontinental United States. Iowa City: University of Iowa.

Kardulias, N. and R. Yerkes

1996 Microwear and metric analysis of threshing sledge flints from Greece and Cyprus. Journal of Archaeological Science 23:657666.

Lombard, M.

2007 The gripping nature of ochre: the association of ochre with Howiesons Poort adhesives and Later Stone Age mastics from South Africa. Journal of Human Evolution 53(4):406-419.

Lombard, M. and L. Wadley

2007 The morphological identification of microresidues on stone tools using light microscopy: progress and difficulties based on blind tests. Journal of Archaeological Science 34:155-165.

Loy, T.

2006 Optical properties of potential look-alikes. In Ancient Starch Research, edited by $\mathrm{R}$. Torrence, and H. Barton, p. 123. Walnut Creek, California, Left Coast Press.
Mansur-Franchomme, M. E.

1986 Microscopie du Matériel Lithique Préhistorique: Traces d'Utilisation, Altération Naturelles, Accidentelles, et Technologiques. National Centre for Scientific Research, Paris.

Odell, G. and F. Odell-Vereecken

1980 Verifying the reliability of lithic usewear assessments by "blind tests": The lowpower approach. Journal of Archaeological Science 7:87-120.

Pearsall, D.

2000 Paleoethnobotany: A Handbook of Procedures. Second edition, Academic Press, New York.

Schultz, J. M.

1992 The use-wear generated by processing bison hides. The Plains Anthropologist 37(141):333-351.

Teerink, B. J.

1991 Hair of West European Mammals: Atlas and Identification Key. Cambridge University Press, Cambridge.

Williamson, B. S.

1996 Preliminary stone tool residue analysis from Rose Cottage Cave. South Africa. Journal of Field Archaeology 5:36-44.

Warren, $\mathrm{R}$.

2009 The potential role of fish in the diet of Neanderthals. Unpublished senior honors thesis. Kenyon College, Gambier, Ohio. 


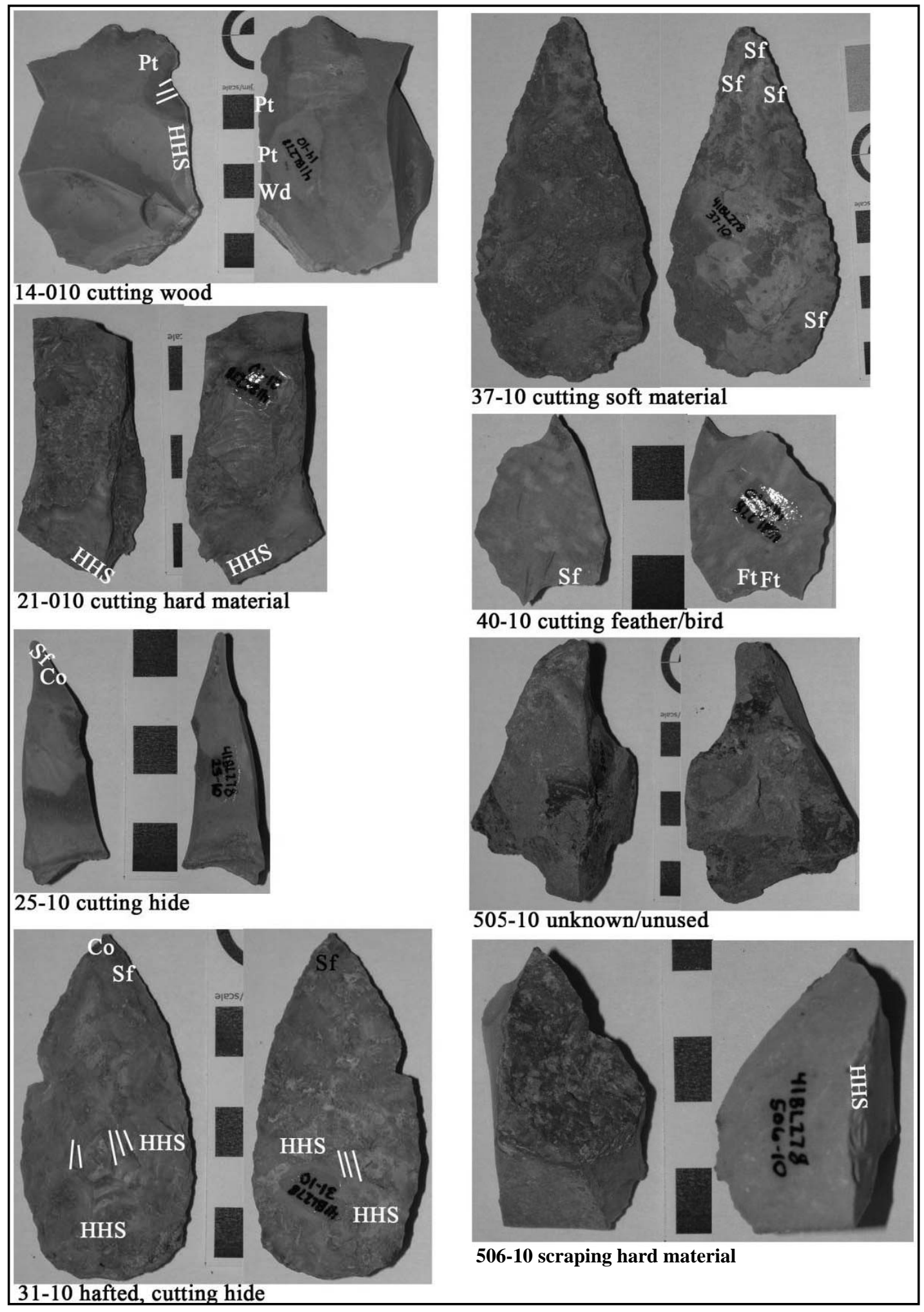

Figure H-1. Visual summary of results. 


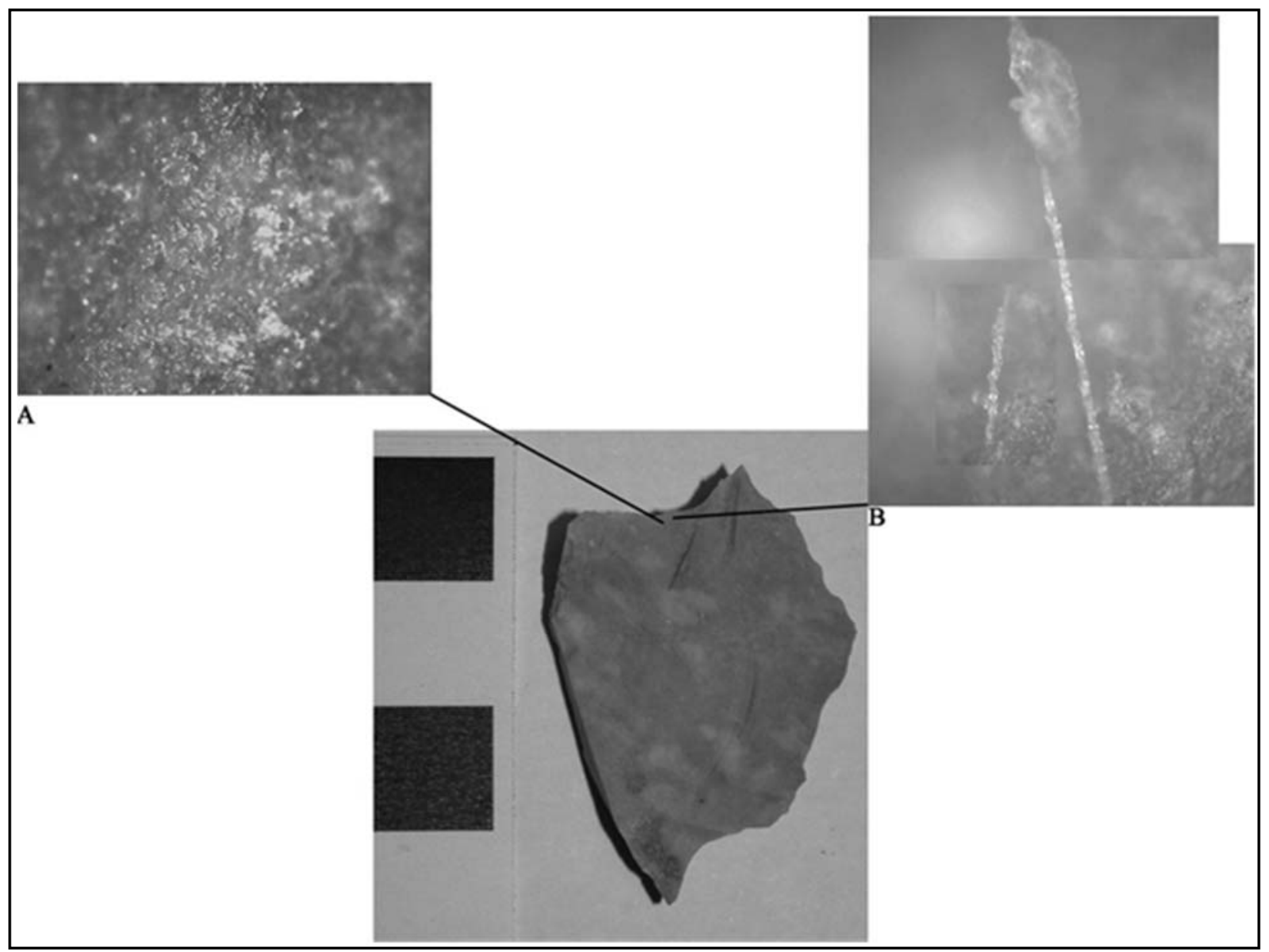

Figure H-2. Specimen \#40-10, A) soft polish; B) photomosaic of feather barbule fragments. 


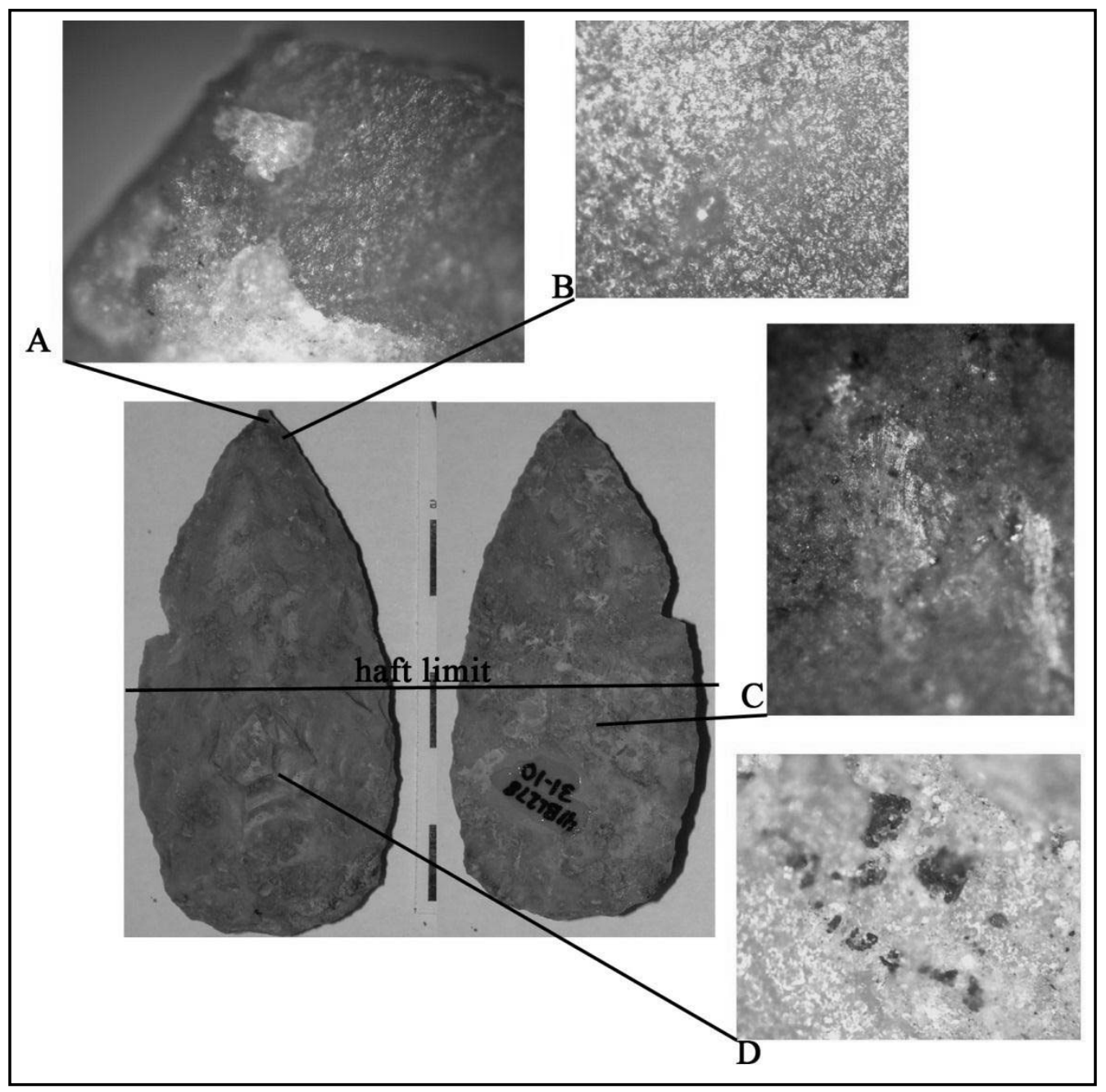

Figure H-3. Specimen \#31-10, A) collagen fragment; B) soft polish; C) striations parallel to long axis; D) plant fragments and bright polish related to haft. 
This page intentionally left blank. 


\title{
APPENDIX I: \\ VERTICAL DISTRIBUTION OF ARTIFACTS RECOVERED DURING TESTING AT 41BL278, BELL COUNTY, TEXAS
}

\author{
Prepared by: \\ Trisha-Ann P. Gonzales \\ Archeological Curation Manager

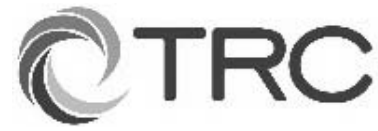 \\ TRC Environmental Corporation \\ 505 East Huntland Drive, Suite 250 \\ Austin, Texas 78752
}


This page intentionally left blank. 


\section{APPENDIX I: VERTICAL DISTRIBUTION OF ARTIFACTS RECOVERED DURING TESTING AT 41BL278, BELL COUNTY, TEXAS}

The following table (Table I-1) shows the vertical distribution of artifacts by material class and test unit.

Table I-1. Vertical Provenience of Artifacts by Class and Test Unit.

\begin{tabular}{|c|c|c|c|c|c|c|c|c|c|c|c|c|c|c|c|c|c|}
\hline \multicolumn{6}{|c|}{ Test Pit 1} & \multicolumn{6}{|c|}{ Test Pit 2} & \multicolumn{6}{|c|}{ Test Pit 4} \\
\hline \multicolumn{6}{|c|}{ Backhoe Trench 8} & \multicolumn{6}{|c|}{ Backhoe Trench 8} & \multicolumn{6}{|c|}{ Backhoe Trench 8} \\
\hline cmbs & $B$ & $\mathrm{BR}$ & LL & LT & MS & $\mathrm{cmbs}$ & $B$ & BR & LL & LT & MS & $\mathrm{cmbs}$ & $B$ & $\mathrm{BR}$ & LL & LT & MS \\
\hline $\begin{array}{c}130- \\
140\end{array}$ & 0 & 8 & 2 & 0 & 2 & $\begin{array}{c}130- \\
140\end{array}$ & 0 & 1 & 0 & 0 & 0 & $\begin{array}{c}130- \\
140\end{array}$ & $\mathrm{n} / \mathrm{a}$ & $\mathrm{n} / \mathrm{a}$ & $\mathrm{n} / \mathrm{a}$ & $\mathrm{n} / \mathrm{a}$ & $\mathrm{n} / \mathrm{a}$ \\
\hline $\begin{array}{c}140- \\
150 \\
\end{array}$ & 0 & 23 & 4 & 0 & 7 & $\begin{array}{c}140- \\
150 \\
\end{array}$ & 0 & 11 & 0 & 0 & 1 & $\begin{array}{c}140- \\
150 \\
\end{array}$ & 2 & 10 & 0 & 0 & 1 \\
\hline $\begin{array}{c}150- \\
160 \\
\end{array}$ & 15 & 58 & 4 & 0 & 2 & $\begin{array}{c}150- \\
160 \\
\end{array}$ & 0 & 35 & 8 & 0 & 3 & $\begin{array}{c}150- \\
160 \\
\end{array}$ & 0 & 54 & 4 & 1 & 1 \\
\hline $\begin{array}{c}160- \\
170\end{array}$ & 2 & 10 & 0 & 0 & 0 & $\begin{array}{c}160- \\
170\end{array}$ & 25 & 20 & 1 & 0 & 2 & $\begin{array}{c}160- \\
170\end{array}$ & 0 & 16 & 1 & 2 & 2 \\
\hline $\begin{array}{c}170- \\
180\end{array}$ & 0 & 5 & 1 & 0 & 1 & $\begin{array}{c}170- \\
180 \\
\end{array}$ & 27 & 13 & 3 & 0 & 2 & $\begin{array}{c}170- \\
180 \\
\end{array}$ & 0 & 15 & 2 & 0 & 1 \\
\hline Total & 17 & 104 & 11 & 0 & 12 & Total & 52 & 80 & 12 & 0 & 8 & Total & 2 & 95 & 7 & 3 & 5 \\
\hline \multicolumn{6}{|c|}{ Test Pit 5} & \multicolumn{6}{|c|}{ Test Pit 6} & \multicolumn{6}{|c|}{ Test Pit 7} \\
\hline \multicolumn{6}{|c|}{ Backhoe Trench 9} & \multicolumn{6}{|c|}{ Backhoe Trench 9} & \multicolumn{6}{|c|}{ Backhoe Trench 9} \\
\hline cmbs & $B$ & $\mathrm{BR}$ & LL & LT & MS & cmbs & $B$ & $B R$ & LL & LT & MS & $\mathrm{cmbs}$ & $B$ & $\mathrm{BR}$ & $\mathrm{LL}$ & LT & MS \\
\hline $\begin{array}{c}130- \\
140 \\
\end{array}$ & 0 & 37 & 0 & 0 & 2 & $\begin{array}{c}130- \\
140\end{array}$ & 0 & 31 & 0 & 0 & 1 & $\begin{array}{c}130- \\
140 \\
\end{array}$ & 0 & 10 & 1 & 0 & 8 \\
\hline $\begin{array}{c}140- \\
150 \\
\end{array}$ & 0 & 62 & 0 & 0 & 3 & $\begin{array}{l}140- \\
150\end{array}$ & 0 & 46 & 4 & 0 & 0 & $\begin{array}{c}140- \\
150 \\
\end{array}$ & 0 & 49 & 3 & 0 & 6 \\
\hline $\begin{array}{c}150- \\
160 \\
\end{array}$ & 0 & 43 & 13 & 0 & 3 & $\begin{array}{l}150- \\
160\end{array}$ & 3 & 34 & 12 & 1 & 5 & $\begin{array}{c}150- \\
160 \\
\end{array}$ & 0 & 64 & 2 & 0 & 1 \\
\hline $\begin{array}{c}160- \\
170 \\
\end{array}$ & 0 & 41 & 9 & 0 & 6 & $\begin{array}{l}160- \\
170\end{array}$ & 0 & 56 & 2 & 0 & 4 & $\begin{array}{l}160- \\
170 \\
\end{array}$ & 8 & 41 & 6 & 1 & 4 \\
\hline $\begin{array}{c}170- \\
180 \\
\end{array}$ & 0 & 18 & 4 & 0 & 2 & $\begin{array}{c}170- \\
180 \\
\end{array}$ & 0 & 5 & 3 & 0 & 5 & $\begin{array}{c}170- \\
180 \\
\end{array}$ & 0 & 40 & 2 & 0 & 2 \\
\hline $\begin{array}{c}180- \\
190 \\
\end{array}$ & 0 & 15 & 3 & 1 & 2 & $\begin{array}{c}180- \\
190 \\
\end{array}$ & $\mathrm{n} / \mathrm{a}$ & $\mathrm{n} / \mathrm{a}$ & $\mathrm{n} / \mathrm{a}$ & $\mathrm{n} / \mathrm{a}$ & $\mathrm{n} / \mathrm{a}$ & $\begin{array}{c}180- \\
190 \\
\end{array}$ & $\mathrm{n} / \mathrm{a}$ & $\mathrm{n} / \mathrm{a}$ & $\mathrm{n} / \mathrm{a}$ & $\mathrm{n} / \mathrm{a}$ & $\mathrm{n} / \mathrm{a}$ \\
\hline Total & 0 & 216 & 29 & 1 & 18 & Total & 3 & 172 & 21 & 1 & 15 & Total & 8 & 204 & 14 & 1 & 21 \\
\hline \multicolumn{6}{|c|}{ Test Pit 8} & \multicolumn{6}{|c|}{ Test Pit 9} & \multicolumn{6}{|c|}{ Test Pit 10} \\
\hline \multicolumn{6}{|c|}{ Backhoe Trench 14} & \multicolumn{6}{|c|}{ Backhoe Trench 14} & \multicolumn{6}{|c|}{ Backhoe Trench 14} \\
\hline cmbs & B & BR & LL & LT & MS & $\mathrm{cmbs}$ & B & BR & LL & LT & MS & $\mathrm{cmbs}$ & B & BR & LL & LT & MS \\
\hline $\begin{array}{c}130- \\
140\end{array}$ & 0 & 14 & 0 & 0 & 2 & $\begin{array}{l}130- \\
140\end{array}$ & 0 & 12 & 0 & 0 & 1 & $\begin{array}{c}130- \\
140\end{array}$ & 0 & 6 & 1 & 0 & 3 \\
\hline $\begin{array}{c}140- \\
150 \\
\end{array}$ & 0 & 28 & 2 & 0 & 1 & $\begin{array}{c}140- \\
150 \\
\end{array}$ & $\mathrm{n} / \mathrm{a}$ & $\mathrm{n} / \mathrm{a}$ & $\mathrm{n} / \mathrm{a}$ & $\mathrm{n} / \mathrm{a}$ & $\mathrm{n} / \mathrm{a}$ & $\begin{array}{c}140- \\
150 \\
\end{array}$ & 0 & 14 & 0 & 0 & 3 \\
\hline $\begin{array}{c}150- \\
160 \\
\end{array}$ & 0 & 25 & 0 & 0 & 2 & $\begin{array}{c}150- \\
160 \\
\end{array}$ & $\mathrm{n} / \mathrm{a}$ & $\mathrm{n} / \mathrm{a}$ & $\mathrm{n} / \mathrm{a}$ & $\mathrm{n} / \mathrm{a}$ & $\mathrm{n} / \mathrm{a}$ & $\begin{array}{c}150- \\
160 \\
\end{array}$ & 0 & 31 & 4 & 1 & 4 \\
\hline $\begin{array}{c}160- \\
170\end{array}$ & $\mathrm{n} / \mathrm{a}$ & $\mathrm{n} / \mathrm{a}$ & $\mathrm{n} / \mathrm{a}$ & $\mathrm{n} / \mathrm{a}$ & $\mathrm{n} / \mathrm{a}$ & $\begin{array}{c}160- \\
170\end{array}$ & $\mathrm{n} / \mathrm{a}$ & $\mathrm{n} / \mathrm{a}$ & $\mathrm{n} / \mathrm{a}$ & $\mathrm{n} / \mathrm{a}$ & $\mathrm{n} / \mathrm{a}$ & $\begin{array}{c}160- \\
170 \\
\end{array}$ & 0 & 27 & 11 & 0 & 1 \\
\hline $\begin{array}{c}170- \\
180 \\
\end{array}$ & $\mathrm{n} / \mathrm{a}$ & $\mathrm{n} / \mathrm{a}$ & $\mathrm{n} / \mathrm{a}$ & $\mathrm{n} / \mathrm{a}$ & $\mathrm{n} / \mathrm{a}$ & $\begin{array}{c}170- \\
180 \\
\end{array}$ & $n / a$ & $\mathrm{n} / \mathrm{a}$ & $\mathrm{n} / \mathrm{a}$ & $\mathrm{n} / \mathrm{a}$ & $\mathrm{n} / \mathrm{a}$ & $\begin{array}{c}170- \\
180 \\
\end{array}$ & 0 & 14 & 5 & 0 & 4 \\
\hline Total & 0 & 67 & 2 & 0 & 5 & Total & 0 & 12 & 0 & 0 & 1 & Total & 0 & 92 & 21 & 1 & 15 \\
\hline
\end{tabular}

L = Lithics; B = Bone; MS = Shell; BR = Burned Rock; LT = Lithic Tools

${ }^{*}$ TU-3 not excavated 
This page intentionally left blank. 